Pós-Graduação em Desenvolvimento Sustentável

\title{
Visitando o século XXI: inovações para a sustentabilidade em destinos turísticos brasileiros
}

Daniela Maria Rocco Carneiro

Tese de doutorado

Brasília - DF, novembro/2014

Universidade de Brasília

Centro de Desenvolvimento Sustentável 
UNIVERSIDADE DE BRASÍLIA

CENTRO DE DESENVOLVIMENTO SUSTENTÁVEL

\section{Visitando o século XXI: inovações para a sustentabilidade em destinos turísticos brasileiros}

Daniela Maria Rocco Carneiro

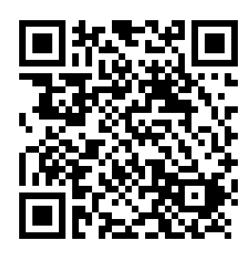

Orientador: PhD. Elimar Pinheiro do Nascimento

Tese de doutorado

Brasília - DF, novembro/2014 
Ficha catalográfica elaborada pela Biblioteca Central da Universidade de Brasília. Acervo 1018893.

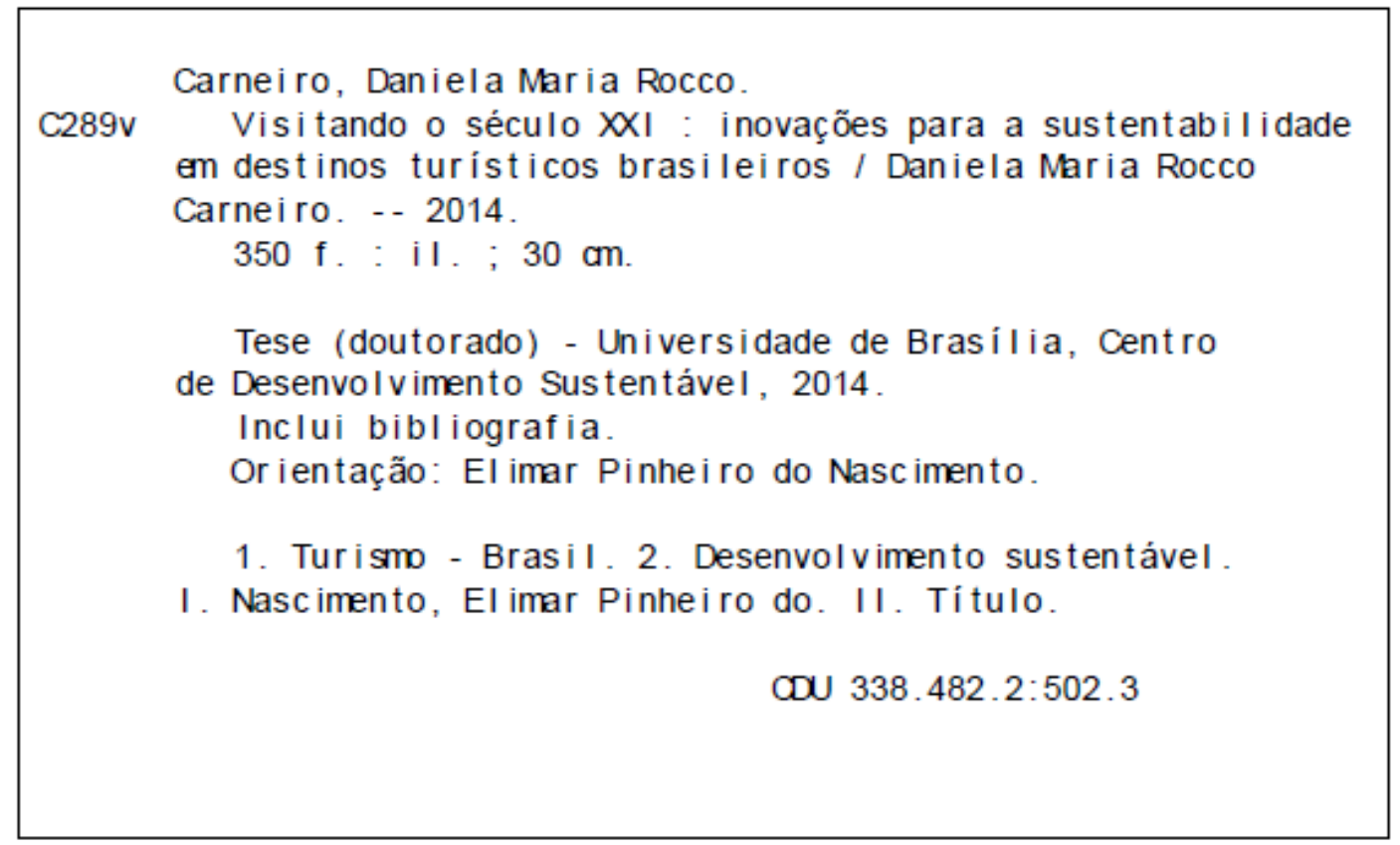

É concedida à Universidade de Brasília permissão para reproduzir cópias desta tese e emprestar ou vender tais cópias, somente para propósitos acadêmicos e científicos. A autora reserva outros direitos de publicação e nenhuma parte desta tese de doutorado pode ser reproduzida sem a autorização por escrito da autora. 
UNIVERSIDADE DE BRASÍLIA

CENTRO DE DESENVOLVIMENTO SUSTENTÁVEL

\section{Visitando o século XXI: inovações para a sustentabilidade em destinos turísticos brasileiros}

\section{Daniela Maria Rocco Carneiro}

Tese de Doutorado submetida ao Centro de Desenvolvimento Sustentável da Universidade de Brasília, como parte dos requisitos necessários para a obtenção do Grau de Doutora em Desenvolvimento Sustentável, área de concentração em Política e Gestão Ambiental.

Aprovada por:

PhD. Elimar Pinheiro do Nascimento (Universidade de Brasília - Centro de Desenvolvimento Sustentável)

(Orientador)

Dr. Armando de Azevedo Caldeira Pires (Universidade de Brasília - Centro de Desenvolvimento Sustentável)

(Examinador Interno)

Dr. Frederic Adelin Georges Mertens (Universidade de Brasília - Centro de Desenvolvimento Sustentável)

(Examinador Interno)

PhD. Alexandre Augusto Biz (Universidade Federal do Paraná - Departamento de Turismo) (Examinador Externo)

Dr. Carlos Manuel Martins da Costa (Universidade de Aveiro, Portugal - Departamento de Economia, Gestão e Engenharia industrial)

(Examinador Externo)

Brasília-DF, 19 de novembro de 2014. 
Especialmente para minha família Rocco \& Carneiro e também para as presentes e futuras gerações. 


\section{AGRADECIMENTOS}

Outono de 2007. Lembro-me como se fosse hoje, primavera de 2014: na rodoviária de Belo Horizonte, da janela do ônibus rumo a Brasília, despedi-me dos meus pais e, com os olhos repletos de lágrimas, assim disse: “- Pai, agora sua filha só volta doutora”. Na época, mudei minha vida em uma semana, pois larguei tudo para iniciar uma disciplina como aluna especial do mestrado do Centro de Desenvolvimento Sustentável (CDS) da Universidade de Brasília (UnB). Foram 6 anos entre encontros e partidas. E enfim voltei... Doutora.

Como fiz bacharelado em Turismo, nos estudos sobre hospitalidade refletimos sobre a teoria da dádiva do francês Marcel Mauss, relativa ao ato de dar, receber e retribuir. Isso é mágico! Nesses últimos anos, entre Brasília e Belo Horizonte, ajudei pessoas e fui ajudada, portanto, para não quebrar o "ciclo", quero "retribuir" em forma de agradecimento! É realmente uma dávida e honra conviver e conhecer tantas pessoas especiais!

Primeiramente não poderia deixar de agradecer e louvar a Deus pelo dom da vida e do saber. Por Ele ter-me presenteado uma família maravilhosa, que é minha base, fortaleza e refúgio. Meus pais Maria Elena e Everaldo, meus irmãos Anna Karina e Christiano e minhas duas lindas sobrinhas, a Isabella e a Laura são os meus grandes "mestres" da vida! Tenho ainda meus "pais e irmãos de Brasília": os tios Xerife e Lena e os "primos-irmãos" Carol, Sil e Tuca. A todos eles manifesto meu eterno agradecimento pelo amor incondicional, assim como aos meus queridos cunhados, tios, primos e nonno.

Verdadeira gratidão sinto pelos meus amigos pelo companheirismo, apoio e compreensão! Aos de Minas Gerais Dani do Valle, Dani Fantoni, Fê Alvarenga, Ju Araújo, Ju Carvalho, Ma e Mari. Aos amigos e parceiros que conheci no Planalto central: Alberto, Alê (Alessandra Santos), Aninha (Ana Rosa), Leninha (Helena Costa), lara Brasileiro, Italo Mendes, Jaime Herzog, Joãozinho (João Paulo Tasso), Karen Basso, Karina Dias, Luiz Lucena, Luiz Spiller, Márcia Camargo, Maru Moesch, Nathan Debortoli, Naty Hallack, Sebastião Magalhães, meus colegas de turma do mestrado e doutorado e meus "ex-alunos" do Centro de Excelência em Turismo da UnB. Tenho costume de dizer que aluno é como filho, logo, não existe "ex"!

De forma muito carinhosa agradeço ao meu orientador, a quem tenho o maior respeito e admiração! Grandíssimo sociólogo. Foi um privilégio e honra receber sua orientação, professor Elimar! Lembrarei com alegria os nossos almoços, encontros com cafés, tardes agradáveis de reflexões e a doce presença de Cristina!

Sou grata à minha querida orientadora do mestrado do CDS, a Dra. Izabel Zaneti, que acreditou no meu potencial para a progressão direta do mestrado para o doutorado, sobretudo porque eu quis voltar "às origens" dos estudos sobre turismo. Minha dissertação sobre a importância da educação e gestão ambiental relacionada à descontaminação das lâmpadas que contêm mercúrio ajudou-me a pensar, professora, ainda mais de forma sistêmica, crítica e integrada.

Agradeço ao Vinicius, parceiro de incontáveis trocas de experiências sobre turismo, principalmente inovação. Amigo especial, um dos homens mais inteligentes e incríveis que 
conheço. Nas nossas conversas eu sempre comentava que ele sabia mais de Turismo que eu, e que um dia ele deveria ser o Ministro do Turismo. E assim foi!

Meu agradecimento especial aos professores do CDS/UnB, principalmente ao Dr. José Augusto Drummond, Dr. José Luiz Franco e Dr. Carlos Hiroo Saito pelo aprendizado e troca de "saberes vivos e vividos". Não poderia deixar de agradecer também aos parceiros da secretaria do CDS, pois sem a atenção, gentileza e disposição deles em me ajudar, realmente teria tido dificuldades para resolver questões burocráticas: Antônio, Ana Paula e Eleusina, meus anjos do CDS!

Como fiz uma parte do meu doutorado em San Sebastián (Espanha), quero agradecer a acolhida maravilhosa no CICtourGUNE e na Universidade de Deusto. Dr. Davide Parrilli, Dra. Aurkene Alzua-Sorzabal, Dr. Carlos Lamsfus, Dr. Jon Kepa Gerrikagoiti, Garikoitz Agote, M.S. Natalia Restrepo, Dra. Sofía Reino e Dra. Nagore Espinosa: Muito obrigada! Muchas gracias! Eskerrik asko!

Meus sinceros agradecimentos a todos os meus 250 entrevistados por terem-me ajudado e cedido, cordialmente, tempo e atenção para a construção do meu trabalho. Destaco os especialistas de Portugal (Lisboa), Espanha (San Sebastián, Bilbao, Vitoria-Gasteiz, Madrid, Barcelona e Santander), Agência USP de Inovação, Ministério do Turismo, EMBRATUR, Ministério do Meio Ambiente, Ministério de Ciência, Tecnologia e Inovação, Ministério da Cultura, Ministério de Minas e Energia, Ministério das Cidades, SEBRAE Nacional, Agência Nacional de Águas, Sindicato, Organização das Cooperativas do Distrito Federal e Cooperativa Sol \& Mar de Turismo e Lazer, os 50 especialistas brasileiros em turismo e inovação e os representantes dos destinos turísticos de Bonito (MS) [Secretaria Municipal de Turismo, Conselho Municipal de Turismo, Bonito Convention \& Visitors Bureau, Lobo Guará Bike Adventure, Promotoria de Justiça, Grutas de São Miguel, Pousada São Jorge, Recanto Ecológico Rio da Prata, Taboa Fábrica de Encantos, Hotel Pirá Miúna, Bonitour Viagens e Turismo e Projeto Jiboia], de Gramado (RS) [Secretaria de Turismo, Secretaria de Meio Ambiente, Sindicato de Guias de Turismo da Região das Hortênsias, Villa Bella Hotel Conceito, Hotel Bangalôs da Serra, Parque Gaúcho, Centro de Apoio ao Turista e produtores rurais da Festa da Colônia] e do Instituto Inhotim (MG) [todos os colaboradores].

À banca examinadora da minha defesa de doutorado composta pelos professores PhD. Alexandre Augusto Biz (Universidade Federal do Paraná), Dr. Armando de Azevedo Caldeira Pires (CDS/UnB), Dr. Carlos Costa (Universidade de Aveiro, Portugal) e Dr. Frederic Adelin Georges Mertens (CDS/UnB) agradeço pelas contribuições, principalmente aquelas que me permitirão dar continuidade a este trabalho!

À Coordenação de Aperfeiçoamento de Pessoal de Nível Superior (CAPES) pela oportunidade da concessão da bolsa de pesquisa na Espanha e no Brasil.

Àqueles que compartilham da ideia de que um desenvolvimento mais sustentável no mundo é possível, e que a inovação pode exercer um papel importantíssimo para as transformações tão necessárias.

Meus sinceros agradecimentos a todos que cooperaram direta e indiretamente para a realização deste trabalho, por terem me ajudado a conquistar esta vitória e a realizar este sonho! 


\section{AUTOAPRESENTAÇÃO}

Especificamente nesta seção peço licença ao leitor para apresentar-me em primeira pessoa. Meu nome é Daniela Maria Rocco Carneiro, sou mineira de Belo Horizonte, brasiliense de coração e cidadã do mundo, além de bacharel em Turismo e agora doutora em Desenvolvimento Sustentável (área de concentração: Política e gestão ambiental).

Essa breve narrativa da minha vida profissional fez-me pensar no discurso de Steve Jobs (1955-2011) para os alunos da Universidade de Stanford. Jobs, um dos homens mais inovadores do século XXI, ressaltou nesse discurso a importância de "conectar os pontos" (connecting the dots). E é nesta perspectiva de conectar os pontos do meu passado com os do meu presente e futuro que esta tese se torna o grande elo entre múltiplas "conexões".

Meu pai é baiano e minha mãe italiana. Conheceram-se e casaram-se em Belo Horizonte (MG), onde eu nasci. Ela, ao cruzar o oceano com destino ao Brasil, encontrou diversas dificuldades, entre as quais, o aprendizado da Língua Portuguesa. Hoje minha mãe é considerada uma das melhores professoras de Língua Portuguesa das escolas que já passou, e ainda mantém a fluência no italiano! Aprendo muito com meus pais em todos os sentidos da vida, porém com minha mãe aprendi que em minhas produções de textos acadêmicos deveria usar a norma-padrão, e preferencialmente, dependendo do contexto, os verbos indeterminando o sujeito. Na academia procurei manter esse modo de escrever nos meus trabalhos, provas, monografia e nas minhas duas dissertações de mestrado. Ocorre que especialmente neste período doutoral desejei não "somente" escrever sobre inovação no âmbito científico e acadêmico. Imersa nos estudos, aspirava neste momento realizar uma inovação muito pessoal no meu próprio estilo de escrita científica, criar novas "conexões". Em princípio pensei escrever a tese em primeira pessoa do singular, pois isso era algo que jamais imaginei em um passado recente dos meus trabalhos científicos, portanto, seria uma "inovação pessoal". No entanto, ao refletir melhor sobre todo esse processo e o desejo de romper com um modo de escrita de anos, concluí que esta tese, felizmente, não foi feita por duas mãos e uma cabeça. Além do meu orientador Dr. Elimar Nascimento, outras mãos e mentes de pessoas-chave foram fundamentais para a construção deste estudo. Meu orientador e eu facilitamos e organizamos as informações, e por isso, ao longo de todo esse trabalho, consideramos melhor escolher a primeira pessoa do plural como o tempo verbal da tese. Sim, porque esta pesquisa já nasceu plural: a inovação que se "conjuga" com a sustentabilidade, que por sua vez se "conecta" à competitividade e, em seguida, ao turismo brasileiro. Um verdadeiro trabalho de "quebra-cabeça", mas cujo nível de complexidade é diretamente proporcional ao grau de satisfação ao estudar algo que realmente acredita e que proporciona prazer. O tema da tese surgiu a partir das incontáveis reflexões 
compartilhadas com meu amigo Dr. Vinicius Lages. Em 2012 ofertamos juntos a primeira disciplina sobre inovação do curso de bacharelado em Turismo do Centro de Excelência em Turismo (CET) da Universidade de Brasília (UnB). A disciplina, optativa, se chamava "Inovação em Serviços Turísticos", e contou com a participação de vinte alunos.

Costumo dizer que esta tese é, literalmente, transcontinental por duas razões: a primeira porque fui buscar em um doutorado sanduíche na Europa algumas respostas para minhas perguntas e segundo porque, graças ao "mundo d.i." (depois da internet), tal como cunhou "Joi" Ito (Diretor do MIT Media Lab), pude ter acesso com maior facilidade ao conhecimento gerado em várias partes do mundo. Se a própria atividade turística é capaz de ultrapassar as fronteiras dos territórios, o conhecimento e informação também, sobretudo porque inovação e sustentabilidade podem ser apropriadas em qualquer lugar do planeta.

Após o período de estudos no exterior (morei em San Sebastián, País Basco, Espanha - uma das regiões mais inovadoras do mundo) retornei ao Brasil com mais perguntas que respostas, o que foi bastante positivo, pois pude amadurecer ainda mais meu objeto de estudo e lapidá-lo com melhor precisão. Foi uma experiência que marcou minha vida profissional e que me possibilitou dialogar com o mundo e, ao mesmo tempo, com os desafios e oportunidades da inovação para a sustentabilidade no turismo do Brasil.

Penso que, embora diagnósticos, análises históricas, retratos de determinadas situações sejam bastante relevantes, ainda são insuficientes. É preciso saber também "como" criar e desenvolver soluções, estabelecendo diálogo efetivo entre governo, mercado, universidade e sociedade. Essa pergunta, o "como fazer", pairou em minha mente praticamente todos os dias desde 2012 (o ano que ofertei a disciplina com o Vinicius), e provavelmente estará sempre presente, pois o mundo inova e se renova continuamente. Busco, por meio da minha pesquisa, não apresentar uma "receita de bolo", e sim caminhos, indícios, experiências, oportunidades, ameaças, pontos fortes, pontos fracos, boas e melhores práticas que possam contribuir, efetivamente, para o aumento da competitividade dos nossos destinos brasileiros via inovação para a sustentabilidade. É esse conhecimento e reflexão crítica que me faz querer ser porta-voz, conectando-os, compartilhando-os e fazendo-os disseminar a todos. Tudo isso começou em uma disciplina de graduação, se estendeu para meu blog pessoal Innovatur (disponível na rede social Facebook desde 2013 - até novembro de 2014 são mais de 5.000 fãs) e neste momento se concretiza por meio desta tese. Hoje percebo claramente que a tese não é o ponto de chegada de um pesquisador, ao contrário, é apenas o começo. Como educadora, pesquisadora, consultora e blogger, posso afirmar que a educação e o conhecimento são virtudes que me impulsionam! Paulo Freire (1921-1997), um dos mais respeitados educadores brasileiros, dizia que "sem a curiosidade que me move, que me inquieta, que me insere na busca, não 
aprendo nem ensino". As possibilidades de conhecimento são inesgotáveis, e se "conectam" com o discurso de Jobs, que também afirmou: "Stay hungry. Stay foolish". Esse é o meu caminho, de postura atenta, inquietante e curiosa para as fontes inspiradoras e estimulantes da vida. 


\section{"Eu arrasto minha barriga no chão para dar a}

vocês o que eu não pude ter" Silvino Carneiro*

*Meu avô paterno, homem de origem simples e visionário. O primeiro a comprar e levar para um vilarejo do sertão baiano um dicionário e lousa, repassando para seus oito filhos o valor da educação que é capaz de transformar vidas e realidades. 
Referência: ROCCO, Daniela Maria Carneiro. Visitando o século XXI: inovações para a sustentabilidade em destinos turísticos brasileiros. 2014. 350f. Tese (Doutorado em Desenvolvimento Sustentável) - Centro de Desenvolvimento Sustentável, Universidade de Brasília, Brasília.

A inovação é, paradoxalmente, uma das práticas humanas das mais antigas e recentes, tanto quanto, a necessidade do deslocamento, que se justifica desde a procura por alimento, proteção e manifestação da religiosidade até a busca por lazer, descanso, negócios e outras experiências por meio do turismo contemporâneo. O Homo sapiens sapiens, com o desenvolvimento de sua capacidade cognitiva, tem deixado para a sociedade legados materiais e imateriais incalculáveis. Entretanto, no "mundo d.i." (depois da internet), tal como qualificou "Joi" Ito, os avanços e legados não necessariamente correspondem a impactos positivos para a coletividade. A relação nem sempre é diretamente proporcional: mesmo com mais acesso a inovações (tecnológicas ou não), ainda existem no "mundo d.i." diversas mazelas sociais. Para combatê-las a ONU estabeleceu os 8 Objetivos do Milênio, que correspondem, portanto, a uma proposta de sociedade e economia mais sustentáveis. Para se chegar a esse caminho é preciso estabelecer um equilíbrio entre pelo menos quatro dimensões básicas, que são: social, ambiental, cultural e econômica. Como forma de colaborar para o desenvolvimento científico do turismo, esta tese possui como objetivo identificar e analisar como os destinos turísticos brasileiros adotam inovações para a sustentabilidade. A literatura demonstra que já são tautológicos os motivos pelos quais as empresas fracassam, bem como as evidências de que a inovação e sustentabilidade são fortes fatores de competitividade. Sendo assim, o presente trabalho visa contribuir para que os destinos turísticos brasileiros (dependentes, obviamente, de empresas) possam ser mais inovadores e sustentáveis, inclusive como forma de aumento da competitividade no País. A construção deste trabalho está respaldada na análise qualitativa e focada na identificação de experiências de inovação para a sustentabilidade nos principais destinos turísticos do País. Para facilitar a compreensão do objeto de pesquisa foi construída uma inovadora matriz de análise denominada Matriz de Inovação para a Sustentabilidade no Turismo (MIST). Ademais, foram realizadas pesquisas junto a especialistas em turismo e inovação, turistas e representantes da iniciativa privada e do setor público. Tais pesquisas contribuíram para definir o campo empírico da tese, representado por três destinos turísticos, quais sejam: Bonito (MS), Gramado (RS) e Instituto Inhotim (MG). Os resultados em geral não só indicaram práticas inovadoras nos três destinos turísticos pesquisados, mas também distintas ênfases atribuídas às dimensões da sustentabilidade (ambiental, cultural, social e econômica). Embora as práticas de inovação para a sustentabilidade dos destinos turísticos brasileiros em geral sejam ainda muito pontuais e embrionárias, o presente estudo pode ajudar aqueles que desejam ser mais competitivos via inovação, principalmente na criação de valor turístico e valor sustentável. As inovações disruptivas no turismo (sobretudo vinculadas à sustentabilidade), por enquanto, são raras no Brasil. Apesar de o País ser signatário de diversos acordos ambientais, tendo inclusive sediado a Rio92 e Rio+20, tenha uma das legislações ambientais mais avançadas do mundo, possui uma legislação muito recente quanto ao incentivo à inovação. No entanto, constatamos um esforço de diversas frentes (governamentais, privadas, sociais e de terceiro setor) no diálogo entre inovação e sustentabilidade. Esta pesquisa evidencia alguns caminhos rumo a ganhos de competitividade turística que prezem as pessoas, o ambiente e a cultura.

PALAVRAS-CHAVE: Inovação, Desenvolvimento sustentável, Turismo, Economia imaterial e Competitividade. 
Innovation is, paradoxically, one of the oldest human practices and recent as well as the need of the displacement, which is justified since the demand for food, protection and manifestation of religiosity to search for leisure, rest, and other business experiences by means of contemporary tourism. Homo sapiens sapiens, with the development of their cognitive capacity, has left the legacies society incalculable material and immaterial. However, the "a.i. world" (after the Internet), as described "Joi" Ito, advances and legacy does not necessarily correspond to positive impacts for the community. The relationship is not always directly proportional: even with more access to innovation (technological or not), still exist in the "world says" various social ills. To combat them established the 8 UN Millennium Development Goals, which therefore correspond to a proposal for more sustainable society and economy. To reach this path we must establish a balance between at least four basic dimensions, which are: social, environmental, cultural and economic. As a way to contribute to the scientific development of tourism, this thesis has aimed to identify and analyze how Brazilian tourist destinations adopt innovations for sustainability. The literature shows that are already tautological reasons why businesses fail, and the evidence that innovation and sustainability are strong factors of competitiveness. Therefore, this paper aims to contribute to the Brazilian tourist destinations (dependent, of course, companies) can be more innovative and sustainable, even as a way to increase competitiveness in the country. Designing this study is underpinned by qualitative analysis and focused identifying experiences of innovation for sustainability in major tourist destinations of the country. To facilitate understanding of the research object was built an innovative analysis matrix called Matrix Innovation for Sustainability in Tourism (MIST). In addition, surveys were conducted with experts of tourism and innovation, tourists and representatives from the private sector and the public sector. These studies helped to define the empirical field of the thesis consists of three tourist destinations, namely: Bonito (MS), Gramado (RS) and Inhotim Institute (MG). The overall results indicated not only innovative practices in the three tourist destinations surveyed, but also different emphases given to the dimensions of sustainability (environmental, cultural, social and economic). Although the practices of innovation for sustainability of Brazilian tourist destinations in general are still very punctual and embryonic, this study may help those who wish to be more competitive through innovation, especially in creating sustainable value and tourist value. Disruptive innovations in tourism (especially related to sustainability), meanwhile, are rare in Brazil. Despite the country being a signatory to various environmental agreements, including having hosted the Rio 92 and Rio +20 , has one of the most advanced environmental legislation in the world, has a very recent legislation as encouraging innovation. However, noted a effort on several fronts (governmental, private, social and third sector) in the dialogue between innovation and sustainability. This research highlights some ways towards the tourist competitiveness gains that prize the people, the environment and culture.

KEYWORDS: Innovation, Sustainable Development, Tourism, Immaterial Economy and Competitiveness. 


\section{RESUMEN}

La innovación es, paradójicamente, una de las prácticas humanas más antiguas y recientes, tanto cuánto, la necesidad del desplazamiento, que se justifica desde la demanda de alimentos, protección y manifestación de la religiosidad hasta la búsqueda por el ocio, descanso, negocios y otras experiencias del turismo contemporáneo. El Homo sapiens sapiens, con el desarrollo de su capacidad cognitiva, ha dejado para la sociedad legados materiales e inmateriais incalculables. Sin embargo, el "mundo d.i." (después de la internet), tal como calificó "Joi" Ito, los avances y legados no necesariamente corresponden a impactos positivos para la coletividad. La relación ni siempre es directamente proporcional: mismo con más accedo a innovaciones (tecnológicas o no), aún existen en el "mundo d.i." diversas mazelas sociales. Para combatirlas la ONU estableció los 8 Objetivos del Milenio, que corresponden, por lo tanto, a una propuesta de sociedad y economía más sostenibles. Para llegarse a ese camino es preciso establecer un equilibrio entre por lo menos cuatro dimensiones básicas, que son: social, ambiental, cultural y económica. Como forma de colaborar para el desarrollo científico del turismo, esta tesis posee como objetivo identificar y analizar como los destinos turísticos brasileños adoptan innovaciones para la sostenibilidad. La literatura demuestra que ya son tautológicos los motivos por los cuales las empresas fracasan, así como las evidencias de que la innovación y sostenibilidad son fuertes factores de competitividad. Siendo así, el presente trabajo visa contribuir para que los destinos turísticos brasileños (dependientes, obviamente, de empresas) puedan ser más innovadores y sostenibles, inclusive como forma de aumento de la competitividad en el País. La construcción de este trabajo está respaldada en el análisis cualitativo y centrada en la identificación de experiencias de innovación para la sostenibilidad en los principales destinos turísticos del País. Para facilitar la comprensión del objeto de investigación fue construida una innovadora matriz de análisis denominada Matriz de Innovación para la Sostenibilidad en el Turismo (MIST). Además, fueron realizadas investigaciones junto a expertos en turismo e innovación, turistas y representantes de la iniciativa privada y del sector público. Tales investigaciones contribuyeron para definir el campo empírico de la tesis, representado por tres destinos turísticos, cuáles sean: Bonito (MS), Gramado (RS) e Instituto Inhotim (MG). Los resultados en general no sólo indicaron prácticas innovadoras en los tres destinos turísticos investigados, pero también distinguidas énfasis atribuidas a las dimensiones de la sostenibilidad (ambiental, cultural, social y económica). Aunque las prácticas de innovación para la sostenibilidad de los destinos turísticos brasileños en general sean aún muy puntuales y embrionárias, el presente estudio puede ayudar aquellos que desean ser más competitivos por medio de la innovación, principalmente en la creación de valor turístico y valor sostenible. Las innovaciones disruptivas en el turismo (sobre todo vinculadas a la sostenibilidad), de momento, son raras en Brasil. A pesar del País ser signatário de diversos acuerdos ambientales, teniendo inclusive acogido a Río92 y Río+20, tenga una de las legislaciones ambientales más avanzadas del mundo, posee una legislación muy reciente cuánto al incentivo a la innovación. Sin embargo, constatamos un esfuerzo de diversas frentes (gubernamentales, privadas, sociales y de tercer sector) en el diálogo entre innovación y sostenibilidad. Esta investigación evidencia algunos caminos rumbo a ganancias de competitividad turística que valoren las personas, el ambiente y la cultura.

PALABRAS CLAVE: Innovación, Desarrollo Sostenible, Turismo, Economía inmaterial y Competitividad inmaterial. 
Paradoxalement l'innovation est l'une des pratiques humaines les plus anciennes et en même temps les plus récentes autant que l'est le besoin humain de se déplacer, justifié aussi bien pour chercher de quoi manger, de la protection et pour manifester sa religiosité que pour partir en quête de loisirs, de repos, de nouvelles affaires et de nouvelles expériences grâce au tourisme contemporain. L'être humain, l'Homo sapiens, avec le développement de sa capacité cognitive, a laissé en héritage à la société un legs matériel et immatériel incalculable. Cependant, aujourd'hui au XXle siècle, - dans le « monde d'après l'internet ", comme l'a décrit "Joi" Ito - le progrès et l'héritage ne signifient pas forcément des retombées positives pour la communauté. La relation n'est pas toujours directement proportionnelle: même avec un plus grand accès aux innovations (technologiques ou non), il existe encore dans le dit monde divers maux sociaux. Pour les combattre, l'ONU s'est fixé huit objectifs du Millénaire qui correspondent en fait à proposer une société et une économie plus durables. Pour parvenir à cette voie, il est nécessaire d'établir un équilibre entre au moins quatre dimensions de base qui sont : le social, l'environnemental, le culturel et l'économique. Comme manière de collaborer au développement scientifique du tourisme, cette thèse a pour objectif d'identifier et d'analyser comment les destinations touristiques brésiliennes adoptent-elles des innovations en matière de durabilité. La littérature démontre que les raisons pour lesquelles les entreprises échouent sont en elles-mêmes tautologiques, tout comme les évidences que l'innovation et la durabilité sont de forts facteurs de compétitivité. Par conséquent, le présent document a pour objectif de contribuer à ce que les destinations touristiques brésiliennes (en fonction, bien sûr, des entreprises) puissent être plus innovantes et durables, y compris d'ailleurs pour augmenter la compétitivité au Brésil. La conception de cette étude s'appuie sur l'analyse qualitative et ciblée pour identifier dans les principales destinations touristiques du pays les expériences en matière d'innovation pour le développement durable. Pour faciliter la compréhension de l'objet de recherche une matrice d'analyse innovatrice a été construite appelée " Matrix Innovation pour la durabilité dans le tourisme (MIST) ». En outre, des enquêtes ont été menées auprès d'experts en tourisme et en innovation, mais aussi auprès de touristes et de représentants du secteur privé et du secteur public. Ces études ont permis de définir le domaine empirique de la thèse qui se compose de trois destinations touristiques, à savoir: Bonito (MS), Gramado (RS) et I'Institut Inhotim (MG). Les résultats montrent en général non seulement des pratiques innovatrices dans les trois destinations touristiques étudiées, mais aussi des accents différents donnés aux dimensions de la durabilité (environnementale, culturelle, sociale et économique). Bien que les pratiques innovatrices pour la durabilité de certaines destinations touristiques brésiliennes soient encore très ponctuelles et embryonnaires, cette étude peut aider ceux qui veulent être plus compétitifs grâce à l'innovation, en particulier dans la création de valeur touristique et de valeur durable. Ces innovations de rupture dans le tourisme (surtout celles liées à la durabilité) sont pour l'instant rares au Brésil. Bien que le pays soit signataire de différents accords environnementaux et ait accueilli entre autres le Sommet de la Terre ECO 92 et Rio + 20, qu'il ait une des législations environnementales les plus avancées du monde, il possède une législation très récente pour ce qui est de l'incitation à l'innovation. Nous notons cependant un effort sur plusieurs fronts (à niveau gouvernemental, privé, social et dans le secteur tertiaire) en matière de dialogue entre l'innovation et la durabilité. Cette recherche met en évidence quelques voies en direction de gains de compétitivité touristique qui tiennent compte des personnes, de l'environnement et de la culture.

MOTS CLÉS: innovation, développement durable, la compétitivité, l'économie des services brésiliens et les destinations touristiques. 


\section{LISTA DE ILUSTRAÇÕES}

Figura 1 - Mind map da tese. 28

Figura 2 - Estatísticas do Ministério do Turismo do Brasil.. 34

Figura 3 - Proposta de modelo de Cadeia de valor do turismo. 39

Figura 4 - Representação objetiva de um sistema turístico. 43

Figura 5 - Representação objetiva de uma rede turística. 44

Figura 6 - Sprint através da história: progressos da sociedade e do valor econômico... 49

Figura 7 - Motores da sociedade da informação e da sociedade do sonho. 50

Figura 8 - Progresso do valor econômico...... 51

Figura 9 - Ciclo ideal de geração de valor sustentável. 62

Figura 10 - Estado da gestão para a sustentabilidade no Brasil 2014. 62

Figura 11 - Representação de processo de inovação no ambiente interno de empresas... 82

Figura 12 - Cartograma do Portal Inovação: total de atores de inovação no Brasil...... 89

Figura 13 - Principais pilares da competitividade. 90

Figura 14 - Representação objetiva da metodologia do Índice de Competitividade Nacional...... 98

Figura 15 - Índices de Competitividade por dimensão em ordem decrescente de desempenho - Brasil: 2013.....

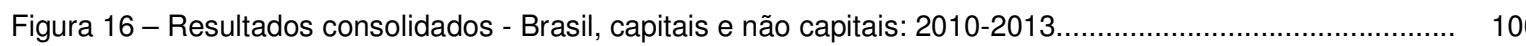

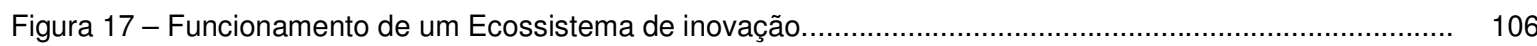

Figura 18 - Representação esquemática das etapas de desenvolvimento da pesquisa.................................... 110

Figura 19 - Relação dos conceitos-chave da tese com os principais autores.............................................. 111

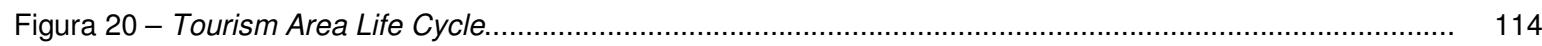

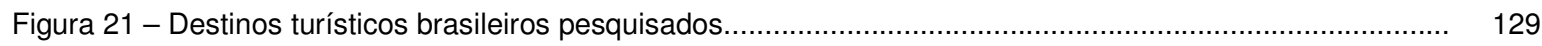

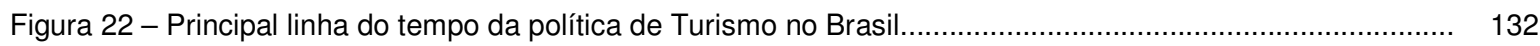

Figura 23 - Guia de Soluções de Inovação e Sustentabilidade no Turismo do SEBRAE...................................138

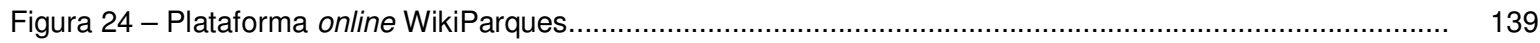

Figura 25 - Cartografia de destinos turísticos brasileiros com práticas de inovação para a sustentabilidade....... 164

Figura 26 - Cartografia de regiões brasileiras versus lista de 12 práticas de inovação para a sustentabilidade... 165

Figura 27 - Pictogramas que expressam as dimensões da sustentabilidade em proporção............................. 166

Figura 28 - Modelo de pictogramas criado por Veyret \& Arnoulg (2008) ..................................................... 167

Figura 29 - Mapa do turismo sustentável e pontos de turismo de massa no mundo........................................168

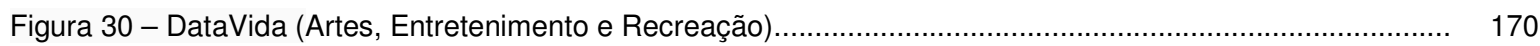

Figura 31 - DataVida (Serviços de Alimentação e Hospitalidade) ............................................................. 170

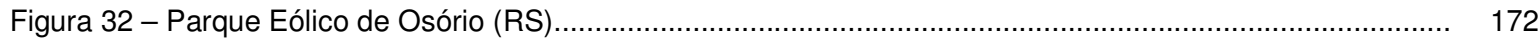


Figura 33 - Experiências de Bonito oferecidas pelo Tour da Experiência.

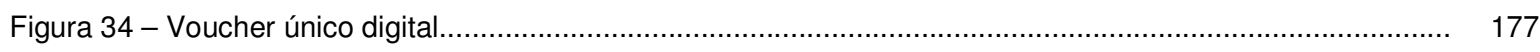

Figura 35 - Representação de um smartphone com o app Guia de Bonito (MS) …......................................178

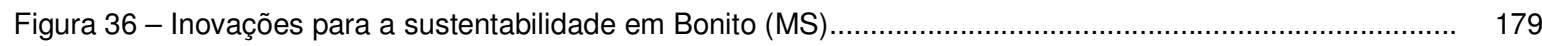

Figura 37 - Exposição e comercialização de produtos da Casa do Vidro no evento ESTC................................ 179

Figura 38 - Lixeiras ecológicas no microcentro de Bonito (MS) ........................................................ 181

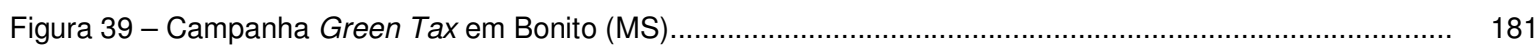

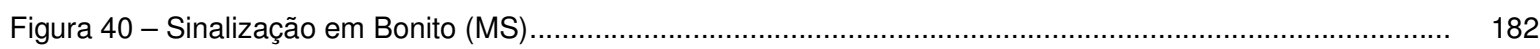

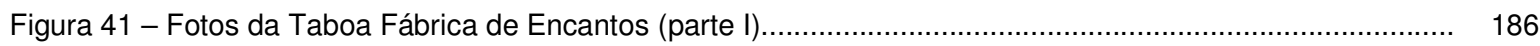

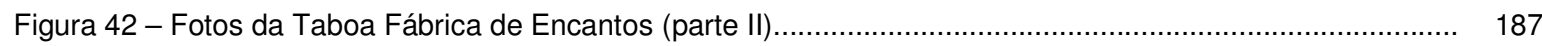

Figura 43 - Plano De Manejo RPPN Fazenda Cabeceira Do Prata, Jardim/MS......................................... 188

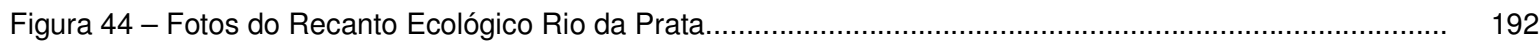

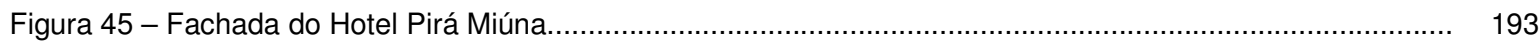

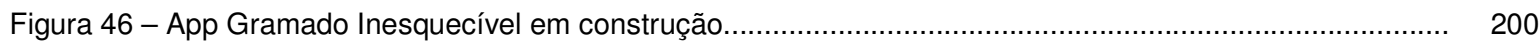

Figura 47 - Praça das Etnias com energia renovável (Gramado) ......................................................... 200

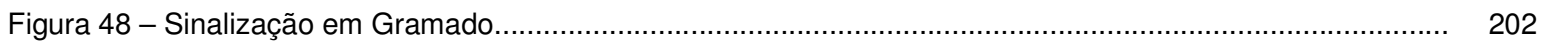

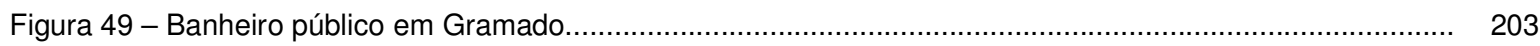

Figura 50 - Casa do Colono sede da Feira Orgânica e Artesanato............................................................... 203

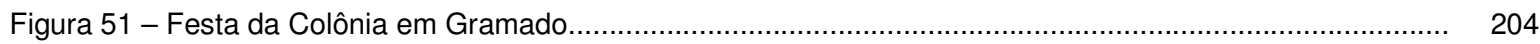

Figura 52 - Fotos de banheiro adaptado de um apartamento do Villa Bella Hotel Conceito.............................. 206

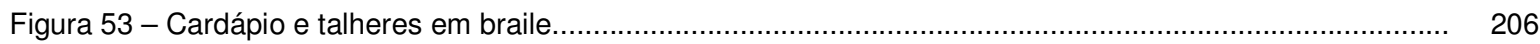

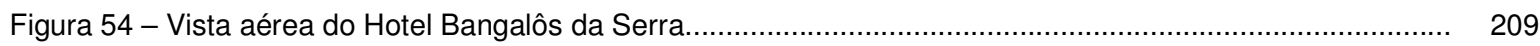

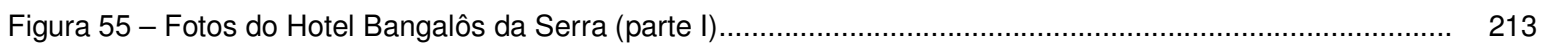

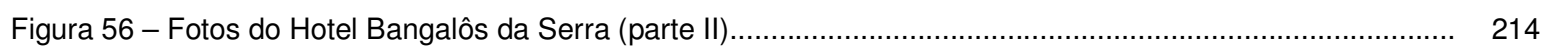

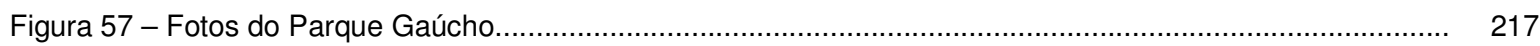

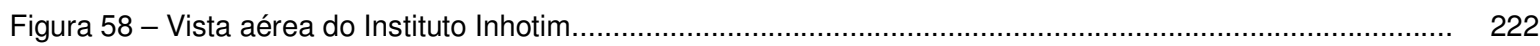

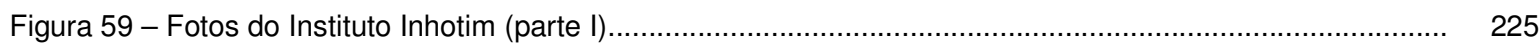

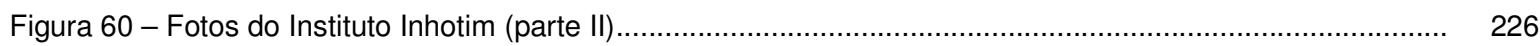

Figura 61 - Mind map da MIST com foco na construção da interface entre inovação e sustentabilidade............. 237

Figura 62 - Representação da dinâmica da economia imaterial na rede de valor do turismo............................ 241

Figura 63 - Como as empresas brasileiras podem avançar a partir da sustentabilidade.................................. 242

Figura 64 - Matriz de Análise SWOT do Turismo Brasileiro: Inovação, Sustentabilidade e Competitividade........ 244 


\section{LISTA DE TABELAS}

Tabela 1 - Total de atores entrevistados no período de estágio doutoral na Europa.

Tabela 2 - Total de atores entrevistados no Brasil.

Tabela 3 - Total de atores entrevistados na pesquisa de campo (3 destinos turísticos)........

Tabela 4 - População total e PEA dos três destinos pesquisados...... 130

Tabela 5 - Principais índices dos três destinos pesquisados... 


\section{LISTA DE QUADROS}

Quadro 1 - Comparativo entre os modelos clássicos de sistemas turísticos.................................... 35

Quadro 2 - Características e atributos específicos dos serviços....................................................... 48

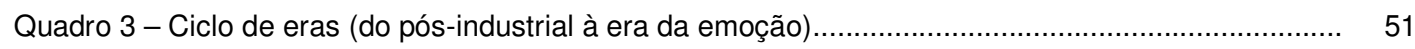

Quadro 4 - Evolução dos conceitos de inovação.................................................................. 73

Quadro 5 - Modelos de inovações (da primeira à sexta geração) ….............................................. 74

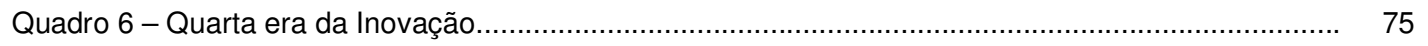

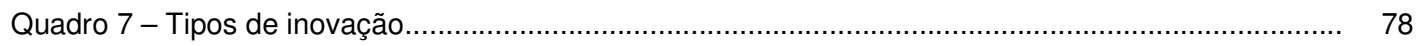

Quadro 8 - Elementos tóxicos presentes em diversas partes de um computador................................ 85

Quadro 9 - Quadro geral da situação brasileira a partir da década de 1990 no contexto da inovação.... 86

Quadro 10 - Pilares e variáveis do Índice de competitividade turística do WEF................................ 92

Quadro 11 - Pilares e variáveis do Índice de competitividade turística do Brasil................................. 94

Quadro 12 - Mudanças de condições a partir do processo inovativo................................................... 105

Quadro 13 - MIST (Matriz de Inovação para a Sustentabilidade no Turismo) ..................................... 117

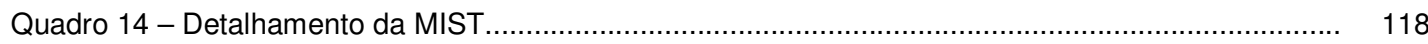

Quadro 15 - Características do território dos três destinos pesquisados......................................... 130

Quadro 16 - Quadro de programas, ações e campanhas de sustentabilidade, inovação e inovação para a sustentabilidade do MTur e parceiros.

Quadro 17 - Indicação dos especialistas quanto a práticas de inovação para a sustentabilidade nos destinos turísticos brasileiros.

Quadro 18 - MIST da Taboa Fábrica de Encantos: Bonito (MS) .................................................... 185

Quadro 19 - MIST do Recanto Ecológico Rio da Prata: Bonito (MS) .............................................. 190

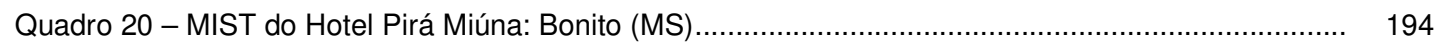

Quadro 21 - MIST do Villa Bella Hotel Conceito: Gramado (RS) ................................................. 207

Quadro 22 - MIST do Hotel Bangalôs da Serra: Gramado (RS) ................................................... 210

Quadro 23 - MIST do Parque Gaúcho: Gramado (RS) .............................................................. 216

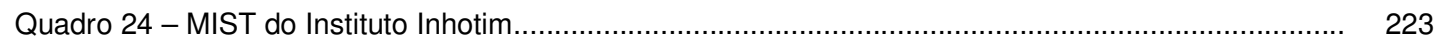

Quadro 25 - Quadro comparativo: análise entre Bonito (MS), Gramado (RS) e Instituto Inhotim (MG)... 234

Quadro 26 - A Era da Emoção no contexto do turismo................................................................ 246

\section{LISTA DE BOXES:}

Box 1 - Inovação aberta..................................................................................... 77

Box 2 - Inovações tecnológicas para estacionamento de carros........................................ 137

Box 3 - As 12 práticas de inovação para a sustentabilidade no turismo................................ 143

Box 4 - As 10 principais premissas da tese ............................................................ 238 


\section{LISTA DE GRÁFICOS}

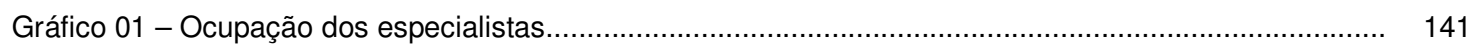

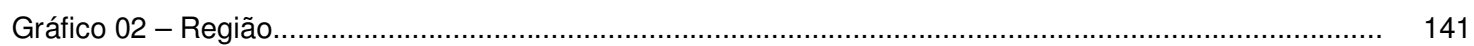

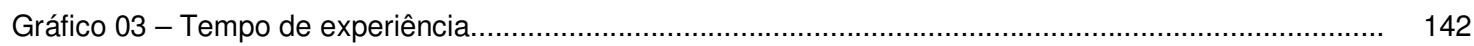

Gráfico 04 - Práticas mais importantes de inovação para a sustentabilidade para os destinos.................. 145

Gráfico 05 - Grau de importância das práticas quanto à competitividade................................................ 149

Gráfico 06 - Potencial de disseminação nos destinos turísticos brasileiros no longo prazo........................ 150

Gráfico 07 - Estados com mais destinos com práticas de inovação para a sustentabilidade..................... 154

Gráfico 08 - Regiões com mais destinos com práticas de inovação para a sustentabilidade...................... 154

Gráfico 09 - Motivação para conhecer Bonito (MS) ...................................................................... 196

Gráfico 10 - Frequência que usa serviços turísticos sustentáveis: turistas de Bonito (MS)........................ 197

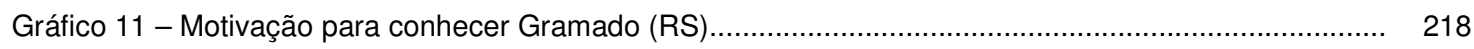

Gráfico 12 - Frequência que usa serviços turísticos sustentáveis: turistas de Gramado (RS)................... 219

Gráfico 13 - Motivação para conhecer o Instituto Inhotim (MG) …................................................... 227

Gráfico 14 - Frequência que usa serviços turísticos sustentáveis: turistas do Instituto Inhotim (MG) .......... 228

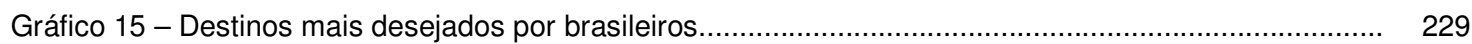

\section{LISTA DE INFOGRÁFICOS:}

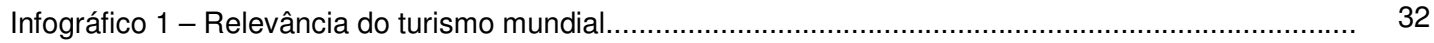

Infográfico 2 - Turismo internacional em 2013............................................................................. 33

Infográfico 3 - Destinos turísticos brasileiros: inovação para a sustentabilidade.................................... 153 


\section{LISTA DE ABREVIATURAS E SIGLAS}

ABETA - Associação Brasileira das Empresas de Ecoturismo e Turismo de Aventura

ABNT - Associação Brasileira de Normas Técnicas

APP - Aplicativo

BNDES - Banco Nacional de Desenvolvimento Econômico e Social

CAPES - Coordenação de Aperfeiçoamento de Pessoal de Nível Superior

C\&T - Ciência e Tecnologia

CT\&I - Ciência, Tecnologia e Inovação

CICtourGUNE - Centro de Pesquisa Cooperativa em Turismo [Centro de Investigación Cooperativa en Turismo]

CNPq - Conselho Nacional de Desenvolvimento Científico e Tecnológico

CNUMAD - Conferência das Nações Unidas sobre Meio Ambiente e Desenvolvimento

CNUMH - Conferência das Nações Unidas sobre o Ambiente Humano

CONAMA - Conselho Nacional do Meio Ambiente

COMTUR - Conselho Municipal de Turismo [de Bonito]

COPAM - Conselho Estadual de Política Ambiental de Minas Gerais

DS - Desenvolvimento sustentável

EMBRAER - Empresa Brasileira de Aeronáutica

EMBRAPA - Empresa Brasileira de Pesquisa Agropecuária

FAPESP - Fundação de Amparo à Pesquisa do Estado de São Paulo)

FINEP - Financiadora de Estudos e Projetos

MCTI - Ministério da Ciência, Tecnologia e Inovação do Brasil

MIST - Matriz de Inovação para a Sustentabilidade no Turismo

MTur - Ministério do Turismo do Brasil

"Mundo d.i." - Mundo depois da internet

OCDE - Organização para a Cooperação Econômica e Desenvolvimento [Organisation for Economic Cooperation and Development]

OMT - Organização Mundial de Turismo

OSCIP - Organização da Sociedade Civil de Interesse Público

P\&D - Pesquisa e Desenvolvimento

PIA - Prática inovadora com foco na dimensão ambiental da sustentabilidade

PIC - Prática inovadora com foco na dimensão cultural da sustentabilidade

PIE - Prática inovadora com foco na dimensão econômica da sustentabilidade

PIS - Prática inovadora com foco na dimensão social da sustentabilidade

PME - Pequenas e Médias Empresas

RPPN - Reserva Particular do Patrimônio Natural

SEBRAE - Serviço de Apoio às Micro e Pequenas Empresas

SETUR - Secretaria Municipal de Turismo [de Bonito]

SETUR RS - Secretaria do Turismo do Rio Grande do Sul

TIC - Tecnologias de Informação e Comunicação

UNEP - Programa de Meio Ambiente das Nações Unidas [United Nations Environment Programme]

UNESCO - Organização das Nações Unidas para a Educação, a Ciência e a Cultura

WEF - Fórum Econômico Mundial [World Economic Forum] 


\section{SUMÁRIO}

INTRODUÇÃO...

1. DESENVOLVIMENTO RECENTE DO TURISMO E A IMPORTÂNCIA DE SUA MULTIDIMENSIONALIDADE E SETORIALIDADE PARA A ECONOMIA DO BRASIL

1.1 DA LÓGICA INDUSTRIAL À IMATERIALIDADE: A INFLUÊNCIA DA ECONOMIA DE SERVIÇOS, CRIATIVA, DO SONHO E DA EXPERIÊNCIA NO TURISMO.

1.1.1 ECONOMIA DE SERVIÇOS.

1.1.2 SOCIEDADE DO SONHO E ECONOMIA DA EXPERIÊNCIA ........................... 49

1.1.3 ECONOMIA CRIATIVA.

1.1.4 A INTERFACE ENTRE A ECONOMIA IMATERIAL COM A ECONOMIA DO TURISMO.

1.2 VALOR TURÍSTICO E VALOR SUSTENTÁVEL: A SUSTENTABILIDADE COMO VALOR LEGÍTIMO DE UM PROCESSO DE DESENVOLVIMENTO SUSTENTÁVEL

2. INOVAÇÃO PARA A SUSTENTABILIDADE: OPORTUNIDADES E DESAFIOS PARA OS DESTINOS TURÍSTICOS BRASILEIROS.

2.1 INOVAÇÃO: CONSTRUINDO CONCEITOS E DESCONTRUINDO MITOS E FALÁCIAS.

2.2 MARCOS REGULATÓRIOS DA INOVAÇÃO E DESENVOLVIMENTO DA C,T\&I NO BRASIL

2.3 A INOVAÇÃO PARA A SUSTENTABILIDADE COMO FATOR-CHAVE DE COMPETITIVIDADE TURÍSTICA.....

2.3.1 PRINCIPAIS ÍNDICES DE COMPETITIVIDADE TURÍSTICA MUNDIAL E NACIONAL RELACIONADOS AOS PILARES INOVAÇÃO E SUSTENTABILIDADE..

2.4 INOVAÇÃO PARA A SUSTENTABILIDADE NO TURISMO: A LEGITIMAÇÃO DE UM NOVO CONCEITO E VALOR

3. CONSTRUÇÃO DA PESQUISA E MATRIZ DE INOVAÇÃO PARA A SUSTENTABILIDADE NO TURISMO.

3.1 PESQUISA EXPLORATÓRIA

3.2 CRIAÇÃO DE INSTRUMENTO DE ANÁLISE PARA A PESQUISA QUALITATIVA: MIST (MATRIZ DE INOVAÇÃO PARA A SUSTENTABILIDADE NO TURISMO).

3.2.1 MIST: ATRIBUTOS, VARIÁVEIS, CRITÉRIOS E LIMITAÇÕES. 
4. EXPERIÊNCIAS BRASILEIRAS DE INOVAÇÃO PARA A SUSTENTABILIDADE NO TURISMO: BOAS PRÁTICAS, DESAFIOS, NOVOS RUMOS E PERSPECTIVAS PARA A COMPETITIVIDADE DO PAÍS.

4.1 A VISÃO DE ESPECIALISTAS BRASILEIROS EM TURISMO E INOVAÇÃO....... 140

4.1.1 BREVE CARACTERIZAÇÃO DOS ESPECIALISTAS.................................... 140

4.1.2 PRÁTICAS DE INOVAÇ̃̃O PARA A SUSTENTABILIDADE NOS DESTINOS TURÍSTICOS BRASILEIROS E A RELAÇÃO COM A COMPETITIVIDADE...

4.1.3 OS DESTINOS TURÍSTICOS BRASILEIROS QUE MAIS POSSUEM PRÁTICAS DE INOVAÇÃO PARA A SUSTENTABILIDADE.

4.1.4 CRUZAMENTO DAS PERGUNTAS E RESPOSTAS.

4.1.5 CENÁRIOS DE DESTINOS TURÍSTICOS: UM ESBOÇO DE CARTOGRAFIA BRASILEIRA DE PRÁTICAS DE INOVAÇÃO PARA A SUSTENTABILIDADE..

5. ESTUDOS DE CASO: BONITO (MS), GRAMADO (RS) E INSTITUTO INHOTIM (MG).

5.1 BONITO (MS).

5. 2 GRAMADO (RS)...

5.3 INSTITUTO INHOTIM (MG).

5.4 ANÁLISE COMPARATIVA ENTRE OS TRÊS DESTINOS PESQUISADOS.

APÊNDICE A - Questionário online enviado a especialistas em turismo e inovação.

APÊNDICE B - Formulário aplicado junto a atores locais do poder público e trade turístico.

APÊNDICE C - Formulário aplicado junto aos turistas (Bonito/Gramado/Instituto Inhotim)

APÊNDICE D - Tendências futuras e práticas de inovação para a sustentabilidade em destinos turísticos internacionais e brasileiros.

ANEXO 1 - Critérios de sustentabilidade segundo OMT/GSTC.

ANEXO 2 - Tabelas geradas pelo Sistema PNUD (Comparação entre Bonito, Brumadinho e Gramado). 


\section{INTRODUÇÃO}

Refletir sobre a inovação e a sustentabilidade não é necessariamente algo novo na literatura, e, ainda que esses temas sejam cada vez mais incorporados na discussão de governantes, empresários e sociedade em geral, o diálogo consistente entre ambos ainda é uma lacuna. Mais ainda é o gap na reflexão da inovação para a sustentabilidade no turismo, muito embora existam claros esforços da OMT (Organização Mundial de Turismo), instituições públicas, academia e trade turístico em geral para a validação e consolidação desse tema especificamente.

O tema da inovação no turismo reveste-se de natureza ímpar para a sua competitividade, pois esta também deve considerar pelo menos quatro principais dimensões da sustentabilidade: ambiental, econômica, social e cultural. Tais dimensões se referem, basicamente, à conservação da natureza e da cultura, prosperidade econômica com inclusão produtiva e equidade social. Para o melhor desenvolvimento de qualquer atividade econômica, considerar essas dimensões é essencial, e no turismo isso não é diferente. Isto porque a "matéria-prima turística", em grande parte, é constituída por recursos ambientais, socioculturais e paisagísticos, e os destinos turísticos dependem de tais recursos para se manterem competitivos.

A competitividade traz consigo, entre outros, cinco pilares essenciais no mercado atual: a produtividade, qualidade, marketing, inovação e sustentabilidade. Estes, por sua vez, aplicados ao turismo, podem gerar condições de produção destinadas a demandas do nível local ao global que vão além das vantagens comparativas. A literatura apresenta diversos conceitos sobre competitividade turística, porém optamos por adotar o da OCDE (Organização para a Cooperação Econômica e Desenvolvimento), que diz respeito à capacidade de otimização da atratividade dos lugares, com serviços de qualidade, inovação e uso eficiente e sustentável dos recursos, garantindo bem-estar para residentes e visitantes. Escolhemos, portanto, focar nos pilares inovação e sustentabilidade, uma vez que a interface real entre esses dois pilares não se encontra nos modelos mais tradicionais e citados de competitividade turística.

A inovação está presente em qualquer nível de competitividade e setor econômico. Por sua vez, a sustentabilidade se confunde, de certa maneira, com a própria competitividade, pois é sustentável a atividade que, não destruindo os recursos que a alimenta, e reduzindo e recuperando os dejetos que gera, pode se reproduzir "indefinidamente".

A inovação é um conceito bastante diverso e amplo, e nesta tese é entendida como um processo e até mesmo uma estratégia capaz de fazer algo diferente para fazer melhor. 
Ela pode se referir tanto a um produto novo, como a um processo diferente de fazer algo já existente que seja comercializável. Além disso, a inovação se configura como um dos elementos-chave para o desenvolvimento sustentável de países, regiões e empresas. Explorar os contornos conceituais desse tema é importante na medida em que se pode aproximar os estudos acadêmicos de Turismo de políticas, programas e projetos voltados ao setor.

A grande questão é como implementar as inovações, sobretudo porque já são tautológicos os motivos pelos quais as empresas fracassam e as evidências de que a inovação e sustentabilidade são fortes fatores de competitividade. Diante dessa questão, esta tese possui o seguinte objetivo geral: identificar e analisar como os destinos turísticos brasileiros adotam inovações para a sustentabilidade. Com relação aos objetivos específicos:

1. Identificar quais são as inovações para a sustentabilidade no turismo mais recorrentes no Brasil, bem como a situação atual da competitividade turística do País;

2. Criar uma matriz de análise centrada na inovação para a sustentabilidade de turismo como mecanismo de apoio à análise do tema;

3. Estudar três destinos turísticos brasileiros que mais apresentam práticas de inovação para a sustentabilidade;

4. Criar uma cartografia temática da inovação para a sustentabilidade de destinos turísticos brasileiros;

5. Caracterizar as políticas públicas e gestão do turismo brasileiro quanto à inovação para a sustentabilidade, destacando as práticas, oportunidades, ameaças, pontos fortes e pontos fracos.

A diversidade de atrativos naturais, culturais e paisagísticos confere aos destinos turísticos do Brasil um elevado potencial para apropriação consciente de seus espaços por meio de atividades turísticas sustentáveis. Por isso questionamos:

- Quais são as oportunidades, ameaças, pontos fortes, pontos fracos e melhores práticas dos três destinos turísticos brasileiros que mais apresentam características de inovação para a sustentabilidade?

- De que maneira as atividades turísticas baseadas na inovação e na sustentabilidade podem contribuir para a competitividade dos destinos turísticos brasileiros?

O presente estudo representa uma forma de contribuir para o desenvolvimento científico do Brasil, principalmente para disseminar a cultura da inovação para a 
sustentabilidade em redes científico-tecnológicas e junto a instituições públicas, privadas e do terceiro setor de distintas regiões do País. Adicionalmente, esta tese representa um estímulo à cultura da C,T\&I (Ciência, Tecnologia e Inovação) e à criação de insumos para políticas públicas que visam aumentar a competitividade das regiões brasileiras, particularmente no setor turístico.

Este é um trabalho inédito para o País, não somente pelo tema, mas também pelas inovações criadas a partir do próprio desenvolvimento da pesquisa, tais como: a criação de uma matriz de análise chamada MIST (Matriz de Inovação para a Sustentabilidade no Turismo), a construção da matriz de análise SWOT (acróstico formado pelas primeiras letras das palavras em Inglês: Strengths, Weaknesses, Opportunities e Threats) quanto ao cenário de inovação para a sustentabilidade do turismo brasileiro, a produção de uma cartografia temática com indicação dos destinos turísticos do País que mais possuem práticas de inovação para a sustentabilidade e a criação da plataforma virtual e-tese, com possibilidade do leitor acessar, por meio de um blog, os principais documentos utilizados neste trabalho e informações relevantes, bem como interagir com os autores da tese. É transportar o conhecimento para uma de suas principais fontes e elos: a internet.

Do ponto de vista da relevância social e econômica, a análise empreendida nesta tese é também propositiva, no sentido de explicitar oportunidades e alternativas sobre como o turismo pode apresentar soluções de inovação para a sustentabilidade nos territórios que ocorre. Isto com vistas ao aumento da competitividade desse importante e crescente setor para a economia brasileira. No cenário turístico brasileiro ainda há uma grande carência de mais pesquisas, políticas públicas disseminadas por todo País, empresários bem orientados, universidades/centros de pesquisa que dialoguem com as empresas e moradores e, enfim, turistas mais satisfeitos.

A inovação nem sempre é sustentável, uma vez que também destrói produtos para que outros novos sejam comercializados, elimina empregos, cria produtos e serviços supérfluos e inúteis, associa-se a processos produtivos sem condições dignas de trabalho e nem sempre se apropria racionalmente dos recursos naturais. Por isso, uma inovação orientada para a sustentabilidade inverte essa lógica perversa de produção (e consumo), na medida em que se reconfiguram os processos produtivos na esfera empresarial.

Esta pesquisa é, portanto, uma contribuição pequena diante da complexidade e multisetorialidade do sistema turístico. No entanto, é uma forma de tentar buscar caminhos, alternativas e indícios de soluções para determinadas realidades de um país de dimensões continentais como é o caso do Brasil.

Assim, no primeiro capítulo deste trabalho, optamos por abordar na discussão teórica o desenvolvimento recente do turismo no Brasil. Aqui empreendemos, sobretudo, uma discussão inovadora sobre o setor de serviços, relacionando-o ao conceito de 
economia imaterial, economia criativa e economia da experiência. Além disso, abordamos os conceitos de cadeia produtiva, cadeia de valor, sistema, rede e encadeamentos produtivos. O último tópico deste capítulo diz respeito ao discurso sobre desenvolvimento sustentável (DS) versus sustentabilidade, como tentativa de propor reflexões sobre essa diferenciação conceitual que muitas vezes na literatura não é encontrada, pois diversos autores consideram ambos os conceitos como sinônimos. Entendemos que o DS é processo e a sustentabilidade é valor. Desse modo, sendo o turismo uma experiência (intangível), o que se oferta ao turista é um produto/serviço imbuído de valor turístico (igualmente intangível).

A inovação emerge no capítulo segundo como importante campo de diálogo com a sustentabilidade. Primeiramente realizamos uma discussão teórica sobre o que é inovação, bem como sua origem, principais fundamentos, tipos, formas e estruturas. Nessa parte também apresentamos: i) breve descrição sobre o marco regulatório da inovação no Brasil e ii) apresentação do conceito de inovação para a sustentabilidade, com uma reflexão crítica sobre outros conceitos utilizados na literatura, como inovação sustentável, inovação verde, eco-inovação e inovação ambiental. É neste capítulo que discorremos também sobre a competitividade turística e a respectiva importância da inovação para a sustentabilidade no turismo.

Todo o processo de construção da pesquisa da tese consta no capítulo terceiro, inclusive a matriz de análise que foi construída. A MIST (Matriz de Inovação para a Sustentabilidade no Turismo) é um check-list estruturado especialmente em atributos, variáveis e critérios e que está organizada em formato de matriz. No que tange aos procedimentos metodológicos optamos por adotar a pesquisa do tipo qualitativa. Isto porque o tema em questão ainda não foi aprofundado no Brasil e requer, primeiramente, maior compreensão do fenômeno como um todo. Para isso, foram realizadas pesquisas de ordem documental e bibliográfica, bem como entrevistas e a aplicação de um formulário online com especialistas de inovação e turismo do Brasil. Após esse trabalho definimos o campo empírico desta pesquisa: Bonito (MS), Gramado (RS) e Instituto Inhotim (MG). Além da evidência de práticas de inovação para a sustentabilidade (verificadas na pesquisa de campo), os referidos destinos também se destacam por sua competitividade e atendimento a segmentos turísticos distintos e que se sobressaem no Brasil: ecoturismo, turismo gastronômico e de inverno e turismo cultural.

O quarto capítulo apresenta primeiramente uma contextualização sobre a inovação para a sustentabilidade no turismo brasileiro com a respectiva atuação dos principais players do turismo por meio de exemplos do poder público, iniciativa privada e terceiro setor. Em seguida, são apresentados os resultados obtidos na pesquisa online realizada com especialistas brasileiros de turismo e inovação, bem como uma cartografia temática com a 
indicação dos principais destinos turísticos do País que mais possuem práticas de inovação para a sustentabilidade. A pesquisa online aliada aos estudos de caráter bibliográfico e documental auxiliou a identificação dos três destinos turísticos que mais possuem práticas de inovação para a sustentabilidade, cujos resultados estão dispostos no próximo capítulo.

Por fim, o quinto capítulo apresenta dados e informações sobre os três destinos turísticos selecionados para a pesquisa de campo: Bonito (MS), Gramado (RS) e Instituto Inhotim (MG). Esta pesquisa consistiu na realização de entrevistas com representantes do poder público, trade turístico e turistas. A partir dessas entrevistas, foram escolhidos três equipamentos/atrativos turísticos de cada destino para aplicação da MIST (com exceção do Instituto Inhotim, pois este destino foi o próprio objeto de análise da Matriz). A última seção deste capítulo conta com uma análise comparativa entre os três destinos estudados, bem como a análise final dos resultados que conta, inclusive, com a Matriz de análise SWOT. Esta Matriz explicita o cenário de oportunidades, ameaças, pontos fortes e pontos fracos do tema em questão no Brasil.

Nas conclusões constam os principais resultados obtidos no desenvolvimento desta tese, além das inovações do próprio trabalho e indicação de pesquisas futuras que possam aprofundar ainda mais o tema.

\section{PONTO DE PARTIDA PARA O LEITOR: APRESENTANDO OS CONCEITOS-CHAVE DA TESE}

Para esclarecer ainda mais o processo de pesquisa, a Figura 1 abaixo tem como finalidade representar o mapa mental da tese, que foi construído por meio do software Edraw Mind Map (free version). Tony Buzan (2005) patenteou o sistema de mapas mentais (mind maps) e desde então esse sistema, que permite formar um "diagrama de pensamentos", vem sendo utilizado por professores, pesquisadores, empresários e demais interessados. Trata-se de uma ferramenta que se utiliza de um formato visual e colorido de anotações, desencadeando, por sua vez, relações com outras ideias, estratégias, fotos, histórias, entre outros elementos para resolver problemas de maneira criativa ou, apenas, estruturar a lógica de um pensamento, como é o caso deste trabalho. Pode-se afirmar que o mind map é, ao mesmo tempo, uma técnica de brainstorming (tempestade de ideias) e de design thinking (processo criativo que busca também estruturar e esclarecer ideias, estratégias, entre outros).

Nesse mapa constam as três principais categorias de análise da tese de forma conectada: inovação (1), sustentabilidade (2) e destinos turísticos brasileiros (3). A inovação 
possui três tipos (incremental, radical/disruptiva e aberta) e a sustentabilidade possui quatro dimensões: ambiental, social, cultural e econômica. Por sua vez, a dimensão econômica, no contexto dos destinos turísticos, está associada à noção de economia imaterial, pois o turismo é considerado nesta tese como experiência, portanto, dotado de subjetividades e marcado, sobretudo, pela intangibilidade. A economia criativa, economia da experiência, economia de serviços e a lógica da sociedade do sonho compõem a economia imaterial.

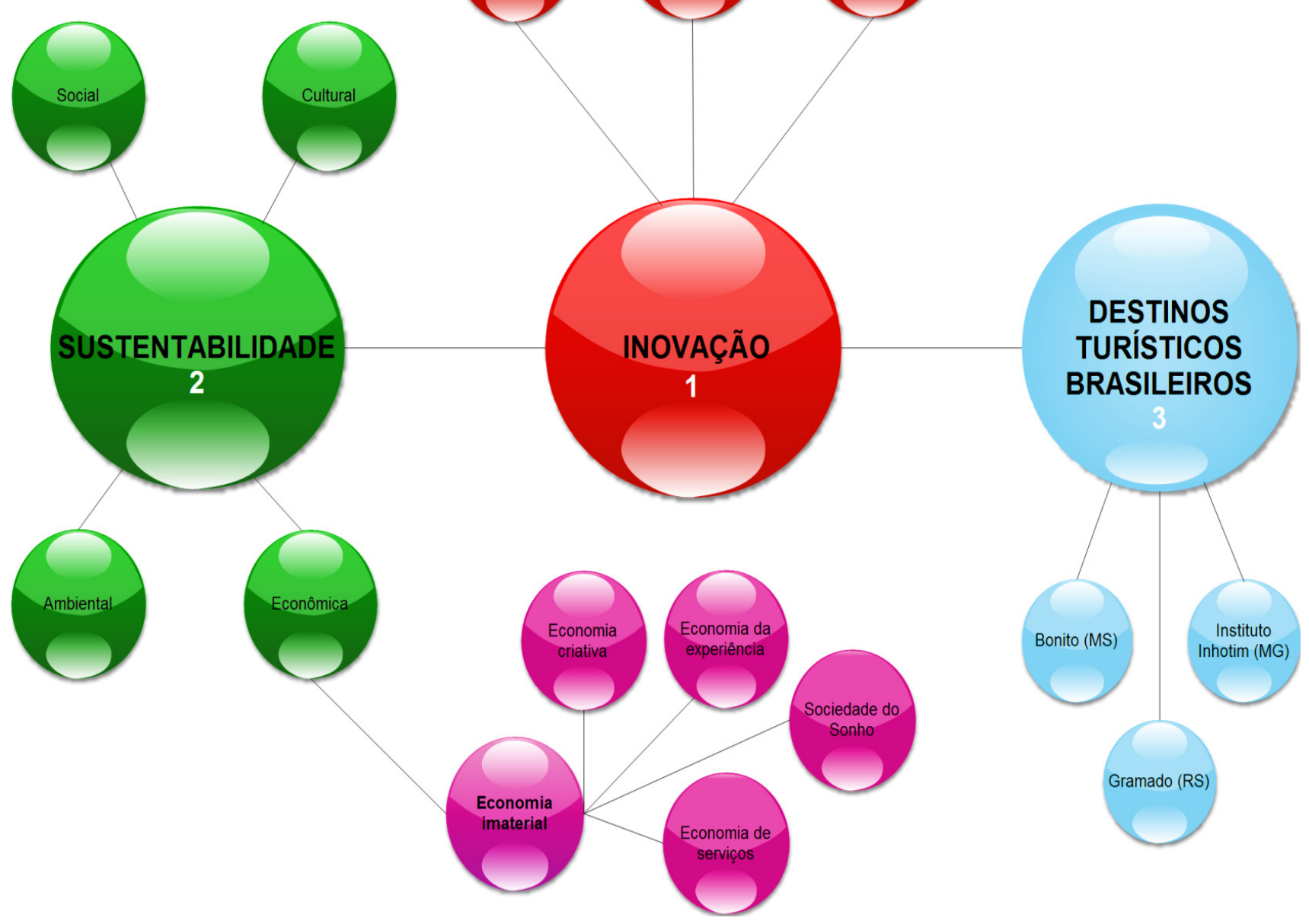

Figura 1 - Mind map da tese

Fonte: Daniela Rocco (2014). 


\section{Como os conceitos centrais desta tese são polissêmicos, sugerimos citar como os entendemos e definimos nesta tese.}

Sustentabilidade: valor respaldado na prosperidade econômica, inclusão produtiva, equidade social, conservação da natureza e cultura em um contexto de ética, moral, compromisso, responsabilidade e solidariedade.

Fonte: Elaborado por Daniela Rocco (2014).

Desenvolvimento sustentável: é um processo complexo de desenvolvimento sistêmico, dinâmico, orgânico e integrado que requer valores respaldados na prosperidade econômica, inclusão produtiva, equidade social, conservação da natureza e cultura em um contexto de ética, moral, compromisso, responsabilidade e solidariedade. Estes valores devem ser estimulados entre as atuais e próximas gerações. Além disso, pelo menos as três dimensões (ambiental, social e econômica) devem ser sempre combinadas. A combinação de duas dimensões ou o fortalecimento de apenas uma não é o suficiente para assegurar o desenvolvimento sustentável de uma organização ou território.

Fonte: Elaborado por Daniela Rocco (2014) com base em Brundtland (1987), Veiga (2010a) e Costa (2013).

Inovacão: é processo e estratégia capaz de fazer algo diferente para fazer melhor (não necessariamente para produzir algo novo). A inovação se caracteriza pelo uso mercadológico (deve ser comercializável para deixar de ser invenção) e acadêmico para criar o diferente ou melhorar o que já existe, mudar o status das coisas, dos paradigmas, das tecnologias, das formas institucionais, dos processos, do design e da função dos produtos e serviços oferecidos até o momento. A inovação como um processo e não apenas como uma coisa, um objeto, algo imóvel. Ela cria valor para as pessoas e pode contribuir para a sustentabilidade, muito embora, paradoxalmente, pode também gerar impactos desastrosos sobre as pessoas e o ambiente. Vale registrar que a inovação normalmente é vista como risco para as empresas, mas nem sempre é tecnológica e nem requer, necessariamente, investimentos financeiros altíssimos.

Inovação para a sustentabilidade: é um processo que preferencialmente deve ocorrer em todo o ciclo de vida de produtos e serviços. Por sua vez, ao longo de qualquer processo de produção desde uma pequena empresa até mesmo a gestão de um território, devem ser incluídos valores éticos e princípios de sustentabilidade de maneira inovadora, como: trabalho justo, menor uso de recursos não-renováveis, tecnologias de ecoeficiência, métodos inteligentes de reciclagem e reaproveitamento, desenvolvimento de soluções criativas, entre outras. 
Turismo: É uma experiência multimotivacional, que requer deslocamento físico e relações de hospitalidade, sendo capaz de proporcionar um fenômeno econômico de dimensões sociais e culturais que se expressam em um dado território, em um determinado tempo e com repercussões ambientais e socioculturais, sejam elas positivas e/ou negativas. Organiza-se, a partir de um estágio mais avançado e consolidado, em territórios inovadores por meio de redes abertas de encadeamentos produtivos e múltiplas cadeias de valor. Aqueles territórios que ainda não avançaram nesse nível o turismo se organiza por meio de sistemas, compostos por sua vez por cadeias de valor. A centralidade do turismo está no fator humano, uma vez que está vinculado ao setor terciário (de serviços). Isto porque a experiência positiva ou negativa de um turista dependerá direta e até mesmo indiretamente dos próprios provedores das atividades características do turismo, como recepcionistas, agentes de viagens, comissários de bordo, recreadores, garçons, guias de turismo, consultores, entre outros. Muitas vezes o turismo é refém de visões simplistas: ora está assocido ao mundo dos negócios, ora como atividade de lazer, setor da economia, cadeia produtiva, segmento, deslocamento, fenômeno e indústria. O turismo é multisetorial e complexo, contudo, para menções breves ao longo do presente trabalho o turismo será nomeado como experiência (base conceitual) e sistema (como se organiza). Ainda não é uma ciência, porém um proeminente campo do conhecimento científico.

Fonte: Elaborado por Daniela Rocco (2014).

Destino turístico: O conceito de destino turístico é bastante complexo e amplo, podendo ser entendido tanto do ponto de vista da oferta quanto da demanda. Geograficamente, desde o nível de um país (exemplo: destino Brasil) até uma rua atrativa de um município, sendo um espaço dotado de estrutura, serviços, atrativos e informações que estão em constante circulação. O destino turístico surge em função das pessoas que começam a visitá-lo e é consolidado pelo fluxo de pessoas e intercâmbios estabelecidos.

Fonte: Elaborado por Daniela Rocco (2014) com base em Alzua-Sorzabal \& Abad Galzacorta (2008) e Cooper, Hall \& Trigo (2011).

Competitividade turística: é a capacidade de otimização da atratividade dos destinos turísticos, com produtividade para os negócios locais, acesso a serviços de qualidade, inovação e uso eficiente e sustentável dos recursos, garantindo bem-estar para residentes e visitantes. 


\title{
1. DESENVOLVIMENTO RECENTE DO TURISMO E A IMPORTÂNCIA DE SUA
} MULTIDIMENSIONALIDADE E SETORIALIDADE NA ECONOMIA DO BRASIL

\begin{abstract}
Tags: multidimensionalidade, economia, serviços, atividades improdutivas, cadeia de valor, cadeia produtiva, encadeamentos produtivos, sistema, rede, complexidade, economia imaterial, economia criativa, economia da experiência, sociedade dos sonhos, valor turístico, valor sustentável, sustentabilidade, turismo sustentável.
\end{abstract}

\begin{abstract}
"No novo século, exatamente quanto de nossas vidas iremos vivenciar no espaço físico e quanto no ciberespaço? De uma coisa, no entanto, podemos estar certos: muito mais de nossa experiência diária provavelmente acontecerá no mundo hiper-real da realidade virtual, onde tudo é abstrato, simbólico e imaterial".
\end{abstract}

Jeremy Rifkin, A era do acesso.

Em um passado recente (meados da década de 1960) atribuía-se ao turismo a expressão "indústria sem chaminés", que não polui, tal como ainda ocorre no nível industrial. Entretanto, o turismo "pode ser tão prejudicial quanto as indústrias de transformação mais poluidoras, com um agravante: seus efeitos podem ocorrer num espaço de tempo mais curto" (DIAS, 2005, p. 86). Ainda se encontra na literatura e discursos governamentais menção a uma "indústria do turismo", no entanto, percebemos dois equívocos nessas afirmações relativas ao termo "indústria": i) a atividade turística pertence ao setor terciário (de serviços), e não secundário, caracterizado pela produção industrial majoritariamente - a lógica e processos de produção no turismo diferenciam-se da produção industrial clássica e ii) houve uma tradução equivocada da expressão industry of tourism, uma vez que a tradução mais adequada para a Língua Portuguesa seria "setor do turismo" ou "setor turístico" (HALLACK; BURGOS \& ROCCO, 2011). Certamente, tratar o turismo como "indústria" pode ser uma forma de evidenciar que a atividade turística produz e é tão rentável quanto as indústrias de transformação, como é o caso da França, o país mais visitado do mundo. O PIB francês de turismo, que corresponde de $6 \%$ a $7 \%$, equivale ao PIB gerado no País pela indústria automobilística (BBC BRASIL, 2011). Por outro lado, tratar turismo como indústria e sem qualquer contextualização adicional é uma visão simplista quanto à amplitude de conceito, pois conduz a uma perspectiva limitada e pautada meramente no produtivismo e economicismo.

Enquanto atividade econômica, o turismo é um dos segmentos da economia que mais cresce mundialmente (OMT, 2014). Isto se ratifica porque a atividade turística possui caracteristicamente um efeito multiplicador (LOHMANN \& PANOSSO NETTO, 2012), capaz 
de influenciar diretamente mais de 50 segmentos da economia (BRASIL, 2012a), como agências de viagens e turismo, operadoras, meios de hospedagem, alimentação fora do lar, entre outros. Indiretamente, esse efeito se espalha ainda mais, atingindo, além do próprio setor terciário, os setores primário e secundário, como obras públicas, sistema de transportes, telecomunicações e saneamento (DURBARRY, 2004).

De acordo com o Infográfico 1, o turismo é responsável por $9 \%$ do produto interno bruto total (efeitos diretos, indiretos e induzidos), 1/11 dos empregos do mundo (efeitos diretos, indiretos e induzidos), movimenta US\$1,4 trilhões em exportações e contribui com $6 \%$ das exportações mundiais e com $29 \%$ das exportações de serviços.

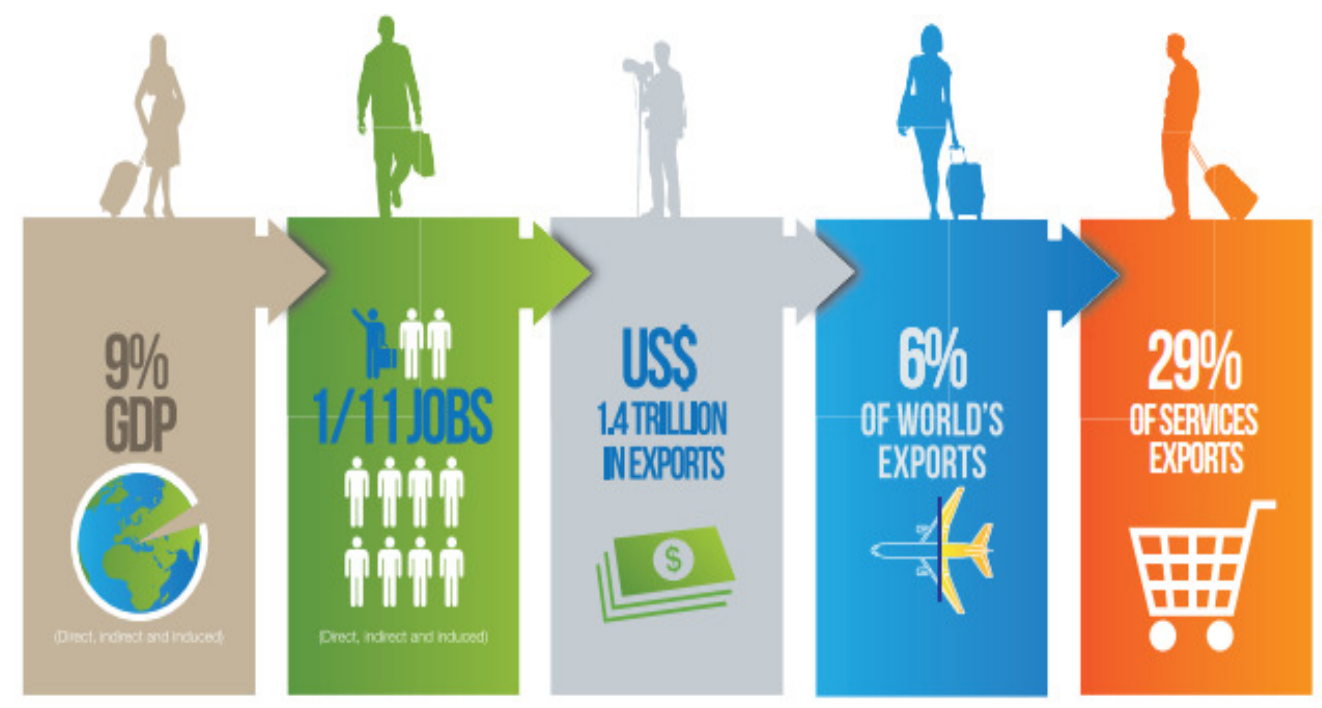

Infográfico 1 - Relevância do turismo mundial Fonte: OMT (2014)

Em termos de chegadas de turistas internacionais e receita gerada pelo turismo internacional, o Infográfico 2 mostra que em 2013 foram 1,1 bilhões e US\$ 1,2 trilhões, respectivamente. Houve aumento do turismo internacional em todos os continentes, com grande destaque para a Europa. A OMT prevê que em 2020 as chegadas de turistas internacionais em todo o mundo deve atingir a marca de 1,4 bilhões e de 1,8 bilhões até o ano 2030 (o primeiro bilhão de turistas internacionais foi alcançado em 2012) (OMT, 2014). 


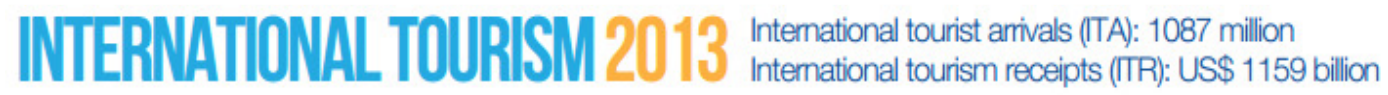

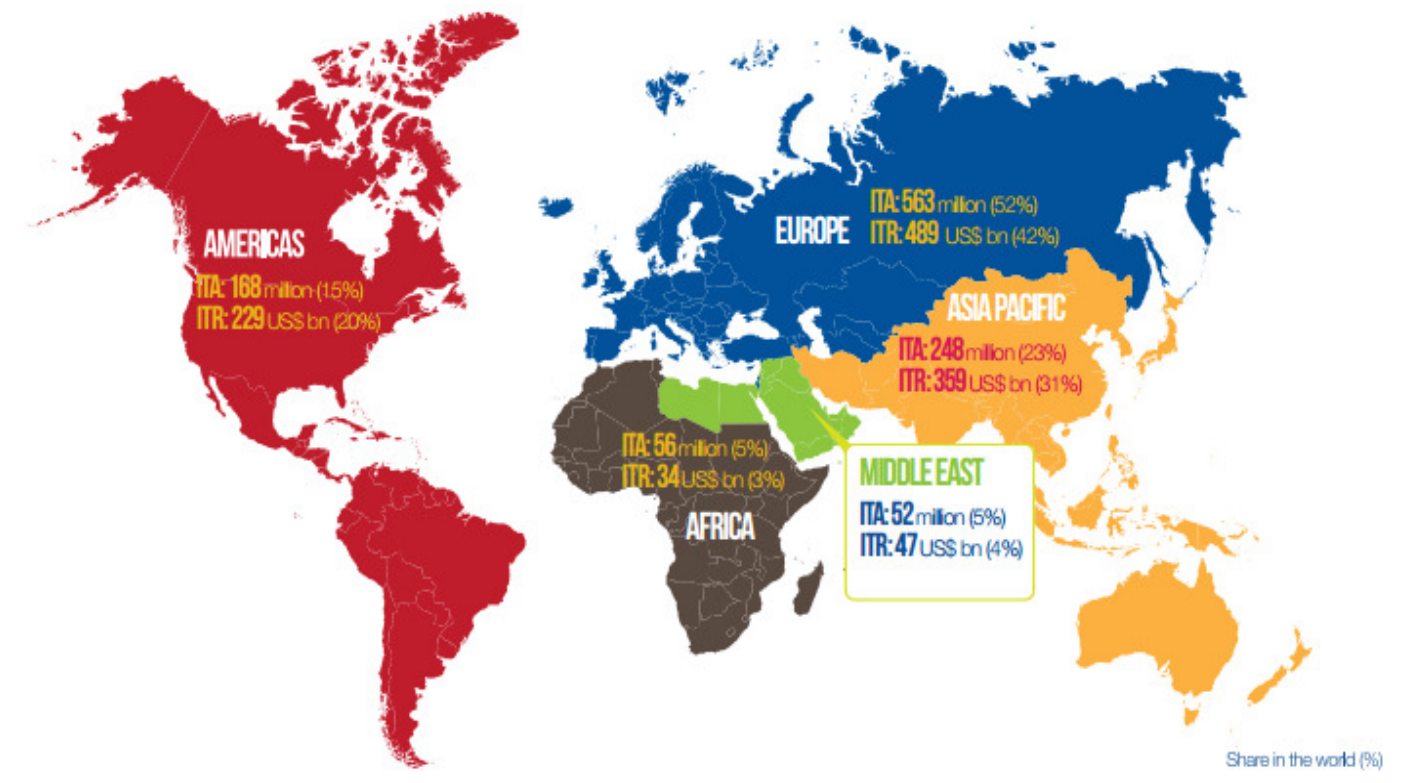

Infográfico 2 - Turismo internacional em 2013

Fonte: OMT (2014)

No caso do Brasil, e apesar do relativo crescimento turístico (BRASIL, 2014a; 2014b), comparativamente com outros países, pode-se afirmar que o País ainda está muito abaixo, quantitativamente, dos destinos mais procurados do mundo: França, Estados Unidos e Espanha. Estes países receberam, respectivamente, e no quesito turista internacional, 83 milhões em 2012 (dados de 2013 ainda não publicados), 69,8 milhões em 2013 e 60,7 milhões em 2013. Em 2012 o Brasil recebeu 5,6 milhões de turistas internacionais (dados de 2013 ainda não publicados). Entretanto, o País passou a ocupar a 10ª posição no ranking dos países que mais recebem divisas, arrecadando US $\$ 25,1$ bilhões (OMT, 2014).

De acordo com a Figura 2, que se refere a um conjunto de três gráficos disponíveis no site do Ministério do Turismo do Brasil (MTur), é possível verificar o crescimento do turismo no País em termos de desembarques internacionais e domésticos e a receita cambial. Em 2012 foram 9.236.947 desembarques internacionais, 85.471.710 desembarques domésticos e US\$ 6.645 milhões de receita cambial gerada. Em função da Copa do Mundo de Futebol da FIFA no País, as estatísticas relativas ao ano de 2014 serão maiores $^{1}$ (Figura 2).

\footnotetext{
${ }^{1}$ Segundo dados do MTur, o Brasil recebeu aproximadamente 700 mil turistas internacionais (de $1^{\circ}$ de junho a 12 de julho de 2014) e foram registradas 203 nacionalidades no Mundial (BRASIL, 2014c). De acordo com entrevista realizada em outubro de 2014 junto a um representante do Departamento de Estudos e Pesquisas (DEPES) do MTur, no período entre junho e julho de 2013 a receita cambial foi de US\$ 993 milhões, enquanto que no mesmo período, em 2014, foi de US\$1.586 milhões. Segundo o MTur, o ganho de imagem do "destino Brasil" foi bastante positivo, e isso se refletirá no incremento de chegadas de turistas internacionais nos próximos anos.
} 


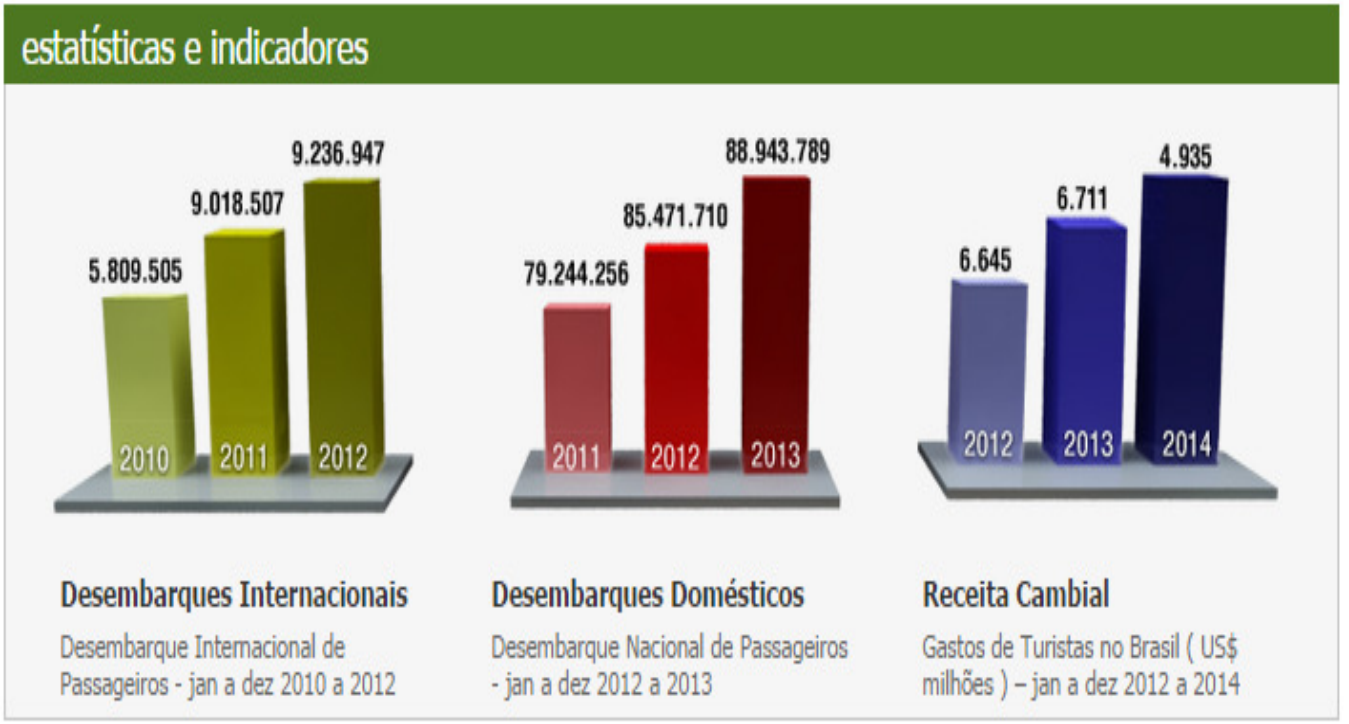

Figura 2 - Estatísticas do Ministério do Turismo do Brasil Fonte: Brasil (2014b)

Além de ser um proeminente campo do conhecimento ${ }^{2}$, o turismo é mais que atividade (de lazer e/ou negócios), setor da economia, deslocamento e fenômeno: é uma experiência. Por isso entendemos que o turismo é uma experiência multimotivacional, que requer deslocamento físico e relações de hospitalidade, sendo capaz de proporcionar um fenômeno econômico de dimensões sociais e culturais que se expressam em um dado território, em um determinado tempo e com repercussões ambientais e socioculturais, sejam elas positivas e/ou negativas.

A natureza do turismo é sistêmica, envolvendo, assim, um conjunto de informações, atividades, fluxos e atores que interagem entre si a partir de um complexo processo de encadeamento ${ }^{3}$ de produtos e serviços desenvolvidos por diversos ambientes. $O$ turismo também é um sistema caracteristicamente multisetorial, pois é capaz de promover a afluência de turistas (por motivações várias), fluxos monetários e intercâmbio sociocultural pautado sempre na lógica da experiência e da fruição da oferta turística (COOPER; HALL \& TRIGO, 2011). Além disso, é um sistema que está predominantemente inserido na economia, sendo enquadrado no setor terciário (de serviços). Tal sistema combina, por sua vez, a produção de bens tangíveis (como artesanato, alimentos, a construção de um hotel, entre outros) com ativos intangíveis (serviços e experiências).

Atribui-se ao biólogo Ludwing von Bertalanffy (1901-1972) o trabalho pioneiro de estudar e disseminar a abordagem sistêmica, o que ocorreu a partir da década de 1930

\footnotetext{
${ }^{2}$ Entendemos que o Turismo ainda não é uma ciência, mas que vem produzindo, enquanto proeminente campo do conhecimento científico, reflexões e publicações significativas.

${ }^{3}$ Daí a expressão "cadeia" do turismo, que neste caso, se expressa em um "encadeamento" de produtos e serviços turísticos.
} 
(COSTA \& SOUTO-MAIOR, 2006). As contribuições no que se refere à Teoria Geral de Sistemas Turísticos, representada por pesquisadores "clássicos" como Cuervo, Leiper, Jafari, Krippendorf, Boullón, Beni e Molina (LOHMANN \& PANOSSO NETTO, 2012) constam no Quadro 1 a seguir.

\begin{tabular}{|c|c|c|c|}
\hline PESQUISADOR & ABORDAGEM & PRINCIPAIS VANTAGENS & PRINCIPAIS DESVANTAGENS \\
\hline $\begin{array}{c}\text { Raymundo } \\
\text { Cuervo (1967) }\end{array}$ & algébrica & $\begin{array}{l}\text { Cuervo foi o primeiro pesquisador a criar um } \\
\text { modelo de turismo a partir da abordagem } \\
\text { sistêmica. O modelo dele baseia-se na } \\
\text { noção de um grande conjunto (turismo) } \\
\text { composto por subconjuntos (meios de } \\
\text { transporte, hospedagem, agências, etc.). }\end{array}$ & $\begin{array}{l}\text { Não revela a complexidade do } \\
\text { sistema turístico e está estritamente } \\
\text { ligado com a questão do } \\
\text { deslocamento. Não apresenta } \\
\text { dinamismo e possui uma linguagem } \\
\text { bastante técnica, dificultando o } \\
\text { entendimento. }\end{array}$ \\
\hline $\begin{array}{l}\text { Neil Leiper } \\
(1979 ; 2002)\end{array}$ & $\begin{array}{l}\text { espacial / } \\
\text { geográfica }\end{array}$ & $\begin{array}{l}\text { O modelo de Leiper é composto } \\
\text { basicamente por cinco elementos: origem } \\
\text { (espaço geográfico), turistas, rotas } \\
\text { turísticas, chegada (destino turístico) e } \\
\text { cadeia turística. Possui foco no fluxo } \\
\text { turístico e nos ambientes, bem como } \\
\text { apresenta o sistema turístico como sistema } \\
\text { aberto. De fácil compreensão, é flexível, } \\
\text { pode ser utilizado em qualquer escala e } \\
\text { indica interação. }\end{array}$ & $\begin{array}{l}\text { Não revela a complexidade dos } \\
\text { subsistemas do sistema turístico. }\end{array}$ \\
\hline $\begin{array}{c}\text { Jafar Jafari \& } \\
\text { Brent Ritchie } \\
\text { (1981) }\end{array}$ & epistemológica & $\begin{array}{l}\text { Trata-se de um modelo que busca } \\
\text { compreender como ocorre a produção de } \\
\text { conhecimento científico de turismo. No } \\
\text { artigo original publicado no periódico Annals } \\
\text { of Tourism Research eram } 16 \text { disciplinas } \\
\text { vinculadas ao estudo do turismo. Entretanto, } \\
\text { em } 2005 \text { Jafari aumentou para 18. Entre } \\
\text { elas vale mencionar: Administração, Direito, } \\
\text { Economia, Sociologia, Agricultura, } \\
\text { Geografia, Transporte, Ecologia, etc. }\end{array}$ & $\begin{array}{l}\text { Restrito à } \\
\text { interdisciplinar do turismo. }\end{array}$ \\
\hline $\begin{array}{c}\text { Jost } \\
\text { Krippendorf } \\
\text { (1984) }\end{array}$ & sociológica & $\begin{array}{l}\text { Trata-se do Modelo Existencial da } \\
\text { Sociedade Industrial cujo respaldo está na } \\
\text { relação trabalho-moradia-lazer-viagem. O } \\
\text { autor analisa a sociedade e o lazer de modo } \\
\text { sistêmico, ressaltando que as pessoas } \\
\text { viajam (e até mesmo não viajam) em função } \\
\text { de influências sociais e status. Ele } \\
\text { questiona, ainda, o "ter" que sobrepõe o } \\
\text { "ser". }\end{array}$ & $\begin{array}{l}\text { Para Krippendorf as práticas sociais } \\
\text { que reestabelecem o equilíbrio } \\
\text { físico e emocional por meio do lazer } \\
\text { só ocorrem em lugares distantes da } \\
\text { residência do indivíduo. Entretanto, } \\
\text { Gastal e Moesch (2007) } \\
\text { contrapõem essa perspectiva, uma } \\
\text { vez que o "turista cidadão" é capaz } \\
\text { de vivenciar tais práticas no próprio } \\
\text { ambiente que vive. }\end{array}$ \\
\hline $\begin{array}{c}\text { Roberto } \\
\text { Boullón (1985) }\end{array}$ & $\begin{array}{l}\text { espacial / } \\
\text { geográfica }\end{array}$ & $\begin{array}{l}\text { O modelo de Boullón é baseado na teoria do } \\
\text { espaço turístico, que por sua vez distingue } \\
\text { os seguintes conceitos: zona, área, } \\
\text { complexo, centro, unidade, núcleo, conjunto, } \\
\text { corredor, corredor de translado e corredor } \\
\text { de estada. É didático e demonstra interação } \\
\text { e dinamismo do fluxo turístico associado aos } \\
\text { aspectos físicos e geográficos. }\end{array}$ & $\begin{array}{l}\text { Restrito à perspectiva geográfica do } \\
\text { turismo. }\end{array}$ \\
\hline
\end{tabular}




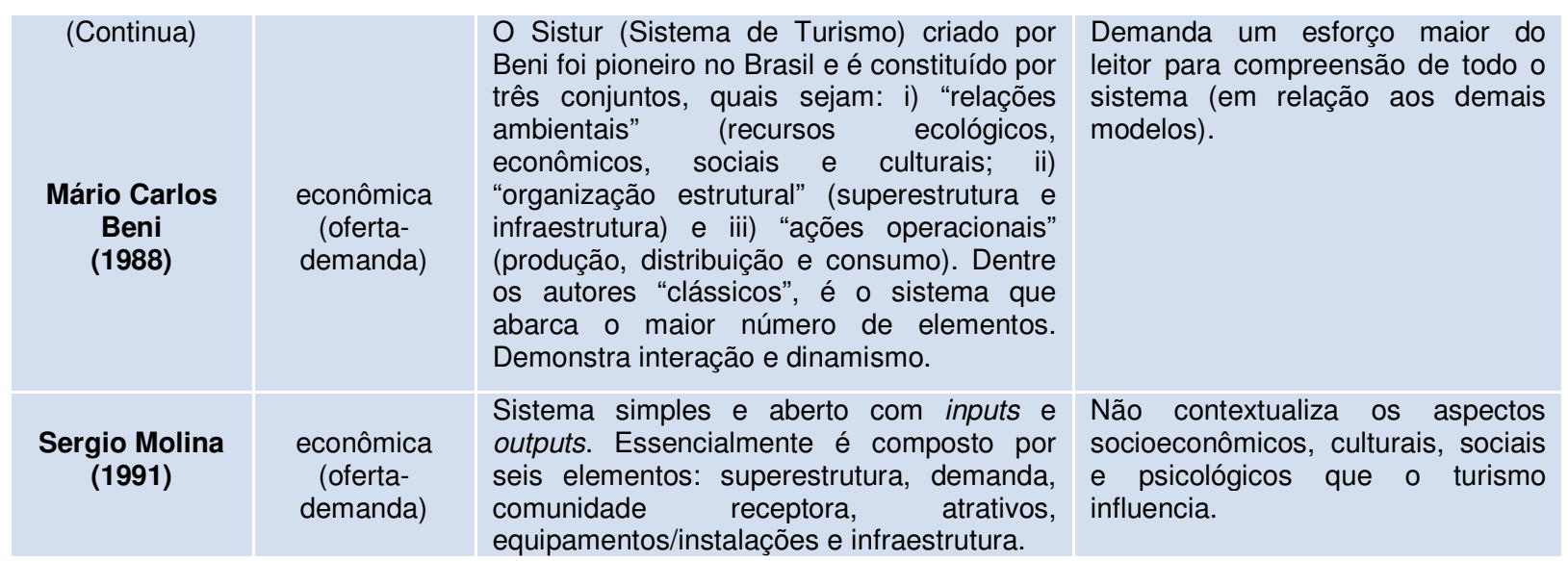

Quadro 1 - Comparativo entre os modelos clássicos de sistemas turísticos

Fonte: Elaborado por Daniela Rocco (2014) com base em Panosso Netto (2005), Gastal e Moesch (2007) e Lohmann \& Panosso Netto (2012)

O Quadro 1 expôs as principais vantagens e desvantagens dos modelos clássicos de sistemas de turismo, bem como as distintas abordagens. Embora a perspectiva sistêmica associada ao turismo seja a mais aceita pela academia, além de facilitar o processo de planejamento e gestão do turismo (PANOSSO NETTO, 2005), a separação do sistema turístico para analisá-lo isoladamente em relação aos demais sistemas gera um resultado fragmentado (LOHMANN \& PANOSSO NETTO, 2012). De todo modo, há que se reconhecer as contribuições acadêmicas aqui apresentadas, sobretudo porque a literatura em geral sobre turismo ainda é bastante escassa.

Além da forma sistêmica, o turismo se organiza pelo uso do território, desde o nível nacional ao local. Este território é composto pelo destino turístico (ou um conjunto de destinos), que por sua vez possui múltiplas e dinâmicas cadeias de valor constituídas por atrativos, serviços e equipamentos turísticos. De acordo com Santos (2002, p. 84), "o território não é apenas um conjunto de formas naturais, mas um conjunto de sistemas naturais e artificiais, junto com as pessoas, as instituições e as empresas que abriga, não importa o seu poder". O produto turístico (formado basicamente pelas cadeias de valor) pode ser comercializado em qualquer ponto do mundo, porém sua produção e consumo necessariamente ocorrem no território turístico. Por isso o turista, após comprar uma experiência turística no local onde reside, precisa se deslocar para consumi-la in loco, pois o produto que ele comprou ("mercadoria") só será produzido e consumido concomitantemente no território onde o destino turístico que ele está motivado a visitar/revisitar está localizado (BASSO, 2009).

O conceito de destino turístico pode ser entendido tanto do ponto de vista da oferta quanto da demanda. Geograficamente, desde o nível de um país até uma rua atrativa de um município, sendo um território dotado de estrutura, serviços, atrativos e informações que 
estão em constante circulação. O destino turístico surge em função das pessoas que começam a visitá-lo e é consolidado pelo fluxo de pessoas e intercâmbios estabelecidos (ALZUA-SORZABAL \& ABAD GALZACORTA, 2008). O destino é

[...] é um conceito espacial ou geográfico definido principalmente pelos visitantes de fora do local, embora muitos lugares busquem se tornar destinos para visitantes, a fim de conseguirem beneficiar-se economicamente do turismo. [...] [O destino] passa a existir em virtude das pessoas que o visitam (COOPER, HALL \& TRIGO, 2011, p. 70).

A partir das contribuições teóricas de Hunter (1997; 2002), Costa (2013) apresenta a classificação de quatro estágios de destinos turísticos, que são: i. pré-turismo (o local possui atração turística potencial, no entanto há pobreza e degradação ambiental. Considerando este cenário, a atividade turística nasce como alternativa para mitigar o contexto negativo); ii. destinos iniciantes (são aqueles que estão desenvolvendo ações ainda primárias e que ocupam, portanto, a posição inicial do ciclo de vida do turismo ${ }^{4}$ ); iii. destinos em desenvolvimento (tais destinos já apresentam um nível maior em termos de produção turística) e iv. destinos consolidados (consolidação da produção turística. Inclusive, parte da economia local já se encontra vinculada ao turismo).

O conceito de destino turístico - objeto de análise territorial desta tese - é bastante complexo, amplo e cuja definição ainda não é consensual na literatura (COSTA, 2013). Normalmente, o destino turístico é associado a uma cidade ou município. Entretanto, entendemos que o destino turístico (o locus principal do turista, aquele que o motiva a visitar e revisitar) pode ser também um cruzeiro marítimo e até mesmo um museu. Caso peculiar é o do Instituto Inhotim (MG), que é um museu de arte contemporânea a céu aberto e que nesta pesquisa é considerado como destino turístico, situado por sua vez em um território. Isto se justifica porque o poder de atratividade de um local pode ser tão elevado e se encontrar em um estágio de "destino consolidado", que este local deixa de ser um atrativo turístico ${ }^{5}$ meramente e passa a assumir características de destino. A cidade de Brumadinho, onde está localizado o referido museu, pode até ser o destino principal para alguns turistas, no entanto, quem busca a região, majoritariamente, é em função do Instituto Inhotim, tornando-o, assim, o destino turístico principal e Brumadinho o destino secundário. Inclusive, ambos os destinos, situados em um mesmo território, vivenciam estágios distintos: o Instituto Inhotim já se encontra consolidado e Brumadinho é ainda um destino em

\footnotetext{
${ }^{4}$ O modelo de Butler (1980), conhecido como TALC (Tourism Area Life Cycle), diz respeito à análise do ciclo de vida de destinos turísticos, que corresponde basicamente a uma relação entre o número de turistas versus tempo. No capítulo 3 esse modelo é detalhado.

${ }^{5} \mathrm{O}$ conceito de atrativo turístico está relacionado a "[...] locais, objetos, equipamentos, pessoas, fenômenos, eventos ou manifestações capazes de motivar o deslocamento de pessoas para conhecê-los" (BRASIL, 2007, p. 27). Os atrativos turísticos podem ser naturais, culturais, atividades econômicas, realizações técnicas, científicas e artísticas e eventos programados.
} 
desenvolvimento, conforme enquadramento teórico de Hunter (1997; 2002) e informações obtidas por meio da pesquisa de campo desta tese.

A literatura apresenta uma profusão de adjetivos relativos aos destinos turísticos e às cidades como "destinos sustentáveis", "destinos inteligentes", "cidades sustentáveis", "cidades criativas", "cidades inteligentes" (smart cities), "territórios criativos", "clusters criativos", entre outros (REIS \& MARCO, 2009; REIS \& KAGEYAMA, 2011; ABRAMOVAY, 2012; COSTA, 2013; REIS, 2011; BUHALIS \& AMARANGGANA, 2014). Diante dessa diversidade conceitual é preciso ficar claro que nem todo destino turístico é cidade e nem toda cidade é destino turístico. Idealmente, toda cidade e destino deveriam ser sustentáveis, bem como poderiam assumir características como criatividade, inovação e eficiência.

Com relação ao conceito de cadeia de valor, essa expressão foi cunhada por Porter (1989). No contexto do turismo, existem outras nomenclaturas associadas à noção de cadeia, como "Polo", "Indústria", "Cluster", "Supply Chain", "Cadeia produtiva”, "Arranjo Produtivo Local (APL)" e "Sistema" (SILVA, 2004; CAPORALI \& VOLKER, 2004; COOPER; HALL \& TRIGO, 2011; LOHMANN \& PANOSSO NETTO, 2012). Todavia, associar o termo cadeia à atividade turística é a prática mais recorrente na literatura, uma vez que traduz uma ideia de "encadeamento" de pelo menos 50 elos/segmentos da economia (BRASIL, 2012a). Esse termo também é adotado na legislação turística brasileira ${ }^{6}$. No entanto, é nos conceitos de "cadeia de valor de turismo" (que interage com outras cadeias de forma sistêmica e em um dado território) que esta tese está fundamentada. Isto porque a imaterialidade é inerente ao setor de serviços (além de ser o turismo uma experiência que gera valor).

De acordo com o Plano de Desenvolvimento Turístico do Conselho de Sesimbra, município este situado em Portugal, explica que a cadeia de valor do turismo é o "conjunto de actividades (sic) de valor acrescentado que, de forma articulada, permitem que o 'produto turístico' esteja disponível para o consumo" (PORTUGAL, [s.d.]). Quanto aos elos da cadeia de valor do turismo esse Conselho define:

Actividades (sic) centrais, isto é, actividades com um papel estruturante na cadeia de valor; Actividades conexas, isto é, actividades com uma

\footnotetext{
${ }^{6}$ O Decreto no 7.381 , de 02 de Dezembro de 2010 e a Lei no 11.771, de 17 de setembro de 2008, por exemplo, utilizam o termo "cadeia produtiva do turismo". De acordo com o Art. 21 da Lei 11.771, as atividades econômicas relacionadas à cadeia produtiva do turismo são: "I - meios de hospedagem; II - agências de turismo; III transportadoras turísticas; IV - organizadoras de eventos; V - parques temáticos; e VI - acampamentos turísticos. Parágrafo único: Poderão ser cadastradas no Ministério do Turismo, atendidas as condições próprias, as sociedades empresárias que prestem os seguintes serviços: I - restaurantes, cafeterias, bares e similares; II centros ou locais destinados a convenções e/ou a feiras e a exposições e similares; III - parques temáticos aquáticos e empreendimentos dotados de equipamentos de entretenimento e lazer; IV - marinas e empreendimentos de apoio ao turismo náutico ou à pesca desportiva; $\mathrm{V}$ - casas de espetáculos e equipamentos de animação turística; VI - organizadores, promotores e prestadores de serviços de infra-estrutura (sic), locação de equipamentos e montadoras de feiras de negócios, exposições e eventos; VII - locadoras de veículos para turistas e VIII - prestadores de serviços especializados na realização e promoção das diversas modalidades dos segmentos turísticos, inclusive atrações turísticas e empresas de planejamento, bem como a prática de suas atividades" (BRASIL, 2008).
} 
relação ainda directa com a oferta do "produto turístico", mas que não desempenham necessariamente um papel-chave; Actividades potenciadas, isto é, actividades com relações mais indirectas com a oferta do "produto turístico", mas que são condição necessária para a sua existência e Actividades da órbita da oferta turística, isto é, actividades que consubstanciam áreas críticas para o desenvolvimento do turismo (áreas, de algum modo, transversais a outras cadeias de valor) (PORTUGAL, [s.d.]).

Os autores Gollub, Hoisier \& Woo (2004) entendem que a cadeia de valor do turismo é uma complexa e dinâmica rede de serviços e produtos turísticos inter-relacionados, cujos processos produtivos enquadram-se dentro da lógica de sistemas, com inputs (entradas) e outputs (saídas). Este sistema é composto, basicamente, pelas Atividades Características do Turismo $(\mathrm{ACT})^{7}$, pela comunidade receptora e pelos turistas propriamente ditos.

A Figura 3 abaixo representa um modelo de cadeia de valor do turismo.

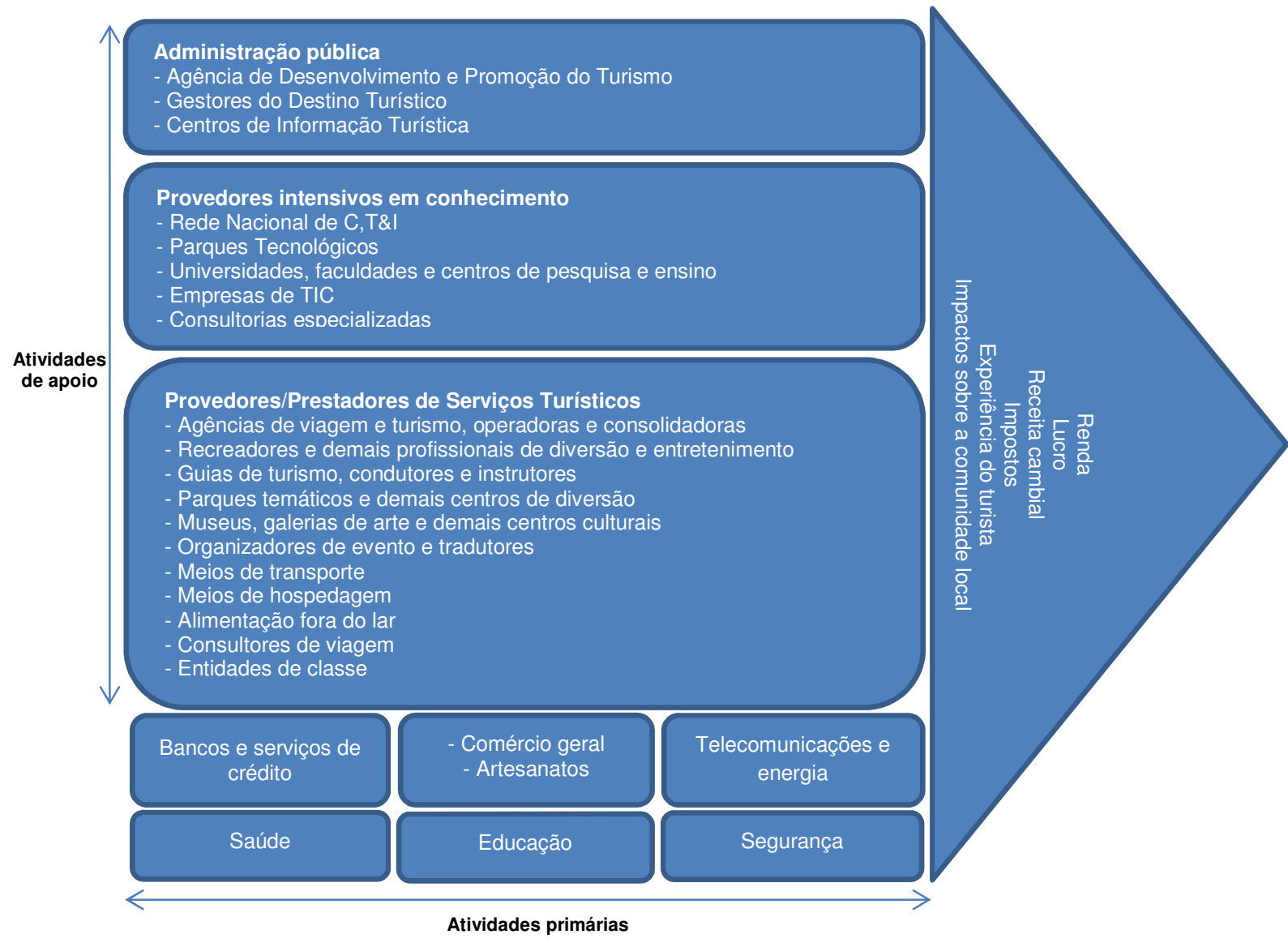

Figura 3 - Proposta de modelo de Cadeia de valor do turismo

Fonte: Elaborado por Daniela Rocco (2014) com base no modelo de Porter (1989) e no modelo apresentado na aula da profa. Dra. Aurkene Alzua-Sorzabal para o mestrado Agenda 21 da Universidade do País Basco (2013).

\footnotetext{
7 As ACT correspondem ao maior gasto dos turistas, que por sua vez estão relacionados com: "alojamento; alimentação; transporte aéreo; transporte terrestre; transporte aquaviário; agências de viagem; aluguel de transporte; e cultura e lazer" (COELHO \& SAKOWSKI, 2014).
} 
Tal como apresenta o modelo de Porter (1989), o modelo proposto da Figura 3 está dividido em dois grupos. O primeiro deles diz respeito às atividades primárias, constituídas por bancos e serviços de crédito; comércio em geral, com destaque para os artesanatos e souvenirs; telecomunicações e energia; saúde, educação e segurança. As atividades primárias, em sua maioria, impactam indiretamente o turismo, no entanto, são fundamentais para o funcionamento de toda a cadeia. No que se refere ao segundo grupo, denominado de atividades de apoio, será apresentado a seguir um detalhamento maior e que esteja adequado ao contexto brasileiro para exemplificar.

- Administracão pública: equivale a todas as instituições de caráter público responsáveis diretamente pela governança do turismo, bem como aquelas que influenciam indiretamente. É composta pelo Ministério do Turismo (poder descentralizado com gestão participativa que envolve conselhos, entidades de classe e instâncias de governança regional), pelas secretarias estaduais de turismo e afins, instituições municipais de turismo de caráter público, centros oficiais de informação turística do destino e demais representantes que atuam na gestão pública do destino.

\section{- Provedores intensivos em conhecimento:}

- Rede Nacional de C,T\&I: a rede Brasileira de C,T\&I (Ciência, Tecnologia e Inovação) é composta por instituições públicas do nível federal como MCTI (Ministério da Ciência, Tecnologia e Inovação do Brasil), a FINEP (Financiadora de Estudos e Projetos), a CAPES (Coordenação de Aperfeiçoamento de Pessoal de Nível Superior), o CNPq (Conselho Nacional de Desenvolvimento Científico e Tecnológico), entre outras instituições públicoprivadas do nível federal, estadual e municipal.

- Parques Tecnológicos: exemplos no caso do Brasil são o do Porto Digital de Recife (PE), do Sapiens Parque de Florianópolis (SC), do Parque Tecnológico Itaipu do Paraná (PR) e do Porto Maravilha no Rio de Janeiro (RJ).

- Universidades, faculdades e centros de pesquisa e ensino: cursos de pós-graduação, bacharelado, tecnólogos e técnicos na área de Turismo, Inovação, Competitividade, Gestão e afins.

- Empresas de TIC: capazes de operar/gerar buscas inteligentes; informação personalizada; links com recursos relacionados; imagens dos produtos/serviços; vídeos online; visita virtual; ofertas; promoções; calendário de eventos e programas; gerador de itinerários; catálogos multimídia; informação a smatphones e tablets; registro de visitas em base de dados; fóruns de discussão e chats; fotos; vídeos e outras páginas na internet para difundir a inovação e uso de dispositivos móveis com tecnologias como GPS (Global 
Positioning System), GPRS (General Packet Radio Services) e PDA (Personal Digital Assitant).

- Consultorias especializadas: de gestão de destinos turísticos.

\section{- Provedores/prestadores de serviços turísticos:}

- Agências de viagem e turismo, operadoras e consolidadoras: prestadores de serviços e empresas (as agências de viagem e turismo podem ser "atacadistas", pois criam e vendem pacotes turísticos e "receptivas", responsáveis pela assessoria ao viajante no local do destino; as operadoras criam e comercializam seus próprios pacotes, bem como estabelecem parcerias com pequenas agências de viagem e turismo e as consolidadoras interagem com as transportadoras aéreas - são "repassadoras" de bilhetes às agências que não estão credenciadas para isso).

- Recreadores e demais profissionais de diversão e entretenimento: prestadores de serviços e empresas de lazer e recreação.

- Guias de turismo, condutores e instrutores: guias de turismo são credenciados pelo MTur, condutores não possuem esse credenciamento, mas podem conduzir visitantes em determinadas áreas e situações e instrutores são de turismo de aventura e de demais atividades que geram risco.

- Museus, galerias de arte e demais centros culturais: prestadores de serviços e centros/atrações de arte e cultura.

- Organizadores de evento e tradutores: prestadores de serviços e empresas de eventos.

- Meios de transporte: prestadores de serviços e empresas relacionadas ao modal aéreo (avião, helicóptero, etc.); ferroviário (trem, metrô, etc.); rodoviário (ônibus, automóvel, motocicleta, bicicleta, etc.); marítimo e fluvial (barco, ferry, caiaque, transatlânticos, lancha, etc.) e empresas de aluguel (rent a car).

- Meios de hospedagem: prestadores de serviços e empresas (Resort, Hotel, Hotel fazenda, Hotel histórico, Flat/apart, Pousada, Cama \& café e Camping).

- Alimentação fora do lar: prestadores de serviços e empresas (bares, restaurantes, cafeterias, lanchonetes, sorveterias, quiosques de rua, fast food, etc.).

- Parques temáticos e demais centros de diversão: prestadores de serviços e empresas/atrativos de diversão.

- Consultores de viagem: profissionais geralmente autônomos (Personal Trip Advisor).

- Entidades de classe: de alimentação fora do lar (ABRASEL - Associação Brasileira de Bares de Restaurantes), de agências de viagem e turismo (ABAV - Associação Brasileira de Agências de Viagens), hotéis (ABIH - Associação Brasileira da Indústria de Hotéis), etc. 
As atividades de apoio, indicadas na Figura 3, são fundamentais para a criação de valor turístico e, juntas, são capazes de gerar renda (por meio de impostos) e receita cambial para o governo e lucro para as empresas. O desempenho de tais atividades impacta positiva e/ou negativamente a comunidade local e a experiência do turista.

A Figura 4 ilustra de forma mais objetiva a organização (de parte) do sistema turístico, que por sua vez é composto por diversas cadeias de valor que impactam direta e indiretamente o turismo em um dado território. O traçado aberto do sistema é em razão das influências externas positivas e negativas recebidas por meio de outros setores e segmentos que estão vinculados direta e indiretamente à atividade turística. Já o traçado aberto das cadeias (subsistemas ou elos - parte interna do sistema) se justifica não apenas pelas influências externas, mas também pelo fluxo e troca de informações, conexões e interações entre as demais cadeias e com o todo. O sistema turístico, assim, é formado por cadeias de valor relacionadas a sete "verbos" básicos: i) informar (o turista que busca informação por meio de operadoras, agências, internet, aplicativos e centros de apoio ao turista no próprio destino); ii) deslocar (por meio aéreo, terrestre, marítimo e fluvial); iii) hospedar (distintas formas de hospedagem: desde hotéis luxuosos até campings e casas de particulares); iv) alimentar (restaurantes, bares, cafeterias, sorveterias, quiosques de comidas de rua, entre outros); v) entreter (atrativos turísticos naturais, culturais e artificiais); vi) comprar (artigos de uso pessoal, para revenda e souvenirs) e vii) compartilhar (a experiência pessoalmente ou via redes sociais, em tempo real ou não).

Obviamente, outros "verbos" podem ser acrescentados a essa representação de sistema turístico e que chancelam seu caráter dinâmico e multisetorial, como ações relacionadas ao planejar, gerir, desenvolver, promover, controlar, conservar, zonear (áreas), fiscalizar, mitigar (impactos), inovar, competir, cooperar e gerar (riqueza). Um ponto crucial e que deve estar claro é que todas essas cadeias geram valor (oferta) e também são valoradas pelo turista e comunidade local. Por isso em cada "verbo"/cadeia da figura abaixo está registrada a letra "v" de valor.

\footnotetext{
${ }^{8} \mathrm{Na}$ apresentação do Livro "Turismo Contemporâneo", de Cooper, Hall \& Trigo (2011), Eduardo Sanovicz afirma que trabalhar turismo requer a integração de quatro verbos: comer, dormir, comprar e visitar.
} 


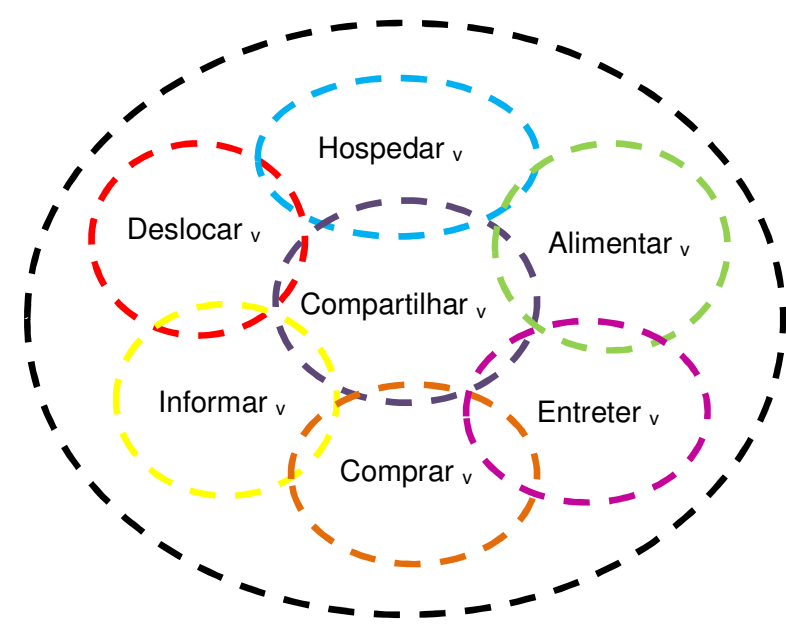

Figura 4 - Representação objetiva de um sistema turístico Legenda:

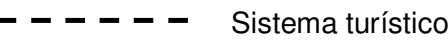
Fonte: Daniela Rocco (2014).

$\mathrm{v}=$ valor

O modelo de sistema turístico, acima apresentado, é atemporal. Com relação à escala geográfica, ele pode ser considerado desde o nível internacional até o local. O que vai diferenciá-lo são as características (materiais e simbólicas) que cada destino turístico possui. Segundo Costa (2013, p. 22) os destinos turísticos "comportam-se como sistemas complexos dinâmicos e evolutivos, acompanhando os inúmeros vetores e as múltiplas atividades que atuam, de modo interdependente, sobre eles".

Entendemos que, sob uma condição de alto nível de complexidade, conexão, interatividade, inovação e avanços substanciais na organização e estruturação do destino/território turístico, o sistema turístico se transforma em uma ampla rede aberta, composta por sua vez por grandes encadeamentos produtivos e que também geram valor (mesma lógica citada anteriormente sobre cadeia de valor). O conceito de rede aplicado ao turismo está respaldado em Castells (1999), que escreveu sobre "A Sociedade em Rede"9. O autor (1999) analisa a sociedade globalizada, que faz uso intensivo de informação, conhecimento e comunicação, gerando, assim, a criação e desenvolvimento de novas tecnologias e transformações profundas não apenas nas relações sociais, como também nos sistemas econômicos e políticos. Quanto ao conceito de encadeamento produtivo o SEBRAE (Serviço de Apoio às Micro e Pequenas Empresas) explica que é

\footnotetext{
9 "A sociedade em rede, em termos simples, é uma estrutura social baseada em redes operadas por tecnologias de comunicação e informação fundamentadas na microelectrónica ( $\mathrm{sic}$ ) e em redes digitais de computadores que geram, processam e distribuem informação a partir de conhecimento acumulado nos nós dessas redes. A rede é a estrutura formal (vide Monge e Contractor, 2004). É um sistema de nós interligados. E os nós são, em linguagem formal, os pontos onde a curva se intersecta a si própria. As redes são estruturas abertas que evoluem acrescentando ou removendo nós de acordo com as mudanças necessárias dos programas que conseguem atingir os objectivos ( $\mathrm{sic}$ ) de performance para a rede. Estes programas são decididos socialmente fora da rede mas a partir do momento em que são inscritos na lógica da rede, a rede vai seguir eficientemente essas instruções, acrescentando, apagando e reconfigurando, até que um novo programa substitua ou modifique os códigos que comandam esse sistema operativo" (CASTELLS, 2006, p. 20).
} 
um modelo para aumentar a competitividade, a cooperação e a competência tecnológica e de gestão das empresas, através de relacionamentos de longo prazo e mutuamente atraentes, que se estabeleçam entre grandes companhias e pequenas empresas de sua cadeia de valor (SEBRAE, 2012, p. 1, grifo nosso).

O encadeamento produtivo, além de estimular a competitividade e inovação entre grandes e PME (pequenas e médias empresas), é uma estratégia para que as próprias PME possam qualificar ainda mais seus processos, práticas e serviços de tal modo que possam se adequar às demandas e exigências do mercado em geral. Com efeito, esta é uma oportunidade para que as PME possam interagir competitivamente nas cadeias de valor das grandes empresas. A Figura 5 é uma representação objetiva de uma rede (aberta) de turismo composta por encadeamentos produtivos e cadeias de valor entre grandes e PME.

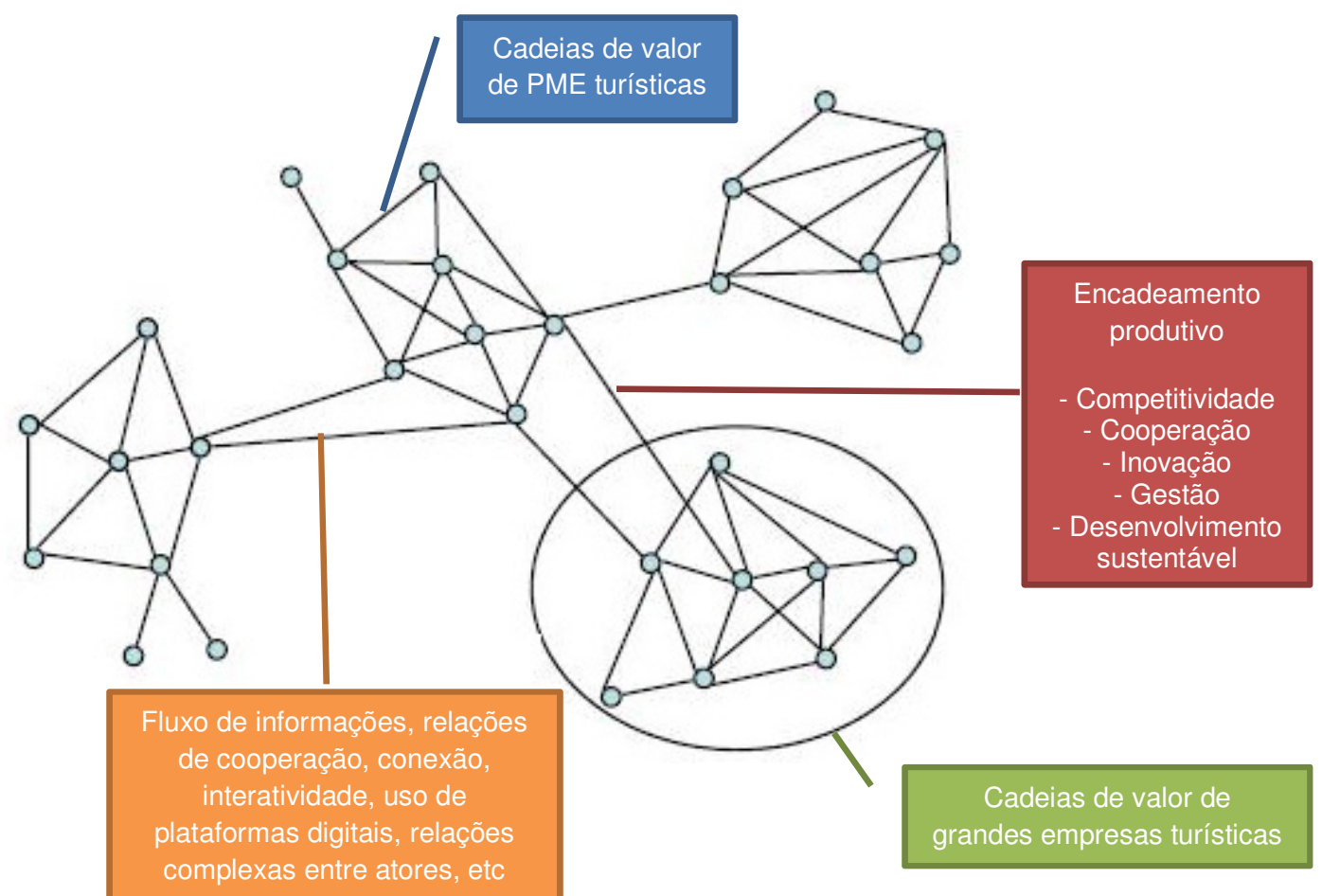

Figura 5 - Representação objetiva de uma rede turística

Fonte: Elaborado por Daniela Rocco (2014); figura adaptada de GTA/UFRJ (2010).

Esta dinâmica de rede aberta no turismo faz a diferença, porém ainda são poucos destinos turísticos que alcançaram tamanho nível de complexidade, conexão, cooperação, competitividade, inovação, gestão e desenvolvimento sustentável. Costa \& Souto-Maior (2006, p. 2) afirmam que 
[...] parece incompleto caracterizar os sistemas de turismo sem levar em consideração aspectos como a complexidade desses sistemas abertos; dotados de auto-organização, com uma imensa variedade de elementos de diferentes hierarquias e não-linearidade das relações.

Diante dessa perspectiva apresentada pelas autoras (2006), é válido ressaltar que ainda não foi esboçado nenhum modelo de rede de turismo composta por encadeamentos produtivos e cadeias de valor do turismo. É preciso avançar mais no desenvolvimento de tais modelos, pois os mesmos auxiliam na compreensão do todo e de suas partes, no planejamento e gestão do turismo contextualizado nas novas e crescentes demandas do "mundo d.i.".

Qualquer que seja a forma pela qual o turismo se organize, é preciso salientar que, se as próprias cadeias de valor do turismo são dinâmicas e passíveis de transformação, essa tendência é recorrente entre os novos perfis de consumo. O jornal Clarín entrevistou em 2011 as especialistas em comportamento do consumidor Trendsity, W, Mindshare e Kantar Worldpanel, que definiram um novo perfil do turista, o consumidor i: inteligentes, inflexíveis, informados e impulsivos (CLARÍN, 2011).

Neste contexto, Biz, Neves \& Bettoni (2014) destacam um novo perfil do consumidor do turismo, que é formado por três características básicas: i) ele é usuário das novas Tecnologias de Informação e Comunicação (TIC) ${ }^{10}$ pela variedade de informações que o auxiliam na tomada de decisão, bem como ter mais transparência e controle de quem presta o serviço turístico; ii) ele é coprodutor de experiências, pois os valores e emoções são centrais na experiência turística e iii) ele é contador de história, uma vez que tende a relatar para outras pessoas a experiência que vivenciou. Podemos afirmar que este relato normalmente não é exclusivo nos encontros entre famílias e amigos, como se estende para as redes sociais, sejam experiências bem ou mal vividas. O agravante, se o relato for negativo, é a força de disseminação que pode ser desencadeada e prejudicar a marca/empresa. Por outro lado, existem empresas cujos próprios usuários se tornaram "evangelistas" da marca. Esse "rótulo", segundo McConnell \& Huba (2005), se refere aos usuários realmente fiéis e satisfeitos com a marca e que são propensos a realizar marketing boca a boca da marca espontaneamente.

Caldeira (2010, p. 191) também defende um novo perfil do turista: o metaconsumidor, que é "aquele consumidor cujas preocupações transcendem ao benefício econômico esperado do produto ou serviço adquirido, para incorporar aquelas que digam respeito à sua produção, distribuição e consumo e seu impacto na sociedade e na

\footnotetext{
${ }^{10}$ A empresa DM9 lançou em 2012 um documentário pautado no estudo inédito sobre os "Perfis Digigráficos", uma nova classificação do consumidor que convive com o ambiente digital. São, no total, cinco perfis: Imersos, Ferramentados, Fascinados, Emparelhados e Evoluídos. Para aprofundar 0 tema acesse 0 link: http://www.dm9ddb.com.br/?p=1982.
} 
sustentabilidade" (CALDEIRA, 2010, p. 191). Hoje existe um nicho pequeno, porém crescente de consumidores mais conscientes quanto à sustentabilidade, e o perfil do metaconsumidor no turismo é reflexo dessa tendência.

A próxima seção dialoga com esse novo perfil de usuários do turismo do "mundo d.i.", pois muitas transições na economia, como podem ser vistas a seguir, ocorreram graças aos avanços relacionados à informação, conhecimento e inovação.

1.1 DA LÓGICA INDUSTRIAL À IMATERIALIDADE: A INFLUÊNCIA DA ECONOMIA DE SERVIÇOS, CRIATIVA, DO SONHO E DA EXPERIÊNCIA NO TURISMO

O atual mundo globalizado começa a vivenciar um intenso processo de "desmaterialização" da economia. Isto se deve, principalmente, ao crescimento mundial do setor de serviços, à concomitante redução de recursos naturais por unidade produzida nos sistemas econômicos (por exemplo, energia, água e solos) e à preponderância dos ativos conhecimento e informação, produzidos economica e socialmente no mundo inteiro (TANIMOTO, 2010). Essas são algumas evidências da Economia imaterial, uma das que mais cresce no mundo e que congrega a economia de serviços, a economia criativa, a economia da experiência e a lógica da sociedade do sonho. A centralidade da Economia imaterial reside no intangível, simbólico e subjetivo, portanto, são experiências e serviços prestados que são dotados de valor, inclusive turístico (JENSEN, 1999; PINE II \& GILMORE, 1999; REIS \& MARCO, 2009; REIS, 2011; REIS \& KAGEYAMA, 2011; ABRAMOVAY, 2012; ÁLVARES \& ROCCO, 2014). As seções a seguir apresentam uma breve contextualização sobre cada tipo de economia. Ao final, há uma seção que abordará a interface entre a Economia imaterial com o turismo.

\subsubsection{ECONOMIA DE SERVIÇOS}

Os primeiros estudos sobre a economia de serviços ocorreram na década de 1950, porém, foi a partir da década de 1980 que tais estudos se intensificaram, inclusive entre economistas de várias partes do mundo. Isto porque eles começaram a perceber a grande representatividade dos serviços para o emprego, a renda gerada e o valor agregado (na década de 1980 os serviços representavam cerca de 70\% da economia) (KON, 2004).

Se antes os serviços representavam uma forma de atendimento intermediário e complementar aos outros setores da economia, com a internacionalização do capital através 
da multinacionalização das organizações, a economia de serviços passou a receber maior destaque. Adicionalmente, com o desenvolvimento tecnológico aliado à criação de empresas de caráter internacional, gerou-se um processo de terceirização dos serviços como estratégia competitiva e de crescimento das organizações (KON, 2004).

Kon (2004, p. 26) destaca que "no contexto da industrialização, os rótulos mais comuns encontrados sobre o setor de serviços são de setor 'terciário'11, 'residual' ou 'pósindustrial'". Outra questão que vale refletir é sobre a origem da palavra serviço, que vem do latim servitiu, cujo significado é "a escravidão", "os escravos", "ato ou efeito de servir". Fitzsimmons \& Fitzsimmons (2010) citam que para a maioria das pessoas o serviço é visto como sinônimo de "servidão".

Gallouj (2007, p. 7) explica que "[...] do ângulo da criação de empregos, a sociedade de serviços não seria nada mais que uma 'sociedade de servidores', uma hamburger society $^{12}$, uma bad jobs socity". O autor busca desmistificar essa visão pejorativa e subordinada do setor terciário quando alega que é a sociedade de serviços que mais emprega executivos de alto nível.

No tocante ao conceito moderno de serviço, podemos compreendê-lo como: "o processo de aplicação de um conhecimento para a realização de um trabalho ${ }^{13}$ a fim de satisfazer uma necessidade cujo resultado poderá ser tangível ou intangível" (SEBRAE, 2008, p. 30). Para Meirelles (2006, p. 134), "serviço é trabalho em processo, e não o resultado da ação do trabalho; por esta razão elementar, não se produz um serviço, e sim se presta um serviço". De forma complementar a ambos os conceitos, o Quadro 2 apresenta as principais características e atributos específicos dos serviços.

\footnotetext{
11 Em 1935 Fischer introduziu o termo "terciário", paralelamente aos termos "primário" e "secundário", apropriados na Austrália e Nova Zelândia. Para Gallouj (2007, p. 10) "[...] essa concepção [terciário] não é de todo falsa. Ela é [...] simplesmente incompleta e incapaz de levar em conta a inovação nos serviços em toda sua diversidade".

${ }^{12}$ Fitzsimmons \& Fitzsimmons (2010) citam que o serviço, entendido de forma geral como servidão, remete a uma ideia de trabalhadores que preparam e servem hamburguers nas mesas (emprego mal remunerado e desinteressante).

13 "Trabalho realizado por intermédio de atividade física, atividade intelectual (por meio de experiência ou conhecimento acumulado) ou ainda com o apoio de máquinas e equipamentos. Em suma, constitui-se no 'saber' ou no 'saber fazer' de uma determinada pessoa" (SEBRAE, 2008, p. 30).
} 
"Atividades de produção e de consumo acontecem de forma simultânea, sendo difícil às vezes distinguir entre concepção e resultado";

"Importância de fatores organizacionais, tais como gestão de recursos humanos, capacitação e treinamento, marketing, estratégias de venda, estratégias de distribuição, gestão da inovação, customização e diferenciação de produtos, serviços, processos, definição de novas interfaces com o cliente etc";

"Importância no estabelecimento de parcerias entre produtorprodutor, produtor-associações empresariais, produtor-consultor etc";

Características gerais atribuídas aos serviços

"Importância das atividades interativas entre produtor-consumidor para a definição do serviço prestado ou do produto resultante do serviço prestado";

"Papel preponderante do fator humano na concepção, organização e entrega dos serviços, sendo necessário, por vezes, substancial investimento em capacitação em todos os níveis da empresa";

"Limitada apropriabilidade dos resultados das inovações (geralmente organizacionais e incrementais)";

"Serviços podem ser intensivos em informação e conhecimento (caso de consultorias, serviços de engenharia, atividades jurídicas etc.), intensivos em recursos humanos (caso dos segmentos de asseio, limpeza e conservação, vigilância e segurança etc.) ou ainda intensivos em capital (caso de algumas atividades de infra-estrutura econômica: energia, saneamento, obras públicas etc.)";

"Natureza intangível de grande parte dos serviços prestados".

Quadro 2 - Características e atributos específicos dos serviços

Fonte: Adaptado de SEBRAE (2007, p. 37).

Mesmo na economia do século XXI, segundo Kon (2004; 2007), ainda prevalece a noção de que os serviços não são produtivos e mensuráveis. Isto é bastante evidente uma vez que

[...] um produto de serviços tem uma condição de transformação que é diferente da de um produto material e, em muitos casos, não pode ser delineada claramente [...]. Isso significa que é difícil aplicar aos serviços a mensuração de conceitos econômicos básicos, como de valor agregado e produtividade (KON, 2004, p. 48).

Essa reflexão crítica também é reforçada por Meirelles (2006, p. 134), ao alegar que "a visão essencialmente material e tangível da economia implicitamente presente nos padrões de contabilidade nacional e internacional conduz a um tratamento, classificação e mensuração dos serviços como um produto (um produto intangível) e não como processo". 
Esta visão tradicional de se pensar economia vai de encontro com a lógica da sociedade do sonho e da economia da experiência, pautados na intangibilidade como é visto a seguir.

\subsubsection{SOCIEDADE DO SONHO E ECONOMIA DA EXPERIÊNCIA}

O dinamarquês Rolf Jensen publicou no final da década de 1990 o livro "The Dream Society" (A Sociedade do Sonho). A Figura 6 abaixo representa a síntese dessa expressão que ganhou bastante força na literatura, especialmente de turismo. Para Jensen (1999), a história de evolução da sociedade começa com a sociedade agrícola há 100.000 anos, tendo como valor econômico as "commodities". Em seguida há uma progressão para a sociedade industrial (há 150 anos - valor econômico: produtos), posteriormente para a sociedade da informação (há 20 anos - valor econômico: serviços) e, por fim, se configura nos dias atuais como sociedade emocional, cujo principal valor econômico está pautado nas experiências.

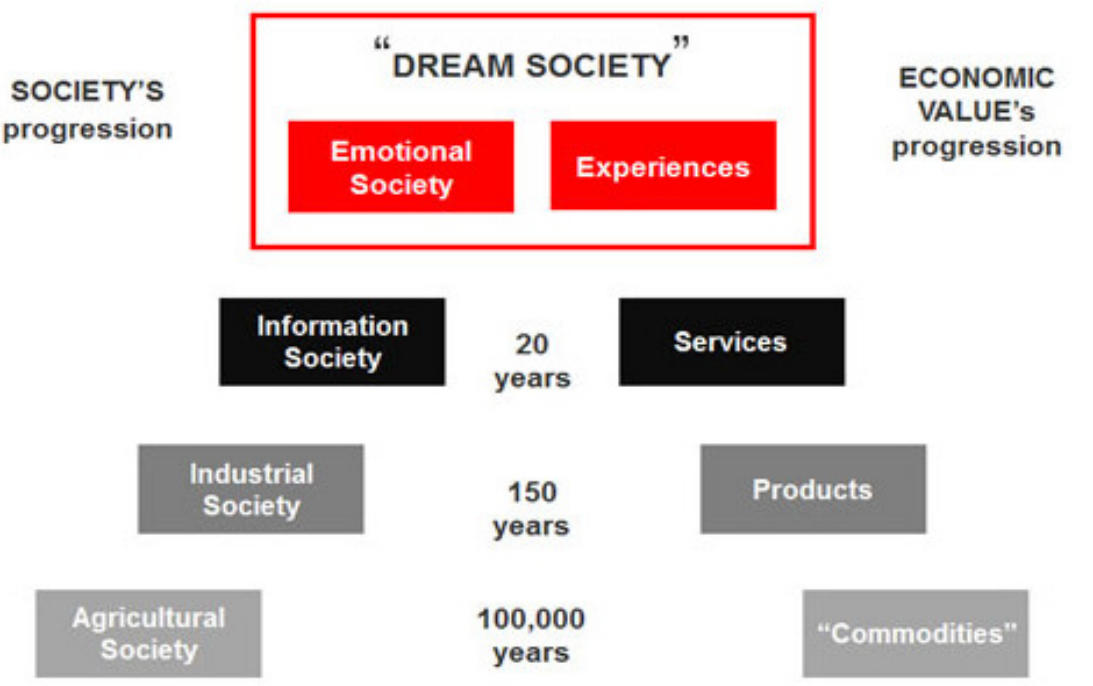

Figura 6 - Sprint através da história: progressos da sociedade e do valor econômico Fonte: Jensen (1999); figura de THR (Innovative Tourism Advisors) (2014).

Segundo a lógica de Jensen (1999), não é que a agricultura e indústria irão desaparecer, porém o foco será ainda maior nas emoções criadas por negócios que vendem experiências. Ou, ainda, mercadorias (materiais) vendidas com uma história e que possuem, portanto, um altíssimo valor (simbólico) agregado.

Para complementar essa reflexão, a Figura 7 a seguir apresenta os principais "motores" da sociedade da informação e da sociedade do sonho. Na primeira o conjunto de motores está relacionado à Tecnologia, Racionalismo, Pragmatismo, Conforto físico e 
Inteligência racional. De forma oposta, no segundo formato de sociedade o conjunto de motores está vinculado às Emoções, Histórias, Valores, Conforto espiritual e Inteligência emocional.

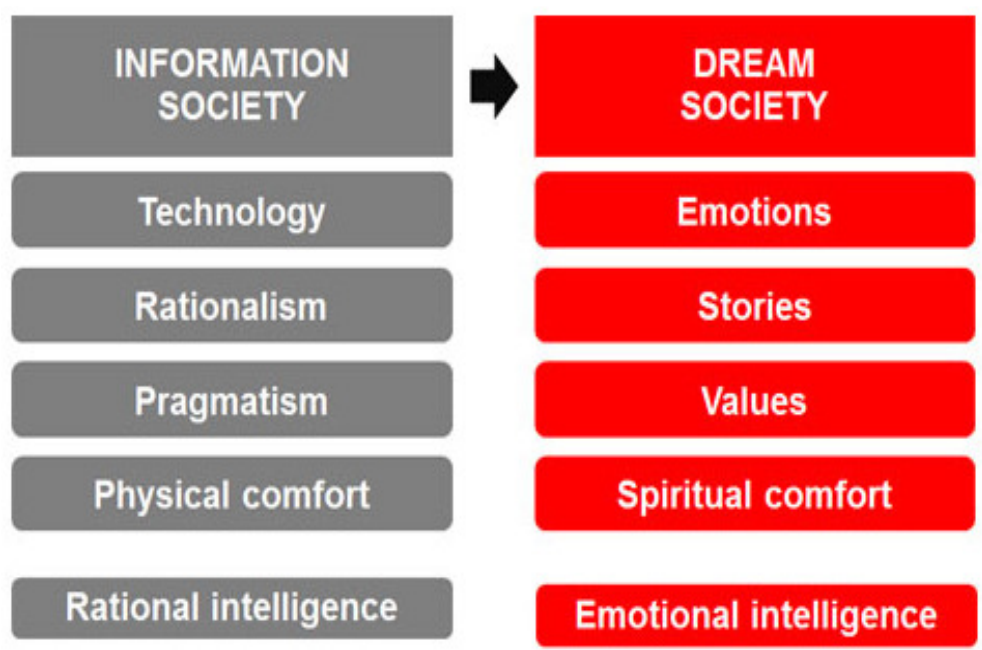

Figura 7 - Motores da sociedade da informação e da sociedade do sonho Fonte: Jensen (1999); figura de THR (Innovative Tourism Advisors) (2014).

A perspectiva tratada por Jensen (1999) está bastante alinhada com a economia da experiência, popularizada por B. Joseph Pine II e James H. Gilmore por meio do livro homônimo "The Experience Economy" (A Economia da Experiência). A experiência "[...] acontece quando uma empresa usa intencionalmente os serviços como um palco e os produtos como suportes para atrair os consumidores de forma a criar um acontecimento memorável" (PINE II \& GILMORE, 1999, p. 39).

A Figura 8 abaixo apresenta a relação do progresso do valor econômico. De forma semelhante à reflexão teórica de Jensen (1999), Pine II \& Gilmore (1999) mostram a transição da economia agrária, para a economia industrial (produtos), para a economia de serviços e, por fim, para a economia da experiência. Como os bens e serviços foram "comodotizados" ao longo dos anos, a posição competitiva foi diminuída (indiferenciação/irrelevância) e isso requer, portanto, um novo valor econômico: a experiência como relevante diferencial de mercado, um valor para as organizações e consumidores. 


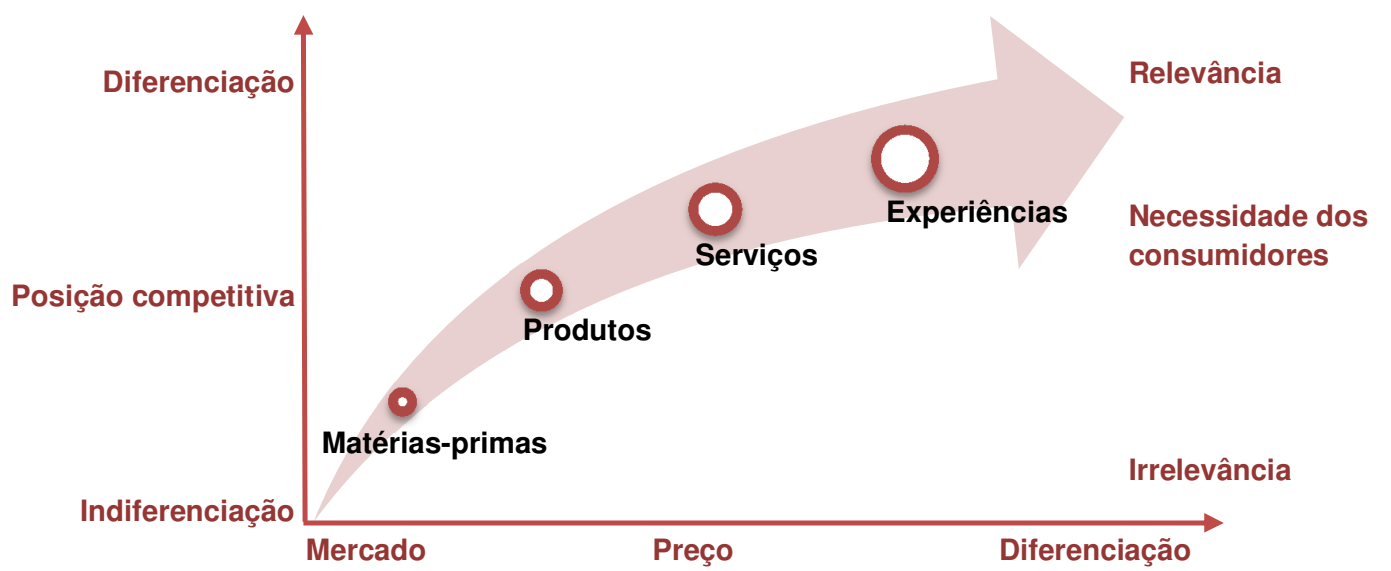

Figura 8 - Progresso do valor econômico Fonte: Adaptado de Pine II \& Gilmore (1999).

O Quadro 3 criado por Portella (2012) está bastante alinhado com o pensamento desenvolvido por Jensen (1999) e Pine II \& Gilmore (1999). Nele consta as principais características da Era industrial, da Era do Conhecimento e da Era da Emoção, bem como indica as principais mudanças mercadológicas ocorridas ao longo do tempo. Nesta Era, temse como foco a qualidade de vida, rede de parcerias, associação, criatividade e inovação, visão quântica, gestão participativa e cooperação. Portella (2012, p. 64) enfatiza que a palavra "emoção" não é um sentimento como "[...] alegria, tristeza, medo, angústia, solidão, amor, rejeição, paixão... [...] [A palavra] Está espelhada no sentir, no enxergar, na sensibilidade de perceber o que está por trás, no intuir, criar e identificar o coletivo no plano individual".

\begin{tabular}{ccc}
\hline ERA INDUSTRIAL & ERA DO CONHECIMENTO & ERA DA EMOÇÃO \\
\hline Sobrevivência & Expectativa de vida & Qualidade de vida \\
Emprego & Trabalho & Rede de parcerias \\
Operário & Autônomo & Associação \\
Produção em série & Produção tecnológica & Criatividade e Inovação \\
Visão mecânica & Visão biológica & Visão quântica \\
Gestão vertical & Gestão horizontal & Gesão participativa \\
Chefia & Liderança & Cooperação \\
\hline
\end{tabular}

Quadro 3 - Ciclo de eras (do pós-industrial à era da emoção)

Fonte: Portella (2012, p. 64).

Para Rifkin (2001), a economia vivencia um momento de transição de uma cultura de posses (como salas de negócios, máquinas, instrumentos, etc.) para uma cultura de acessos, pois não é necessário ter salas de negócios e máquinas, por exemplo, se é possível alugá-las. Com isso, abre-se espaço para o fortalecimento da cultura da terceirização, do leasing e do aluguel. Essa transição conduz à consolidação de dois ativos universais: a informação e o conhecimento, e revela, tal como argumentam Jensen (1999), 
Pine II \& Gilmore (1999) e Portella (2012), que a perspectiva imaterial dos produtos proporciona maior vantagem em relação à perspectiva material.

Podemos afirmar que lógica da Sociedade dos Sonhos e da Economia de Experiência tem sido amplamente adotada no Turismo, como mostra a última seção.

Diante do exposto, podemos verificar que os estudos sobre uma economia pautada na experiência e nas emoções (sociedade do sonho) são ainda muito recentes, embora tenha conquistado uma abrangência muito grande na literatura e no modo em que produtos e serviços são criados e comercializados. Na economia criativa essa repercussão não é diferente, e por isso a importância de abordá-la na próxima seção.

\subsubsection{ECONOMIA CRIATIVA}

Segundo Reis (2009) os setores criativos compõem a base estratégica da economia de um país ou região, e o crescimento da economia criativa é evidente, pois atualmente movimenta US\$ 3 trilhões ao ano, com a previsão de que, em 2020, esse montante deve duplicar (HIAR, 2014).

O conceito de economia criativa é bastante novo e possui maior disseminação nos países escandinavos, Inglaterra, Austrália, Espanha, França e Alemanha (FANTONI \& ROCCO, 2014). Verhagen (2011) defende que o livro The Creative Economy de John Howkins, publicado em 2001, apresentou os princípios da economia criativa, no entanto, foi com o livro de Richard Florida (The Rise of the Creative Class - A Ascenção da Classe Criativa), que o tema alcançou maior abrangência internacional, muito embora o livro The Dream Society de Rolf Jensen tenha, definitivamente, popularizado o tema. No Brasil, a primeira tese de doutorado sobre o tema foi da Dra. Ana Carla Fonseca Reis, que realizou estudo sobre cidades criativas com ênfase na capital paulistana (REIS, 2011).

Em 2011 o Martin Prosperity Institute (MPI) publicou o Índice Global de Criatividade (Global Creativity Index - GCl), composto por, basicamente, três "Ts" do desenvolvimento econômico:

i) Tecnologia: direcionada para pesquisa e desenvolvimento, investimento em pesquisadores e número de patentes per capita;

ii) Talento: proveniente dos trabalhadores de áreas relacionadas à ciência e tecnologia, negócios e administração, saúde e educação e artes, cultura e entretenimento;

iii) Tolerância: como imigrantes, minorias étnicas e raciais, gays e lésbicas são tratados (MPI, 2011). 
Esses três "Ts" estão relacionados a fatores econômicos, sociais e culturais e, segundo $\circ \mathrm{GCl}$, que apresenta o ranking de 82 países, os principais investidores em economia criativa são, em ordem decrescente, Suíça, EUA, Finlândia, Dinamarca e Austrália. De acordo com Portella (2012), o Brasil ocupa a 12ª posição entre os países que possuem o maior potencial criativo do mundo, porém, conforme o $\mathrm{GCl}$, o País está muito abaixo desse potencial, pois ocupa a 46ª posição (MPI, 2011) - mais da metade dos países pesquisados. De forma complementar à publicação do MPI, o World Economic Forum revelou em um estudo feito com 140 países que a China, EUA, Alemanha, Hong Kong e Itália lideram o ranking de "exportação de indústrias criativas". O Brasil está na $41^{\text {a }}$ posição (WEF, 2013a).

Mesmo ocupando posições regulares quanto a rankings mundiais vinculados à economia criativa, o Brasil tem começado a se destacar nesse setor. Em 2012 o Ministério da Cultura criou a Secretaria da Economia Criativa, uma ação pioneira não só para institucionalizar o tema no País, como para conduzir políticas públicas cujos eixos centrais sejam a cultura, criatividade e inovação.

Os setores criativos contribuem no Brasil com $\mathrm{R} \$ 104,37$ bilhões, equivalente a $2,84 \%$ do PIB brasileiro. Nos últimos cinco anos o setor criativo registrou um crescimento do de $6,13 \%$ a.a., bem como emprega, no núcleo dos setores criativos, 865.881 pessoas (1,96\% do total de empregados formais). Nesses núcleos atuam 63.373 empresas, cuja renda média dos trabalhadores formais é de $R \$ 2.293,64$ (BRASIL, 2011).

1.1.4 A INTERFACE ENTRE A ECONOMIA IMATERIAL COM A ECONOMIA DO TURISMO

Como pôde ser visto nas seções anteriores, a economia imaterial, uma das que mais cresce no mundo, é composta pela economia de serviços, economia da experiência, economia criativa e a lógica da sociedade do sonho. Kon (2004) evidencia que recentemente os países de economia industrial têm se tornado de economia de serviços, e esta é uma tendência inclusive entre os países menos desenvolvidos. Outros autores, como Jensen (1999), Pine II \& Gilmore (1999) e Portella (2012) citam uma economia além da prestação de serviços: aquela cujo valor central reside nas emoções e experiências. Embora neste capítulo tenha sido mencionado que o turismo está enquadrado no setor de serviços, a diferença entre o conceito de serviço e experiência é sutil, e isso merece uma análise mais cuidadosa. Tomemos como ponto de partida essa reflexão de Pine II \& Gilmore (1999, p. 12): 
[...] quando uma pessoa paga por um serviço, ela está adquirindo um conjunto de atividades intangíveis executadas em seu interesse. Mas quando ela adquire uma experiência, está pagando para dedicar seu tempo a desfrutar de uma série de eventos memoráveis que uma empresa encena - como em uma peça de teatro - para envolvê-la de modo pessoal.

Os autores (1999) exemplificam no trecho acima o teatro, porém o turismo é também, tal como visto na literatura (PANOSSO NETTO \& GAETA, 2010; COOPER, HALL \& TRIGO, 2011) uma experiência memorável e única, que por sua vez vai além da lógica dos serviços. Tamanha é a força do entendimento do turismo como experiência que em 2010 foi lançado no Brasil o livro "Turismo de experiência", organizado por Alexandre Panosso Netto e Cecília Gaeta. Trata-se de um trabalho pioneiro no País com a reunião de capítulos escritos por diversos autores da área.

No que se refere à interface entre economia criativa e turismo, o Plano da Secretaria da Economia Criativa: políticas, diretrizes e ações (2011-2014) define ações em conjunto com diversas secretarias e ministérios, inclusive com o MTur. Esta ação se divide em duas formas: i) Estudos e Pesquisas (realização de estudos sobre competitividade e em parceria com o Projeto Economia da Experiência) e ii) Territórios Criativos (requer a articulação e incentivo à institucionalização de territórios criativos - trabalho alinhado com projetos de Turismo Comunitário e Cidades do Turismo de Experiência) (BRASIL, 2011).

Após refletirmos sobre a importância, complexidade e organização do turismo é incompreensível o fato de que até nos dias de hoje a economia de serviços (da qual o turismo faz parte) ainda seja pouco explorada e compreendida (KON, 2007; GALLOUJ, 2007). Lemos (2005, p. 26) afirma que "[...] parte da ciência econômica considera que o turismo não gera riqueza". O autor ressalta também que "há, ainda, aqueles que entendem que os serviços gerados pelo turismo não geram valor, apenas absorvem o valor produzido por outros setores da economia" (LEMOS, 2005, p. 31). Se para o autor o valor "é a essência da riqueza produzida pelo homem em sociedade", e se o turismo é resultado de uma produção social, econômica, cultural, ambiental, histórica e política, o valor que é percebido por turistas e comunidade local é resultante de um vigoroso processo de riqueza social.

Diante do exposto, é preciso sublinhar que a literatura nos conduz a pensar que a teoria econômica encabeçada pelos fisiocratas do século XVII, que enquadra o serviço como atividade improdutiva, servil, estéril, terciária e subordinada, ainda está cristalizada no século XXI, tal como ocorre em diversos níveis das decisões governamentais e políticas do Brasil. No que tange aos demais setores produtivos (primário e secundário), historicamente - País privilegiou a agropecuária do ponto de vista da pesquisa, que gerou, principalmente através da EMBRAPA, uma competitividade muito elevada desse setor no cenário internacional. O parque industrial no Brasil também foi e ainda é muito beneficiado com 
políticas e incentivos fiscais do governo. Inclusive, no ano de 2011 foi criada a EMBRAPII (Empresa Brasileira de Pesquisa e Inovação Industrial), qualificada como organização social em 2013. Quanto ao setor de serviços, no Brasil, entre 1970 e 2005, houve uma contribuição na PEA (População Economicamente Ativa) de $38 \%$ para 58\%, e no ano de 2005 o setor já era responsável por 57\% do PIB nacional - valor adicionado (CNC, 2008). Apesar do crescimento do setor terciário e relativa queda no crescimento das indústrias, ainda se percebe no País menos incentivo (de quaisquer ordens) aos serviços de maneira geral em relação aos setores primário e secundário. O turismo, embora tenha contribuído para o desenvolvimento econômico e sustentável no cenário mundial, ainda não está presente na agenda de prioridades de muitos países, inclusive no Brasil (OLIVEIRA \& ROSSETTO, 2013).

Lemos (2005) destaca, no contexto do turismo, que a riqueza gerada por essa atividade econômica ainda é limitada às medições de produto, insumo e consumo, principalmente. Muitas vezes os processos relacionados ao turismo não são considerados nessas medições. Além disso, a maioria das análises de turismo se restringe a uma lógica mercantil, não contemplando, frequentemente, a componente social. O autor (2005, p. 24) ainda enfatiza que:

\begin{abstract}
[...] a economia deve gerar uma forma de reprodução que não desvalorize as formas de riqueza social e ambiental, preservando-as e agregando-lhes valor, bem como gerando benefícios que os participes desse processo, a fim de que se estabeleça a realimentação evolutiva e permanente do sistema, respeitando os limites de capacidade de acolhida da comunidade.
\end{abstract}

Neste contexto, para Abramovay (2012), a nova economia demonstra a finitude dos recursos, devendo, assim, estimular a criatividade para que bens e serviços tenham um uso inteligente, eficiente e moderado da matéria, energia e biodiversidade. Consideramos, portanto, que o turismo pode ser porta-voz dessa nova lógica de produção econômica, ainda que seja uma atividade complementar ${ }^{14}$ da economia de um país, estado, cidade ou território.

$\mathrm{Na}$ seção a seguir apresentamos componentes essenciais para o melhor desenvolvimento dessa "nova economia", a serem exemplificados pelos conceitos valor turístico e valor sustentável.

\footnotetext{
${ }^{14}$ Acreditamos que o turismo não pode ser a atividade principal de uma economia, justamente por assumir características muito específicas, como a instabilidade econômica (derivada, por exemplo, da sazonalidade) e a possibilidade de um determinado destino sofrer catástrofes ambientais, afetando, assim, a visitação de atrativos turísticos. O fato de ser uma atividade econômica complementar não quer dizer que seja menos importante e gere menos riqueza local.
} 
1.2 VALOR TURÍSTICO E VALOR SUSTENTÁVEL: A SUSTENTABILIDADE COMO VALOR LEGÍTIMO DE UM PROCESSO DE DESENVOLVIMENTO SUSTENTÁVEL

Ao longo dos últimos anos ${ }^{15}$ o discurso sobre desenvolvimento sustentável (DS) esteve (e ainda permanece) na pauta de governos e está presente nos diversos âmbitos da economia e da sociedade. Inclusive, Nascimento \& Costa (2010) afirmam que o DS se firmou nas últimas décadas através de cinco distintos espaços: 1) Governos/entidades multilaterais; 2) Empresas; 3) Sociedade civil; 4) Mídia e 5) Academia.

De acordo com Boff (2012), o conceito de sustentabilidade para a maioria das pessoas se originou na década de 1970 , por meio das reuniões da ONU ${ }^{16}$. No entanto, tal conceito surgiu há mais de 400 anos e que uma minoria possui conhecimento. Foi em 1560, na Província Saxônia da Alemanha, que se começou a despertar uma preocupação pelo uso das florestas de forma mais racional. Surgiu, então, a palavra "nachhaltigkeit", que significa "sustentabilidade". Boff (2012) explica que foi apenas em 1713 que a referida palavra recebeu um caráter mais estratégico. Isso graças ao Capitão Hans Carl von Carlowitz, quando escreveu na Saxônia um tratado sobre sustentabilidade ${ }^{17}$. Segundo o Capitão, cada vez mais se devastava grandes áreas de florestas para abastecer, com carvão vegetal, os fornos de mineração. Era necessário, portanto, tratar a madeira com cuidado, de forma sustentável. Nas palavras dele: "corte somente aquele tanto de lenha que a floresta pode suportar e que permite a continuidade de seu crescimento". Do contrário, o negócio teria grande chance de acabar e, consequentemente, o lucro (BOFF, 2012, p. 33).

As repercussões sobre o manejo das florestas foram bastante evidentes na Saxônia e Prússia, onde foram fundadas academias relacionadas à nova ciência: silvicultura. De acordo com Boff (2012), estudantes de toda a Europa, Escandinávia, EUA e Índia foram à busca desse conhecimento, chegando inclusive até o recém-criado Clube de Roma, na época, década de 1970. O relatório Meadows, publicado pelo Clube de Roma, foi um dos

\footnotetext{
${ }^{15}$ Foi a partir da década de 1970 que houve maior impacto dos debates ambientais. Com efeito, no ano de 1972 ocorreu em Estocolmo a Conferência das Nações Unidas sobre o Ambiente Humano (CNUMH). A pauta do encontro consistiu em debater o Relatório Meadows (também denominado Limites do Crescimento), elaborado pelo Clube de Roma, e que representou o primeiro grande alarme com relação aos efeitos da degradação da natureza (LOUREIRO, 2006). Em 1987, foi lançado o Relatório Brundtland (Nosso Futuro Comum), resultado de vários anos de trabalho de um comitê de estudos de alto nível que chancelou o conceito de desenvolvimento sustentável (DS). No ano de 1992 foi promovida a Conferência das Nações Unidas sobre Meio Ambiente e Desenvolvimento (CNUMAD), denominada "Rio- 92" ou "Eco- 92", que consolidou o conceito de DS (LOUREIRO, 2006) e teve como um dos seus principais documentos a Agenda 21. Dez anos depois, realizou-se em Johanesburgo, África do Sul, a Cúpula Mundial sobre o Desenvolvimento Sustentável ("Rio+10"), cuja finalidade principal foi ratificar os acordos e tratados internacionais firmados na CNUMAD (CMDS, 2003). Recentemente ocorreu a Rio+20, no Rio de Janeiro, com a finalidade, sobretudo, de avaliar os compromissos políticos, progressos, lacunas e desafios. O resultado desta Conferência foi o documento denominado "O futuro que queremos" (UNCSD, 2012).

${ }_{17}^{16} \mathrm{Na}$ verdade, o termo que surgiu por meio das reuniões da ONU foi "desenvolvimento sustentável".

17 "Nachhaltig wirtschaften: organizar de forma sustentável" (BOFF, 2012, p. 33).
} 
argumentos-chave para embasar a importância do desenvolvimento sustentável (DS), conceito adotado pela Organização das Nações Unidas (ONU) no final da década de 1980. Significa um processo que visa "o atendimento das necessidades das gerações atuais, sem comprometer a possibilidade de satisfação das necessidades das gerações futuras" (BRUNDTLAND, 1991, p. 46).

Quase invariavelmente, o conceito de DS está vinculado à equidade social, conservação da natureza e prosperidade econômica. Esses três aspectos e que qualificam a sustentabilidade do desenvolvimento frequentemente são encontrados na literatura associados à ideia do triple-bottom-line. Esta expressão de origem inglesa foi cunhada em 1994 pelo britânico John Elkington, fundador da empresa de consultoria SustainAbility, e significa a união de 3 P: 1) Profit (lucro), 2) People (pessoas) e 3) Planet (planeta) (THE ECONOMIST, 2009). Desde então, outras expressões semelhantes também foram adotadas, como: tripé, três pilares, três dimensões, três esferas e até mesmo "trevo de três folhas" (VAN BELLEN, 2006; NASCIMENTO, 2012; COSTA, 2013).

Nascimento (2012) questiona se a adoção do "tripé" é suficiente para que haja sustentabilidade de forma efetiva, e por isso propõe o "trevo de cinco folhas", ao acrescentar a dimensão política e cultural da sustentabilidade. $O$ autor argumenta que a inclusão da dimensão política nos atenta para politização do próprio DS, assim como para as mudanças dos padrões de produção e consumo que dizem respeito às decisões e estruturas políticas. Com relação à cultura ${ }^{18}$, o autor $(2012$, p. 57) afirma:

Outro aspecto olvidado na definição do DS em três dimensões é a cultura. Ora, não será possível haver mudança no padrão de consumo e no estilo de vida se não ocorrer uma mudança de valores e comportamentos; uma sublimação do valor ter mais para o valor ter melhor; se a noção de felicidade não se deslocar do consumir para o usufruir; se não se verificar a transferência da instantaneidade da moda para a durabilidade do produto; se não tivermos pressões para a adoção e valorização, por exemplo, do transporte público e, se possível, para o melhor transporte, o não transporte.

Boff (2012, p. 43) também critica o Triple Botton Line e diz haver um "vazio" no famoso tripé de Elkington, pois nesse modelo não existem aspectos humanísticos e éticos. O "modelo-padrão" de desenvolvimento sustentável e que é amplamente adotado por empresas e nos discursos oficiais, sendo aquele que "[...] deve ser economicamente viável, socialmente justo e ambientalmente correto" é uma armadilha, segundo o autor.

18 Para efeitos de recorte desta pesquisa, e considerando que a cultura é um dos ativos centrais do turismo, assumimos neste este trabalho a análise de um quarto pilar (além dos pilares ambiental, social e econômico): 0 cultural, formando, assim, um "quadripé". Isto não quer dizer que a questão política seja descartada, pois o turismo, por ser um complexo sistema multisetorial, requer governança e gestão política para que seja melhor desenvolvido e promovido. 
É por esta razão [o tipo de desenvolvimento industrialista/capitalista que produz degradação, exclusão social e pobreza] que a utilização política da expressão desenvolvimento sustentável representa uma armadilha do sistema imperante: assume os termos da ecologia (sustentabilidade) para esvaziá-los e assume 0 ideal da economia (crescimento/desenvolvimento), mascarando, porém, a pobreza que ele mesmo produz (BOFF, 2012, p. 46).

Nascimento (2012) ressalta que o DS ora é entendido como discurso (respaldo em Foucault) (MACHADO, 2005), ora como conceito político-normativo (respaldo no Relatório Brundtland) (NOBRE \& AMAZONAS, 2002). Além disso, o autor menciona que a sustentabilidade é entendida como valor (VEIGA, 2010a) e que o desenvolvimento, para Sen (2000), é entendido como liberdade (superação das privações) e ampliação das oportunidades.

A literatura pesquisada imprime a falta de consenso a respeito do conceito de DS, e, por vezes, manifesta severas críticas ${ }^{19}$. Após exaustivo estudo sobre o tema, verificamos que existem diversos autores (MACHADO, 2005; VAN BELLEN, 2006; KRONEMBERGER et al., 2008; KELMAN, 2010; VEIGA, 2010a; HORLINGS \& MARSDEN, 2011; SILVA et al., 2013) que consideram o conceito de sustentabilidade como sinônimo de DS. Entendemos que, para a ciência, não devem existir sinônimos. Por isso muitos pesquisadores podem cometer equívocos em seus textos do ponto de vista teórico, uma vez que, na tentativa de não causarem repetição textual em frases próximas, buscam sinônimos para o conceito que utilizam. Um exemplo: "De que modo o desenvolvimento sustentável se manifestará nos lugares, não está claro. Não há um caminho único para a sustentabilidade [...]" (HORLINGS \& MARSDEN, 2011, p. 145, grifo nosso).

Em entrevista à Folha de São Paulo, Gro Harlem Brundtland, ao ser questionada se estava "de saco cheio" da palavra sustentabilidade, assim respondeu:

Para mim a expressão é "desenvolvimento sustentável". Esse é o conceito. Nos últimos dez anos, mais ou menos, as pessoas começaram a usar "sustentabilidade" como uma forma alternativa de dizer. Eu sempre tive muito cuidado em não usar a palavra "sustentabilidade" sozinha enquanto conceito que cobre a visão para o futuro. Nós precisamos de sustentabilidade em diversas áreas, mas também precisamos de desenvolvimento sustentável. E eu não estou de saco cheio disso, porque não aconteceu ainda (ANGELO, 2012).

Na verdade, acreditamos que Desenvolvimento sustentável e Sustentabilidade são diferentes, embora muito próximos semelhantes. No trecho a seguir percebemos uma

\footnotetext{
${ }^{19}$ Machado (2005) realizou um amplo estudo sobre o debate teórico do DS. Para a autora, é possível inferir que esse discurso não é apenas genuinamente polissêmico, como também dicotômico. O primeiro está vinculado à noção de que o desenvolvimento de maneira sustentável é a via para a constituição de um modelo econômico inclusivo; e o segundo parte do princípio que o DS é um artifício ou possui caráter ideológico para encobrir a perversidade do sistema capitalista.
} 
tentativa (insuficiente) de diferenciação, muito embora nos parece que a ideia de sustentabilidade esteja incorporada à de Desenvolvimento sustentável:

O 'desenvolvimento sustentável' é proposto ou como um ideal a ser atingido ou então como um qualitativo de um processo de produção ou de um produto, feito pretensamente dentro de critérios de sustentabilidade, o que, na maioria dos casos, não corresponde à verdade. Geralmente, entende-se a sustentabilidade de uma empresa se ela consegue se manter e ainda crescer, sem analisar os custos sociais e ambientais que ela causa. Hoje o conceito é tão usado e abusado que se transformou num modismo, sem que seu conteúdo seja esclarecido ou criticamente definido (BOFF, 2012, p. 37).

Diante dessa imprecisão conceitual, faltava, então, diferenciar com maior clareza na literatura o DS (enquanto processo) e sustentabilidade (enquanto valor). Atribuímos, portanto, a diferenciação dos conceitos, conforme exposto abaixo:

- Desenvolvimento sustentável: é um processo complexo de desenvolvimento sistêmico, dinâmico, orgânico e integrado que requer valores respaldados na prosperidade econômica, inclusão produtiva, equidade social, conservação da natureza e cultura em um contexto de ética, moral, compromisso, responsabilidade e solidariedade. Estes valores devem ser estimulados entre as atuais e próximas gerações. Além disso, pelo menos as três dimensões (ambiental, social e econômica) devem ser sempre combinadas. A combinação de duas dimensões ou o fortalecimento de apenas uma não é o suficiente para assegurar o desenvolvimento sustentável de uma organização ou território ${ }^{20}$.

- Sustentabilidade: valor respaldado na prosperidade econômica, inclusão produtiva, equidade social, conservação da natureza e cultura em um contexto de ética, moral, compromisso, responsabilidade e solidariedade.

Ao se discutir a relação DS e sustentabilidade, é preciso deixar claro que, como há confusão dos conceitos (considerando-os sinônimos), as citações na literatura ora podem apresentar o real significado daquilo que compreendemos por sustentabilidade e ora de DS. Em geral, existem alguns consensos sobre o conceito de DS, tais como: 1) deve contemplar, no mínimo, os três pilares principais (ambiental, social e econômico) do tão citado triplebottom-line; 2) é um conceito vinculado a uma questão temporal; 3) a situação contrária é a insustentabilidade; 4) a ética deve ser um valor transversal a todo processo e 5) possui

\footnotetext{
${ }^{20}$ Este conceito foi parcialmente inspirado no Relatório Brundtland (Nosso Futuro Comum), publicado em 1987 e que adotou a expressão "atuais e futuras gerações", no livro de Veiga (2010a), que entende a sustentabilidade como valor e no livro de Costa (2013), sobre sustentabilidade de destinos turísticos.
} 
sempre base comparativa, isto é, não há uma cidade, um município, um bairro, uma empresa que sejam os mais sustentáveis do mundo. A análise sempre será comparativa e ainda dependerá dos tipos de indicadores adotados.

Para Dahl (1997) o conceito de DS é imbuído de valores, sobretudo a ética. Para Gorz (2005), o conceito de valor, no sentido econômico, está associado ao "valor de troca", chamado pelo autor de "relação de equivalências" das mercadorias. Esta relação, por conseguinte, é permutável por meio de dinheiro. Segundo o autor (2005), a fonte do valor, no contexto da economia imaterial (cuja reflexão teórica será aprofundada na próxima seção), está na imaginação, na inteligência e nos saberes vivos e vividos ${ }^{21}$. O saber "[...] que se tornou a fonte mais importante da criação de valor é particularmente o saber vivo, que está na base da inovação, da comunicação e da auto-organização criativa continuamente renovada" (GORZ, 2005, p. 20). O valor, conforme Abramovay (2012, p. 80), é "capacidade de juntar pontas que estavam separadas, de fazer acontecer coisas que não existiam e de ser útil para as pessoas". Para Dolan \& Garcia (2006) o valor constitui a essência da liberdade humana, pois é formado, no médio e longo prazos, a partir de escolhas feitas por deliberação ou preferência. Garcia (2003) entende que o valor é uma relação dinâmica entre sujeito e objeto, uma vez que o sujeito é incentivado pelo desejo de buscar um objeto que para ele possui valor. Este valor, material e/ou imaterial, se estabelece por relações de troca e circulação no âmbito mercadológico e/ou das relações pessoais. O valor, no caso de um produto/serviço, pode ser um aspecto subjetivo ou a combinação/sobreposição de vários deles, como uma experiência memorável, exclusividade, qualidade, luxo, simplicidade, eficiência, conforto, tradição, caráter sustentável, entre outros.

Embora Veiga (2010a) considere a importância da legitimação da sustentabilidade como um valor, não difere a mesma do DS. De acordo com Boff (2012, p. 11, grifo nosso) "a sustentabilidade, mais que qualquer outro valor, deve ser também globalizada". Tomando por base que a sustentabilidade é valor, em Hart (2011) e Hart \& Milstein (2003; 2004) verificamos a aplicação do conceito "valor sustentável", cujo significado é: a identificação de estratégias e práticas que conduzam para um mundo mais sustentável e que, ao mesmo tempo, gerem valor para o acionista. Para os autores, que adotam o conceito para o contexto dos negócios, a oportunidade de se criar valor sustentável nas empresas é muito grande. Entretanto, tal oportunidade ainda não é plenamente abraçada, justamente porque a maioria dos executivos entende que a sustentabilidade, que é multidimensional, é um "incômodo unidimensional". Para auxiliá-los a perceber a sustentabilidade como oportunidade, Hart e Milstein (2004, p. 69, grifo nosso) criaram um modelo multidimensional

\footnotetext{
${ }^{21}$ Para Gorz (2005, p. 32) "o saber é, antes de tudo, uma capacidade prática, uma competência que não implica necessariamente conhecimentos formalizáveis, codificáveis [...]. Eles [os saberes] não são ensinados; aprendem-se-nos pela prática, pelo costume [...]".
} 
de criação de valor para o acionista que descreve quatro conjuntos de componentes "motivadores", que são:

Primeiro, as empresas podem criar valor reduzindo o nível de consumo de matéria-prima e de poluição associado com a rápida industrialização. Segundo, as empresas podem criar valor ao operar com níveis mais amplos de transparência e responsabilidade, uma vez que são impulsionadas pela sociedade civil. Terceiro, as empresas podem criar valor por meio do desenvolvimento de novas e revolucionárias tecnologias que tenham o potencial para reduzir as pegadas do homem sobre o planeta. Finalmente, as empresas podem criar valor ao atender às necessidades daqueles localizados no extremo inferior da pirâmide de renda do mundo, e isso de uma forma que facilite a criação e distribuição de renda inclusiva.

O modelo de valor sustentável de Hart \& Milstein (2003; 2004) é limitado quanto à complexidade e abrangência do desenvolvimento sustentável, pois as ações não devem se restringir à prevenção de poluição e uso de tecnologias limpas. No entanto, os autores (2003; 2004) contribuem na medida em que trazem a importância da inovação para a sustentabilidade no âmbito empresarial e como isso pode impactar favoravelmente no consumo.

O que se põe em xeque é uma mudança de paradigma, cujo cerne reside no valor. A noção de valor aqui assume um conceito extremamente complexo, mas que está umbilicalmente integrado. Começa, idealmente, com a educação para a sustentabilidade, tendo como consequência a ética nos processos. Em seguida, tomadas de decisão (sociedade civil, governo mercado e terceiro setor) devem ser feitas de forma coerente, responsável e justa, de tal modo que as externalidades negativas, uso da matéria, energia e biodiversidade sejam também incluídos no valor dos bens e produtos. Todo esse processo deve gerar por fim, utilidade para as pessoas (melhor experiência com bens e serviços e bem-estar coletivo) e mudança comportamental. A Figura 9 representa esse ciclo, porém, embora contenha cinco componentes para gerar o valor sustentável, é preciso considerar que os processos que propiciam esse ciclo virtuoso ("ideal") demandam esforços que podem ser provenientes de um substancial trabalho de governança global. 


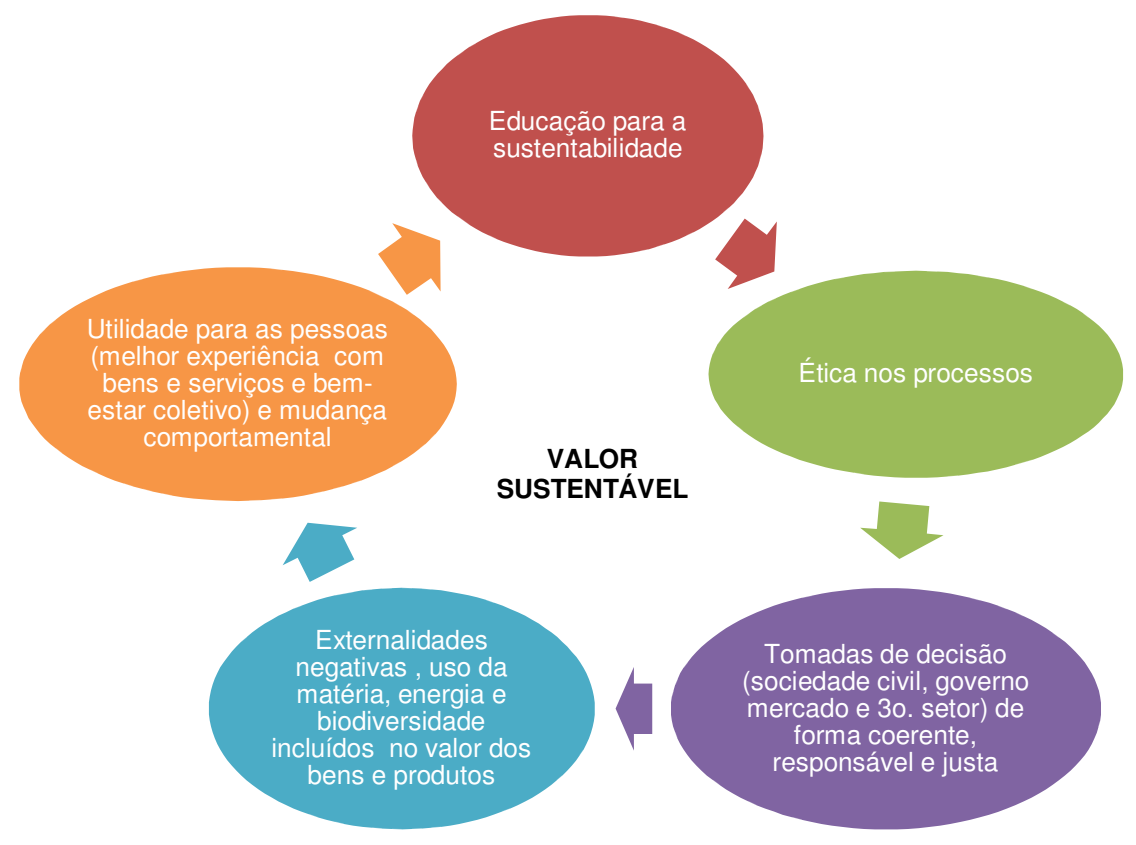

Figura 9 - Ciclo ideal de geração de valor sustentável Fonte: Elaborado por Daniela Rocco (2014).

Com relação à sustentabilidade no contexto empresarial brasileiro, um estudo publicado em 2014 pelo Núcleo de Sustentabilidade da Fundação Dom Cabral (FDC) apresentou o estado da gestão para a sustentabilidade no País. A pesquisa envolveu 602 profissionais de mais de 400 empresas de todos os setores e regiões do Brasil. Os resultados indicaram que ainda existe diferença expressiva entre discurso e prática. A sustentabilidade é considerada como importante e estratégica para as organizações, contudo, é preciso ainda criar metas, políticas e diretrizes alinhadas com essa questão (FDC, 2014). A Figura 10 expõe a síntese dos principais resultados dessa pesquisa:

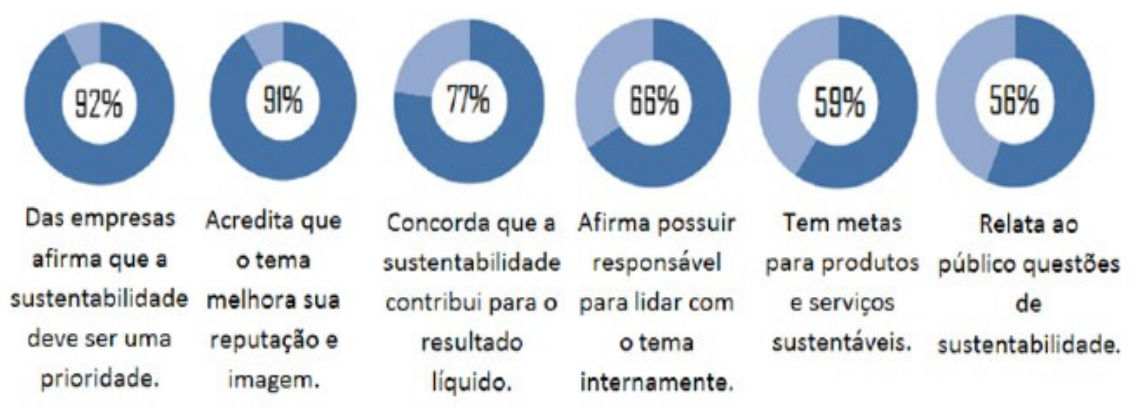

Figura 10 - Estado da gestão para a sustentabilidade no Brasil 2014 Fonte: FDC, 2014. 
Diante do que foi exposto, a discussão de valor sustentável dialoga diretamente com as ideias de Sachs $(1993 ; 2002 ; 2004 ; 2012)$ sobre desenvolvimento sustentável, que por sua vez requer uma visão de longo prazo, primordialmente pondo "[...] fim ao escândalo da desigualdade abissal nas condições e na qualidade de vida existentes hoje em cada nação e entre as nações" (SACHS, 2012, p. 9). No caso do Brasil, mesmo que ocupe a 6 posição de maior economia do mundo (STEINBRUCH, 2013), e a renda esteja se desconcentrando há mais de 15 anos graças aos recentes programas governamentais de transferências de renda, é preciso evidenciar que ainda existe exclusão social e pobreza.

Não obstante, é necessário fomentar a diversificação produtiva, gerando, assim, mais renda, emprego e riqueza para as pessoas, bem como desenvolver, concomitantemente, condições factíveis para que os setores produtivos gerem o menor impacto ambiental. Um setor produtivo em ascensão e com forte potencial para a sustentabilidade é o de serviços, e destacamos especialmente no presente estudo o turismo. A literatura revela que é inegável que esta é uma atividade econômica capaz de contribuir para o desenvolvimento sustentável dos destinos turísticos. No entanto, se no passado recente o turismo era conhecido como "indústria sem chaminés", hoje é perceptível a amplitude de impactos negativos que são gerados quando a atividade não é planejada e monitorada.

O turismo, como já foi explicitado, é uma experiência, portanto, dotada de múltiplas subjetividades aliadas ao contato concreto com uma agência, avião, carro, hotel, restaurante, mar, museu, cachoeira, montanha, centros de informação, entre outros. O valor pago por uma viagem (oferta) nem sempre é igual/proporcional ao valor de uma experiência (consumo), que pode ser positiva ou negativa. Neste contexto, Valduga (2008, p. 13) afirma que "[...] o produto turístico transcende o valor monetário estipulado pelos agentes e atores do sistema turístico, e as relações também ultrapassam a dinâmica da compra e venda".

A centralidade da atividade turística reside no fator humano, pois são as pessoas as reais provedoras da experiência turística: operadores, agentes de viagem, comissários de bordo, motoristas de táxi, recepcionistas, garçons e demais profissionais que atuam direta e indiretamente na área. Toda a dinâmica que move essa atividade especificamente está respalda no intangível, na proposta de valor (pago e simbólico) da experiência de um turista ${ }^{22}$, assim como no valor do patrimônio local que é percebido pela própria comunidade receptora. Este valor, na literatura, é nomeado como "valor turístico", que

[...] é gerado por um conjunto de relações sociais historicamente constituídas, e passa a ser compreendido não só na forma mercantil do valor ou na forma de dinheiro, mas também no conteúdo pleno de seus

\footnotetext{
${ }^{22}$ Turista: "conserva um conjunto de valores e necessidades que traz consigo" (LEMOS, 2005, p. 30).
} 
atributos e de seu processo de produção e consciência histórica (LEMOS, 2005, p. 49).

Segundo Lemos (2005), que realizou um profundo estudo sobre esse tema, valor turístico é o resultado da riqueza social produzida no tempo e espaço de um destino turístico, especialmente a partir da construção da imagem, imaginário e percepção de um patrimônio. É um processo social contínuo de agregação (em termos de atratividade e hospitalidade) e é constituído por bens naturais e coletivos e de produtos humanos. Por sua vez, essa produção é percebida pelo turista, que além de valorar monetariamente um produto/serviço turístico, pode valorar positiva e/ou negativamente parte do que é ofertado ou a totalidade da prestação de serviços (experiência a partir da oferta). Para Arbix (2007, p. 41), "a produção e a apropriação da riqueza social estão cada vez mais baseadas no conhecimento e na informação". Por ser o turismo um sistema, complexo e dinâmico per si, essa riqueza social não é somente produzida por atrativos turísticos, mas também pelo conjunto de informações que é disponibilizado por redes sociais, aplicativos e demais tecnologias. Todo esse processo contribui para a melhoria da experiência turística e, consequentemente, uma valoração positiva do sistema de forma geral.

Por ser o turismo um sistema complexo, que gera valor e é valorado, Lemos (2005) indicou quatro processos que serão listados a seguir e que possuem grande importância para o planejamento e geração de valor turístico:

1) Agregação: procura compreender como a divisão do trabalho é feita na comunidade local, além dos mecanismos pelos quais a produção do valor turístico é produzido;

2) Transformação: busca o entendimento sobre como o valor turístico é transformado em valor mercantil com diferenciação;

3) Chancelamento: visa compreender as formas que o valor turístico assume tanto para turistas quanto para a comunidade local;

4) Valorização: investiga as maneiras de se avaliar a estrutura, a conduta e o desempenho das empresas, que por sua vez valoram o capital de forma diferenciada.

Encontramos também em Lemos (2005, p. 23, grifo nosso) a relação entre valor turístico e sustentabilidade no seguinte trecho:

[...] o valor turístico, capaz de realizar a reprodução do capital diferencial dentro da reprodução ampliada do capital, de forma a obter-se variáveis e indicadores para medir o próprio impacto do turismo no processo de produção e distribuição de riquezas e, portanto, de sua sustentabilidade.

Se a questão ambiental, cultural, social e econômica do turismo é tão complexa, o debate sobre o desenvolvimento sustentável, sustentabilidade, valor sustentável e valor 
turístico corrobora para a tentativa de obter e legitimar as melhores soluções quanto ao turismo sustentável. Esta discussão especificamente consta na seção a seguir.

\subsubsection{AS DIMENSÕES DO TURISMO SUSTENTÁVEL}

Como já se sabe o turismo acarreta inevitavelmente impactos positivos e/ou negativos no território que se estabelece. Muitos destinos, produtos turísticos e prestadores de serviços turísticos não apresentam um planejamento - quando há - que estabeleça, por exemplo, os limites para que haja uma prática mais sustentável capaz de tentar maximizar, efetivamente, impactos positivos (renda, lucro, empregabilidade, etc.) e mitigar os negativos (degradação ambiental e paisagística, problemas socioculturais na comunidade local, etc.).

Desta maneira, o estabelecimento de padrões sustentáveis de desenvolvimento vem merecendo, nos últimos anos, a atenção de todos os âmbitos da sociedade. A contribuição que o turismo pode aportar a esse esforço é de grande relevância (PENA; BRASILEIRO \& SANTOS, 2010) em vista dos grandes investimentos que são feitos, do volume de pessoas que mobiliza, dos contatos que promove entre realidades e costumes de povos, etnias e grupos sociais diversos e dos empregos que pode gerar. A isso se poderia considerar o fato de que a "matéria-prima" do turismo, em grande parte, seja constituída dos recursos ambientais e culturais das comunidades onde se estabelecem os destinos turísticos (OMT, 1996).

A OMT (1996; 2005; 2012) enfatiza que o turismo sustentável ${ }^{23}$ visa atender as necessidades atuais dos turistas e das regiões receptoras, protegendo e valorizando ao mesmo tempo as oportunidades para o futuro. A esse modo de se desenvolver o turismo se associa também a gestão de todos os recursos, de tal modo que possam ser cumpridas as necessidades econômicas, sociais e estéticas, mantendo, inclusive, a integridade cultural, os processos ecológicos, a biodiversidade e os sistemas de apoio de vida. Evidentemente, o turismo sustentável não é um segmento turístico, e sua prática pode ser adotada (dadas as reais características e circunstâncias de um equipamento/serviço turístico ${ }^{24}$ ) em todos os segmentos turísticos, inclusive naqueles que não necessariamente estão vinculados à

${ }^{23}$ O conceito da OMT de turismo sustentável é: "Tourism that takes full account of its current and future economic, social and environmental impacts, addressing the needs of visitors, the industry, the environment and host communities" (OMT, 2005).

${ }^{24}$ Equipamentos e serviços turísticos "representam o conjunto de edificações, de instalações e de serviços indispensáveis ao desenvolvimento da atividade turística. Compreendem os meios de hospedagem, os serviços de alimentação, o entretenimento e diversão, o agenciamento, os transportes, a locação de veículos, os eventos, os guias, a informação e outros serviços turísticos" (BRASIL, [s.d.]). 
visitação de áreas naturais, por exemplo, turismo de compras, turismo de negócios e eventos, turismo gastronômico, entre outros ${ }^{25}$.

Vale ressaltar que existe distinção conceitual entre turismo sustentável e turismo sustentado. Costa (2013, p. 14) explica que o turismo sustentável é "[...] aquele que favorece um desenvolvimento na trajetória da sustentabilidade, na medida em que proporciona equilíbrio entre preservação de recursos naturais e promoção de crescimento econômico com inclusão social". Com relação ao turismo sustentado:

[...] é aquele que garante sua reprodução econômica e sua viabilidade por um certo prazo. Entretanto, ele poderia ser degradador dos recursos naturais e/ou ser excludente, considerando a incapacidade de oferecer oportunidades de acesso às pessoas que assim desejam, seja em seu usufruto, seja em sua produção (COSTA, 2013, p. 52).

Como já registrado, Hunter $(1997 ; 2002)$ indicou quatro estágios relacionados aos destinos turísticos. É preciso ressaltar que em todos esses estágios a sustentabilidade é transversal, além de se apresentar em distintas realidades e formas de aplicabilidade nos diferentes destinos turísticos. Assim, segundo a autora (2013), destinos diferentes devem ser tratados de forma igualmente distinta quando se deseja alcançar um turismo mais sustentável, justamente porque as realidades e especificidades de cada destino variam.

Com o intuito de criar critérios universais fundamentados na concepção do turismo sustentável, foi criado em 2009 o Global Sustainable Tourism Council (GSTC), uma organização internacional composta por mais de 80 stakeholders do turismo, entre eles empresas, governos, organizações não governamentais, universidades e representantes de comunidades. O GSTC funciona sob a égide da Organização das Nações Unidas (ONU), com apoio de suas agências OMT e PNUMA (Programa das Nações Unidas para o Ambiente). Como é um Conselho, reúne opiniões e estudos sobre o tema para promover a compreensão e adoção de práticas mais sustentáveis no turismo por todo o mundo. Para isso, compila, desenvolve e adapta técnicas e ferramentas que realmente possam fomentar o turismo sustentável, que deve ser interdisciplinar, holístico e integral. A finalidade dessa parceria com o trade turístico é estimular todos os agentes envolvidos no sistema turístico a adotarem de forma homogênea os critérios de sustentabilidade estabelecidos (OMT, 2012; GSTC, 2012).

O Critério Global de Turismo Sustentável para Destinos é composto por quatro objetivos primordiais: i) Demonstrar gestão sustentável eficaz de destino; ii) Maximizar os

\footnotetext{
${ }^{25}$ Não se pode esquecer que a sustentabilidade tem em sua dimensão cultural um componente bastante relevante para o desenvolvimento, pois, a partir do acesso à aprendizagem sobre a importância de se conservar a biodiversidade, por exemplo, pode-se, consequentemente, favorecer a tomada de consciência para a não destruição/degradação da fauna, flora e paisagem.
} 
benefícios sociais e econômicos para a comunidade local e minimizar os impactos negativos; iii) Maximizar benefícios para as comunidades, visitantes e patrimônio cultural e minimizar os impactos negativos e iv) Maximizar os benefícios para o meio ambiente e minimizar os impactos negativos. Tais objetivos possuem seus próprios critérios (no total são 45), como consta no Anexo1. Além disso, os critérios foram concebidos para que possam ser utilizados por todos os tipos e escalas de destinos turísticos.

Oliveira \& Rossetto (2013) afirmam que, embora o turismo tenha evoluído relativamente no Brasil e existam programas governamentais de estímulo ao turismo sustentável, ainda são desperdiçados os potenciais de ampliação da atividade (e consequente obtenção de benefícios), bem como é pequeno o direcionamento no tocante à sustentabilidade. Além disso, segundo os autores (2013, p. 329)

É fato que alguns dos principais destinos turísticos do país se encontram a caminho de uma condição insustentável, pois almejaram um crescimento apenas econômico. Ignoraram ou não consideraram os riscos existentes de sua própria extinção face ao descaso com que tratam o meio ambiente, ou simplesmente relegaram este a um segundo plano.

Deve-se, pois, reconhecer a pressão exercida sobre o meio ambiente, de tal modo que a atividade turística possa contribuir para a otimização de recursos econômicos com relevância social e cultural, bem como a mitigação de passivos ambientais. Teles et al. (2011, p. 10) afirmam que "aliar a prática turística aos princípios da sustentabilidade requer exercício constante por parte dos profissionais da área".

Dada a limitação do tempo para desenvolver a tese, e tomando por base que o turismo é um amplo e complexo sistema, é reconhecida a impossibilidade de analisar a sustentabilidade do turismo em sua totalidade. Embora o turismo cause impactos ambientais negativos, a exemplo do modal aéreo e terrestre, com elevadas emissões de $\mathrm{CO}_{2}$ na atmosfera, reconhecemos que existe a sustentabilidade geral (neste caso, o sistema turístico como um todo) e a sustentabilidade local, ou seja, a do destino propriamente dito. Ademais, Caldeira (2010, p. 191) alerta que "não é apenas no local de estadia do turista que o turismo sustentável se manifesta. [...] o turismo, ao longo do processo, também gera subprodutos que podem ser prejudiciais". O autor citou exemplos como embalagens descartadas, pilhas, baterias, entre outros.

O turismo já nasceu híbrido, e hoje é onipresente. Da mesma forma, é impensável planejar e gerir a atividade turística sem considerar a sustentabilidade de maneira onipresente nos processos e tomadas de decisões.

Costa (2013) alega que muitas vezes as questões vinculadas ao mercado e empresas turísticas são "abandonadas" da discussão relativa à sustentabilidade, o que é um grande equívoco, pois ambas são fatores-chave para a própria existência da prática 
turística, que, por conseguinte, necessita de uma abordagem sistêmica das quatro dimensões da sustentabilidade (ambiental, cultural, social e econômica). Vejamos alguns exemplos de turismo sustentável que correspondem a essas dimensões:

\section{- Dimensão social e econômica da sustentabilidade no turismo}

Para que haja desenvolvimento econômico dos destinos turísticos, além de agregar valor à oferta e aumentar a lucratividade do mercado, deve-se incluir benefícios promovidos via inclusão produtiva, acarretando assim, na melhoria da qualidade de vida da comunidade local receptora do turismo em termos de educação, saúde, moradia e trabalho. Neste contexto, a inclusão produtiva é entendida pela geração de trabalho formal que seja justo e digno, com possibilidade de crescimento e capacitação dos trabalhadores vinculados ao sistema turístico. Além disso, o turismo pode ser vetor de encadeamentos de negócios que estimulam o empreendedorismo local, incorporando novos atores econômicos ao longo de todo um sistema. O aspecto ambiental é incorporado a essa inclusão produtiva como vetor de conservação dos próprios espaços naturais, onde turismo se reproduz.

Um esforço direcionado para a diminuição da desigualdade social pode ser exemplificado pelo Projeto "Produção Associada ao Turismo", que ocorreu em Barreirinhas (MA), no ano de 2009. O objetivo do referido projeto foi fortalecer a cadeia do turismo local, particularmente os produtos alimentícios típicos relacionados à culinária local. Tasso, Nascimento e Assad (2009) analisaram essa experiência e constataram, entre outras questões, que, a partir da identificação das limitações nos processos produtivos vinculados ao turismo, foi possível traçar oportunidades de inserção socioeconômica para que os habitantes do município (ora desprovidos de orientações de base teórico-metodológica) pudessem otimizar as potencialidades turísticas da região. A problemática social acrescida da ambiental requer um pensamento crítico, uma vez que a riqueza de recursos naturais de uma região ou país não está associada necessariamente com a prosperidade e bem-estar da comunidade local.

\section{- Dimensão ambiental e cultural da sustentabilidade}

As preocupações e movimentos em prol do meio ambiente surgiram na década de 1960, enquanto que, na década posterior, um novo olhar foi despertado para o turismo praticado na natureza (CÂNDIDO, 2003). Com a intensificação e concentração de atividades econômicas nos grandes centros urbanos, e por se tratar de um momento em que a sociedade vivencia intensos processos de globalização, o ser humano cada vez mais busca na natureza uma valiosa oportunidade de descanso, refúgio e até mesmo contato com a 
wilderness $^{26 .}$ De maneira complementar, percebemos claramente que a experiência do homem versus natureza demanda, cada vez mais, o desejo por uma vida salutar, e as atividades de lazer e recreação no meio ambiente, com viés turístico, constituem base fundamental para a efetivação deste desejo. É a necessidade do homo ludens ${ }^{27}$ ou, quiçá, o homo turisticus, de evasão, experiência, fruição.

Para Miller (1997), a biodiversidade é o principal recurso que dá respaldo ao ecoturismo e turismo rural. Almeida (1999) atenta que a natureza se tornou "recurso turístico" mais utilizado pelas economias capitalistas, e é nesse contexto que surgiu a valorização por espaços naturais e, consequentemente, o advento de segmentos turísticos como o ecoturismo e turismo de aventura (ABETA, 2010). Vale ressaltar que esses dois segmentos turísticos estão entre os que mais crescem nacional e internacionalmente, favorecendo, por conseguinte, o aumento significativo de ofertas turísticas que propiciem experiências a partir do contato com a natureza (WEARING \& NEIL, 2001; PIRES, 2002; ABETA, 2010).

O turismo em áreas naturais pode proporcionar o pleno exercício da cidadania, a coparticipação para ações de conservação/preservação da cultura e dos próprios espaços naturais e a inclusão produtiva da comunidade local. Conforme pesquisas citadas por Honey (2009 apud Franco, 2011), o ecoturismo é considerado o mais vantajoso monetariamente em relação a outras atividades econômicas alternativas, por exemplo: 1) em três países da América Central, a estadia em função do ecoturismo rende de 18 a 28 vezes em relação a um cruzeiro marítimo; 2) nas fazendas do Quênia o turismo de natureza selvagem é 50 vezes mais lucrativo em relação à pecuária; 3) estima-se que um leão e uma arara que estejam livres geram, pela atividade turística, 575 mil dólares/ano e 4.700 dólares/ano, respectivamente; 3) Na África do Sul, precisamente em Bophuthatswana, a pecuária poderia gerar 80 empregos, enquanto que 1.200 empregos poderiam ser criados por meio da manutenção de uma reserva de caça para fins de visitação; 4) estima-se que o ecoturismo seja 60 vezes mais lucrativo que a pecuária e 5) em Santa Lucia, na África do Sul, acreditase que o ecoturismo seja mais rentável em relação à atividade mineradora da região.

Com relação à cultura, o turismo

desencadeia muitas associações positivas: como catalisador de negócios locais, de desenvolvimento do setor de serviços e do aumento da demanda cultural, garantindo ainda a viabilidade de muitos projetos culturais que se mostrariam insustentáveis, caso dependessem apenas da demanda local (Pardo); como promotores do encontro de ideias e diversidades (Strickland);

\footnotetext{
${ }^{26}$ Região propícia para observar a natureza praticamente em seu estado original (NASH, 1989).

${ }^{27} \mathrm{O}$ homo ludens foi um termo criado por Johan Huizinga. Esse autor lançou na década de 1930 o livro "Homo Ludens: o jogo como elemento da cultura", cujo objetivo central foi realizar uma discussão histórica explicitando que o jogo é uma característica culturalmente inata ao homem. De todo modo, para este trabalho, o termo homo ludens está sendo aplicado no sentido de necessidade de lazer, diversão, descanso e evasão do ser humano.
} 
e por funcionarem como um espelho de traços da cidade, com os quais a população local está acostumada demais para perceber (Kageyama) (REIS \& KAGEYAMA, 2011, p. 28).

No mundo existem diversos casos exitosos de valorização da cultura e transformação urbana e social, como as cidades espanholas Bilbao e Barcelona e Medellín na Colômbia. No Brasil, vale destacar o caso de Guaramiranga (CE). Este município, de aproximadamente cinco mil habitantes, passou a promover o "Festival de Jazz e Blues de Guaramiranga". Antes da realização deste evento, o cenário não era favorável para os grandes talentos cearenses da música instrumental. Além disso, o interior do estado era em geral desconhecido pela maioria dos brasileiros e o próprio carnaval dos cearenses era "importado" de outros estados e seus ritmos musicais característicos. Hoje o evento é um grande sucesso e é valorizado e apropriado pela comunidade local, que criou a AAGUA (Associação dos Amigos de Guaramiranga). Os principais aspectos e impactos positivos são: $70 \%$ da programação cultural é gratuita, promove-se a identificação de talentos musicais e fomenta-se a economia local por meio do turismo, na medida em que casas e fazendas se tornam pousadas, restaurantes, cafés, entre outros negócios. Atualmente os indicadores econômicos, turísticos, sociais e culturais da região são melhores em relação ao passado e impactam positivamente na economia até do estado (REIS \& MARCO, 2009).

Diante do exposto, é possível afirmar que desde a publicação na década de 1980 do Relatório Brundtland, iniciativas inovadoras no campo da sustentabilidade vêm sendo criadas e desenvolvidas em múltiplos setores produtivos. Inclusive, no DNA das empresas nascentes já se verifica a preocupação com o meio ambiente e pessoas (do ponto de vista sociocultural), algo que não existia antes. Por isso, a busca pelo conhecimento no contexto do paradigma da "ciência para a sustentabilidade", faz-nos refletir que o processo de inovação vinculada à sustentabilidade no turismo requer uma atenção especial, de tal modo que impactos negativos sejam mitigados e porque não evitados. Essa inovação de caráter específico é um caminho, e começamos a atravessá-lo a partir da próxima "ponte": o capítulo 2. 


\section{INOVAÇÃO PARA A SUSTENTABILIDADE: OPORTUNIDADES E DESAFIOS}

PARA OS DESTINOS TURÍSTICOS BRASILEIROS

Tags: sistema nacional de inovação, ecossistema de inovação,
marcos regulatórios, competitividade, competitividade turística,
pilares, inovação sustentável, eco-inovação, inovação ambiental,
inovação ambientalmente sustentável, inovação para a
sustentabilidade, turismo.
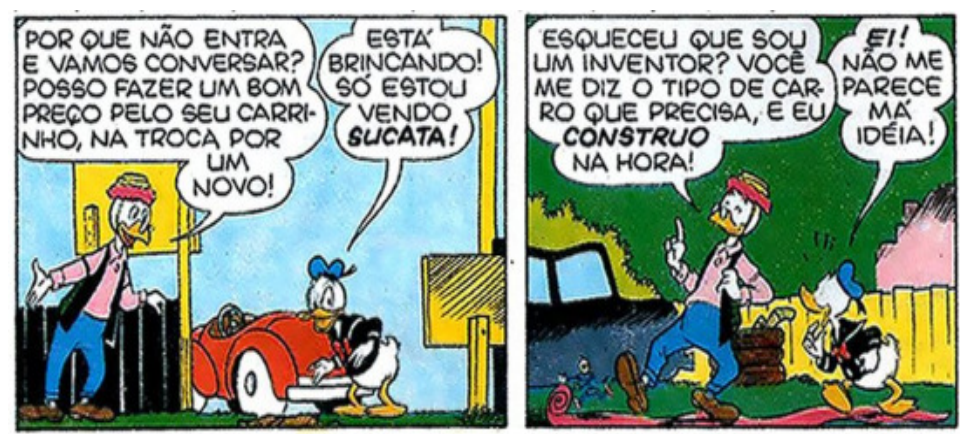

Almanaque do Prof. Pardal, O gênio da sucata, Walt Disney, 1989.

A inovação tem sido incorporada cada vez mais nos processos produtivos e decisórios no mundo todo como fator-chave de competitividade, especialmente no turismo. No caso da competitividade, escolhemos focar nos pilares inovação e sustentabilidade, uma vez que a interface real entre ambos não se encontra nos modelos mais tradicionais e citados de competitividade turística, como os de Crouch \& Ritchie e os de Dwyer \& Kim (ALVES, 2013).

Ao revisitarmos o objetivo geral desta tese, que é identificar e analisar como os destinos turísticos brasileiros adotam inovações para a sustentabilidade, consideramos a importância de se pensar a inovação diferentemente do que há grande recorrência na literatura, retratada, por vezes, pela gestão de custos e riscos, criação industrial de produtos, implementação de tecnologias, entre outros. Não que isso não seja relevante, porém o verdadeiro diálogo entre inovação e sustentabilidade ainda é incipiente, e é sobre esse "novo" olhar para a inovação que discorremos adiante. 


\title{
2.1 INOVAÇÃO: CONSTRUINDO CONCEITOS E DESCONSTRUINDO MITOS E
}

\section{FALÁCIAS}

O conceito de inovação é diferente de invenção ${ }^{28}$, ideia, descobrimento, novidade e criação, muito embora, possa abarcá-los. Etimologicamente, a palavra inovação é proveniente do latim in e novare (realizar algo que seja novo, alterar). Com relação à distinção entre inovação e invenção, Freeman (1974, p. 22) assim argumenta:

\begin{abstract}
Uma invenção é uma ideia, um esboço ou um modelo para um novo ou aperfeiçoado dispositivo, produto, processo ou sistema. Tais invenções podem frequentemente (não sempre) ser patenteadas porém não conduzem necessariamente a inovações técnicas. Na verdade a maioria não faz isso. Uma inovação no sentido econômico é conseguida apenas com a primeira transação comercial envolvendo o novo produto, processo, sistema ou dispositivo, embora a palavra seja usada também para descrever o processo todo.
\end{abstract}

Joseph A. Schumpeter (1883-1950) foi um dos pioneiros ${ }^{29}$ na discussão do que atualmente se entende por inovação. Entre outras contribuições, ele distinguiu inovação de invenção (FREEMAN, 1974) e cunhou no século XX a noção de "destruição criadora". Isto significa que a economia capitalista se renova e é impulsionada em função de novas tecnologias que são incorporadas no mercado, favorecendo, consequentemente, a "destruição" da tecnologia que antecede a atual (SCHUMPETER, 1961). O Quadro 4 abaixo apresenta sinteticamente a evolução do entendimento de inovação por meio dos seus principais precursores e pensadores.

\footnotetext{
${ }^{28} \mathrm{Nem}$ toda invenção é inovação, mas (quase) toda invenção é inovação (quando levada ao mercado, a invenção se torna inovação). Segundo o ditado popular, "a necessidade é mãe da invenção", e para Arbix (2007), a inovação sempre acompanha a história da humanidade. No entanto, nem sempre a necessidade foi a maior motivadora para a criação de invenções e, consequentemente, inovações. Podemos citar exemplos como a curiosidade do ser humano e o desejo de se propiciar mais conforto e diversão (produtos/serviços que não necessariamente são indispensáveis à sobrevivência humana).

${ }^{29}$ Lazzarotti, Dalfovo \& Hoffmann (2010) afirmam que Walker (1888) e Andrews (1890) foram precursores quanto ao uso do conceito de inovação que remete a uma noção de algo inusitado. Entretanto, os autores (2010, p. 1) defendem que Schumpeter foi o mais influente dentre eles, sendo até mesmo considerado como o "profeta e pai dos estudos da inovação".
} 


\section{CRONOLOGIA TEÓRICO/ORGANIZAÇÃO/ PESQUISADOR}

\begin{tabular}{|c|c|c|c|}
\hline Séc. XVIII & Adam Smith & $\begin{array}{l}\text { A relação entre a acumulação de } \\
\text { capital e tecnologia da manufatura } \\
\text { associada com a mudança tecnológica, } \\
\text { a divisão do trabalho, o crescimento da } \\
\text { produção e a competição. }\end{array}$ & (STAL, 2006) \\
\hline Séc. XIX & David Ricardo & $\begin{array}{l}\text { Consequências da mecanização que } \\
\text { influenciam no capital e no emprego. }\end{array}$ & (STAL, 2006) \\
\hline Séc. XIX & List & $\begin{array}{l}\text { Pioneiro ao criar o conceito de } \\
\text { "investimento intangível", resultante do } \\
\text { acúmulo de descobertas, invenções, } \\
\text { melhorias, aperfeiçoamentos e } \\
\text { esforços das gerações anteriores. } \\
\text { Segundo List, isso constitui o "capital } \\
\text { intelectual da raça humana". }\end{array}$ & (STAL, 2006) \\
\hline
\end{tabular}

intelectual da raça humana".

Maior aprofundamento sobre estudos relacionados à tecnologia. Estudou os efeitos positivos da inovação de processo e produto. Divisão da mudança tecnológica em 3 categorias:

Séc. $X X \quad$ Schumpeter invenção, inovação e difusão. Abordou também 0 conceito de inovação incremental e cunhou o conceito de "destruição criadora". Freeman (1974) atribui a Schumpeter a distinção entre inovação e invenção.
REFERÊNCIAS

(FREEMAN, 1924)

(SCHUMPETER, 1961)

(STAL, 2006)
Focou no Sistema Nacional de Inovação na empresa.
(FREEMAN, 1924) (STAL, 2006)

Manual Frascati: nele consta a definição de pesquisa e desenvolvimento. A finalidade era padronizar os conceitos.

"A inovação essencialmente está relacionada à descoberta, experimentação, desenvolvimento, imitação e adoção de novos produtos, novos processos de produção e novos arranjos organizacionais" Trouxe o conceito de "paradigma tecnológico".

Manual de Oslo: diferencia inovação tecnológica e atividade inovativa. Em 2005 optou-se por remover a palavra "tecnológica" do conceito geral de inovação.

A PINTEC (Pesquisa de Inovação) é desenvolvida pelo Instituto Brasileiro de Geografia e Estatística (IBGE) e possui respaldo metodológico no Manual de Oslo. Se antes a PINTEC também considerava a "inovação tecnológica", conforme a Nota técnica do IBGE de 2008 passou-se a considerar as inovações não tecnológicas (mesma justificativa da OCDE).

Quadro 4 - Evolução dos conceitos de inovação

Fonte: Elaborado e adaptado por Daniela Rocco (2014). 
Da mesma forma que os conceitos evoluíram com o passar dos anos, os modelos de inovação também. Barbieri \& Álvares (2014) apresentam no Quadro 5 as seis gerações de modelos de inovação e os principais autores.

\begin{tabular}{|c|c|c|c|c|c|c|}
\hline Geração & $\begin{array}{l}\text { Rothwell } \\
(1994)\end{array}$ & $\begin{array}{c}\text { Sweening; } \\
\text { Davies (1995) }\end{array}$ & $\begin{array}{c}\text { Marinova e Phillimore } \\
(2003)\end{array}$ & Tidd (2006) & $\begin{array}{l}\text { Berkhout et } \\
\text { al. } \\
(2006)\end{array}$ & $\begin{array}{l}\text { Bochm; } \\
\text { Frederick } \\
\text { (2010) }\end{array}$ \\
\hline $1^{\mathrm{a}}$ & \multicolumn{2}{|c|}{$\begin{array}{l}\text { Modelo linear empurrado pela } \\
\text { tecnologia (technology push) }\end{array}$} & $\begin{array}{c}\text { Caixa preta (black box } \\
\text { model) }\end{array}$ & $\begin{array}{l}\text { Technology } \\
\text { push }\end{array}$ & $\begin{array}{l}\text { Technology } \\
\text { push }\end{array}$ & $\begin{array}{l}\text { Technology } \\
\text { push }\end{array}$ \\
\hline $2^{\mathrm{a}}$ & \multicolumn{2}{|c|}{$\begin{array}{c}\text { Modelo linear puxado pela } \\
\text { demanda (market pull, need } \\
\text { pull) }\end{array}$} & $\begin{array}{l}\text { Lineares, (inclusive } \\
\text { technology push e } \\
\text { need pull) }\end{array}$ & Need pull & Market pull & Market pull \\
\hline $3^{\mathbf{a}}$ & \multicolumn{2}{|c|}{$\begin{array}{l}\text { Modelo combinado (coupling } \\
\text { model) }\end{array}$} & $\begin{array}{l}\text { Interativos (inclusive o } \\
\text { combinado e o } \\
\text { integrado) }\end{array}$ & $\begin{array}{c}\text { Modelo } \\
\text { combinado } \\
\text { (coupling } \\
\text { model) }\end{array}$ & $\begin{array}{l}\text { Modelo } \\
\text { combinado }\end{array}$ & $\begin{array}{l}\text { Gestão de } \\
\text { portfolio }\end{array}$ \\
\hline $4^{\mathrm{a}}$ & \multicolumn{2}{|c|}{$\begin{array}{l}\text { Modelo integrado (integrated } \\
\text { model) }\end{array}$} & $\begin{array}{l}\text { Sistêmicos (inclusive } \\
\text { em rede e sistema } \\
\text { nacional de inovação) }\end{array}$ & $\begin{array}{l}\text { Modelo linear } \\
\text { paralelo }\end{array}$ & $\begin{array}{l}\text { Modelo cíclico } \\
\text { (cyclic } \\
\text { innovation } \\
\text { model) }\end{array}$ & $\begin{array}{l}\text { Gestão } \\
\text { integrada }\end{array}$ \\
\hline 5 & $\begin{array}{l}\text { Modelo } \\
\text { paralelo e } \\
\text { integrado }\end{array}$ & $\begin{array}{l}\text { Sistemas } \\
\text { integrados e } \\
\text { em rede }\end{array}$ & Modelo evolucionário & $\begin{array}{l}\text { Sistemas } \\
\text { integrados e } \\
\text { em rede }\end{array}$ & & $\begin{array}{l}\text { Integração } \\
\text { sistêmica }\end{array}$ \\
\hline $6^{a}$ & & & Meio inovador & & & $\begin{array}{l}\text { Integração } \\
\text { em rede }\end{array}$ \\
\hline
\end{tabular}

Quadro 5 - Modelos de inovações (da primeira à sexta geração)

Fonte: Barbieri \& Álvares (2014)

A primeira geração é marcada pela linearidade e as estratégias são "empurradas" pela tecnologia (technology push). Esse modelo surgiu com Schumpeter, iniciando-se com invenções e encerrando-se com o êxito mercadológico. Nos modelos de segunda geração (market pull), também com característica linear, o processo é inverso: é o mercado que define as inovações. De forma um pouco mais complexa, os modelos de terceira geração são resultantes da combinação (coupling model) dos dois modelos lineares (push versus pull). Trata-se da produção simultânea de P\&D (Pesquisa e Desenvolvimento), manufatura e marketing. Quanto à quarta geração, a linearidade já não é mais o foco, uma vez que se passou a valorizar a interação entre diversas atividades e setores. A quinta geração avança na perspectiva não linear e destaca a intensidade e flexibilidade das interações entre redes de colaboração e sistemas integrados com o intuito de se gerar inovações de forma rápida e contínua, bem como gerenciar a complexidade e incertezas. Por fim, os modelos de sexta geração, baseados no "meio inovador", representam uma abordagem ainda mais avançada em relação às gerações anteriores, pois consideram criatividade, relações de confiança, conhecimentos genéricos e específicos, questões socioculturais, entre outros. O modelo de sexta geração mais difundido recentemente é o de Chesbrough (2003), relativo ao open 
innovation (inovação aberta). A estratégia de inovação, segundo este modelo, ocorre por meio da interação entre colaboradores da própria empresa e externos a ela (OLIVEIRA, 2012; BARBIERI \& ÁLVARES, 2014). Trott e Hartmann (2009) criticam o open innovation de Chesbrough porque essencialmente este modelo não apresenta nada de novo, principalmente porque é um tema que já vem sendo discutido há $40 \operatorname{anos}^{30}$.

Lara (2013) destaca, tal como mostra o Quadro 6, que a inovação possui quatro eras, quais sejam: Primeira era (inventores solitários); Segunda era (laboratórios corporativos); Terceira era (start-ups suportadas por capital de risco) e Quarta era (catalisadores corporativos). Como é possível perceber por meio do quadro abaixo, a inovação evoluiu bastante ao longo dos séculos e adquiriu hoje um nível altíssimo de complexidade, assim como os conceitos de inovação e seus respectivos modelos.

\begin{tabular}{|c|c|c|c|}
\hline Primeira Era & Segunda Era & Terceira Era & Quarta Era \\
\hline $\begin{array}{l}\text { Inventores } \\
\text { Solitários }\end{array}$ & $\begin{array}{l}\text { Laboratórios } \\
\text { Corporativos }\end{array}$ & $\begin{array}{l}\text { Start-ups suportadas por } \\
\text { Capital de Risco }\end{array}$ & Catalisadores Corporativos \\
\hline $\begin{array}{l}\text { Dos primórdios até } \\
1915 . \\
\text { Inovações ligadas aos } \\
\text { inventores por trás } \\
\text { delas. } \\
\text { Exemplos: lâmpada } \\
\text { (Thomas Edison); } \\
\text { avião (irmãos Wright); } \\
\text { linha de produção } \\
\text { (Henry Ford). }\end{array}$ & $\begin{array}{l}\text { De } 1915 \text { a meados da } \\
\text { década de } 1950 \text {. } \\
\text { Aumento da complexidade } \\
\text { e custos para inovar } \\
\text { moveu essa tarefa para } \\
\text { dentro das empresas. } \\
\text { Perspectivas de longo } \\
\text { prazo e baixa burocracia } \\
\text { n as co r p o r a çõ es } \\
\text { criaram a mbientes } \\
\text { propícios e tolerantes a } \\
\text { experimentações. } \\
\text { Exemplos: laboratórios } \\
\text { de P\&D de empresas } \\
\text { como DuPont; Procter \& } \\
\text { Gamble e IBM. }\end{array}$ & $\begin{array}{l}\text { De meados da década de } \\
1950 \text { até } 2000 \\
\text { Empresas cresceram muito } \\
\text { e se tornaram burocráticas; } \\
\text { impróprias para "rebeldes" } \\
\text { inovadores - que preferiam } \\
\text { a brir suas próprias } \\
\text { empresas. } \\
\text { Surgimento da indústria } \\
\text { de Capital de Risco, que } \\
\text { financiou o crescimento e } \\
\text { o ganho de escala dessas } \\
\text { empresas. } \\
\text { Exemplos: DEC; Apple; } \\
\text { Microsoft; Cisco; Facebook; } \\
\text { Google; Amazon. }\end{array}$ & $\begin{array}{l}\text { Desde } 2000 \\
\text { Intensificação da globalização. } \\
\text { Ambientes extremamente } \\
\text { competitivos. Ciclos de vida } \\
\text { mais curtos. } \\
\text { Desafios crescentes para as } \\
\text { start-ups. Oportunidades para } \\
\text { grandes corporações. } \\
\text { Ecossistemas de inovação } \\
\text { lidera dos por grandes } \\
\text { corporações. } \\
\text { Maioria das inovações envolve } \\
\text { novos modelos de negócios. } \\
\text { Exemplos: iPhone (Apple); } \\
\text { Android (Google); Starbucks, } \\
\text { Pureit (Unilever); SmartCities } \\
\text { (IBM). }\end{array}$ \\
\hline
\end{tabular}

Quadro 6 - Quarta era da Inovação

Fonte: Lara (2013, p. 03).

Para Cechin (2010), as atividades humanas podem ser divididas em três grandes eras tecnológicas e que determinaram o aumento do poder do homem sobre o ambiente: domínio do fogo, surgimento da agricultura e invenção da máquina a vapor. Nesta lógica de Cechin (2010), consideramos que vale a pena acrescentar uma quarta era tecnológica, que é a criação da internet, mesmo porque vivemos atualmente no "mundo d.i.", tal como denomina “Joi" Ito (Diretor do MIT Media Lab).

${ }^{30}$ Trott e Hartmann (2009) citam: Carter \& Williams (1959); Allen (1969); Tilton (1971); Griffithsd \& Pearson (1973); Allen (1977); Pearson et al. (1979); Mowery (1983); Rothwell \& Zegveld (1985) e Cohen \& Levinthal (1989). 
A definição mais clássica de inovação é a do Manual de Oslo, produzido pela Organização para Cooperação Econômica e Desenvolvimento (OCDE) e Eurostat, e se refere à

[...] implementação de um produto (bem ou serviço) novo ou significativamente melhorado, ou um processo, ou um novo método de marketing, ou um novo método organizacional nas práticas de negócios, na organização do local de trabalho ou nas relações externas" (OCDE, 2005, p. $55)$.

Entendemos que a inovação, embora assuma múltiplos conceitos na literatura - pois é uma "palavra-valise" (que comporta diversos sentidos) (ARBIX, 2007) -, é um processo sistêmico, uma prática, uma estratégia. É o fazer diferente para fazer melhor, pois ela se caracteriza pelo uso mercadológico e acadêmico ao criar o diferente ou melhorar o que já existe, mudar o status das coisas, dos paradigmas, das tecnologias, das formas institucionais, dos processos, do design e da função dos produtos e serviços oferecidos até o momento. A inovação como um processo e não apenas como uma coisa, um objeto, algo imóvel. Ela cria valor para as pessoas e pode contribuir para a sustentabilidade, embora, paradoxalmente, gera também impactos desastrosos sobre as pessoas e o ambiente.

Toda inovação deve ser comercializável (para deixar de ser invenção), logo, são produtos e serviços levados ao mercado (OCDE, 2004; 2005). Por isso distinguem-se inovações de processo (modo de fazer, procedimentos) e de produto (mercadoria ou serviço novo ou diferente), assumindo desde características muito simples até com altíssimos níveis de investimento, sofisticação e uso tecnológico. Além disso, Rogers (1995) ensina que a mesma inovação, que se difunde por um processo sistêmico através de canais de comunicação, pelo tempo e de acordo com as relações sociais, pode ser desejável para uma pessoa e em uma determinada situação, contudo, pode ser indesejável para outra pessoa. Analogamente, o que pode ser inovação para uma pessoa, empresa, território, pode não ser para outros por duas razões básicas: i) não é o perfil de uma empresa, não atende um território e não é necessário/desejável para uma pessoa e ii) a inovação, mesmo sendo desejável/necessária, ainda não foi implementada por uma empresa. Exemplo: empresas norte-americanas que lançaram uma determinada tecnologia, mas que só vai chegar ao Brasil anos depois (e vice-versa).

A literatura indica que existem na literatura essencialmente três formas de inovação, quais sejam:

i) incremental: representa melhorias incrementais em um produto/serviço. Para Arbix (2007, p. 109) "[...] são as que melhoram, adaptam, refinam ou aperfeiçoam um bem a partir de tecnologias e produtos maduros e estabelecidos". 
ii) radical ou disruptiva: este tipo de inovação desloca a cadeia de produção de bens e serviços. As inovações radicais "[...] são as que provocam descontinuidades no mercado e na tecnologia estabelecida, simultaneamente [...]. Quando ocorrem, deflagram um processo de destruição criativa, com a segregação ou mesmo supressão da infra-estrutura (sic) estabelecida" (ARBIX, 2007, p. 109).

iii) aberta: constitui uma rede aberta de compartilhamento de informações, envolvendo diversos atores no processo de inovação, seja ela incremental e/ou disruptiva (CHESBROUGH, 2003; ARBIX, 2007; BESSANT \& TIDD, 2009). Se antes a inovação era fechada, pautada, sobretudo, no ambiente interno de produção de uma empresa e/ou de um laboratório, hoje ela tem se tornado cada vez mais aberta. Inclusive, somam-se nesse processo os consumidores que contribuem para a melhoria de um produto/serviço. Eles se tornam, portanto, coprodutores daquilo que visa beneficiá-los direta e indiretamente.

\section{Box 1 - Inovação aberta}

A necessidade e curiosidade movem o ser humano, o que o levou a, desde o "tempo das cavernas", transformar a realidade que vive. Os primórdios da inovação estão vinculados a invenções como a roda, fogo e escrita. Com o passar do tempo. o homem, que é naturalmente um ser evolucionário e revolucionário, passou a reunir em um ambiente fechado um local para a criação de invenções. Isto fez surgir a primeira "fábrica de invenções", assim intitulada por seu dono: Thomas Edison, o criador da lâmpada incandescente e outras invenções. Hoje o processo de inovação não deve estar apenas concentrado em laboratórios ou espaços de invenção como os do professor Pardal, personagem das histórias em quadrinhos famoso por suas engenhocas. A inovação deve preferencialmente ocorrer além das fronteiras do ambiente interno das empresas, com a interação de diversos atores. Caso é o da Philips, que em 2003 eliminou literalmente seu grandioso centro de pesquisa para investir em processos abertos de inovação colaborativa. Henry Chesbrough disseminou no início deste século o conceito de inovação aberta, e se antes a inovação se concentrava nos gênios e "inventores" como Santos Dumont e Edison, agora ela é resultado proveniente da interação de vários colaboradores.
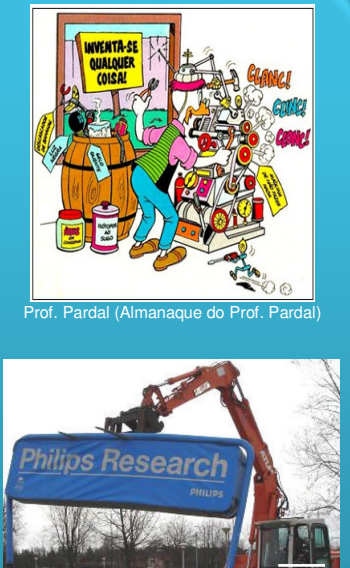

Philips Research (Ronald Wolf)

Christensen (2000) propôs também duas maneiras de se qualificar as formas de inovação: inovações mantenedoras (são capazes de melhorar o desempenho de um produto/serviço) e as inovações rompedoras (são resultantes de piores desempenhos no curto prazo). Já para Gallouj (2007) as inovações incrementais são de back-office, enquanto que as inovações radicais são de front-office.

Quanto aos tipos de inovação, selecionamos aqueles que estejam em sintonia com a metodologia proposta no capítulo 3. O Manual de Oslo (2005) define quatro tipos de inovação, que são: de produto, de processo, de marketing e organizacional. Contudo, no Quadro 7 abaixo apresentamos mais quatro tipos de inovação: de serviço, de modelo de negócio, tecnológica e inovação social. 
Existem autores que tipificam, ainda, a inovação no contexto do meio ambiente, como é o caso da inovação sustentável, a inovação verde e a inovação ambiental. Na seção 2.4 deste capítulo problematizaremos esses conceitos com maior profundidade. No entanto, desde já ressaltamos que a inovação para a sustentabilidade, o tema-chave desta tese, não é um tipo de inovação, e sim um processo transversal (ou que pelo menos deveria ser) a todos os tipos de inovação, inclusive nesses indicados no quadro a seguir:

\begin{tabular}{lll}
\hline TIPO DE INOVAÇÃO & CONCEITO REFERÊNCIA
\end{tabular}

\begin{tabular}{|c|c|c|}
\hline Produto & $\begin{array}{l}\text { "é a introdução de um bem ou serviço novo ou } \\
\text { significativamente melhorado no que concerne a suas } \\
\text { características ou usos previstos. Incluem-se melhoramentos } \\
\text { significativos em especificações técnicas, componentes e } \\
\text { materiais, softwares incorporados, facilidade de uso ou outras } \\
\text { características funcionais". }\end{array}$ & (OCDE, 2005, p. 57) \\
\hline Processo & $\begin{array}{l}\text { "é a implementação de um método de produção ou distribuição } \\
\text { novo ou significativamente melhorado. Incluem-se mudanças } \\
\text { significativas em técnicas, equipamentos e/ou softwares". }\end{array}$ & (OCDE, 2005, p. 58) \\
\hline Marketing & $\begin{array}{l}\text { "é a implementação de um novo método de marketing com } \\
\text { mudanças significativas na concepção do produto ou em sua } \\
\text { embalagem, no posicionamento do produto, em sua promoção } \\
\text { ou na fixação de preços". }\end{array}$ & (OCDE, 2005, p. 59) \\
\hline Organizacional & $\begin{array}{l}\text { "é a implementação de um novo método organizacional nas } \\
\text { práticas de negócios da empresa, na organização do seu local } \\
\text { de trabalho ou em suas relações externas". }\end{array}$ & (OCDE, 2005, p. 61) \\
\hline Serviços & $\begin{array}{l}\text { A inovação de serviços é a mudança gerada a partir de um } \\
\text { processo inovador que envolve características técnicas } \\
\text { (materiais e imateriais) e competências do prestador de serviços } \\
\text { ou do cliente, gerando, assim, valores de uso e utilidades para o } \\
\text { cliente. }\end{array}$ & $\begin{array}{l}\text { Adaptado de Gallouj } \\
(2007)\end{array}$ \\
\hline Modelo de negócio & $\begin{array}{l}\text { "Nós definimos o modelo de negócios de uma empresa como } \\
\text { um sistema de atividades interligadas e interdependentes que } \\
\text { determina a forma como a empresa "faz negócios" com seus } \\
\text { clientes, parceiros e fornecedores". } \\
\text { "Um modelo de negócio inovador pode criar um novo mercado } \\
\text { ou permite que uma empresa crie e explore novas } \\
\text { oportunidades em mercados existentes". } \\
\text { O modelo de negócio inovador, segundo os autores, pode } \\
\text { ocorrer de três formas: i) mudança no conteúdo das atividades; } \\
\text { ii) mudança na estrutura das atividades (exemplo: estrutura de } \\
\text { custos, financeira, clientes, entre outros) e governança (relação } \\
\text { com os stakeholders). }\end{array}$ & $\begin{array}{l}\text { (AMIT \& } \begin{array}{r}\text { ZOTT, } \\
2012, \\
\text { nossa) }\end{array} \quad \text { tradução } \\
\end{array}$ \\
\hline Tecnológica & $\begin{array}{l}\text { "A inovação tecnológica é caracterizada pela presença de } \\
\text { mudanças tecnológicas em produtos (bens ou serviços) } \\
\text { oferecidos à sociedade, ou na forma pela qual produtos são } \\
\text { criados e oferecidos (que é usualmente denominada de } \\
\text { inovação no processo). Inovações tecnológicas em produto e } \\
\text { processo evidentemente não se excluem mutuamente; pelo } \\
\text { contrário, podem se combinar, como, por exemplo, na } \\
\text { comercialização de DVDs (produto inovador) pela Internet } \\
\text { (processo inovador)". }\end{array}$ & $\begin{array}{l}\text { (PLONSKI, 2005, p. } \\
27)\end{array}$ \\
\hline Inovação social & $\begin{array}{l}\text { "é concebida como o conjunto de atividades que pode englobar } \\
\text { desde a P\&D até a introdução de novos métodos de gestão da } \\
\text { força de trabalho, tendo como objetivo a disponibilização de um } \\
\text { novo bem ou serviço para a sociedade. Faz referência ao } \\
\text { conhecimento intangível, tácito ou codificado relacionados à } \\
\text { satisfação das necessidades sociais". }\end{array}$ & $\begin{array}{l}\text { (FREITAS et al., } \\
\text { 2012, p. 368) }\end{array}$ \\
\hline
\end{tabular}


Com base no Quadro 7 é possível reconhecer lacunas entre alguns conceitos, como é o caso da inovação de processo, de marketing e organizacional, publicados pela OCDE (2005). Estes conceitos não explicitam que é possível também a introdução de uma melhoria significativa de um produto/serviço já existente. Por outro lado, tal como foi citado no conceito de produto da própria OCDE (2005), a inovação não é necessariamente a implementação de algo novo.

Como pôde ser visto, a inovação está vinculada a produtos, processos, recursos e estratégias, porém Rao e Chuán (2012) questionam no livro "Innovación 2.0" por que quando se fala sobre inovação nos esquecemos das pessoas. Ora, é o fator humano o maior provedor do conhecimento e que propicia, portanto, a criação e desenvolvimento de inovações. Se para Arbix (2007, p. 149) a "inovação carrega sempre uma história passada e uma história futura", isso revela que a inovação também é produto de uma construção social.

Gallouj (2007) explica que a economia contemporânea é concomitantemente economia de serviços e economia de inovação. Entretanto, existe uma relação paradoxal: essa economia de inovação por vezes não considera a importância dos serviços, como se estes ocorressem paralelamente ao mundo das inovações tecnológicas e da produção industrial. Essa relação paradoxal pode ser compreendida, como já foi mencionado no capítulo 1, a partir das teorias do pensamento clássico que ainda hoje estão presentes, na medida em que a produção da riqueza é, majoritariamente, proveniente da indústria.

Para o autor (2007), existem as "enquetes subordinadas" (os serviços são enquadrados na mesma lógica da inovação gerada pela indústria, como é o caso das definições da OCDE, por meio do Manual de Frascati e Manual de Oslo) e as "enquetes autônomas" (embora sejam raras, o objetivo geral é considerar as características específicas da inovação nos serviços). Um esforço para distinguir a inovação gerada pela indústria e pelos serviços estimulou a criação de quatro tipos de inovação relacionados aos serviços, uma vez que os tipos de inovação citados na literatura em geral são, para Gallouj (2007), muito focados na tecnologia industrial. Gallouj (2007, p. 18) propôs, então, esses quatro conceitos:

inovação do produto-serviço: tomada em uma acepção suficientemente larga para permitir captar, ao mesmo tempo, produtos materiais e "imateriais" (por exemplo, uma fórmula de treinamento, um novo campo de consultoria, etc.);

inovação do processo: ainda aí, quer se trate de sistemas técnicos ou de processos mais imateriais (como o método dos consultores);

inovação organizacional (interna): que difere da precedente na medida em que constitui a estrutura de atendimento das atividades e dos processos; 
inovação de relação externa: definida como a implantação de relações particulares com os parceiros da empresa, sejam eles clientes, fornecedores, poderes públicos ou concorrentes.

Embora a tipologia que se propõe acima seja um avanço para a reflexão teórica sobre o tema, ainda é insuficiente diante da riqueza e complexidade do setor de serviços, foco desta tese. Gallouj (2007) ressalta que é preciso refutar mitos que ainda imperam na economia contemporânea e que têm respaldo no pensamento econômico clássico, assim como criar análises integradoras de inovação que não desconsiderem a importância nem das inovações tecnológicas e nem das inovações não tecnológicas.

O livro de Rogers Everett, intitulado Diffusion of innovations, possui um dos maiores fatores de impacto quando é citada na literatura a inovação. Desde a primeira edição do livro de Rogers, em 1962, até a quarta edição, em 1995, o autor considera a inovação como sinônimo. Por muitos anos a inovação esteve equivocadamente associada como sinônimo de inovação tecnológica, tal como advogam Arbix (2007) e De Bes \& Kotler (2011), e ainda hoje encontramos essa interpretação na literatura, o que demonstra uma visão reducionista sobre o tema em questão. Outros equívocos conceituais também existem, e Plonski (2005) lista três deles: reducionismo (o centro da inovação está apenas na tecnologia); encantamento (creditar à inovação tecnológica o status de mais "espetacular") e descaracterização (considerar que quaisquer inovações são tecnológicas).

O "Manual de Oslo"31 apresentava até 2004 o conceito de inovação basicamente inspirado nos aspectos tecnológicos. Desde então essa situação mudou, e isto pode ser comprovado na $3^{\underline{a}}$ edição do referido Manual, publicado em 2005. A OCDE (2005) optou por remover a palavra "tecnológica" de suas definições justamente para acomodar melhor aqueles setores menos intensivos em P\&D (Pesquisa \& Desenvolvimento), como é o caso do setor de serviços e da indústria de transformação de baixa tecnologia. Isto está de acordo com a visão de Arbix (2007), pois afirma que no mercado existem as empresas hightech e as low-tech. Respectivamente, tais empresas fazem maiores e menores usos de tecnologia.

Segundo Arbix (2007, p. 29), a "inovação tende atualmente a se revestir de um sentido mais amplo, que abrange todos os processos capazes de transformar uma ideia em um produto ou processo com diferencial de mercado, seja na indústria, nos serviços, no comércio ou na agricultura". Esses processos de inovação citados pelo autor (2007) podem ser realizados em quatro níveis, que são: local, setorial, regional e nacional.

${ }^{31}$ Embora esta primeira versão não tenha contemplado as atividades inovadoras no âmbito dos serviços, percebe-se um esforço da OCDE para estabelecer diretrizes de coleta e utilização de dados também nesse setor (OCDE, 2005). 
No nível nacional, alguns autores (FREEMAN ${ }^{32}$, 1995; EDQUIST, 1997; PAVITT, 1999), entendendo que a inovação é um sistema, se apropriam do conceito Sistema Nacional de Inovação (SNI). O SNI é uma rede de instituições públicas e privadas que promovem diversas atividades e interagem entre si para iniciar, importar, modificar e difundir tecnologias novas (FREEMAN, 1995).

Atribui-se a Jorge Sábato as primeiras representações de SNI. Ele publicou em 1968 um modelo que ficou conhecido como "Triângulo de Sábato", que considerava o governo, as instituições de ensino/pesquisa e o sistema produtivo em um processo de inovação (STAL, 2006). Para Stal (2006, p. 19) $)^{33}$ o SNI é uma

[...] rede de instituições públicas e privadas que interagem para promover o desenvolvimento científico e tecnológico de um país. Inclui empresas, dos mais variados tipos, associações empresariais, Universidades, escolas técnicas, institutos de pesquisa, governo, agências de fomento e agências reguladoras, num esforço de geração, importação, modificação, adaptação e difusão de inovações tecnológicas.

Entretanto, modelos de sistemas (anteriores e semelhantes) também surgiram, como o Modelo da Hélice Tripla (Triple Helix) de Etzkowitz e Leydesdorff. Trata-se de um modelo focado na educação e pesquisa, tendo três atores (por isso o uso do termo "triple"): universidade, indústria e governo (ETZKOWITZ; LEYDESDORFF, 2001). Como uma "hélice", os três estão integrados e propiciam o "movimento" de inovação e desenvolvimento.

De forma complementar a essa discussão de inovação que se organiza sob forma de sistema, e considerando a escala local desse sistema, a Figura 11 abaixo expõe a representação de um processo de inovação no ambiente interno das empresas, pois são elas os loci principais da própria geração e/ou desenvolvimento de inovação. As características principais desse sistema de nível local estão relacionadas a uma estrutura de: i) inovação na empresa; ii) interação com outras empresas e instituições de pesquisa; iii) operação das empresas e suas respectivas estruturas institucionais e iv) demanda (OCDE, 2005).

\footnotetext{
32 "Há uma elegante e divertida 'polêmica' entre Freeman e Lundvall sobre a primeira referência ao conceito de sistema nacional de inovação. Lundvall $(1992$, p.16) atribui a Freeman o termo. Freeman, por sua vez, na primeira frase do artigo reproduzido na RBI atribui a Lundvall. Fagerberg, na Conferência comemorativa dos 80 anos do Freeman em 2001, desenterrou um texto de 1982 preparado para a OCDE - e não publicado - no qual o homenageado faz uma referência a "sistemas nacionais de inovação". Lundvall reproduziu o texto, mas Freeman devolve a prioridade ao grupo dinamarquês, afirmando que ouvira essa expressão durante período sabático em Aalborg, Dinamarca, no início dos anos 1980 [...]" (ALBUQUERQUE, 2004, p. 9).

${ }^{33}$ Embora Stal (2006) tenha focado em seu livro a inovação tecnológica, empobrecendo a discussão geral sobre inovação, é possível verificar que o SNI é caracteristicamente complexo, envolvendo múltiplos atores e de distintas áreas.
} 


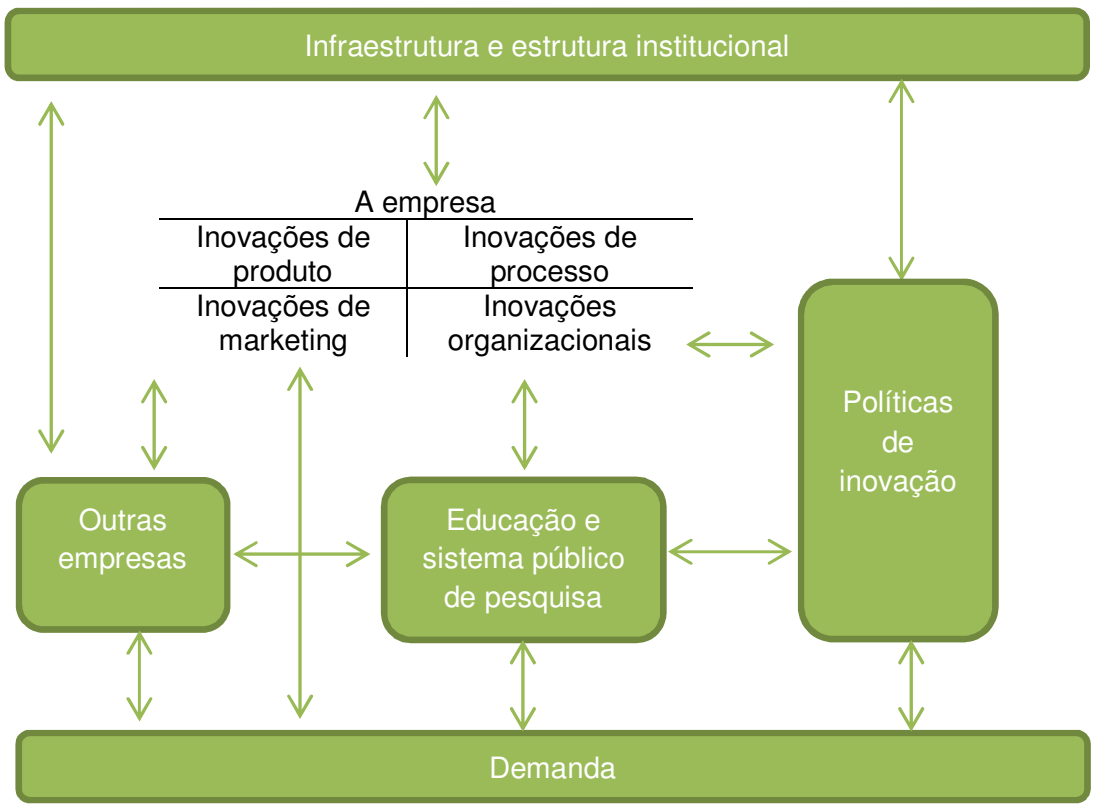

Figura 11 - Representação de processo de inovação no ambiente interno de empresas Fonte: OCDE (2005).

Para Arbix (2007), a inovação é um processo que demanda colaboração e comunicação, e isso deve ser resultado de um contínuo fluxo de informações. Consequentemente, esse processo favorece a criação e desenvolvimento de interações complexas entre indivíduos, empresas, universidades, entre outros entes que compõem o SNI de qualquer país. Para Stal (2006, p. 22) "[...] não é a debilidade de cada componente que inibe a inovação, mas a ausência de articulação entre eles e de um ambiente estimulador". De acordo com Viotti (2003), a ciência, tecnologia e inovação são componentes-chave para a competitividade e desenvolvimento de países, regiões e indústrias. São também importantes para a criação e solução de problemas sociais e ambientais. Por isso, é importante a criação e incentivo à cultura da inovação em um país, como forma de fomentar efetivamente a participação e integração dos diferentes entes públicos e privados.

Não obstante, de forma a contrapor essa perspectiva dos numerosos benefícios gerados pela inovação, Fontenelle (2012) advoga que há uma "inflação discursiva" do conceito de inovação e criatividade. A autora ressalta que os imperativos de uma inovação ininterrupta são percebidos de forma tão positiva que, aparentemente, não é possível questioná-la. Bruce Nussbaum, especialista em inovação e professor da Parsons The New School of Design, escreveu que

A "inovação" morreu em 2008, assassinada pelo uso excessivo, o mau uso, o incrementalismo e o fracasso em sua evolução. Os autores dessas más práticas foram diretores executivos, consultores, comerciantes, publicitários 
e jornalistas da imprensa de negócios que degradaram e desvalorizaram a ideia, confundindo-a com mudança, tecnologia, design, globalização, o último do último e qualquer coisa "nova". O motivo foi a obsessão por medidas, métricas e matemática, e uma demanda de previsões em um mundo imprevisível (NUSSBAUM, 2008) ${ }^{34}$.

Segundo Gorz (2005), na sociedade do século XXI por vezes há submissão e até reprodução acrítica do modelo capitalista. Embora exista uma inteligência artificial, temos abundância em capital humano, que se encontra na inteligência dos saberes, do dia-a-dia. Por outro lado, o autor (2005) se revela a favor das inovações, das tecnologias que facilitam a vida das pessoas, mas desde que não sejam ferramentas do "eu-sociedade-anônima", uma mera mercadoria e que inclusive pode incentivar o crime, como tráfico de órgãos, barriga de aluguel, entre outros. No contexto produtivo, a inovação também destrói produtos para que outros novos sejam comercializados, elimina empregos, cria produtos e serviços supérfluos/inúteis, associa-se a processos produtivos sem condições dignas de trabalho e nem sempre se apropria racionalmente dos recursos naturais.

Por ser um tema bastante amplo e complexo, invariavelmente existem mitos e falácias sobre inovação. Com o intuito de desconstruí-los, Rao e Chuán (2012, p. 20) apresentaram os principais mitos da inovação:

- A inovação é invenção.

- A inovação é só para os que trabalham com Pesquisa e Desenvolvimento (P\&D).

- A inovação é uma questão tecnológica.

- A inovação é um tema único para produtos.

- A inovação é desenvolver produtos novos.

- A inovação não funciona em minha indústria.

- A inovação não funciona em meu país.

- A inovação é uma questão de sorte.

- A inovação é cara.

- A inovação é dar aos trabalhadores $10 \%$ de tempo de trabalho livre para fazerem o que querem.

- A inovação ocorre quando compramos um software de geração de ideias.

34 "'Innovation" died in 2008, killed off by overuse, misuse, narrowness, incrementalism and failure to evolve. It was done in by CEOs, consultants, marketeers, advertisers and business journalists who degraded and devalued the idea by conflating it with change, technology, design, globalization, trendiness, and anything "new." It was done it by an obsession with measurement, metrics and math and a demand for predictability in an unpredictable world".

35 - La innovación es invención.

- La innovación es sólo para los de I + D.

- La innovación es una cuestión tecnológica.

- La innovación es un tema de únicamente de productos.

- La innovación es desarrollar de productos nuevos.

- La innovación no funciona en mi industria.

- La innovación no funciona en mi país.

- La innovación es una cuestión de suerte.

- La innovación es cara.

- La innovación es darle a todos un $10 \%$ de su tiempo de trabajo libre para hacer lo que quieran.

- La innovación ocurre cuando compramos un software de generación de ideas.

- La innovación ocurre cuando implementamos un modelo secuencial de paso a paso como proceso. 
- A inovação ocorre quando implementamos um modelo sequencial de passo-a-passo como processo.

Para Cruz (2011), o Brasil apresenta casos emblemáticos de inovação ${ }^{36}$, entretanto, as empresas que realmente inovam são ainda minoria. Isto está vinculado a um dos mitos citados acima, na medida em que empresários confundem P\&D com inovação. Para muitos deles, a inovação é incerta, investe-se elevadas quantias de dinheiro e não há segurança de retorno do investimento.

Diante do exposto, na tentativa de descontruir mitos e falácias, é preciso também explicitar o que não é inovação, e a $\operatorname{OCDE}(2005$, p. 67) listou cinco mudanças que não são consideradas inovações. São elas:

- Interromper o uso de um processo, um método de marketing ou organizacional, ou a comercialização de um produto

- Simples reposição ou extensão de capital

- Mudanças resultantes puramente de alterações de preços

- Personalização

- Mudanças sazonais regulares e outras mudanças cíclicas

- Comercialização de produtos novos ou substancialmente melhorados

Ao mesmo tempo em que as inovações são capazes de propiciar mais valor para a sociedade (como conforto, segurança, prazer e utilidade), geram, paradoxalmente, diversos impactos negativos. Os exemplos mais expressivos são: redução de mão-de-obra (reengenharia e mecanização dos processos), passivo ambiental (externalidades negativas) e incentivo contínuo ao consumo, por vezes, descontrolado.

Podemos afirmar que um dos maiores "vilões" do século XXI com relação às inovações tecnológicas são os equipamentos eletroeletrônicos (EEE). Os benefícios para seus usuários são diversos, contudo, se tomarmos como exemplo os resíduos que são gerados, sobretudo em função da obsolescência programada e culto ao consumo, as repercussões negativas sobre o ambiente e sociedade são incontáveis. Somente em um computador existem oito elementos tóxicos, tal como está exposto no Quadro 8, que também cita os respectivos efeitos no ser humano.

\footnotetext{
${ }^{36}$ Casos emblemáticos: Petrobrás (Petróleo Brasileiro S.A. - referência nacional na extração de petróleo), Embrapa (Empresa Brasileira de Pesquisa Agropecuária - em menos de trinta anos o Brasil passou a ser um dos maiores produtores mundiais de alimentos) e Embraer (Empresa Brasileira de Aeronáutica - a única do País e que é competitiva no mercado mundial na comercialização de aeronaves). Também são dignas de menção a FINEP (Financiadora de Estudos e Projetos), o BNDES (Banco Nacional de Desenvolvimento Econômico e Social) e as agências estaduais como a FAPESP (Fundação de Amparo à Pesquisa do Estado de São Paulo).
} 


\begin{tabular}{|c|c|c|}
\hline ELEMENTO & ONDE SE LOCALIZA & EFEITOS TÓXICOS NO SER HUMANO \\
\hline Chumbo & Tubos de raios catódicos e soldas & Danos neurológicos, renais e sanguíneos \\
\hline Vanádio & Tubos de raios catódicos & Distúrbios gastrointestinais, inapetência \\
\hline Bromo & $\begin{array}{l}\text { Retardantes de chama em circuitos } \\
\text { impressos, fios e cabos }\end{array}$ & Desordem hormonal, nervosa e reprodutiva \\
\hline Antimônio & Alguns tipos de retardantes de chama & $\begin{array}{l}\text { Nefrite, problemas cardiovasculares } \\
\text { gastrointestinais }\end{array}$ \\
\hline Cádmio & $\begin{array}{l}\text { Algumas baterias, soldas e circuitos } \\
\text { integrados }\end{array}$ & $\begin{array}{l}\text { Danos aos ossos, rins, dentes e pulmões. Possível } \\
\text { agente cancerígeno }\end{array}$ \\
\hline Bário & $\begin{array}{l}\text { Vidro (tela) de um tubo de raios } \\
\text { catódicos }\end{array}$ & $\begin{array}{l}\text { Distúrbios gastrointestinais, } \\
\text { hipertensão, lesões renais e cardíacas }\end{array}$ \\
\hline Mercúrio & Soldas, termostatos e sensores & Danos neurológicos e hepáticos \\
\hline Berílio & Liga antifricção (cobre-berílio) & Edema e câncer pulmonar \\
\hline
\end{tabular}

No tocante à obsolescência programada, que é a diminuição planejada do tempo útil de um produto, Packard (1965) afirma que existem três formas: por função (não é visto de forma pejorativa, uma vez que um produto se torna obsoleto quando outro é introduzido no mercado por desempenhar melhor a função), por durabilidade (quando um produto é planejado intencionalmente para quebrar ou deixa de funcionar normalmente em um período curto de tempo em relação ao que poderia durar - esta forma de obsolescência é duramente criticada por Packard) e por desejabilidade (quando um produto, mesmo em perfeitas condições de funcionamento, se torna menos desejável para consumo - geralmente por uma questão de modismo).

O exemplo dos resíduos de EEE, que geralmente está associado a riscos sanitários, ambientais e sociais, nos leva a pensar sobre a inovação de forma ainda mais abrangente, por dois motivos: i) o surgimento de empresas especializadas na reciclagem de resíduos eletrônicos e que, portanto, inovam em seus processos e ii) no caso do Brasil, a legislação específica de resíduos sólidos é marcada por obrigações legais inovadoras, tais como: a obrigatoriedade da logística reversa e responsabilidade compartilhada ${ }^{37}$.

A seção a seguir apresenta os marcos regulatórios da inovação no Brasil, com destaque para a Lei da Inovação, sancionada em 2004.

\footnotetext{
37 De acordo com a PNRS, a logística reversa é "o instrumento de desenvolvimento econômico e social caracterizado por um conjunto de ações, procedimentos e meios destinados a viabilizar a coleta e a restituição dos resíduos sólidos ao setor empresarial, para reaproveitamento, em seu ciclo ou em outros ciclos produtivos, ou outra destinação final ambientalmente adequada. Com relação à responsabilidade compartilhada: é o "conjunto de atribuições individualizadas e encadeadas dos fabricantes, importadores, distribuidores e comerciantes, dos consumidores e dos titulares dos serviços públicos de limpeza urbana e de manejo dos resíduos sólidos, para minimizar o volume de resíduos sólidos e rejeitos gerados, bem como para reduzir os impactos causados à saúde humana e à qualidade ambiental decorrentes do ciclo de vida dos produtos, nos termos desta Lei" (BRASIL, 2010).
} 
2.2 MARCOS REGULATÓRIOS DA INOVAÇÃO E DESENVOLVIMENTO DA C,T\&I NO BRASIL

O grande avanço das pesquisas sobre inovação ocorreu a partir da segunda metade do século XX (ARBIX, 2007). Do ponto de vista econômico, foi criado na década de 1970 o pacote de inovações financeiras, o que proporcionou novos mercados. Vale ressaltar que foi também a partir da década de 1970 que países no mundo inteiro começaram a criar seus ministérios relacionados à inovação ${ }^{38}$. Segundo a $\operatorname{OCDE}(2004$, p. 32), "o novo pensamento sobre inovação fez surgir a importância dos sistemas e levou a uma abordagem mais integrada da formulação e implantação de políticas ligadas à inovação".

Considerando as transformações da época, em 1980 os pacotes de inovações tecnológicas no âmbito da ciência e informação foram adicionados, favorecendo a criação de novos mercados. Segundo Cruz (2011), o nascimento de empresas inovadoras está diretamente vinculado à internacionalização da economia. Foi o que aconteceu no caso do Brasil: com a abertura da economia brasileira a partir do final da década de 1980, empresas internacionais passaram a hospedar suas filiais no território nacional e criar possibilidades de investimentos.

Por isso, o debate sobre inovação no Brasil é muito recente e, embora esteja na "primeira infância", possui um futuro de muitas possibilidades (ARBIX, 2007). Cruz (2011) ressalta que a inovação, ao mesmo tempo em que depende das empresas, requer um cenário favorável, especialmente com o auxílio de medidas governamentais. Tais medidas constam no Quadro 9, assim como a situação brasileira em geral no contexto da inovação a partir da década de 1990.

\begin{tabular}{|c|c|}
\hline ANO & SITUAÇÃO BRASILEIRA NO CONTEXTO DA INOVAÇÃO \\
\hline 1991 & $\begin{array}{l}\text { Lei de Informática (Lei } n^{\circ} 8.248 / 91 \text { alterada pelas Leis } n^{\circ} 10.176 / 01 \text { e } 11.077 / 04 \text { - dispõe sobre a } \\
\text { capacitação e competitividade do setor de informática e automação, e dá outras providências. } \\
\text { Contribuiu para a redução do IPI de computadores e equipamentos de telecomunicações). }\end{array}$ \\
\hline 1998 & Lançamento do Prêmio FINEP de Inovação (a premiação existe até hoje) \\
\hline 1999 & Criação dos Fundos setoriais de C\&T (são instrumentos de financiamento). \\
\hline 2000 & $\begin{array}{l}\text { - A PINTEC (Pesquisa de Inovação) foi a primeira pesquisa satélite do Subsistema de Estatísticas } \\
\text { Econômicas e pertenceu ao Programa de Modernização das Estatísticas Econômicas). Até hoje a } \\
\text { pesquisa é realizada e é sob a égide do Instituto Brasileiro de Geografia e Estatística (IBGE), com } \\
\text { apoio da Financiadora de Estudos e Projetos (FINEP) e do Ministério da Ciência e Tecnologia. O } \\
\text { objetivo principal é pesquisar as atividades inovativas e suas repercussões nas empresas industriais. } \\
\text { - Lançamento do Projeto Inovar pela FINEP. O objetivo é estimular a criação e o desenvolvimento de } \\
\text { empresas de base tecnológica por meio de investimentos em capital de risco ou venture capital. }\end{array}$ \\
\hline 2001 & $\begin{array}{l}\text { Foi realizada a } 1 \text { a Conferência Nacional de Ciência e Tecnologia e Inovação com vistas à } \\
\text { consolidação do conceito de inovação. }\end{array}$ \\
\hline
\end{tabular}

\footnotetext{
${ }^{38}$ A Ciência, Tecnologia e Inovação (CT\&I) atualmente estão na pauta de ministérios e agências governamentais do mundo inteiro. Na Coreia do Sul existe o Ministério da Economia do Conhecimento e em 2005 foi criado no Japão o Ministério da Inovação (hoje corresponde ao Ministério da Educação, Cultura, Esportes, Ciência e Tecnologia).
} 
2002 Lei no 10.332 (Equalização de juros).

2004 - Lei de Inovação (Lei no 10.973, de 02 de dezembro - dispõe sobre incentivos à inovação e à pesquisa científica e tecnológica no ambiente produtivo, formado por agências de fomento, instituições científicas e tecnológicas, núcleos de inovações tecnológicas, instituições de apoio, pesquisadores públicos, entre outros. Esta Lei também criou a subvenção econômica, que diz respeito a recursos públicos não reembolsáveis);

- Fundação do Centro para a Competitividade e Inovação do Cone Leste Paulista (Cecompi) organização sem fins lucrativos;

- Política Industrial, Tecnológica e de Comércio Exterior (PITCE).

2005 - Lei do Bem (Lei no 11.196, de 21 de novembro - estabelece os mecanismos para desonerar os investimentos realizados em projetos de inovação);

- Decreto no 5.563, de 11 de outubro que regulamenta a Lei da Inovação (no 10.973, de 2 de dezembro de 2004);

- Criação do projeto Índice Brasil de Inovação (IBI) pela Universidade Estadual de Campinas (Unicamp). A finalidade é medir e avaliar o desempenho das empresas brasileiras em inovação tecnológica.

2006 - Neste ano, o investimento em P\&D no Brasil foi de $1 \%$ do PIB, enquanto que no Japão o investimento foi de $3,4 \%$ do PIB (2006) e nos EUA de 2,7\% do PIB;

- Decreto № 5.798, de 08 de junho (regulamenta os incentivos fiscais à inovação);

2007 PACTI (Plano de Ação em Ciência, Tecnologia e Inovação) 2007-2010, com o lema "investir e inovar para crescer". Prioridades: expansão e consolidação do sistema nacional de C,T\&I; promoção da inovação tecnológica nas empresas; pesquisa, desenvolvimento e inovação em áreas estratégicas e C,T\&I para o desenvolvimento social.

2008 Situação do Brasil pelo Global Innovation Scoreboard (ranking criado pela União Europeia): $42^{\circ}$ lugar. São considerados três grupos de indicadores: situação das empresas, recursos humanos e infraestrutura.

2009 CNI lança o documento "Inovação: a construção do futuro" e cria a Mobilização Empresarial pela Inovação (MEl), uma iniciativa que envolveu o setor privado e o governo federal.

2010 Petrobrás ocupou a posição 41 entre as cinquenta empresas mais inovadoras do mundo, segundo estudo do Boston Consulting Group. Inclusive, foi a primeira brasileira que compôs a lista.

2011 Lançamento do Plano Brasil Maior (2011-2014) para estimular a inovação e produção nacional com vistas à competitividade do País, mudança de MCT (Ministério de Ciência e Tecnologia) para MCTI (Ministério de Ciência, Tecnologia e Inovação) e criação da EMBRAPII (Empresa Brasileira de Pesquisa e Inovação Industrial).

- ENCTI (Estratégia Nacional de Ciência, Tecnologia e Inovação) 2012-2015. É a continuação do

2012 PACTI 2007-2010 e possui cinco eixos estruturantes: i) promoção da inovação; ii) novo padrão de financiamento público; iii) pesquisa e infraestrutura; iv) recursos humanos e v) C,T\&l para 0 desenvolvimento social.

- TI MAIOR (Programa Estratégico de Software e Serviços de Tecnologia da Informação) 2012-2015. Este programa está vinculado à ENCTI 2012-2015.

2013 Situação do Brasil pelo Global Innovation Scoreboard (ranking criado pela União Europeia): 64 lugar (caiu seis posições em relação a 2012). De acordo com esse Índice, os países mais inovadores do mundo são: Suíça $\left(1^{\circ}\right)$, Suécia $\left(2^{\circ}\right)$, Reino Unido $\left(3^{\circ}\right)$, Holanda $\left(4^{\circ}\right)$, Estados Unidos (5ำ), Finlândia $\left(6^{\circ}\right)$, Hong Kong $\left(7^{\circ}\right)$, Cingapura $\left(8^{\circ}\right)$, Dinamarca $\left(9^{\circ}\right)$ e Irlanda $\left(10^{\circ}\right)$ - esta pesquisa foi realizada com 142 países.

Quadro 9 - Quadro geral da situação brasileira a partir da década de 1990 no contexto da inovação

Fonte: Elaborado por Daniela Rocco (2014) com base em UNICAMP (2007); IBGE (2008); Cruz (2011) e BRASIL (2012c; 2012d).

Nos dias de hoje, embora o Brasil seja um dos países mais inovadores em relação à extração de petróleo pela PETROBRÁS (Petróleo Brasileiro S.A.), à agropecuária por meio da EMBRAPA (Empresa Brasileira de Pesquisa Agropecuária) e tenha um dos sistemas bancários e eleitorais mais modernos do mundo, a competitividade ainda está bastante aquém em relação a outras economias do mundo. Investe-se muito pouco em P\&D quando se compara com países como EUA, Japão, China, Alemanha e Coreia do Sul (Battelle, R\&D Magazine, 2014).

Em 2013 o Brasil investiu 1,3\% do PIB em P\&D, e a previsão para 2014 é que esse índice se mantenha. Os países que mais investem em P\&D são (previsão para 2014 - 
investimento percentual do PIB): Israel (4,2\%), Coreia do Sul (3,6\%), Finlândia (3,5\%), Japão (3,4\%), Suécia (3,4\%), Suíça (2,9\%), Alemanha (2,9\%) e EUA (2,8\%) (Battelle, R\&D Magazine, 2014).

O fomento à inovação no País ocorre principalmente através de incentivos fiscais, financiamento (reembolsável e não reembolsável), subvenção econômica, concessão de bolsas de pesquisa no Brasil e exterior e participação societária (private equity e venture capital) $^{39}$. Em nível federal, basicamente existem três instituições de fomento, que por sua vez estão associadas ao MCTI (Ministério de Ciência, Tecnologia e Inovação). São elas: FINEP (Financiadora de Estudos e Projetos), BNDES (Banco Nacional de Desenvolvimento Econômico e Social) e CNPq (Conselho Nacional de Desenvolvimento Científico e Tecnológico). A ENCTI (Estratégia Nacional de Ciência, Tecnologia e Inovação) 2012-2015 definiu alguns programas e estratégias de apoio e financiamento público, e essas são as áreas prioritárias para impulsionar a competitividade brasileira: i) Programas prioritários: TICs (tecnologias da informação e comunicação); Fármacos e complexo industrial da saúde; Petróleo e gás; Complexo industrial da defesa; Aeroespacial; Nuclear; Fronteiras para a inovação (Biotecnologia e Nanotecnologia e novos materiais); Fomento da economia verde (Energia; Biodiversidade; Mudanças climáticas e Oceanos e zonas costeiras) e C,T\&I para o Desenvolvimento Social (Popularização da C,T\&I e melhoria do ensino de ciências; Inclusão produtiva e tecnologia social; Tecnologias assistivas e Tecnologias para Cidades Sustentáveis) e ii) Programas complementares: Indústria química; Bens de capital;

\footnotetext{
${ }^{39}$ Conceitos de acordo com o MCTI: 1. Incentivos fiscais: Podem ser "1. dedução, na apuração do Imposto de Renda devido, dos dispêndios com P\&D, inclusive aqueles com instituições de pesquisa, universidades ou inventores independentes; 2 . exclusão, na determinação do lucro real para cálculo do IRPJ e da base de cálculo da CSLL, do valor correspondente a até $60 \%$ da soma dos dispêndios efetuados com P\&D. Este percentual poderá atingir $70 \%$ em função do acréscimo de até $5 \%$ no número de empregados que forem contratados exclusivamente para atividades de P\&D; e $80 \%$, no caso deste aumento ser superior a $5 \%$. Além disto, poderá haver também uma exclusão de $20 \%$ do total dos dispêndios efetuados em P\&D objeto de patente concedida ou cultivar registrado; 3 . redução de $50 \%$ de IPI na compra de equipamentos destinados a P\&D; 4 . depreciação integral dos equipamentos comprados para P\&D; 5. amortização acelerada dos dispêndios para aquisição de bens intangíveis para $\mathrm{P} \& \mathrm{D} ; 6$. redução a zero da alíquota do imposto de renda retido na fonte nas remessas efetuadas para o exterior destinadas ao registro e manutenção de marcas, patentes e cultivares e 7. dedução, como despesas operacionais no cálculo do IRPJ e da Contribuição Social sobre o Lucro Líquido - CSLL, dos valores transferidos a microempresas e empresas de pequeno porte, destinados à execução de $P \& D$, de interesse e por conta da pessoa jurídica que promoveu a transferência"; 2. Financiamento reembolsável: "É uma linha de crédito oferecida a empresas que demonstrem a capacidade de pagamento e condições para desenvolver projetos de P,D\&I. Os prazos de carência e amortização, assim como os encargos financeiros, variam de acordo com as características do projeto e da instituição tomadora do crédito"; 3 . Financiamento não reembolsável: "Consiste em apoio financeiro oferecido pelo Governo Federal, concedido a instituições públicas ou organizações privadas sem fins lucrativos, para a realização de projeto de pesquisa científica, tecnológica ou de inovação e ainda para a realização de estudos ou de eventos e seminários, voltados ao intercâmbio de conhecimento entre pesquisadores. Esta modalidade é oferecida tanto pelo CNPq quanto pela FINEP"; 4. Subvenção econômica: "É um instrumento de estímulo à inovação tecnológica nas empresas, mediante o qual a União, por intermédio das agências de fomento de ciência e tecnologia, promove e incentiva a implementação de atividades de pesquisa e desenvolvimento tecnológico com a concessão de recursos financeiros" e 5. Participação societária: "O Capital Empreendedor, ou Capital de Risco, é uma nova forma eficiente de financiamento direcionado para empresas inovadoras. Os investimentos em Capital Empreendedor subdividem-se em duas modalidades: Private Equity e Venture Capital. A primeira modalidade está direcionada para empresas de grande porte, e a segunda, para empresas inovadoras ainda em formação, as chamadas startups. No caso dessas start-ups, esse tipo de financiamento é extremamente valorizado, devido a grande dificuldade em obter recursos pelos meios tradicionais de financiamento" (BRASIL, 2012c).
} 
Energia elétrica; Carvão mineral; Minerais estratégicos; Produção agrícola sustentável; Recursos hídricos; Amazônia e Semiárido e Pantanal e Cerrado (BRASIL, 2012d).

O governo brasileiro, ciente de que a cultura da inovação não está disseminada por todo o território brasileiro (sobretudo nas regiões Norte, Nordeste e Centro-oeste) e de que o nível de competitividade permanece baixo, lançou leis, programas e outras iniciativas com a finalidade de promover a mudança desse cenário. Dentre as ações mais recentes cabe mencionar a Lei da Inovação (2004), a Lei do Bem (2005), o Plano Brasil Maior (2011-2014), com o lema "Inovar para competir. Competir para crescer" e a mudança em 2011 do então Ministério de Ciência e Tecnologia (MCT) para MCTI, incorporando a "l" de inovação na agenda do governo. Além disso, como forma de estímulo, foi criado o "Prêmio FINEP de Inovação" para reconhecer os projetos mais inovadores do País.

A Figura 12 a seguir, extraída do Portal Inovação (mantido pelo MCTI), exibe onze formas de busca por informações sobre a situação do Brasil quanto à inovação. São elas: atores de inovação; tipos em demanda; acessos ao Portal; contatos de especialistas; contatos de ICTIs; contatos de agentes de inovação; tipos em oferta; ofertas e demandas por área; interações; contatos de empresas e contatos de NITs. A figura abaixo foi extraída no $1^{\circ}$ semestre de 2014, e quanto ao quesito de busca por "atores de inovação" destacamos: 3.332.459 especialistas (CV-Lattes), 9.828 (empresas Portal Inovação), 6.527 ICTIs, 1.479 agentes de inovação (pessoas) e 670 agentes de inovação (Organizações).

\section{TOTAL DE ATORES DE INOVAÇÃO}

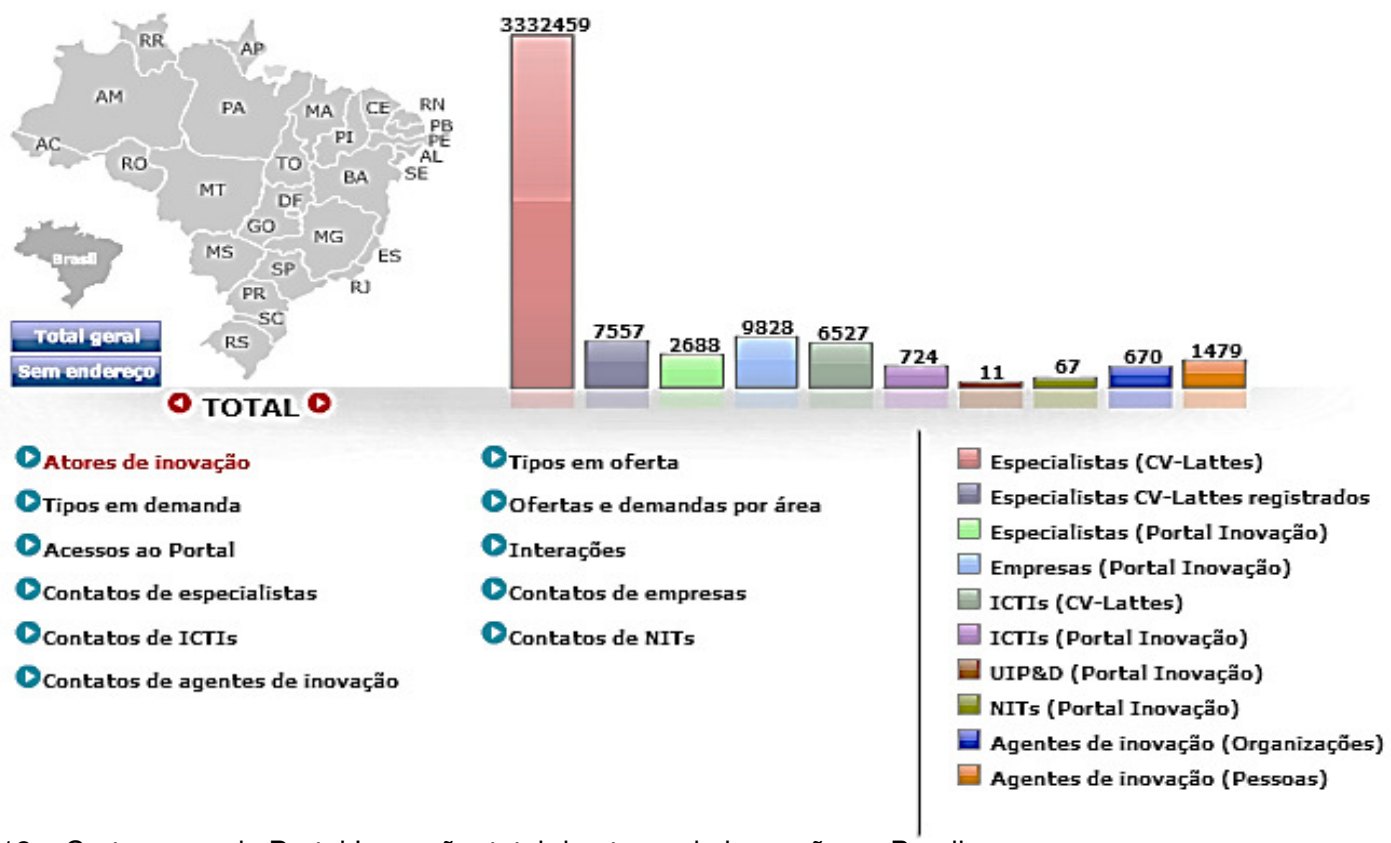

Figura 12 - Cartograma do Portal Inovação: total de atores de inovação no Brasil 
Vale lembrar a oportunidade que se abre para MPE (micro e pequenas empresas) se tornarem mais competitivas, uma vez que elas são os principais motores da economia brasileira. Os empreendimentos de pequeno porte, que são mais de seis milhões, correspondem a 99\% do total das empresas formais do País, empregando mais da metade da mão-de-obra e cuja massa salarial chega a 40\% (BRASIL, 2012b).

Como é possível inferir, a predominância das MPE é notória. Porém elas compartilham as mesmas limitações das empresas de grande porte: o baixo grau de competitividade do País e os poucos investimentos e incentivos específicos para se consolidar um sistema nacional de CT\&I (Ciência, Tecnologia e Inovação).

Para Costa (2013), as relações de cooperação entre as MPE do turismo são essenciais para a boa governança e competitividade das próprias empresas e dos destinos turísticos, proporcionando desenvolvimento social nas respectivas comunidades locais e tendo como princípio norteador nesses processos a sustentabilidade. Neste sentido, Kon (2007) evidencia a importância da economia de serviços (baseada no conhecimento) para alavancar a competitividade e o desenvolvimento. Falta, segundo a autora (2007), que organizações públicas e privadas considerem os serviços como indutores desse processo. Essa problemática é aprofundada na próxima seção.

\subsection{A INOVAÇÃO PARA A SUSTENTABILIDADE COMO FATOR-CHAVE DE} COMPETITIVIDADE TURÍSTICA

O processo de inovação cada vez mais tem determinado a competitividade global, sendo visto por diversos autores (ARBIX, 2007; BESSANT; TIDD, 2009; CRUZ, 2011; DE BES; KOTLER, 2011; CHRISTENSEN, 2012; GALEMBECK, 2013) como fator-chave de mudanças e melhorias nos processos e encadeamentos produtivos de todas as escalas e territórios. Não obstante, a competitividade é dependente de cinco pilares essenciais no mercado atual, que são: produtividade, qualidade, marketing, inovação e sustentabilidade (PORTER; VAN DER LINDE, 1995; CROUCH, 2007; LOWITT, 2011; BRASIL, 2013a; VIEIRA \& HOFFMANN, 2013), tais como são vistos na Figura 13.

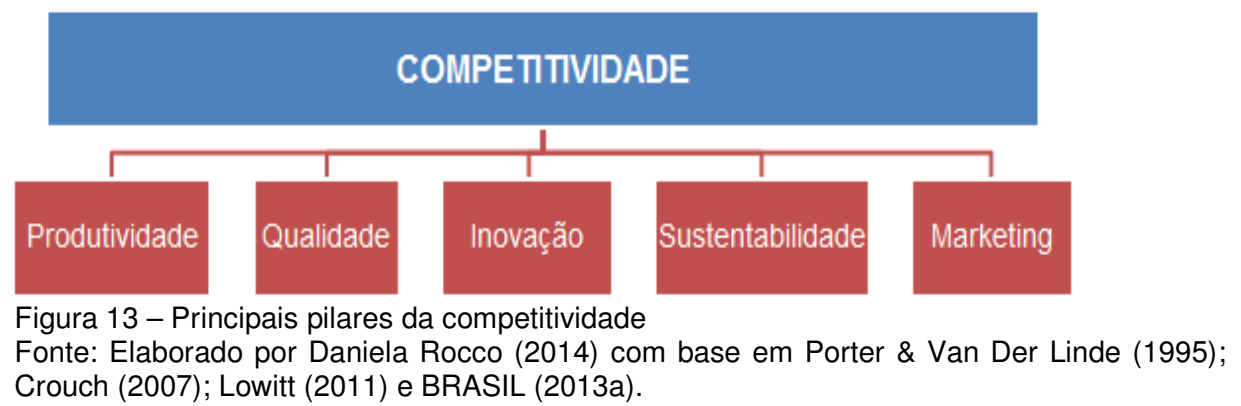


Desde 2005, o World Economic Forum (WEF) fundamenta sua análise no Índice de Competitividade Global, que é uma ferramenta que mede a microeconomia e a macroeconomia de mais de cem países. O conceito de competitividade adotado nos relatórios, publicados anualmente, é o seguinte:

[...] O conjunto de instituições, políticas e fatores que determinam o nível de produtividade de um país. O nível de produtividade, por sua vez, define o nível de prosperidade que pode ser conquistada por uma economia. O nível de produtividade também determina as taxas de retorno obtidas por investimentos em uma economia, que por sua vez são fatores fundamentais para as taxas de crescimento. Em outras palavras, uma economia mais competitiva é aquela que é capaz de crescer mais rápido ao longo do tempo (WEF, 2012, p. 04, tradução nossa ${ }^{40}$ ).

Os mais tradicionais e citados índices de competitividade mundial, tais como os do WEF, adotam 12 pilares, distribuídos por sua vez em três grupos: fatores básicos de competitividade, fatores de eficiência e fatores de inovação e sofisticação de negócios. Os componentes do pilar inovação do WEF são: capacidade para inovar, gastos de empresas em pesquisa e desenvolvimento (P\&D), colaboração entre universidades e indústria em $P \& D$, qualidade das instituições de pesquisa científica, patentes de utilidade, disponibilidade de cientistas e engenheiros e compras governamentais de produtos avançados de tecnologia (WEF, 2012).

Para a OCDE (Organização para a Cooperação Econômica e Desenvolvimento) a competitividade do turismo em um destino está ligada à

[...] capacidade do lugar de otimizar sua atratividade para os residentes e não residentes, oferecer serviços turísticos de qualidade, inovadores e atraentes para os consumidores (por exemplo, proporcionando uma boa relação custo/benefício) e ganhar participação no mercado doméstico e global, assegurando que os recursos disponíveis para apoiar o turismo sejam utilizados de forma eficiente e sustentável (DUPEYRAS \& MACCALLUM, 2013, p. 07, tradução nossa ${ }^{41}$ ).

A própria OCDE vem reconhecendo recentemente a importância da sustentabilidade nos índices de competitividade, pois sem ela, não há competitividade que se sustente econômica, ambiental e socialmente. Para isso, é necessário, portanto, medir a competitividade, e isto é efetuado por meio de índices compostos por diversos pilares. $\mathrm{O}$

\footnotetext{
40 "We define competitiveness as the set of institutions, policies, and factors that determine the level of productivity of a country. The level of productivity, in turn, sets the level of prosperity that can be earned by an economy. The productivity level also determines the rates of return obtained by investments in an economy, which in turn are the fundamental drivers of its growth rates. In other words, a more competitive economy is one that is likely to grow faster over time".

41 "Tourism competitiveness for a destination is about the ability of the place to optimise its attractiveness for residents and non-residents, to deliver quality, innovative, and attractive (e.g. providing good value for money) tourism services to consumers and to gain market shares on the domestic and global market places, while ensuring that the available resources supporting tourism are used efficiently and in a sustainable way".
} 
índice corresponde ao "valor agregado final de todo um procedimento de cálculo onde se utilizam, inclusive, indicadores como variáveis que o compõem" (SICHE et al., 2007, p. 139).

No tocante à mensuração da competitividade do turismo mundial, o WEF adota 14 pilares, quais sejam: 1) Normas e regulamentos; 2) Sustentabilidade ambiental; 3) Segurança e proteção; 4) Saúde e higiene; 5) Priorização de Viagens e Turismo; 6) Infraestrutura de transporte aéreo; 7) Infraestrutura de transporte terrestre; 8) Infraestrutura turística; 9) Infraestrutura de TIC; 10) Competitividade dos preços no setor de T\&T; 11) Recursos humanos; 12) Vocação para Viagens e Turismo; 13) Recursos naturais e 14) Recursos culturais (WEF, 2013b). O Quadro 10 expõe tais pilares e as respectivas variáveis.

\section{SUBíNDICE A: PARÂMETROS DAS VIAGENS \& TURISMO (V\&T)}

1. Normas e regulamentos

2. Sustentabilidade ambiental

3. Segurança e proteção

4. Saúde e higiene

5. Priorização de Viagens e Turismo
1.1 Prevalência de propriedade estrangeira

1.2 Direitos de propriedade

1.3 Impacto dos negócios das regras em matéria de investimento externo direto

1.4 Requisitos de visto

1.5 Abertura de acordos bilaterais de serviços aéreos

1.6 Transparência da política governamental

1.7 Tempo necessário para começar um negócio

1.8 Custo para começar um negócio

1.9 Restritividade dos compromissos (Acordo Geral de Comércio de Serviços)

2.1 Rigor da legislação ambiental

2.2 Cumprimento da legislação ambiental

2.3 Sustentabilidade do desenvolvimento do setor de V\&T

2.4 Emissões de dióxido de carbono

2.5 Concentração de material particulado no ar

2.6 Espécies ameaçadas

2.7 Ratificação de Tratados Ambientais

3.1 Custos empresariais devido ao terrorismo

3.2 Confiabilidade dos serviços de polícia

3.3 Custos empresariais devido à criminalidade e violência

3.4 Acidentes de tráfego

4.1 Relação médico / 1.000 habitantes

4.2 Acesso a saneamento básico

4.3 Acesso a água potável

4.4 Leitos de hospital / 10.000 habitantes

5.1 Prioridade governamental quanto ao setor de V\&T

5.2 Gastos do governo em V\&T

5.3 Eficácia do marketing e branding para atrair turistas

5.4 Abrangência dos dados anuais de V\&T

5.5 Prazo de fornecimento de dados de V\&T mensal/trimestral

\section{SUBÍNDICE B: AMBIENTE DE NEGÓCIOS E INFRAESTRUTURA DO SETOR DE V\&T}

6.1 Qualidade da infraestrutura de transporte aéreo

6.2 Disponibilidade de assentos $/ \mathrm{Km} / \mathrm{semana}$ (voos domésticos)

6.3 Disponibilidade de assentos/ $\mathrm{Km} / \mathrm{semana}$ (voos internacionais)

6.4 Partidas por 1.000 habitantes

6.5 Densidade dos Aeroportos / milhão de habitantes

6.6 Número de companhias aéreas em operação

6.7 Rede de transporte aéreo internacional 


\begin{tabular}{ll}
\hline (Continua) & 7.1 Qualidade da estradas \\
& 7.2 Qualidade da infraestrutura ferroviária \\
7. Infraestrutura de transporte terrestre & 7.3 Qualidade de infraestrutura portuária \\
& 7.4 Qualidade da rede de transporte terrestre \\
& 7.5 Densidade das estradas / milhão de habitantes \\
& 8.1 Quartos de hotéis / 100 habitantes \\
8. Infraestrutura turística & 8.2 Presença de grandes locadoras de veículos \\
& 8.3 Caixas eletrônicos que operam Visa / milhão de habitantes \\
& 9.1 Uso das TIC para transações entre empresa-empresa \\
& 9.2 Uso das TIC para transações entre empresa-consumidores \\
& 9.3 Pessoas que utilizam Internet (\%) \\
& 9.4 Linhas de telefonia fixa / 100 habitantes \\
9. Infraestrutura de TIC & 9.5 Assinantes de Internet banda larga / 100 habitantes \\
& 9.6 Assinantes de telefonia móvel / 100 habitantes \\
& 9.7 Assinantes de banda larga móvel / 100 habitantes \\
& 10.1 Impostos sobre passagens e taxas aeroportuárias \\
10.2 Paridade de poder de compra \\
10. Competitividade dos preços no setor & 10.3 Extensão e efeitos da tributação \\
de T\&T & 10.4 Preço do combustível \\
& 10.5 Índice de preços dos Hotéis
\end{tabular}

\section{SUBÍNDICE C: RECURSOS HUMANOS, CULTURAIS E NATURAIS NO SETOR DE V\&T}

\section{Recursos humanos}

12. Vocação para Viagens e Turismo

13. Recursos naturais

\section{Recursos culturais}

Educação e formação

11.1 Matrículas no ensino primário (\% líquida)

11.2 Matrículas no ensino secundário (\% bruta)

11.3 Qualidade do sistema educacional

11.4 Disponibilidade de local de formação e pesquisa especializada 11.5 Extensão da formação de pessoal

Disponibilidade de mão-de-obra qualificada

11.6 Práticas de contratação e demissão

11.7 Facilidade de contratação de mão-de-obra estrangeira

11.8 Predomínio da AIDS/HIV (\% população adulta)

11.9 Impacto nos negócios relacionado à AIDS/HIV

11.10 Expectativa de vida (anos)

12.1 Abertura para o Turismo (\% PIB)

12.2 Atitude da população quanto aos visitantes estrangeiros

12.3 Extensão das viagens de negócios (por recomendação)

12.4 Grau de orientação ao consumidor

13.1 № de sítios naturais classificados como Patrimônio da Humanidade

13.2 Qualidade do ambiente natural

13.3 Total de espécies conhecidas

13.4 Proteção do bioma terrestre

13.5 Áreas marinhas protegidas (\%)

14.1 № de sítios culturais classificados como Patrimônio da Humanidade

14.2 Estádios desportivos, assentos / milhão de habitantes

$14.3 \mathrm{~N} \cong$ de feiras e exposições internacionais

14.4 Exportações por indústrias criativas (\% do total mundial)

Quadro 10 - Pilares e variáveis do Índice de competitividade turística do WEF

Fonte: Adaptado de WEF (2013b, tradução nossa).

Quanto ao índice de competitividade turística do Brasil, o Ministério do Turismo (MTur) adota 13 pilares, que são: 1) Infraestrutura geral; 2) Acesso; 3) Serviços e equipamentos turísticos; 4) Atrativos turísticos; 5) Marketing e promoção do destino; 6) Políticas públicas; 7) Cooperação regional; 8) Monitoramento; 9) Economia local; 10) Capacidade empresarial; 11) Aspectos sociais; 12) Aspectos ambientais e 13) Aspectos culturais (BRASIL, 2013a). O Quadro 11 apresenta tais pilares e as respectivas variáveis. 


\begin{tabular}{|c|c|}
\hline PILAR & ESPECIFICAÇÃO (VARIÁVEIS) \\
\hline 1. Infraestrutura geral & $\begin{array}{l}\text { 1.1 Capacidade de atendimento médico para o turista no destino } \\
\text { 1.2 Estrutura urbana nas áreas turísticas } \\
\text { 1.3 Fornecimento de energia } \\
\text { 1.4 Serviço de proteção ao turista }\end{array}$ \\
\hline 2. Acesso & $\begin{array}{l}\text { 2.1 Acesso aéreo } \\
\text { 2.2 Acesso rodoviário } \\
\text { 2.3 Acesso aquaviário } \\
\text { 2.4 Acesso ferroviário } \\
\text { 2.5 Sistema de transporte no destino } \\
\text { 2.6 Proximidade de grandes centros emissivos de turistas }\end{array}$ \\
\hline $\begin{array}{l}\text { 3. Serviços e equipamentos } \\
\text { turísticos }\end{array}$ & $\begin{array}{l}\text { 3.1 Sinalização turística } \\
\text { 3.2 Centro de atendimento ao turista } \\
\text { 3.3 Espaço para eventos } \\
\text { 3.4 Capacidade dos meios de hospedagem } \\
\text { 3.5 Capacidade do turismo receptivo } \\
\text { 3.6 Estrutura de qualificação para o turismo } \\
\text { 3.7 Capacidade dos restaurantes }\end{array}$ \\
\hline 4. Atrativos turísticos & $\begin{array}{l}\text { 4.1 Atrativos naturais } \\
\text { 4.2 Atrativos culturais } \\
\text { 4.3 Eventos programados } \\
\text { 4.4 Realizações técnicas, científicas e artísticas }\end{array}$ \\
\hline $\begin{array}{l}\text { 5. Marketing e promoção do } \\
\text { destino }\end{array}$ & $\begin{array}{l}\text { 5.1 Planejamento de marketing } \\
\text { 5.2 Participação em feiras e eventos } \\
\text { 5.3 Promoção do destino } \\
\text { 5.4 Página do destino na internet (website) }\end{array}$ \\
\hline 6. Políticas públicas & $\begin{array}{l}\text { 6.1 Estrutura municipal para apoio ao turismo } \\
\text { 6.2 Grau de cooperação com o governo estadual } \\
\text { 6.3 Grau de cooperação com o governo federal } \\
\text { 6.4 Planejamento para a cidade e para a atividade turística } \\
\text { 6.5 Grau de cooperação público-privada }\end{array}$ \\
\hline 7. Cooperação regional & $\begin{array}{l}\text { 7.1 Governança } \\
\text { 7.2 Projetos de cooperação regional } \\
\text { 7.3 Planejamento turístico regional } \\
\text { 7.4 Roteirização e promoção } \\
\text { 7.5 Apoio à comercialização }\end{array}$ \\
\hline 8. Monitoramento & $\begin{array}{l}\text { 8.1 Pesquisas de demanda } \\
\text { 8.2 Pesquisas de oferta } \\
\text { 8.3 Sistema de estatísticas do turismo } \\
\text { 8.4 Medição dos impactos da atividade turística } \\
\text { 8.5 Setor específico de estudos e pesquisas }\end{array}$ \\
\hline 9. Economia local & $\begin{array}{l}\text { 9.1 Aspectos da economia local } \\
\text { 9.2 Infraestrutura de comunicação } \\
\text { 9.3 Infraestrutura de negócios e empreendimentos } \\
\text { 9.4 Eventos alavancadores }\end{array}$ \\
\hline 10. Capacidade empresarial & $\begin{array}{l}\text { 10.1 Capacidade de qualificação e aproveitamento do pessoal local } \\
\text { 10.2 Presença de grupos nacionais e internacionais do setor de turismo } \\
\text { 10.3 Concorrência e barreiras de entrada } \\
\text { 10.4 Presença de empresas de grande porte, filiais ou subsidiárias }\end{array}$ \\
\hline 11. Aspectos sociais & $\begin{array}{l}\text { 11.1 Acesso à educação } \\
\text { 11.2 Empregos gerados pelo turismo } \\
\text { 11.3 Política de enfrentamento e prevenção à exploração sexual infanto- } \\
\text { juvenil } \\
\text { 11.4 Uso de atrativos e equipamentos turísticos pela população } \\
\text { 11.5 Cidadania, sensibilização e participação na atividade turística }\end{array}$ \\
\hline 12. Aspectos ambientais & $\begin{array}{l}\text { 12.1 Estrutura e legislação municipal de meio ambiente } \\
\text { 12.2 Atividades em curso potencialmente poluidoras } \\
\text { 12.3 Rede pública de distribuição de água } \\
\text { 12.4 Rede pública de coleta e tratamento de esgoto } \\
\text { 12.5 Coleta e destinação pública de resíduos } \\
\text { 12.6 Unidades de Conservação no território municipal }\end{array}$ \\
\hline 13. Aspectos culturais & $\begin{array}{l}\text { 13.1 Produção cultural associada ao turismo } \\
\text { 13.2 Patrimônio histórico e cultural } \\
\text { 13.3 Estrutura municipal de apoio à cultura }\end{array}$ \\
\hline
\end{tabular}

Quadro 11 - Pilares e variáveis do Índice de competitividade turística do Brasil

Fonte: Adaptado de BRASIL (2013a). 
Como mencionado, a competitividade possui basicamente cinco pilares, que são: produtividade, qualidade, marketing, inovação e sustentabilidade. De acordo com os Quadros 10 e 11, o índice do WEF possui 56 variáveis e o índice do MTur abarca 62 variáveis. O primeiro mostra a inovação de forma mais explícita, pois nele constam variáveis relacionadas às TIC e às indústrias criativas. De todo modo, a inovação pode ser transversal a todos os pilares e variáveis. Se agruparmos os 13 pilares do MTur conforme os três grupos de indicadores do WEF, assim teríamos: fatores básicos de competitividade (Infraestrutura geral, Acesso, Políticas públicas e Economia local), fatores de eficiência (Cooperação regional e Monitoramento) e fatores de inovação e sofisticação de negócios (Serviços e equipamentos turísticos, Marketing e promoção do destino, Atrativos turísticos, Capacidade empresarial, Aspectos sociais, Aspectos ambientais e Aspectos culturais). Em ambos os índices está muito clara a presença de pilares e variáveis associadas às quatro dimensões da sustentabilidade (ambiental, social, cultural e econômica), bem como os pilares vinculados à produtividade, qualidade e marketing. É preciso ressaltar que o índice do WEF não abrange a complexidade da dimensão territorial do Brasil, seus regionalismos e respectivos ciclos de vida dos destinos turísticos, pois eles possuem maior e menor grau de competitividade na cadeia de valor do sistema turístico.

Como registrado no capítulo 1 , as chegadas de turistas internacionais no Brasil tem aumentado relativamente (BRASIL, 2014a; 2014b), porém o País ainda se encontra muito abaixo no ranking dos países mais visitados do mundo por turistas internacionais: $1^{\circ}$ ) França, $\left.2^{\circ}\right)$ Estados Unidos e $3^{\circ}$ ) Espanha (OMT, 2014). Isto se deve, em grande parte, pela pouca estruturação do setor turístico e pelo fato de que ainda as empresas turísticas brasileiras são competitivas e com falhas de gestão (COSTA, 2009; 2013).

Segundo os resultados obtidos a partir do Relatório de Competitividade sobre Viagens e Turismo do WEF, em relação ao total de 140 países pesquisados o Brasil ocupava em 2013 a 51ำ posição e em 2008 a 49ํำ posição. Os principais pontos positivos da competitividade turística brasileira são: Número de espécies $\left(1^{\circ}\right)$, Recursos culturais $\left(23^{\circ}\right)$ e Sustentabilidade ambiental $\left(30^{\circ}\right)$. Quanto aos principais pontos negativos, se destacam: Infraestrutura de transportes (129), Competitividade nos preços (126ํ) e Número de dias para se criar um negócio (138) (WEF, 2013b).

Ainda que o Brasil seja o País mais competitivo da América do Sul e um dos principais detentores de recursos naturais, a competitividade brasileira em nível global está diminuindo (IMD, 2013) e, em termos de turismo, nos anos anteriores ocupava estas

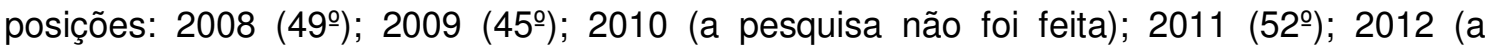
pesquisa não foi feita) e 2013 (51ํ) (WEF, 2013a).

O relatório publicado em 2013 pelo Ministério do Turismo do Brasil quanto ao Índice de Competitividade do Turismo Nacional apresenta muitos obstáculos a serem superados, 
contudo, obteve a maior nota desde que foi criado o referido Índice, em 2008. Conforme o MTur, em 2013 foram realizadas diversas ações para aumentar a competitividade dos destinos turísticos brasileiros, por exemplo: i) premiação dos destinos que mais evoluíram em competitividade; ii) a inclusão da cadeia turística no Plano Brasil Maior, do governo federal, que visa o aumento da competitividade global do País; iii) a informatização da Ficha Nacional de Registro de Hóspedes e iv) a assinatura de acordo de cooperação entre MTur, Embratur e Sebrae com vistas ao aumento da competitividade turística. Neste acordo estão previstos investimentos conjuntos que chegam a $R \$ 35,5$ milhões (BRASIL, 2014a).

A inovação assume um caráter extremamente complexo, porém, mesmo com a diversidade conceitual e forte recorrência na literatura, ainda reconhecemos uma lacuna quando é relacionada à sustentabilidade. Tomando por base o contexto atual de escassez dos recursos e tempos de crises, acreditamos que a inovação orientada para a sustentabilidade pode ser grande aliada para fortalecer a competitividade das empresas e dos países, criando ciclos virtuosos que repercutirão na geração de valor para sociedade e meio ambiente.

Apesar das ações embrionárias e bastante pontuais para estimular a atividade turística, o Brasil pode fortalecer ainda mais suas potencialidades turísticas e minimizar fragilidades como infraestrutura e burocracia nos negócios para aumentar sua competitividade. Os pilares inovação e sustentabilidade são chave nesse processo, como está exposto na seção a seguir.

\subsubsection{PRINCIPAIS ÍNDICES DE COMPETITIVIDADE TURÍSTICA MUNDIAL E} NACIONAL RELACIONADOS AOS PILARES INOVAÇÃO E SUSTENTABILIDADE

Segundo Baños e Jiménez (2012), a medição da competitividade turística mundial originou por meio do Monitor de Competitividade do Conselho Mundial de Viagens e Turismo (WTTC), publicado entre 2001 e 2004. Para eles, embora haja um esforço para consolidação desse tipo de medição, os modelos de competitividade turística ainda são escassos.

Alves (2013), que realizou exaustiva revisão da literatura no campo da competitividade turística, organizou os principais modelos e índices relacionados a esse tema. Ela os dividiu em três grandes grupos e de acordo com a sequência evolutiva de estudos empreendidos a partir da década de 1990 até os dias atuais. São esses: 
1) Modelos conceituais e descritivos: neste grupo Alves (2013) agrega os modelos propostos no período 1995-2004 e que consideram os fatores que determinam a competitividade turística. Para a autora (2013), tais modelos não identificam especificamente quais variáveis seriam mais bem associadas aos fatores, e tampouco realizam distinção entre as variáveis independentes das dependentes de desempenho turístico no destino. Exemplos: Modelo das vantagens competitivas de Porter (conhecido como "diamante das vantagens competitivas") aplicado ao contexto turístico e os modelos de Crouch e Ritchie (1995-2003);

2) Modelos de índices agregados: sem dúvida, o primeiro grupo contribuiu para a evolução dos demais índices de competitividade turística mundial. Neste segundo grupo a autora (2013) fez uma análise dos modelos propostos a partir do ano 2000 , tendo como principal referência a criação de um índice global de competitividade no turismo. Exemplos: na esfera mundial, o índice de viagens e turismo do World Economic Forum (WEF), o do WTTC, os modelos de Dwyer \& Kim (2000-2004) e o modelo de Gooroochurn e Sugiyarto (2005). No Brasil, o índice do Ministério do Turismo (2008-2013), inspirado nos pilares do índice de competitividade do WEF;

3) Modelos explicativos e preditivos: neste grupo Alves (2013) organizou os modelos criados a partir do fim da década de 2000. Possuem uma proposta de análise multivariada de dados mais robusta, pois contemplam fatores que influenciam a competitividade turística nos destinos, as variáveis que atuam de forma independente a tais fatores e as variáveis dependentes que determinam o desempenho turístico. Para que o cálculo seja coerente, foi estabelecido o peso relativo das variáveis que determinam, em maior e menor grau, a competitividade nos destinos turísticos. Exemplos: os modelos de Mazanec et al. (2007 e 2011), o modelo de Assaker, Vinzi e O'Connor (2001) e o modelo de Wu, Lan e Lee (2012).

Uma das conclusões da autora (2013) sobre os três grupos citados acima é que a maioria dos modelos teóricos vinculados à competitividade turística de destinos é de ordem descritiva, ao passo que os modelos quantitativos correspondem à minoria dos estudos. Além disso, a maior parte dos modelos, sejam eles teóricos e empíricos, foi proposta com intuito de avaliar a competitividade turística de países.

No tocante à medição mais recente de competitividade turística do Brasil, a Figura 14 exibe de forma sucinta a metodologia utilizada e publicada no relatório do Índice de Competitividade Nacional (BRASIL, 2013a). 


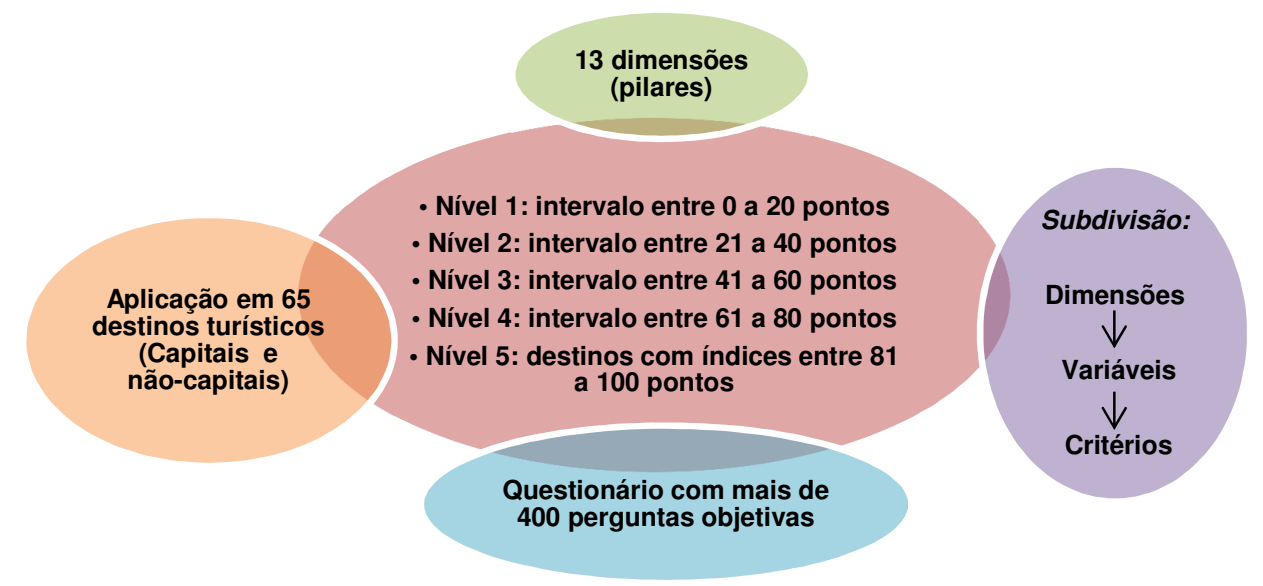

Figura 14 - Representação objetiva da metodologia do Índice de Competitividade Nacional Fonte: Elaborado por Daniela Rocco (2014) com base em BRASIL (2013a).

O referido relatório expõe as 13 dimensões da competitividade turística ${ }^{42}$, no entanto não revelam as variáveis e critérios adotados. Um questionário com mais de 400 perguntas objetivas (considerando os pilares, variáveis e critérios) foi aplicado em 65 destinos turísticos brasileiros, divididos por sua vez em 27 capitais e 38 não capitais. Além disso, para que se estabeleça um ranking (e bases comparativas), optou-se por adotar uma escala de cinco níveis, sendo que a última, que corresponde a um intervalo entre 81 e 100 pontos, indica que um determinado destino é o mais competitivo (BRASIL, 2013a).

A Figura 15 abaixo, extraída do relatório, expõe os índices de competitividade por dimensão e em ordem decrescente de desempenho. É possível notar que a dimensão que obteve maior pontuação foi "Infraestrutura geral" e a que alcançou menor pontuação foi a dimensão "Monitoramento". A competitividade possui um caráter bastante dinâmico, mas como é apresentado na Figura abaixo, variáveis como monitoramento, cooperação e marketing/promoção, apresentam um dos menores índices.

\footnotetext{
${ }^{42} \mathrm{Na}$ literatura em geral usa-se o termo "pilar" para competitividade. No relatório do Índice de Competitividade Nacional utilizou-se o termo "dimensão" (BRASIL, 2013a). Para que não haja confusão conceitual no decorrer desta tese, adotamos "pilar" quando nos referimos à competitividade e "dimensão" para sustentabilidade. Todavia, nessa parte especificamente sobre a apresentação dos resultados do relatório, consideraremos os 13 pilares da competitividade turística brasileira como dimensões.
} 


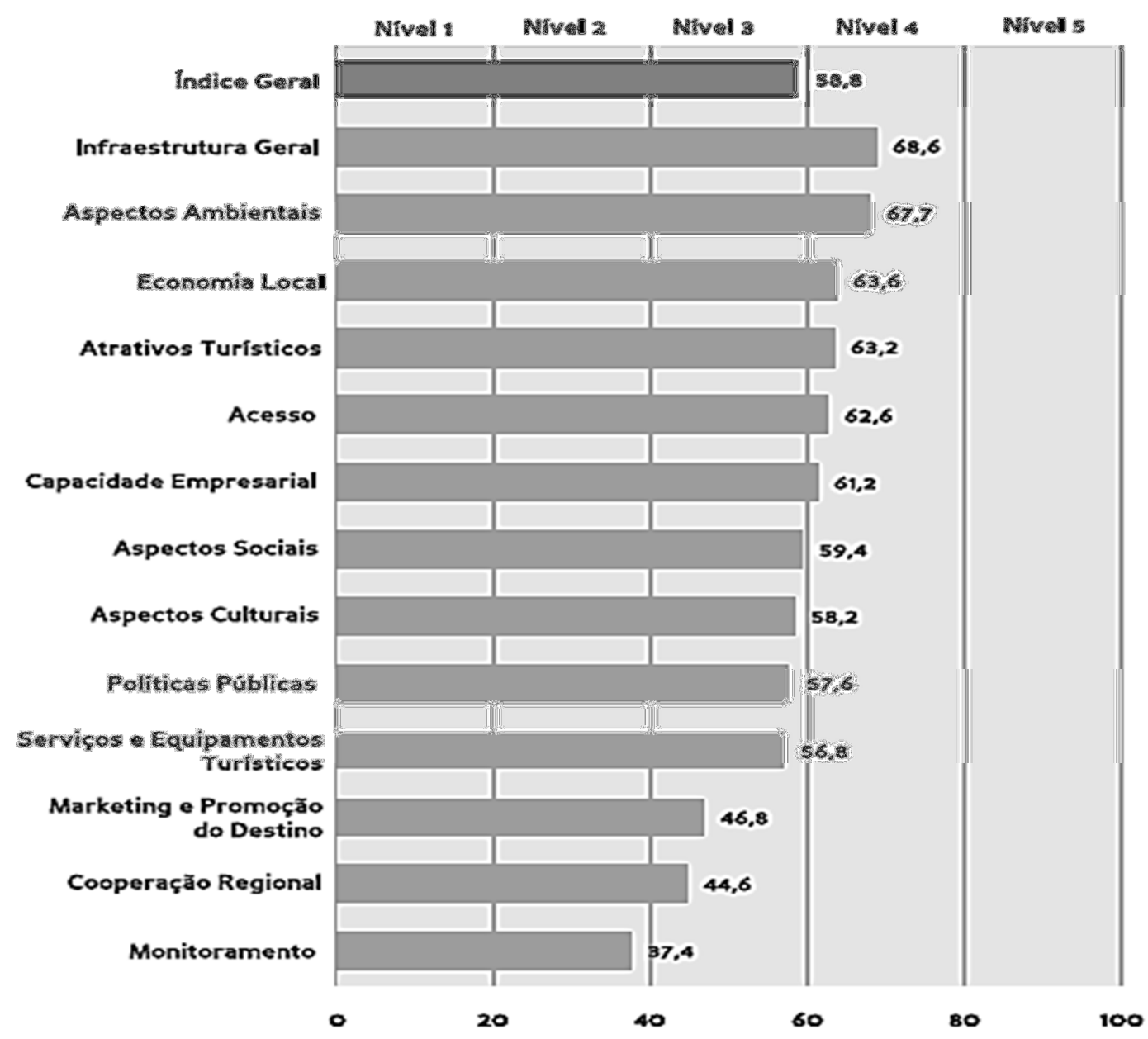

Figura 15 - Índices de Competitividade por dimensão em ordem decrescente de desempenho - Brasil: 2013 Fonte: BRASIL (2013a).

Com relação aos resultados consolidados (capitais e não capitais), na Figura 16 a seguir estão organizados os dados obtidos entre 2010 e 2013. De forma geral, verifica-se que ocorreram avanços. A média do nível de competitividade geral dos 65 destinos pesquisados em 2013 foi de 58,8 pontos (na escala limite são 100 pontos), enquanto que em 2010 a pontuação geral foi de 56,0. Segundo o relatório, a média dos 65 destinos corresponde ao nível 3 (estágio intermediário de competitividade, em um intervalo entre 41 e 60 pontos), entretanto, das 27 capitais pesquisadas, 20 encontram-se no nível 4 (61 a 80 pontos). O grupo de capitais alcançou em 2013 uma média maior: se na pesquisa anterior agregava 65,5 pontos, neste último relatório aumentou para 66,9 pontos. No tocante ao grupo das não capitais, a média também registrou acréscimo: de 51,8 pontos em 2011 para 53,1 pontos em 2013 (esta foi, inclusive, a média que apresentou maior aumento em relação a 2011). A maioria das não capitais (28 destinos) encontra-se no nível 3, contudo, oito não capitais passaram a ocupar o nível 4 e apenas dois destinos ainda não ultrapassaram o nível 2. 


\begin{tabular}{|c|c|c|c|c|c|c|c|c|c|}
\hline \multirow{3}{*}{ Dimensões } & \multicolumn{9}{|c|}{ Média } \\
\hline & \multicolumn{3}{|c|}{ Brasil } & \multicolumn{3}{|c|}{ Capitais } & \multicolumn{3}{|c|}{ Não capitais } \\
\hline & 2010 & 2011 & 2013 & 2010 & 2011 & 2013 & 2010 & 2011 & 2013 \\
\hline Total geral & 56,0 & 57,5 & 58,8 & 64,1 & 65,5 & 66,9 & 50,3 & 51,8 & 53,1 \\
\hline Infraestrutura geral & 65,8 & 68,4 & 68,6 & 74,3 & 75,8 & 75,4 & 59,8 & 63,2 & 63,8 \\
\hline Acesso & 60,5 & 61,8 & 62,6 & 72,0 & 74,0 & 74,9 & 52,3 & 53,1 & 53,8 \\
\hline $\begin{array}{l}\text { Serviços e equipamentos } \\
\text { turísticos }\end{array}$ & 50,8 & 52,0 & 56,8 & 63,3 & 64,1 & 69,1 & 41,9 & 43,4 & 48,1 \\
\hline Atrativos turisticos & 60,5 & 62,0 & 63,2 & 59,5 & 61,3 & 62,9 & 61,3 & 62,5 & 63.4 \\
\hline $\begin{array}{l}\text { Marketing e promoçāo } \\
\text { do destino }\end{array}$ & 42,7 & 45,6 & 46,8 & 46,8 & 50,0 & 50,1 & 39,8 & 42,5 & 44,4 \\
\hline Políticas públicas & 55,2 & 56,1 & 57,6 & 61,5 & 61,3 & 62,1 & 50.7 & 52,4 & 54,4 \\
\hline Cooperaçāo regional & 51,1 & 49,9 & 44,6 & 48,3 & 47,7 & 44,2 & 53,1 & 51.4 & 44,9 \\
\hline Monitoramento & 35,3 & 36,7 & 37,4 & 42,6 & 44,3 & 45.1 & 30,0 & 31,2 & 31,9 \\
\hline Economia local & 59,5 & 60,8 & 63,6 & 70,7 & 70,6 & 75,4 & 51,5 & 53,7 & 55,2 \\
\hline Capacidade empresarial & 57,0 & 59,3 & 61,2 & 82,7 & 85,1 & 86,0 & 38,6 & 41,0 & 43,5 \\
\hline Aspectos sociais & 58,4 & 59,1 & 59,4 & 64,2 & 64,7 & 63.1 & 54,2 & 55,2 & 56,7 \\
\hline Aspectos ambientais & 65,6 & 67,2 & 67,7 & 71,3 & 72,7 & 73.5 & 61,5 & 63,3 & 63.6 \\
\hline Aspectos culturais & 55,9 & 57,5 & 58,2 & 64,1 & 66,2 & 66.4 & 50,0 & 51,2 & 52,4 \\
\hline
\end{tabular}

Figura 16 - Resultados consolidados - Brasil, capitais e não capitais: 2010-2013 Fonte: BRASIL (2013a).

É possível inferir que o Índice de Competitividade Nacional dialoga com o conceito de sustentabilidade abordado nesta tese, pois no referido Índice são contemplados os "aspectos sociais", "aspectos ambientais", "aspectos culturais" e, no âmbito econômico, a "economia local" e "capacidade empresarial". Entretanto, a inovação não é considerada diretamente no índice brasileiro, o que já é objeto de estudo recente do próprio MTur.

Para Baños e Jiménez (2012), a competitividade de um destino turístico não pode ser considerada se os rendimentos são adquiridos por meio da degradação dos recursos e acentuação da desigualdade e de outros custos sociais. Esta prática, segundo os autores, é autodestruidora da própria atividade turística.

É preciso ressaltar que o pilar inovação é encontrado de forma direta e/ou indireta desde os primeiros modelos de competitividade, porém a literatura (CROUCH \& RITCHIE, 1999; BUHALIS, 2000; WEF, 2013a; 2013b; ALVES, 2013) revela que a o pilar sustentabilidade vem sendo incorporado aos poucos nos modelos de competitividade global, inclusive nos modelos de competitividade turística.

De acordo com Alves (2013), os modelos mais tradicionais de competitividade turística adotados na literatura, que são os de Crouch \& Ritchie (1995-2003) e os de Dwyer 
\& Kim (2003), incluem a sustentabilidade como pilar. No entanto, variáveis ou fatores vinculados direta ou indiretamente às dimensões ambiental, social e cultural são tratados isoladamente.

Se os destinos turísticos brasileiros dependem, obviamente, de empresas, se já são tautológicos os motivos pelos quais as empresas fracassam e se é evidente que a inovação e sustentabilidade são fortes fatores de competitividade (PORTER \& VAN DER LINDE, 1995), a próxima seção apresenta a interface entre esses dois pilares tão importantes para uma atividade turística brasileira que se quer mais competitiva.

\subsection{INOVAÇÃO PARA A SUSTENTABILIDADE NO TURISMO: A LEGITIMAÇÃO} DE UM NOVO CONCEITO E VALOR

O ser humano, com todo o desenvolvimento de sua capacidade cognitiva na condição de Homo sapiens sapiens, tem deixado para a humanidade legados materiais e imateriais incalculáveis. No "mundo d.i." os avanços e legados não necessariamente correspondem a impactos positivos para a coletividade. A relação nem sempre é diretamente proporcional: mesmo com mais acesso a inovações (tecnológicas ou não), sensação de conforto, atividades e resultados eficientes, desenvolvimento da medicina, entre outros vários progressos, ainda existem no "mundo d.i." diversas mazelas sociais, como a extrema pobreza (CASTELLS, 2002).

Diante da impossibilidade de se manter a atual economia, tendo em vista os incontáveis impactos negativos que tem gerado, Abramovay (2012) propõe a transição para uma nova economia, que por sua vez se orienta a partir de algumas estratégias: 1) Sociedade e natureza (limite dos ecossistemas e inovação para o uso eficiente, inteligente e moderado da matéria, energia e biodiversidade); 2) Metabolismo industrial e 3) Relação entre economia e ética. $\mathrm{O}$ "metabolismo industrial" é capaz de diminuir o uso de $\mathrm{CO}_{2}$ em termos de matéria e energia, oferecendo oportunidades para a satisfação das necessidades básicas. Esse processo pode reduzir a desigualdade e aumentar, através da inovação, a produtividade dos processos.

Abramovay (2012) afirma que a referida transição para uma nova economia passa pelo caminho da economia verde e da sociedade da informação em rede. Estas, por sua vez, abrem novos rumos para a inovação, inclusive para o desenvolvimento de sistemas de inovação voltados para a sustentabilidade, assim como define o autor: 
[...] inovação não se confunde genericamente com o aumento de produtividade, com produzir mais e mais com cada vez menos trabalho ou menos capital. Inovação hoje é, antes de tudo, melhorar como se obtém e transforma energia, os materiais e a própria biodiversidade em produtos e serviços úteis para a sociedade. É nesse sentido que se fala hoje da necessidade de sistemas de inovação orientados para a sustentabilidade, ou seja, voltados a reduzir a dependência em que se encontra a vida econômica no uso crescente de recursos materiais e energéticos (ABRAMOVAY, 2012, p. 18, grifo nosso).

Nussbaum (2008) explica que as redes globais de relações de confiança serão cada vez mais comuns e organizadas em plataformas colaborativas. Isso implicará grandes mudanças socioeconômicas e políticas, refletidas no conceito de "Transformação", pois colocam em evidência as pessoas, que por sua vez se conectam por redes e sistemas em um processo de "tecnologia humanizada". Daí a importância de se atribuir maior robustez ao conceito de inovação, associando-a à noção de transformação a qual a sociedade contemporânea está inserida.

Como forma de atenuar os riscos desencadeados pelo modelo de produção industrial e crises decorrentes, tem-se adotado conceitos como "inovação sustentável" (BESSANT \& TIDD, 2009; BARBIERI et al., 2010), "inovação ambientalmente sustentável" (BESSANT \& TIDD, 2009; MEDEIROS; RIBEIRO \& CRUZ, 2012), "inovação ambiental" (AGRA FILHO et al., 2003; ANGELO; GALINA \& JABBOUR, 2011), "inovação verde/green innovation" (RADONS; BATTISTELLA \& GROHMANN, 2012), "eco-inovação/eco-innovation" (PASTOR et al., 2011; HORBACH; RAMMER \&RENNINGS, 2012) e "inovação limpa" (VEUGELERS, 2012).

Para Arbix (2007, p. 29) "inovação é um conceito móvel que acompanha a evolução das sociedades e se desenvolve num involucro de incerteza. A compreensão de seus mecanismos mais sutis exige intenso tratamento multidisciplinar". A produção científica se enriquece quando pesquisadores avançam em suas pesquisas, rompendo paradigmas e até mesmo criando novos conceitos, metodologias e técnicas. Entretanto, encontramos exemplos de que, em um só artigo (MEDEIROS; RIBEIRO \& CRUZ, 2012), são apresentados quatro conceitos ("inovação ambientalmente sustentável", "inovação verde", "inovação de produtos verdes" e "inovação sustentável") como sinônimos, sendo que se encontra inclusive na literatura a distinção entre os mesmos. Usam-se, habitualmente, vários conceitos imprecisos.

O conceito "inovação sustentável" é problemático na medida em que sugere serem os processos de produção industrial duradouros, constantes e ilimitados, o que Georgescu- 
Roegen $^{43}$ (2012), entre outros, têm demonstrado impossível. Conclusão em parte de acordo com a obra de Schumpeter (1961), anteriormente citada. A obsolescência programada, que incentiva o consumo e o descarte de forma cada vez mais rápida, compromete a finitude dos recursos naturais e gera o consumismo desenfreado e estimulado pela moda. À medida que a produção industrial esteja regida pela obsolescência programada, a inovação se torna insustentável, pois os produtos (e os serviços agregados a determinados tipos de produção) inevitavelmente serão descartados no curto/médio prazo. A "inovação sustentável" só tem sentido em um contexto, não apenas de mudança do processo produtivo, mas igualmente de mudança do consumo, do estilo de vida e da noção de felicidade, agora descolada do consumo desenfreado. A natureza não pode ser concebida como fonte inesgotável de recursos e local incomensurável de despejo. A inovação, portanto, nem sempre é sustentável, uma vez que também destrói produtos para que outros novos sejam comercializados, elimina empregos, cria produtos e serviços supérfluos/inúteis e nem sempre se apropria racionalmente dos recursos naturais.

Quanto aos conceitos de "eco-inovação", "inovação ambiental" e "inovação ambientalmente sustentável", se os três comportam explicitamente a dimensão ambiental e econômica, não indicam as dimensões social e cultural da sustentabilidade. Vide a obra de Pastor, Oña e Signes (2011) que, ao medir "eco-inovação" no setor turístico, desconsideram a dimensão social. Por sua vez, o conceito de "green innovation" não aborda a totalidade dos aspectos das relações sociedade e natureza, pois desconsidera, uma vez mais, a finitude dos recursos naturais, sobretudo em face do ingresso esperado de 2,4 bilhões de pessoas no mercado de consumo nos próximos 20 anos (ONU, 2013).

Considerando apenas as nomenclaturas que dizem respeito às tecnologias no contexto do meio ambiente, Jabour (2007, p. 02) listou uma diversidade delas, adotadas em periódicos científicos nacionais e internacionais.

- Tecnologias ambientais alternativas (KOLAR, 2000);

- Tecnologias ambientalmente interessantes (UNEP, 2002);

- Tecnologias verdes (KIVIMAA e MICKWITZ, 2006);

- Tecnologias ambientalmente amigáveis (BARBIERI, 2004);

- Eco-tecnologias (SMITH, 2001);

- Inovações tecnológicas ambientalmente saudáveis (BARBIERI, 1997);

- Tecnologias limpas (MAZON, 1992);

- Tecnologias mais limpas (ONU, 1992);

- Tecnologias ambientalmente sensíveis (MAZON, 1992);

- Tecnologias ambientalmente avançadas (OLSON, 1991);

- Tecnologias naturais avançadas (OLSON, 1991);

- Soluções ambientalmente amigáveis (MARTINSONS, SO, TIN e WONG, 1997);

- Tecnologias ambientalmente benéficas (JAFFE, NEWELL e STAVINS, 2005);

\footnotetext{
${ }^{43}$ Para Cechin (2010, p. 162) "Georgescu considerou o processo econômico irreversível, assim como a evolução
} biológica, e o motor dessa evolução sendo as inovações radicais". 
- Tecnologias mais verdes (CONWAY e STEWARD, 1998);

- Tecnologias não-agressivas ao meio ambiente (DONAIRE, 1999); e

- Tecnologias ambientalmente sustentáveis (HALL e VRENDENBURG, 2003).

Todos os conceitos supracitados pecam pela inobservância da multiplicidade de aspectos envolvidos nas relações sociedade-natureza. E são, assim, incapazes de apreender a complexidade do fenômeno. Embora Agra Filho et al. (2003, p. 21) utilizem o conceito "inovação ambiental", reforçam que "sem inovação não se tem como atingir a sustentabilidade". De forma alinhada a esse pensamento, Freitas et al. (2012, p. 367, grifo nosso) afirmam que

A inovação se constitui em fator fundamental para que as organizações estabeleçam padrões de sustentabilidade nas dimensões mencionadas, no entanto, essas inovações devem ser caracterizadas por bases sistemáticas. Além disso, as inovações devem ser equitativas com o suporte de recursos naturais existentes, introduzindo novidades que atendam às múltiplas dimensões da sustentabilidade em bases sistemáticas.

Diante do exposto, não basta somente a inovação para redução de custos e aumento de produtividade com vistas à melhor competitividade. Embora nos conceitos específicos de inovação acima apresentados haja preocupação com o meio ambiente, a inovação que não seja direcionada para uma causa específica, (no caso, a sustentabilidade) é anacrônica, e por isso é fundamental considerar as dimensões essenciais da sustentabilidade. Dessa forma adotamos nesta pesquisa o conceito de "inovação para a sustentabilidade" por três motivos: 1) considera as dimensões da sustentabilidade em sua totalidade, 2) trata de uma inovação na contramão da lógica da obsolescência programada e da cultura de produção mercadológica voltada para a "destruição criadora" e 3) representa uma mudança de paradigma, em que governos, sociedades civis e empresas, por meio da disseminação do conhecimento e da cooperação, podem ser os protagonistas para se alcançar uma situação de bem-estar coletivo.

O Quadro 12 abaixo indica algumas condições que o processo inovativo permite mudar. Trata-se de uma melhoria ou mudança de condição, por exemplo, de uma realidade menos sustentável para uma realidade mais sustentável graças à inovação; de uma situação de insegurança para segurança e assim por diante como mostra o quadro abaixo. Vale ressaltar que em alguns casos específicos como mudar um status de analógico para digital nem sempre é a melhor solução, sobretudo porque investir no tradicional e/ou no "vintage", também pode ser uma alternativa inovadora para um determinado negócio. De todo modo, o Quadro 12 indica algumas possibilidades de mudanças que a inovação pode estimular em todos os setores produtivos, inclusive no turismo. 


\begin{tabular}{|l|l|}
\hline \multicolumn{1}{|c|}{ A INOVAÇÃO PODE MELHORAR/MUDAR UMA CONDIÇÃO DE... } & \multicolumn{1}{c|}{ PARA.... } \\
\hline não-sustentabilidade & sustentabilidade \\
\hline insegurança & segurança \\
\hline morosidade & rapidez/eficiência \\
\hline menos ergométrico & mais ergométrico \\
\hline local & global \\
\hline fixo & móvel \\
\hline máximo & mínimo \\
\hline sujo & limpo \\
\hline não-reciclável & biodegradável \\
\hline desconexo & integrado \\
\hline fragmentado & sistêmico \\
\hline microscópico & macroscópico \\
\hline assincrônico & tempo real \\
\hline analógico & digital \\
\hline real & virtual \\
\hline isolamento & redes sociais \\
\hline
\end{tabular}

Quadro 12 - Mudanças de condições a partir do processo inovativo

Fonte: Elaborado pelo professor Dr. Vinicius Lages e Ma. Daniela Rocco para a disciplina Inovação em

Serviços Turísticos do curso de bacharelado em Turismo do Centro de Excelência em Turismo da

Universidade de Brasília (2012).

Compreendemos que a inovação para a sustentabilidade é um processo que preferencialmente deve ocorrer em todo o ciclo de vida de produtos e serviços ${ }^{44}$. Por sua vez, ao longo de qualquer processo de produção desde uma pequena empresa até mesmo a gestão de um destino turístico nacional, devem ser incluídos valores éticos e ecológicos de maneira inovadora, como: trabalho justo, menor uso de recursos não-renováveis, tecnologias de ecoeficiência, métodos inteligentes de reciclagem e reaproveitamento, desenvolvimento de soluções criativas, entre outras. Vale lembrar, tal como mencionando no início deste capítulo, que a inovação para a sustentabilidade não é um tipo de inovação, e sim um processo transversal (ou que pelo menos deveria ser) a todos os tipos de inovação.

A inovação para a sustentabilidade é um processo que ocorre de forma sistêmica. Alinhando-se ao conceito de "sistema de inovação", conforme já explicado, adotamos o conceito de "ecossistema de inovação" do País Basco (Espanha) ${ }^{45}$ para exemplificar a forma como a inovação para a sustentabilidade pode ser organizar, independentemente de escala e território. A Figura 17 mostra o referido ecossistema, que é composto por elementos que

\footnotetext{
${ }^{44}$ Uma vez avançado o processo de inovação para a sustentabilidade entre produtos e serviços, acreditamos que essa cultura se disseminará com maior força no mundo, e isto já começa a ser visto. Um exemplo é que, por meio do maior acesso à conectividade e mobilidade, pessoas se conectam física e virtualmente a comunidades de atitudes colaborativas voltadas para causas socioculturais, ambientais, entre outras.

${ }^{45}$ O País Basco é uma das regiões mais inovadoras do mundo, por concentrar parques tecnológicos e centros de cooperação (exemplo: Mondragón), estimular a cultura da C,T\&I e incentivar processos de transformação social e urbana, tal como ocorreu em Bilbao. Hoje, a Innobasque (Agência Basca de Inovação), possui como objetivo: "favorecer e impulsar el desarrollo de la innovación en Euskadi, tanto la tecnológica como la no tecnológica, fomentando el espíritu emprendedor y la creatividad, con el fin de elevar la competitividad de las organizaciones vascas de todo tipo y de su economía, en los sectores primario, secundario y terciario y mejorar la calidad de vida presente y futura de toda la sociedad vasca. Como entidad de carácter estratégico, el objetivo general de Innobasque es impulsar, dinamizar y monitorizar el proceso de transformación de Euskadi hacia una sociedad innovadora en todos los ámbitos" (art.2y 3)" (INNOBASQUE, 2008?).
} 
interagem entre si. São eles: i) conectividade (conectar pessoas e instituições através de nossa rede de valor); ii) impactos (captação de iniciativas inovadoras de alto impacto); iii) investimentos (financiamento de iniciativas inovadoras) e iv) recursos (provisão de recursos, talentos, tecnologias e prospecção de mercados para projetos de grupos privados/públicos). O núcleo central do ecossistema, chamado como "quadri-hélice da inovação", é formado por: i) economia de eco-inovação (sustentabilidade ambiental); ii) sociedade eficientemente saudável (desenvolvimento social, saúde e qualidade de vida); iii) aceleração de empreendedorismo e iv) quarto setor (desenvolvimento econômico e novos cenários).

\section{Connectivity}

Connect people and instiutions through our value netwok"

\section{New scenarios}

Impact

Capture innovative initiatives with high.impoct

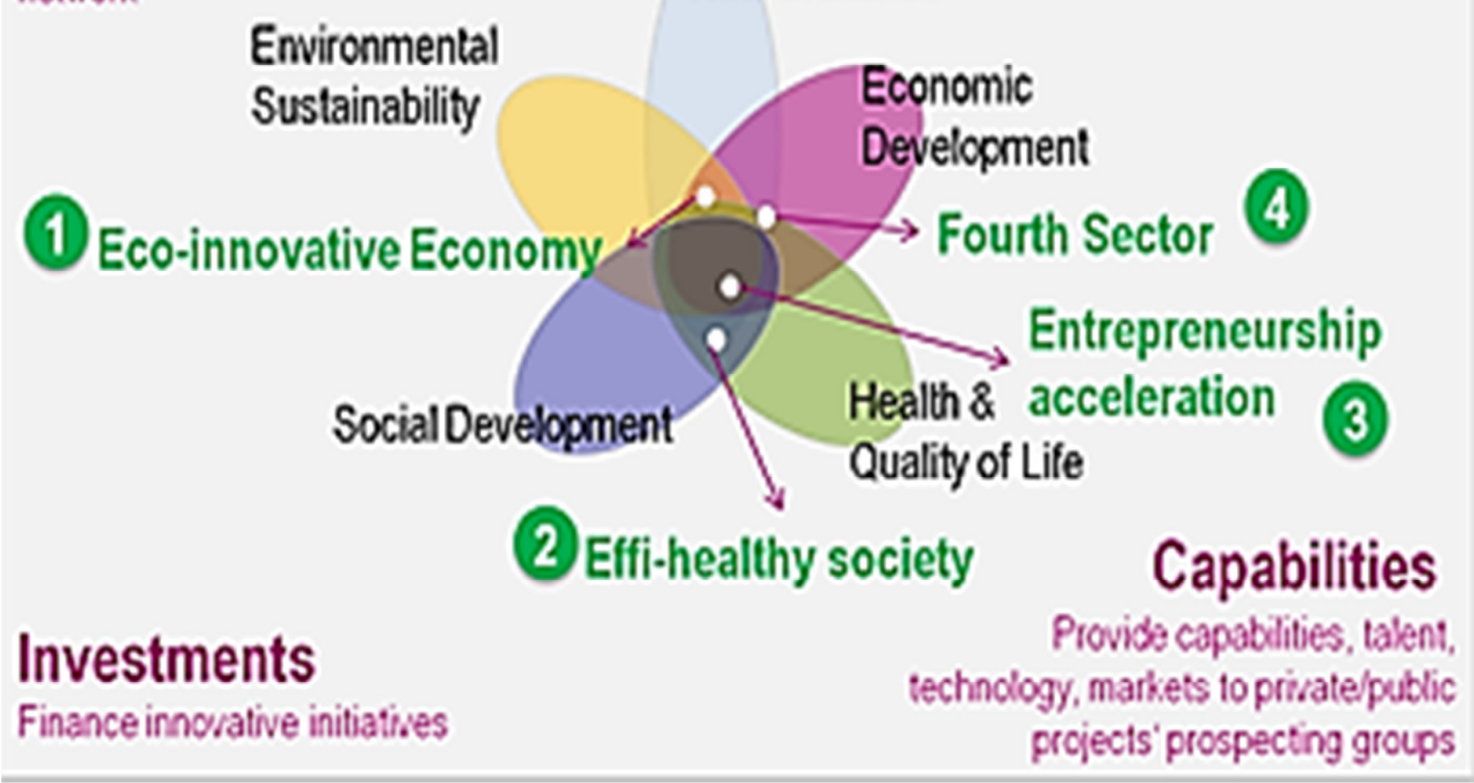

Figura 17 - Funcionamento de um Ecossistema de inovação Fonte: Innobasque (2013?)

A principal finalidade do Ecossistema de Inovação Basco é dar apoio e acompanhamento aos processos colaborativos de inovação que auxiliam na criação de valor das empresas e organizações públicas e privadas. Isso desencadeia a internacionalização das empresas e organizações envolvidas, conhecimento que é convertido em riqueza, geração de novos postos de trabalho e bem-estar coletivo. Tais processos são respaldados por uma "dinâmica transformadora" que consiste na interlocução e cooperação entre 
diversos agentes como empresas, universidades, centros de pesquisa, representantes do governo e da sociedade civil. Esses agentes são capazes, por sua vez, de converter boas ideias em valor, valor em negócios, negócios em empregos e envolvimento de recursos humanos mais qualificados. Consequentemente, isso leva a um aumento de competitividade das empresas e organizações, inclusive no mercado internacional (INNOBASQUE, 2013?).

O conceito de ecossistema de inovação nos convida a pensar a partir de uma perspectiva mais orgânica dos processos, tal como ocorre na esfera da biologia. "Joi" Ito acredita que a inovação pode responder, em grande parte, aos desafios das cidades e as associa à "biologia de sistemas", uma vez que tudo está organicamente conectado (POULSEN, 2013).

A base do conceito de inovação para a sustentabilidade reside na lógica da gestão do pensamento sobre a Avaliação do Ciclo de Vida - ACV (Life Cycle Assessment - LCA), pois este é um método de análise sistêmica que considera os impactos ambientais de produtos, processos e serviços, assim como as entradas/saídas de energia e de matéria, desde a extração da própria matéria-prima até a disposição final (CALDEIRA-PIRES; SOUZAPAULA \& VILLAS BÔAS, 2005). Por outro lado, é preciso considerar na ACV de produtos e serviços as dimensões social e cultural da sustentabilidade, do início ao final.

No caso do turismo, a aplicação da ACV é também uma forma de se criar/melhorar esses negócios sustentáveis a partir da lógica da inovação. Isto é: quando o uso da inovação impacta a sustentabilidade no turismo, a probabilidade de se ter um retardamento no esgotamento do tempo de vida desse destino é muito maior, pois este permanece mais tempo com alta atratividade.

Scott e Cooper (2010), que estudaram o turismo urbano da Austrália, elencaram duas formas de inovação para a sustentabilidade nas cidades, quais sejam: i) direta, como o uso de mapas verdes, promoção do uso de transportes locais, incentivo às ciclovias e o andar a pé, a conservação do patrimônio cultural e o consumo de produtos das redondezas e ii) indireta, como a adoção de energia renovável, reciclagem, uso do transporte turístico de baixo impacto e reduções no uso da água.

De acordo com a ONU (2012), até 2030 aproximadamente $60 \%$ da população mundial habitará zonas urbanas. Atualmente, dois em cada três europeus vivem em cidades. As áreas urbanas concentram, consequentemente, a maior parte dos desafios que nossa sociedade enfrenta, e os esforços para unir compromisso e inovação para resolvê-los são fundamentais (EUROPEAN COMMISSION, 2014a).

Hoje a mobilidade urbana é uma questão emblemática nas atuais discussões, e os problemas enfrentados repercutem, sem dúvida, sobre moradores e visitantes. Existe uma demanda real e potencial por destinos turísticos eficientes em mobilidade urbana e que prezem pela qualidade dos serviços em geral. 
No contexto do turismo, Costa (2013, p. 15, grifo nosso) alerta:

\begin{abstract}
Uma atividade que cria enclaves, segrega os turistas dos moradores, marginaliza culturas; em que os ganhos são concentrados para poucos e extraídos em curto prazo, que repassa danos e imprudências ambientais a terceiros, que consome inadequada ou excessivamente os recursos comuns, entre eles os ativos ambientais e culturais. Esse turismo mantém ou agrava condições de pobreza e fragilidades ambientais, ocasionando queda de competitividade para os destinos e comprometendo as condições para o equilíbrio dinâmico requerido pelo tripé da sustentabilidade.
\end{abstract}

Os problemas e desafios dos destinos turísticos brasileiros devem ser enfrentados de maneira inteligente, sistêmica, integrada e contextualizada, e a inovação para a sustentabilidade pode contribuir nesse processo. Pode favorecer a criação de novas formas de organização entre as pessoas e modelos de negócios que efetivamente possam garantir a competitividade turística, sem que isso comprometa a matéria-prima e recursos dos próprios destinos.

Não basta considerar apenas a sustentabilidade do destino em si, e sim de todo o sistema turístico, composto por distintas e complexas cadeias de valor. Devemos lembrar que a inovação no campo da Administração é um tema bastante recorrente, haja vista a repercussão das publicações de Drucker (1986), Porter (1989; 1995) e Kotler (2011). Não obstante, a sustentabilidade também vem sendo amplamente debatida na Academia, incorporada em governos e praticada pela iniciativa privada, sociedade civil e terceiro setor.

No entanto, o diálogo consistente entre inovação e sustentabilidade é uma lacuna e mais ainda é o gap na reflexão da inovação para a sustentabilidade no turismo, muito embora existam claros esforços da própria OMT por meio de desenvolvimento de projetos, assim como de publicações, de incentivos com prêmios e de eventos como feiras e congressos que abordam a temática. O trade turístico em geral e a Academia também têm se manifestado recentemente e, no caso do Brasil, as principais ações constam no capítulo 4. No próximo capítulo estão explicitadas as etapas necessárias para a construção da presente pesquisa. 


\title{
3. CONSTRUÇÃO DA PESQUISA E MATRIZ DE INOVAÇÃO PARA A SUSTENTABILIDADE NO TURISMO
}

Tags: pesquisa qualitativa, entrevistas, formulários, questionários, modelos, modelos de inovação, modelos de desenvolvimento sustentável, modelos de turismo, modelos de competitividade, MIST, atores, Bonito, Gramado, Instituto Inhotim.

"A parte mais relevante da história é uma história contada em palavras, mesmo quando é acompanhada por algumas séries temporais que marcam a passagem do tempo". Nicholas Georgescu-Roegen, economista do século XX

Esta pesquisa é de natureza exploratória e descritiva, pois foram realizadas visitas a destinos turísticos (observação direta), além de análises de dados primários e secundários. As técnicas de pesquisa adotadas neste trabalho foram: entrevistas, questionários e formulários. A entrevista diz respeito a um roteiro de perguntas previamente estruturadas ou semiestruturadas e que envolve duas pessoas: uma formula as perguntas e a outra as responde ("face to face"). O questionário é o conjunto de perguntas formuladas por escrito pelo pesquisador, porém são respondidas por escrito pelo pesquisado. Quanto ao formulário, este é um instrumento que contém perguntas que são feitas pelo pesquisador e ele mesmo anota as respostas de seu respondente. No caso dos formulários e questionários, as perguntas podem ser abertas, semiabertas ou fechadas (GIL, 2002).

O método adotado neste trabalho está respaldado basicamente pela análise qualitativa, pois o tema em questão ainda não foi aprofundado no Brasil e requer, portanto, maior compreensão do fenômeno como um todo. Esta escolha está apoiada, ainda, em Georgescu-Roegen (1980), que faz uma reflexão sobre a relação da análise do processo de inovação com o uso de "palavras" ${ }^{\text {"6 }}$, e não necessariamente por meio de "números".

\begin{abstract}
É por causa do surgimento constante de inovações que não é possível compreender a realidade apenas com a ajuda da análise. A análise consiste em uma descrição sistemática da realidade somente com a ajuda de conceitos aritmomórficos. A propriedade característica destes conceitos pode ser melhor ilustrada por um número. Por exemplo, o número "um" está completamente isolado de todos os outros números. Não existe nenhum número que é ao mesmo tempo "um" e "não um" [...]. Além disso, um número não pode mudar com o tempo. O que "um" significou nos primórdios dos tempos em que se começou a contar é ainda válido hoje e será sempre. O mesmo não é verdade para a maior parte de nossas ações básicas (GEORGESCU-ROEGEN, 1980, p. 119).
\end{abstract}

\footnotetext{
${ }^{46}$ Segundo Cechin (2010), Georgescu-Roegen aprendeu com Schumpeter (seu principal tutor em economia) que as transformações essenciais na economia devem ser analisadas principalmente do ponto de vista qualitativo.
} 
Para facilitar o entendimento dos procedimentos metodológicos desta pesquisa foi criada a Figura 18 abaixo. Nela consta em cada canto inferior à direita a indicação das três grandes partes deste trabalho. A Parte I, que corresponde aos capítulos 1 e 2 , se refere neste capítulo 3 à seção 13.1 Pesquisa exploratória. A Parte II é essencialmente o presente capítulo, cujas seções são a 3.2 Criação da MIST (Matriz de Inovação para a Sustentabilidade no Turismo) e a 3.3 Pesquisa qualitativa. Por fim, a Parte III é composta pelos resultados (capítulos 4 e 5) e análise final (Conclusões).

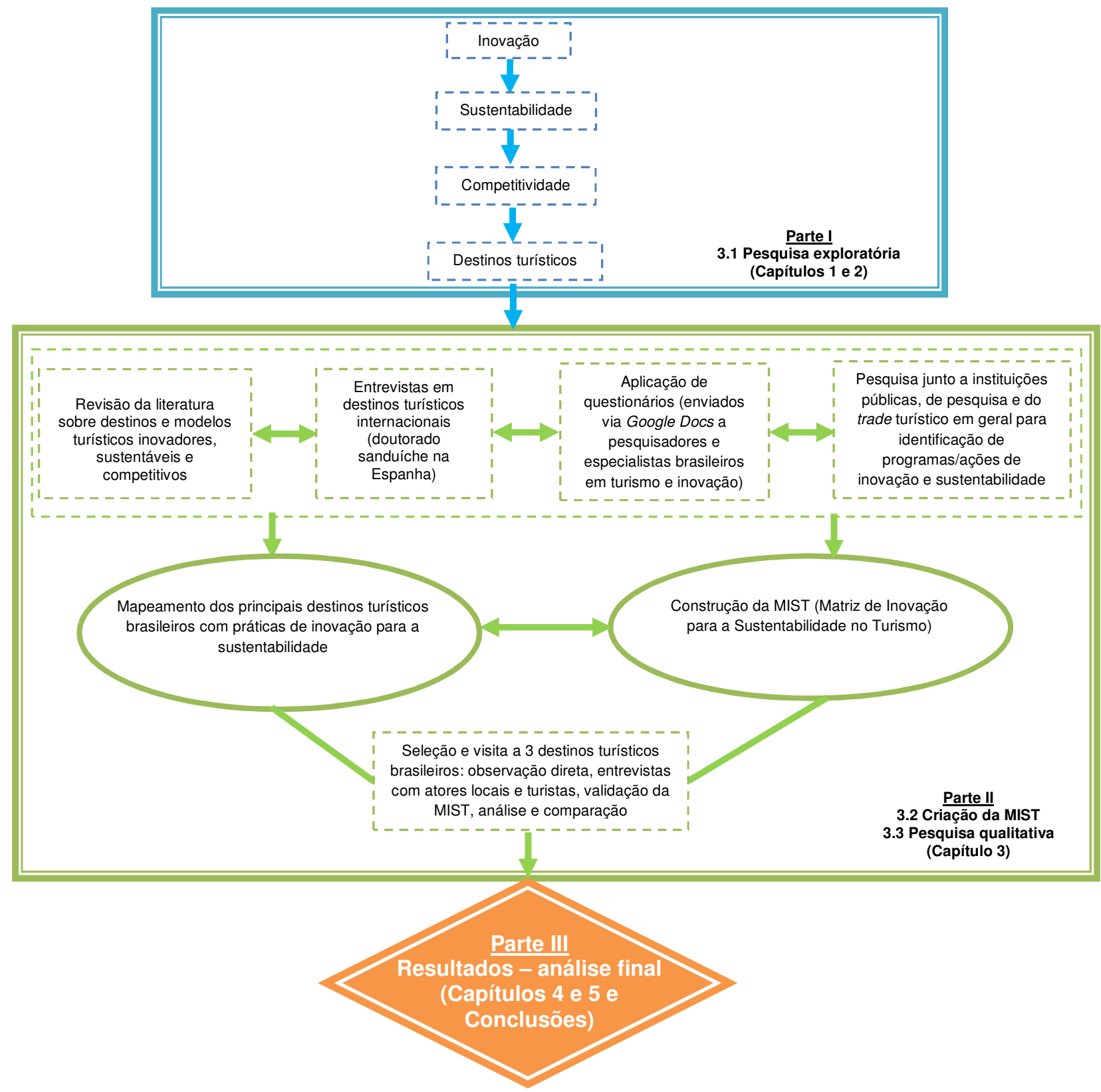

Figura 18 - Representação esquemática das etapas de desenvolvimento da pesquisa Fonte: Elaborado por Daniela Rocco (2014). 


\subsection{PESQUISA EXPLORATÓRIA}

Esta etapa consistiu na fundamentação teórico-metodológica da tese por meio de levantamento bibliográfico e documental. Recorremos, assim, à leitura e análise de livros, artigos científicos de periódicos nacionais e internacionais reconhecidos pela CAPES, teses, dissertações, legislação brasileira, documentos disponíveis em websites governamentais e relatórios oficiais de gestão pública e privada. A Figura 19 a seguir indica os principais conceitos adotados com os respectivos autores e abordagens que mais se destacam nesta tese.

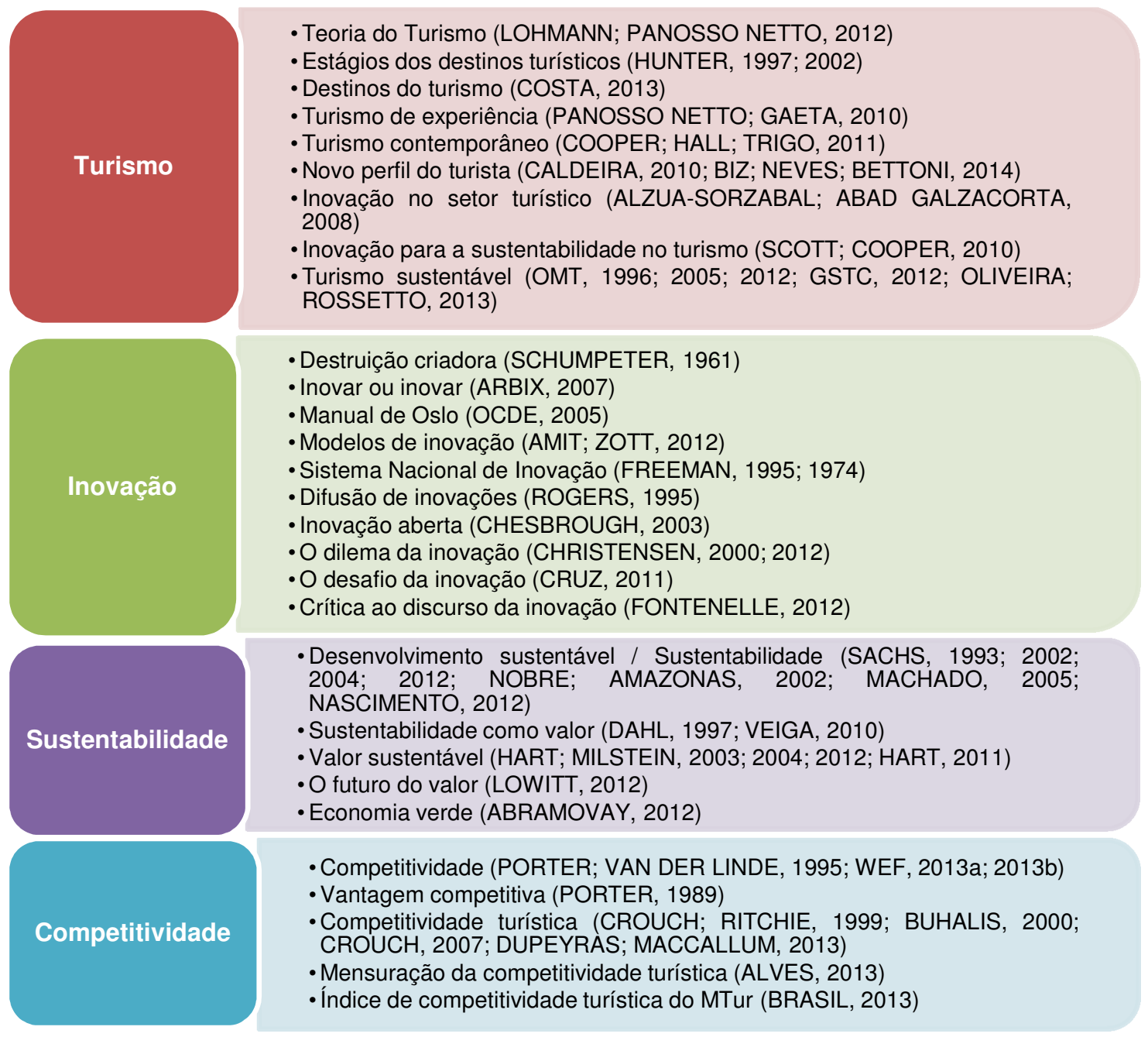

Figura 19 - Relação dos conceitos-chave da tese com os principais autores Fonte: Elaborado por Daniela Rocco (2014).

Vale ressaltar que esta etapa ocorreu durante todo o processo de pesquisa. 


\subsection{CRIAÇÃO DE INSTRUMENTO DE ANÁLISE PARA A PESQUISA}

QUALITATIVA: MIST (MATRIZ DE INOVAÇÃO PARA A SUSTENTABILIDADE NO TURISMO)

Com base nas premissas de modelos vinculados a turismo, bem como na construção teórica do objeto de pesquisa, criamos a MIST (Matriz de Inovação para a Sustentabilidade no Turismo), que se refere ao segundo objetivo específico desta pesquisa.

Modelos são representações de um sistema que permitem realizar a análise de seus elementos, propriedades e interações, e, em alguns casos, fazer previsões sobre sua evolução (BOISIER, 2003). Em geral, a análise de modelos implica na realização de estudos quantitativos e/ou qualitativos. A seguir discorremos sobre quatro tipos de modelos: de inovação, desenvolvimento sustentável, turismo e competitividade turística.

\section{- Modelos de inovação}

É possível considerar modelos de geração (da primeira à sexta), de sistemas de inovação, as formas de inovação e tipos de inovação. Neste contexto, é importante considerar a inovação que sai gradualmente de um enfoque mais centrado na tecnologia (ARBIX, 2007; DE BES; KOTLER, 2011) até se aproximar dos modelos atuais de inovação, mais pautados para atitudes colaborativas (modelo de inovação aberta) (CHESBROUGH, 2003). Tais modelos se caracterizam pelo uso mercadológico e acadêmico para criar o diferente ou melhorar o que já existe, mudar o status das coisas, dos paradigmas, das tecnologias, das formas institucionais, dos processos, do design e da função dos produtos e serviços oferecidos até o momento. A inovação como um processo e não apenas como uma coisa, um objeto. Por isso, hoje há uma grande ênfase nos modelos de gestão dos processos de inovação, como ocorre ao longo de uma cadeia de valor, e não como algo imóvel.

\section{- Modelos de desenvolvimento sustentável}

É necessário enfatizar o avanço do debate ambiental e como a partir das principais referências foram observados "modelos" de desenvolvimento sustentável, sejam eles teóricos, políticos/institucionais e sociais/educacionais. No entanto, é necessário efetuar alguns recortes. É possível pensar em alguns "modelos" ou recortes teóricos/normativos que podem fazer frente aos desafios do desenvolvimento sustentável, como: o modelo de sustentabilidade fraca e sustentabilidade forte (GEORGESCU-ROEGEN, 1971; SOLOW, 
1974; VEIGA, 2010b); o princípio do decrescimento (corrente de pensamento francês) (LATOUCHE, 2012); as práticas de educação ambiental (LAYRARGUES, 2000; ZANETI \& SÁ, 2002); os mecanismos de produção mais limpa (CETESB; PNUMA, 2004); o comércio de créditos de carbono (carbono zero) (ONU, 1998); a criação e o desenvolvimento de indicadores ambientais (VAN BELLEN, 2006); as formas de governança global para conter os impactos (mudanças climáticas, biodiversidade e assim por diante) (OSTROM, 1990; 2003); o princípio do poluidor-pagador (quem polui paga) (BRASIL, 1988); o fortalecimento da regulação/licenciamento/zoneamento/punição (BRASIL, 1988); os modelos voltados para os problemas urbanos; os modelos centrados no tema da energia; os modelos mais focados em temas sociais; os modelos cuja centralidade está na mudança dos padrões de consumo e comportamento; os modelos de comércio justo (fair trade); os modelos com ênfase nas mudanças filosóficas dos seres humanos (movimentos de contracultura de consumo consciente), entre outros.

Ainda que a problemática que envolve o tema social, cultural, ambiental e econômico seja muito complexa, o debate sobre o desenvolvimento sustentável confirma a tentativa de se legitimar e obter as melhores soluções para a sustentabilidade dos destinos turísticos, por exemplo.

Com tantos modelos de desenvolvimento sustentável (que se aplicam em diferentes situações, setores e empresas), considera-se que a inovação no contexto do turismo pode ser um fator-chave para a facilitação do turismo sustentável nos destinos turísticos, sendo capaz de gerar, de maneira criativa, a inclusão produtiva dos trabalhadores e até mesmo incentivar a competitividade do próprio destino. Além disso, a inovação a partir de processos de governança pode contribuir para o fortalecimento da cooperação e criação de redes sociais que sejam produtivas e valorizadas no sistema de turismo.

\section{- Modelos de turismo}

Modelos de análise do turismo são muito utilizados na literatura específica desse campo do conhecimento, e segundo Hall (2006) e Buhalis (2000), o modelo de Butler (1980) é um dos mais referidos, em função da análise do ciclo de vida de destinos turísticos, conhecida como TALC (Tourism Area Life Cycle). A Figura 20 abaixo representa o modelo que evidencia basicamente uma relação de número de turistas versus tempo. 


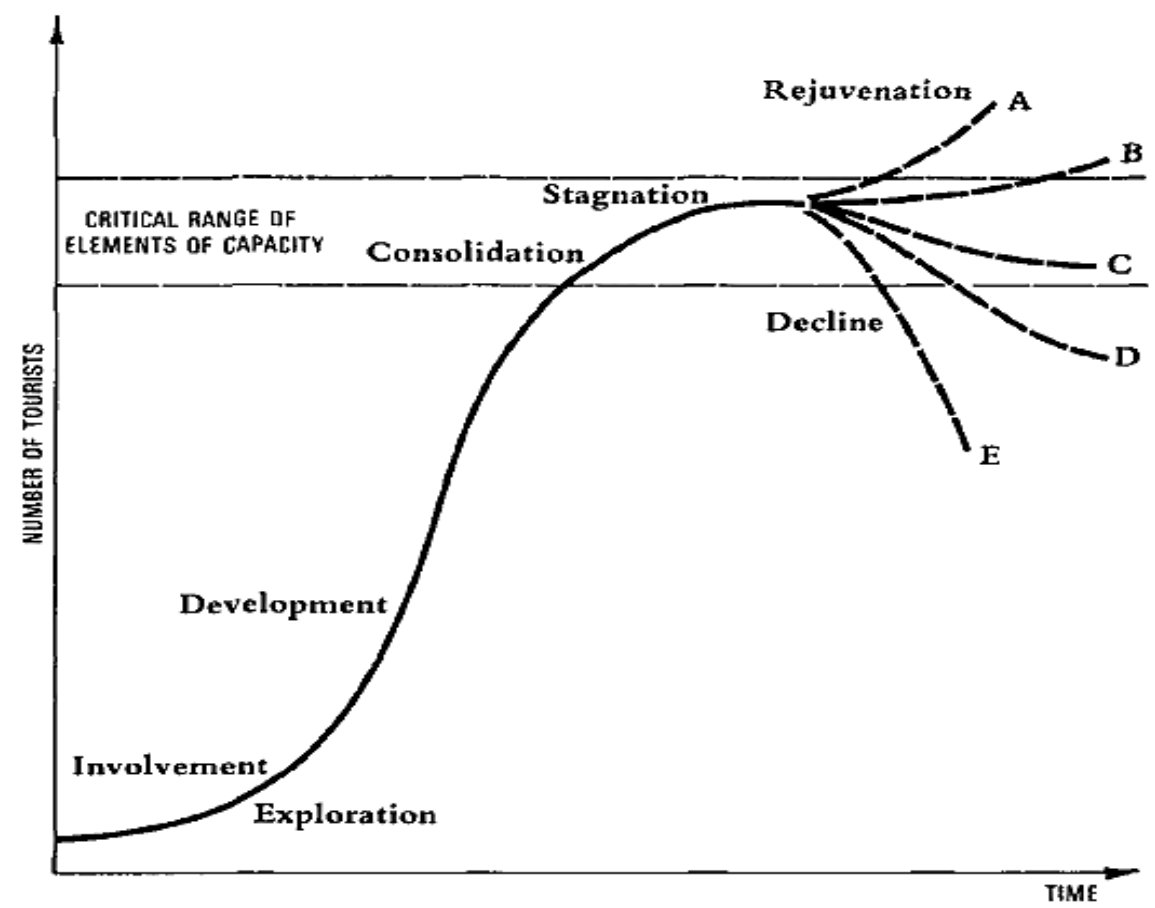

Figura 20 - Tourism Area Life Cycle Fonte: Butler (1980).

Embora outros modelos semelhantes tenham sido criados antes de Butler (particularmente a partir da década de $1960^{47}$ ), outros modelos semelhantes tenham sido criados recentemente ${ }^{48}$ e o fato de o modelo de Butler (1980) ser aquele que a academia mais se apropria, o TALC ainda apresenta algumas deficiências, por exemplo: muita dependência na relação de oferta e demanda (COOPER et al., 2002), a dificuldade de se mensurar quantitativamente a capacidade de carga (AGARWAL, 1994), considerar apenas as dinâmicas internas da atividade turística, uma vez que também existem fatores externos, por exemplo, concorrência (DEBBAGE, 1990) e apresentar um cenário ideal de ciclo de vida de um destino turístico, mas que possui pouca aderência com o cenário real (WEAVER, 2000). Diante dessas fragilidades relativas ao modelo de Butler (1980), e considerando a importância de se analisar um destino turístico, acreditamos que a construção de uma matriz pautada na inovação e na sustentabilidade pode auxiliar nos processos sobre como o turismo pode ser mais competitivo no país. Ou seja, como a inovação e a sustentabilidade podem ser critérios relevantes de um "modelo" mais adequado aos desafios contemporâneos em que ambas são parte da mesma equação para solucionar ou introduzir novos valores e novas "propostas de valor" em um mercado que necessita de um novo paradigma econômico, ambiental e social de produção.

\footnotetext{
${ }^{47}$ Vide Christaller (1963), Cohen (1972), Brougham e Butler (1972 apud Butler, 2006), Plog (1974), Fox (1973) e Fuster (1979).

${ }^{48}$ Vide Knowles (1996), Berry (2001), Russo (2002), Cooper e Jackson (1989), Cooper (1990, 1992, 2001, 2002), Hernández e León (2003), Flores (2006) e Álvares (2008).
} 


\section{- Modelos de competitividade turística}

Existem modelos e índices de competitividade turística reconhecidos no mundo inteiro, entre eles:

- WEF (World Economic Forum): Índice de Competitividade de Viagens e Turismo;

- OCDE (Organisation for Economic Co-operation and Development): Indicators for Measuring Competitiveness in Tourism: A Guidance Document;

- Banco Mundial (Doing business);

- GEM (Global Entrepreneurship Monitor): Níveis de empreendedorismo e crescimento econômico;

- WTTC (World Travel \& Tourism Council);

- EXCELTUR/Monitur: Destinos regionais da Espanha (Comunidades Autônomas), mas não está centrado na sustentabilidade;

- ETIS: Sistema europeu de indicadores para medir o turismo e a sustentabilidade (em processo de aplicação);

- Crouch \& Ritchie (1992; 2003; 2007): Não especificam a dimensão territorial (modelo teórico, entretanto, está centrado na sustentabilidade).

Com relação ao Brasil, o principal modelo de competitividade turística que é adotado é o Índice de Competitividade do Turismo Nacional, desenvolvido pela FGV em parceria com o SEBRAE e MTur.

Alves (2013) explica que tais modelos, em sua maioria, são fragmentados, adotam como unidade de análise o país (âmbito nacional), são testados em destinos turísticos internacionais, não possuem estudos comparativos, não conciliam oferta com demanda, entre outros fatores.

Os modelos anteriormente citados possuem especificidades que foram consideradas e adaptadas para construir um modelo que contribuísse na análise da inovação para a sustentabilidade no turismo: a MIST. A seção a seguir apresenta os atributos, variáveis e critérios de análise da matriz que foi elaborada.

\subsubsection{MIST: ATRIBUTOS, VARIÁVEIS, CRITÉRIOS E LIMITAÇÕES}

A MIST (Matriz de Inovação para Sustentabilidade no Turismo) é principal instrumento de análise construído para auxiliar na interpretação dos dados e informações obtidos na pesquisa de campo junto a equipamentos e atrativos turísticos. Ela é 
representada na forma de uma grade de análise (grille d'analyse ${ }^{49}$ ). Também pode ser entendida como um check-list baseado especialmente em atributos, variáveis e critérios e organizado em formato de matriz.

Propomos a construção da MIST porque o resultado principal nos forneceria dados e informações de maneira estruturada e organizada sobre atrativos e equipamentos turísticos que mais possuem características de inovação para a sustentabilidade. O processo geral, que será detalhado nas próximas seções, subsidiou, assim, análises mais aprofundadas a respeito dos três destinos turísticos selecionados como campo empírico deste trabalho. Em termos de estrutura, a MIST é composta por atributos, variáveis, critérios e segmentos da atividade turística, cuja construção e seleção foram assim realizadas:

- Atributos: são os dois pilares da competitividade (conceitos-chave: inovação e sustentabilidade) que já foram apresentados na revisão da literatura (pesquisa exploratória);

- Variáveis: de duas naturezas, de inovação e de sustentabilidade, escolhidas pela relevância na literatura e sua contribuição na pesquisa, supracitada (autores citados na Figura 19);

- Critérios: construídos e selecionados a partir desses estudos: i) "Criação de valor através da inovação de Modelo de Negócio" de Amit \& Zott (2012); ii) Diagnóstico de inovação do setor turístico no País Basco, desenvolvido por Tecnalia \& CICtourGUNE (2008) e iii) Método CANVAS (OSTERWALDER; PIGNEUR, 2009). Quanto aos critérios de sustentabilidade, optamos por adotar e adaptar os requisitos da Agenda 21 para o Turismo, da OMT (OMT, 1996; 2005; 2012) e do Plano EcoEuskadi 2020 (GOBIERNO VASCO, 2011).

- Segmentos da atividade turística: Foram eleitos a partir dos estudos desenvolvidos por Alzua-Sorzabal \& Abad Galzacorta (2008). As autoras realizaram um diagnóstico da inovação no setor turístico do País Basco (Espanha) com os sete principais segmentos do turismo. Adaptamos e selecionamos esses: 1) Meios de transporte; 2) Meios de Hospedagem; 3) Alimentos e bebidas; 4) Atrativos turísticos; 5) Agências de viagens; 6) Governo e informação turística e 7) Cooperação/Terceiro setor. Tais segmentos ou estão inseridos em um sistema aberto que contém a cadeia de valor do turismo ou, em um contexto mais avançado de inovação, em uma complexa rede aberta de encadeamentos produtivos e a cadeia de valor do turismo.

A seguir serão apresentados os Quadros 13 e 14, que apresentam respectivamente a MIST e seu detalhamento.

\footnotetext{
${ }^{49}$ Procedimento popularmente utilizado na França, a "grade de análise" permite modos de operação, análise e síntese, bem como uma análise detalhada sobre um determinado tema/contexto. Também pode ser usada para estabelecer metas, identificar indicadores, auxiliar no processo de tomada de decisão, entre outros tipos de avaliação (VILLENEUVE; RIFFON, 2011).
} 


\begin{tabular}{|c|c|c|c|}
\hline \multicolumn{4}{|c|}{ MIST - MATRIZ DE INOVAÇÃO PARA A SUSTENTABILIDADE NO TURISMO } \\
\hline ATRIBUTOS & VARIÁVEIS & CRITÉRIOS & $\begin{array}{c}\text { SEGMENTOS DA ATIVIDADE } \\
\text { TURÍSTICA }\end{array}$ \\
\hline $\begin{array}{l}\text { I. Inovação } \\
3 \text { formas: } \\
\text { - Incremental } \\
\text { - Disruptiva/radical } \\
\text { - Aberta }\end{array}$ & $\begin{array}{l}\text { Tipos de inovação (de produto, de processo, } \\
\text { etc.) } \\
\text { Criatividade } \\
\text { Logística } \\
\text { Diferenciação } \\
\text { Tecnologias, conectividade, mobilidade e } \\
\text { rastreabilidade } \\
\text { Valor proposto compartilhado } \\
\text { Redes de valor } \\
\text { Relações - produtores/consumidores } \\
\text { Competitividade }\end{array}$ & $\begin{array}{l}\text { 1. Perfil da organização } \\
\text { 2. Motivo da criação da organização } \\
\text { 3. Forma(s) e tipo(s) de inovação } \\
\text { 4. Produto(s)/serviço(s) inovador(es) com } \\
\text { princípios sustentáveis } \\
\text { 5. Motivo porque é considerado inovador } \\
\text { 6. Descrição do modelo inovador } \\
\text { 7. Uso de tecnologias (TICs) } \\
\text { 8. Principal valor ofertado/diferencial } \\
\text { 9. Investimento e retorno com inovação(es) } \\
\text { 10. Prêmioda(s) para a sustentabilidade } \\
\text { 11. Colaboradores externos } \\
\text { 12. Desafios }\end{array}$ & $\begin{array}{l}\text { 1. Meios de transporte } \\
\text { 2. Meios de hospedagem } \\
\text { 3. Alimentos e bebidas } \\
\text { 4. Atrativos turísticos } \\
\text { 5. Agências de viagens } \\
\text { 6. Governo e informação } \\
\text { turística } \\
\text { 7. Cooperação/Terceiro } \\
\text { setor }\end{array}$ \\
\hline $\begin{array}{l}\text { II. Sustentabilidade } \\
4 \text { dimensões: } \\
\text { - Conservação da natureza } \\
\text { - Conservação e } \\
\text { valorização da cultura } \\
\text { - Prosperidade econômica } \\
\text { com inclusão produtiva } \\
\text { - Equidade social }\end{array}$ & $\begin{array}{l}\text { Conservação da biodiversidade e diversidade } \\
\text { cultural } \\
\text { Certificação, selos ambientais e prêmios } \\
\text { Inclusão produtiva e social } \\
\text { Acessibilidade } \\
\text { Cooperação } \\
\text { Segurança } \\
\text { Educação }\end{array}$ & $\begin{array}{l}\text { Conservação da natureza e cultura: } \\
\text { 1. Minimização de resíduos } \\
\text { 2. Conservação e controle de energia } \\
\text { 3. Controle de recursos de água potável e } \\
\text { residuais } \\
\text { 4. Controle de substâncias perigosas no ar } \\
\text { 5. Controle e planejamento da exploração do } \\
\text { solo } \\
\text { 6. Conservação da biodiversidade e diversidade } \\
\text { cultural } \\
\text { Prosperidade econômica: } \\
\text { 7. Geração de emprego e renda } \\
\text { 8. Certificação, selos ambientais e prêmios } \\
\text { 9. Melhoria quanti-quali de capital produtivo com } \\
\text { competitividade } \\
\text { Equidade social: } \\
\text { 1. Responsabilidade social / comunidade } \\
\text { 2. Promoção de ações culturais, educativas, } \\
\text { esportivas e de ócio } \\
\text { 3. Saúde e segurança dos colaboradores }\end{array}$ & $\begin{array}{l}\text { Rede aberta de encadeamentos } \\
\text { produtivos e a cadeia de valor do turismo }\end{array}$ \\
\hline
\end{tabular}

Fonte: Elaborado por Daniela Rocco (2014). 
O Quadro 14 abaixo representa a descrição da MIST, com pormenores sobre a construção da Matriz.

\begin{tabular}{|c|c|c|c|c|c|}
\hline $\begin{array}{l}\text { DETALHAMENTO } \\
\text { ATRIBUTO I: } \\
\text { INOVAÇÃO }\end{array}$ & DESCRIÇÃO ATRIBUTO I & $\begin{array}{l}\text { DETALHAMENTO } \\
\text { ATRIBUTO II: } \\
\text { SUSTENTABILIDADE }\end{array}$ & $\begin{array}{l}\text { DESCRIÇÃO ATRIBUTO II: } \\
\text { SUSTENTABILIDADE }\end{array}$ & $\begin{array}{l}\text { SETORES DA } \\
\text { ATIVIDADE } \\
\text { TURÍSTICA }\end{array}$ & $\begin{array}{c}\text { DESCRIÇÃO DOS SEGMENTOS } \\
\text { DA ATIVIDADE TURÍSTICA }\end{array}$ \\
\hline Perfil da organização & $\begin{array}{l}\text { - Organização: pública, privada ou } \\
\text { de terceiro setor } \\
\text { - Setor / Segmento / Nicho }\end{array}$ & Minimização de resíduos & $\begin{array}{l}\text { - Gestão para usar a menor quantidade de } \\
\text { recursos } \\
\text { - Coleta seletiva } \\
\text { - Reutilização } \\
\text { - Controle de qualidade e monitoramento } \\
\text { - Compostagem } \\
\text { - Cooperativas de reciclagem de resíduos } \\
\text { - Legislação }\end{array}$ & $\begin{array}{l}\text { Meios de } \\
\text { transporte }\end{array}$ & $\begin{array}{l}\text { - Aéreo (avião, helicóptero, etc.) } \\
\text { - Ferroviário (trem, metrô, etc.) } \\
\text { - Rodoviário (ônibus, automóvel, } \\
\text { motocicleta, bicicleta, etc.) } \\
\text { - Marítimo e fluvial (barco, ferry, } \\
\text { caiaque, transatlânticos, lancha, } \\
\text { etc.) } \\
\text { - Empresas de aluguel (rent a car) }\end{array}$ \\
\hline $\begin{array}{l}\text { Motivo da criação da } \\
\text { organização }\end{array}$ & $\begin{array}{l}\text { Problema que a organização tem } \\
\text { como objetivo para prever ou } \\
\text { enfrentar demanda }\end{array}$ & $\begin{array}{l}\text { Conservação e controle } \\
\text { de energia }\end{array}$ & $\begin{array}{l}\text { - Eficiência energética / uso de energia } \\
\text { renovável } \\
\text { - Redução de recursos energéticos } \\
\text { fósseis } \\
\text { - Redução de consumo energético } \\
\text { (colaboradores/clientes) } \\
\text { - Ações corretivas / preventivas }\end{array}$ & $\begin{array}{l}\text { Meios de } \\
\text { hospedagem }\end{array}$ & $\begin{array}{l}\text { - Resort } \\
\text { - Hotel } \\
\text { - Hotel fazenda } \\
\text { - Hotel histórico } \\
\text { - Flat/apart } \\
\text { - Pousada } \\
\text { - Cama \& café } \\
\text { - Camping }\end{array}$ \\
\hline $\begin{array}{l}\text { Forma(s) e tipo(s) de } \\
\text { inovação }\end{array}$ & $\begin{array}{l}\text { Formas: } \\
\text { - Incremental } \\
\text { - Radical } \\
\text { - Aberta } \\
\\
\text { Tipos: } \\
\text { - Produto } \\
\text { - Serviço } \\
\text { - Processo } \\
\text { - Marketing } \\
\text { - Organizacional } \\
\text { - Modelo de negócio } \\
\text { - Tecnológica }\end{array}$ & $\begin{array}{l}\text { Controle de recursos de } \\
\text { água potável e águas } \\
\text { residuais }\end{array}$ & $\begin{array}{l}\text { - Redução do consumo de água } \\
\text { (colaboradores/clientes) } \\
\text { - Ações contra contaminação } \\
\text { - Controle de externalidades hídricas } \\
\text { - Ações corretivas/preventivas } \\
\text { - Legislação } \\
\text { - Tecnologias de reuso da água } \\
\text {-Tecnologias de redução de impacto }\end{array}$ & $\begin{array}{l}\text { Alimentos e } \\
\text { bebidas }\end{array}$ & $\begin{array}{l}\text { - Restaurantes } \\
\text { - Bares } \\
\text { - Fast food } \\
\text { - Cafeterias } \\
\text { - Sorveterias } \\
\text { - Quiosques de rua }\end{array}$ \\
\hline $\begin{array}{l}\text { Produto(s)/serviço(s) } \\
\text { inovador(es) com } \\
\text { princípios sustentáveis }\end{array}$ & $\begin{array}{l}\text { Descrição do(s) produto(s) } \quad / \\
\text { serviço(s) inovador(es) com } \\
\text { princípios sustentáveis }\end{array}$ & $\begin{array}{l}\text { Controle de substâncias } \\
\text { perigosas no ar }\end{array}$ & $\begin{array}{l}\text { - Tecnologias de redução de emissão de } \\
\text { gases } \\
\text { - Legislação } \\
\text { - Créditos de carbono }\end{array}$ & Atrativos turísticos & $\begin{array}{l}\text { - Naturais } \\
\text { - Culturais } \\
\text { - Artificiais } \\
\text { - Eventos programados }\end{array}$ \\
\hline $\begin{array}{l}\text { Motivo porque é } \\
\text { considerado inovador }\end{array}$ & $\begin{array}{lcr}\text { Elementos que diferenciam } & 0 \\
\text { modelo } & \text { padrão } & \text { de } \\
\text { negócio/atuação em relação } & \text { à } \\
\text { proposta } & \text { inovadora } & \text { da } \\
\text { organização } & & \\
\end{array}$ & $\begin{array}{l}\text { Controle e planejamento } \\
\text { da exploração do solo }\end{array}$ & $\begin{array}{l}\text { - Controle para a utilização/qualidade dos } \\
\text { solos } \\
\text { - Áreas de manejo/zoneamento } \\
\text { - Legislação }\end{array}$ & $\begin{array}{l}\text { Agências de } \\
\text { viagens }\end{array}$ & $\begin{array}{l}\text { - Agência de turismo emissivo } \\
\text { - Agência de turismo receptivo } \\
\text { - Agencia virtual de turismo } \\
\text { - Consolidadora }\end{array}$ \\
\hline
\end{tabular}




\begin{tabular}{|c|c|c|c|c|c|}
\hline $\begin{array}{l}\text { (Continua) } \\
\text { Descrição do modelo } \\
\text { inovador }\end{array}$ & $\begin{array}{l}\text { - Ano de implementação do } \\
\text { modelo inovador } \\
\text { - Perfil dos clientes } \\
\text { - Principais canais de distribuição } \\
\text { - Fatores que influenciam a } \\
\text { demanda }\end{array}$ & $\begin{array}{lr}\text { Conservação } & \text { da } \\
\text { biodiversidade } & \text { e } \\
\text { diversidade cultural } & \end{array}$ & $\begin{array}{l}\text { Gestão de impactos e campanhas de } \\
\text { proteção: } \\
\text { - Fauna e flora } \\
\text { - Recursos bióticos e abióticos } \\
\text { - Patrimônio cultural (material e imaterial) } \\
\text { e paisagístico }\end{array}$ & $\begin{array}{l}\text { Governo e } \\
\text { informação } \\
\text { turística }\end{array}$ & $\begin{array}{l}\text { - Secretaria Municipal de Turismo } \\
\text { - Agências de fomento ao Turismo } \\
\text { - Centros de informação turística } \\
\text { - Centros de pesquisa em turismo }\end{array}$ \\
\hline $\begin{array}{l}\text { Uso de tecnologias } \\
\text { (TICs) }\end{array}$ & $\begin{array}{l}\text { Conexão à Internet: } \\
\text { - MODEM ou adaptador de } \\
\text { rede } \\
\text { - ADSL } \\
\text { - Cabo (Fibra óptica) } \\
\text { - WIFI } \\
\text { E-mail } \\
\text { Disponibilização de página web } \\
\text { em que estejam incluídos(as): } \\
\text { Relação com as redes sociais / } \\
\text { Ferramentas de busca / Buscas } \\
\text { inteligentes / Informação } \\
\text { personalizada / Links com } \\
\text { recursos relacionados / Imagens } \\
\text { dos produtos/serviços / Vídeos } \\
\text { online / Visita virtual / Ofertas / } \\
\text { promoções / Calendário de } \\
\text { eventos e programas / Gerador de } \\
\text { itinerários / Catálogos multimídia / } \\
\text { Informação a smatphones e } \\
\text { tablets / Registro de visitas em } \\
\text { base de dados / Fóruns de } \\
\text { discussão e chats / Fotos, vídeos } \\
\text { e outras páginas na internet para } \\
\text { difundir inovação } \\
\text { Dispositivos móveis: } \\
\text { - Tecnologia GPS } \\
\text { - Tecnologia GPRS } \\
\text { - PDA (Personal Digital Assitant) }\end{array}$ & $\begin{array}{l}\text { Geração de emprego e } \\
\text { renda }\end{array}$ & $\begin{array}{l}\text { - Relatório interno da organização com } \\
\text { estatísticas sobre o nível de emprego e } \\
\text { renda }\end{array}$ & $\begin{array}{l}\text { Cooperação/Tercei } \\
\text { ro setor }\end{array}$ & $\begin{array}{l}\text { - Cooperativas } \\
\text { - Iniciativas entre cooperativas } \\
\text { - ONG / OSCIP }\end{array}$ \\
\hline $\begin{array}{l}\text { Principal valor ofertado/ } \\
\text { diferencial }\end{array}$ & $\begin{array}{l}\text { - Novidade } \\
\text { - Performance } \\
\text { - Personalização } \\
\text { - Efetuar determinado serviço } \\
\text { - Design } \\
\text { - Preço } \\
\text { - Marca / status } \\
\text { - Redução de custos } \\
\text { - Redução de risco } \\
\text { - Acessibilidade } \\
\text { - Conveniência / Usabilidade }\end{array}$ & $\begin{array}{l}\text { Certificação, selos } \\
\text { ambientais e prêmios }\end{array}$ & $\begin{array}{l}\text { Existência ou não de: } \\
\text { - ISO 14.001 (Sistema de Gestão } \\
\text { Ambiental) } \\
\text { - ISO } 9.001 \text { (Qualidade) } \\
\text { - ISO } 26000 \text { (Trabalho) } \\
\text { - ISO } 20121 \text { (Eventos sustentáveis) } \\
\text { - Selos ambientais } \\
\text { - Prêmios em geral }\end{array}$ & & \\
\hline
\end{tabular}




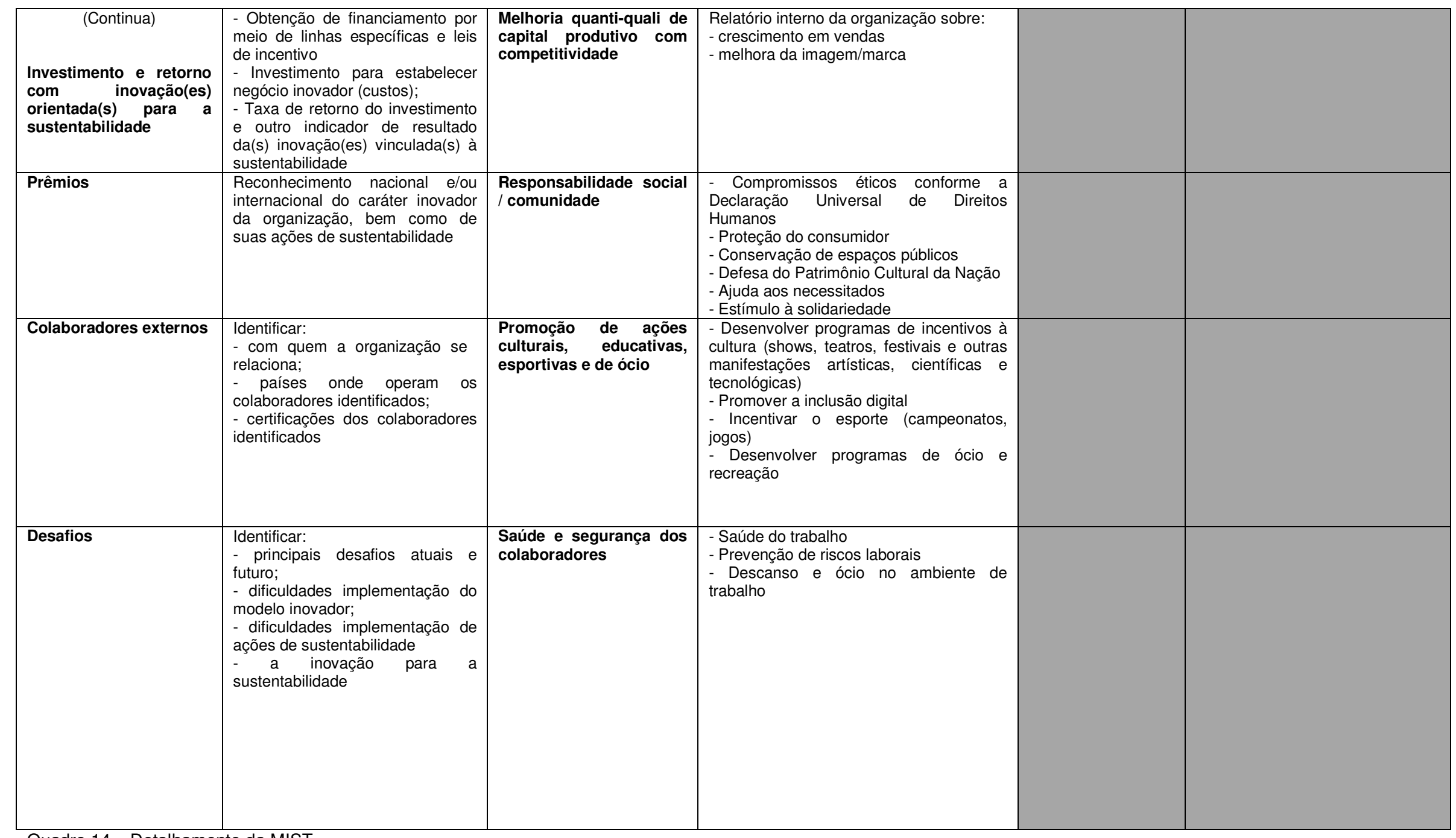

Quadro 14 - Detalhamento da MIST

Fonte: Elaborado por Daniela Rocco (2014). 
Temos ciência que a MIST não é uma proposta robusta de modelo de competitividade de destinos turísticos brasileiros. Não obstante, é uma matriz que pode auxiliar na análise quanto à interface real entre os pilares inovação e sustentabilidade, tão citados nos modelos de competitividade turística e que, mesmo assim, são pouco relacionados (ALVES, 2013). Nossa proposta metodológica, portanto, representa uma etapa inicial de análise, mas que foi passível de validação através das pesquisas de campo desenvolvidas por meio desta tese. As principais fases da etapa de pesquisa qualitativa (com a aplicação da MIST) estão detalhadas na próxima seção.

\subsection{PESQUISA QUALITATIVA}

Esta etapa da pesquisa dividiu-se em cinco grandes fases:

\section{Fase 1: Estágio doutoral na Europa:}

O doutorado sanduíche na Universidade de Deusto ${ }^{50}$ Instituto Orkestra de Competitividade e CICtourGUNE (Centro de Investigación Cooperativa en Turismo) - ambos situados em San Sebastián, País Basco, Espanha - foi fundamental para avançar na revisão da literatura, lapidar o objeto de pesquisa, refinar os procedimentos metodológicos, estar em contato com as principais think tanks do turismo (maioria delas localizadas na Espanha, como a OMT) e entrevistar atores-chave do turismo, especialmente aqueles que lidam com políticas públicas relacionadas à inovação e sustentabilidade. Embora a Europa de forma geral esteja atravessando um longo período de crise, a Espanha continua sendo uma das referências mundiais em termos de metodologias na área de turismo. Inclusive, em 2013 voltou para a 3a posição como país mais visitado por turistas internacionais (OMT, 2013). Caso particular é o do País Basco, que além de ser uma das regiões mais inovadoras do mundo (por concentrar parques tecnológicos e grandes centros de cooperação como o Mondragón), estimular a cultura da C,T\&I e incentivar processos de transformação social e urbana, tal como ocorreu em Bilbao, abriga em San Sebastián o CICtourGUNE, que se destaca mundialmente por ser um centro de excelência de inovação em turismo. Além disso, o Instituto Orkestra de Competitividade, que pertence à Universidade de Deusto, é um dos mais renomados da área. O período de estágio doutoral ocorreu entre 01 de abril de 2013 e 30 de agosto de 2013. Além de entrevistas e conhecimento dos projetos e ações do CICtourGUNE e do Instituto Orkestra de Competitividade, foi possível também nesse período entrevistar representantes das seguintes instituições, conforme a Tabela 1:

${ }^{50} \mathrm{O}$ programa de pós-graduação desta Instituição possui doutorado na área de concentração: "Sistemas de Inovação, Crescimento e Competitividade territorial". Além disso, existe em San Sebastián o "Centro de Investigação Cooperativa em Turismo", autointitulado de "núcleo científico do Polo de Inovação Turística do País Basco". Vide mais em: www.tourgune.org/es/index.html 
Tabela 1 - Total de atores entrevistados no período de estágio doutoral na Europa

\begin{tabular}{|c|c|c|c|c|}
\hline Data & Instituição & Cargo / Área & $\begin{array}{l}\text { Quantidade de } \\
\text { entrevistados }\end{array}$ & Cidade/País \\
\hline $\begin{array}{l}\text { Abril } \\
\text { agosto/2013 }\end{array}$ & $\begin{array}{l}\text { CICtourGUNE (Centro de } \\
\text { Investigación Cooperativa } \\
\text { en Turismo) }\end{array}$ & $\begin{array}{l}\text { Direção, pesquisadores sêniors e } \\
\text { pesquisadores analistas }\end{array}$ & 7 & $\begin{array}{l}\text { San } \\
\text { Sebastián, } \\
\text { Espanha }\end{array}$ \\
\hline $21 / 05 / 2013$ & $\begin{array}{l}\text { DBus (Empresa de } \\
\text { transporte público) }\end{array}$ & Chefe de oficinas & 1 & $\begin{array}{l}\text { San } \\
\text { Sebastián, } \\
\text { Espanha }\end{array}$ \\
\hline $25 / 06 / 2013$ & $\begin{array}{l}\text { INNOBASQUE (Agencia } \\
\text { Vasca de la Innovación) }\end{array}$ & Diretora Corporativa & 1 & $\begin{array}{l}\text { Bilbao, } \\
\text { Espanha }\end{array}$ \\
\hline $26 / 06 / 2013$ & $\begin{array}{l}\text { IHOBE (Sociedad pública } \\
\text { de gestión ambiental) }\end{array}$ & $\begin{array}{l}\text { Diretora de projetos (mudanças } \\
\text { climáticas e biodiversidade) }\end{array}$ & 1 & $\begin{array}{l}\text { Bilbao, } \\
\text { Espanha }\end{array}$ \\
\hline $28 / 06 / 2013$ & $\begin{array}{l}\text { BASQUETOUR (Agencia } \\
\text { Vasca de Turismo) }\end{array}$ & $\begin{array}{l}\text { Áreas: Produtos, } \text { Qualidade } \mathrm{e} \\
\text { Inovação }\end{array}$ & 3 & $\begin{array}{l}\text { Bilbao, } \\
\text { Espanha }\end{array}$ \\
\hline $03 / 07 / 2013$ & $\begin{array}{l}\text { TOURESPAÑA (Instituto } \\
\text { de Turismo de España) }\end{array}$ & $\begin{array}{l}\begin{array}{l}\text { Diretor da Área de } \\
\text { Sustentável }\end{array} \\
\end{array}$ & 1 & $\begin{array}{l}\text { Madrid, } \\
\text { Espanha }\end{array}$ \\
\hline $04 / 07 / 2013$ & $\begin{array}{l}\text { OMT } \quad \text { (Organización } \\
\text { Mundial de Turismo) }\end{array}$ & $\begin{array}{l}\text { Diretora Adjunta de Desenvolvimento } \\
\text { sustentável do turismo e Responsável } \\
\text { pela Iniciativa de los Tour Operadores } \\
\text { para el Desarrollo Sostenible del } \\
\text { Turismo }\end{array}$ & 2 & $\begin{array}{l}\text { Madrid, } \\
\text { Espanha }\end{array}$ \\
\hline $04 / 07 / 2013$ & $\begin{array}{l}\text { SEGITTUR } \\
\text { (Sociedad Estatal para la } \\
\text { Gestión de la Innovación y } \\
\text { las Tecnologías Turísticas) }\end{array}$ & Diretor corporativo & 1 & $\begin{array}{l}\text { Madrid, } \\
\text { Espanha }\end{array}$ \\
\hline $05 / 08 / 2013$ & Prefeitura de Barcelona & Diretor de Gestão de Resíduos & 1 & $\begin{array}{l}\text { Barcelona, } \\
\text { Espanha }\end{array}$ \\
\hline $05 / 08 / 2013$ & $\begin{array}{l}\text { Empresa inovadora de } \\
\text { Viagens no 22@Barcelona }\end{array}$ & Sócio proprietário & 1 & $\begin{array}{l}\text { Barcelona, } \\
\text { Espanha }\end{array}$ \\
\hline $12 / 08 / 2013$ & $\begin{array}{l}\text { Associação de Turismo de } \\
\text { Lisboa, Observatório do } \\
\text { Turismo de Lisboa }\end{array}$ & $\begin{array}{l}\text { Coordenador do Observatório do } \\
\text { Turismo de Lisboa }\end{array}$ & 1 & $\begin{array}{l}\text { Lisboa, } \\
\text { Portugal }\end{array}$ \\
\hline $12 / 08 / 2013$ & $\begin{array}{l}\text { Ministério do Meio } \\
\text { Ambiente, Ordenamento } \\
\text { do Território e Energia, } \\
\text { Agência Portuguesa do } \\
\text { Ambiente }\end{array}$ & $\begin{array}{l}\text { Técnica do DAI - Departamento de } \\
\text { Assuntos Internacionais }\end{array}$ & 1 & $\begin{array}{l}\text { Lisboa, } \\
\text { Portugal }\end{array}$ \\
\hline $28 / 08 / 2013$ & Prefeitura de Santander & $\begin{array}{l}\text { Conselheira de Meio ambiente e } \\
\text { mobilidade sustentável }\end{array}$ & 1 & $\begin{array}{l}\text { Santander, } \\
\text { Espanha }\end{array}$ \\
\hline $28 / 08 / 2013$ & Prefeitura de Santander & $\begin{array}{l}\text { Técnica do Conselho de Meio } \\
\text { ambiente e mobilidade sustentável }\end{array}$ & 1 & $\begin{array}{l}\text { Santander, } \\
\text { Espanha }\end{array}$ \\
\hline $28 / 08 / 2013$ & Governo de Santander & $\begin{array}{l}\text { Conselheira de Cultura, Turismo e } \\
\text { Esportes }\end{array}$ & 1 & $\begin{array}{l}\text { Santander, } \\
\text { Espanha }\end{array}$ \\
\hline $28 / 08 / 2013$ & Governo de Santander & $\begin{array}{l}\text { Diretor geral de Inovação e Indústria } \\
\text { (Conselho de Inovação, Indústria, } \\
\text { Turismo e Comércio) }\end{array}$ & 1 & $\begin{array}{l}\text { Santander, } \\
\text { Espanha }\end{array}$ \\
\hline \multicolumn{3}{|c|}{ TOTAL DE ATORES ENTREVISTADOS NO EXTERIOR } & 2 & \\
\hline
\end{tabular}

Fonte: Dados da pesquisa, 2014.

O propósito dessas entrevistas foi identificar quais são os destinos turísticos (em geral) que mais possuem inovações vinculadas à sustentabilidade. Adicionalmente, foi possível realizar observação direta e identificação de experiências de inovação para a sustentabilidade in $10 c 0$, citadas ou não pelos entrevistados. A análise das respostas contribuiu na produção do questionário online, cujas etapas foram desenvolvidas na Fase 2. 


\section{Fase 2: Pesquisa junto a pesquisadores e especialistas brasileiros}

Esta fase foi iniciada em novembro de 2013 e terminou em fevereiro de 2014. Primeiramente criamos um questionário online na plataforma virtual do Google Docs composto por cinco perguntas (vide Apêndice A), que foram inspiradas a partir da revisão da literatura (pesquisa exploratória) e entrevistas realizadas na fase 1. Em seguida, realizamos um pré-teste com seis pessoas. Finalizados os ajustes, foram enviados e-mails para 150 especialistas brasileiros com o link de acesso para o questionário online. Recebemos 50 respostas válidas e cancelamos duas por estarem incompletas. A busca por especialistas ocorreu basicamente de duas formas. A primeira foi por meio de uma pesquisa de quem publicou sobre o tema em periódicos nacionais reconhecidos pela CAPES. Os artigos que relacionavam apenas o turismo à sustentabilidade/desenvolvimento sustentável não foram considerados, pois necessariamente os textos deveriam vincular, no mínimo, o turismo à inovação. Sendo assim, foram adotadas na procura essas oito palavras-chave: "turismo", "turístico", "turísticos", "inovação", "inovações", "inovativo", "inovador" e "inovadores". Nos artigos selecionados constam, em sua maioria, professores e consultores do $3^{\circ}$ setor. A segunda forma de identificação foi também através de pesquisa exploratória e contatos (emails, números de telefones e redes sociais) dos próprios pesquisadores desta tese. Os especialistas contatados nessa segunda forma de busca possuem notório reconhecimento pela mídia e publicações diversas, bem como atuam no setor público, iniciativa privada, academia e $3^{\circ}$ setor, o que nos permitiu obter um maior equilíbrio na relação especialista versus setor de atuação. Quando não conseguíamos o e-mail do especialista, entrávamos em contato com ele por meio da plataforma do Sistema de Currículo Lattes do CNPq. A fase 2 contribuiu, essencialmente, para a identificação dos três destinos turísticos brasileiros que mais apresentam práticas de inovação para a sustentabilidade, trabalho este somado à pesquisa exploratória. Assim, selecionamos Bonito (MS), Gramado (RS) e Instituto Inhotim (MG) para aprofundarmos a pesquisa, validar a MIST e criar bases comparativas de análise. O detalhamento da justificativa dessa escolha encontra-se mais adiante, na seção 3.1.1 Caracterização dos destinos turísticos pesquisados.

Fase 3: Pesquisa junto a instituições públicas, de pesquisa e do trade turístico para identificação de programas/ações de inovação e sustentabilidade no turismo

De setembro de 2013 a agosto de 2014 foram realizadas 225 entrevistas com diversos atores que atuam direta/indiretamente no turismo, conforme mostra a Tabela 2 a seguir: 
Tabela 2 - Total de atores entrevistados no Brasil

\begin{tabular}{|c|c|c|c|c|c|}
\hline Data & Instituição & Cargo / Área & $\begin{array}{l}\text { Quantidade de } \\
\text { entrevistados }\end{array}$ & Cidade & Técnica \\
\hline $16 / 09 / 2013$ & Agência USP de Inovação & $\begin{array}{lll}\text { Diretoria de } & \text { Empresas } & \text { e } \\
\text { Empreendedorismo } & & \end{array}$ & 1 & São Paulo (SP) & Entrevista semiestruturada \\
\hline $2013 / 2014$ & Pesquisadores e especialistas el & n turismo e inovação & 50 & Diversas & Questionário online \\
\hline $12 / 02 / 2014$ & Ministério do Turismo & Diretoria de Gestão Estratégica & 1 & Brasília (DF) & Entrevista semiestruturada \\
\hline $13 / 02 / 2014$ & Ministério da Cultura & Ouvidoria & 1 & Brasília (DF) & Entrevista semiestruturada \\
\hline $13 / 02 / 2014$ & Ministério de Minas e Energia & Diretor e Analista de Infraestrutura & 2 & Brasília (DF) & Entrevista não-estruturada \\
\hline $14 / 02 / 2014$ & Ministério de Meio Ambiente & Gerência de Resíduos Sólidos & 1 & Brasília (DF) & Entrevista semiestruturada \\
\hline $14 / 02 / 2014$ & Ministério de Minas e Energia & $\begin{array}{l}\text { Assessoria Especial de Gestão } \\
\text { Socioambiental }\end{array}$ & 1 & Brasília (DF) & Entrevista não-estruturada \\
\hline $17 / 02 / 2014$ & SEBRAE Nacional & Gerência Assessoria Internacional & 1 & Brasília (DF) & Entrevista não-estruturada \\
\hline $18 / 02 / 2014$ & $\begin{array}{l}\text { Sistema OCDF (Sindicato e Organização das } \\
\text { Cooperativas do Distrito Federal) e Cooperativa } \\
\text { Sol \& Mar de Turismo e Lazer }\end{array}$ & Superintendência & 1 & Brasília (DF) & Entrevista semiestruturada \\
\hline $18 / 02 / 2014$ & Embratur (Instituto Brasileiro de Turismo) & Diretoria de Produtos e Destinos & 1 & Brasília (DF) & Entrevista semiestruturada \\
\hline $19 / 02 / 2014$ & $\begin{array}{l}\text { Ministério das Cidades (Secretaria Nacional de } \\
\text { Transporte e da Mobilidade Urbana) }\end{array}$ & Analista de Infraestrutura & 1 & Brasília (DF) & Entrevista semiestruturada \\
\hline $19 / 02 / 2014$ & Ministério de Ciência, Tecnologia e Inovação & Analistas (Gestão e Inovação) & 2 & Brasília (DF) & Entrevista semiestruturada \\
\hline $19 / 02 / 2014$ & Agência Nacional de Águas (ANA) & $\begin{array}{l}\text { Coordenação da Área de Inovação e } \\
\text { Coordenação de Gestão } \\
\text { Estratégica/Ambiental }\end{array}$ & 2 & Brasília (DF) & Entrevista semiestruturada \\
\hline Abril/2014 & Turistas & (Diversas cidades) & 50 & Bonito (MS) & Aplicação de formulário in loco \\
\hline $28 / 04 / 2014$ & Bonito Convention \& Visitors Bureau & Secretaria executiva & 1 & Bonito (MS) & Entrevista semiestruturada \\
\hline $28 / 04 / 2014$ & $\begin{array}{l}\text { Secretaria Municipal de Turismo (SETUR) e } \\
\text { Conselho Municipal de Turismo (COMTUR) }\end{array}$ & Diretoria & 1 & Bonito (MS) & Entrevista semiestruturada \\
\hline $28 / 04 / 2014$ & Lobo Guará Bike Adventure & Idealizador e proprietário & 1 & Bonito (MS) & Entrevista não-estruturada \\
\hline $28 / 04 / 2014$ & Hotel da Praça & Gerência (recepção e eventos) & 1 & Bonito (MS) & Entrevista não-estruturada \\
\hline $30 / 04 / 2014$ & Promotoria de Justiça & Promotor & 1 & Bonito (MS) & Entrevista semiestruturada \\
\hline $01 / 05 / 2014$ & Taxista & Taxista & 1 & Bonito (MS) & Entrevista não-estruturada \\
\hline $01 / 05 / 2014$ & Grutas de São Miguel & Gerência & 1 & Bonito (MS) & Entrevista semiestruturada \\
\hline
\end{tabular}




\begin{tabular}{|c|c|c|c|c|c|}
\hline $01 / 05 / 2014$ & Pousada São Jorge & Sócio proprietário & 1 & Bonito (MS) & Entrevista semiestruturada \\
\hline $01 / 05 / 2014$ & Recanto Ecológico Rio da Prata & Gerência & 1 & Bonito (MS) & Aplicação da MIST \\
\hline $02 / 05 / 2014$ & Taboa Fábrica de Encantos & Relações públicas & 1 & Bonito (MS) & Aplicação da MIST \\
\hline $02 / 05 / 2014$ & Hotel Pirá Miúna & Gerência (recepção e eventos) & 1 & Bonito (MS) & Aplicação da MIST \\
\hline $02 / 05 / 2014$ & Bonitour Viagens e Turismo & Sócio proprietário & 1 & Bonito (MS) & Entrevista não-estruturada \\
\hline $02 / 05 / 2014$ & Projeto Jiboia & Idealizador e proprietário & 1 & Bonito (MS) & Entrevista não-estruturada \\
\hline Maio/2014 & Turistas & (Diversas cidades) & 36 & Gramado (RS) & Aplicação de formulário in loco \\
\hline $12 / 05 / 2014$ & Recepcionista de hotel & Recepcionista & 1 & Gramado (RS) & Entrevista não-estruturada \\
\hline $13 / 05 / 2014$ & Secretaria de Turismo & Direção e coordenação & 2 & Gramado (RS) & Entrevista semiestruturada \\
\hline $14 / 05 / 2014$ & Secretaria de Meio Ambiente & Direção & 1 & Gramado (RS) & Entrevista semiestruturada \\
\hline $14 / 05 / 2014$ & $\begin{array}{l}\text { Sindicato de Guias de Turismo da Região das } \\
\text { Hortênsias }\end{array}$ & Guia de turismo local & 1 & Gramado (RS) & Entrevista semiestruturada \\
\hline $14 / 05 / 2014$ & Villa Bella Hotel Conceito & Concierge & 1 & Gramado (RS) & Aplicação da MIST \\
\hline $15 / 05 / 2014$ & Parque Gaúcho & Direção & 1 & Gramado (RS) & Aplicação da MIST \\
\hline $15 / 05 / 2014$ & Garçom e taxista & Garçom e taxista & 1 & Gramado (RS) & Entrevista não-estruturada \\
\hline $15 / 05 / 2014$ & Atendente Centro de Apoio ao Turista & Atendente & 1 & Gramado (RS) & Entrevista não-estruturada \\
\hline $16 / 05 / 2014$ & Produtor rural (Festa da Colônia) & Produtor rural & 1 & Gramado (RS) & Entrevista não-estruturada \\
\hline $17 / 05 / 2014$ & Hotel Bangalôs da Serra & Sócia-proprietária & 1 & Gramado (RS) & Aplicação da MIST \\
\hline $17 / 05 / 2014$ & Recepcionista de hotel & Recepcionista & 1 & Gramado (RS) & Entrevista não-estruturada \\
\hline 09/08/2014 & Turistas & (Diversas cidades) & 45 & I. Inhotim (MG) & Aplicação de formulário in loco \\
\hline $09 / 08 / 2014$ & Instituto Inhotim & Representantes & 4 & I. Inhotim (MG) & $\begin{array}{l}\text { Entrevista não-estruturada } \\
\text { Aplicação da MIST }\end{array}$ \\
\hline \multicolumn{3}{|c|}{ TOTAL DE ATORES ENTREVISTADOS NO BRASIL } & 225 & & \\
\hline
\end{tabular}

Fonte: Dados da pesquisa, 2014.

Como pode ser visto na Tabela 2, as visitas de campo (e respectivas entrevistas) no Brasil ocorreram em São Paulo (Agência USP de Inovação), Brasília (instituições públicas e do trade turístico), Bonito (MS), Gramado (RS) e Instituto Inhotim (MG). A finalidade das entrevistas realizadas nesses lugares foi criar um mapeamento de práticas de inovação para sustentabilidade do turismo brasileiro, bem como produzir uma Matriz de Análise SWOT sobre o tema em questão. 


\section{Fase 4: Pesquisa de campo nos 3 destinos turísticos brasileiros selecionados}

Com a MIST construída e os três destinos turísticos já selecionados, o próximo passo foi realizar a pesquisa de campo, que ocorreu entre abril e agosto de 2014 em Bonito (MS), Gramado (RS) e Instituto Inhotim (MG). Antes de cada viagem foi feito um estudo teórico dos três destinos e identificação de possíveis atores que poderiam participar das entrevistas in loco. Inclusive, foram agendadas algumas reuniões antes da visita de campo. Em Bonito (MS) e Gramado (RS) o processo de pesquisa ocorreu de forma semelhante. Inicialmente foram feitos o reconhecimento do local e observações diretas com registros em diário de bordo. Em seguida, foram entrevistados alguns atores locais do poder público, assim como aqueles envolvidos diretamente no trade turístico do próprio destino. A esses atores foram questionados, entre outras perguntas (vide Apêndice B), quais eram, dentre os sete segmentos indicados ${ }^{51}$, os serviços, equipamentos e/ou atrativos turísticos que naquele destino mais se evidenciam por práticas inovadoras voltadas para a sustentabilidade. Posteriormente, os locais mais citados pelos referidos atores foram localizados para que também seus representantes fossem entrevistados. No entanto, essa pesquisa ocorreu de forma distinta, pois a entrevista consistiu no cruzamento de atributos, variáveis e critérios da MIST (check-list de perguntas com base no detalhamento da matriz) com as características daquele atrativo ou equipamento turístico. Assim, em Bonito (MS) a aplicação da MIST ocorreu nos atrativos turísticos Recanto Ecológico Rio da Prata, Taboa Fábrica de Encantos e no Hotel Pirá Miúna. Em Gramado (RS) a MIST foi aplicada no Villa Bella Hotel Conceito, Hotel Bangalôs da Serra e Parque Gaúcho (atrativo turístico). Com relação ao Instituto Inhotim (MG) o processo foi um pouco diferente. Como o Instituto é destino e atrativo ao mesmo tempo, ele já foi definido previamente como o objeto de análise da MIST. De toda forma, antes da aplicação da MIST junto ao representante do Instituto, também foram realizados o reconhecimento do local e observações diretas com registros em diário de bordo. Durante toda a pesquisa de campo nos três destinos turísticos foram aplicados formulários junto a turistas (vide Apêndice C). O tamanho da amostra foi definido pelo princípio da saturação teórica, quando, a partir de determinado momento, começa a ocorrer repetição das respostas ou redundância (FONTANELLA \& MAGDALENO JÚNIOR, 2012). A finalidade da pesquisa de campo foi analisar como os serviços, equipamentos e atrativos turísticos que possuem práticas de inovação para a sustentabilidade podem contribuir para a competitividade turística daquele destino. Por isso comparamos as respostas dos atores locais (poder público e trade turístico em geral) com as respostas dos representantes dos atrativos e equipamentos (validação da MIST), com as respostas dos turistas, com a

\footnotetext{
${ }^{51}$ Os sete segmentos da atividade turística indicados aos entrevistados foram: 1. Meios de transporte; 2. Meios de hospedagem; 3. Alimentos e bebidas; 4. Atrativos turísticos; 5 . Agências de viagens; 6 . Governo e informação turística e 7. Cooperação/Terceiro setor. Tais segmentos constam na MIST, matriz de análise adotada nesta pesquisa.
} 
observação direta e, finalmente, com a revisão da literatura. A Tabela 3 apresenta o total de atores entrevistados na pesquisa de campo, assim como a quantidade de turistas e de aplicações da MIST por destino.

Tabela 3 - Total de atores entrevistados na pesquisa de campo (3 destinos turísticos)

\begin{tabular}{c|c|c|c}
\hline Pesquisa de campo & Bonito (MS) & Gramado (RS) & Instituto Inhotim (MG) \\
\hline Ator(es) & 10 & 9 & 3 \\
\hline MIST & 3 & 3 & 1 \\
\hline Turistas & 50 & 36 & $\mathbf{4 9}$ \\
\hline TOTAL/destino & $\mathbf{6 3}$ & $\mathbf{4 8}$ & \\
\hline \multicolumn{2}{r|}{ TOTAL } & & $\mathbf{1 6 0}$ entrevistados \\
\hline Fonte: Dados da pesquisa, 2014.
\end{tabular}

Vale sublinhar que esta fase da pesquisa contribuiu bastante para atender ao objetivo geral desta tese. A MIST foi relevante nesse processo, uma vez que, por ser um check-list baseado em atributos, variáveis e critérios, as informações obtidas foram estruturadas em forma de matriz, facilitando a visualização dos resultados.

\section{Fase 5: Análise final}

As respostas obtidas nas fases anteriores colaboraram para uma análise da inovação para a sustentabilidade em destinos turísticos brasileiros de forma mais ampliada, e como isso pode contribuir para a competitividade turística dos mesmos. Os principais resultados obtidos estão sob forma de gráficos, exemplos de aplicação da MIST, mapa do Brasil com indicação de 40 destinos turísticos que possuem práticas de inovação para a sustentabilidade e uma Matriz de Análise SWOT referente ao tema em questão. Estes resultados constam nos capítulos 4 e 5, porém na próxima seção é apresentada uma breve caracterização dos três destinos turísticos escolhidos para a pesquisa de campo. 


\subsubsection{BREVE CARACTERIZAÇÃO DOS DESTINOS TURÍSTICOS}

Do universo dos 40 destinos turísticos identificados na fase 2 pelos 50 especialistas da pesquisa via questionário online destacamos os três destinos que, segundo eles, mais possuem práticas de inovação para a sustentabilidade. São eles: $1^{\circ}$ ) Bonito (MS), com 15\% das respostas; $2^{\circ}$ ) Fernando de Noronha (PE), com 9\% e $3^{\circ}$ ) Serra Gaúcha (RS), com 7\%. O total das respostas em relação a "desconhece" corresponde a $22 \%$ no total acumulado (os demais resultados constam no capítulo 4).

Após revisão da literatura e pesquisa realizada na fase 3 (representantes do poder público e do trade turístico em geral), consideramos melhor selecionar esses três destinos turísticos para a pesquisa de campo: Bonito (MS), Gramado (RS) e Instituto Inhotim (MG). A justificativa de escolha de cada destino é apresentada abaixo:

Bonito (MS): Foi, de fato, o destino mais citado entre os profissionais envolvidos nas pesquisas das fases 2 e 3 da pesquisa qualitativa. Em 2013 Bonito foi eleita pelo World Responsible Tourism Awards como o melhor destino de turismo responsável do mundo (BONITO, 2014) e é considerada um dos mais importantes polos de ecoturismo e turismo de aventura do Brasil (BRASIL, 2014e). A principal inovação citada pelos profissionais foi a criação do voucher único, que hoje é digital. Com ele, o acesso aos atrativos só é feito mediante reserva em agências de turismo locais. Esta medida visa controlar o acesso diário de visitantes, pois cada atrativo possui um limite de visitação, uma vez que o ecossistema local é bastante frágil. Além disso, essa iniciativa garante também a sustentabilidade econômica, pois gera renda e riqueza no local.

Gramado (RS): Embora os especialistas da fase 2 tenham citado a Serra Gaúcha, Gramado é, segundo revisão da literatura sobre a região, o destino da Serra Gaúcha que recentemente tem apresentado mais inovações em termos de atrativos turísticos, como o Parque Gaúcho (único parque temático do mundo sobre a cultura gaúcha) e o Snowland (primeiro parque de neve indoor das Américas). Seria, portanto, importante investigar outras inovações adjacentes na cidade, sobretudo aquelas que estão vinculadas à sustentabilidade (GRAMADO, 2014a).

Instituto Inhotim (MG): Como foi citado no capítulo 1, o Instituto Inhotim (MG) tem assumido, curiosamente, o status de destino principal, em contraposição à cidade que abriga o museu: Brumadinho. Além disso, o Inhotim é considerado como um dos maiores museus de arte contemporânea a céu aberto do mundo (do Brasil é o único) (INHOTIM, 
2014a). Vale mencionar que nenhum dos 50 especialistas da fase 2 citou o Instituto Inhotim, entretanto, na fase 3, apenas o entrevistado do SEBRAE Nacional destacou a relevância das inovações produzidas pelo museu, inclusive relacionadas à sustentabilidade. Para o entrevistado, a criação do museu atraiu diversos turistas estrangeiros, tem repercutido favoravelmente para o turismo de Minas Gerais e hoje é mais conhecido no exterior que no próprio Brasil.

O destino Fernando de Noronha (PE) não foi escolhido para aprofundamento dos estudos em função da limitação financeira para a pesquisa de campo. Além disso, como $22 \%$ dos especialistas participantes na fase 2 não indicaram destinos turísticos, esse índice nos permitiu escolher um terceiro destino, no caso, o Instituto Inhotim (MG).

A Figura 21 indica a localização no mapa do Brasil dos três destinos selecionados para esta pesquisa. Eles estão situados em estados distintos: Mato Grosso do Sul (Bonito), Minas Gerais (Instituto Inhotim) e Gramado (Rio Grande do Sul).

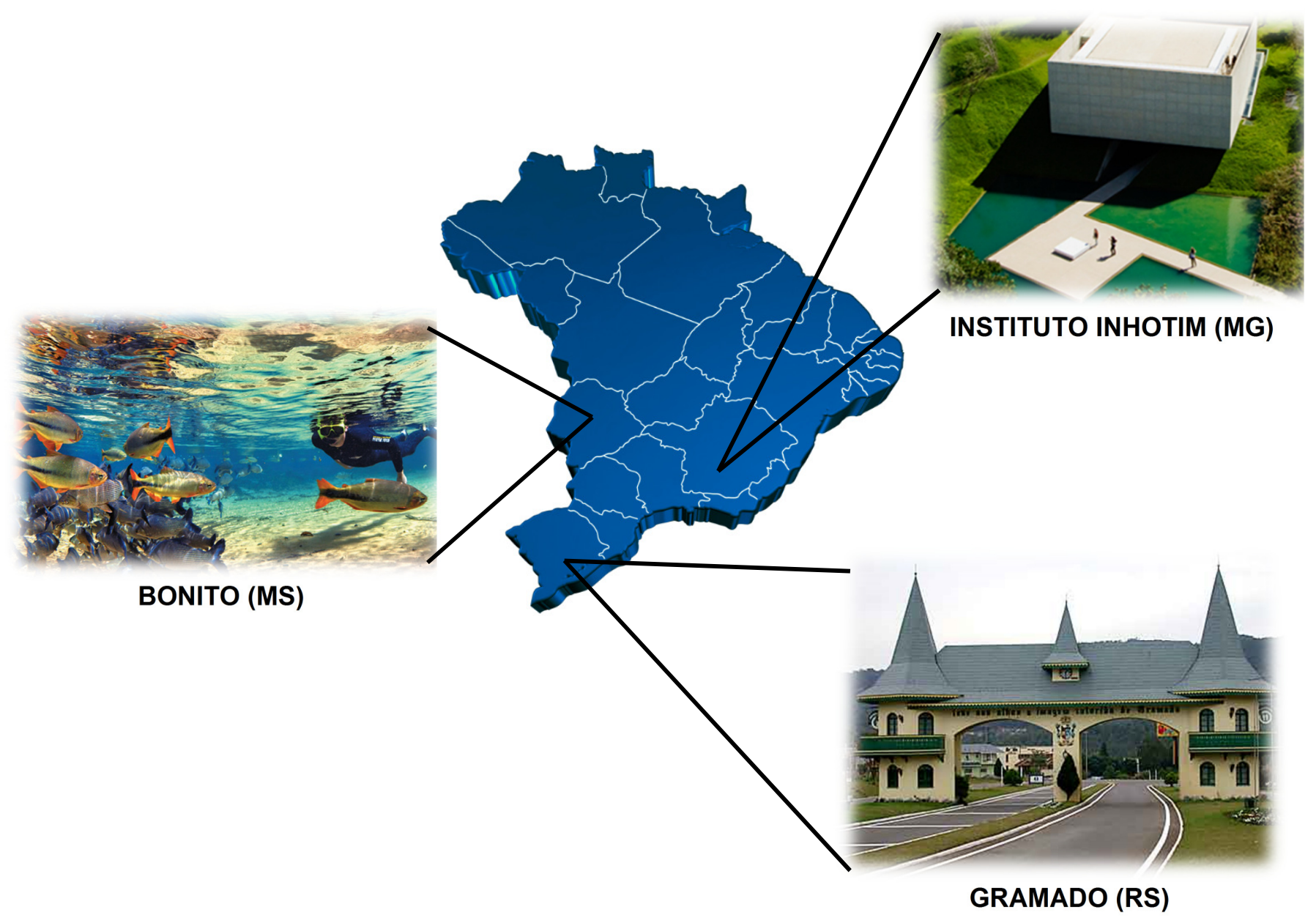

Figura 21 - Destinos turísticos brasileiros pesquisados Fonte: Elaborado por Daniela Rocco (2014)

Créditos: Imagem do Brasil (Ymagine Publicidade \& Design); foto de Bonito (Márcio Cabral); foto do Instituto Inhotim (Instituto Inhotim) e foto de Gramado (Prefeitura Municipal de Gramado). 
O Quadro 15 a seguir expõe um resumo sobre as principais características de cada destino. Bonito (MS) possui a maior área $\left(\mathrm{km}^{2}\right)$ e Gramado (RS) a menor. A relação se inverte no quesito densidade demográfica: em Gramado (RS) a densidade é a maior e em Bonito é menor. Com relação às características como altitude, clima e vegetação, estas são diferenciadas, uma vez que os destinos estão localizados em regiões distintas do Brasil.

\begin{tabular}{|c|c|c|c|c|c|c|}
\hline DESTINO & $\begin{array}{l}\text { ÁREA } \\
\left(\mathrm{km}^{2}\right)\end{array}$ & $\begin{array}{c}\text { DENSIDADE } \\
\text { DEMOGRÁFICA }\end{array}$ & $\begin{array}{c}\text { MICRO E } \\
\text { MESORREGIÃO }\end{array}$ & ALTITUDE & CLIMA & VEGETAÇÃO \\
\hline $\begin{array}{l}\text { Bonito } \\
\text { (MS) }\end{array}$ & $\begin{array}{c}4.947,7 \\
2 \mathrm{~km}^{2}\end{array}$ & $3,96 \mathrm{hab} . / \mathrm{km}^{2}$ & $\begin{array}{l}\text { Microrregião: } \\
\text { Bodoquena } \\
\text { Mesorregião: } \\
\text { Sudoeste de Mato } \\
\text { Grosso do Sul }\end{array}$ & $\begin{array}{l}350 \text { metros } \\
\text { acima do } \\
\text { nível do mar. } \\
\text { Ponto mais } \\
\text { alto chega a } \\
720 \text { metros } \\
\text { (Serra da } \\
\text { Bodoquena) }\end{array}$ & $\begin{array}{l}\text { Tropical úmido. } \\
\text { Temperatura } \\
\text { média anual: } 22^{\circ} \mathrm{C} \\
\text { Precipitação anual } \\
\text { entre } 1.000 \text { e } \\
2.000 \text { mm. } \\
\text { No inverno a } \\
\text { temperatura varia } \\
\text { entre } 15^{\circ} \mathrm{C} \text { e } \\
20^{\circ} \mathrm{C} \text {. }\end{array}$ & $\begin{array}{l}\text { Cerrado, } \\
\text { Cerradão, } \\
\text { Campo } \\
\text { Cerrado e } \\
\text { Campo Limpo }\end{array}$ \\
\hline $\begin{array}{c}\text { Brumadinho } \\
\text { (MG) }\end{array}$ & $\begin{array}{c}643,52 \\
\mathrm{~km}^{2}\end{array}$ & 52,85 hab. $/ \mathrm{km}^{2}$ & $\begin{array}{l}\text { Microrregião: } \\
\text { Belo Horizonte } \\
\text { Mesorregião: } \\
\text { Metropolitana de } \\
\text { Belo Horizonte }\end{array}$ & $\begin{array}{l}1.465 \text { metros } \\
\text { acima do } \\
\text { nível do mar } \\
\text { (Serra da } \\
\text { Moeda) }\end{array}$ & $\begin{array}{l}\text { Tropical de } \\
\text { altitude com } \\
\text { inverno seco e } \\
\text { verão chuvoso. } \\
\text { Temperatura } \\
\text { média anual } \\
\text { entre: } 18^{\circ} \text { e } 21^{\circ} \mathrm{C} \text {. } \\
\text { Precipitação anual } \\
\text { entre } 1.300 \quad \text { e } \\
2.100 \mathrm{~mm}\end{array}$ & $\begin{array}{l}\text { Cerrado e } \\
\text { Mata Atlântica }\end{array}$ \\
\hline $\begin{array}{l}\text { Gramado } \\
\text { (RS) }\end{array}$ & $\begin{array}{c}236,93 \\
\mathrm{~km}^{2}\end{array}$ & 136,33 hab./km² & $\begin{array}{l}\text { Microrregião: } \\
\text { Gramado-Canela } \\
\text { Mesorregião: } \\
\text { Metropolitana de } \\
\text { Porto Alegre }\end{array}$ & $\begin{array}{l}885 \text { metros } \\
\text { acima do } \\
\text { nível do mar. } \\
\text { (Serra } \\
\text { Gaúcha) }\end{array}$ & $\begin{array}{l}\text { Temperado } \\
\text { chuvoso } \\
\text { No inverno: entre } \\
9 \text { e } 12^{\circ} \mathrm{C} \\
\text { Verão: entre } 20 \text { e } \\
26^{\circ} \mathrm{C}\end{array}$ & $\begin{array}{l}\text { Mata Atlântica } \\
\text { (floresta } \\
\text { ombrófila } \\
\text { mista) }\end{array}$ \\
\hline
\end{tabular}

Quadro 15 - Características do território dos três destinos pesquisados

Fonte: Elaborado por Daniela Rocco (2014) com base em Tomazzoni (2007); Guarçoni; Paula \& Costa (2010); Grechi (2011); PNUD (2013).

A Tabela 4 abaixo apresenta dados relativos à população total (rural e urbana) de Bonito (MS), Brumadinho (MG) e Gramado (RS), assim como a população com mais de 18 anos e a população economicamente ativa (PEA) com mais de 18 anos.

Tabela 4 - População total e PEA dos três destinos pesquisados

\begin{tabular}{|c|c|c|c|c|c|}
\hline & $\begin{array}{c}\text { População } \\
\text { total } \\
2010\end{array}$ & $\begin{array}{c}\text { População } \\
\text { rural } \\
2010\end{array}$ & $\begin{array}{c}\text { População } \\
\text { urbana } \\
2010\end{array}$ & $\begin{array}{c}\text { População de } \\
18 \text { anos ou } \\
\text { mais } \\
2010\end{array}$ & $\begin{array}{c}\text { PEA - } 18 \\
\text { anos ou mais } \\
2010\end{array}$ \\
\hline Brasil & 190755799 & 29830007 & 160925792 & 134460298 & 89464856 \\
\hline Bonito (MS) & 19587 & 3428 & 16159 & 13279 & 9928 \\
\hline Brumadinho (MG) & 33973 & 5331 & 28642 & 24741 & 17206 \\
\hline Gramado (RS) & 32273 & 3260 & 29013 & 24242 & 19028 \\
\hline
\end{tabular}

Fonte: PNUD (2013). 
Como pôde ser verificado, Brumadinho (MG) possui a maior população total e população de 18 anos ou mais e Bonito (MS) a menor em relação a esses dois indicadores. Entretanto, Gramado (RS) possui a maior PEA e Bonito (MS) a menor.

No Ranking IDHM Municípios do PNUD (2013), dos 5.565 municípios avaliados e entre os três destinos turísticos estudados, Gramado (RS) está na melhor posição: 304ํㅜำ lugar. Em seguida Brumadinho (MG), na posição 599 e Bonito (MS), na posição 2.663․ Segundo a Tabela 5 abaixo, o maior Índice de Desenvolvimento Humano (IDHM) pertence a Gramado (RS), com 0,764\%, e o menor IDHM é de Bonito (MS), com 0,670\%. Com relação ao Índice de Gini, que mede o nível de desigualdade, Gramado (RS) também possui a melhor taxa: 0,48\% (menor grau de desigualdade). Já Brumadinho (MG) possui a maior taxa de desigualdade entre os três destinos pesquisados: 0,57\%.

Tabela 5 - Principais índices dos três destinos pesquisados

\begin{tabular}{|c|c|c|c|c|c|c|}
\hline & $\begin{array}{l}\text { IDHM } \\
2010\end{array}$ & $\begin{array}{c}\text { IDHM Renda } \\
2010\end{array}$ & $\begin{array}{c}\text { IDHM } \\
\text { Longevidade } \\
2010\end{array}$ & $\begin{array}{c}\text { IDHM } \\
\text { Educação } \\
2010\end{array}$ & $\begin{array}{l}\text { Índice de Gini } \\
\qquad 2010\end{array}$ & $\begin{array}{c}\text { Índice de Theil } \\
-\mathrm{L} \\
2010\end{array}$ \\
\hline Brasil & 0,727 & 0,739 & 0,816 & 0,637 & 0,60 & 0,68 \\
\hline Bonito (MS) & 0,670 & 0,714 & 0,831 & 0,508 & 0,54 & 0,51 \\
\hline Brumadinho (MG) & 0,747 & 0,761 & 0,857 & 0,639 & 0,57 & 0,59 \\
\hline Gramado (RS) & 0,764 & 0,783 & 0,861 & 0,662 & 0,48 & 0,39 \\
\hline
\end{tabular}

Fonte: PNUD (2013).

Os dados e informações acima dispostos representam uma breve caracterização dos três destinos pesquisados, assim como comparação entre os mesmos. O maior detalhamento sobre a pesquisa de campo consta no capítulo 5, mas, primeiramente, apresentamos no capítulo 4 as principais experiências brasileiras de inovação para a sustentabilidade do poder público, iniciativa privada e terceiro setor. 


\title{
4. EXPERIÊNCIAS BRASILEIRAS DE INOVAÇÃO PARA A SUSTENTABILIDADE NO TURISMO: BOAS PRÁTICAS, DESAFIOS, NOVOS RUMOS E PERSPECTIVAS PARA A COMPETITIVIDADE DO PAÍS
}

\begin{abstract}
"Da janela do avião vejo São Paulo. Do alto, um céu triste, cinzento, sem brilho; lá embaixo, um mar de carros. Um completo contraste com o céu estrelado de Gramado. Dos arranha-céus paulistanos mais modernos aos edifícios gramadenses de até quatro andares, de arquitetura europeia. Um lugar pequeno, como Gramado, tendo mais de 30 milhões de habitantes, é mais fácil de gerenciar a sustentabilidade. No entanto, da janela do avião, vendo a intensa São Paulo, core business do Brasil, lembro-me de iniciativas inovadoras com foco na sustentabilidade criadas na própria cidade [...]. Vejo uma São Paulo com possibilidades de ser mais sustentável. Por que não? Precisamos de soluções urbanas. É urgente. Aprender com os pequenos exemplos é pensar que "small is beautiful" [...]".
\end{abstract}

Trecho de diário de bordo de Daniela Rocco. Registrado na viagem de volta de Gramado, passando por São Paulo.

O planejamento formal do Turismo no Brasil foi iniciado na década de 1940, porém foi a partir da criação da Empresa Brasileira de Turismo (EMBRATUR), em 1966, que os processos começaram a se tornar mais concretos. A Figura 22 mostra a principal linha do tempo da política de Turismo no País. Como se pode verificar, a agenda do Turismo passou a integrar outros ministérios ao longo do tempo, todavia, somente em 2003 que foi criado o primeiro Ministério do Turismo do Brasil. Neste mesmo ano a EMBRATUR mudou de função e passou a divulgar exclusivamente o turismo brasileiro no exterior. A sigla foi mantida, mas o significado da mesma mudou para Instituto Brasileiro de Turismo.

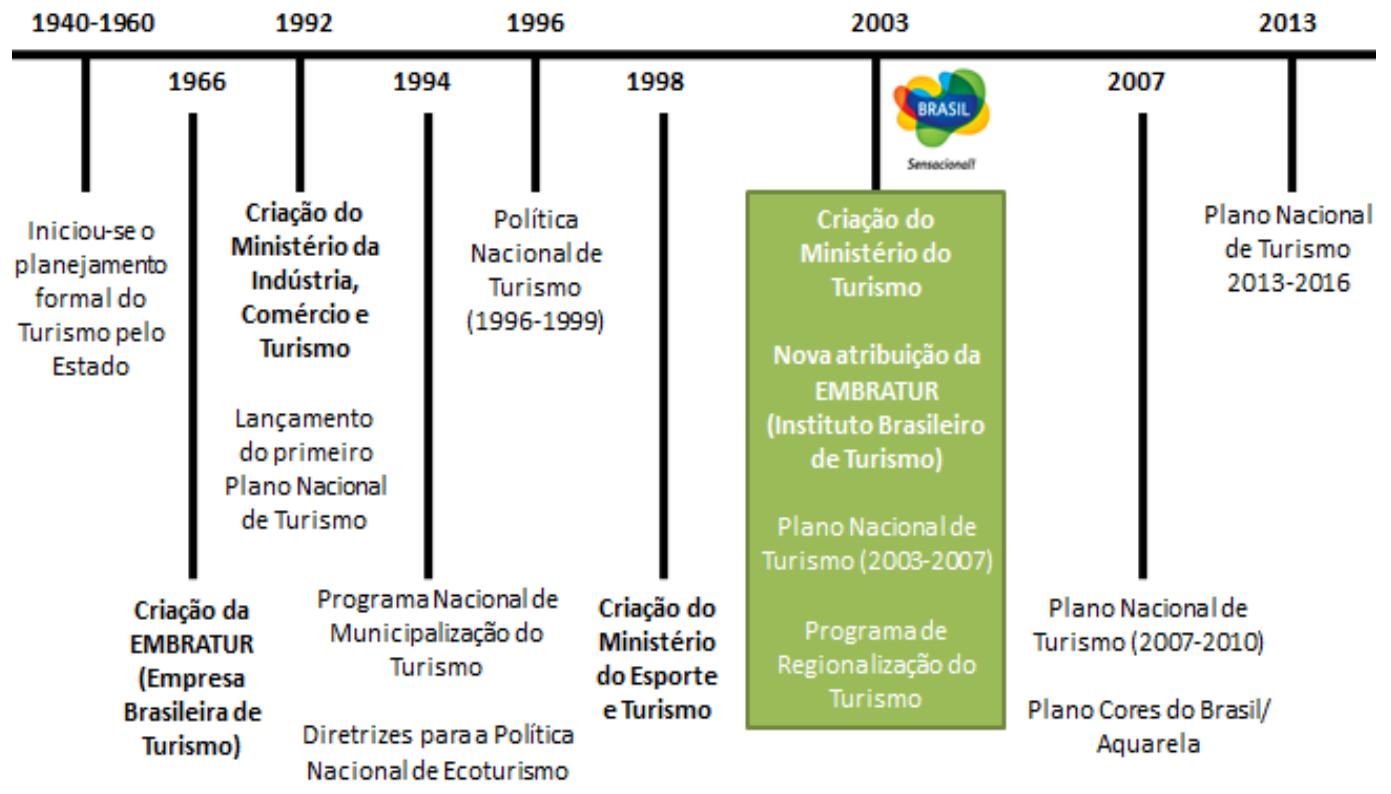

Figura 22 - Principal linha do tempo da política de Turismo no Brasil Fonte: Elaborado por Daniela Rocco (2014) 
O governo brasileiro apresentou o primeiro plano de turismo em 1992, porém apenas se tornou lei, sendo implementado de fato, a partir de 1996. Antes, as intervenções no campo do turismo eram bastante pulverizadas e direcionadas, sobretudo, para a regulação da iniciativa privada do setor.

Com relação aos planos nacionais de turismo mais recentes (2003-2007; 2007-2010; 2013-2016), os dois primeiros se destacaram pela tentativa de evidenciar a importância do turismo para o País e como forma de estimular a articulação e participação dos distintos atores. Em 2011 vários problemas surgiram no Ministério, e no período 2011-2013 somente um documento referencial foi publicado, sem muitas orientações estruturais.

Desde a criação do Ministério do Turismo, em 2003, foram criados 5 planos distintos em 10 anos, o que revela pouca sincronicidade. No entanto, de forma geral, a política brasileira de turismo tende a propor um plano mais articulador, e isso já é um avanço positivo, embora relativo. Com a crise que o Ministério vivenciou em 2011 houve um intenso trabalho de busca pela transparência em todos os processos. De certo modo, nesse período não foram priorizados programas mais vigorosos de desenvolvimento do próprio do turismo.

A situação do MTur começou a melhorar em 2012, quando duas inovações pioneiras no País foram criadas por técnicos do próprio Ministério para dar suporte à transparência da gestão pública dos recursos. São eles: i) o Sistema de Acompanhamento de Contratos de Repasse (Siacor). Acessível a qualquer cidadão (http://repasse.turismo.gov.br/), o sistema permite a consulta, em tempo real, da situação das obras e projetos executados com os recursos do MTur e ii) o Sistema de Controle das Demandas Externas, que é um cadastro inteligente de solicitações de órgãos de controle. Por meio deste sistema eletrônico é possível direcionar os pedidos para as áreas específicas do MTur, bem como monitorar os prazos das demandas da pasta. Essas duas inovações foram decisivas para que o MTur recebesse o prêmio do I Concurso de Boas Práticas promovido pela Controladoria Geral da União. Neste primeiro concurso foram inscritos 47 projetos de 17 ministérios brasileiros (BRASIL, 2013b).

Em 2014 o MTur cumpriu papel fundamental na realização da Copa do Mundo de Futebol da FIFA no Brasil, assim como criou e reativou alguns programas. Atualmente os programas e ações do MTur são: i) Conhecer o turista, mercado e território; ii) Estimular o desenvolvimento sustentável da atividade turística; iii) Estruturar os destinos turísticos; iv) Regular, fomentar e qualificar os serviços turísticos; v) Programa Turismo Sustentável e Infância; vi) Fortalecer a gestão descentralizada, parcerias e participação social; vii) Promover os produtos turísticos e viii) Pronatec Turismo. Além do Pronatec (programa do governo federal), existem ações de turismo no PAC (Programa de Aceleração do Crescimento) (BRASIL, 2014f). 
No bojo das políticas públicas de turismo adotadas no País tem-se como prioridade o uso sustentável de todos os recursos, porém foi no Plano Nacional de Turismo 2013/2016 que foi incorporado o conceito de desenvolvimento sustentável. O Quadro 16 apresenta os principais programas, ações e campanhas de sustentabilidade, inovação e inovação para a sustentabilidade do MTur, bem como aqueles realizados em parceria com o próprio MTur.

\begin{tabular}{|c|c|c|}
\hline NÍVEIS DE ANÁLISE & MINISTÉRIO DO TURISMO & $\begin{array}{l}\text { PARCERIAS COM O MINISTÉRIO DO } \\
\text { TURISMO }\end{array}$ \\
\hline SUSTENTABILIDADE & $\begin{array}{l}\text { Programa Turismo Sustentável e Infância: } \\
\text { até o momento é o mais consolidado do } \\
\text { MTur } \\
\text { Programa de Desenvolvimento do } \\
\text { Turismo (PRODETUR): financia a } \\
\text { elaboração do Plano de Desenvolvimento } \\
\text { Integrado do Turismo Sustentável (PDITS) } \\
\text { para desenvolver polos de turismos nos } \\
\text { estados e municípios. } \\
\text { Programa Turismo Acessível: transversal } \\
\text { aos demais programas - inclusão social } \\
\text { (http://turismoacessivel.gov.br/ta/sobre.mtur) }\end{array}$ & \\
\hline INOVAÇÃO & $\begin{array}{l}\text { Sistema de Acompanhamento de } \\
\text { Contratos de Repasse e Sistema de } \\
\text { Controle das Demandas Externas: } \\
\text { sistemas eletrônicos para transparência na } \\
\text { gestão pública } \\
\text { Hangout: trata-se de uma ferramenta criada } \\
\text { pela Google+, propiciando uma plataforma } \\
\text { online de videoconferência com áudio entre } \\
\text { os usuários. Além da facilidade de acesso } \\
\text { em relação a outros recursos, esse serviço é } \\
\text { gratuito (diferentemente do Skype). Em } \\
\text { janeiro de } 2014 \text { foram realizadas } \\
\text { videoconferências com profissionais do } \\
\text { turismo } \\
\text { Fellow Trip: lançado em } 2014 \text { pelo MTur e a } \\
\text { Embratur, o app Fellow Trip ("parceiro de } \\
\text { viagem") é um guia interativo de viagens } \\
\text { para proporcionar uma experiência ainda } \\
\text { mais personalizada ao turista que viaja por } \\
\text { nosso país. O app está disponível em três } \\
\text { idiomas (português, inglês e espanhol) na } \\
\text { plataforma Android, porém em breve terá } \\
\text { versão também para o sistema operacional } \\
\text { iOS. } \\
\text { Mapa interativo: é um recurso na Fanpage } \\
\text { do MTur que permite ao usuário criar, } \\
\text { compartilhar e pesquisar roteiros turísticos }\end{array}$ & 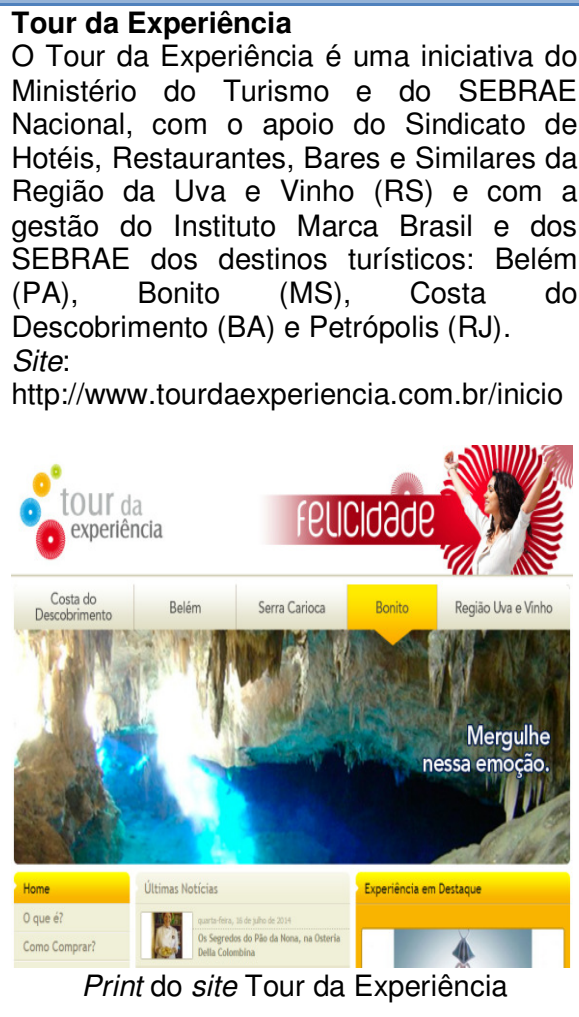 \\
\hline
\end{tabular}




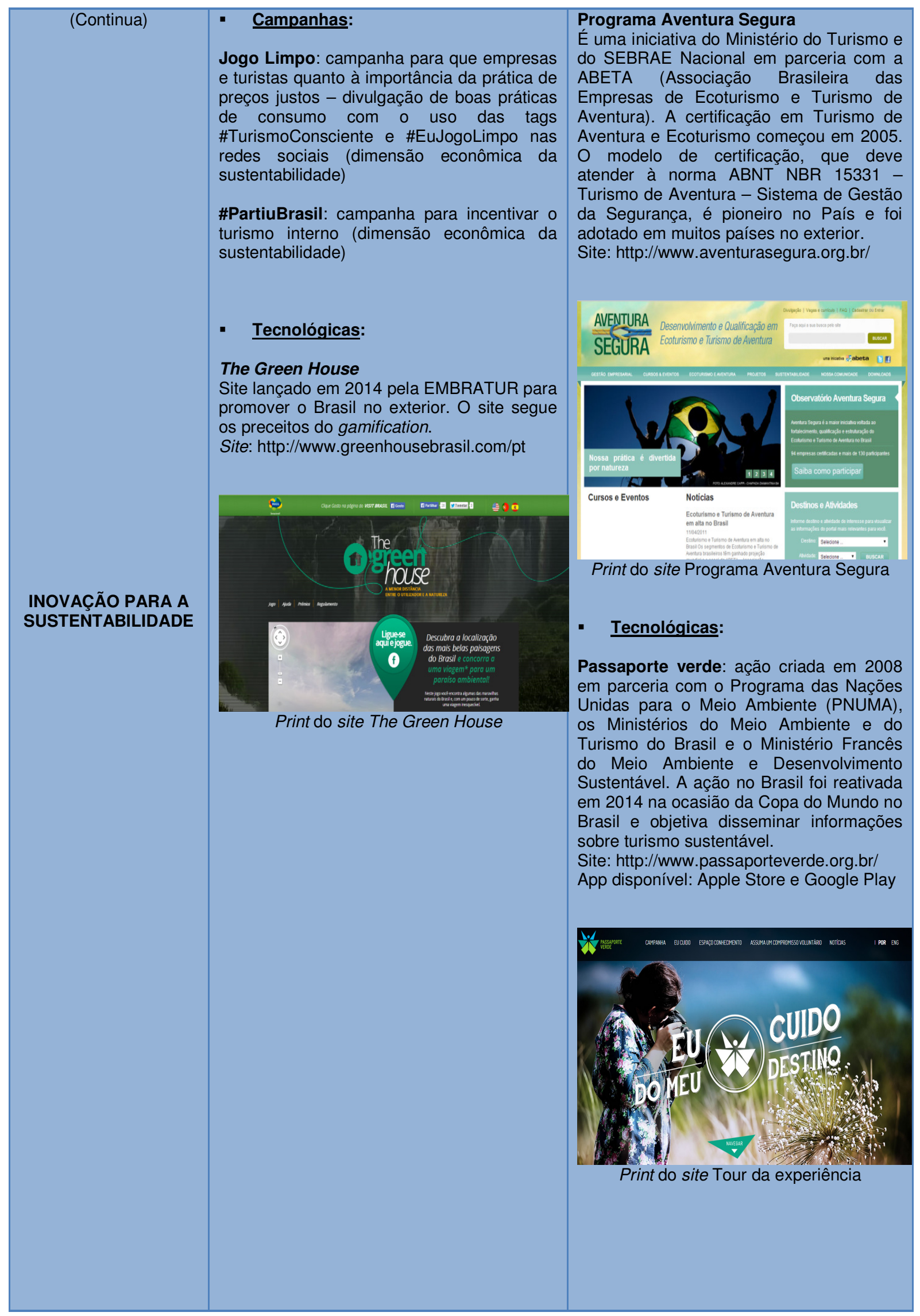




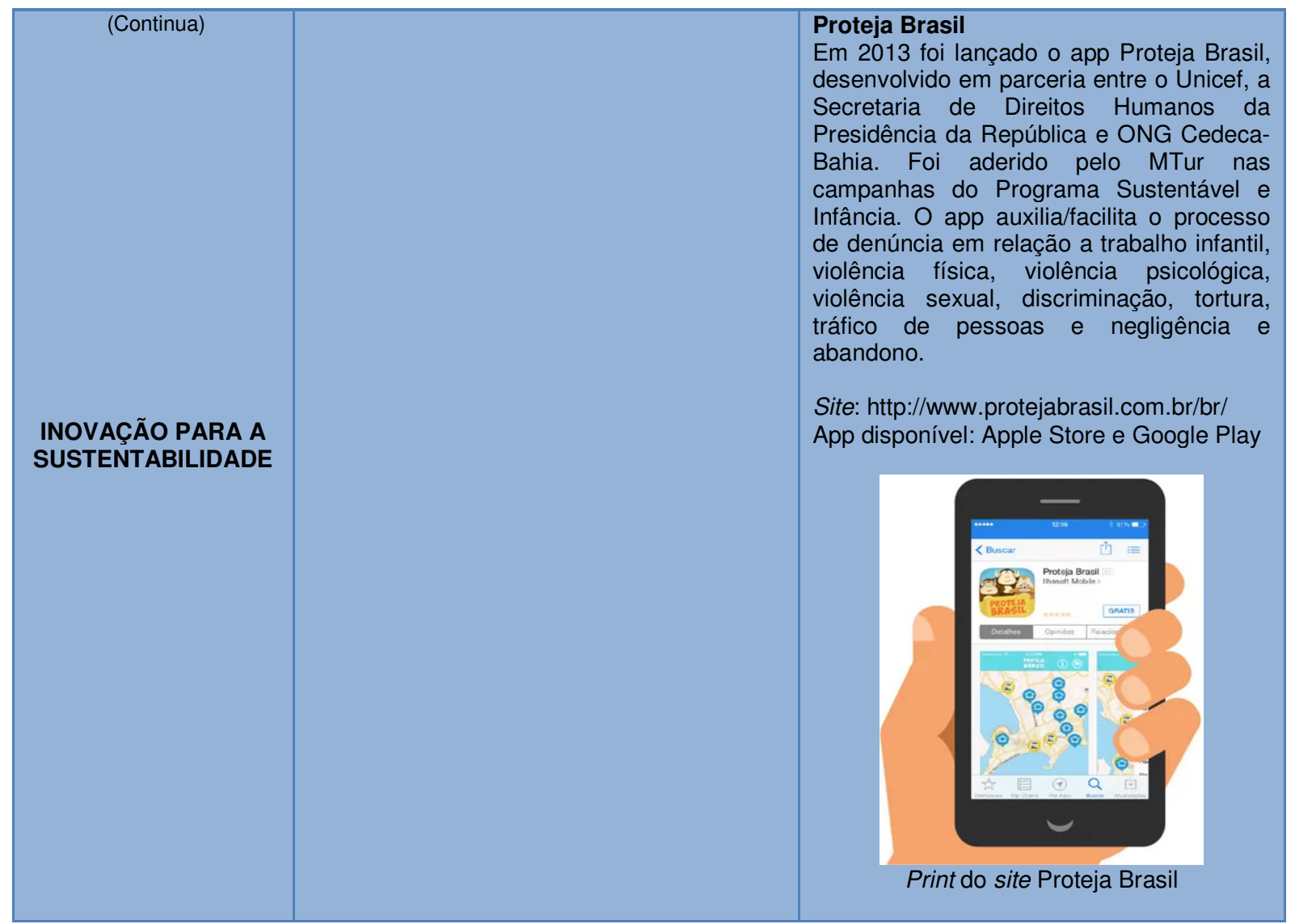

Quadro 16 - Quadro de programas, ações e campanhas de sustentabilidade, inovação e inovação para a sustentabilidade do MTur e parceiros

Fonte: Elaborado por Daniela Rocco (2014) com base em Brasil (2013b; 2014f; 2014g; 2014h); Tour da Experiência (2014); Aventura Segura (2014); Passaporte Verde (2014); Proteja Brasil (2014).

Pode-se afirmar que até o momento são poucos os programas, ações e campanhas de sustentabilidade no nível do governo federal, sobretudo porque os ativos do Brasil, em termos de competitividade, estão relacionados aos recursos naturais e paisagísticos do País. Embora o Brasil seja "deitado em berço esplêndido", a quantidade de programas de turismo vigorosos e pautados na sustentabilidade também é menor.

O MTur é, de fato, a maior think tank do sistema turístico nacional, mas ainda enfrenta diversos desafios, como consolidar e divulgar as plataformas de estatísticas, melhorar estrutura e qualificação nos destinos e contribuir no aumento do turismo interno e internacional. Na internet o Ministério está presente em dez plataformas: Facebook, Twitter, Google +, Instagram, Pinterest, Blog, Orkut, Flickr, Youtube e Soundcloud.

No que se refere às ações brasileiras de inovação para a sustentabilidade no contexto da iniciativa privada, vale destacar duas boas práticas. Uma desenvolvida pela Embraer (influencia indiretamente no turismo) e outra pelo Sebrae (influencia diretamente o turismo). 
De acordo com Cruz (2011, p. 63), "apesar de Alberto Santos Dumont com seu 14Bis ter voado sobre Paris, em 23 de outubro de 1906, o Brasil não ocupou um lugar de destaque no cenário da aviação até a segunda metade do século passado". A Embraer (Empresa Brasileira de Aviação) (http://www.embraer.com/pt-BR/Paginas/Home.aspx), criada em 1969, hoje é uma das empresas mais inovadoras do País, porém é a única competitiva do ramo de aviação no mercado internacional. A empresa tem inovado na medida em que começou a desenvolver aeronaves compatíveis com o uso de biocombustíveis. O Box 2 evidencia maior detalhamento sobre essas novas mudanças e que têm repercutido na competitividade dos negócios.

\section{Box 2 - Inovação para a sustentabilidade no setor aéreo}

Considerando que as viagens aéreas internacionais atualmente são responsáveis por $5 \%$ das emissões de dióxido de carbono $\left(\mathrm{CO}_{2}\right)$ no mundo e que existem diversos segmentos na sociedade que clamam por um desenvolvimento mais sustentável, verificamos soluções inovadoras e sustentáveis no setor aéreo, sobretudo para mitigação do aquecimento global.

A segunda maior empresa aérea australiana, Virgin Blue, publicou oficialmente seu compromisso para diminuir os impactos negativos causados por suas operações. Algumas ações podem ser citadas, como a adequação de escalas de voos com o intuito de minimizar o consumo de combustível, a aquisição dos aviões Boing New Generation 737 e E-Jets da Embraer (mais eficientes quanto ao uso de combustíveis) e a disponibilização de uma calculadora no próprio site da empresa para que os passageiros possam calcular a emissão média de gases de efeito estufa gerados por suas viagens. Além disso, está à disposição do cliente, se assim ele o desejar, uma seção no site de reservas que ele pode contribuir pata a redução dos referidos gases.

Vale mencionar, ainda, a parceria estabelecida entre a Embraer, a Azul Linhas Aéreas e a GE para produzir um bioquerosene próprio para o setor de aviação. O "biocombustível", como assim é popularmente conhecido, é formado à base de cana de açúcar. Ele apresenta poder calorífico igual ou maior à substância derivada do petróleo, no entanto, a quantidade de emissão de $\mathrm{CO}_{2}$ é quase igual ao do etanol e, obviamente, menor em relação ao petróleo. Em 2012, na ocasião da Rio+20 (evento promovido pela ONU), foi realizado o primeiro voo mais longo com o uso de "biocombustível" saindo de Amsterdam com destino ao Rio de Janeiro.

Há, no entanto, controvérsias sobre o verdadeiro grau de sustentabilidade do "biocombustível", uma vez que existem relatos de queimas da cana-de-açúcar (emitindo, consequentemente, $\mathrm{CO}_{2}$ ), o uso de mãode-obra escrava ou muito barata. De todo modo, é notório o esforço para que se adote soluções menos impactantes.

Fonte: Adaptado de Caldeira (2010).

No âmbito das micro e pequenas empresas, em 2014 foi lançado pelo Sebrae Turismo um Guia de Soluções bastante inovador, tendo inclusive formato de jogo, conforme apresenta a Figura 23. É um material mais atraente para o leitor/empreendedor e cujo objetivo visa auxiliar micro e pequenos empresários na busca por soluções inovadoras e sustentáveis na atividade turística. 


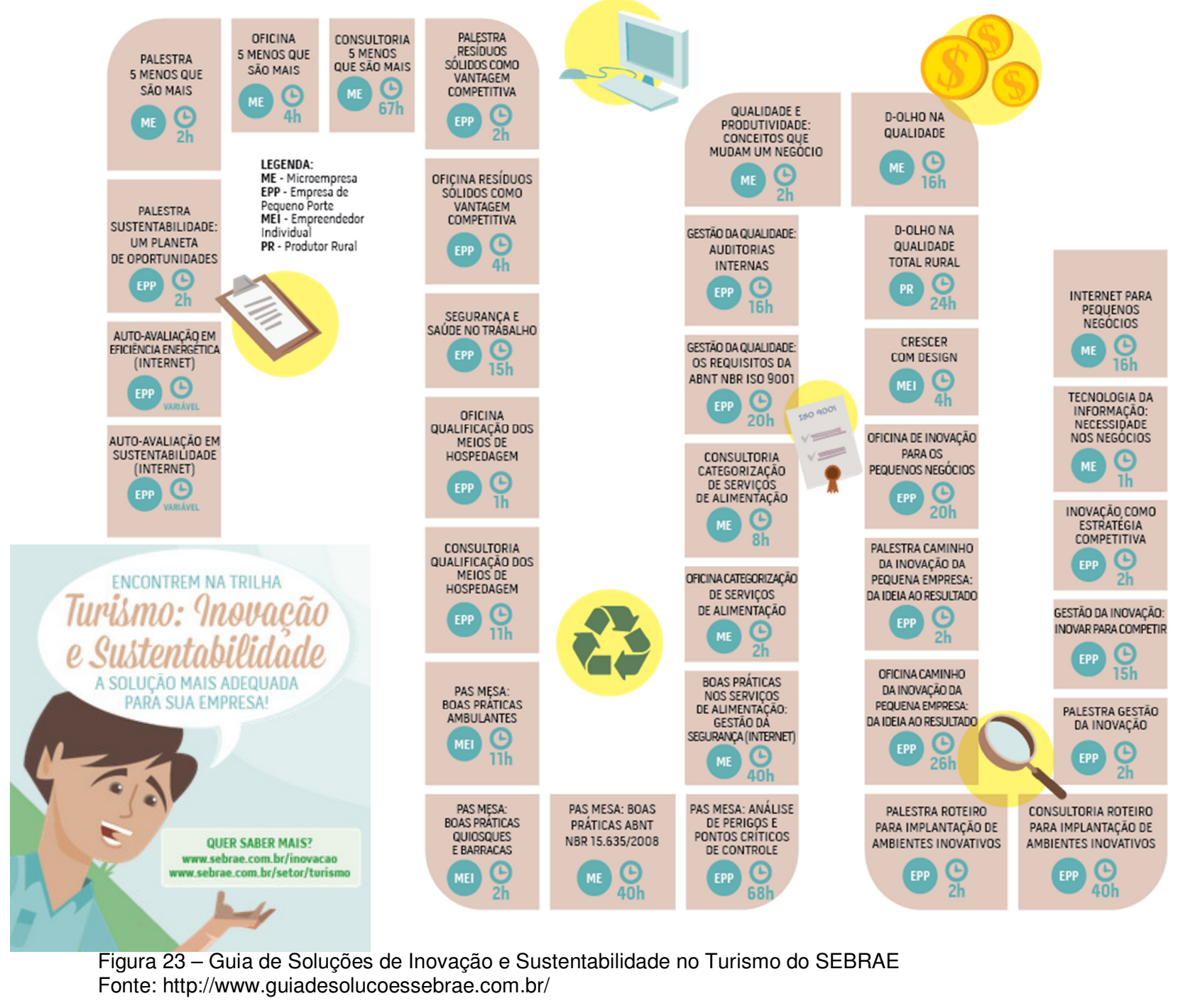

Por fim, é válido evidenciar duas boas práticas desenvolvidas no contexto do Terceiro setor de inovação para a sustentabilidade no turismo. A primeira diz respeito à plataforma online WikiParques e a segunda sobre o Plano de Negócios de Turismo em Terras Indígenas, criado pela Conservation Strategy Fund (CSF).

\section{- Plataforma online WikiParques}

Essa plataforma (http://www.wikiparques.com/wiki/P\%C3\%A1gina_principal) é um projeto da Associação O Eco, organização brasileira sem fins lucrativos em parceria com a Fundação Grupo Boticário. Embora ainda esteja na versão beta (vide Figura 24), o objetivo principal é compartilhar de forma colaborativa o conhecimento sobre Parques Nacionais e demais áreas protegidas. À medida que o conteúdo esteja sendo inserido em um só site e atualizado por seus usuários, a plataforma facilitará bastante o acesso ao conhecimento sobre flora e fauna, bem como definição de roteiros turísticos (uma vez que informações 
sobre os atrativos também estarão disponíveis) e identificação dos meios de hospedagem mais próximos das áreas protegidas.

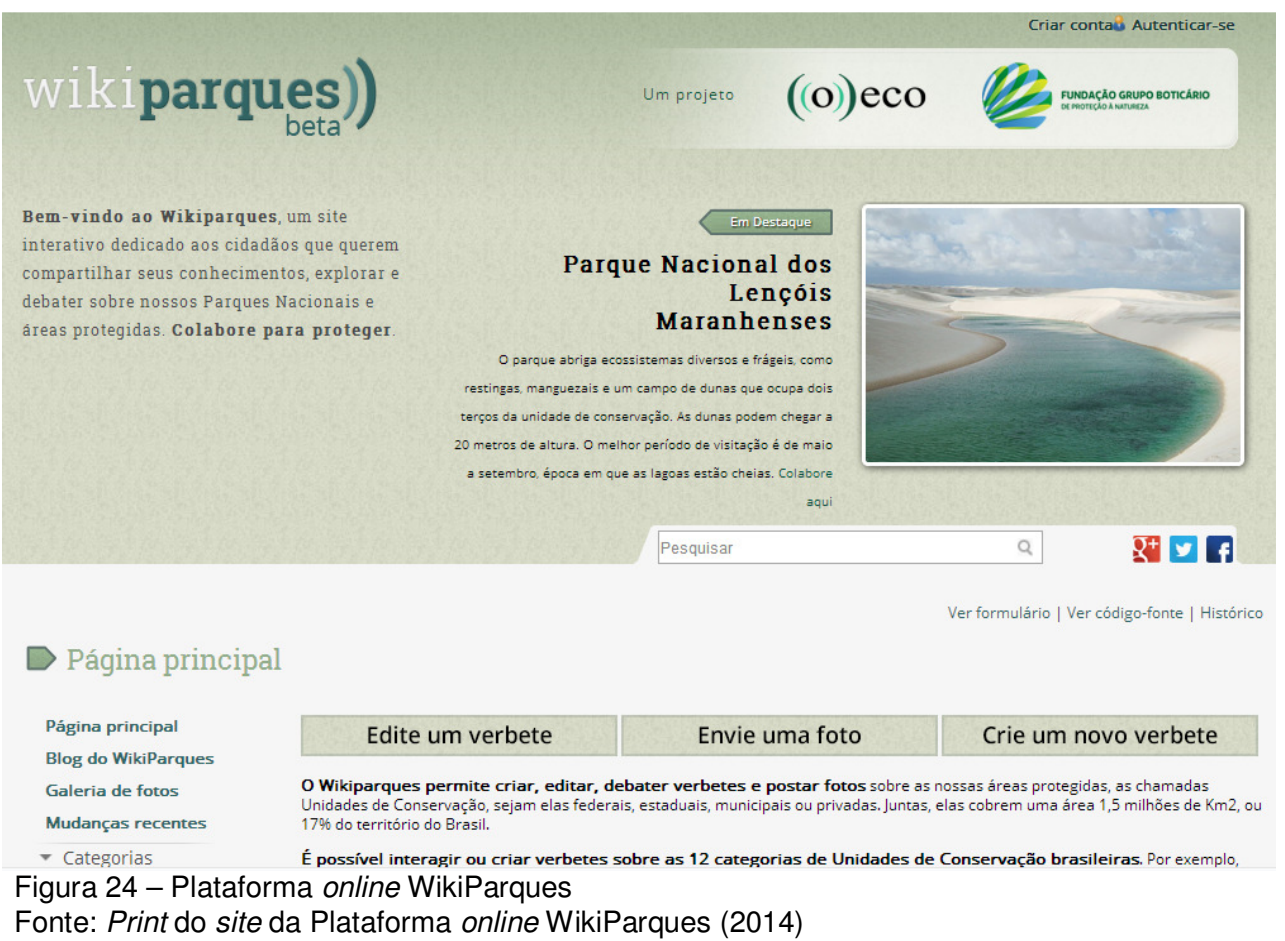

\section{- Conservation Strategy Fund (CSF)}

A Conservation Strategy Fund (CSF) (http://conservation-strategy.org/pt) foi criada em 1998 com o intuito de dar apoio a ações conservacionistas por meio de ferramentas econômicas que sejam capazes de encontrar soluções inovadoras para problemas ambientais de determinadas localidades. Hoje a CSF é referência mundial no desenvolvimento dessas soluções. Com 16 anos de criação, a CSF já investiu mais de $R \$$ 20 bilhões em projetos de desenvolvimento que resultaram na conservação de mais de 20 milhões de hectares. Além disso, a CSF (2013) envolveu mais de 2000 pessoas, 650 organizações e 90 países.

A CSF está presente nos EUA, Bolívia e Brasil, porém possui também pontos de apoio na Costa Rica, Colômbia, Peru, Uganda e Reino Unido. Em termos acadêmicos, parte da equipe de pesquisadores está vinculada a essas universidades: Harvard, Duke, Universidade de Brasília, Universidade dos Andes (Colômbia), Universidade de Concepción (Chile), Oregon State University, University of Cape Town e Makerere University (Uganda). Entre os principais parceiros da CSF destacam-se: ativistas locais, tribos indígenas, ONG internacionais e bancos de desenvolvimento (CSF, 2012). A equipe de colaboradores da CSF busca construir a melhor infraestrutura com menor custo e dano ambiental, realiza 
cursos de capacitação personalizados (conforme o ecossistema que se deseja estudar/criar solução) e desenvolve modelos de negócios sustentáveis e participativos, inclusive na área de turismo.

Em 2012 foram concluídos dois Planos de Negócio de Turismo nas Terras Indígenas Sete de Setembro (Povo Paiter-Surui) e Nove de Janeiro (Parintintin). A proposta do ecoturismo em terras indígenas é uma alternativa ao desmatamento, de tal modo que se possa gerar benefícios econômicos, sociais e ambientais. Esta iniciativa é uma boa prática de inovação para a sustentabilidade no turismo por três motivos: i) um plano de negócios criado e personalizado para comunidades indígenas; ii) realizado por equipe de consultores do terceiro setor e iii) construído de forma participativa e coletiva por meio de oficinas com consultores e indígenas. Depois de concluída essa etapa, a equipe de consultores faz o estudo de viabilidade econômica e financeira dos roteiros propostos de ecoturismo e cria, através de outros dados e informações, o Plano de Negócio de Turismo.

A seção deste capítulo apresentou, no âmbito do poder público, iniciativa privada e terceiro setor, experiências de inovação para a sustentabilidade no turismo. A análise comparada entre essas experiências está presente no capítulo 5 , pois nele também consta a interface dessas experiências com os resultados da pesquisa junto aos especialistas brasileiros (próxima seção) e a pesquisa de campo.

\subsection{A VISÃO DE ESPECIALISTAS BRASILEIROS EM TURISMO E INOVAÇÃO}

Nesta seção serão analisadas as informações obtidas na pesquisa realizada com especialistas brasileiros de inovação e turismo. Foram enviados e-mails para 130 especialistas com o link de acesso para um questionário online, composto por sua vez por cinco perguntas (vide Apêndice A). Recebemos 50 respostas, e esta é a amostra da pesquisa.

\subsubsection{BREVE CARACTERIZAÇÃO DOS ESPECIALISTAS}

Como se pode verificar no gráfico 01 , relativo à ocupação dos especialistas, os professores universitários representam quase a metade da amostra, com 44\%. Participaram também consultores autônomos e do Sistema S (32\%), empresários (18\%), profissionais do terceiro setor (4\%) e funcionários públicos/representantes do governo (2\%). 


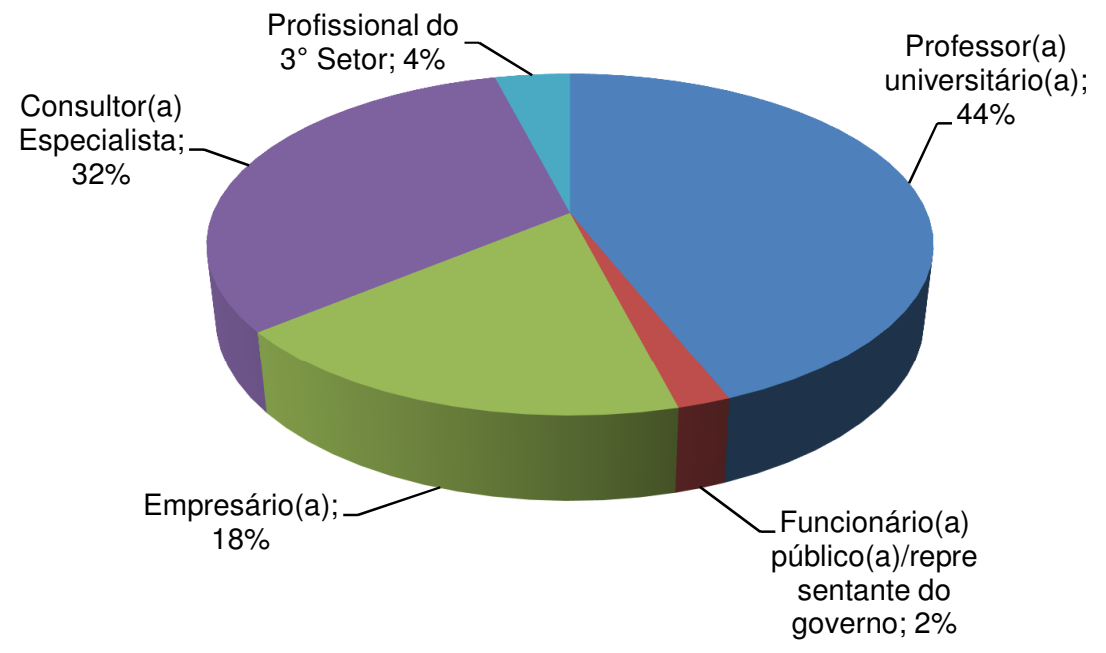

Gráfico 01 - Ocupação dos especialistas

Fonte: Elaborado por Daniela Rocco (2014)

De acordo com o gráfico 02 abaixo, mais da metade da amostra é proveniente da região sudeste $(52 \%)$, com destaque para a cidade de São Paulo. A região menos abrangida é a Norte, com $4 \%$. Tal como é evidenciado nas pesquisas desenvolvidas pelo IBGE, a população intelectual do Brasil ainda se concentra na região sudeste do país e menos na região norte (IBGE, 2010).

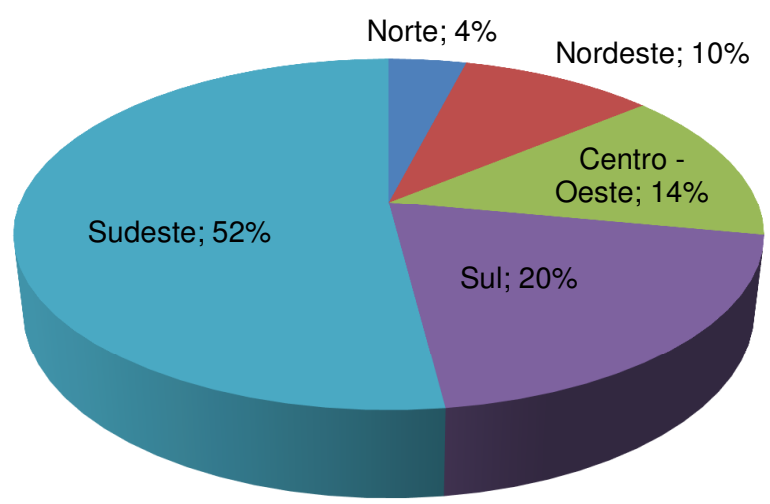

Gráfico 02 - Região

Fonte: Elaborado por Daniela Rocco (2014) 
Como demonstra o gráfico 03 , sobre o tempo de atuação na área, 30\% dos especialistas possuem mais de 20 anos de experiência. Por outro lado, $52 \%$ da amostra tem menos de 15 anos de experiência.

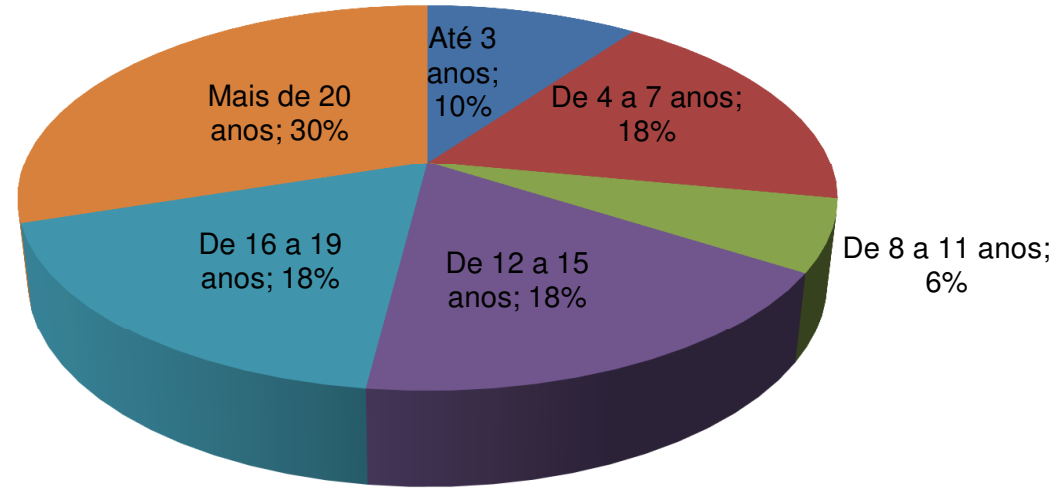

Gráfico 03 - Tempo de experiência

Fonte: Elaborado por Daniela Rocco (2014)

Esta seção apresentou uma breve caracterização do perfil dos especialistas entrevistados. O cruzamento entre alguns itens desta caracterização com os demais resultados obtidos na pesquisa online está presente na seção 4.1 .4 (Cruzamento das perguntas e respostas).

\subsubsection{PRÁTICAS DE INOVAÇÃO PARA A SUSTENTABILIDADE NOS DESTINOS TURÍSTICOS BRASILEIROS E A RELAÇÃO COM A COMPETITIVIDADE}

O Box 3 apresenta a listagem de 12 práticas de inovação para a sustentabilidade recorrentes em destinos turísticos que foram selecionadas a partir de recorrências na revisão da literatura e pesquisa de campo na Europa. A partir delas, foi solicitado aos especialistas que escolhessem as três que seriam mais importantes para os destinos turísticos brasileiros. Vale salientar que em cada uma das práticas existe correlação com as seguintes siglas:

PIS = Prática inovadora com foco na dimensão social da sustentabilidade

PIA = Prática inovadora com foco na dimensão ambiental da sustentabilidade

PIC = Prática inovadora com foco na dimensão cultural da sustentabilidade

PIE = Prática inovadora com foco na dimensão econômica da sustentabilidade 


\section{Box 3 - As 12 práticas de inovação para a sustentabilidade no turismo}

1. Políticas públicas menos burocráticas (gestão eficiente), adoção de "compras públicas verdes" e estímulo à cultura da C,T\&l (Ciência, Tecnologia e Inovação) repercussão direta/indireta no turismo [PIE].

2. Incentivo ao empreendedorismo e à gestão empresarial focada na inovação, com programas de financiamento e subvenções econômicas tendo como requisitos a inovação e a sustentabilidade [PIE].

3. Ações de marketing e comunicação social que ampliem a consciência pública sobre a necessidade de modelos de negócios mais sustentáveis, incentivando inclusive a redução do consumo - repercussão direta/indireta no turismo [PIC].

4. Certificação de destinos e empresas turísticas - Sistema de Gestão Ambiental, de Qualidade, do Trabalho e Eventos Sustentáveis, além de iniciativas voluntárias e selos [PIE].

5. Plataforma de intercâmbio gratuito de informações gerida por alianças públicoprivadas para fomentar a cooperação, especialmente entre micro e pequenas empresas de turismo [PIE].

6. O uso das TIC (Tecnologia da Informação e Comunicação) destinadas a turistas (facilitação da mobilidade) e para o planejamento e prevenção de impactos negativos (ex: geoprocessamento para identificar pontos de crimes e prevenir queimadas) [PIA].

7. Aplicação de taxas de uso ambiental retornando à sociedade como forma de investimento em inovações e sustentabilidade, como melhoria da infraestrutura, manutenção de trilhas, proteção dos ecossistemas, uso de novas tecnologias, entre outros [PIA].

8. Inovações sociais com melhoria das condições de trabalho, educação, saúde, além de socialização nos espaços públicos - repercussão direta/indireta no turismo [PIS].

9. Atividades econômicas nos destinos turísticos que sejam de uso sustentável da biodiversidade, valorizando a cultura local e considerando os princípios de mercado justo/economia solidária [PIS].

10. Criação/consolidação de programas de eficiência energética e gestão da água e resíduos nas empresas, instituições públicas e terceiro setor - repercussão direta/indireta no turismo [PIA].

11. Premiação de iniciativas de inovações vinculadas à sustentabilidade nos destinos turísticos [PIE].

12. Uso de veículos e meios de transporte (rodoviário, ferroviário, aéreo e hidroviário) ecologicamente adequados com redução da pegada ecológica (ex: biocombustível, energia solar, energia eólica, etc) [PIA]. 
O gráfico 04 a seguir diz respeito às práticas de inovação para a sustentabilidade mais citadas pelos especialistas no quesito importância para os destinos turísticos brasileiros. As práticas mais citadas pelos especialistas foram:

- "Incentivo ao empreendedorismo e à gestão empresarial focada na inovação, com programas de financiamento e subvenções econômicas tendo como requisitos a inovação e a sustentabilidade", com 15\% (prática n. 2 no Box 3);

- "Políticas públicas menos burocráticas (gestão eficiente), adoção de "compras públicas verdes" e estímulo à cultura da C,T\&I (Ciência, Tecnologia e Inovação) repercussão direta/indireta no turismo", com 14\% (prática n. 1 no Box 3);

- "Atividades econômicas nos destinos turísticos que sejam de uso sustentável da biodiversidade, valorizando a cultura local e considerando os princípios de mercado justo/economia solidária", com 11\% (prática n. 9 no Box 3).

A prática n. 12, relativa ao "uso de veículos e meios de transporte (rodoviário, ferroviário, aéreo e hidroviário) ecologicamente adequados com redução da pegada ecológica (ex: biocombustível, energia solar, energia eólica, etc.)" foi a menos citada, com apenas $1 \%$ das respostas. 
Uso de veículos e meios de transporte (rodoviário, ferroviário, aéreo e hidroviário) ecologicamente...

Premiação de iniciativas de inovações vinculadas à sustentabilidade

O uso das TIC (Tecnologia da Informação e Comunicação) destinadas a turistas

Criação/consolidação de programas de eficiência energética e gestão da água e resíduos

Plataforma de intercâmbio gratuito de informações gerida por alianças público-privadas

Certificação de destinos e empresas turísticas

Ações de marketing e comunicação social que ampliem a consciência pública

Aplicação de taxas de uso ambiental retornando à sociedade como forma de investimento em...

Inovações sociais com melhoria das condições de trabalho, educação, saúde

Atividades econômicas nos destinos turísticos que sejam de uso sustentável da biodiversidade

Políticas públicas menos burocráticas (gestão eficiente)

Incentivo ao empreendedorismo e à gestão empresarial focada na inovação
$1 \%$ [PIA]

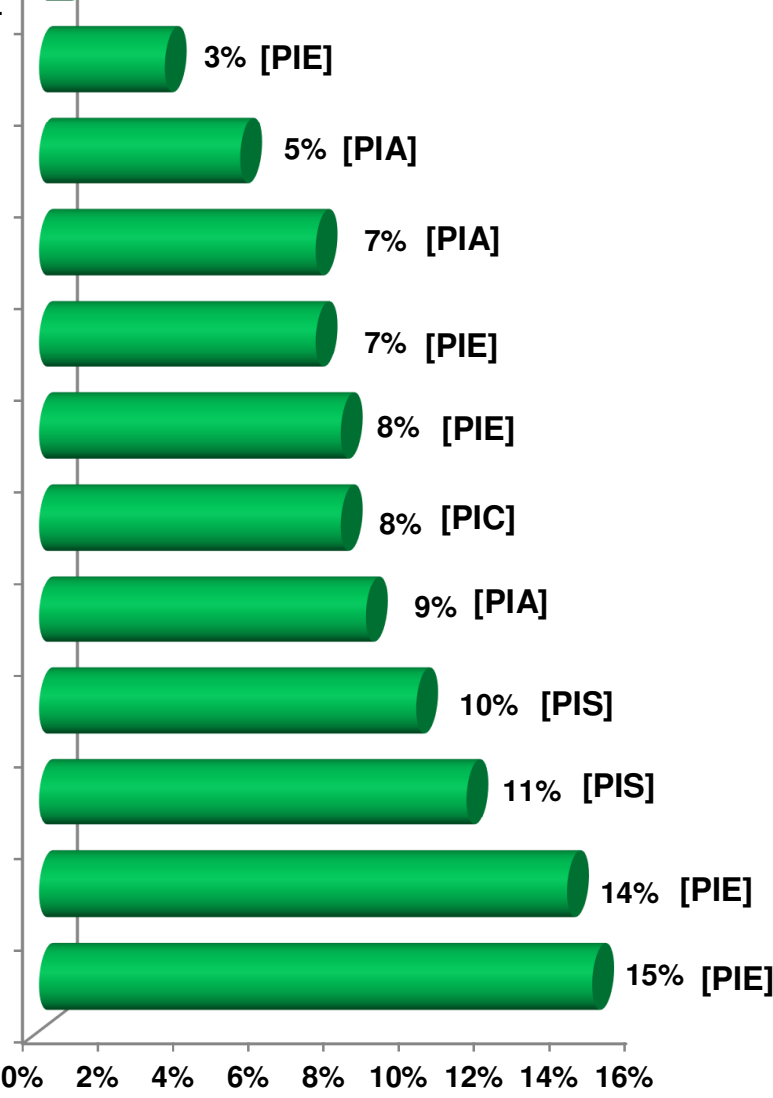

Gráfico 04 - Práticas mais importantes de inovação para a sustentabilidade para os destinos Fonte: Elaborado por Daniela Rocco (2014)

O gráfico 04 nos mostra também que dentre as práticas mais citadas como importantes, as duas que mais se destacam possuem foco na dimensão econômica da sustentabilidade (PIE). A importância de se ter políticas públicas menos burocráticas e o incentivo ao empreendedorismo no contexto da inovação para a sustentabilidade é, segundo a maioria dos especialistas, as práticas mais relevantes para os destinos turísticos. Isto representa uma demanda conjuntural e estrutural no sistema turístico e respectivos encadeamentos produtivos, uma vez que remete às atividades de apoio como a da Administração pública no modelo de cadeia de valor do turismo proposto no capítulo 1.

Uma vez perguntados se existiria outra prática inovadora vinculada à sustentabilidade que é adotada (ou poderia ser adotada) nos destinos turísticos brasileiros, 27 especialistas assim responderam (Quadro 17): 
1. "Já está respondida no contexto das alternativas anteriores, mas saliento que formação profissional de qualidade e saneamento das más práticas públicas e privadas em relação ao lazer e turismo". Professor universitário, São Paulo, mais de 20 anos de experiência.

2. "Formação de uma rede de destinos turísticos voltados à inovação e à sustentabilidade, para troca online de experiências e desafios; prestação de contas permanente dos projetos voltados a essa temática". Consultora especialista, São Paulo, mais de 20 anos de experiência.

3. "Considero que programas associados a tributos poderia estimular a adoção de práticas sustentáveis, pois na verdade as atividades sustentáveis são menos onerosas ao Estado e portanto devem ter tributos diferenciados - a menor". Empresário, Goiás, mais de 20 anos de experiência.

4. "Captação de parcerias internacionais; inclusão em redes internacionais". Consultor especialista, Brasília/DF, de 4 a 7 anos de experiência.

5. "Desenvolvimento de uma metodologia prática e de fácil aplicação que contemple desde a etapa de um diagnóstico que identifique os principais aspectos a serem aprimorados quanto à inovação e sustentabilidade, passado por boas praticas para fácil aplicabilidade, avaliação periódica através de indicadores específicos para essas finalidades e premiação para aqueles que apresentarem maiores evoluções positivas e os casos de benchmarking". Consultor especialista, Rio de Janeiro, de 16 a 19 anos de experiência.

6. "Desenvolvimento de projetos de design territorial, articulando os diversos atores envolvidos na oferta de produtos e serviços inovadores mas vinculados ao território". Consultor especialista, Santa Catarina, mais de 20 anos de experiência.

7. "Iniciativa dos Geoparks". Professora universitária, Paraná, de 12 a 15 anos de experiência.

8. "Definido um território de vocação turística e necessário: estudá-lo, conhecer sua história e outras vocações, definir sua interface com outros setores: cultura, o meio ambiente, artesanato, outros; reconhecer lideranças e debater com elas os resultados da pesquisa e estudos; mobilizar pessoas das áreas do trade turístico e das áreas de interface para um Seminário; apontar problemas e soluções coletivas para o desenvolvimento sustentável; listar ideias, ações e projetos (viáveis); montar um Grupo Gestor e com ele elaborar um Plano, estabelecendo prioridades; capacitar para implantar o Plano (cada ideia, ação e projeto); acompanhar os resultados. Nada é possível sem envolvimento. A palavra 'desenvolvimento' implica em não se envolver, mas não se pode crescer sem conhecer e se envolver. $O$ Plano pode se chamar de 'Plano de Envolvimento Turístico'”. Empresário, Rio de Janeiro, mais de 20 anos de experiência.

9. "Capacitação de pessoal em sustentabilidade. Maior vinculação do mundo acadêmico com o mundo empresarial no setor turístico buscando a realização de pesquisas aplicadas com foco em inovação e resolução de problemas que gerem sustentabilidade". Professor universitário, Brasília/DF, mais de 20 anos de experiência.

10. "Existe uma iniciativa no Espírito Santo de adoção de moeda própria em comunidade, com bancos que trocam por reais. É uma alternativa interessante". Professor universitário, Paraná, de 12 a 15 anos de experiência.

11. "Capacitação (educação) da mão de obra envolvida com o turismo local, com foco na sustentabilidade". Professora universitária, Santa Catarina, de 12 a 15 anos de experiência.

12. "Gestão do conhecimento em nível do destino com vistas à inovação". Consultor especialista, Rio de Janeiro, mais de 20 anos de experiência.

13. "Perspectiva de clusters regionais de inovação turística conformando produtos criativos focados em demandas especificas gerando benefícios diretos e indiretos para visitantes e visitados". Professor universitário, Paraná, mais de 20 anos de experiência.

14. "Embora haja citação ao fomento de capacitação em gestão, cita-se que o foco seria inovação e subsídios. Considero inovação muito importante, mas percebo que o maior interesse está na perna econômica do tripé da sustentabilidade. As pessoas querem entender práticas de controle de faturamento e margem de lucro para investir em inovação. Sugeriria, pois, capacitação em gestão econômica e financeira. Isso daria maior segurança para investir em algo tão caro e arriscado como o novo". Consultor especialista, Amazonas, de 4 a 7 anos de experiência.

15. "Valorização da cultura local e ampliação dos programas de educação para as comunidades impactadas pelo turismo. (com a educação é possível ampliar debates, valorizar os usos e costumes locais, valorizar os cidadãos e, com isso, aplicar os conhecimentos comunitários nas melhorias dos produtos e serviços)". Consultor especialista, São Paulo, mais de 20 anos de experiência.

16. "Cooperação entre as empresas de um mesmo destino para o desenvolvimento do destino". Consultor especialista, Minas Gerais, de 16 a 19 anos de experiência.

17. "Capacitação contínua dos gestores visando a melhora gerencial dos negócios diretamente ligados ao turismo, e esses gestores serem os facilitadores ou replicadores para suas equipes ou comunidades". Professor universitário, São Paulo, de 04 a 07 anos de experiência.

18. "As 'práticas' listadas são agregações muito genéricas, abrangendo coisas distintas e diferentes. A lista não me pareceu prática nem discriminatória para apontar caminhos. O uso do termo 'inovadora' é suficientemente impreciso para prejudicar a objetiva da avaliação. Mas, para citar uma, que me parece 
importante e estratégica e, além disso é pouco usada, se é que é, é o estabelecimento de políticas formais para o turismo sustentável, pelos destinos e o sua implementação. desdobramento mediante planos de ação e processos participativos e inclusivos. Definir uma visão brasileira de sustentabilidade de destinos também seria muito útil (embora isso já não seja necessariamente uma boa prática)". Consultor especialista, Rio de Janeiro, mais de 20 anos de experiência.

19. "Estudos de monitoramento de variáveis ambientais, sociais e econômicas, sobretudo de longo prazo". Professor universitário, São Paulo, de 12 a 15 anos de experiência.

20. "Creio que a inclusão de programas pedagógicos relacionados a sustentabilidade nas escolas publicas e privadas dos destinos turísticos brasileiros". Empresário, Brasília/DF, mais de 20 anos de experiência.

21. "Criação de institutos (formais) de preservação ambiental e cultural (ex.: Caso de Praia do Forte-BA com o Instituto Projeto Tamar e a Fundação Garcia D’Avila)". Professora universitária, Rio de Janeiro, de 08 a 11 anos de experiência.

22. "Creio que as mais significativas estejam descritas na sua relação". Professor universitário, Rio de Janeiro, de 04 a 07 anos de experiência.

23. "A lista anteriormente apresentada parece-me suficientemente completa. Ainda que não seja um tema especificamente ligado ao turismo, penso que o efetivo combate à corrupção e ao desperdício de recursos públicos (que, de certa forma, está relacionado a vários dos temas da lista) é um aspecto importante para a melhoria das condições dos nossos destinos". Professor universitário, São Paulo, de 16 a 19 anos de experiência.

24. "Desenvolver práticas inovadoras sustentáveis nas cadeias de suprimento das empresas envolvidas no turismo (trade) tendo em vista o conceito de ciclo de vida do produto". Professor universitário, São Paulo, mais de 20 anos de experiência.

25. "Poderia haver uma maior exploração dos recursos ligados á tecnologia das redes sociais, de modo mais específico e direcionado a determinados aspectos do turismo. Um exemplo seria um aplicativo destinado a alertar quanto a degradação ambiental em pontos turísticos. Na verdade poderiam ser estudadas duas formas de abordagem: uma mais específica e pontual (um aplicativo para um objetivo específico com o acima), ou uma mais abrangente (onde o aplicativo permitisse uma série de qualificações, observações, denúncias quanto a: segurança, abuso de menores, limpeza, conservação, etc.. e permitisse a inserção de imagens, etc...)". Empresário, Santa Catarina, de 12 a 15 anos de experiência.

26. "Reaproveitamento dos resíduos gerados pelos turistas e munícipes, por exemplo, lixo (gerando energia, reciclagem), água (reaproveitamento d'água para outros usos, uso de água da chuva mudanças estruturais nas edificações, construção verde, uso da energia solar)". Professor universitário, Paraná, de 16 a 19 anos de experiência.

27. "Criação de benchmarks, ou seja, apontar o que poderia servir de inspiração - vindo de outros setores, de outras cidades, enfim, algo que pudesse inspirar os envolvidos". Professora universitária, São Paulo, de 04 a 07 anos de experiência.

Quadro 17 - Indicação dos especialistas quanto a práticas de inovação para a sustentabilidade nos destinos turísticos brasileiros

Fonte: Elaborado por Daniela Rocco (2014) com base nas informações obtidas na pesquisa.

O gráfico 05, quanto ao grau de importância das 12 práticas anteriormente mencionadas para a competitividade dos destinos turísticos brasileiros, destaca:

- "Incentivo ao empreendedorismo e à gestão empresarial focada na inovação, com programas de financiamento e subvenções econômicas tendo como requisitos a inovação e a sustentabilidade", com 98\% (muito importante e importante - PIE);

- "Inovações sociais com melhoria das condições de trabalho, educação, saúde, além de socialização nos espaços públicos - repercussão direta/indireta no turismo", com 92\% (muito importante e importante - PIS); 
- "Políticas públicas menos burocráticas (gestão eficiente), adoção de "compras públicas verdes" e estímulo à cultura da C,T\&I (Ciência, Tecnologia e Inovação) repercussão direta/indireta no turismo", com 90\% (muito importante e importante PIE).

A prática n. 12, relativa ao "uso de veículos e meios de transporte (rodoviário, ferroviário, aéreo e hidroviário) ecologicamente adequados com redução da pegada ecológica (ex: biocombustível, energia solar, energia eólica, etc.)" foi considerada como "muito importante" para apenas $12 \%$ dos especialistas. Além disso, as práticas "Premiação de iniciativas de inovações vinculadas à sustentabilidade nos destinos turísticos" e "Certificação de destinos e empresas turísticas - Sistema de Gestão Ambiental, de Qualidade, do Trabalho e Eventos Sustentáveis, além de iniciativas voluntárias e selos" foram consideradas, cada uma, como "sem importância" para a competitividade turística brasileira segundo $8 \%$ dos especialistas.

De forma geral, todas as práticas foram consideradas como muito importantes para a competitividade dos destinos turísticos brasileiros. O menor índice alcançado foi a prática "Premiação de iniciativas de inovações vinculadas à sustentabilidade nos destinos turísticos", com 60\% (muito importante e importante).

Por fim, com relação ao grau "sem importância" para a competitividade turística, poucas práticas foram assim caracterizadas pelos especialistas:

- "Inovações sociais com melhoria das condições de trabalho, educação, saúde, além de socialização nos espaços públicos - repercussão direta/indireta no turismo"; "Uso de veículos e meios de transporte (rodoviário, ferroviário, aéreo e hidroviário) ecologicamente adequados com redução da pegada ecológica (ex: biocombustível, energia solar, energia eólica, etc.)" e "Certificação de destinos e empresas turísticas Sistema de Gestão Ambiental, de Qualidade, do Trabalho e Eventos Sustentáveis, além de iniciativas voluntárias e selos", com $2 \%$ cada uma (sem importância);

- "O uso das TIC (Tecnologia da Informação e Comunicação) destinadas a turistas (facilitação da mobilidade) e para o planejamento e prevenção de impactos negativos (ex: geoprocessamento para identificar pontos de crimes e prevenir queimadas)", com 6\% (sem importância).

É mister registrar que o gráfico 05 revela que, no caso da competitividade dos destinos turísticos, esta depende, sobretudo, de questões de ordem política e econômica, como o incentivo ao empreendedorismo (PIE) e de ordem social (PIS), como novas formas de se conduzir o trabalho, educação, saúde, a socialização nos espaços públicos, etc. Isto dialoga diretamente com a perspectiva tão sistêmica do turismo, bem como o próprio 
conceito de competitividade turística, que deve priorizar nos processos não apenas o bem estar dos turistas, como da sociedade em geral.

Criação/consolidação de programas de eficiência energética e gestão da água e resíduos

Atividades econômicas nos destinos turísticos que sejam de uso sustentável da biodiversidade

Inovações sociais com melhoria das condições de trabalho, educação, saúde

Premiação de iniciativas de inovações vinculadas à sustentabilidade

Uso de veículos e meios de transporte (rodoviário, ferroviário, aéreo e hidroviário) ecologicamente adequados

Aplicação de taxas de uso ambiental retornando à sociedade como forma de investimento em inovações e sustentabilidade

Ações de marketing e comunicação social que ampliem a consciência pública

Incentivo ao empreendedorismo e à gestão empresarial focada na inovação

O uso das TIC (Tecnologia da Informação e Comunicação) destinadas a turistas

Certificação de destinos e empresas turísticas

Plataforma de intercâmbio gratuito de informações gerida por alianças público-privadas

Políticas públicas menos burocráticas (gestão eficiente)

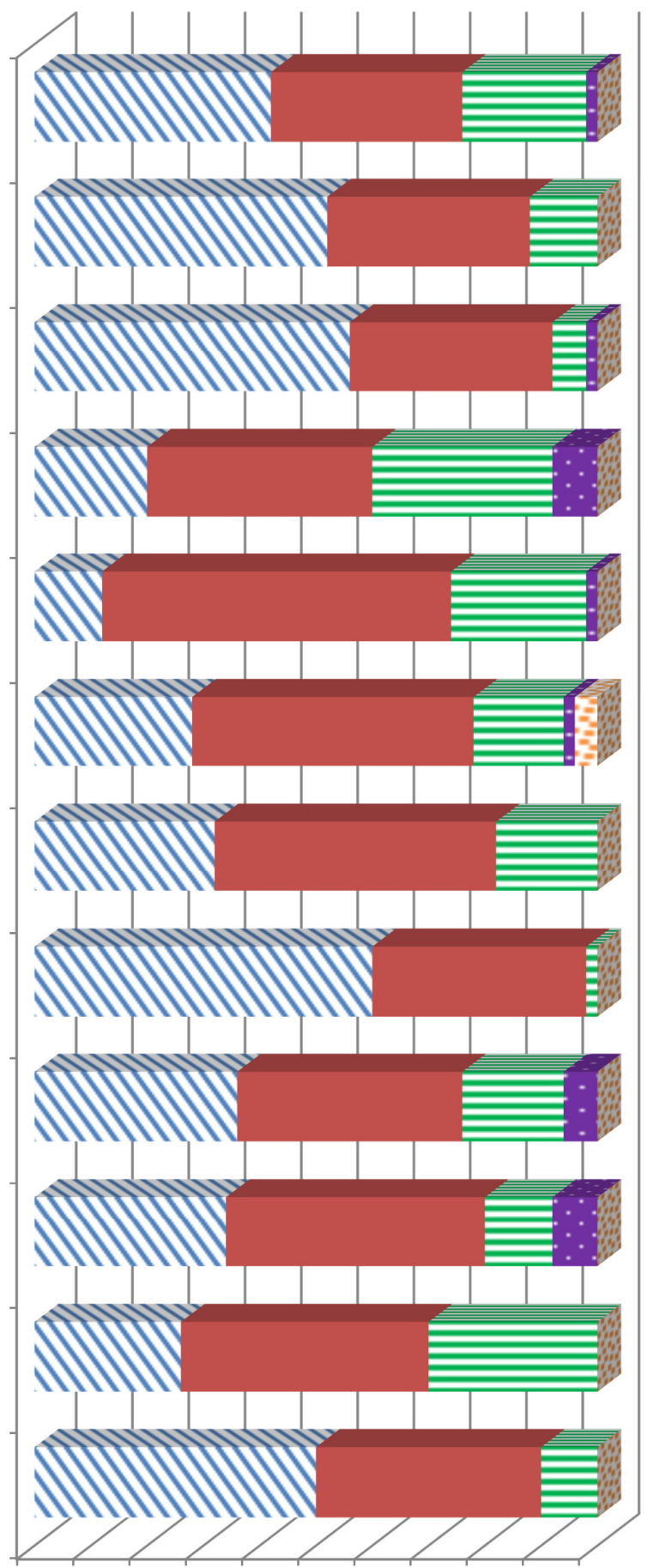

0\% 10\% 20\% 30\% 40\% 50\% 60\% 70\% 80\% 90\% $100 \%$
[PIA]

[PIS]

[PIS]

[PIE]

[PIA]

[PIA]

[PIC]

[PIE]

[PIA]

[PIE]

[PIE]

[PIE]

\section{" Muito Importante घImportante = Menos Importante - Sem Importância Não Sabe}


O gráfico 06 indica o potencial de disseminação das 12 práticas no futuro. A que possui maior potencial de disseminação no futuro é a prática "Ações de marketing [...]" (prática n. 3 - PIC), com 68\%. Em seguida destacam-se: "Premiação de iniciativas [...]" (prática n. 11 - PIE), com 56\% e "Incentivo ao empreendedorismo e à gestão empresarial [...]" (prática n. 2 - PIE), também com 56\%. Com relação ao menor potencial de disseminação no futuro é a prática "Premiação de iniciativas [...]", segundo $2 \%$ dos entrevistados. De forma geral, quando se soma o potencial mediado e elevado de disseminação das práticas no futuro, todas são expressivas.

Criação/consolidação de programas de eficiência
energética e gestão da água e resíduos

Atividades econômicas nos destinos turísticos que sejam de uso sustentável da biodiversidade

Inovações sociais com melhoria das condições de trabalho, educação, saúde

Premiação de iniciativas de inovações vinculadas à sustentabilidade

Uso de veículos e meios de transporte (rodoviário, ferroviário, aéreo e hidroviário) ecologicamente...

Aplicação de taxas de uso ambiental retornando à sociedade como forma de investimento em...

Ações de marketing e comunicação social que ampliem a consciência pública

Incentivo ao empreendedorismo e à gestão empresarial focada na inovação

O uso das TIC (Tecnologia da Informação e Comunicação) destinadas a turistas

Certificação de destinos e empresas turísticas

Plataforma de intercâmbio gratuito de informações gerida por alianças público-privadas

Políticas públicas menos burocráticas (gestão eficiente)

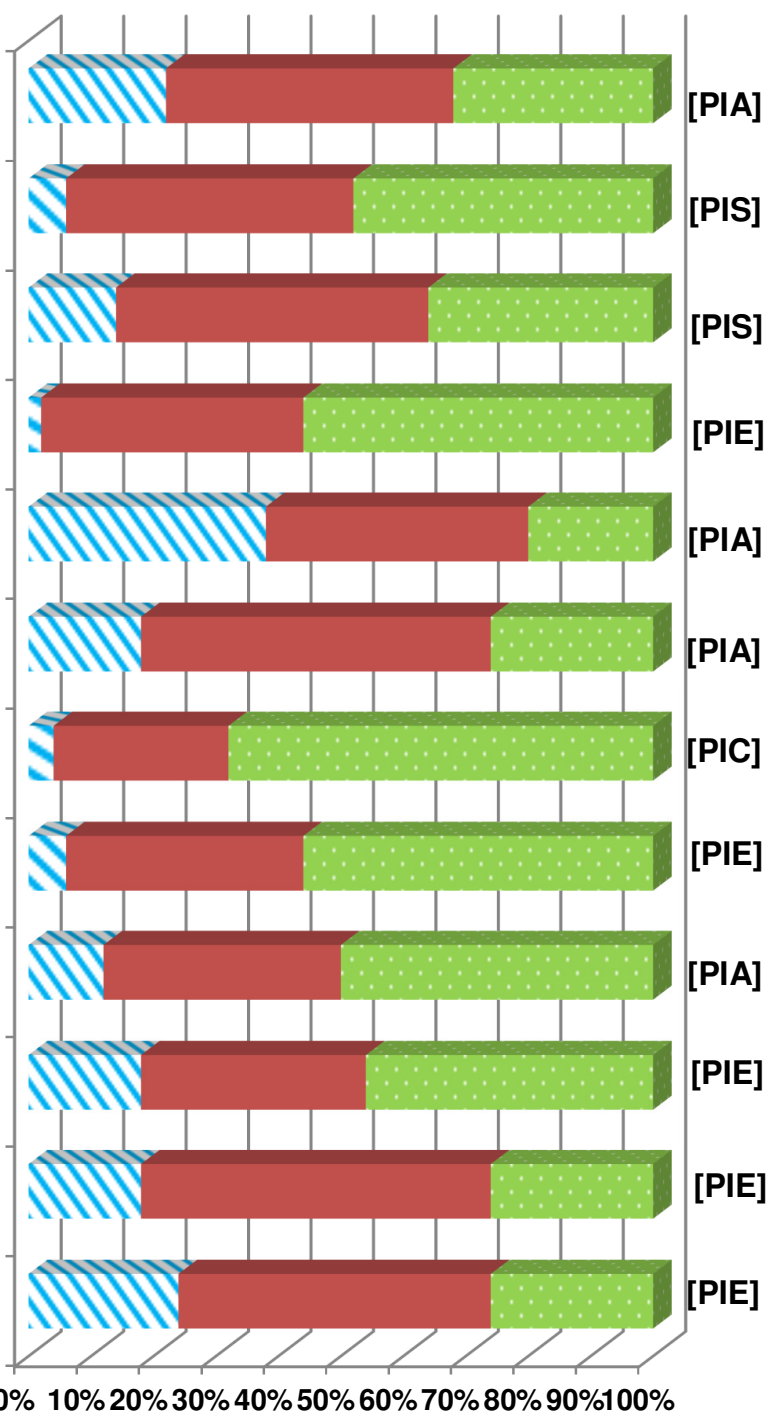

0\% $10 \% 20 \% 30 \% 40 \% 50 \% 60 \% 70 \% 80 \% 90 \% 100 \%$
[PIA]

[PIS]

[PIS]

[PIE]

[PIA]

[PIA]

[PIC]

[PIE]

[PIA]

[PIE]

[PIE]

[PIE]

\section{"Potencial BAIXO Potencial MEDIANO Potencial ELEVADO}

Gráfico 06 - Potencial de disseminação nos destinos turísticos brasileiros no longo prazo

Fonte: Elaborado por Daniela Rocco (2014) 
A partir dos resultados dos gráficos 04, 05 e 06 é possível inferir que: se no presente ações de ordem estrutural e conjuntural como a implementação de políticas públicas menos burocráticas e o incentivo ao empreendedorismo (PIE) são as práticas mais importantes para a competitividade turística brasileira (condição básica), as práticas que tendem a se disseminar no futuro estão relacionadas a algo mais sofisticado, como ações de marketing e de comunicação social (PIS).

\subsubsection{OS DESTINOS TURÍSTICOS BRASILEIROS QUE MAIS POSSUEM} PRÁTICAS DE INOVAÇÃO PARA A SUSTENTABILIDADE

Esta seção possui quatro grupos de respostas: 1) o primeiro destino turístico mais citado; 2) o segundo destino turístico mais citado; 3) o terceiro destino turístico mais citado e 4) os três destinos turísticos mais citados de forma geral.

\section{Primeiro destino turístico mais citado:}

Quando questionados sobre qual seria o destino turístico brasileiro que mais possui práticas de inovação para a sustentabilidade, 32\% dos especialistas indicaram Bonito (MS). Para 14\% dos especialistas é a Serra Gaúcha (RS) e para $8 \%$ é Fernando de Noronha (PE). Percebemos, de acordo com as respostas, uma grande variedade e disseminação de destinos turísticos com tais práticas em todas as regiões brasileiras. Isto porque $36 \%$ dos especialistas citaram 15 destinos turísticos diferentes (uma única vez), não proporcionando, por sua vez, representatividade na contagem. A pergunta de resposta aberta foi assim escolhida para justamente conhecer o universo de possibilidades de destinos turísticos que possuem as referidas práticas, uma vez que este estudo nunca foi realizado no Brasil e porque se abre um campo para investigação de destinos não conhecidos pelos autores desta pesquisa. Um dado que despertou atenção é que $10 \%$ dos especialistas não fizeram nenhuma indicação de destino, por razões diversas. Ora por não saberem efetivamente qual destino turístico possui mais práticas de inovação para a sustentabilidade, ora por não acreditarem que tais práticas ocorram no país de forma integral e a partir da abordagem sistêmica da sustentabilidade, que considera as dimensões ambiental, social e econômica. Destacamos abaixo as justificativas de alguns especialistas que optaram, portanto, não realizar indicação de um destino turístico especificamente:

Desconheço qual o destino que tenha mais inovações vinculadas à sustentabilidade. Em geral, os prêmios concedidos aos municípios para conceder tal titularidade tem [sic] critérios pontuais, sem uma análise sobre a relação sistêmica que envolve a sustentabilidade em seu todo. Desta 
forma, creio que seja imprudente afirmar um único destino. Consultora Terceiro setor, Paraná, de 08 a 11 anos de experiência.

Em minha opinião, nego conheço [sic] tantos destinos sustentáveis, além do meu próprio Estado [sic]. Sendo rigorosamente técnico quanto ao conceito amplo de sustentabilidade, desconheço um roteiro economicamente viável, socialmente justo e ambientalmente correto. Normalmente o foco fica na terceira variável. No passado, tive experiências positivas nos município de Barcelos - am [sic]. Entretanto, o excesso de turistas e a baixa capacidade de qualificação da mão de obra [sic], deterioraram a pesca esportiva. Hoje, Barcelos cobra por uma taxa de ressarcimento ambiental, mas tem violência e prostituição - inclusive infantil. Apontaria o Roteiro Tucurim, como topo da lista, com ressalvas, considerando que o roteiro está em desenvolvimento com grande potencial. Consultor especialista, Amazonas, de 04 a 07 anos de experiência.

Desconheço o destino que mais possui inovações, mas acredito que poderá ser Rio de Janeiro por ser o destino que mais recebe turistas no Brasil e pela atividade ser mais consolidada e organizada no estado em questão. Professor universitário, Rio Grande do Norte, até 03 anos de experiência.

Honestamente, não conheço exemplos de destinos que se encaixem nos aspectos elencados anteriormente. Eu poderia citar alguns exemplos pontuais de empreendimentos, como o Campo dos Sonhos, no município de Socorro/SP (http://www.campodossonhos.com.br/ - ver Reconhecimentos e Certificações), mas não me arriscaria a citar destinos. Os municípios de Bonito/MS e Brotas/SP foram, há algum tempo, muito mencionados como bons exemplos, mas não sei como estariam atualmente, pois não tenho acompanhado a questão. Professor universitário, São Paulo, de 16 a 19 anos de experiência.

\section{Segundo destino turístico mais citado:}

Para $24 \%$ dos especialistas, Bonito (MS) é o segundo destino turístico brasileiro que mais possui práticas de inovação para a sustentabilidade. Blumenau (SC) foi citada por $10 \%$ e a Serra Gaúcha (RS) por 6\%. Em contrapartida, 14\% dos especialistas desconhecem qual poderia ser o segundo destino turístico brasileiro que mais possui as referidas práticas. Além disso, 46\% mencionaram diversos destinos, inclusive, foram citados 13 destinos turísticos distintos uma única vez.

\section{Terceiro destino turístico mais citado:}

Esta pergunta apresentou um dado que também despertou bastante atenção por dois motivos: i) $60 \%$ das respostas indicaram diferentes destinos turísticos (foram citados 20 destinos uma única vez cada) e ii) $32 \%$ dos especialistas desconhecem qual poderia ser o terceiro destino turístico brasileiro que mais possui práticas de inovação para a sustentabilidade. De todo modo, para $8 \%$ dos especialistas o terceiro destino é Foz do Iguaçu (PR). Empataram com 4\% cada destino: Bonito (MS), Bento Gonçalves (RS), Ilha do Mel (PR) e Pantanal (MS e MT). Diante de tais dados, é possível verificar que não há, neste caso, uma unanimidade de respostas, ora por desconhecimento, ora em função da grande 
pulverização das respostas, justamente por ser o Brasil um país de dimensões continentais. Como foi demonstrado, Bonito (MS) foi citado nos três grupos de perguntas e é o que apresenta maior unanimidade entre os especialistas. O Brasil, que possui 5.561 municípios e 65 destinos indutores do turismo, além de ativos em termos de competitividade pautados em recursos que são apropriados pelo turismo, como a natureza e cultura, perde uma valiosa oportunidade de investir e inovar em serviços turísticos, pautados por sua vez pela sustentabilidade ambiental, cultural, econômica e social.

\section{Os 3 destinos turísticos mais citados de forma geral:}

O Infográfico 3 abaixo apresenta os três destinos turísticos mais citados de forma geral pelos 50 especialistas participantes da pesquisa. O destino turístico Bonito (MS) uma vez mais ocupa a primeira posição, com 15\%, seguido de Fernando de Noronha (PE), com 9\% e Serra Gaúcha (RS), com 7\%. O total das respostas em relação a "desconhece" corresponde a $22 \%$ no total acumulado.
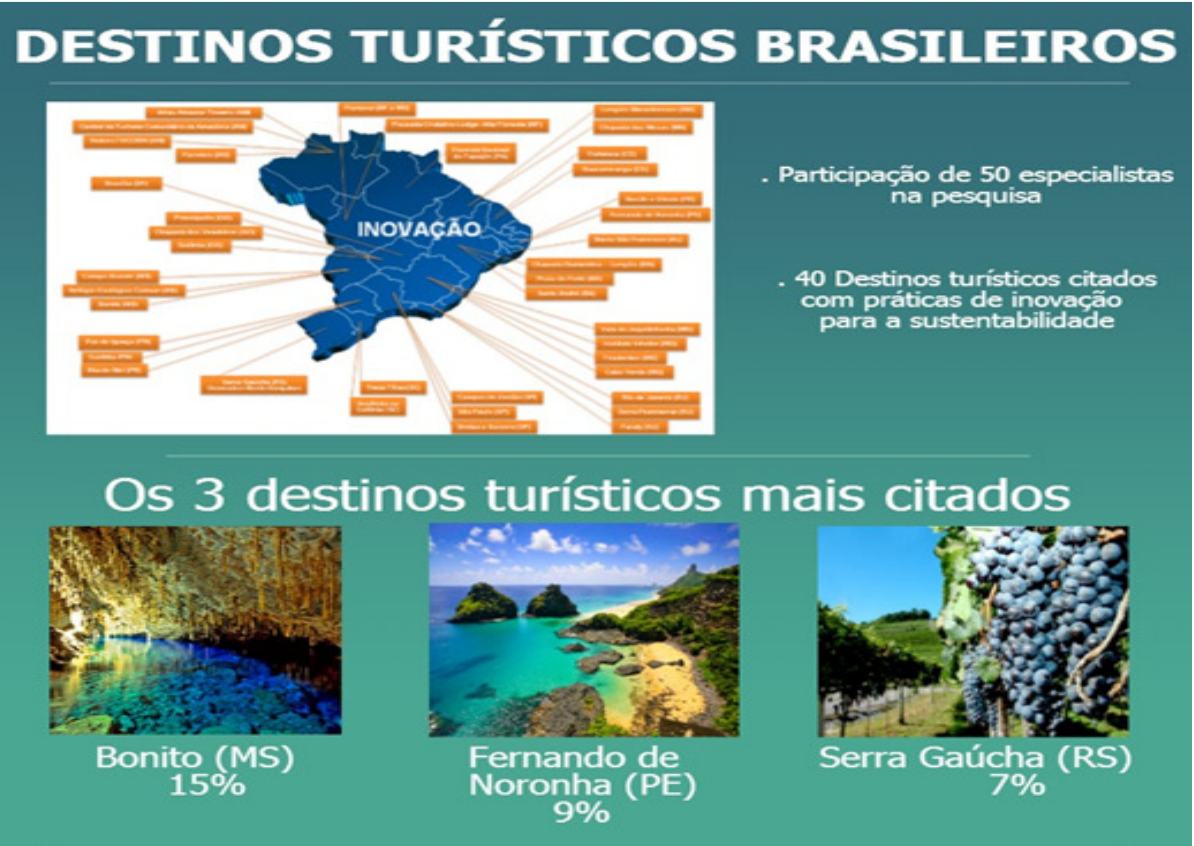

Regiões brasileiras: destinos turísticos com mais práticas de inovação para a sustentabilidade

Regiōes brasileiras:

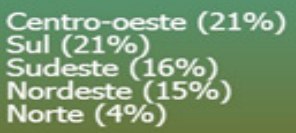
Norte $(4 \%)$

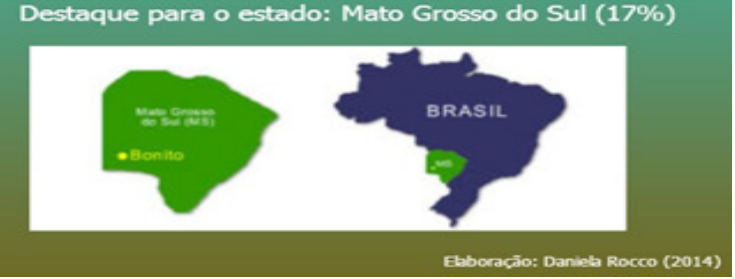

Infográfico 3 - Destinos turísticos brasileiros: inovação para a sustentabilidade Fonte: Elaborado por Daniela Rocco (2014) 
O Infográfico 3 também apresenta destaque para os estados e regiões brasileiras que mais possuem práticas de inovação para a sustentabilidade. De forma complementar, os gráficos 07 e 08 demonstram as porcentagens alcançadas.

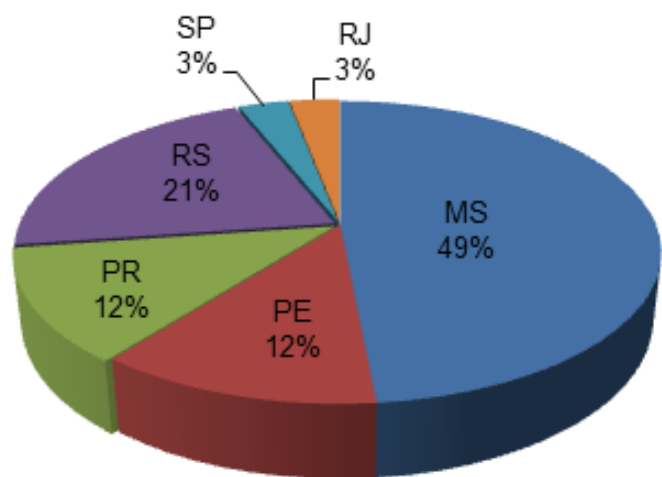

Gráfico 07 - Estados com mais destinos com práticas de inovação para a sustentabilidade Fonte: Elaborado por Daniela Rocco (2014)

Da pesquisa relativa ao gráfico 07 vale mencionar que os estados Pará, Ceará e Alagoas alcançaram apenas $1 \%$ entre as menções dos especialistas. Ademais, nove estados brasileiros não foram citados: Acre, Rondônia, Roraima, Amapá, Tocantins, Rio Grande do Norte, Paraíba, Sergipe e Espírito Santo. Provavelmente existam práticas de inovação para a sustentabilidade nos destinos turísticos dos estados não mencionados, mesmo porque a presente pesquisa não abrangeu o universo de especialistas em inovação e turismo do Brasil, é um tema recente de estudos e o território brasileiro é extremamente vasto.

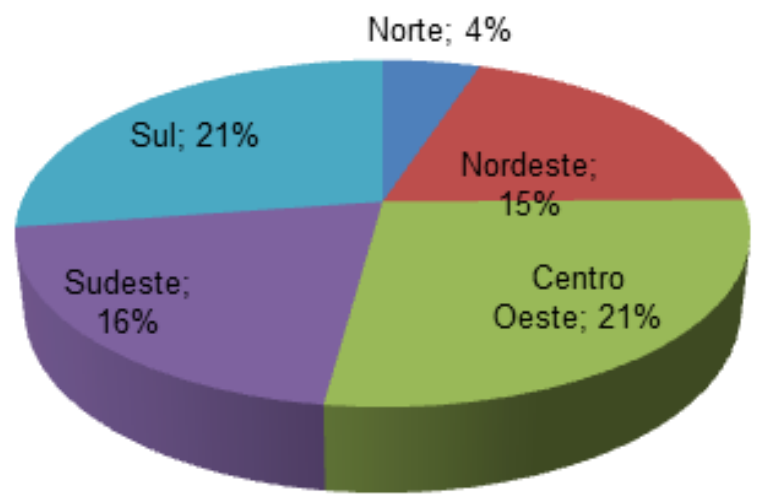

Gráfico 08 - Regiões com mais destinos com práticas de inovação para a sustentabilidade Fonte: Elaborado por Daniela Rocco (2014)

De fato, o estado do Mato Grosso do Sul se destaca em função, principalmente, das boas e melhores práticas conduzidas por atores locais de Bonito. Em algumas justificativas 
é possível verificar que ora os especialistas visitaram o destino, ora somente o conhece por meio das iniciativas publicadas na literatura, mídia em geral e experiências de pessoas próximas que já visitaram o destino. Pode-se inferir, ainda, que tanto Bonito (MS) quanto Fernando de Noronha (PE) são os destinos que possuem forte posicionamento em relação à inovação para a sustentabilidade no turismo.

\subsubsection{CRUZAMENTO DAS PERGUNTAS E RESPOSTAS}

A seguir serão apresentadas análises entre os cruzamentos mais relevantes na pesquisa. Além disso, é importante diferenciar as análises por região brasileira, uma vez que, tal como é possível constatar a seguir, as demandas por inovação no Norte e Nordeste são diferentes das da região Sudeste, por exemplo.

\section{- Importância das práticas}

A prática mais citada é a n. 2, "Incentivo ao empreendedorismo e à gestão empresarial focada na inovação, com programas de financiamento e subvenções econômicas tendo como requisitos a inovação e a sustentabilidade", que foi considerada por $98 \%$ como importante ou muito importante em relação à competitividade (gráfico 05). Além disso, essa prática foi considerada a mais importante para os destinos turísticos (gráfico 04), com $15 \%$ e considerada uma das mais relevantes para se disseminar no futuro, com $56 \%$ (gráfico 06).

No entanto, a prática n. 8 ("Inovações sociais com melhoria das condições de trabalho, educação, saúde, além de socialização nos espaços públicos - repercussão direta/indireta no turismo"), que foi citada apenas por $10 \%$ dos especialistas quanto à importância para os destinos turísticos (gráfico 04), foi considerada importante ou muito importante por $92 \%$ da amostra em relação à competitividade (gráfico 05 ) e com potencial mediano de disseminação no futuro por $50 \%$ (gráfico 06). A inovação social, disposta de forma ordenada, não está entre as mais importantes práticas, porém, quando analisada separadamente, mostra sua importância em relação à competitividade (em relação ao gráfico 04 , pois corresponde a $10 \%$ ).

Quando se analisa a competitividade, as práticas de inovações relacionadas ao empreendedorismo ou à questão social são as mais evidentes. 


\section{- Grau de importância das práticas para a competitividade e a potencial disseminação das mesmas no futuro}

Além da prática n. 2, "Incentivo ao empreendedorismo e à gestão empresarial [...]" ter sido citada como uma das mais importantes para os destinos turísticos (15\%, gráfico 04), apresentar grande potencial de disseminação no futuro (56\%, gráfico 06), no quesito grau de importância para a competitividade é também bastante expressiva ( $98 \%$ importante e muito importante, gráfico 05).

A prática n. 3, "Ações de marketing e comunicação social que ampliem a consciência pública sobre a necessidade de modelos de negócios mais sustentáveis, incentivando inclusive a redução do consumo - repercussão direta/indireta no turismo" possui o potencial mais elevado de disseminação no futuro, com 68\% (gráfico 06). Com relação à competitividade, é considerada por $82 \%$ como importante ou muito importante (gráfico 05).

No tocante à prática n. 11, "Premiação de iniciativas de inovações vinculadas à sustentabilidade nos destinos turísticos", 56\% dos especialistas acreditam que haverá disseminação elevada no futuro (gráfico 06). O próprio Ministério do Turismo recentemente começou a premiar boas práticas de destinos turísticos do País. Quando a prática n. 11 é analisada a partir da competitividade (gráfico 05), ela é 60\% muito importante ou importante, todavia, no mesmo gráfico 05 apresenta o menor índice entre importante e muito importante.

O potencial menos elevado de disseminação no futuro (gráfico 06) está vinculado à prática n. 12: "Uso de veículos e meios de transporte (rodoviário, ferroviário, aéreo e hidroviário) ecologicamente adequados com redução da pegada ecológica (ex: biocombustível, energia solar, energia eólica, etc.)". Este resultado dialoga com o gráfico 04. Além de ter sido pouco citado entre as mais importantes práticas para os destinos turísticos brasileiros (1\%, gráfico 04), apenas $20 \%$ considera que há potencial elevado de disseminação no futuro (gráfico 06).

Todas as práticas foram consideradas importantes em graus distintos, ou seja, nenhuma prática foi considerada sem importância de forma representativa.

\section{- Cruzamento entre região brasileira com destinos mais citados}

Das respostas dos especialistas do Centro-oeste 57\% concentram-se nos destinos Bonito (29\%), Fernando de Noronha (14\%) e Foz do Iguaçu (14\%). Todos os entrevistados dessa região brasileira citaram os três destinos que mais possuem práticas de inovação 
para a sustentabilidade no turismo (nenhum citou desconhecer). Dos entrevistados do Norte e Nordeste $21 \%$ desconhecem quais destinos possuem práticas de inovação para a sustentabilidade. Das respostas dos especialistas do Sudeste, 24\% desconhecem destinos que possuem práticas de inovação para a sustentabilidade. Além disso, da região Sudeste: o destino mais citado foi Bonito (14\%), em seguida da Serra Gaúcha (9\%) e Fernando de Noronha (6\%). Finalmente, das respostas dos especialistas do Sul, 23\% desconhecem destinos que possuem práticas de inovação para a sustentabilidade. Para os especialistas do Sul: 13\% citaram Bonito (MS), 10\% a Serra Gaúcha (RS), 10\% Fernando de Noronha (PE), 7\% Curitiba (PR), 7\% Foz do Iguaçu (PR) e 3\% Blumenau. Estes 6 destinos totalizam $47 \%$, sendo que 4 são da região Sul (total: $27 \%$ ).

\section{- Cruzamento entre profissão com destinos mais citados}

- Professores: $15 \%$ dos professores desconhecem, 20\% citaram Bonito, $8 \%$ Curitiba e 6\%Foz do Iguaçu (somatório: 44\%);

- Empresários: 11\% desconhecem, 19\% citaram Fernando de Noronha, 19\% Bonito e 7\% Bento Gonçalves (somatório: 44\%);

- Consultores e representantes do Terceiro setor: $33 \%$ desconhecem, $11 \%$ citaram a Serra Gaúcha e 9\% Bonito.

\section{- Especialistas do Norte e Nordeste: cruzamento entre as 3 práticas mais importantes para os destinos turísticos brasileiros com as práticas mais importantes para a competitividade e com as práticas que possuem potencial de disseminação no futuro}

De acordo com os especialistas do Norte e Nordeste, a prática mais importante para os destinos turísticos brasileiros é a n. 1, "Políticas públicas menos burocráticas (gestão eficiente), adoção de "compras públicas verdes" e estímulo à cultura da C,T\&I (Ciência, Tecnologia e Inovação) - repercussão direta/indireta no turismo", com 19\% das respostas. Com 14\% cada uma destacam-se as práticas n. 3 ("Ações de marketing e comunicação social que ampliem a consciência pública sobre a necessidade de modelos de negócios mais sustentáveis, incentivando inclusive a redução do consumo - repercussão direta/indireta no turismo"); n. 4 ("Certificação de destinos e empresas turísticas - Sistema de Gestão Ambiental, de Qualidade, do Trabalho e Eventos Sustentáveis, além de iniciativas voluntárias e selos") e n. 8 ("Inovações sociais com melhoria das condições de trabalho, educação, saúde, além de socialização nos espaços públicos - repercussão direta/indireta 
no turismo"). De forma comparativa ao resultado geral dessa análise (gráfico 04), a prática n. 2 ("Incentivo ao empreendedorismo e à gestão empresarial focada na inovação, com programas de financiamento e subvenções econômicas tendo como requisitos a inovação e a sustentabilidade") está entre as mais citadas, enquanto que para o grupo de especialistas do Norte e Nordeste essa prática representa apenas $5 \%$.

Das 12 práticas, sete foram citadas como muito importantes para a competitividade, ou seja, mais da metade das práticas foram consideradas importantes para a competitividade. Infere-se que há uma grande demanda por práticas de inovação em relação aos demais grupos, tal como será constatado a seguir.

Em termos de potencial de disseminação no futuro, $24 \%$ dos especialistas do Norte e Nordeste consideram o uso das TIC (prática n. 6) e ações de marketing (prática n. 3) com potencial elevado de disseminação no futuro, enquanto que $19 \%$ consideram o incentivo ao empreendedorismo (prática n. 2) e premiação (prática n. 11) como potencial elevado de disseminação no futuro.

- Especialistas do Centro-oeste: cruzamento entre as 3 práticas mais importantes para os destinos turísticos brasileiros com as práticas mais importantes para a competitividade e com as práticas que possuem potencial de disseminação no futuro

As mais citadas práticas para o destino são: prática n. 3 ("Ações de marketing e comunicação social que ampliem a consciência pública sobre a necessidade de modelos de negócios mais sustentáveis, incentivando inclusive a redução do consumo - repercussão direta/indireta no turismo"), com 19\% e prática n. 9 ("Atividades econômicas nos destinos turísticos que sejam de uso sustentável da biodiversidade, valorizando a cultura local e considerando os princípios de mercado justo/economia solidária"), também com 19\%. A prática n. 1 ("Políticas públicas menos burocráticas (gestão eficiente), adoção de "compras públicas verdes" e estímulo à cultura da C,T\&I (Ciência, Tecnologia e Inovação) repercussão direta/indireta no turismo") representam $14 \%$.

Das 12 práticas, apenas duas foram citadas como muito importantes para a competitividade: prática n. 2 ("Incentivo ao empreendedorismo e à gestão empresarial focada na inovação, com programas de financiamento e subvenções econômicas tendo como requisitos a inovação e a sustentabilidade") e prática n. 3 ("Ações de marketing e comunicação social que ampliem a consciência pública sobre a necessidade de modelos de negócios mais sustentáveis, incentivando inclusive a redução do consumo - repercussão direta/indireta no turismo"). 
Segundo os especialistas do Centro-oeste, o mais elevado potencial de disseminação no futuro está na prática 6, "O uso das TIC (Tecnologia da Informação e Comunicação) destinadas a turistas (facilitação da mobilidade) e para o planejamento e prevenção de impactos negativos (ex: geoprocessamento para identificar pontos de crimes e prevenir queimadas)", com $71 \%$ e na prática n. 3, "Ações de marketing e comunicação social que ampliem a consciência pública sobre a necessidade de modelos de negócios mais sustentáveis, incentivando inclusive a redução do consumo - repercussão direta/indireta no turismo", com $57 \%$.

- Especialistas do Sudeste: cruzamento entre as 3 práticas mais importantes para os destinos turísticos brasileiros com as práticas mais importantes para a competitividade e com as práticas que possuem potencial de disseminação no futuro

O resultado obtido entre os especialistas do Sudeste tende a permanecer semelhante em relação ao resultado geral. Quanto à competitividade, $100 \%$ dos especialistas consideram que prática n. 1 ("Políticas públicas menos burocráticas (gestão eficiente), adoção de "compras públicas verdes" e estímulo à cultura da C,T\&I (Ciência, Tecnologia e Inovação) - repercussão direta/indireta no turismo") como a mais importante. A segunda prática mais importante para a competitividade, segundo os especialistas do Sudeste, é a n. 2 ("Incentivo ao empreendedorismo e à gestão empresarial focada na inovação, com programas de financiamento e subvenções econômicas tendo como requisitos a inovação e a sustentabilidade"), com 96\%. Por fim, a prática que mais de destaca por ter um elevado potencial de disseminação no futuro é a n. 3 ("Ações de marketing e comunicação social que ampliem a consciência pública sobre a necessidade de modelos de negócios mais sustentáveis, incentivando inclusive a redução do consumo repercussão direta/indireta no turismo"), com 69\%.

- Especialistas do Sul: cruzamento entre as 3 práticas mais importantes para os destinos turísticos brasileiros com as práticas mais importantes para a competitividade e com as práticas que possuem potencial de disseminação no futuro

Para os especialistas do Sul, a prática mais importante para os destinos turísticos é a n. 2 ("Incentivo ao empreendedorismo e à gestão empresarial focada na inovação, com 
programas de financiamento e subvenções econômicas tendo como requisitos a inovação e a sustentabilidade"), com 20\%, seguida da prática n. 7 ("Aplicação de taxas de uso ambiental retornando à sociedade como forma de investimento em inovações e sustentabilidade, como melhoria da infraestrutura, manutenção de trilhas, proteção dos ecossistemas, uso de novas tecnologias, entre outros"), com 16\% e da prática n. 3 ("Ações de marketing e comunicação social que ampliem a consciência pública sobre a necessidade de modelos de negócios mais sustentáveis, incentivando inclusive a redução do consumo repercussão direta/indireta no turismo"), com 13\%.

Em relação à competitividade, a única prática citada por $100 \%$ dos especialistas é a n. 2 ("Incentivo ao empreendedorismo e à gestão empresarial focada na inovação, com programas de financiamento e subvenções econômicas tendo como requisitos a inovação e a sustentabilidade"). Em seguida se destacam: prática n. 4 ("Certificação de destinos e empresas turísticas - Sistema de Gestão Ambiental, de Qualidade, do Trabalho e Eventos Sustentáveis, além de iniciativas voluntárias e selos"), considerada importante ou muito importante por $90 \%$ dos especialistas e a prática n. 7 ("Aplicação de taxas de uso ambiental retornando à sociedade como forma de investimento em inovações e sustentabilidade, como melhoria da infraestrutura, manutenção de trilhas, proteção dos ecossistemas, uso de novas tecnologias, entre outros"), também considerada importante ou muito importante por $90 \%$ dos especialistas.

No que tange ao potencial de disseminação no futuro, $80 \%$ consideram que a prática n. 2 ("Incentivo ao empreendedorismo e à gestão empresarial focada na inovação, com programas de financiamento e subvenções econômicas tendo como requisitos a inovação e a sustentabilidade") possui elevado potencial. Para $70 \%$ dos especialistas do Sul a prática n. 3 ("Ações de marketing e comunicação social que ampliem a consciência pública sobre a necessidade de modelos de negócios mais sustentáveis, incentivando inclusive a redução do consumo - repercussão direta/indireta no turismo") também possui elevado potencial. Os especialistas da região Sul são os que mais acreditam no incentivo ao empreendedorismo (80\%, prática 2).

\section{- $\quad$ Outros destaques: cruzamento entre profissões com as 3 práticas mais} importantes para os destinos turísticos brasileiros

\section{- Professores universitários:}

A prática mais importante para os destinos turísticos brasileiros, segundo $18 \%$ dos professores universitários, é a n. 1 ("Políticas públicas menos burocráticas (gestão eficiente), adoção de "compras públicas verdes" e estímulo à cultura da C,T\&I (Ciência, 
Tecnologia e Inovação) - repercussão direta/indireta no turismo"). A segunda mais importante é a n. $\mathbf{8}$ ("Inovações sociais com melhoria das condições de trabalho, educação, saúde, além de socialização nos espaços públicos - repercussão direta/indireta no turismo"), com 14\%. Em nenhuma região, com exceção do Norte/Nordeste, houve grande representatividade para a questão das inovações sociais (prática n. 8), porém para os professores universitários sim, tais inovações são bastante importantes. As práticas menos citadas foram: n. 11, "Premiação de iniciativas de inovações vinculadas à sustentabilidade nos destinos turísticos", com $2 \%$ e n. 12, "Uso de veículos e meios de transporte (rodoviário, ferroviário, aéreo e hidroviário) ecologicamente adequados com redução da pegada ecológica (ex: biocombustível, energia solar, energia eólica, etc.", tendendo a nulo.

Para a competitividade as seguintes práticas são muito importantes ou importantes: n. 8 ("Inovações sociais com melhoria das condições de trabalho, educação, saúde, além de socialização nos espaços públicos - repercussão direta/indireta no turismo") e n. 2 ("Incentivo ao empreendedorismo e à gestão empresarial focada na inovação, com programas de financiamento e subvenções econômicas tendo como requisitos a inovação e a sustentabilidade"). Cada prática obteve $100 \%$ das respostas. Por outro lado, $41 \%$ consideram que a premiação (prática n. 11) é a menos importante para a competitividade.

Com relação à disseminação no futuro, a prática que possui potencial mais elevado é a n. 3 ("Ações de marketing e comunicação social que ampliem a consciência pública sobre a necessidade de modelos de negócios mais sustentáveis, incentivando inclusive a redução do consumo - repercussão direta/indireta no turismo"), com 59\%. Empataram com 55\% as práticas n. 6, "O uso das TIC (Tecnologia da Informação e Comunicação) destinadas a turistas (facilitação da mobilidade) e para o planejamento e prevenção de impactos negativos (ex: geoprocessamento para identificar pontos de crimes e prevenir queimadas)" e n. 2, "Incentivo ao empreendedorismo e à gestão empresarial focada na inovação, com programas de financiamento e subvenções econômicas tendo como requisitos a inovação e a sustentabilidade". Ambas também possuem potencial elevado de disseminação no futuro. A prática que apresentou baixo potencial de disseminação no futuro foi a n. 12, "Uso de veículos e meios de transporte (rodoviário, ferroviário, aéreo e hidroviário) ecologicamente adequados com redução da pegada ecológica (ex: biocombustível, energia solar, energia eólica, etc.", com $45 \%$.

\section{- Empresários:}

Para 22\% dos empresários, a prática n. 5 ("Plataforma de intercâmbio gratuito de informações gerida por alianças público-privadas para fomentar a cooperação, 
especialmente entre micro e pequenas empresas de turismo") é a mais relevante para o destino e para $15 \%$ é a prática n. 2 ("Incentivo ao empreendedorismo e à gestão empresarial focada na inovação, com programas de financiamento e subvenções econômicas tendo como requisitos a inovação e a sustentabilidade"). Com esses resultados é possível inferir a importância de se fomentar relações de cooperação e criação de alianças público-privadas.

Em relação à competitividade, 100\% dos empresários consideram importante ou muito importante: o uso de plataformas de intercâmbio (prática n. 5), incentivo ao empreendedorismo (prática n. 2) e ações de marketing (prática n. 3). Além disso, nesse quesito, as TIC (prática $\mathbf{n}$. 6) foram consideradas menos importante pelos professores universitários, porém, conforme o grupo de empresários, elas são muito importantes para a competitividade.

No tocante à disseminação no futuro, a prática n. 3 (ações de marketing) apresenta elevado potencial, com 78\%, enquanto que a prática n. 6 (uso das TIC) seria a prática com maior potencial de disseminação para $67 \%$ dos empresários.

\section{- Consultores e Representantes do Terceiro setor:}

De acordo com 19\% dos consultores/representantes do Terceiro setor a prática n. 2 ("Incentivo ao empreendedorismo e à gestão empresarial focada na inovação, com programas de financiamento e subvenções econômicas tendo como requisitos a inovação e a sustentabilidade") é a mais importante para os destinos turísticos brasileiros. Porém, para 15\% desse grupo é a prática n. 9 ("Atividades econômicas nos destinos turísticos que sejam de uso sustentável da biodiversidade, valorizando a cultura local e considerando os princípios de mercado justo/economia solidária") é a mais importante. Somente $2 \%$ considera que a prática n. 12, "Uso de veículos e meios de transporte (rodoviário, ferroviário, aéreo e hidroviário) ecologicamente adequados com redução da pegada ecológica (ex: biocombustível, energia solar, energia eólica, etc." seja a mais importante. De forma geral, esse baixo grau de importância à prática $\mathbf{n} .12$ se deve a outras prioridades, como incentivo ao empreendedorismo, inovações sociais e ações de marketing. É possível verificar, diante de todas as pesquisas realizadas, que o turismo brasileiro requer ainda mudanças estruturais e conjunturais. A prática 12 é importante, porém como é preciso enfrentar outros desafios, ela que é tão avançada e recorrente em países com forte economia, se torna menos prioritária. 
Em relação à competitividade, não tem nenhuma prática citada com unanimidade de importância, porém as mais citadas foram: uso das TIC (89\%, prática n. 6) e incentivo ao empreendedorismo (94\%, prática n. 2).

Para $83 \%$ dos consultores/representantes do Terceiro setor, a prática que possui o maior potencial de disseminação no futuro é a $\mathbf{n} .11$ ("Premiação de iniciativas de inovações vinculadas à sustentabilidade nos destinos turísticos"), seguida da prática de n. 3 ("Ações de marketing e comunicação social que ampliem a consciência pública sobre a necessidade de modelos de negócios mais sustentáveis, incentivando inclusive a redução do consumo repercussão direta/indireta no turismo"), com $72 \%$.

\subsubsection{CENÁRIOS DE DESTINOS TURÍSTICOS: UM ESBOÇO DE CARTOGRAFIA} BRASILEIRA DE PRÁTICAS DE INOVAÇÃO PARA A SUSTENTABILIDADE

A Figura 25 foi construída com o intuito de facilitar a visualização de todos os destinos turísticos citados pelos 50 especialistas participantes desta pesquisa. Trata-se de uma cartografia inédita, pois nela estão registrados os 40 destinos que mais possuem práticas de inovação para a sustentabilidade no País.

Em seguida apresentamos a Figura 26 que indica quais são, dentre as 12 práticas de inovação para a sustentabilidade, as mais importantes para a competitividade turística conforme região de residência dos especialistas: Norte/Nordeste, Centro-oeste, Sudeste e Sul. Além disso, foram indicados os destinos mais citados por grupos de professores, empresários e consultores/representantes do terceiro setor, bem como a opinião deles sobre qual seria a prática mais importante para aumentar a competitividade dos destinos turísticos brasileiros. 


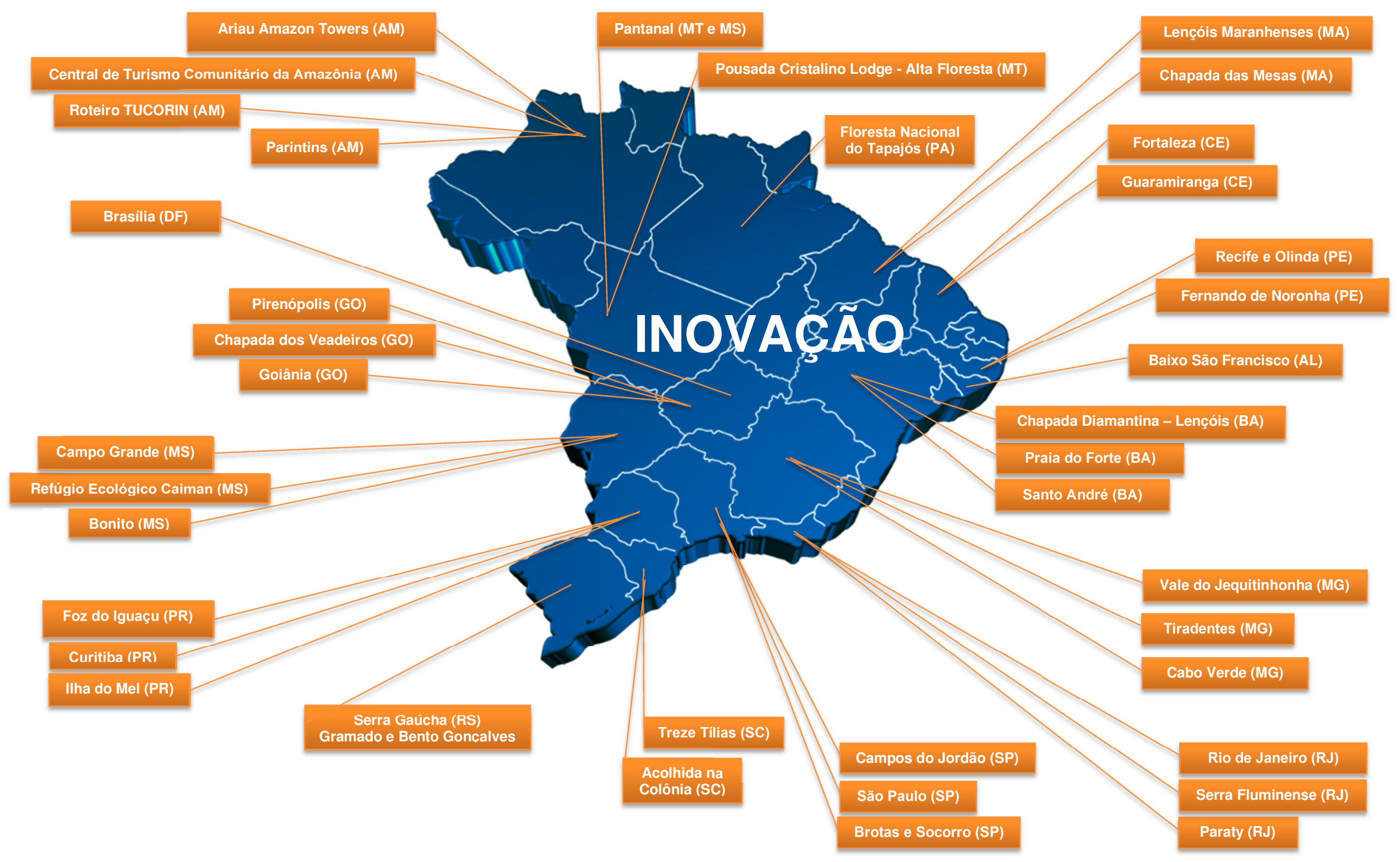

Figura 25 - Cartografia de destinos turísticos brasileiros com práticas de inovação para a sustentabilidade Elaboração: Daniela Rocco (2014)

Arte (imagem do Brasil): Ymagine Publicidade \& Design (2014) 


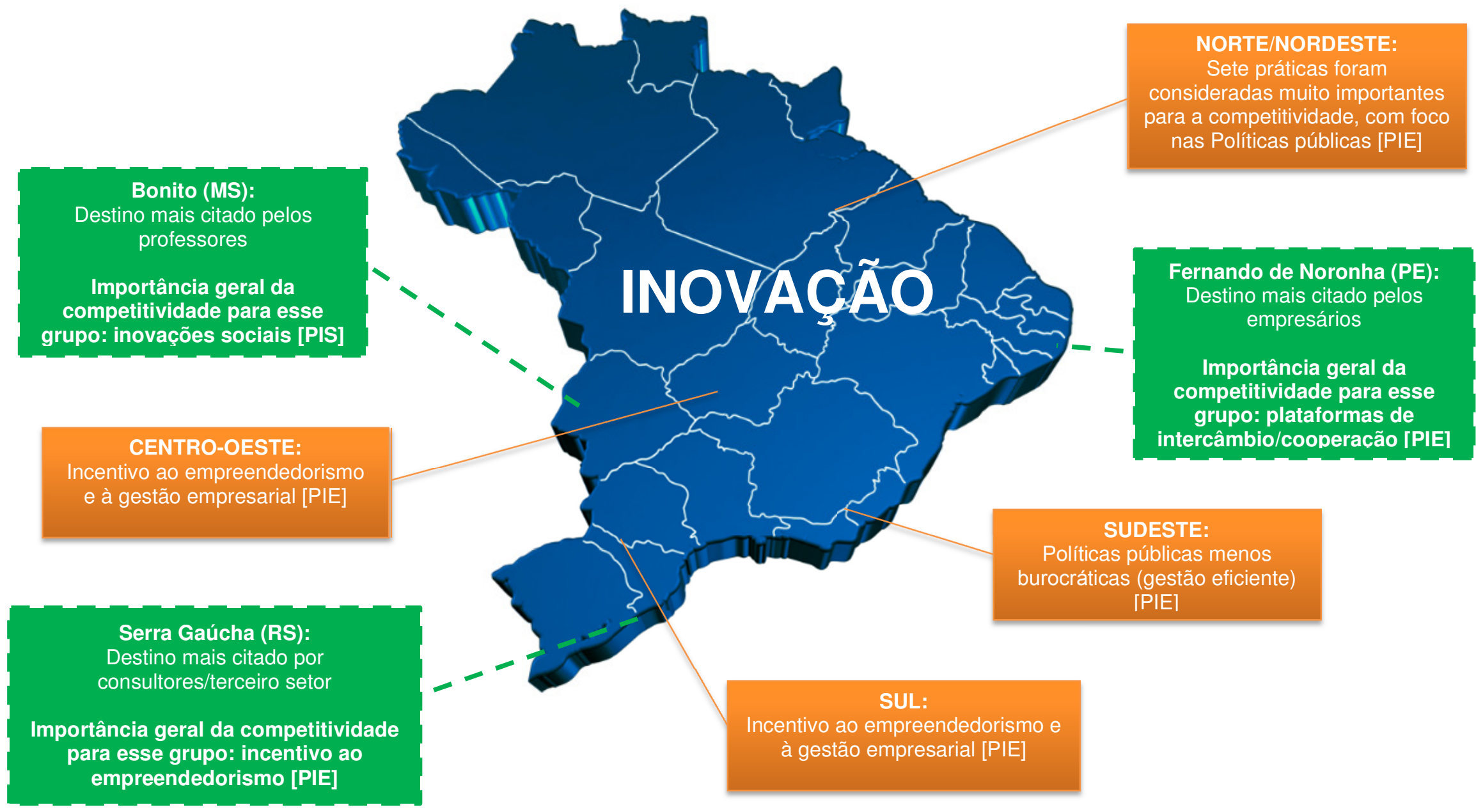

Figura 26 - Cartografia de regiões brasileiras versus lista de 12 práticas de inovação para a sustentabilidade Fonte: Elaborado por Daniela Rocco (2014)

Arte (imagem do Brasil): Ymagine Publicidade \& Design (2014) 
Como é possível constatar, a maioria das práticas de inovação para a sustentabilidade no turismo está relacionada com a necessidade de políticas públicas menos burocráticas e incentivo ao empreendedorismo. Na última seção do capítulo 5 faremos uma análise mais detalhada sobre esse resultado. Vale salientar, ainda, que no Apêndice $D$ são apresentadas tendências turísticas futuras, experiências de inovação para a sustentabilidade em destinos turísticos de várias partes do mundo e demais processos de inovação que repercutem direta e indiretamente no turismo.

A maioria das experiências brasileiras de inovação para a sustentabilidade no turismo nem sempre terão as dimensões ambiental, social, cultural e econômica combinadas ao mesmo tempo. Entretanto, por ser o presente estudo ainda muito recente no âmbito internacional e nacional, acreditamos que seja válido expor a seguir algumas experiências brasileiras relativas aos três estados dos destinos turísticos selecionados: Mato Grosso do Sul, Rio Grande do Sul e Minas Gerais. Práticas de inovação para a sustentabilidade no turismo referentes a outros estados (são contempladas as cinco regiões brasileiras) também podem ser vistas no Apêndice D.

$\mathrm{Na}$ Figura 27 criamos quatro pictogramas com as quatro dimensões da sustentabilidade assim dispostas: i) mesma proporção entre as dimensões ambiental, social, cultural e econômica da sustentabilidade; ii) foco maior na dimensão ambiental da sustentabilidade; iii) foco maior na dimensão social da sustentabilidade e iv) foco maior na dimensão cultural da sustentabilidade. Não foi o propósito encontrar casos de inovação para a sustentabilidade que tivessem foco maior na dimensão econômica, por isso esta não possui pictograma. A dimensão econômica, obviamente, é relevante, todavia, por ser condição sine quan non nos processos produtivos, optamos por priorizar as outras dimensões. Vale citar que a letra "S" no centro de cada pictograma significa sustentabilidade

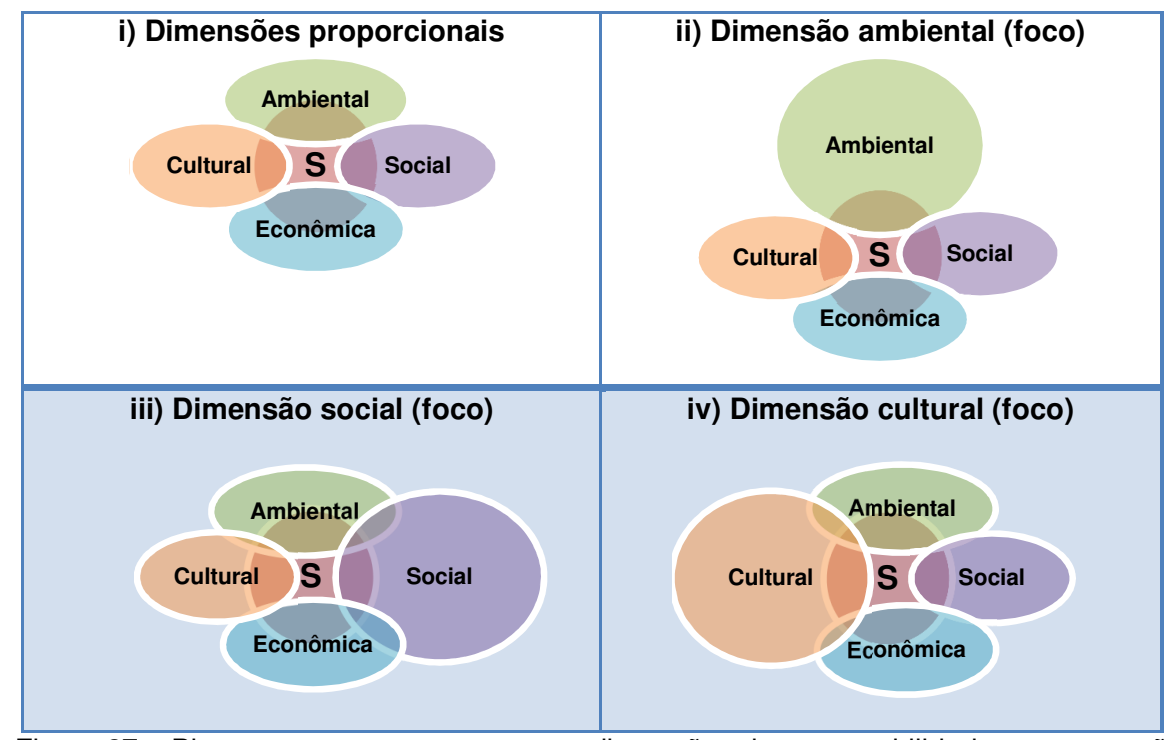


Os pictogramas acima apresentados foram inspirados no trabalho desenvolvido por Veyret \& Arnoulg (2008) sobre desenvolvimento sustentável, conforme mostra a Figura 28 a seguir. Os autores trabalharam a partir da lógica do triple-bottom-line (abordagem das dimensões ambiental, social e econômica), porém consideraram também no modelo a ética na política e a questão cultural.
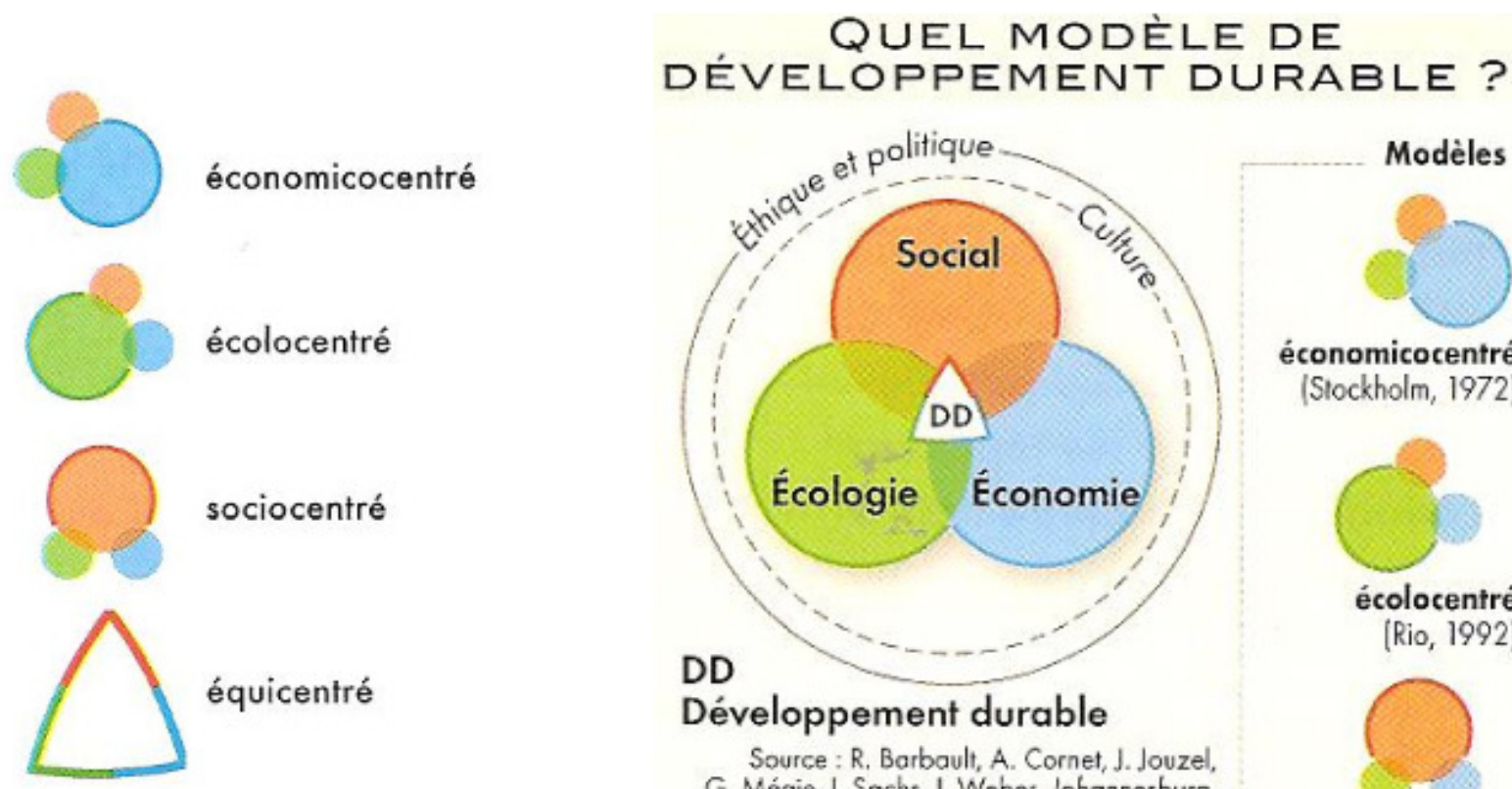

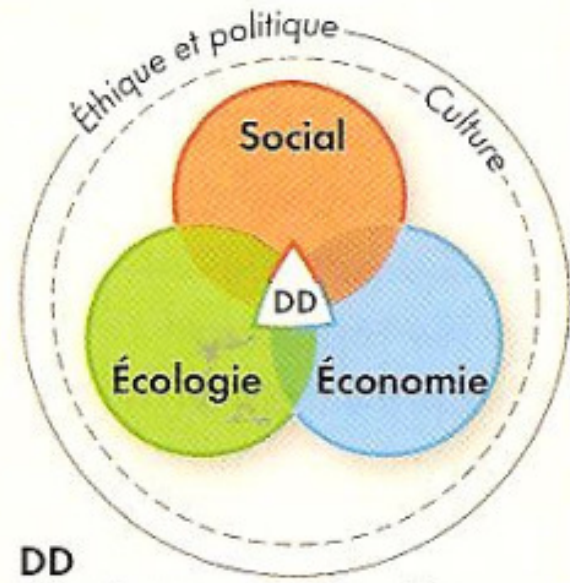

Développement durable

Source : R, Barbault, A. Cornet, J. Jouzel, G. Mégie, I. Sachs, J. Weber, Johannesburg. Sommet mondial du développement durable. Quels enjeux 3 Quelle contribution des scientifiques? 2002.
Modèles

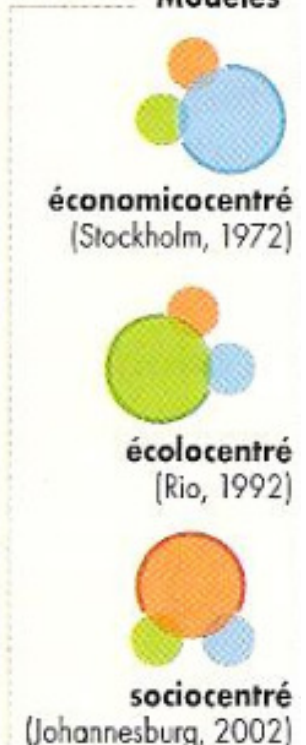

Figura 28 - Modelo de pictogramas criado por Veyret \& Arnoulg (2008) Fonte: Veyret \& Arnoulg (2008)

Esses autores fizeram um mapeamento de várias áreas, inclusive sobre o turismo sustentável, tal como expõe a Figura 29.

Como se pode verificar, o mapa abaixo mostra situações de turismo de massa e espaços de ecoturismo no mundo. Segundo Veyret \& Arnoulg (2008) o Rio de Janeiro é, no Brasil, locus de turismo de massa, enquanto na região da Amazônia existem alguns pontos de práticas de ecoturismo. 


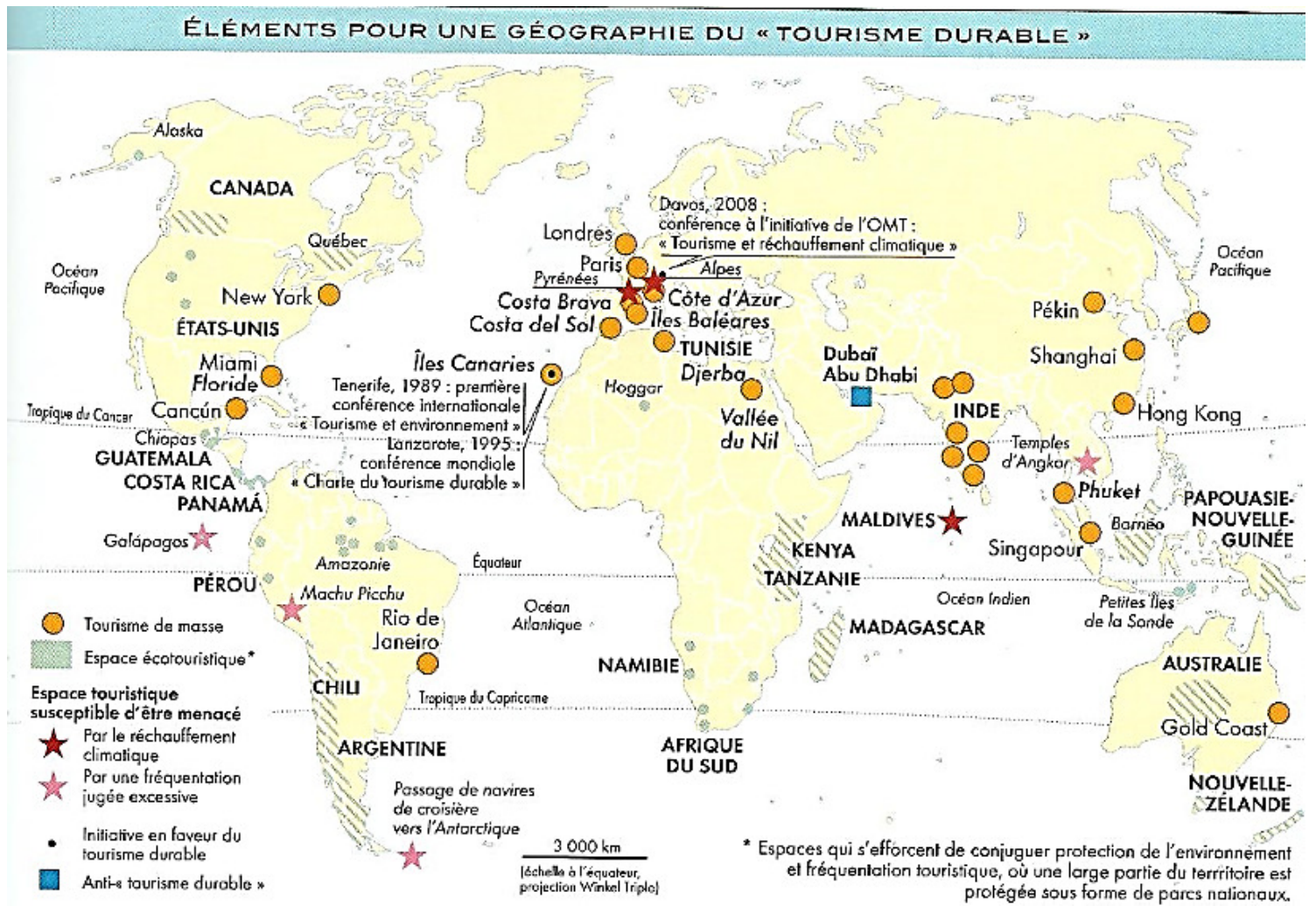

Figura 29 - Mapa do turismo sustentável e pontos de turismo de massa no mundo Fonte: Veyret \& Arnoulg (2008)

Para Veyret \& Arnoulg (2008), em muitos casos há desequilíbrio entre as dimensões (como é o caso do turismo no mundo) e é um desafio pôr em marcha um ciclo harmonioso entre elas. De toda forma, os pictogramas representam uma forma interessante para que o leitor perceba facilmente o desequilíbrio de alguns casos estudados, bem como a necessidade de estudar melhor cada um deles.

A seguir, serão apresentadas algumas práticas de inovação para a sustentabilidade nos três estados brasileiros. Elas foram citadas pelos especialistas participantes desta pesquisa e/ou encontradas por meio da pesquisa exploratória. Além disso, elas possuem correspondência com os pictogramas elaborados de acordo com a Figura 27.

\section{MATO GROSSO DO SUL (MS)}

Destino: Refúgio Ecológico Caiman (Pantanal)

Inovação: Primeira operação de ecoturismo no Pantanal do MS

Iniciativa: privada

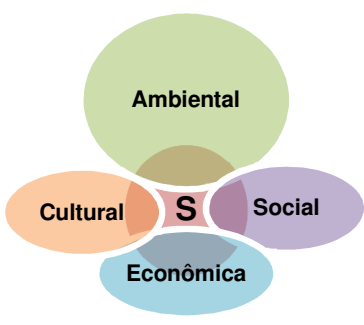


Breve contextualização da inovação: Esta foi uma indicação de um dos especialistas (Professor universitário, Distrito Federal, mais de 20 anos de experiência). É uma fazenda criada em 1985, que possui 53 mil hectares e que desenvolve atividades de ecoturismo e de conservação da natureza (exposições e pesquisas in loco sobre a biodiversidade com a participação de instituições de ensino superior). Os passeios na fazenda também desempenham um trabalho diferenciado de educação ambiental, pois os visitantes são acompanhados por Caimaners (guias naturalistas, graduados e bilíngues em inglês e português) e Condutores Nativos (possuem conhecimento profundo da região). Outra atividade que merece destaque é o Workshop de Astronomia. Na alta temporada um guia especialista se reúne com visitantes para mostrá-los os planetas e constelações. Utilizam-se lunetas e é possível observar, inclusive, os anéis do planeta Saturno.

Fonte: Refúgio Ecológico Caiman (http://caiman.com.br/sobre).

Destino: Fazenda San Francisco (Pantanal)

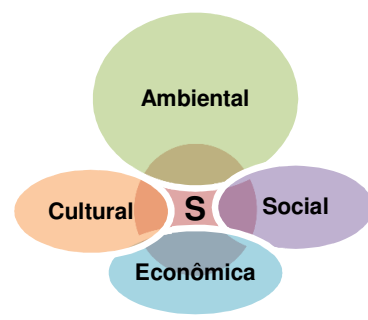

Inovação: Único atrativo do Pantanal (MS) certificado em Gestão da Segurança

Iniciativa: privada

Breve contextualização da inovação: Como já foi apresentado, o processo de certificação para a gestão da segurança em atrativos no Brasil foi inédito e iniciado recentemente. Do Pantanal (estado do MS), a Fazenda San Francisco por enquanto é a única que possui tal certificação. Além disso, são desenvolvidos diversos projetos voltados para a conservação ambiental.

Fonte: Fazenda San Francisco (http://www.fazendasanfrancisco.tur.br/)

\section{MINAS GERAIS (MG)}

Minas Gerais tem sido pioneira em diversos segmentos. Em 2013 foi lançado pelo governo do estado o Data Viva (http://dataviva.info/), que é uma plataforma online de big data construída em parceria com o Massachusetts Institute of Technology (MIT) e a Universidade de Harvard (EUA). Esta plataforma, a primeira do País, reúne dados dos ministérios do Trabalho e Emprego (MTE) e Desenvolvimento, Indústria e Comércio Exterior (MDIC). Qualquer pessoa pode ter acesso a mais de 100 milhões de informações sobre 
diversos setores da economia brasileira (disponíveis em português e inglês). No âmbito do turismo foram identificadas duas categorias de pesquisa, cujos usuários também podem gerar múltiplos cruzamentos de informações. São elas "Artes, Entretenimento e Recreação" (classes: clubes esportivos, instalações esportivas, outras atividades de lazer, artes e entretenimento, parques de diversão, outras atividades esportivas, reservas naturais, outras atividades culturais, bibliotecas e museus e jogos de azar) (Figura 30) e "Serviços de Alimentação e Hospitalidade" (classes: restaurante, hotel, catering, outros serviços de alimentação, serviços de bar, outros serviços de hospitalidade e camping) (Figura 31).

Como é possível verificar por meio das duas figuras abaixo, São Paulo, Rio de Janeiro e Minas Gerais se destacam por mais empregarem pessoas nas duas categorias mencionadas. No total, o Brasil emprega 226 mil pessoas na primeira categoria citada e 1,74 milhões na segunda.

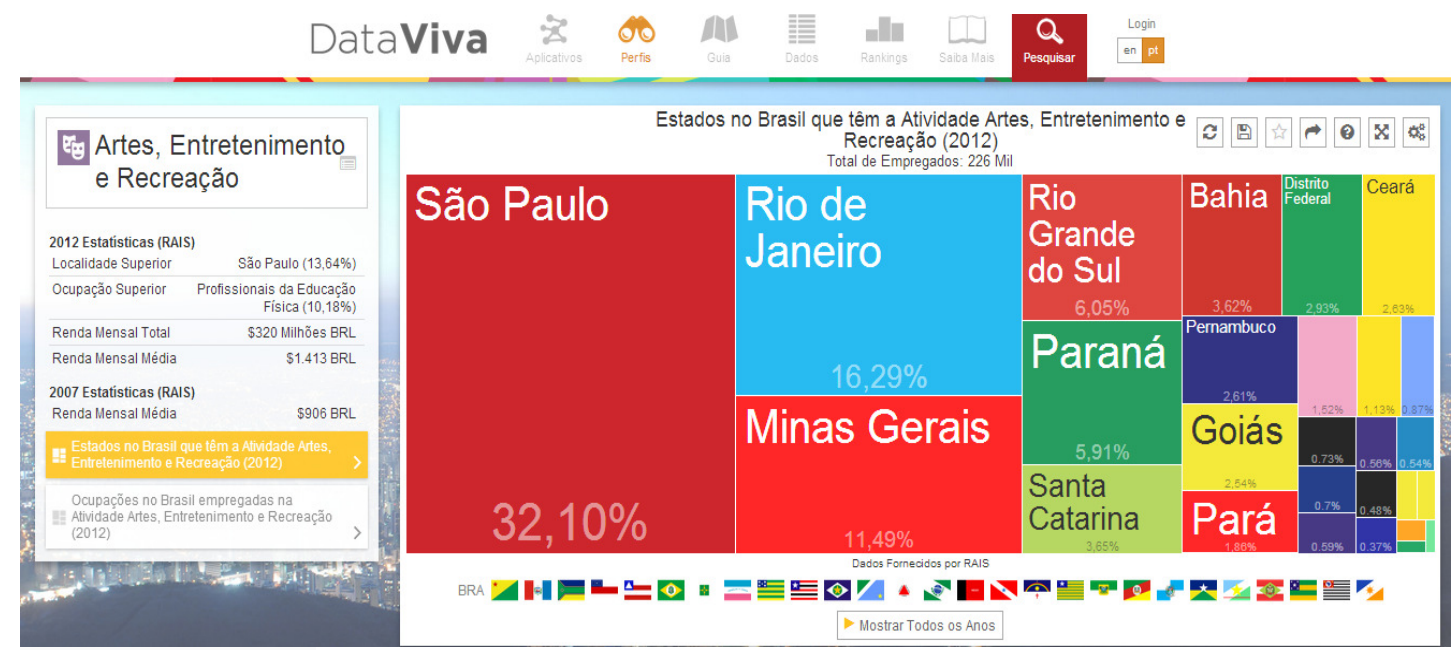

Figura 30 - DataVida (Artes, Entretenimento e Recreação)

Fonte: http://dataviva.info/

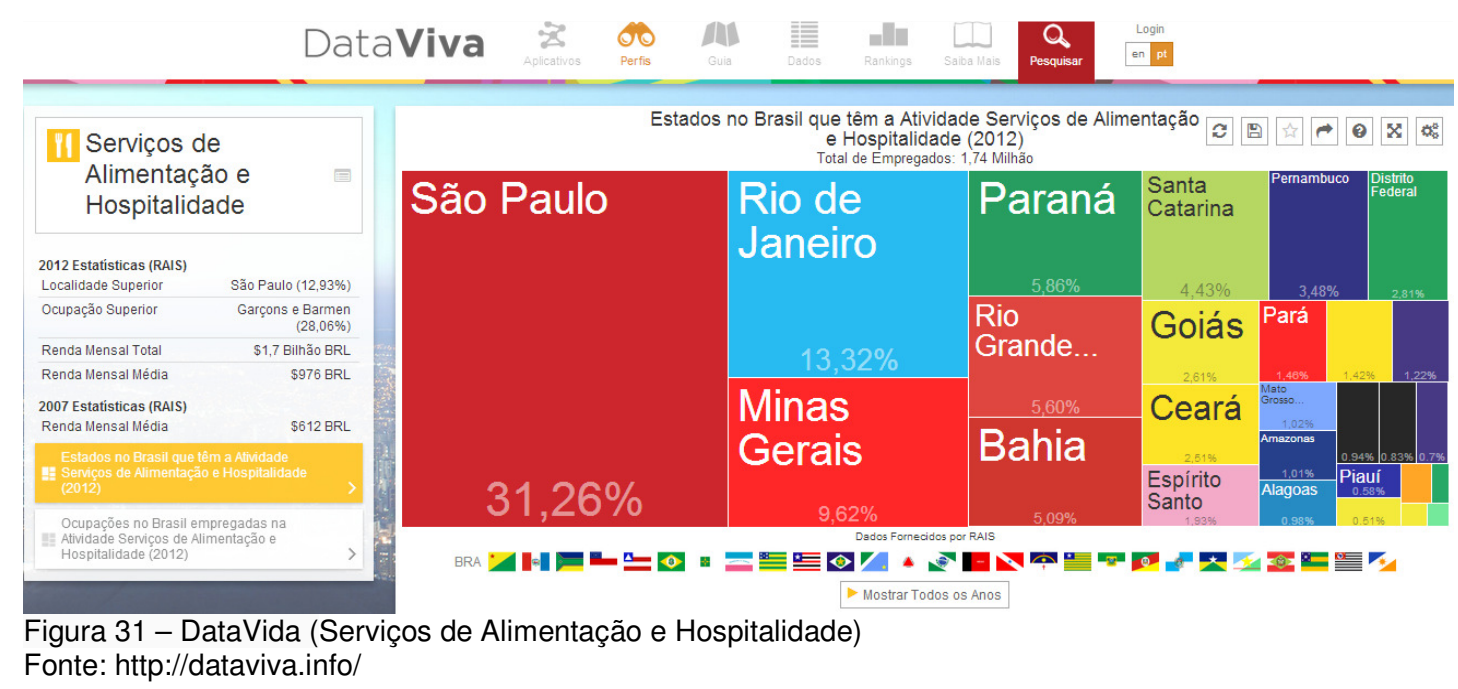


Destino: Vale do Jequitinhonha

Inovação: Crowdfunding para o Turismo Sustentável

Iniciativa: Terceiro setor

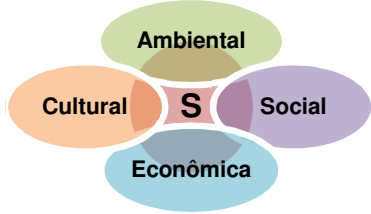

Breve contextualização da inovação: As organizações sem fins lucrativos Garupa e Juntos.com.vc criaram uma plataforma especialmente direcionada para promover o turismo sustentável. A inovação mais recente dessa parceria foi a criação de um canal de crowdfunding exclusivo para financiar projetos de iniciativa social no contexto turístico. Os colaboradores do "Crowdfunding para o Turismo Sustentável" fizeram doação de dinheiro para que o projeto "FAZENDO ARTE COM O BARRO DO JEQUITINHONHA" pudesse ser desenvolvido. Foram no total 80 doadores e a meta já foi alcançada, alcançando $102 \%$.

Fonte: Garupa (http://www.garupa.juntos.com.vc/projetos/raizes/)

Destino: Belo Horizonte

Inovação: "Circuito Cultural da Praça da Liberdade"

Iniciativa: público-privada

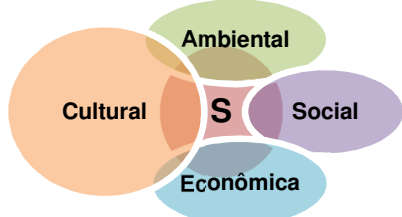

Breve contextualização da inovação: O "Circuito Cultural da Praça da Liberdade" é um pequeno cluster de 12 museus e espaços culturais localizado em um dos pontos turísticos mais importantes da cidade: a Praça da Liberdade. Esse circuito, inaugurado em 2011, é considerado um dos maiores complexos culturais do Brasil e sua implementação foi resultado de uma parceria público-privada. Os museus e espaços são: Centro Cultural Banco do Brasil, Centro de Arte Popular - CEMIG, Espaço TIM UFMG do Conhecimento, Memorial de Minas Gerais - Vale, Museu das Minas e do Metal, Arquivo Público Mineiro, Biblioteca Pública Estadual Luiz de Bessa, Museu Mineiro, Palácio da Liberdade, Museu do Automóvel, Inhotim Escola e Casa Fiat de Cultura.

Fonte: Circuito Liberdade (http://www.circuitoliberdade.mg.gov.br/)

Destino: Tiradentes

Inovação: Calendário de eventos culturais

Iniciativa: público-privada

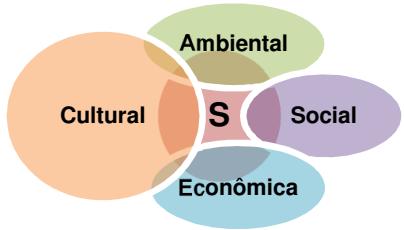

Breve contextualização da inovação: O município incrementou bastante a atividade turística por meio de atividades relacionadas à economia criativa. Foram criados, assim, o Festival de cinema e o Festival de Gastronomia, onde se tem qualidade dos produtos, intercâmbio cultural e de experiências, criação de parcerias público-privadas que geram 
riqueza local e ações que garantem a consolidação do destino (ganho de imagem e repercussão na mídia)

Fonte: Especialista (Consultor, Santa Catarina, mais de 20 anos de experiência)

\section{RIO GRANDE DO SUL (RS)}

Destino: Osório

Inovação: Parque Eólico

Iniciativa: privada

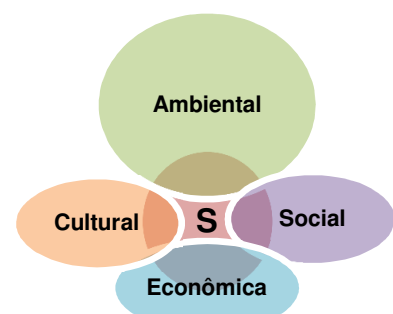

Breve contextualização da inovação: O Parque Eólico de Osório, construído pela empresa Ventos Sul Energia (http://www.ventosdosulenergia.com.br/highres.php), possui estrutura no município de Osório (principal), Sangradouro e Índios. Maior complexo de geração de energia eólica da América Latina, o empreendimento conta com 75 aerogeradores de 2 megawatts cada (Figura 32). Inclusive, em 2006 foi premiado pela Revista Euromoney como melhor "Project Finance" da América Latina (categoria energias renováveis). De acordo com dados da empresa, já foram evitadas até 02 de agosto de 2014 1.003.366 toneladas de $\mathrm{CO}_{2}$. As visitas ao Parque são gratuitas e ocorrem apenas nas terças e quintas-feiras com duas opções de horários: às $09 \mathrm{~h} 00$ e às $15 \mathrm{~h} 00$. A duração da visita é, em média, duas horas e pode ser realizada com grupos de 10 a 40 pessoas (idade mínima: 12 anos). Segundo análises de Goldani (2013), as instalações do Parque se adequam a qualquer perfil de visitante, que geralmente busca design e arquitetura, bem como deseja conhecer a natureza da região. Para a autora, é possível conciliar o uso de energias renováveis com turismo, e o Parque Eólico de Osório pode ser um competitivo produto turístico da região litorânea do Rio Grande do Sul.
Fonte:
Goldani
(2013)
e Ventos
Sul
Energia

(http://www.ventosdosulenergia.com.br/highres.php).
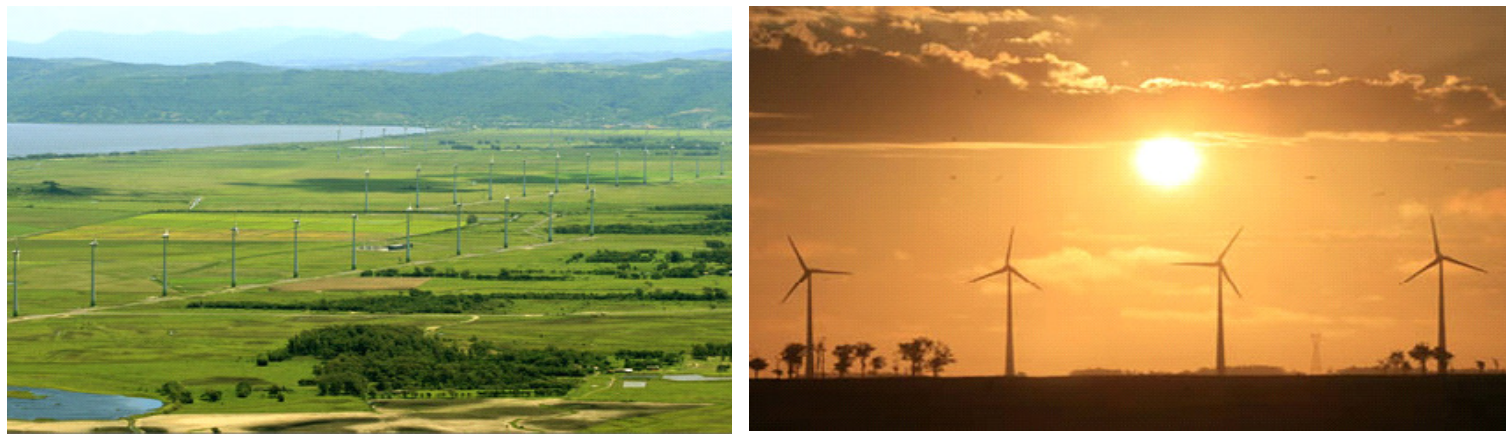

Figura 32 - Parque Eólico de Osório (RS)

Crédito: Ventos Sul Energia (2014) 
Destino: Trecho Carlos Barbosa-Garibaldi-Bento Gonçalves

Inovação: Maria Fumaça - Trem do vinho

Iniciativa: privada

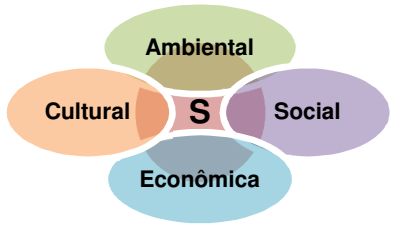

Breve contextualização da inovação: A Maria Fumaça - Trem do vinho é a primeira e única locomotiva turística do Brasil com as certificações ABNT NBR ISO 14001:2004 e ABNT NBR ISO 9001:2008. A locomotiva conta com mecanismo de controle de ruído e da fumaça, coleta seletiva, sistema de captação de água de chuva, uso de madeira reflorestada, caixas separadoras de água e óleo, caixas coletoras nos banheiros (para os efluentes), bacias de contenção de óleo, lâmpadas econômicas, adoção de papel reciclado e plantio de mudas de árvores no trecho da Maria Fumaça. Do ponto de vista social, existem trabalhos na comunidade local quanto à educação ambiental, doações de brinquedos e cortesias para participar do passeio de Maria Fumaça. Do ponto de vista cultural, a empresa apoia alguns projetos, como a Exposição "A Vindima em Vinho Tinta" (pinturas em vinho do artista plástico Assis Costa) e reforma do Museu do Imigrante.

Fonte: Giardini Turismo (http://www.giordaniturismo.com.br/).

Os casos no contexto do turismo apresentados são inovadores quanto à sustentabilidade. No entanto, nem sempre as quatro dimensões da sustentabilidade tomam força de forma equilibrada, pois ora pode-se ter um foco na questão ambiental, ora na cultural, social e econômica.

Após apresentação das principais práticas de inovação para a sustentabilidade no turismo brasileiro nos três estados, bem como análise da opinião de especialistas sobre o tema, o capítulo 5 corresponde ao aprofundamento do 4, pois nele consta os resultados mais relevantes obtidos na pesquisa de campo realizada nos três destinos turísticos selecionados. 
5. ESTUDOS DE CASO: BONITO (MS), GRAMADO (RS) E INSTITUTO INHOTIM (MG)

Neste capítulo apresentamos os dados e informações mais relevantes da pesquisa de campo feita em Bonito (MS), Gramado (RS) e Instituto Inhotim (MG) por meio das entrevistas com representantes do poder público local e trade turístico, bem como os turistas. A composição da MIST e análise comparativa entre os três destinos também fazem parte deste capítulo.

\subsection{BONITO (MS)}

A pesquisa de campo em Bonito foi realizada entre os dias 26 de abril e 03 de maio de 2014. A cidade possui 38 agências de turismo e viagens, 22 estabelecimentos de gastronomia, 70 meios de hospedagem e mais de 40 atrativos turísticos e opções de passeios distribuídos entre grutas, balneários, cachoeiras, flutuação e mergulho, aventura, contemplação de aves e o Pantanal (GUIA BONITO, 2014).

De acordo com dados do Ministério do Turismo, o Brasil investiu na região quase $R \$$ 60 milhões em obras de infraestrutura, como a pavimentação da rodovia MS-178 que liga Bodoquena a Bonito ( $R \$ 58$ milhões) e a construção da pista que conecta Bonito ao balneário Rio Formoso (R\$ 487,5 mil) (BRASIL, 2013c).

Conforme já foi mencionado, Bonito integra o Tour da Experiência, composto por sua vez por 14 experiências distintas, tal como mostra a Figura 33 a seguir.
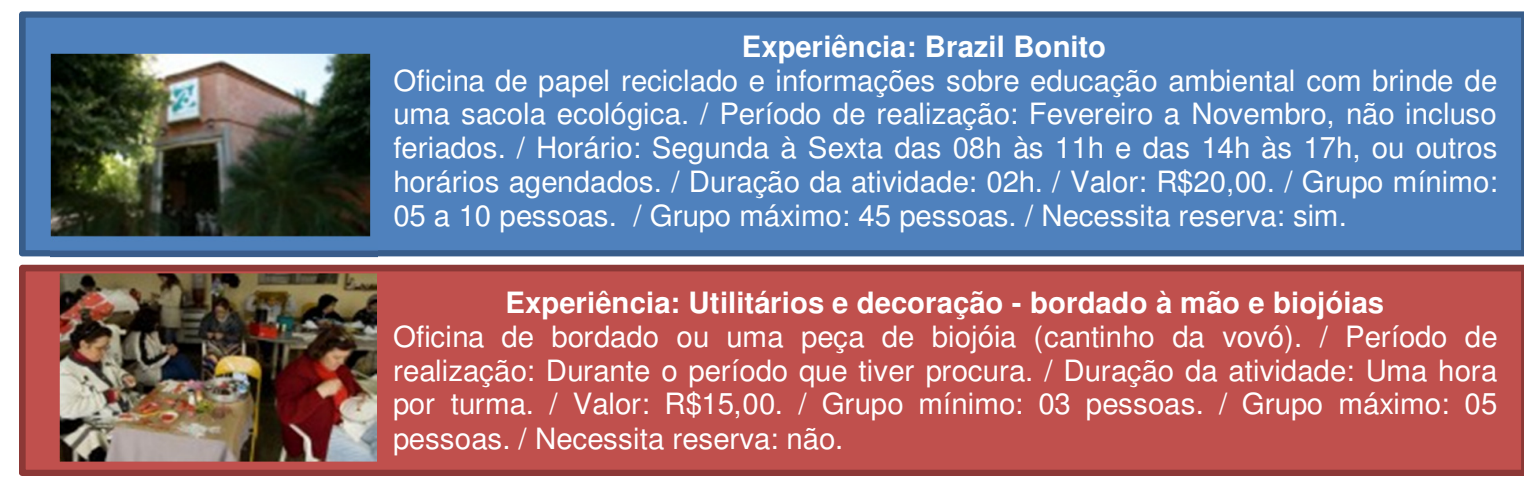

Experiência: Utilitários e decoração - bordado à mão e biojóias

Oficina de bordado ou uma peça de biojóia (cantinho da vovó). / Período de realização: Durante o período que tiver procura. / Duração da atividade: Uma hora por turma. / Valor: R\$15,00. / Grupo mínimo: 03 pessoas. / Grupo máximo: 05 pessoas. / Necessita reserva: não.

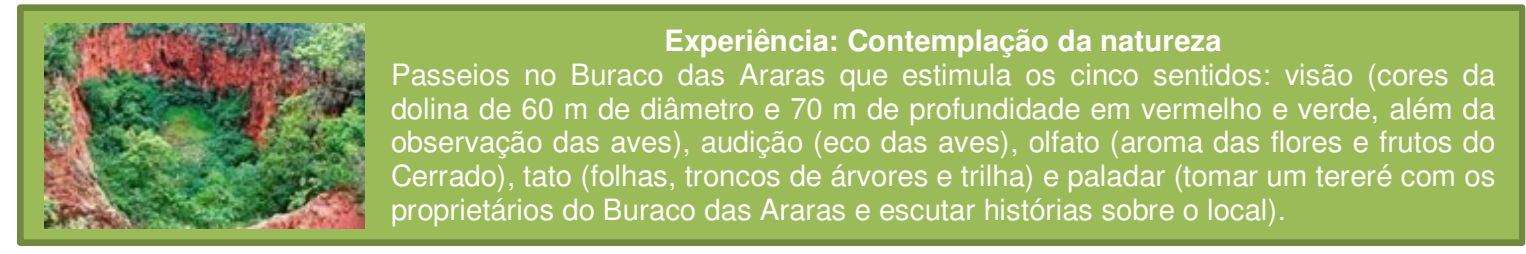




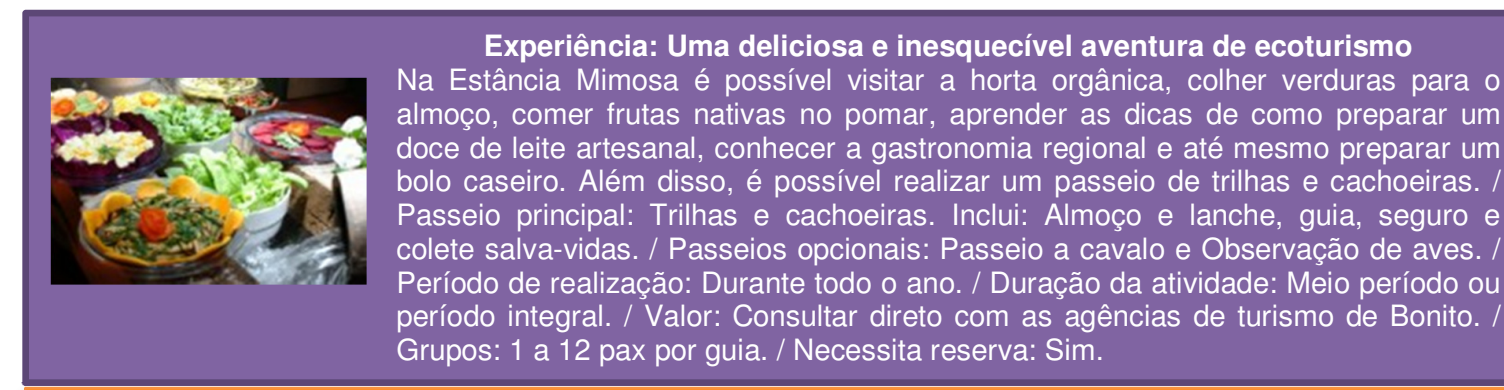

Experiência: Restaurante Cantinho do Peixe
Neste restaurante o visitante pode experimentar tipos de peixes de rio, como o molho de urucum.

Experiência: Traíra sem espinha

No restaurante Casa do João é possível experimentar essa iguaria.

\begin{tabular}{|c|c|}
\hline 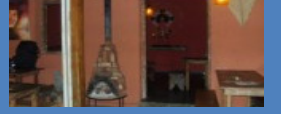 & $\begin{array}{l}\text { Experiência: Oca Bar } \\
\text { Nesse bar é possível experimentar pratos à base de mandioca e carne de jacaré. }\end{array}$ \\
\hline & $\begin{array}{l}\text { Experiência: } \mathbf{X} \text { Jacaré } \\
\text { Sanduíche feito com filé de jacaré, molho especial à base de maionese, alcaparras } \\
\text { e especiarias, queijo muçarela e tomate, servido no pão francês. }\end{array}$ \\
\hline & $\begin{array}{l}\text { Experiência: Merenda pantaneira } \\
\text { O Hotel Pousada Águas de Bonito oferece no final da tarde a "merenda pantaneira" } \\
\text { com quitutes da culinária regional e apresentações culturais. / Duração da atividade: } \\
20 \text { minutos. / Valor: Cortesia para os hóspedes e } \mathrm{R} \$ 10,00 \text { para visitantes. / Grupos: } \\
01 \text { a } 80 \text { pessoas. / Necessita reserva: Somente para grupos de visitantes. }\end{array}$ \\
\hline
\end{tabular}

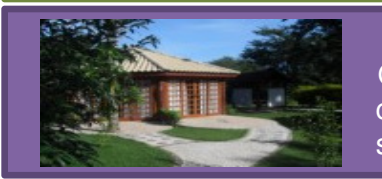

Fil.
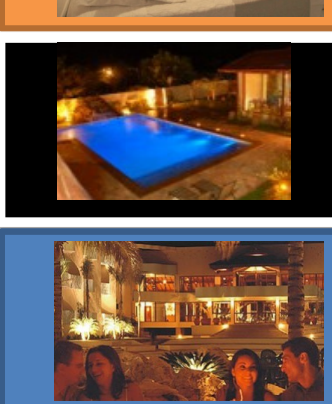

Experiência: Sentir-se em casa

O Hotel Pousada Arizona oferece um ambiente em que os hóspedes possam tomar café de pijama, andar descalço, provar produtos orgânicos, receber massagem ao som de pássaros e observar as estrelas em espreguiçadeiras.

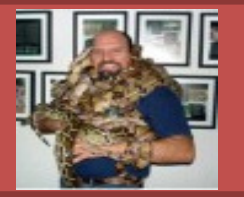

Experiência: Suíte Pantaneira e Suíte Águas de Marruá O Hotel Marruá criou a Suíte Pantaneira para proporcionar ao hóspede uma sensação de estar no Pantanal e, ao mesmo tempo, o conforto de estar em uma fazenda de luxo. A Suíte Águas de Marruá simula um ambiente de cachoeira, reproduz o som dos rios de Bonito e dispõe de uma banheira com cromoterapia.

\section{Experiência: Pousada Chamamé}

Oferece café da manhã personalizado para os hóspedes, sobretudo se precisam sair cedo para os passeios.

\section{Experiência: Espaço da cultura Kadiwéu}

O Hotel Wetiga, construído a partir da cultura indígena, criou o espaço Kadiwéu para oferecer ao hóspede experiência culturais.

Experiência: Desmitificação das serpentes

Experiência de compreender melhor sobre as serpentes e poder tocá-las (Projeto Jiboia). Duração da experiência: de uma a duas horas. / Necessita reserva: Não /

Grupos: de 1 a 130 pessoas

Figura 33 - Experiências de Bonito oferecidas pelo Tour da Experiência Fonte: Elaborado por Daniela Rocco (2014) com base em TOUR DA EXPERIÊNCIA (2014) 
Hoje Bonito recebe, em média, 200 mil turistas por ano, é polo de ecoturismo do Brasil e um dos mais importantes do mundo nesse segmento. Caldeira (2010) cita que a Sociedade Internacional de Ecoturismo estima que no mundo existam aproximadamente 35 milhões de ecoturistas, ou seja, pessoas que viajam internacional e regularmente cuja motivação principal é a natureza. Isto representa cerca de $4 \%$ do fluxo turístico mundial, inclusive com uma taxa média anual de crescimento que oscila entre 10\% e 15\%. Para o autor (2010), não existem dúvidas de que essa demanda crescente cria condições para estimular a prática de turismo sustentável. De acordo com o Ministério do Turismo, que cita a OMT, o turismo de natureza terá uma expansão entre 15\% e 25\% por ano, se configurando como o segmento que mais cresce no mundo. No Brasil, é segundo segmento, depois do segmento de sol e praia, na preferência dos turistas internacionais que visitam o País a lazer (21\% em 2012) (BRASIL, 2014e).

Um dos motivos pelos quais Bonito possui tanto prestígio em relação ao ecoturismo se deve à criação do voucher único. Este é um dos casos mais emblemáticos de inovação para a sustentabilidade no turismo do Brasil e assume, ainda, a forma de inovação disruptiva, pois foi uma iniciativa que transformou substancialmente a forma de se operar o turismo naquele destino. O voucher único, instituído pela Resolução Normativa no 09/95 do COMTUR (Conselho Municipal de Turismo), foi capaz de organizar, já no final da década de 1990, a cadeia de valor do turismo local de forma compatibilizada com a conservação dos recursos naturais. Desde então os atores locais organizam o turismo na cidade (o que gera riqueza local e inclusão produtiva - dimensão social e econômica da sustentabilidade) e o acesso aos atrativos turísticos mediante limitação da quantidade diária de pessoas (capacidade de carga - dimensão ambiental da sustentabilidade). Esse processo precisava, portanto, da integração de um só sistema que conectasse as agências de turismo e viagens locais com os guias locais, os estabelecimentos que operam os passeios e, finalmente, com a Prefeitura (para a arrecadação de impostos, como o ISSQN - Imposto sobre Serviços de Qualquer Natureza) (GRECHI, 2011). Hoje processo do voucher único (vide Figura 34) é quase todo digital, no entanto, ainda demanda melhorias. Para que o visitante possa entrar no atrativo é preciso levar o voucher impresso, o que poderia ser feito por meio de aplicativos de dispositivos móveis como smartphones e tablets. Esta medida (inovação incremental) certamente reduziria o gasto com papel e impressão, pois são impressas cinco vias: para a agência de turismo que fez a reserva do passeio, para o turista, para o guia, para o proprietário do atrativo turístico que oferece o passeio e para a Prefeitura. Por outro lado, uma inovação incremental adotada recentemente foi a aceitação de cartões de crédito para pagar o acesso aos passeios. 


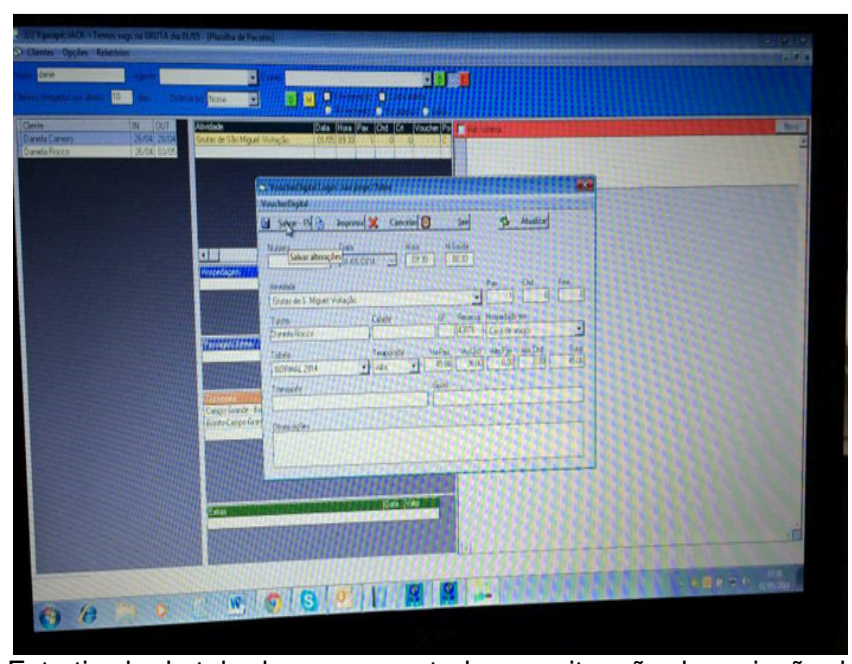

Foto tirada da tela de um computador em situação de emissão de um voucher único digital para acesso a um atrativo

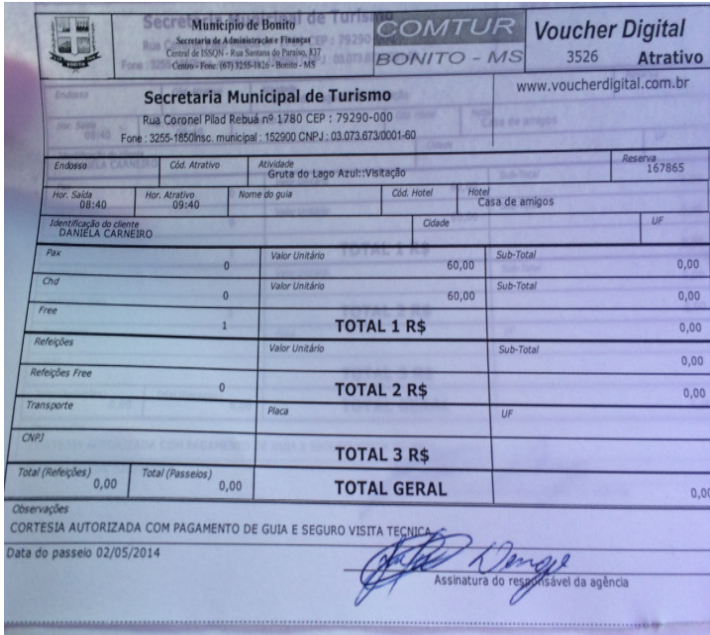

Voucher único digital impresso (obrigatório apresentá-lo na entrada do atrativo)

Figura 34 - Voucher único digital

Crédito: Daniela Rocco (2014)

O voucher único digital é objeto de estudo de vários pesquisadores brasileiros e do exterior. Segundo o representante do COMTUR/SETUR (Secretaria Municipal de Turismo), muitos gestores de outros destinos turísticos visitam Bonito para conhecerem o voucher único, porém não conseguem implementá-lo em seus destinos quando voltam. Para o representante, "não é quantidade e sim qualidade, e esse é o principal fator [de competitividade] de Bonito". No tocante ao modo como Bonito tem inovado, ele acrescenta:

Hoje, tudo é baseado nesse cuidado e nesse zelo com a nossa natureza, porque ela é muito frágil. A natureza como um todo é muito frágil, mas a nossa principalmente, pois tem calcário, tufas. Então, nós temos que inovar nisso: como vamos interferir, como que vamos entrar no ecossistema, mas ao mesmo tempo cuidando, zelando, trazendo benefícios e condições de o ser humano estar ali. Por exemplo, nós temos aqui as nossas cachoeiras. Elas não são de pedra, são de tufas calcárias, então elas são muito frágeis. E aquilo ali, conforme as pessoas forem pisando, elas se decompõem, se desfazem. [...]. Então temos que ter um cuidado muito grande usando madeiras, deques. Só que aí, madeiras? Derrubam-se árvores? Não. Temos os reaproveitamentos de árvores. Você pode ter madeiras que já estão legalizadas pelos institutos de meio ambiente. [...] Então eu acho que isso é inovar (Entrevista concedida pelo representante do COMTUR/SETUR, 2014).

Outra inovação digna de destaque é o recém-lançado aplicativo (app) "Guia Bonito" (Figura 35), o primeiro da cidade. Esse app, criado a partir de uma iniciativa da Prefeitura Municipal de Bonito, disponibiliza informações sobre a cidade, tais como notícias, roteiros turísticos, mapa, telefones úteis, chegadas e partidas de voos, fotos, serviços de saúde e contatos das agências de turismo, dos atrativos turísticos, dos meios de hospedagem e dos bares e restaurantes. $\mathrm{O}$ app, disponível nos idiomas português e inglês, pode ser acessado 
em smartphones mediante download gratuito na Play Store (sistema operacional Android) e na Apple Store (sistema operacional IOS). Embora a cidade tenha lançado esse app, ainda não dispõe de wi-fi gratuito no centro e o sinal de internet $3 G$ é falho.

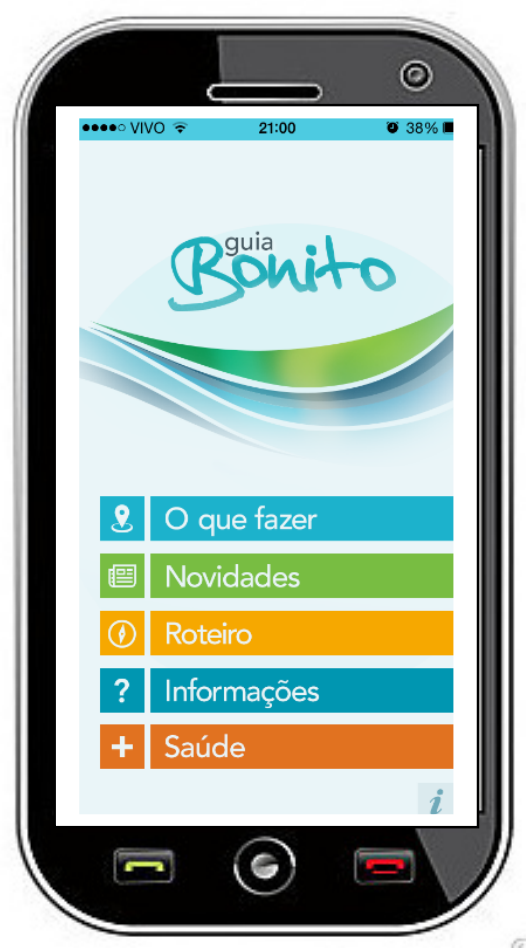

Figura 35 - Representação de um smartphone com o app Guia de Bonito (MS) Fonte: Elaborado por Daniela Rocco (2014) com base no App Guia de Bonito (2014)

Na pesquisa de campo foram identificadas três iniciativas bastante inovadoras e que merecem evidência por apresentarem ações sustentáveis criadas por microempreendedores locais. A primeira delas vem da empresa Lobo Guará Bike Adventure (http://www.loboguarabikeadventure.com.br/), pois é a única que oferece passeios de bicicleta aos turistas e, ao final, cada pessoa planta uma muda de árvore (projeto "Pedalando e plantando" - vide Figura 36, à direita). O Márcio Lima, idealizador, proprietário e condutor dos passeios, vai de carro com as mudas e materiais necessários para dar suporte aos turistas que percorrem a trilha. A segunda iniciativa é o Projeto Jiboia (http://www.projetojiboia.com.br/), criado pelo Henrique Naufal. Ele percebeu que a cidade oferece uma programação noturna muito restrita e que a maioria dos passeios é feita no período diurno e vespertino. Sendo assim, formatou uma palestra bem-humorada em que conta sua relação com as serpentes. Durante todo o tempo da palestra ele mantem uma jiboia no pescoço (vide Figura 36, à esquerda) e, por meio de um trabalho de educação ambiental destaca, por fim, a importância das serpentes no equilíbrio da cadeia alimentar. $O$ Projeto Jiboia, inclusive, recebeu o certificado do Tour da Experiência. 


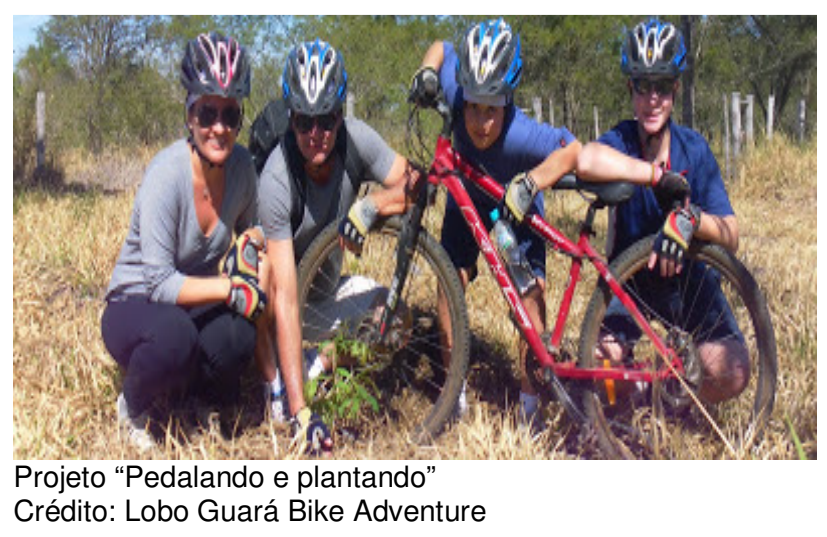

Figura 36 - Inovações para a sustentabilidade em Bonito (MS)

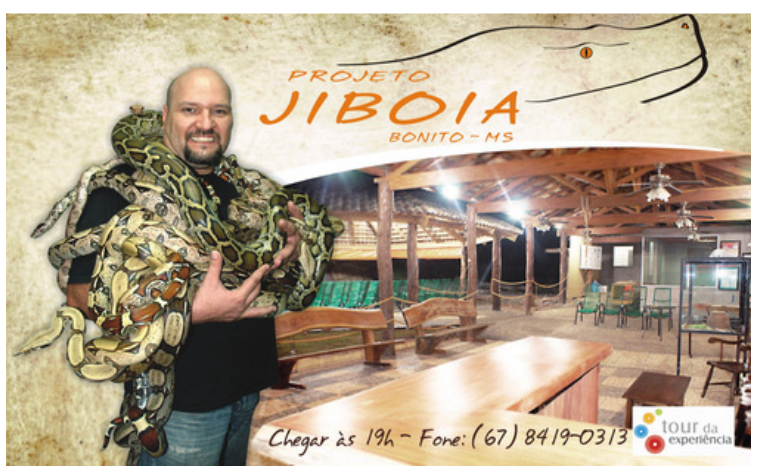

Projeto Jiboia

Crédito: Projeto Jiboia

A terceira iniciativa é a da Casa do Vidro (http://www.casadovidrobonito.com.br/fabrica.html), empresa recém-criada em Bonito (MS). Ela recebe doações de vidros e os transforma em abajures, copos, taças, entre outros, conforme expõe a Figura 37. Mesmo que o vidro venha quebrado, há reaproveitamento do mesmo. Além disso, muitos comerciantes e proprietários de atrativos da região doam os vidros para a Casa do Vidro e, após transformação, compram os produtos da empresa. É o vidro que volta com outra utilidade e valor sustentável.

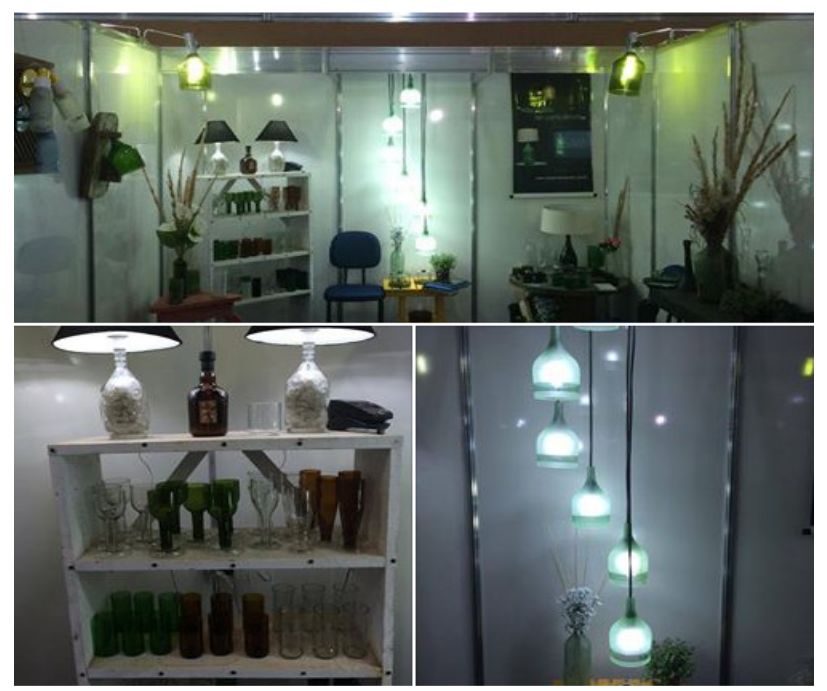

Figura 37 - Exposição e comercialização de produtos da Casa do Vidro no evento ESTC Crédito: Daniela Rocco (2014)

A pesquisa de campo na cidade coincidiu com a participação da pesquisadora em um dos mais importantes eventos internacionais de ecoturismo e turismo sustentável: o ESTC (Ecotourism and Sustainable Tourism Conference), promovido pela TIES (The International Ecotourism Society). Trata-se de uma organização sem fins lucrativos criada 
em 1990 e que até hoje se destaca pela promoção do ecoturismo em nível mundial ${ }^{52}$. Segundo a organização do evento, serão plantadas 317 mudas de plantas na região da Serra da Bodoquena, de tal forma que os $22.188 \mathrm{~kg}$ de $\mathrm{CO}_{2}$ gerados em função do evento sejam compensados.

De forma concomitante à participação no evento, foi realizado um trabalho de reconhecimento do destino, com observação direta e entrevistas com 10 atores locais vinculados ao turismo direta e indiretamente. São eles: i) representante do COMTUR (Conselho Municipal de Turismo) e, ao mesmo tempo, da SETUR (Secretaria Municipal de Turismo); ii) representante do Bonito Convention \& Visitors Bureau; iii) gerente do Hotel da Praça; iv) sócio proprietário da Pousada São Jorge; v) idealizador e proprietário da Lobo Guará Bike Adventure; vi) taxista que oferece serviços de transporte aos atrativos e na cidade; vii) promotor de Justiça; viii) representante do atrativo turístico Grutas de São Miguel; ix) sócio proprietário da agência de viagens e turismo Bonitour e x) idealizador e proprietário do Projeto Jiboia.

No tocante às características gerais da cidade, identificadas via observação e entrevistas com os atores citados acima, pôde-se constatar que a sensação de segurança na cidade é muito alta (são raríssimos os casos de furto), além do respeito às faixas de pedestre (a cidade não possui sinaleiras de trânsito). Com relação às ações sustentáveis, destacam-se três: i) o acesso aos atrativos, na maioria das vezes, se dá por meio de vans compartilhadas (o que reduz a emissão de $\mathrm{CO}_{2}$ ); ii) presença de lixeiras ecológicas (feitas de material reciclado - garrafas PET) no microcentro da cidade. Os dizeres das lixeiras estão em português e inglês, e elas estão divididas em dois tipos: resíduos recicláveis e resíduos não recicláveis, conforme mostra a Figura 38 e iii) Green Tax: é uma campanha realizada pelo IASB (Instituto das Águas da Serra da Bodoquena) (vide a Figura 39), cujos recursos financeiros são provenientes da doação voluntária de turistas. Por sua vez, esses recursos são aplicados em ações socioambientais na cidade e região.

\footnotetext{
${ }^{52}$ Para maiores informações sobre a TIES acesse: http://www.ecotourism.org/
} 


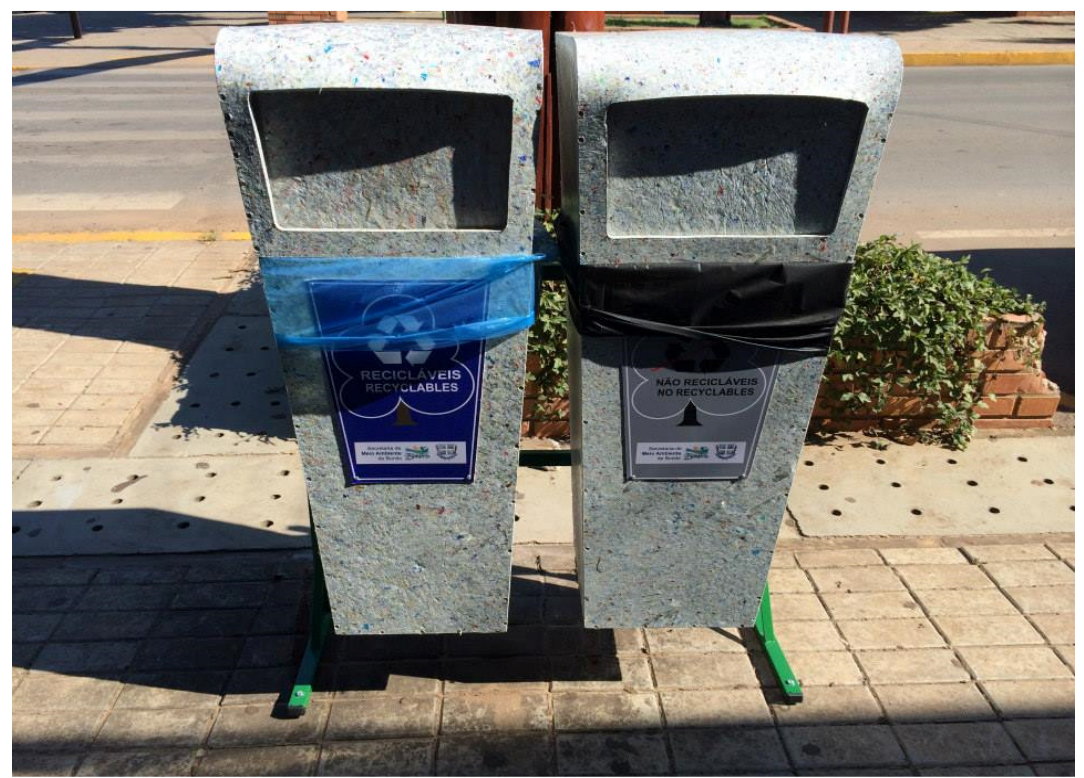

Figura 38 - Lixeiras ecológicas no microcentro de Bonito (MS)

Crédito: Daniela Rocco (2014)

O IASB (http://www.iasb.org.br/) possui forte atuação na cidade em relação às questões socioambientais, porém vale destacar também o Instituto Família Legal (http://www.familialegal.org.br/), que atende crianças e adolescentes em situação de vulnerabilidade social. Uma das formas encontradas por esse Instituto para gerar renda às famílias da cidade foi a produção e comercialização de bolsas ecológicas, cujas artesãs são, sobretudo, mães das crianças e adolescentes sob situação de risco.

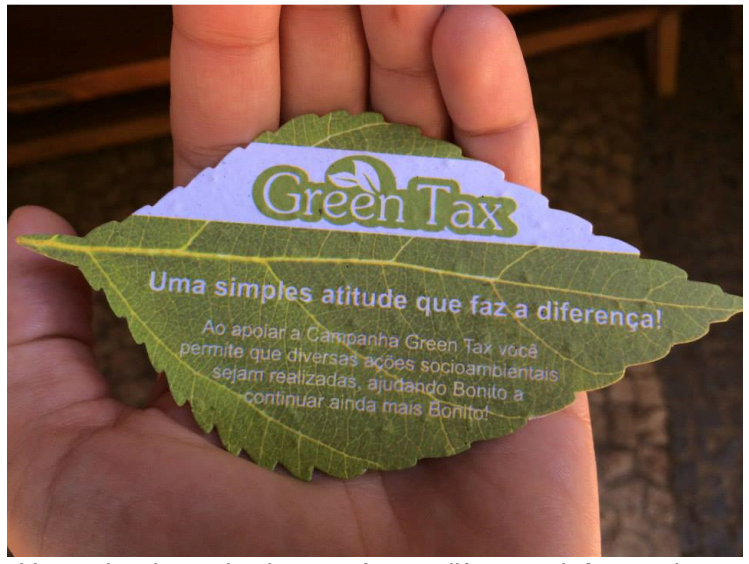

"Uma simples atitude que faz a diferença! Ao apoiar a Campanha Green Tax você permite que diversas ações socioambientais sejam realizadas, ajudando Bonito a continuar ainda mais Bonito!"

Figura 39 - Campanha Green Tax em Bonito (MS) Crédito: Daniela Rocco (2014)

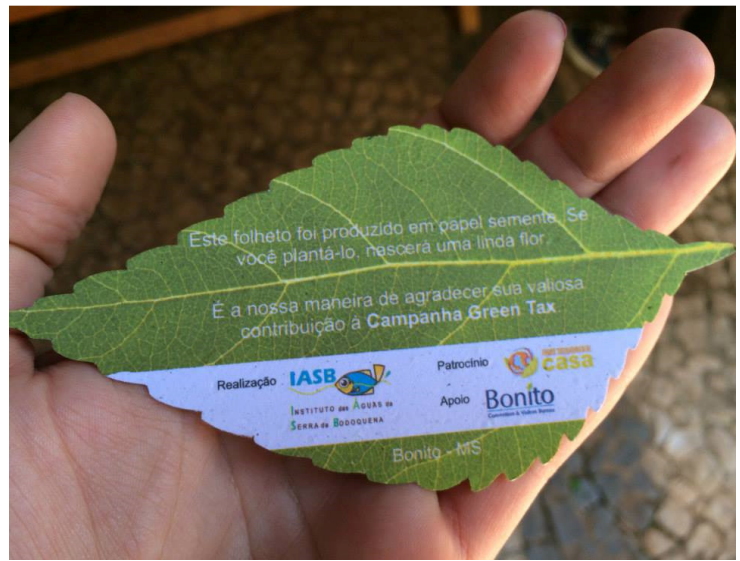

Verso da "folha-campanha", que foi produzido em papel semente (se plantado, nascerá uma flor) 
Segundo o sócio proprietário da Bonitour Viagens e Turismo, "aqui é um Brasil que funciona". Ele justifica que os impostos gerados são aplicados localmente, não há criminalidade e sempre há oportunidade de emprego. Com relação à prostituição e tráfico de drogas, o taxista e morador da cidade há mais de 20 anos alega, em entrevista, que são poucas prostitutas e que estas são de outras cidades. A inserção de drogas não é um problema social da cidade, mas que, embora não haja tráfico, existem alguns usuários (consumo próprio).

A sinalização na cidade é boa e dialoga com o ambiente (são feitas de madeira), conforme apresenta a Figura 40. No quesito ciclovias, estas são pouquíssimas, e os ciclistas se deslocam nas mesmas vias de acesso dos automóveis. Com relação ao uso de produtos orgânicos pelos moradores locais, às quartas-feiras e sábados a Prefeitura busca os pequenos agricultores para que vendam seus produtos no centro da cidade.
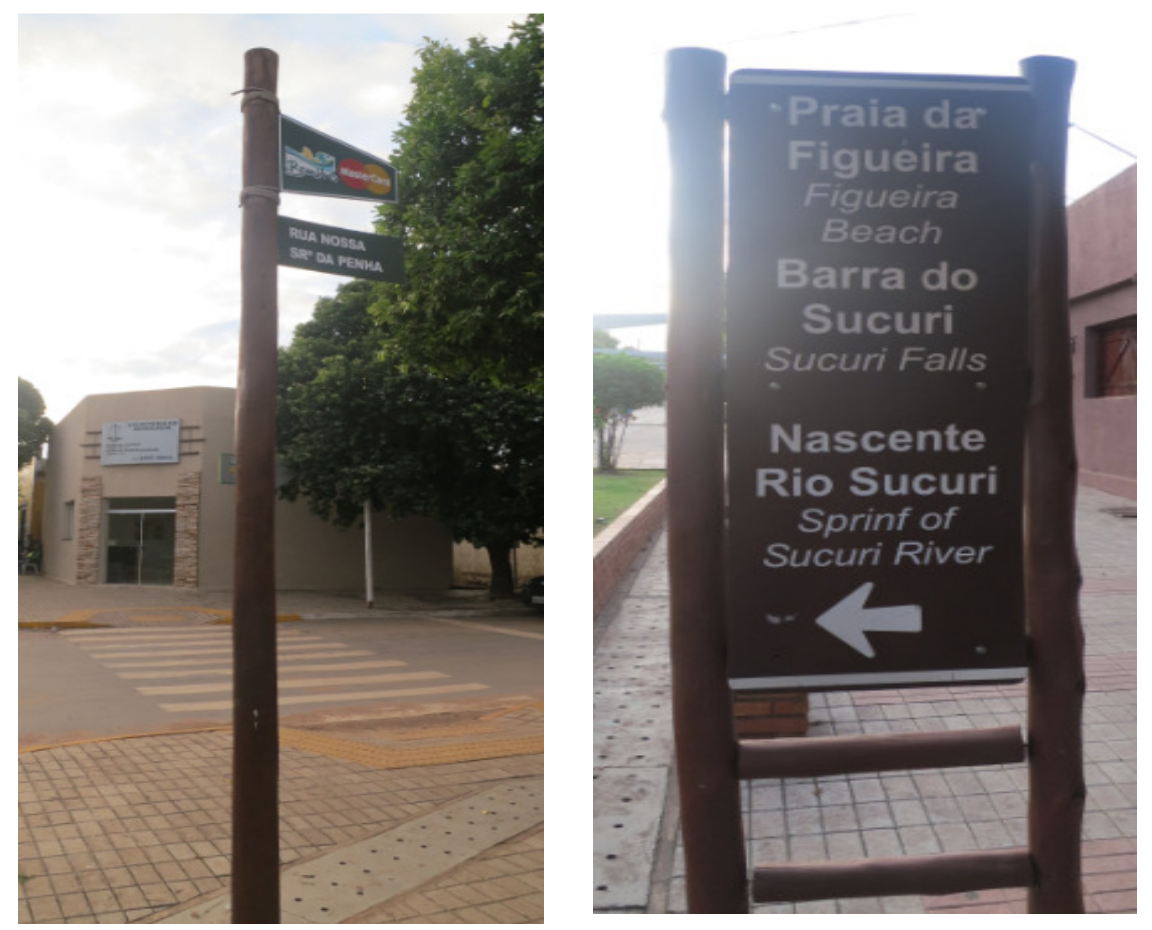

Figura 40 - Sinalização em Bonito (MS) Crédito: Daniela Rocco (2014)

Embora a maioria dos atrativos turísticos de Bonito pertença à iniciativa privada, a população local pode ter acesso na baixa temporada a muitos deles graças a uma parceria com a Atratur (Associação dos Atrativos Turísticos de Bonito e Região). Não é pago o valor da entrada, apenas a taxa do guia e despesas adicionais de consumo, como almoço e bebidas. Há quem diga que, por ser a baixa temporada no período de inverno, as pessoas não vão e, por isso, poucos conhecem os atrativos da cidade (o custo médio dos atrativos em alta temporada é de $R \$ 120,00$, portanto, nem todos bonitenses poderiam arcar com 
esse valor, sobretudo quando são famílias). No entanto, a temperatura da água de rios como o do Sucuri não muda durante o ano: $23^{\circ} \mathrm{C}$, o que viabiliza o passeio em qualquer estação.

Aos atores cujas entrevistas foram semiestruturadas, foram perguntados quais seriam os serviços, equipamentos e/ou atrativos turísticos locais que mais se destacam por práticas de inovação para a sustentabilidade. Optamos por escolher aqueles mais citados entre os atores locais para realizar uma entrevista mais aprofundada, que inclusive contou com a aplicação da MIST. Foram eleitos, assim, os atrativos turísticos Taboa Fábrica de Encantos e Recanto Ecológico Rio da Prata e o Hotel Pirá Miúna. O detalhamento sobre cada "case" é apresentado a seguir.

\section{Aplicação MIST: Taboa Fábrica de Encantos}

Em 1996 foi inaugurado o Taboa Bar, cujo local já foi sede do primeiro banco, cinema e bar-mercearia, assim como da primeira prefeitura e agência de turismo da cidade. A criação da cachaça Taboa surgiu após a abertura do bar, quando a proprietária identificou a necessidade de clientes que gostariam de beber algo que pudesse "esquentar" nos dias frios. A cachaça Taboa desde então é produzida artesanalmente e é resultado da mistura de cachaça, mel, canela, guaraná em pó e ervas naturais. Adicionalmente, é a primeira cachaça da cidade registrada pelo Ministério da Agricultura, sendo a única bebida que pode ser exportada de Mato Grosso do Sul para outros estados e países (TABOA BAR, 2014).

Com o passar do tempo, o negócio se expandiu e, em 2002, foi criada a Taboa Fábrica de Encantos. Este local é aberto ao público para visitação, onde se oferece tours experimentais associados a um trabalho de educação ambiental. Além da degustação de 20 tipos de cachaças, o visitante pode conhecer e sentir diversos aromas de ervas usadas nas próprias cachaças, bem como interagir com os colaboradores por meio de criação de pequenos artesanatos (oficinas de argila). Hoje o modelo de negócio Taboa é a integração do bar, da visitação da fábrica e da comercialização de cachaças e artesanatos. A cachaça é revestida artesanalmente com a palha da $\operatorname{Taboa}^{53}$, o que lhe confere caráter único a cada garrafa. Além disso, com os materiais que sobram do revestimento das garrafas, são criados abajures, bandejas e peças decorativas (CACHAÇA TABOA, 2014).

As ações de inovação para a sustentabilidade estão integradas ao modelo de negócio, porém o foco da MIST é a Taboa Fábrica de Encantos, por ser o maior locus das inovações da Taboa. De todo modo, vale ressaltar a importância histórica do Taboa Bar para o turismo, bem como ações relacionadas à sustentabilidade no próprio bar, como a

\footnotetext{
${ }^{53}$ A Taboa é uma planta hidrófila normalmente encontrada em áreas alagadas, como manguezais e brejos. Ela é
} capaz de depurar poluentes. 
doação do óleo de cozinha usado para reciclagem (parceria com cooperativa) e contratação de pessoas locais. Um dos desafios atuais do bar é a dificuldade de contratar o bonitense para trabalhar no período noturno. Com relação a ações futuras espera-se criar pratos mais elaborados e oferecer mais cursos de capacitação para melhorar o atendimento dos colaboradores. A proprietária do Taboa, Andréa Fontoura, possui forte protagonismo no seu negócio e atuação ativa na cidade. Na Taboa Fábrica de Encantos ela prioriza a contração de jovens aprendizes, de tal modo que eles tenham a primeira oportunidade de emprego, adquirindo, assim, experiência. Tanto o bar quanto a fábrica ficam localizados na região central de Bonito, portanto, o acesso a ambos é fácil. O Quadro 18 a seguir apresenta a síntese das informações coletadas junto a uma representante fábrica e cuja estrutura é a da MIST. 
MIST (MATRIZ DE INOVAÇÃO PARA A SUSTENTABILIDADE NO TURISMO) - SEGMENTO: ALIMENTOS E BEBIDAS - CASE: TABOA FÁBRICA DE ENCANTOS

\begin{tabular}{|c|c|c|c|}
\hline \multicolumn{4}{|c|}{ MIST (MATRIZ DE INOVAÇÃO PARA A SUSTENTABILIDADE NO TURISMO) - SEGMENTO: ALIMENTOS E BEBIDAS - CASE: TABOA FÁBRICA DE ENCANTOS } \\
\hline ATRIBUTOS & $\begin{array}{l}\text { CARACTERIZAÇÃO DO MODELO DE } \\
\text { NEGÓCIO INOVADOR }\end{array}$ & PRÁTICAS DE INOVAÇÃO PARA A SUSTENTABILIDADE & $\begin{array}{l}\text { DESAFIOS, METAS E AVALIAÇÃO } \\
\text { GERAL }\end{array}$ \\
\hline $\begin{array}{l}\text { Inovação } \\
\text { - Incremental } \\
\text { - Revestimento artesanal da } \\
\text { cachaça } \\
\text {. Criação de novos tipos de } \\
\text { souvenirs } \\
\text {. Mudanças nos processos e } \\
\text { cultura organizacional } \\
\text { - Disruptiva/radical } \\
\text { - Primeira cachaça registrada } \\
\text { de Bonito, sendo a única } \\
\text { bebida que pode ser exportada } \\
\text { de Mato Grosso do Sul para } \\
\text { outros estados e países } \\
\text { - Primeira fábrica de cachaça } \\
\text { de Bonito e que oferece ainda } \\
\text { tours experimentais } \\
\text { II. Sustentabilidade } \\
\text { A Fábrica Taboa atende às } 4 \\
\text { dimensões: } \\
\text { - Conservação da natureza } \\
\text { - Conservação e valorização } \\
\text { da cultura } \\
\text { - Prosperidade econômica com } \\
\text { inclusão produtiva } \\
\text { - Equidade social }\end{array}$ & $\begin{array}{l}\text { Modelo de negócio } \\
\text { - Bar criado em } 1996 \\
\text { - Fábrica criada em } 2002 \\
\text { Ao longo dos anos percebe-se que o modelo de } \\
\text { negócio vem criando diversas inovações } \\
\text { incrementais e com valores de sustentabilidade } \\
\text { Valor ofertado / diferencial } \\
\text { - Fábrica/cachaça: produto exclusivo (peças } \\
\text { únicas e feitas a mão) } \\
\text { - Tours experimentais com degustação de } 20 \\
\text { tipos de cachaça e chás aromáticos } \\
\text { (aromaterapia e interação com os visitantes por } \\
\text { meio de educação ambiental). } \\
\text { Interação: oficinas de argila e explicação sobre } \\
\text { as ervas que são utilizadas nas cachaças (é } \\
\text { possível sentir o aroma de cada uma delas) } \\
\text { - Cachaça: a mais tradicional da cidade } \\
\text { - Encantamento (indicação de pessoas e } \\
\text { experiências sensoriais) }\end{array}$ & $\begin{array}{l}\text { Ambiental } \\
\text { - Coleta seletiva } \\
\text { - Cultura do reaproveitamento e transformação de materiais } \\
\text { - Parceria com o IASB (Instituto das Águas da Serra da Bodoquena): doa-se } \\
\text { com frequência uma quantia para que essa ONG faça plantio de árvores } \\
\text { - Reaproveitamento de todo o vidro utilizado no bar (inclusive quebrado) } \\
\text { - Reaproveitamento de todos os materiais utilizados para a confecção do } \\
\text { revestimento da garrafa (papelão, fibra excedente da taboa, restos da argila, } \\
\text { entre outros) } \\
\text { - Educação ambiental com visitantes (princípios da Fábrica e experiências } \\
\text { sensoriais por meio das ervas) } \\
\text { - Educação ambiental com os colaboradores: cursos de capacitação } \\
\text { - Selo ambiental } \\
\text { - Uso de luminárias de garrafas de vidro recicladas (compradas por empresa } \\
\text { local) } \\
\text { - Reaproveitamento de garrafas de vidro para compor algumas passagens } \\
\text { de acesso entre distintos ambientes da Fábrica } \\
\text { Social (colaboradores e comunidade) } \\
\text { - Exigência de contratação: ser bonitense } \\
\text { - Emprego de jovens (preferencialmente para ser o 10 emprego) } \\
\text { - Saúde: no salário não inclui plano de saúde } \\
\text { - Segurança: capacitação local e contínua } \\
\text { - Apoio ao time de voleibol da cidade } \\
\text { - Apoio aos guias locais de turismo, doando brindes de cachaças para que } \\
\text { possam distribuir em eventos de divulgação de Bonito } \\
\text { - Realização anual de evento beneficente (festa de aniversário do Taboa) } \\
\text { Cultural } \\
\text { - Valorização do artesanato local (feito com matéria-prima local) } \\
\text { - Apoio a eventos culturais locais } \\
\text { Econômica } \\
\text { - Negócio viável e competitivo em relação a outros bares do segmento. É } \\
\text { líder na cidade em termos de oferta de produto formatado para a visitação e } \\
\text { experiência turística pautada na cultura da cachaça artesanal } \\
\text { - Comercialização de souvenirs (valor agregado ao bar e à fábrica). Do } \\
\text { reaproveitamento dos materiais são produzidos: abajures e máscaras (fibra } \\
\text { da Taboa), bandejas (palhas da Taboa) e detalhes de artesanato (toalhas de } \\
\text { chitão do bar desgastadas com o tempo) } \\
\text { - Fábrica: Alta temporada: } 500 \text { visitantes/mês / Baixa temporada: } 200 \\
\text { visitantes/mês / Valor da entrada: } R \$ 25,00\end{array}$ & $\begin{array}{l}\text { Metas: } \\
\text { - Empregar no médio prazo } 100 \\
\text { jovens na Fábrica } \\
\text { - Adesão de plano de saúde } \\
\text { empresarial para os colaboradores } \\
\text { - Campanha para que o bonitense } \\
\text { faça o tour gratuito pela fábrica (com } \\
\text { exceção da degustação de bebidas } \\
\text { alcoólicas) } \\
\text { - Repartição de lucros (gestão } \\
\text { participativa); } \\
\text { - Aprimoramento do site. } \\
\text { Avaliação geral: } \\
\text { Modelo de negócio inovador que } \\
\text { adota princípios de sustentabilidade. } \\
\text { Forte protagonismo da proprietária } \\
\text { nesse sentido. }\end{array}$ \\
\hline
\end{tabular}

Quadro 18 - MIST da Taboa Fábrica de Encantos: Bonito (MS)

Fonte: Dados da pesquisa (2014). 
As Figuras 41 e 42 contêm fotos que foram tiradas durante a pesquisa de campo na Taboa Fábrica de Encantos.
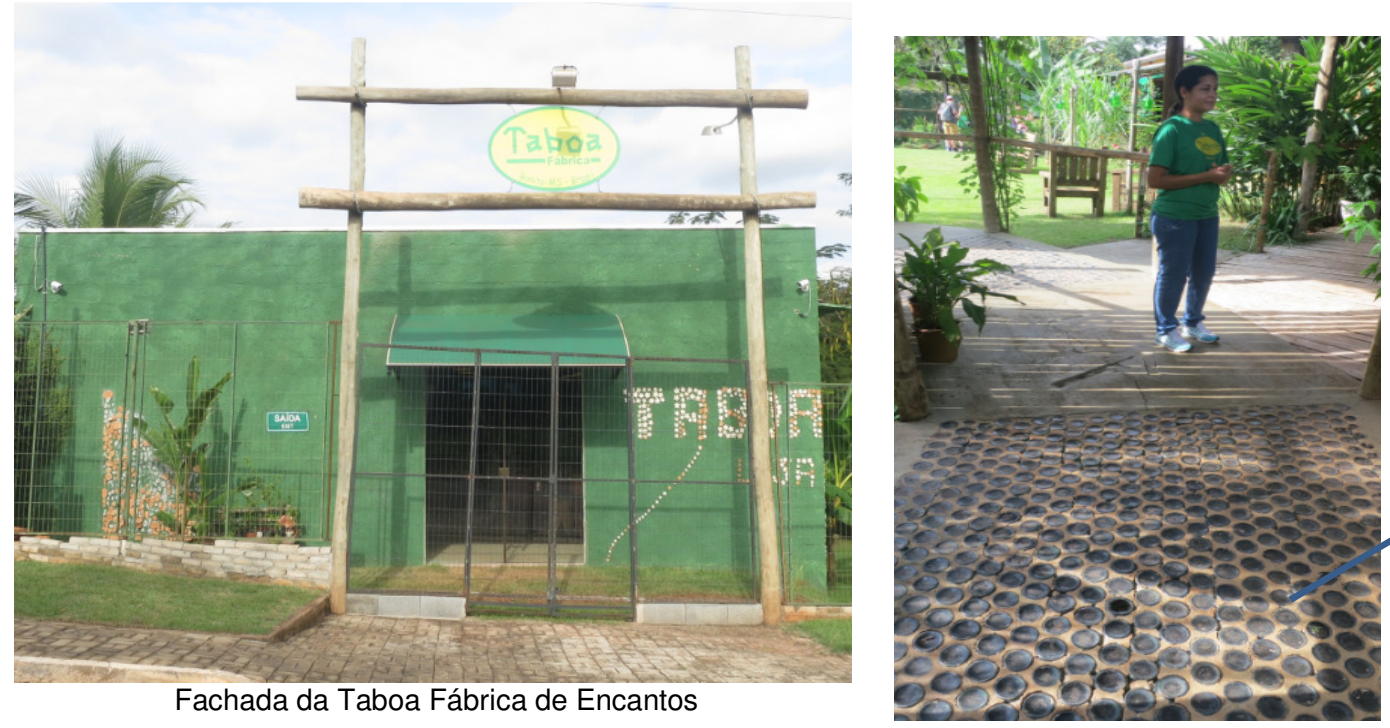

Parte do piso é feito do reaproveitamento de garrafas de vidro

Fachada da Taboa Fábrica de Encantos

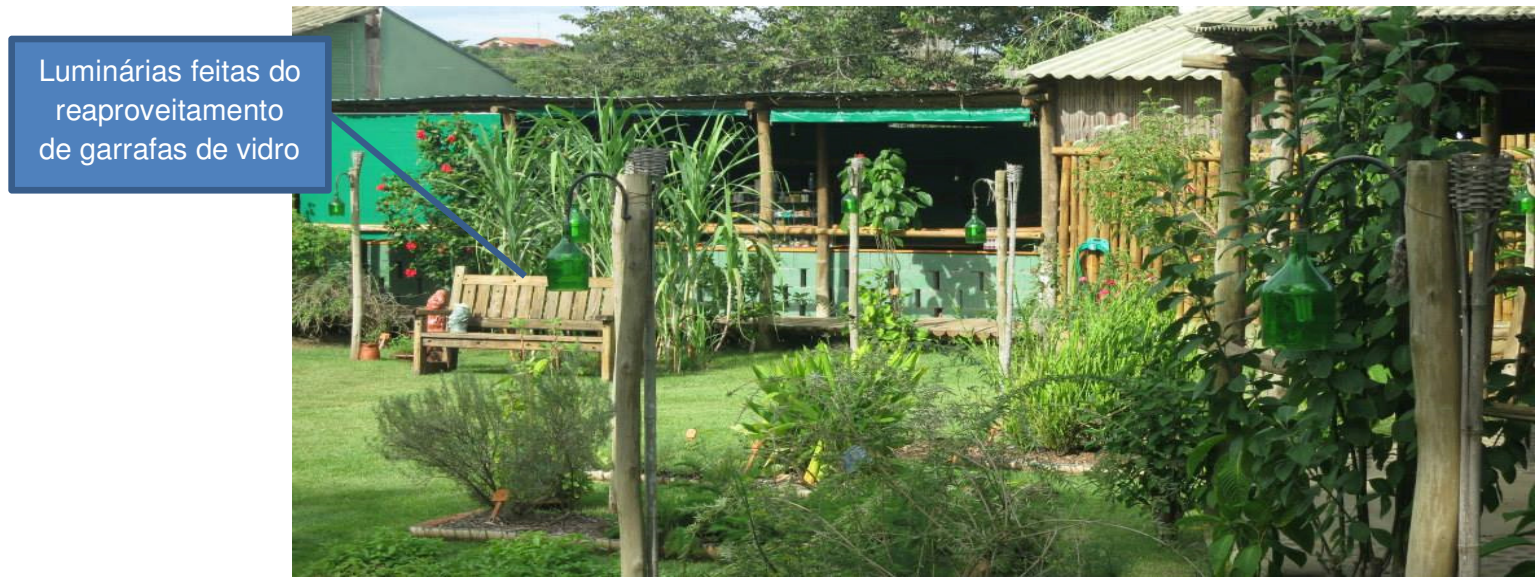

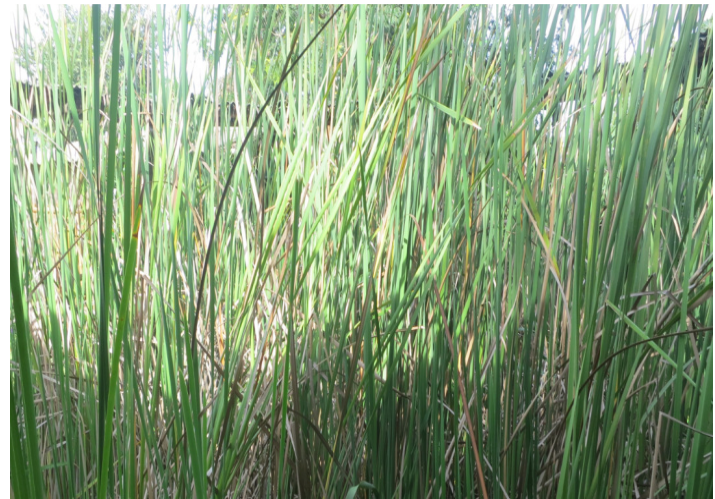

Taboa plantada na fábrica

Figura 41 - Fotos da Taboa Fábrica de Encantos (parte I) Crédito: Daniela Rocco (2014)

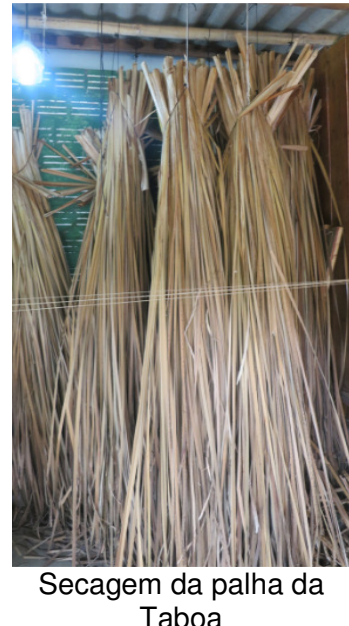

Taboa
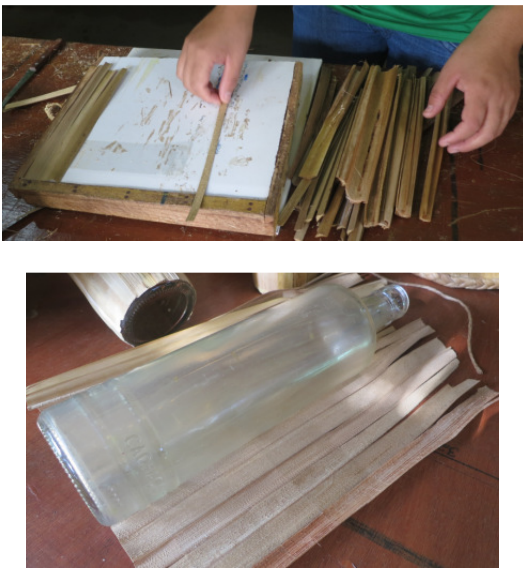

Revestimento artesanal das garrafas de cachaça 


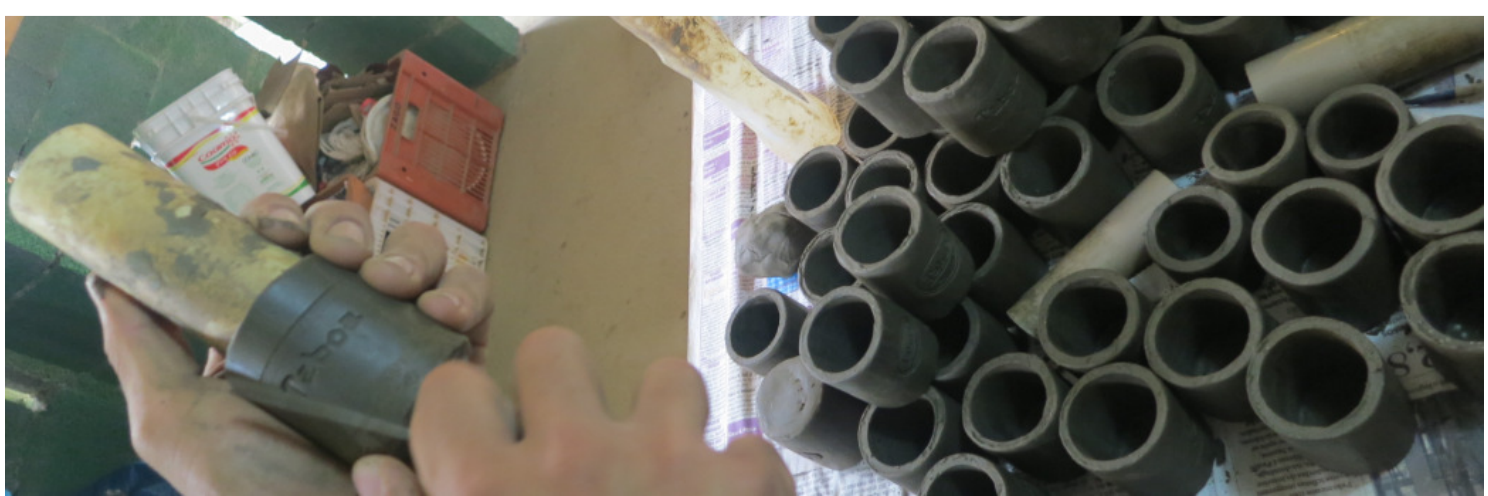

Peças em argila sendo

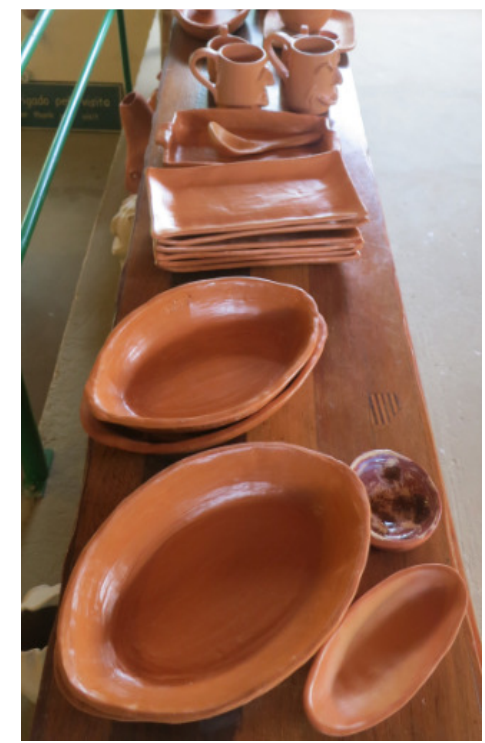

Peças já prontas para comercialização

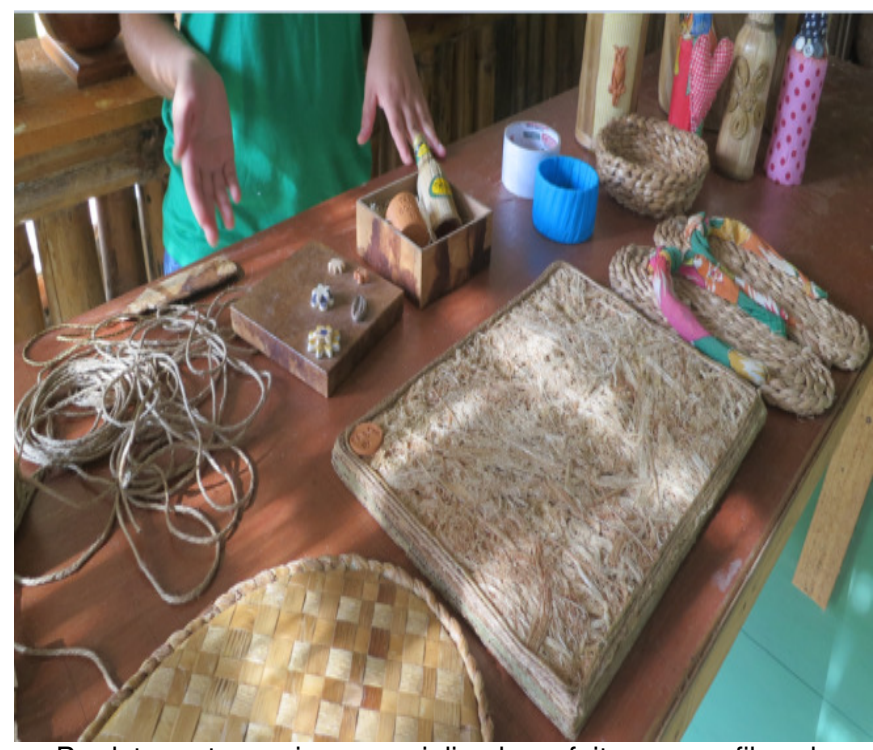

Produtos artesanais comercializados e feitos com a fibra da Taboa: bandejas, cestarias e revestimento de garrafas e minigarrafas de cachaças (souvenir)

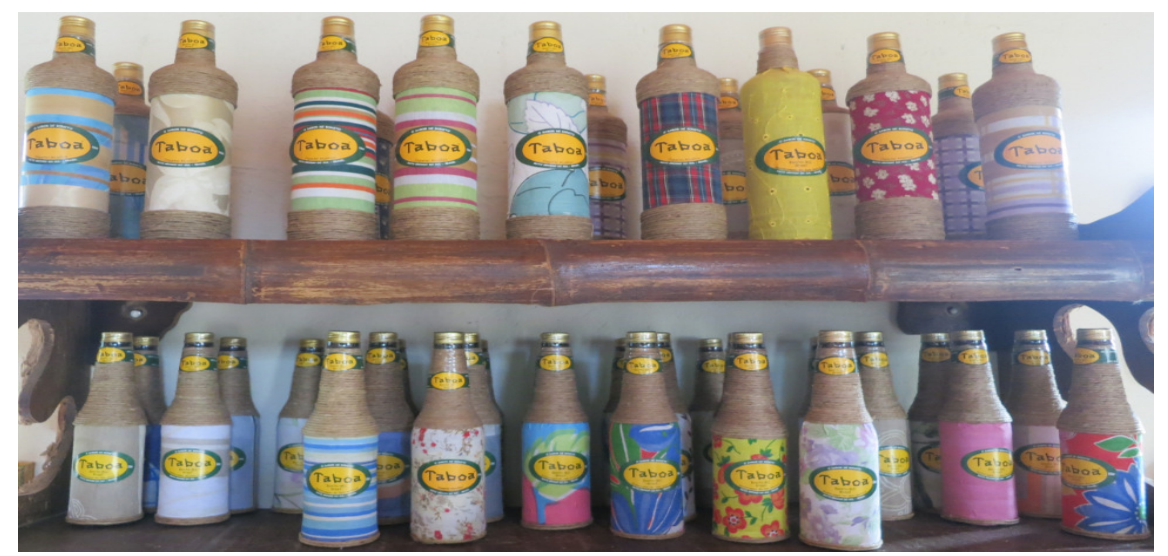

Garrafas artesanais da cachaça Taboa prontas para comercialização e consumo

Figura 42 - Fotos da Taboa Fábrica de Encantos (parte II) Crédito: Daniela Rocco (2014) 


\section{Aplicacão MIST: Recanto Ecológico Rio da Prata}

Em 1995 iniciaram-se os passeios de ecoturismo no Recanto Ecológico Rio da Prata, nome fantasia da Fazenda Cabeceira do Prata. Nesta época, os proprietários registraram diversas diretrizes de sustentabilidade com a finalidade de planejar o desenvolvimento do atrativo turístico no futuro. Uma dessas diretrizes resultou, em 1999, na criação da Reserva Particular do Patrimônio Natural (RPPN) da Fazenda Cabeceira do Prata. A RPPN, próxima do Parque Nacional da Serra da Bodoquena, abrange 307,53 hectares (21,5\% da área total da Fazenda), está situada no município de Jardim (sudoeste de Mato Grosso do Sul) e dista $34 \mathrm{~km}$ da zona urbana de Bonito (COELHO et al., 2011). A Figura 43 indica os limites da RPPN, bem como o deque da nascente, tipos de vegetação e corredeiras.

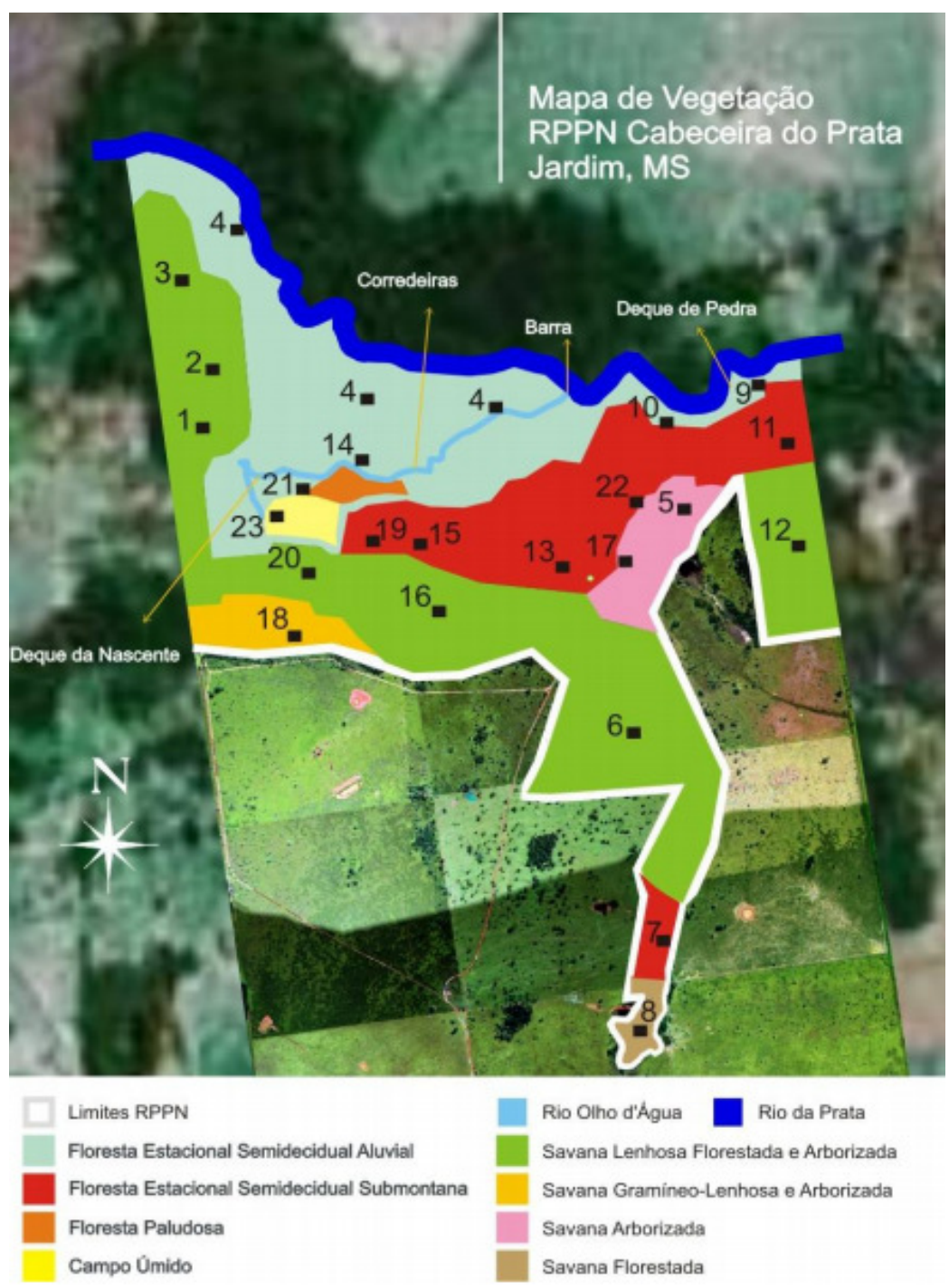

Figura 43 - Plano De Manejo RPPN Fazenda Cabeceira Do Prata, Jardim/MS Fonte: Coelho \& Manço (2006). 
Para se chegar ao Recanto Ecológico Rio da Prata indica-se o acesso pela BR 267, Km 512, na Zona Rural de Jardim (MS). De acordo com informações extraídas do site do Recanto Ecológico Rio da Prata, é possível chegar ao atrativo turístico de:

\footnotetext{
- Bonito: sair da cidade pela MS178/MS382 (vai passar na frente do Centro de Convenções), seguir pela MS 178 por $50 \mathrm{~km}$ até chegar na BR 267, virar a esquerda, sentido Jardim, por mais $2 \mathrm{~km}$, entrar na placa para o Recanto Ecológico Rio da Prata.

- Jardim: pegar a BR 267 para Porto Murtinho, seguir por 36 km, entrar na placa para o Recanto Ecológico Rio da Prata.

- Campo Grande: pegar a BR 060 para Sidrolândia, passando por Nioaque até Guia Lopes. Pegar a BR 267 para Jardim, seguir por $36 \mathrm{~km}$, entrar na placa para o Recanto Ecológico Rio da Prata (RECANTO ECOLÓGICO RIO DA PRATA, 2014).
}

A missão do Recanto Ecológico Rio da Prata é "proporcionar ao visitante uma experiência única de interação com a natureza, por meio de passeios de ecoturismo focados em inovação, conservação ambiental e desenvolvimento sustentável da região". Com relação aos valores, o grupo destaca "Profissionalismo, Autenticidade, Inovação, Criatividade, Cuidado e atenção aos detalhes, Valorização das pessoas e cultura regional" (RECANTO ECOLÓGICO RIO DA PRATA, 2014).

Os passeios oferecidos na RPPN são flutuação, cavalgada e mergulho com cilindro, e todos são certificados pela ABNT (Sistema de Gestão da Segurança). No tocante às atividades na água, primeiramente percorre-se uma trilha interpretativa até chegar à Nascente do Rio Olho D'água (lago fluvial). A flutuação inicia-se a partir desse lago e finaliza-se no Rio da Prata (passeio de quase 2 km sob a água).

Durante a visita técnica realizada em abril de 2014 foram identificadas diversas ações desenvolvidas pelo grupo Rio da Prata (além do Recanto Ecológico Rio da Prata, o grupo é proprietário dos atrativos turísticos Lagoa Misteriosa e Estância Mimosa). De fato, o atrativo turístico tem evoluído bastante desde a década de 1990, inclusive com a criação de inovações vinculadas à sustentabilidade. O resultado pode ser comprovado por meio do recebimento de mais de 10 prêmios relacionados à gestão da sustentabilidade e visibilidade não só nacional, como internacional também. O Quadro 19 apresenta a aplicação da MIST sobre o Recanto Rio da Prata. 
MIST (MATRIZ DE INOVAÇÃO PARA A SUSTENTABILIDADE NO TURISMO) - SEGMENTO: ATRATIVOS TURÍSTICOS - CASE: RECANTO ECOLÓGICO RIO DA PRATA

\begin{tabular}{|c|c|c|c|}
\hline \multicolumn{4}{|c|}{ MIST (MATRIZ DE INOVAÇÃO PARA A SUSTENTABILIDADE NO TURISMO) - SEGMENTO: ATRATIVOS TURÍSTICOS - CASE: RECANTO ECOLÓGICO RIO DA PRATA } \\
\hline ATRIBUTOS & $\begin{array}{l}\text { CARACTERIZAÇÃO DO MODELO DE } \\
\text { NEGÓCIO INOVADOR }\end{array}$ & PRÁTICAS DE INOVAÇÃO PARA A SUSTENTABILIDADE & $\begin{array}{l}\text { DESAFIOS, METAS E AVALIAÇÃO } \\
\text { GERAL }\end{array}$ \\
\hline $\begin{array}{l}\text { - Incremental } \\
\text { Melhorias contínuas nos } \\
\text { passeios e gestão da } \\
\text { sustentabilidade } \\
\text { - Aberta estantada por um } \\
\text { Sugestão apresentadem } \\
\text { visitante se tornou em } \\
\text { inovação: colocar o snorkel } \\
\text { esterilizado em um saco } \\
\text { plástico não lacrado (como era } \\
\text { feito antes), e sim apenas } \\
\text { amarrado com um nó fácil de } \\
\text { abrir. Assim, quando o visitante } \\
\text { tira o snorkel, ele não rasga o } \\
\text { saco e pode reutilizá-lo para } \\
\text { guardar a roupa seca (antes do } \\
\text { passeio na água) e molhada } \\
\text { (após o passeio). Há dois anos } \\
\text { os sacos eram lacrados e } \\
\text { rasgados, impossibilitando, } \\
\text { dessa maneira a reutilização. }\end{array}$ & $\begin{array}{l}\text { Modelo de negócio } \\
\text { É uma fazenda situada em uma RPPN que } \\
\text { oferece passeios turísticos. } \\
\text { Valor ofertado / diferencial } \\
\text { Ecoturismo como ferramenta para a educação } \\
\text { ambiental. Inovação e criatividade nos processos } \\
\text { de gestão. Passeio em águas cristalinas com } \\
\text { observação de distintos cardumes. } \\
\text { Associados / Parceiros: } \\
\text { - TIES (The International Ecotourism Society) } \\
\text { - Ministério do Turismo } \\
\text { - ABETA (Associação Brasileira das Empresas } \\
\text { de Ecoturismo e Turismo de Aventura) } \\
\text { - ABRASEL (Associação Brasileira de Bares e } \\
\text { Restaurantes) - MS } \\
\text { - ATRATUR (Associação dos Atrativos Turísticos } \\
\text { de Bonito e Região) } \\
\text { - Bonito Convention \& Visitors Bureau } \\
\text { - IASB (Instituto das Águas da Serra da } \\
\text { Bodoquena) }\end{array}$ & $\begin{array}{l}\text { Ambiental } \\
\text { - Capacidade de carga definida (até } 150 \text { visitantes/dia) } \\
\text { - Minhocário e compostagem (contribui para a adubação natural do solo) } \\
\text { - Manejo ecológico da produção rural } \\
\text { - Sementário e viveiro de mudas de árvores nativas } \\
\text { - Destinação adequada de lixo (Programa Lixo Mínimo) } \\
\text { - Descarte de efluentes de forma correta: o Glutaraldeído utilizado na } \\
\text { desinfecção das máscaras e snorkels é coletado mensalmente por uma } \\
\text { empresa de Resíduos de Serviço de Saúde } \\
\text { - Implantação de aquecedores solares de água nos banheiros dos } \\
\text { alojamentos dos colaboradores e substituição de duas câmaras frigoríficas } \\
\text { por freezers verticais novos (diminuição do gasto de energia) } \\
\text { - Recebimento de animais silvestres reabilitados (soltura na área do atrativo) } \\
\text { - Monitoramento de flora e fauna (principais métodos: "armadilhas } \\
\text { fotográficas" para identificação de animais silvestres, telemetria nos peixes, } \\
\text { que é a implantação de um transmissor biocompatível, ninhos artificiais para } \\
\text { araras e moldes de gesso das pegadas de animais) } \\
\text { - Monitoramento dos impactos turísticos } \\
\text { - Madeira de reaproveitamento usada para trilhas } \\
\text { - Doação de vidro para uma empresa de reciclagem local } \\
\text { - Mural Ambiental: feito do reaproveitamento de coletes salva-vidas (os } \\
\text { demais coletes sem condições de uso são doados para artesãos locais) } \\
\text { - Troca de todos os lustres e lâmpadas do receptivo por um modelo de } \\
\text { menor gasto energético e maior durabilidade. Os lustres novos são feitos a } \\
\text { partir de garrafas de vidro recicladas } \\
\text { - Em } 2013 \text { foi instalada uma estação meteorológica na fazenda para } \\
\text { aprimorar a coleta de dados }\end{array}$ & $\begin{array}{l}\text { Desafios: } \\
\text { - Consolidar os outros atrativos } \\
\text { turísticos do grupo Rio da Prata, } \\
\text { como a Lagoa Misteriosa e a } \\
\text { Estância Mimosa } \\
\text { - Implantar um sistema de } \\
\text { tratamento de esgoto ecológico } \\
\text { - Diminuir a rotatividade do quadro } \\
\text { de pessoal } \\
\text { - Melhorar a gestão de estoque e } \\
\text { compras }\end{array}$ \\
\hline
\end{tabular}




\begin{tabular}{|c|c|c|c|}
\hline $\begin{array}{l}\text { (continua) } \\
\text { ATRIBUTOS }\end{array}$ & $\begin{array}{l}\text { CARACTERIZAÇÃO DO MODELO DE } \\
\text { NEGÓCIO INOVADOR }\end{array}$ & PRÁTICAS DE INOVAÇÃO PARA A SUSTENTABILIDADE & $\begin{array}{c}\text { DESAFIOS, METAS E AVALIAÇĀO } \\
\text { GERAL }\end{array}$ \\
\hline & $\begin{array}{l}\text { Prêmios / reconhecimentos } \\
\text { - Prêmio TripAdvisor (2014 e 2013) } \\
\text { - Prêmio Braztoa de Sustentabilidade - Categoria } \\
\text { Ambiental - } 2012 \\
\text { - Prêmio MPE Brasil - Vencedor estadual MS - } \\
\text { (2012 e 2009) } \\
\text { - RPPN Fazenda Cabeceira do Prata conquista } \\
\text { prêmio em Congresso Nacional (2011) } \\
\text { - Melhor Trabalho em Ecoturismo - 5o Prêmio } \\
\text { Brasil de Meio Ambiente (2010) } \\
\text { - A melhor Atração Turística do Brasil - Guia } 4 \\
\text { Rodas (2009 e 2008) } \\
\text { - Melhor Trabalho em Ecoturismo - 3o Prêmio } \\
\text { Brasil de Meio Ambiente (2008) } \\
\text { - Prêmio ECO - Gestão Empresarial para a } \\
\text { Sustentabilidade (2008) } \\
\\
\text { Presença na internet: } \\
\text { - Site (Português, Inglês e Espanhol) } \\
\text { - Twitter } \\
\text { - Facebook } \\
\text { - Google+ } \\
\text { - Youtube } \\
\text { - TripAdvisor }\end{array}$ & $\begin{array}{l}\text { Econômica } \\
\text { - Produção própria de parte dos alimentos oferecidos aos visitantes (ex: } \\
\text { doces artesanais, queijos, verduras orgânicas, pães, leite e ovos) } \\
\text { - Locação de máquinas fotográficas digitais subaquáticas de aventura } \\
\text { (GoPro) } \\
\text { - Sede da fazenda: restaurante, bar e loja de souvenirs } \\
\text { - Público estimado: } 30.000 \text { visitantes/ano } \\
\text { - Valor da entrada: } \\
\text { - Adulto e criança: } \mathrm{R} \$ 132,00 \text { (baixa temporada) e } \mathrm{R} \$ 162,00 \text { (alta temporada) } \\
\text { - Almoço: } \mathrm{R} \$ 36,00 \\
\text { - Troca de experiências com outros atores e empreendedores locais } \\
\text { (cooperação para melhoria do sistema turístico local) } \\
\text { - Folder publicitário do atrativo é em formato de mapa da região para ser útil } \\
\text { ao visitante. Foi reformulado recentemente, inclusive possui o mapa de } \\
\text { Campo Grande a Bonito }\end{array}$ & \begin{tabular}{c|c|} 
Ambiental \\
Cultural $\mathrm{S}$ \\
Econômica
\end{tabular} \\
\hline
\end{tabular}

Fonte: Dados da pesquisa (2014). 
A Figura 44 apresenta fotos que foram tiradas durante a pesquisa de campo no Recanto Ecológico Rio da Prata.

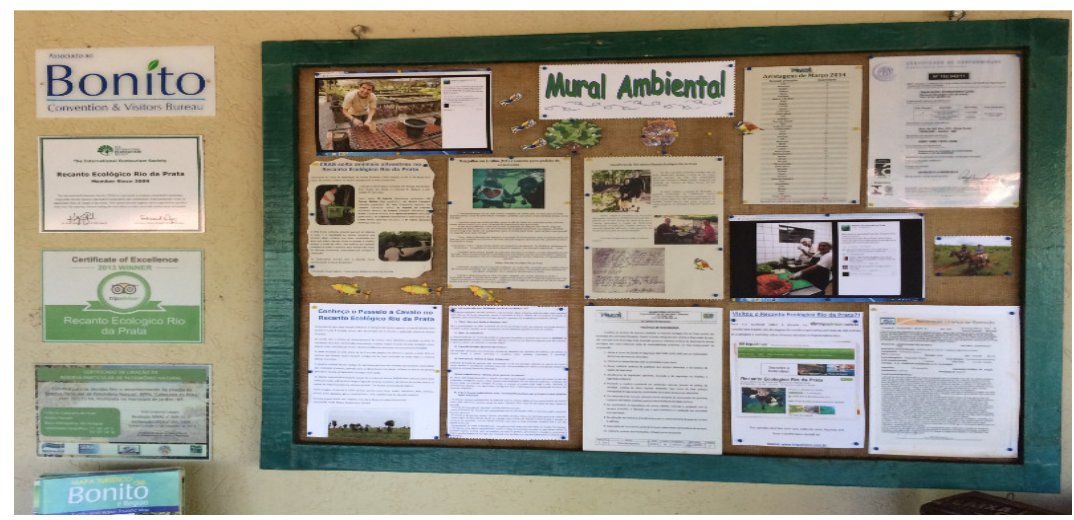

Mural ambiental: feito do reaproveitamento de coletes salva-vidas desgastados

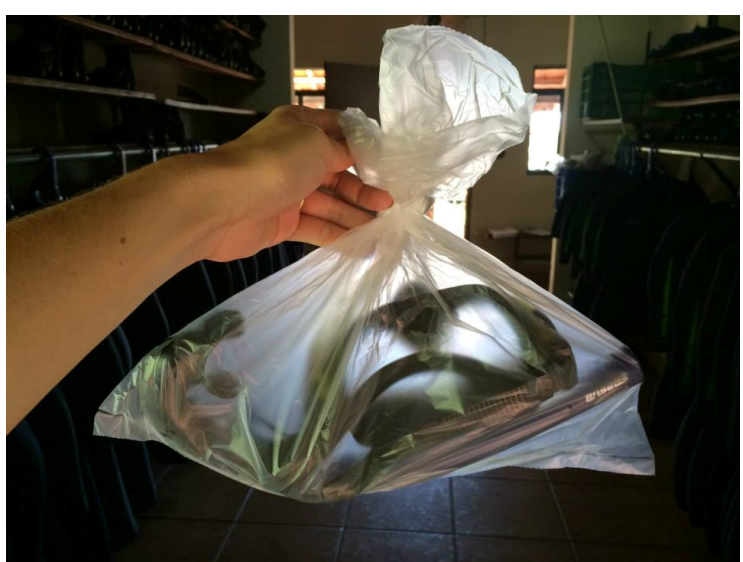

Snorkel no plástico amarrado (inovação aberta)

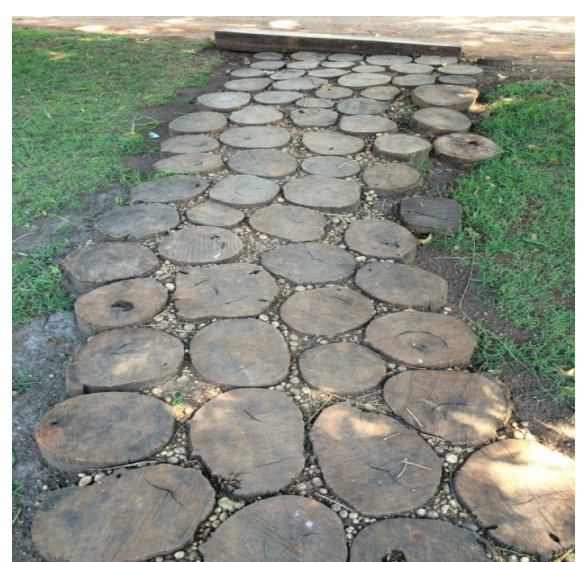

Madeira de reaproveitamento usada para trilhas

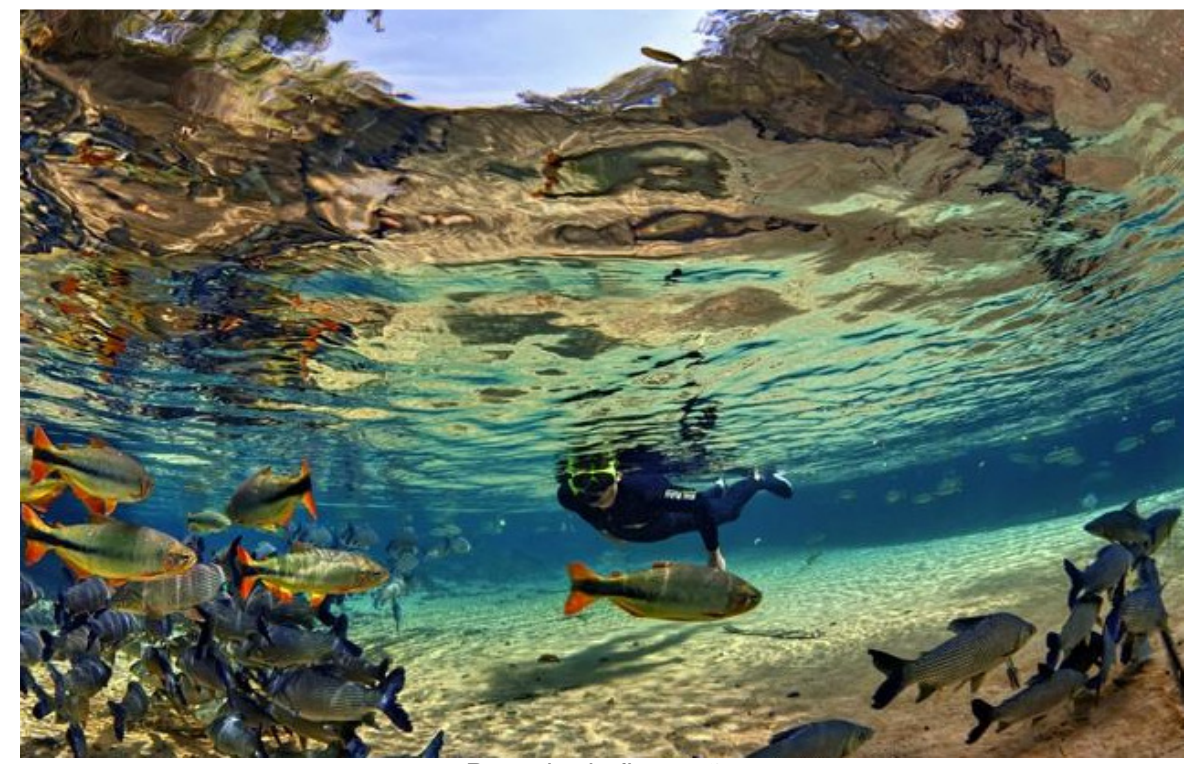

Passeio de flutuação

Figura 44 - Fotos do Recanto Ecológico Rio da Prata

Créditos: Mural ambiental, Snorkel e Trilha (Daniela Rocco) e Flutuação (Grupo Rio da Prata) 


\section{Aplicação MIST: Hotel Pirá Miúna}

A inauguração do Hotel Pirá Miúna foi 2002, porém desde o planejamento e execução da obra os proprietários já indicavam uma preocupação ambiental, por isso optaram por um projeto que considerasse, por exemplo, a iluminação natural, o encanamento adequado para esgoto e o uso de tijolos ecológicos/modulares.

O Hotel, que se considera uma "empresa cidadã e socialmente responsável", está localizado no centro da cidade e possui 39 apartamentos nas categorias single, duplo, triplo e quádruplo (sendo dois deles adaptados para portadores de necessidades especiais) distribuídos em dois pavimentos. A área de lazer contém piscina, piscina com hidromassagem, vestiários, churrasqueira, forno caipira, refeitório, sala de TV com DVD e vídeo cassete e bar. Além disso, o Hotel dispõe de salas de internet com wi-fi e dois espaços climatizados para a realização de eventos e negócios, cuja capacidade é de 40 e 60 pessoas (HOTEL PIRÁ MIÚNA, 2014). A Figura 45 abaixo mostra a fachada do Pirá Miúna e o Quadro 20 a MIST com informações sobre esse meio de hospedagem.

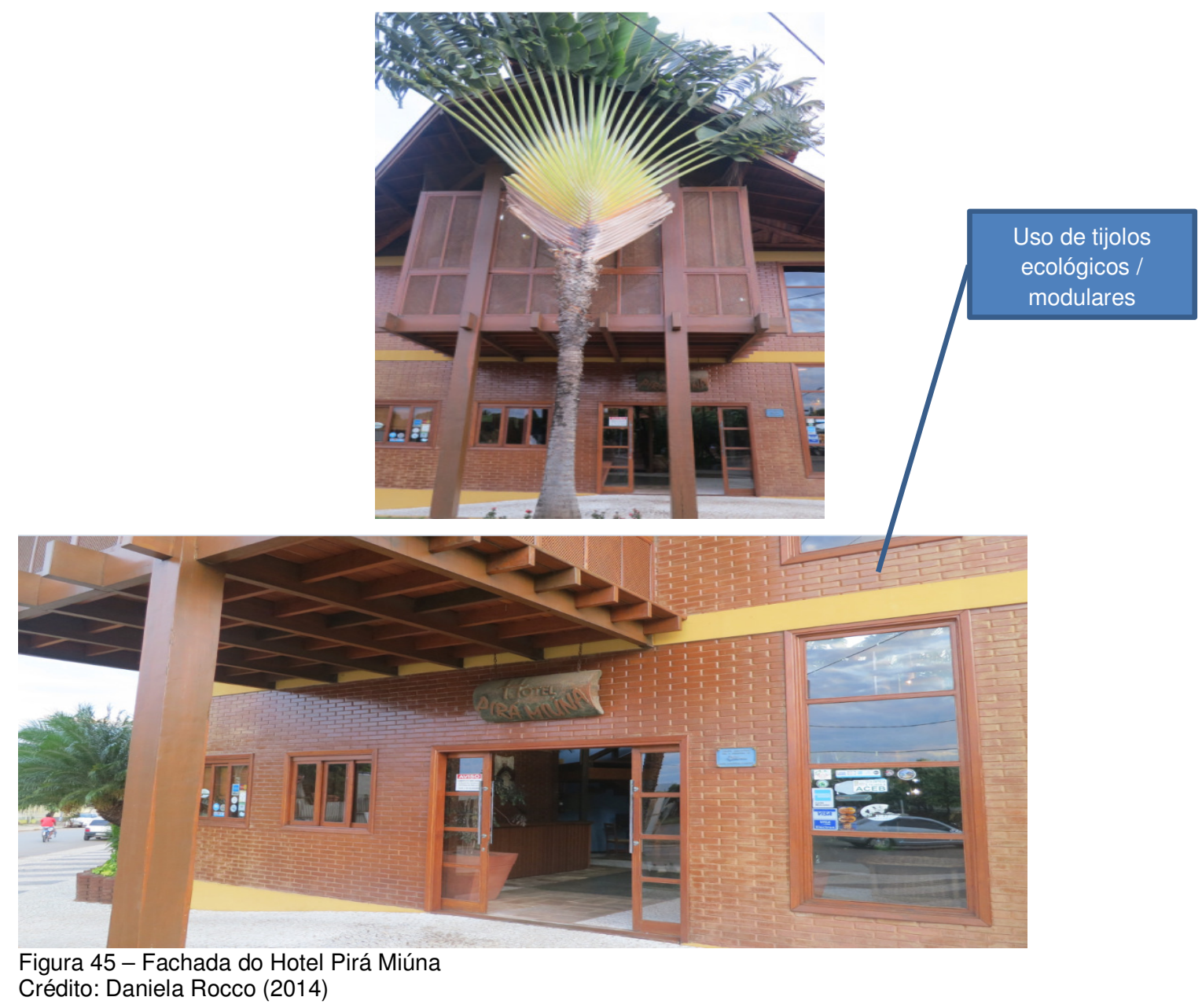




\begin{tabular}{|c|c|c|c|}
\hline \multicolumn{4}{|c|}{ MIST (MATRIZ DE INOVAÇÃO PARA A SUSTENTABILIDADE NO TURISMO) - SEGMENTO: MEIOS DE HOSPEDAGEM - CASE: HOTEL PIRÁ MIÚNA } \\
\hline ATRIBUTOS & $\begin{array}{l}\text { CARACTERIZAÇÃO DO MODELO DE } \\
\text { NEGÓCIO INOVADOR }\end{array}$ & PRÁTICAS DE INOVAÇÃO PARA A SUSTENTABILIDADE & $\begin{array}{c}\text { DESAFIOS, METAS E AVALIAÇÃO } \\
\text { GERAL }\end{array}$ \\
\hline $\begin{array}{l}\text { Inovação } \\
\text { - Incremental } \\
\text { O Hotel criou diversas } \\
\text { inovações incrementais com } \\
\text { princípios de sustentabilidade. } \\
\text { Um exemplo é oferecer café da } \\
\text { manhã a la carte no período de } \\
\text { baixa temporada com livre } \\
\text { escolha do hóspede a partir de } \\
\text { uma seleção de bebidas e } \\
\text { comidas que ele deseja } \\
\text { consumir. Isto acarretou na } \\
\text { diminuição de desperdício. } \\
\text { - Aberta } \\
\text { O Hotel participa de um grupo } \\
\text { de meios de hospedagem que } \\
\text { busca utuação } \\
\text { empresarial mais sustentável. } \\
\text { São, no total, dez membros de } \\
\text { meios de hospedagem. }\end{array}$ & $\begin{array}{l}\text { Modelo de negócio } \\
\text { No DNA do hotel existem princípios de } \\
\text { sustentabilidade e desde então se procura criar e } \\
\text { desenvolver ações sustentáveis e que agreguem } \\
\text { valor à experiência do hóspede. } \\
\text { Valor ofertado / diferencial } \\
\text { Atendimento dos colaboradores e localização } \\
\text { central. Inovações incrementais com princípios } \\
\text { de sustentabilidade. } \\
\text { Associados / Parceiros: } \\
\text { - ACEB (Associação Comercial e Empresarial de } \\
\text { Bonito) } \\
\text { - ABRASEL (Associação Brasileira de Bares e } \\
\text { Restaurantes) - MS } \\
\text { - ABH Associação Bonitense de Hotelaria } \\
\text { - Bonito Convention \& Visitors Bureau } \\
\text { - IASB (Instituto das Águas da Serra da } \\
\text { Bodoquena) } \\
\text { - Fundação Neotrópica do Brasil } \\
\text { - SENAC (Serviço Nacional de Aprendizagem } \\
\text { Comercial) / PRONATEC (Programa Nacional de } \\
\text { Acesso ao Ensino Técnico e Emprego) }\end{array}$ & 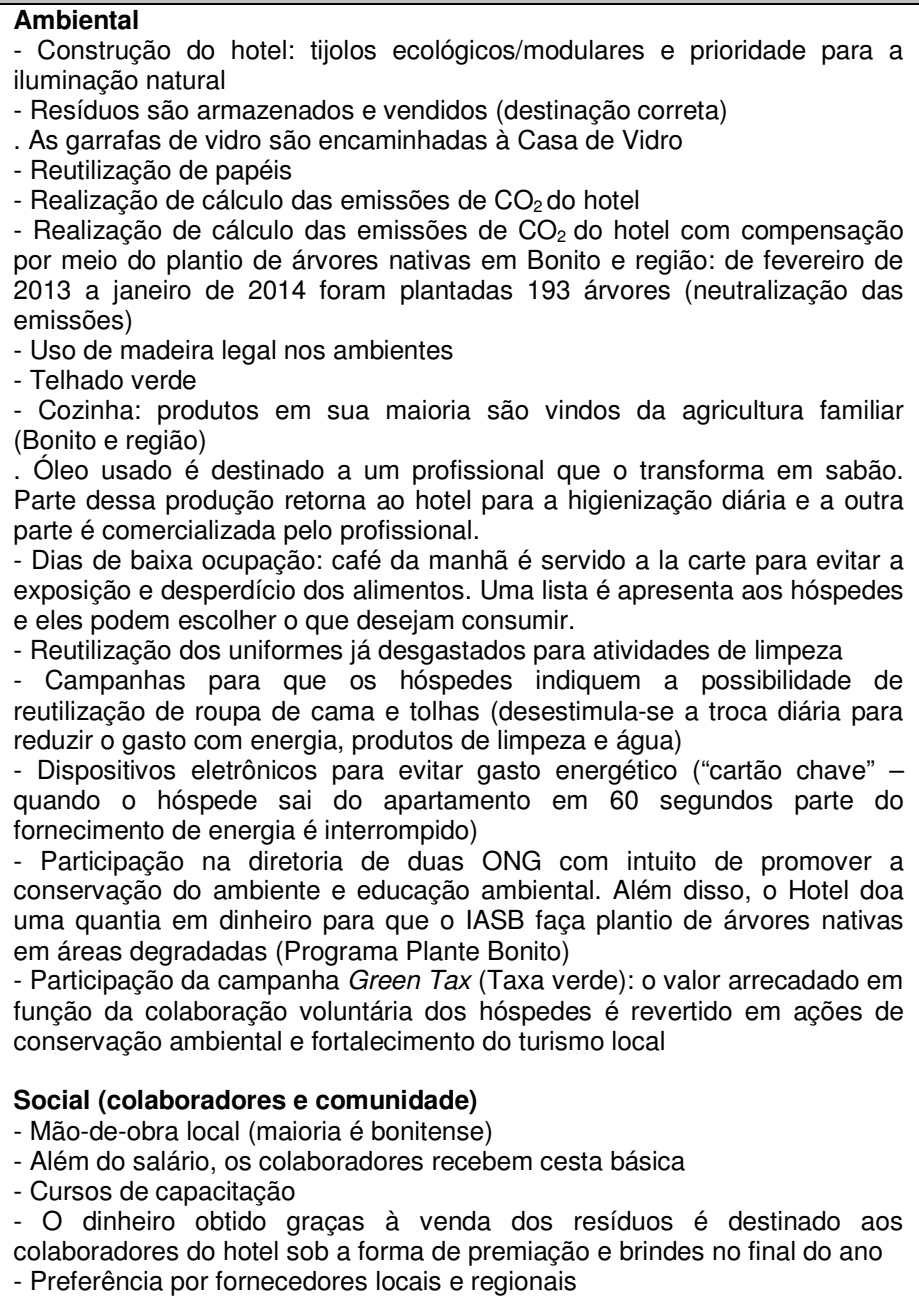 & $\begin{array}{l}\text { Desafios: } \\
\text { - Dificuldade de empregar mão-de- } \\
\text { obra local e consolidar equipes (alta } \\
\text { rotatividade) } \\
\text { - Sazonalidade } \\
\text { - Baixa qualificação da comunidade } \\
\text { local } \\
\text { Metas: } \\
\text { - Reformulação do Marketing da } \\
\text { empresa } \\
\text { - Execução de atividades com maior } \\
\text { abrangência em termos de } \\
\text { sustentabilidade de do } \\
\text { - Manutenção de equipe de } \\
\text { colaboradores } \\
\text { - Capacitação contínua dos } \\
\text { colaboradores } \\
\text { Avaliação geral: } \\
\text { Modelo de negócio inovador que } \\
\text { adota princípios de sustentabilidade. } \\
\text { O foco das ações do hotel encontra- } \\
\text { se na dimensão ambiental da } \\
\text { sustentabilidade, porém neste caso } \\
\text { especificamente, percebe-se maior } \\
\text { integração dessa dimensão com as } \\
\text { demais. Exemplo: Destino correto } \\
\text { dos resíduos (ambiental) e o valor } \\
\text { da venda dos mesmos que é } \\
\text { destinado aos colaboradores } \\
\text { (social). }\end{array}$ \\
\hline
\end{tabular}




\begin{tabular}{|c|c|c|c|}
\hline $\begin{array}{l}\text { (Continua) } \\
\text { ATRIBUTOS }\end{array}$ & $\begin{array}{l}\text { CARACTERIZAÇÃO DO MODELO DE } \\
\text { NEGÓCIO INOVADOR }\end{array}$ & PRÁTICAS DE INOVAÇÃO PARA A SUSTENTABILIDADE & $\begin{array}{c}\text { DESAFIOS, METAS E AVALIAÇĀO } \\
\text { GERAL }\end{array}$ \\
\hline & & $\begin{array}{l}\text { Social (colaboradores e comunidade) - continuação } \\
\text { - Comercialização de produtos (doces, conservas e geleias) do Projeto } \\
\text { Social "Pé da Serra" } \\
\text { - Gratificação no final do ano } \\
\text { - Dos } 41 \text { apartamentos, dois são adaptados para pessoas com } \\
\text { necessidades especiais } \\
\text { Cultural } \\
\text { - Decoração do hotel possui peças da cultura local e regional } \\
\text { - Incentivo para que os colaboradores conheçam os atrativos turísticos de } \\
\text { Bonito e região } \\
\text { - Apoio e participação em eventos locais e regionais } \\
\text { - Parceria com o SENAC/PRONATEC: o hotel disponibiliza gratuitamente } \\
\text { um espaço para a realização de atividades práticas de cursos de } \\
\text { qualificação profissional } \\
\text { Econômica } \\
\text { - Realização de pesquisas contínuas de satisfação dos hóspedes (no } \\
\text { momento do check out) } \\
\text { - Participação do hotel em um grupo de meios de hospedagem que busca } \\
\text { uma atuação empresarial mais sustentável } \\
\text { - Índice de satisfação dos hóspedes (via Booking.com): } 8,4 \\
\text { Valor da diária: R } \$ 260,00 \text { (apartamento duplo na categoria luxo baixa } \\
\text { temporada) } \\
\text { - Na alta temporada a taxa média de ocupação é de } 75 \% \text { e na baixa } \\
\text { temporada a taxa média de ocupação é cerca de } 30 \% \text {. }\end{array}$ & \\
\hline
\end{tabular}

Quadro 20 - MIST do Hotel Pirá Miúna: Bonito (MS)

Fonte: Dados da pesquisa (2014). 


\section{Breve caracterização do perfil de turistas de Bonito (MS)}

Foram entrevistados no destino 50 turistas, dentre os quais $60 \%$ são do sexo feminino. A faixa etária mais recorrente da amostra é de 31 a 45 anos (54\%) e apenas 10\% dos entrevistados encontram-se acima dos 61 anos. São Paulo é o maior estado emissor de turistas para a cidade de Bonito. Em segundo lugar são turistas do próprio estado do Mato Grosso do Sul e em terceiro o Paraná. A maior região emissora de turistas para Bonito é a Sudeste, com 62\%. Em seguida se destacam a região Sul, com 18\% e a região CentroOeste. A região que menos emite turistas, nesta amostra, é a Norte, com $2 \%$. Vale destacar, nesta breve caracterização, que a maior parte dos turistas entrevistados que visita a cidade é proveniente de não capitais, com 58\%.

O gráfico 09 a seguir indica a motivação principal do turista entrevistado para conhecer Bonito. De acordo com 16\% dos turistas as belezas naturais da região foi o fator decisivo, assim como o fato de já terem ouvido falar muito bem do destino, seja na mídia impressa, televisiva e/ou internet (16\%). Para 14\% a curiosidade de se conhecer o destino foi fundamental, enquanto que apenas $2 \%$ dos turistas decidiram visitar o destino em função de indicação de agência de viagem.

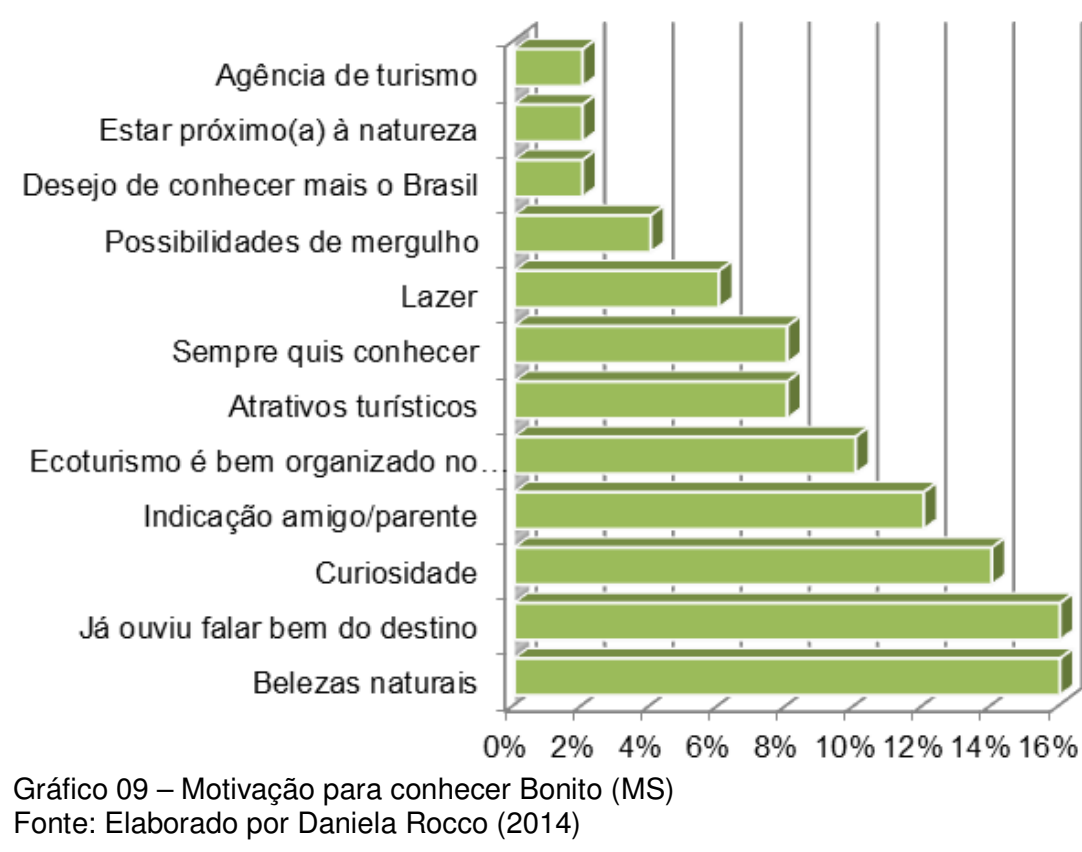

O principal diferencial/inovação de Bonito está nas belezas naturais, com 54\%. De acordo com relatos de alguns turistas a região é peculiar e não existe igual no Brasil e até no mundo. O segundo diferencial mais evidente entre os entrevistados é a organização do ecoturismo, com 14\%. Os diferenciais citados, porém menos expressivos, foram: 
possibilidades de mergulho, o fato de não existir sinaleiras de trânsito na cidade, a Gruta do Lago Azul, a conservação da natureza, guias de turismo bem informados, o ambiente rústico, entre outros. Quando questionados se aquele diferencial/inovação foi decisivo para escolher Bonito, $80 \%$ dos entrevistados disseram que sim. Os que disseram não justificaram, de forma geral, assim:

- Diferencial citado: Ecoturismo é bem organizado no destino; O que foi decisivo: i) visitou Bonito porque tinha curiosidade; ii) existe uma boa infraestrutura para os turistas, cavernas são bem sinalizadas e as ações não prejudicam a natureza; iii) gosta sempre de viajar, é levado pela curiosidade e iv) vontade de conhecer pelo o que viu na TV.

O gráfico 10 está relacionado à frequência que os turistas entrevistados usam serviços turísticos sustentáveis. A maioria disse "às vezes", com 46\%. Em seguida: "quase sempre", com 30\%, "sempre", com 14\%, "nunca", com 6\%, e "raramente"/“não sabe" com $2 \%$ cada um. É preciso salientar que "não sabe" significa o desconhecimento do que seja um "serviço turístico sustentável".

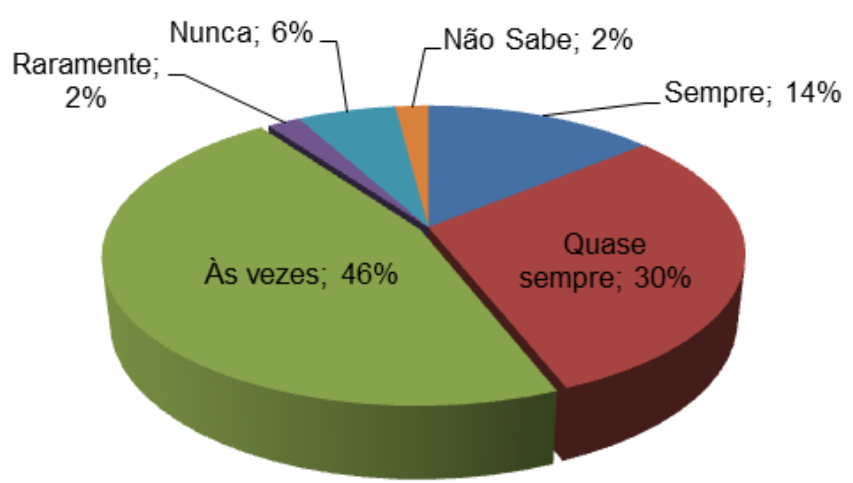

Gráfico 10 - Frequência que usa serviços turísticos sustentáveis: turistas de Bonito (MS) Fonte: Elaborado por Daniela Rocco (2014)

Segundo entrevista com o representante do COMTUR (Conselho Municipal de Turismo) e SETUR (Secretaria Municipal de Turismo), Bonito tem vivido atualmente uma situação delicada: a visitação de turistas que não são tão conscientes com relação à importância da sustentabilidade. Muitos deles querem conhecer o "melhor destino do Brasil", o "mais premiado", e por vezes consideram os passeios caros e não estão atentos a todo processo de conservação, que por sua vez tem um custo. Ou, ainda, consideram importante a conservação, mas não praticam a sustentabilidade no cotidiano e nem sempre estão dispostos a pagar por um serviço turístico sustentável que seja caro. De acordo com o sócio proprietário da agência de viagens e turismo Bonitour, só um passeio de asa delta no Rio de Janeiro custa em média $R \$ 300,00$, e a média do valor dos passeios de Bonito é de $\mathrm{R} \$ 120,00$. De toda forma, a maioria deseja fazer mais de um passeio, o que demanda um 
gasto maior. Seria importante, portanto, aprofundar a pesquisa para identificar um perfil mais completo da demanda turística que visita a cidade ${ }^{54}$.

Por fim, merece destaque as possibilidades de melhoria do destino, uma vez que, depois que foram identificadas as sugestões e observações, os atores locais possam avaliar a viabilidade de cada uma. A pergunta esteve direcionada sobre o que Bonito deveria oferecer para garantir o retorno do visitante e, assim, tentar identificar caminhos para que o destino se torne ainda mais competitivo. A sugestão mais citada pelos turistas foi disponibilizar mais voos regulares no aeroporto de Bonito, com 16\%. Ora, se a cidade busca mais qualidade e menos quantidade, tal como disse o representante do COMTUR/SETUR, então entendemos que seja necessário criar ações de marketing apropriadas para aquele visitante que não seja um "ecoturista nato" e que nem sempre está disposto a pagar pelo grau de excelência em termos de sustentabilidade. É preciso ainda fortalecer ações de marketing que efetivamente sejam direcionadas para o público-alvo que se pretende atingir: os ecoturistas.

\subsection{GRAMADO (RS)}

A Serra Gaúcha se destaca no Brasil por ser pioneira em muitas iniciativas relacionadas direta e indiretamente ao turismo, como a criação da primeira cooperativa do Brasil (em Nova Petrópolis), a certificação ABNT NBR ISO 14001:2004 e ABNT NBR ISO 9001:2008 da única locomotiva com fins turísticos do País (trecho entre Carlos Barbosa e Bento Gonçalves), a implementação do Tour da Experiência na Região da Uva e do Vinho, a formatação de hotéis de charme e o processo de certificação de hotéis sustentáveis (inclusive na categoria "hotel de charme").

Em Gramado as inovações são ainda mais frequentes, como a criação i) da primeira fábrica de chocolate do Brasil a produzir chocolate artesanal; ii) do maior evento de Natal (Natal Luz); iii) do primeiro parque de neve indoor das Américas (Snowland); iv) do único parque temático do mundo sobre a cultura gaúcha (Parque Gaúcho); v) do maior festival de cinema da América Latina (Festival de Cine de Gramado); vi) do primeiro museu de perfume do Brasil (Museu do Perfume - Fragram); vii) do primeiro museu de cera da América Latina a expor ícones do cinema e da cultura pop (Dreamland - Museu de Cera); viii) do primeiro

\footnotetext{
${ }^{54}$ Não foi objetivo do presente trabalho identificar com profundidade o perfil dos turistas dos três destinos turísticos selecionados. De toda forma, a breve caracterização do perfil dos turistas de cada destino é importante para complementar as análises da tese.
} 
espaço da América Latina a expor motos Harley Davidson (Harley Motor Show - Museu de Motos); ix) do primeiro parque de lavanda do Brasil (Le Jardin - Parque de Lavanda) e x) da única fábrica de cristal artístico do Rio Grande do Sul (Cristais de Gramado) (GRAMADO, 2014a). Além disso, em Gramado está localizado o Kurotel (Centro Médico de Longevidade, eleito como o melhor SPA do mundo pela Seven Star Global Luxury Awards) e próximo à cidade está localizado o maior templo budista da América do Sul (Templo Budista de Três Coroas - fica a 26 km de Gramado).

Em 2013 foi realizada a cerimônia do I Prêmio Inovação do Turismo, promovido pela Secretaria do Turismo do Rio Grande do Sul. O prêmio, que foi dividido em sete categorias e por segmentos, recebeu 178 trabalhos, no entanto, foram 25 ganhadores. Entre eles, cinco são de Gramado, a saber:

- Categoria 2 - Melhores Práticas em Estruturação de Produto, segmento turismo de estudos e intercâmbio: Gramadozoo, o zoológico mais brasileiro do Brasil Gramado;

- Categoria 4 - Melhores Práticas em entretenimento e lazer, segmento melhor roteiro turístico: "Roteiros de Agroturismo de Gramado - O Quatrilho, Raízes Coloniais e Tour do Vale";

- Categoria 5 - Melhor prática em acessibilidade e inclusão no turismo, segmento infraestrutura para portadores de deficiência - acessibilidade universal: Villa Bella Hotel Conceito;

- Categoria 7 - Melhor Prática em Promoção de Produtos e Destinos, segmento estratégia de promoção: "Divulgação Internacional de Gramado";

- Hors Concours: Natal Luz de Gramado (o maior atrativo turístico do estado do Rio Grande do Sul) (SETUR RS, 2013).

A cidade também tem investido nas inovações tecnológicas. Se antes existia acesso gratuito a wi-fi apenas no Centro de Apoio ao Turista, agora um dos atrativos da cidade já disponibiliza essa tecnologia também: a Rua Coberta. Essa iniciativa foi anunciada em julho de 2014 em parceria com uma operadora de telefonia, permitindo que o acesso ao wi-fi também seja gratuito (GRAMADO, 2014b). Outra inovação tecnológica é o lançamento em breve do app "Gramado Inesquecível" (http://www.gramadoinesquecivel.tur.br/), cujo formato é exibido na Figura 46. 


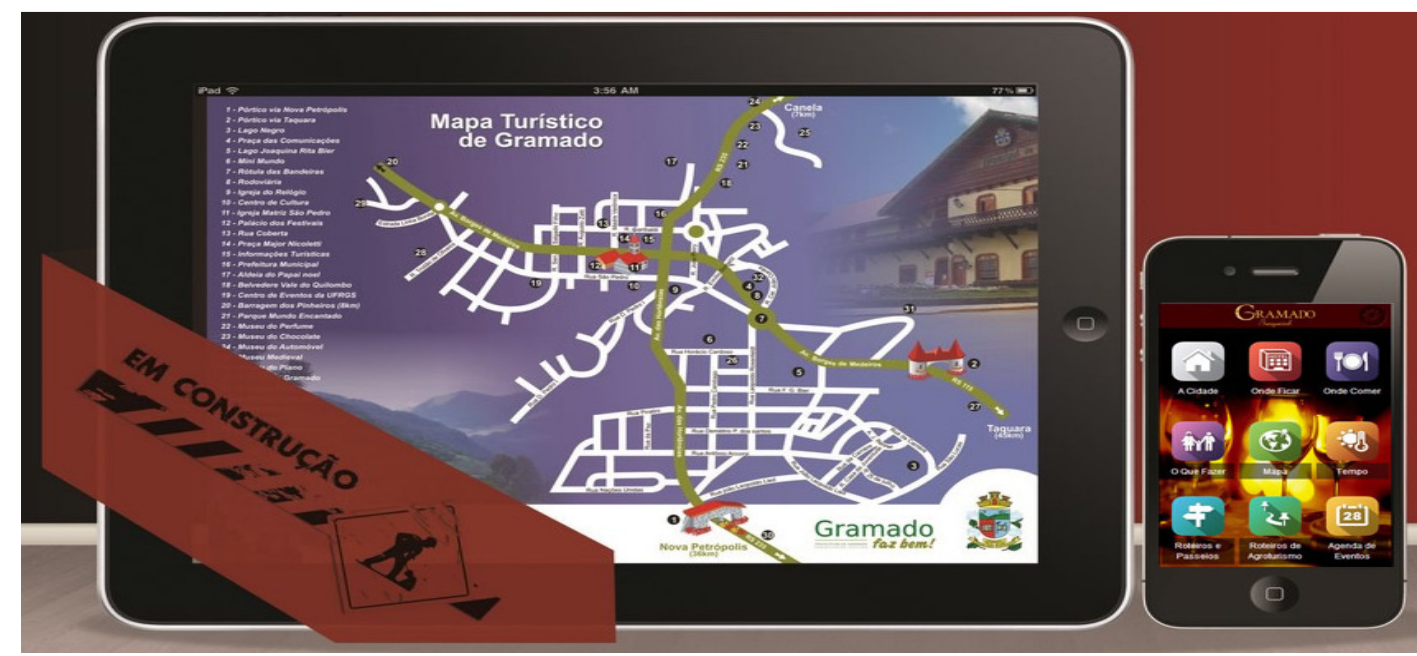

Figura 46 - App Gramado Inesquecível em construção

Fonte: Print do site Gramado Inesquecível (2014)

No tocante à inovação para a sustentabilidade na cidade, merece evidência a Praça das Etnias (vide Figura 47). A iluminação de toda praça é gerada a partir de energia eólica e solar (sistema híbrido). Como a empresa que instalou esse sistema é de Gramado, é uma forma de difundir o uso de energias renováveis nas casas de particulares.

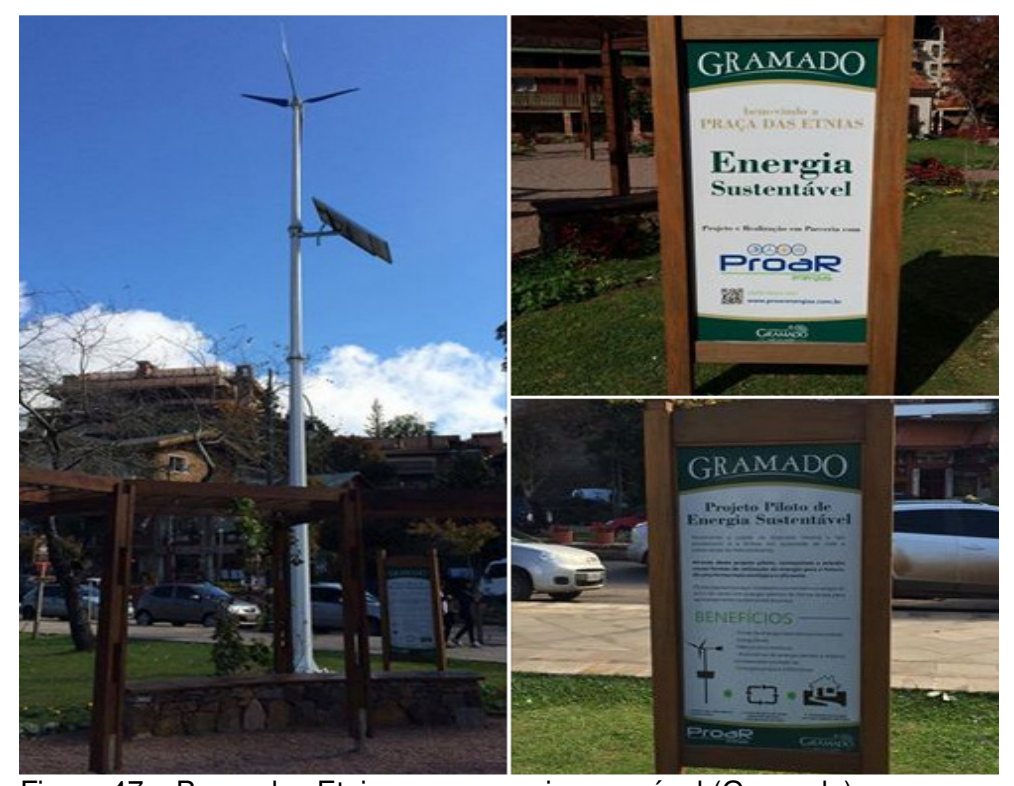

Figura 47 - Praça das Etnias com energia renovável (Gramado) Crédito: Daniela Rocco (2014)

Gramado recebe, por ano, cerca de 6 milhões de visitantes, é o 6ํㅜ destino que os brasileiros mais desejam conhecer (FIPE, 2012) e em 2013 foi considerada pela revista Viagem e Turismo o melhor destino turístico de inverno do Brasil (VIAGEM E TURISMO, 2013). Esse reconhecimento é resultado da escolha do público e de um júri, que avalia, 
entre outros critérios, a inovação, a contemporaneidade e o atendimento ao cliente. $\mathrm{Na}$ cidade são mais de 50 atrativos e passeios entre museus, parques, fábricas de chocolate, roteiros de agroturismo, entre outros, 140 meios de hospedagem, 51 agências de turismo e viagens e 150 estabelecimentos de gastronomia. Aproximadamente $85 \%$ da arrecadação municipal é proveniente do turismo.

A pesquisa de campo em Gramado foi realizada entre os dias 12 e 19 de maio de 2014. Para os turistas que chegam por via aérea em voos comerciais existem basicamente duas formas de se chegar a Gramado. A primeira é pelo Aeroporto Internacional Salgado Filho de Porto Alegre (o maior do estado Rio Grande do Sul). Da capital gaúcha a Gramado são $115 \mathrm{~km}$. A segunda forma é pelo Aeroporto de Caxias do Sul, distante $70 \mathrm{~km}$ de Gramado. A primeira opção oferece mais facilidades aos usuários, pois dentro do próprio aeroporto existe um guichê de transporte rodoviário intermunicipal, bem como um espaço para embarque/desembarque de ônibus (o ônibus que vai para Gramado/Canela parte da rodoviária e depois vai para o aeroporto buscar os outros passageiros). Esta é uma iniciativa inovadora de integração da oferta turística entre a capital gaúcha e cidades da região, sobretudo aquelas situadas na Serra Gaúcha. Embora o aeroporto de Caxias do Sul seja o mais próximo de Gramado, o usuário tende a utilizar as opções convencionais: táxi, aluguel de carro ou ônibus que parte da rodoviária.

Em Gramado foram feitas observação direta e entrevistas com nove atores locais vinculados ao turismo direta e indiretamente. São eles: i) recepcionista de hotel; ii) diretora da Secretaria Municipal de Turismo; iii) coordenadora da Secretaria Municipal de Turismo; iv) diretor da Secretaria Municipal de Meio Ambiente; v) Guia de turismo local do Sindicato de Guias de Turismo da Região das Hortênsias; vi) garçom e taxista; vii) atendente do Centro de Apoio ao Turista; viii) produtor rural (Festa da Colônia) e ix) recepcionista de hotel.

A percepção geral da cidade foi bastante positiva, assim como de seus serviços, equipamentos e atrativos turísticos. A saúde e segurança estão bem organizadas. No caso da saúde, a maioria dos entrevistados disse que a população prefere utilizar o SUS (Serviço Único de Saúde), pois o atendimento é muito bom. Entretanto, algumas especialidades médicas não estão disponíveis, o que faz com que moradores tenham que se deslocar para cidades mais próximas em busca de tais especialidades. Existe padronização das casas, comércio e ruas, e isto é regulado via lei municipal de 1973. As sinalizações (vide Figura 48) dialogam com o ambiente, a cidade é limpa, possui banheiros públicos limpos (vide Figura 49) e existe coleta seletiva (divisão dos resíduos secos e orgânicos), a fiação elétrica do microcentro é cabeada e existe lei municipal de 1973 que dispõe sobre a necessidade da educação para o turismo nas escolas. Na Casa do Colono existe exposição e comercialização de produtos orgânicos, quitutes típicos e artesanatos (vide Figura 50). 
Segundo a maioria dos entrevistados, a população em geral é bastante educada e cuida para que os jardins da cidade e de suas casas não sejam danificados. Todavia, um dos maiores problemas que a cidade enfrenta é na alta temporada, quando se enfrenta um longo período de engarrafamento na própria cidade e no pequeno trecho de estrada entre Gramado e Canela (são 7 km). Outro problema identificado por meio de observação e entrevistas junto aos turistas é a dificuldade de usar transporte público e pouca quantidade de táxis disponíveis na cidade: são apenas 35, distribuídos por sua vez em quatro pontos: rodoviária, Rua Garibaldi, Igreja São Pedro, Rua Coberta e Prefeitura. Apesar de existir poucos táxis, restaurantes e fábricas de chocolate disponibilizam um serviço de transporte gratuito de van compartilhada, buscando e levando de volta as pessoas que estiverem hospedadas em hotéis e pousadas. Para isso, é preciso realizar ligação e reservar o horário para que a van chegue. No centro de Gramado não existe ciclovia, porém existe um projeto em desenvolvimento para se criar uma ciclovia que interliga Gramado de Canela, cidade vizinha e que possui uma oferta turística potencial.

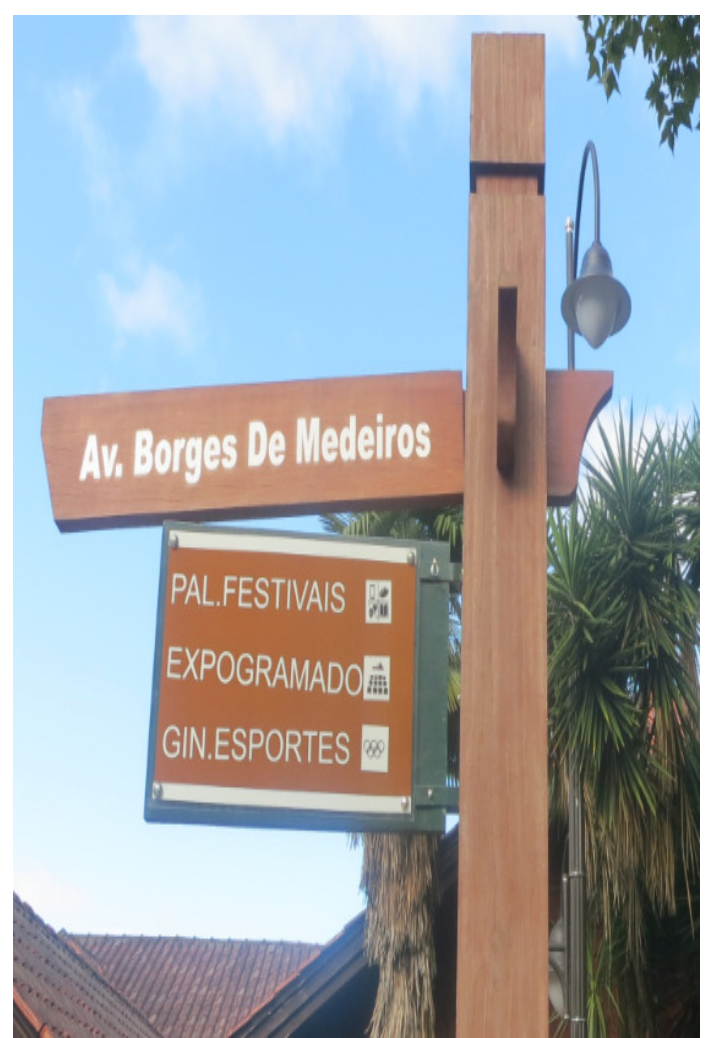

Figura 48 - Sinalização em Gramado Crédito: Daniela Rocco (2014)

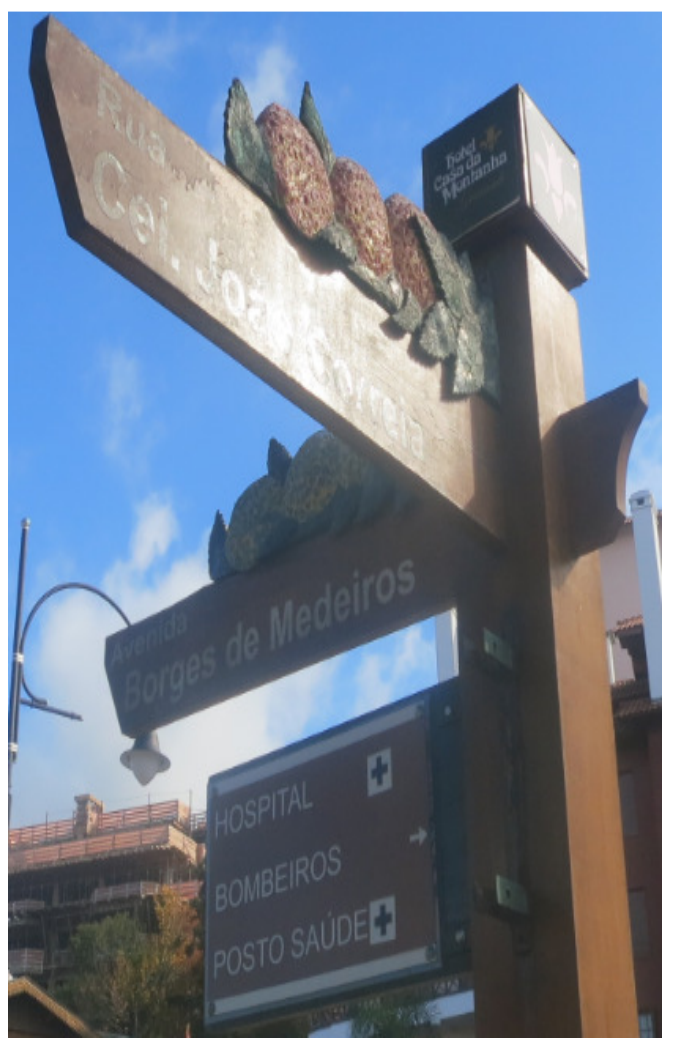



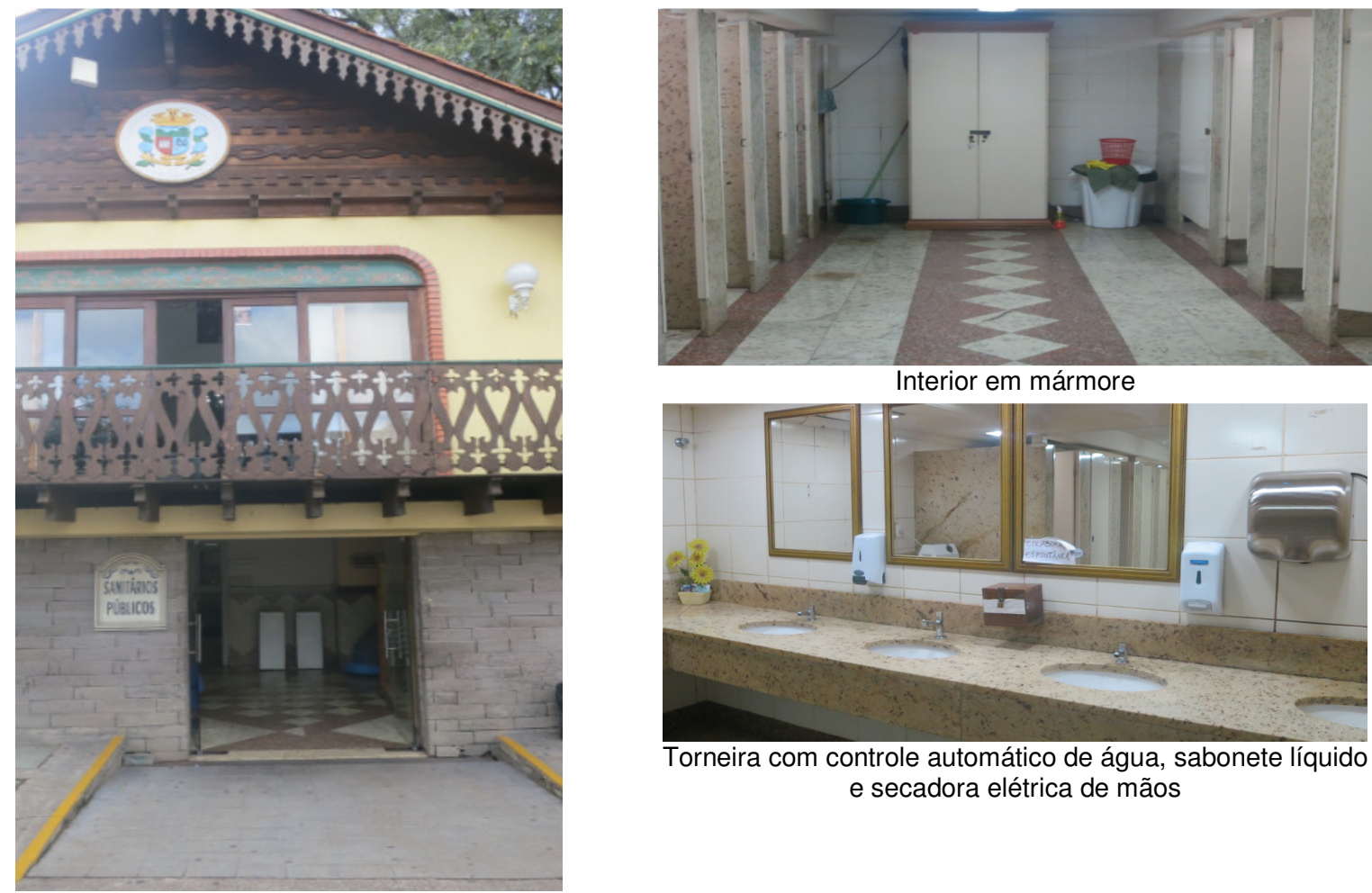

Torneira com controle automático de água, sabonete líquido e secadora elétrica de mãos

Banheiro público no mesmo prédio do Centro de Apoio ao Turista (centro da cidade) e com acessibilidade

Figura 49 - Banheiro público em Gramado

Crédito: Daniela Rocco (2014)

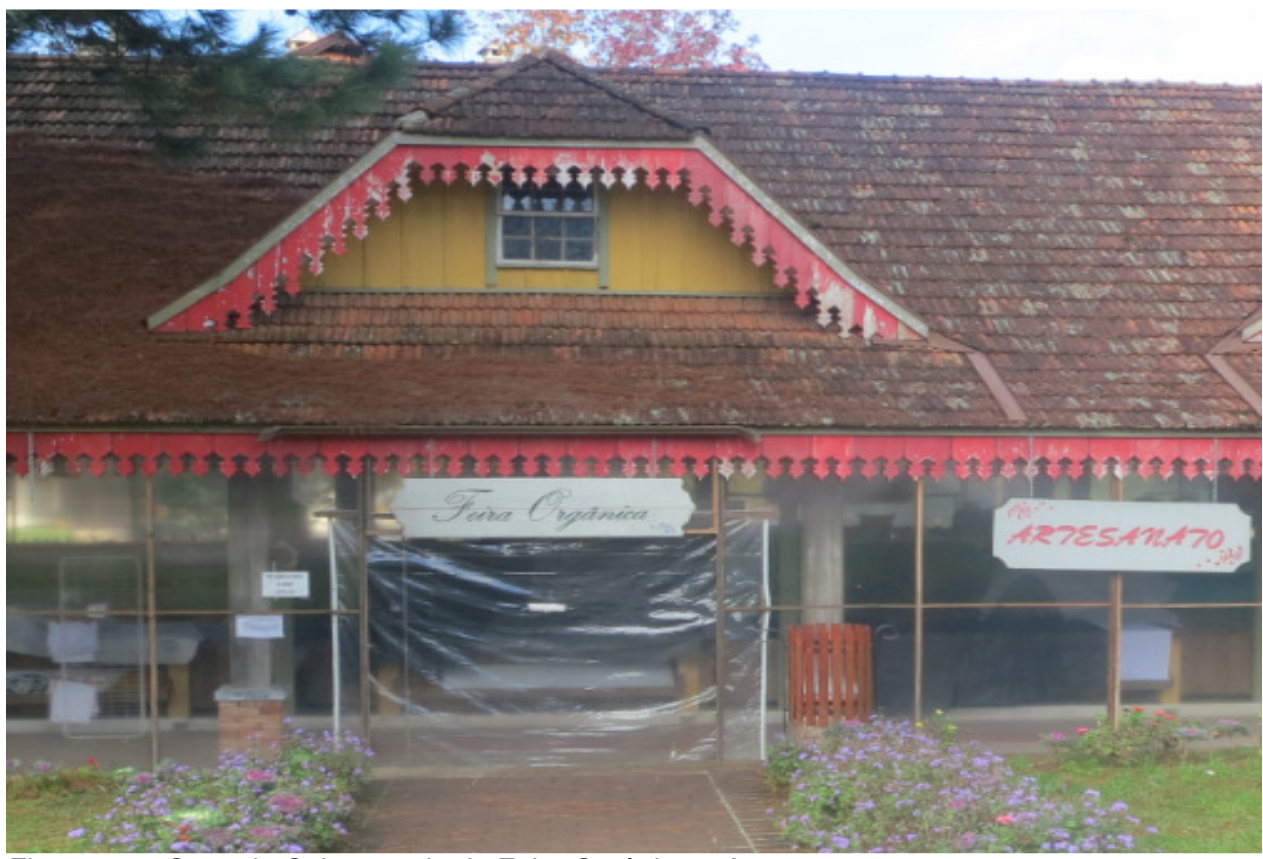

Figura 50 - Casa do Colono sede da Feira Orgânica e Artesanato

Crédito: Daniela Rocco (2014) 
No período de desenvolvimento da pesquisa de campo estava sendo realizada a tradicional Festa da Colônia (http://www.festadacoloniagramado.com.br/). O primeiro evento ocorreu em 1958 e foi importantíssimo para estimular a atividade turística na cidade. Em 2013 foram mais de 300 mil visitantes e, embora o evento não seja mais realizado na rua, e sim na ExpoGramado (centro de convenções), hoje ainda mantém algumas características, como o desfile nas ruas da cidade com carros usados no campo, apresentações culturais típicas e exposição e comercialização de produtos e quitutes artesanais (FESTA DA COLÔNIA, 2014). A Figura 51 mostra fotos da Festa da Colônia 2014.

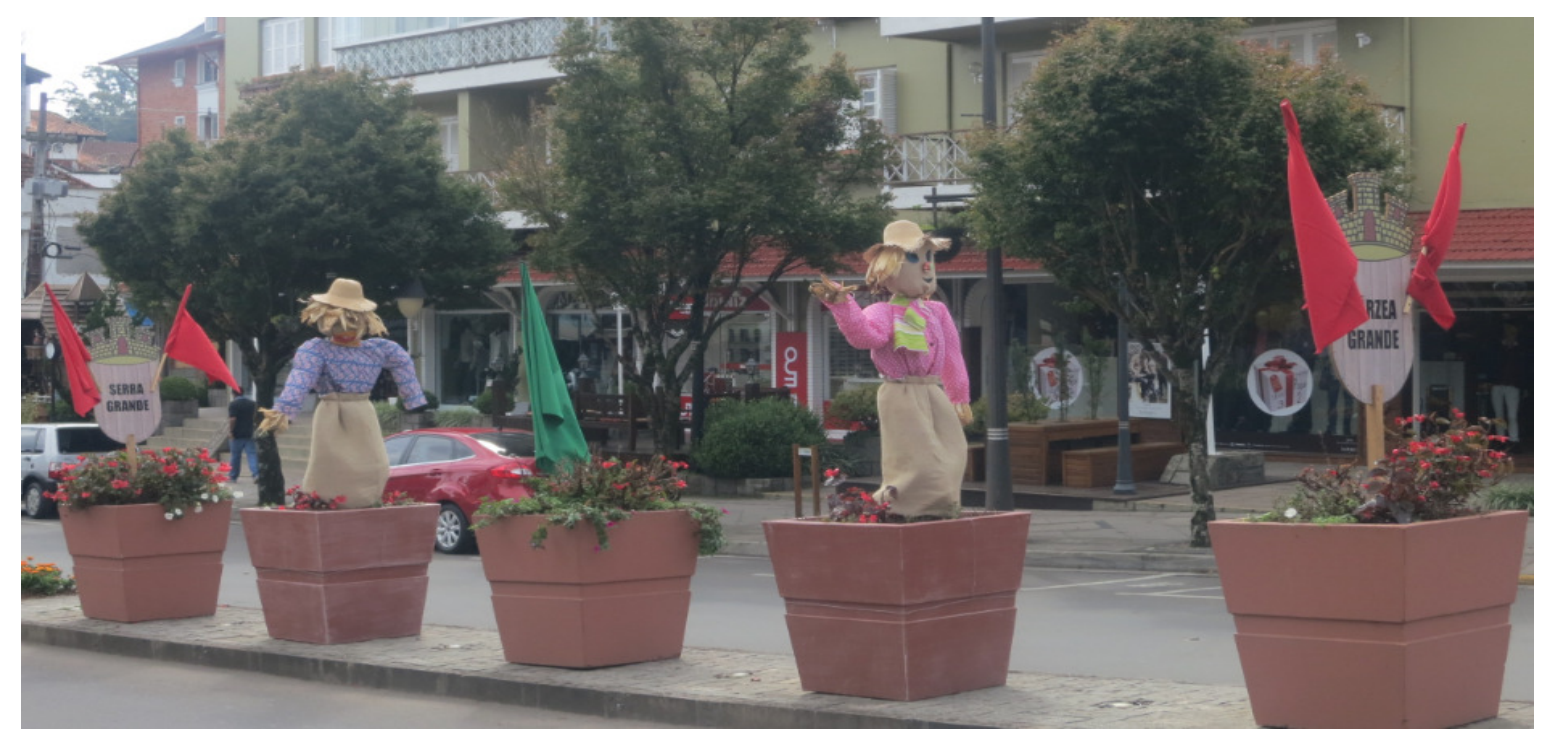

Decoração temática na cidade para a Festa da Colônia

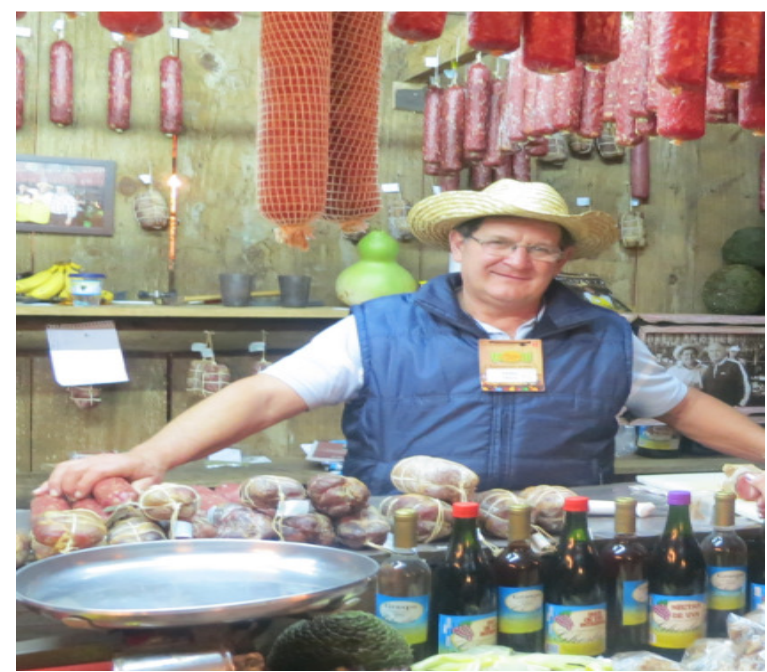

Exposição e comercialização de produtos e quitutes típicos

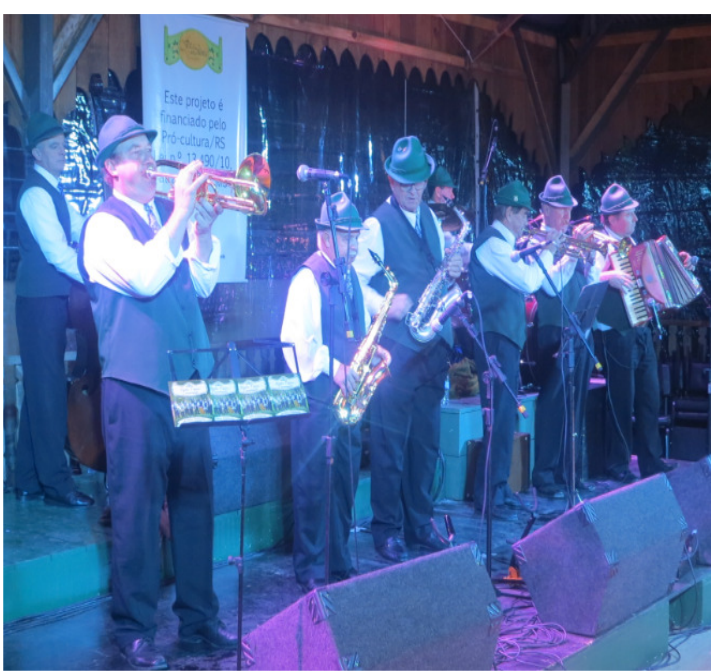

Apresentações culturais em 18 dias de festa

Figura 51 - Festa da Colônia em Gramado Crédito: Daniela Rocco (2014) 
Da mesma forma como ocorreu na pesquisa de campo em Bonito (MS), aos atores entrevistados de Gramado (entrevistas semiestruturadas) foram perguntados quais seriam os serviços, equipamentos e/ou atrativos turísticos locais que mais se destacam por práticas de inovação para a sustentabilidade. Optamos por escolher aqueles mais citados entre os atores locais para realizar uma entrevista mais aprofundada, que inclusive contou com a aplicação da MIST. Foram eleitos, assim, os hotéis Villa Bella Conceito e Bangalôs da Serra e o atrativo Parque Gaúcho. O detalhamento sobre cada "case" está exposto a seguir.

\section{Aplicação MIST: Villa Bella Hotel Conceito}

Em julho de 2014 o Villa Bella Hotel Conceito completou 25 anos e, desde então, tem colecionado prêmios e reconhecimentos, além de desenvolver inovações relacionadas à sustentabilidade. Destacam-se: i) em 2004 foi o primeiro hotel da América Latina a receber o certificado de Total Acessibilidade pelo Instituto Pestalozzi (hoje é o único de Gramado $100 \%$ acessível e integra uma lista de poucos hotéis adaptados do estado do Rio Grande do Sul); ii) em 2012 foi o primeiro hotel do Rio Grande do Sul a receber o título de quatro estrelas, de acordo com a nova reclassificação hoteleira do Sistema Brasileiro de Classificação de Meios de Hospedagem (SBClass), do Ministério do Turismo e iii) em 2013, como já foi apresentado, ganhou o I Prêmio Inovação do Turismo na categoria "Melhor prática em acessibilidade e inclusão no turismo", segmento "infraestrutura para portadores de deficiência".

O Villa Bella Hotel Conceito possui 82 apartamentos (capacidade máxima de 3 pessoas) e 5 suítes. Do total de apartamentos, 10\% são adaptados para pessoas portadoras de necessidades especiais (PPNE) e mobilidade reduzida. Nesses apartamentos existem, por exemplo, cadeiras de rodas e de banho, piso antiderrapante, pias e vasos sanitários adaptados e guias de serviço em braile. A Figura 52 a seguir mostra fotos de um quarto adaptado. A estrutura geral do hotel também é adaptada, pois as portas e corredores são mais largos e com barras de segurança e existem rampas de acesso e elevadores com indicação em braile. A área da piscina dispõe de piso antiderrapante, uma cadeira-elevador para acesso à piscina e, dentro dela, estão fixadas barras de apoio. No restaurante os cardápios (inclusive carta de vinhos) e talheres estão em braile, tal como mostra a Figura 53. A aplicação da MIST do Villa Bella Hotel consta no Quadro 21. 


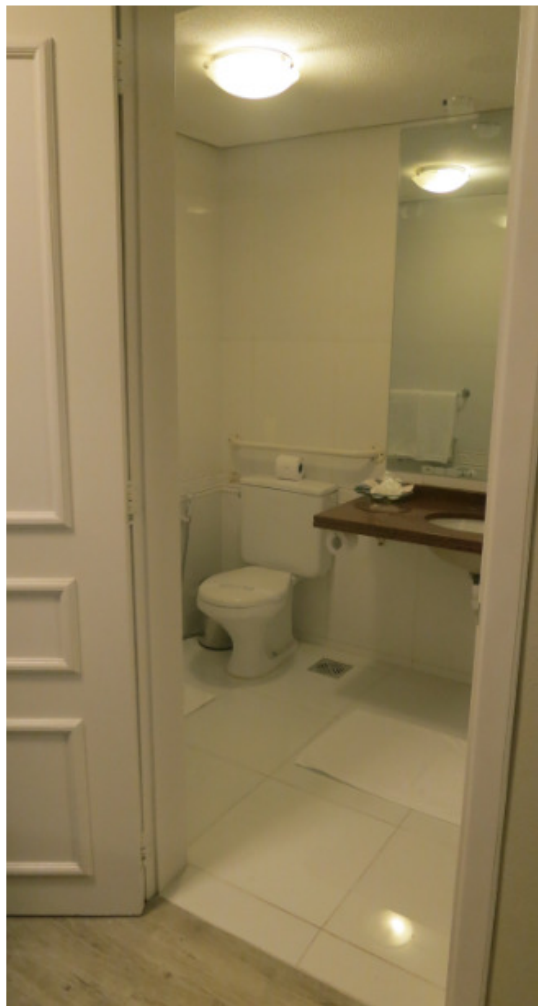

Porta do banheiro é mais larga. Próximo ao vaso sanitário existe barra de segurança

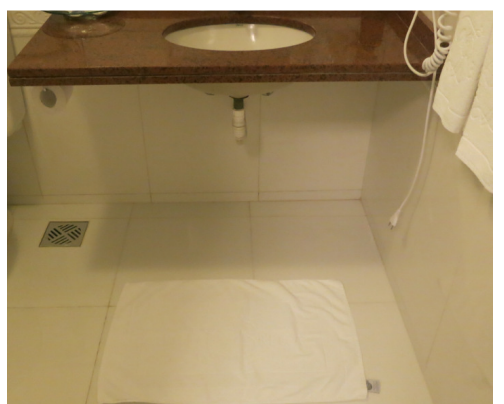

Parte interna da pia é aberta para acomodar uma cadeira de rodas

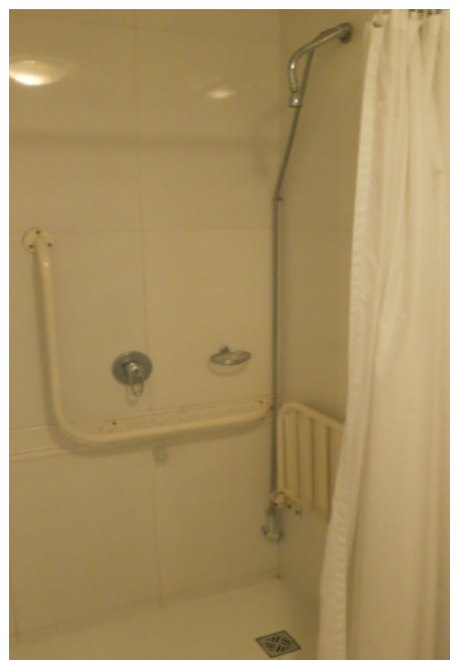

Barra de segurança e cadeira no chuveiro

Figura 52 - Fotos de banheiro adaptado de um apartamento do Villa Bella Hotel Conceito Crédito: Daniela Rocco (2014)
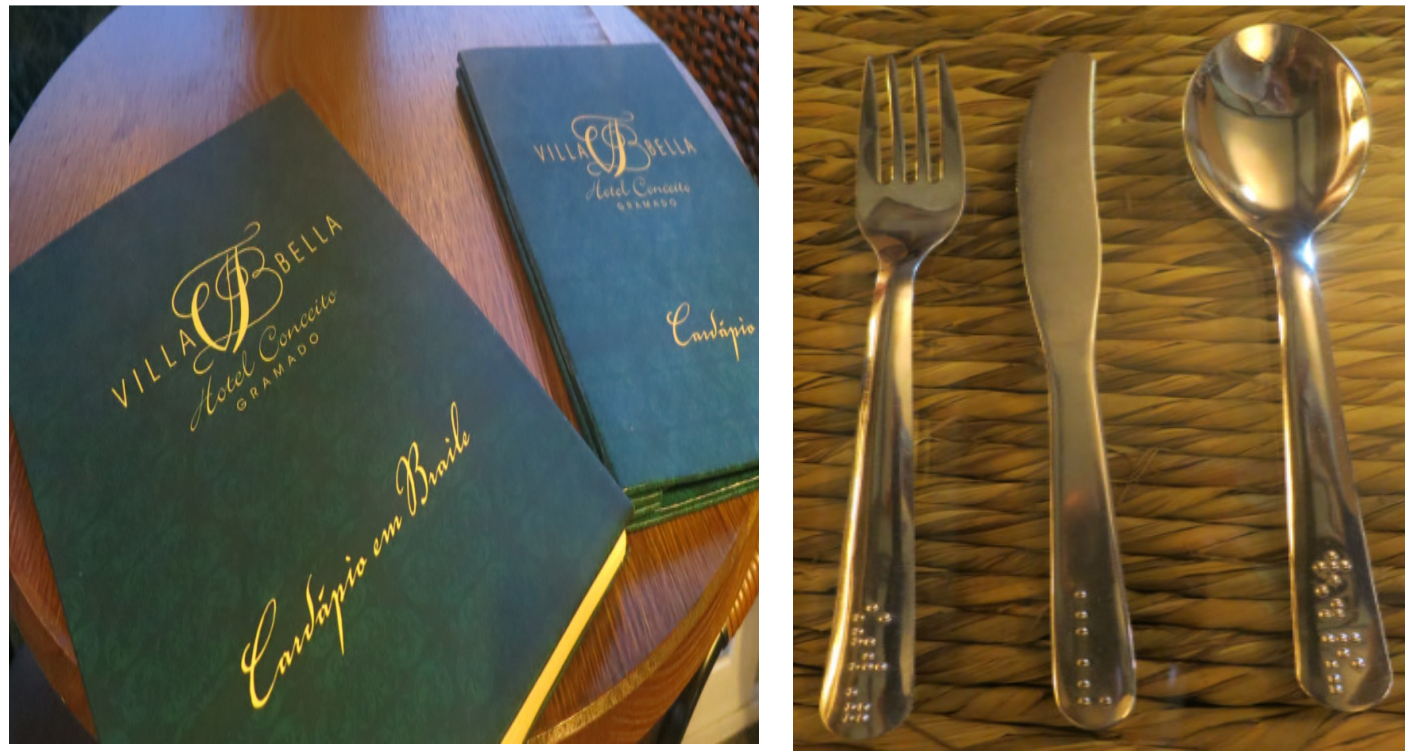

Figura 53 - Cardápio e talheres em braile Crédito: Daniela Rocco (2014) 
MIST (MATRIZ DE INOVAÇÃO PARA A SUSTENTABILIDADE NO TURISMO) - SEGMENTO: MEIOS DE HOSPEDAGEM - CASE: VILLA BELLA HOTEL CONCEITO

\begin{tabular}{|c|c|c|c|}
\hline \multicolumn{4}{|c|}{ MIST (MATRIZ DE INOVAÇÃO PARA A SUSTENTABILIDADE NO TURISMO) - SEGMENTO: MEIOS DE HOSPEDAGEM - CASE: VILLA BELLA HOTEL CONCEITO } \\
\hline ATRIBUTOS & $\begin{array}{l}\text { CARACTERIZAÇÃO DO MODELO DE } \\
\text { NEGÓCIO INOVADOR }\end{array}$ & PRÁTICAS DE INOVAÇÃO PARA A SUSTENTABILIDADE & $\begin{array}{l}\text { DESAFIOS, METAS E AVALIAÇÃO } \\
\text { GERAL }\end{array}$ \\
\hline $\begin{array}{l}\text { II. Sustentabilidade } \\
\text { O Villa Bella Hotel Conceito } \\
\text { atende às } 4 \text { dimensões: } \\
\text { - Conservação da natureza } \\
\text { - Conservação e valorização } \\
\text { da cultura } \\
\text { - Prosperidade econômica com } \\
\text { inclusão produtiva }\end{array}$ & $\begin{array}{l}\text { Certificação/ selos: } \\
\text { - Certificado de Total Acessibilidade expedido } \\
\text { pelo Instituto Pestalozzi. } \\
\text { Prêmios / reconhecimentos } \\
\text { - I Prêmio Inovação do Turismo na categoria } \\
\text { "Melhor prática em acessibilidade e inclusão no } \\
\text { turismo", segmento "infraestrutura para } \\
\text { portadores de deficiência". } \\
\text { Presença na internet: } \\
\text { - Site (Português, Inglês e Espanhol) } \\
\text { - Facebook } \\
\text { - Instagram } \\
\text { - Flicker } \\
\text { - Blog } \\
\text { - TripAdvisor }\end{array}$ & $\begin{array}{l}\text { Ambiental } \\
\text { - Coleta seletiva: } \\
\text {. Vidro e plástico: doação para empresas locais } \\
\text { - Orgânico: doação para agricultores locais (compostagem) } \\
\text { - Café da manhã: objetos são reciclados por uma empresa local } \\
\text { - Sensores de energia } \\
\text { Social (colaboradores e comunidade) } \\
\text { - Colaboradores/fornecedores externos: } \\
\text { - Maioria é local (apenas enxoval e amenities são comprados do sudeste) } \\
\text { - Serviço terceirizado de saúde (casos de emergência) } \\
\text { - Doação de agasalhos } \\
\text { - Colaboradores: } \\
\text { - Capacitação semestral dos colaboradores para melhor receberem PPNE, } \\
\text { além de cursos de profissionalização, como o PRONATEC (Programa } \\
\text { Nacional de Acesso ao Ensino Técnico e Emprego) } \\
\text {. Incentivo a realizar cursos de idiomas e graduação } \\
\text { Plano de saúde é opcional } \\
\text { Para quem sai muito tarde do hotel leva-se o colaborador para casa } \\
\text { Sistema de reconhecimento por pontuação (recompensa salarial) } \\
\text { - Conceito de administração: sem hierarquia, só o Diretor do hotel (na } \\
\text { recepção não existe o tradicional balcão de atendimento, e sim mesas de } \\
\text { atendimento) } \\
\text {. Dispõem do Manual do colaborador (orientações) } \\
\text { - Participam de workshops: 1) Conduta Villa Bella e 2) Conduta } \\
\text { Sustentabilidade } \\
\text { - Acessibilidade: } \\
\text {. Áreas comuns: corredores largos e rampas } \\
\text { Apartamentos: adaptados, com piso antiderrapante e guia de serviços em } \\
\text { braile } \\
\text {. Áreas de lazer: piscina com cadeira-elevador, barras de segurança e piso } \\
\text { antiderrapante } \\
\text {. No restaurante: cardápio de pratos, carta de vinhos e talheres em braile } \\
\text {. Elevadores e áreas sociais: também são adaptados } \\
\text { - Transporte: o hotel dispõe de uma van adaptada para cadeirantes } \\
\text { Cultural } \\
\text { - Incentivo à cultura com concertos de piano } \\
\text { - Disponibilização de um espaço amplo para artistas exporem seus } \\
\text { trabalhos (inclusive de reciclagem) } \\
\text { envolvimento com crianças: clown, atores e educação ambiental (e mais } \\
\text { - Colaboradores: primeira turma de Gramado a concluir o PRONATEC } \\
\text { (Espanhol básico) }\end{array}$ & $\begin{array}{l}\text { Avaliação geral: } \\
\text { Modelo de negócio inovador que } \\
\text { adota princípios de sustentabilidade. } \\
\text { Embora as principais ações tenham } \\
\text { um foco maior na dimensão social } \\
\text { da sustentabilidade, as demais } \\
\text { dimensões também rara são } \\
\text { consideradas no meio de } \\
\text { hospedagem. }\end{array}$ \\
\hline
\end{tabular}




\begin{tabular}{|c|c|c|c|}
\hline $\begin{array}{c}\text { (Continua) } \\
\text { ATRIBUTOS }\end{array}$ & $\begin{array}{l}\text { CARACTERIZAÇÃO DO MODELO DE } \\
\text { NEGÓCIO INOVADOR }\end{array}$ & PRÁTICAS DE INOVAÇÃO PARA A SUSTENTABILIDADE & $\begin{array}{c}\text { DESAFIOS, METAS E AVALIAÇÃO } \\
\text { GERAL }\end{array}$ \\
\hline & $\begin{array}{l}\text { Tecnologias: } \\
\text { - Display card (totem eletrônico com informações } \\
\text { turísticas de Gramado - perto do espaço do } \\
\text { Concierge) } \\
\text { - Portáteis: } \\
\text { Equipamento para digitação ("messenger"): } \\
\text { intercomunicador deficientes auditivos e e } \\
\text { colaboradores do hotel } \\
\text { Sistemas acionados com LEDS que simulam } \\
\text { campanhas/toques de telefone }\end{array}$ & $\begin{array}{l}\text { Econômica } \\
\text { - Hotel conceito (4 estrelas, conforme classificação do MTur) } \\
\text { - Oferece transporte gratuito até o centro (hóspedes) } \\
\text { - Colaboradores qualificados (exemplo: concierge com título internacional) } \\
\text { Alta temporada: não informado } \\
\text { Baixa temporada: não informado } \\
\text {. Valor médio da diária: não informado }\end{array}$ & \\
\hline
\end{tabular}

Quadro 21 - MIST do Villa Bella Hotel Conceito: Gramado (RS)

Fonte: Dados da pesquisa (2014). 


\section{Aplicação MIST: Bangalôs da Serra}

O Hotel Pousada do Vale foi inaugurado em 1986 com quatro bangalôs com 11 apartamentos no total. Anos depois, passou a se chamar Hotel Bangalôs da Serra e hoje conta com uma área de $30.000 \mathrm{~m}^{2}, 10$ prédios e 48 bangalôs divididos em cinco tipos distintos de hospedagem, acomodando de uma a cinco pessoas.

Conforme pode ser visto, o Hotel possui diversas inovações relacionadas à sustentabilidade. Além disso, os proprietários, peças-chave para a gestão sustentável do empreendimento, também inovam de forma indireta. Um exemplo é oferecer aos hóspedes a possibilidade de personalizar os apartamentos durante suas estadias. Por um custo adicional é possível colocar: buquê de rosas, cesta de chocolates, espumante, roupões personalizados, pétalas de rosa espalhadas pelo Bangalô, cesta de piquenique e almofada bordada com poesia à escolha do hóspede.

Segundo a sócia-proprietária do hotel, antes o que sobrava do café da manhã era dado aos pássaros. Porém, a partir das reuniões de orientação para conquistar a certificação ambiental, ela descobriu que aquele processo era errado. Essa constatação estimulou, assim, a profissionalização e registro dos processos, bem como o plantio de árvores frutíferas compatíveis com os pássaros recorrentes na região. A partir desse exemplo surgiram outras ações.

A Figura 54 mostra a vista aérea do Hotel e o Quadro 22 a aplicação da MIST.

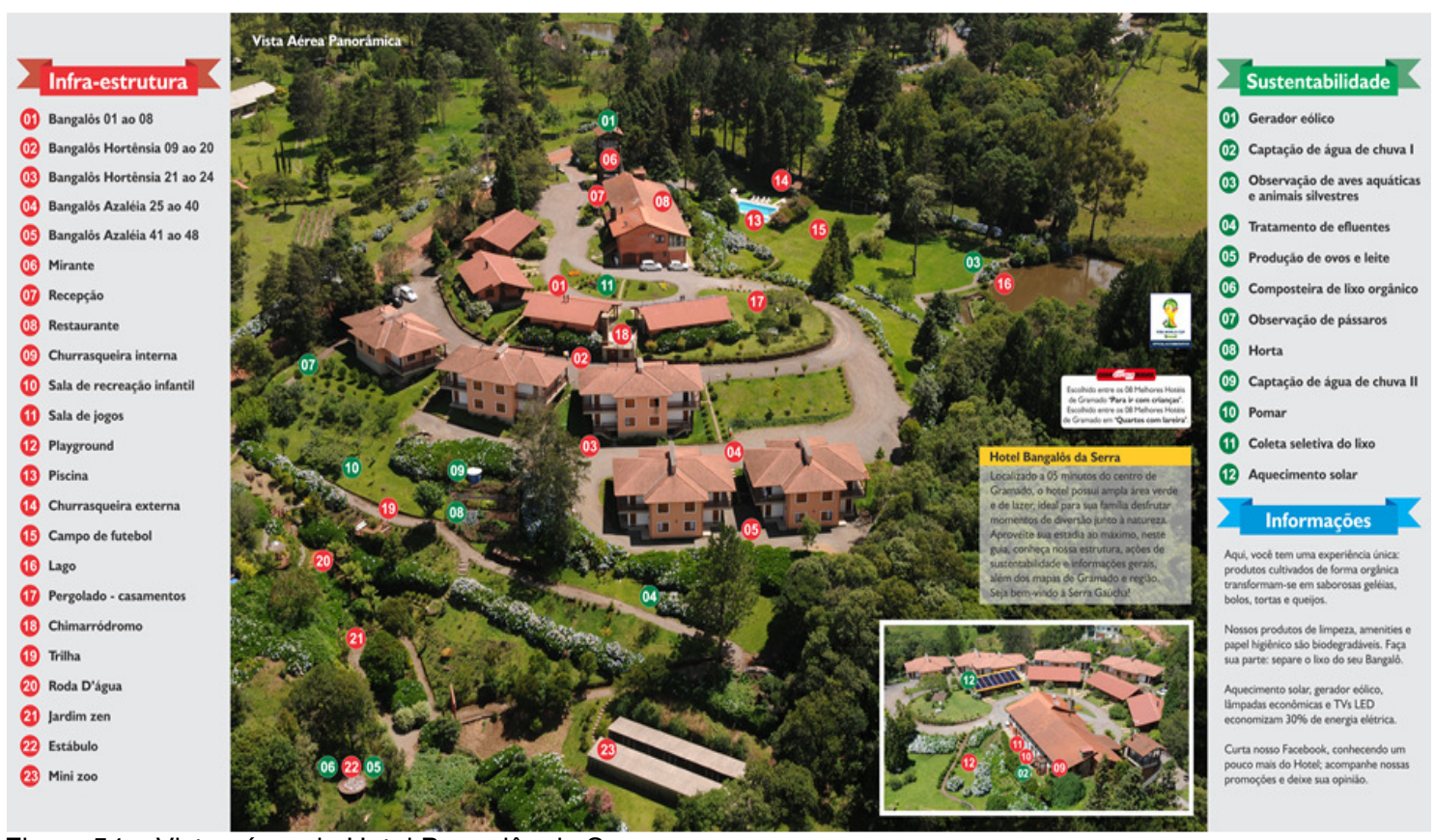

Figura 54 - Vista aérea do Hotel Bangalôs da Serra

Fonte: Bangalôs da Serra (2014) 
MIST (MATRIZ DE INOVAÇÃO PARA A SUSTENTABILIDADE NO TURISMO) - SEGMENTO: MEIOS DE HOSPEDAGEM - CASE: HOTEL BANGALÔS DA SERRA

\begin{tabular}{|c|c|c|c|}
\hline \multicolumn{4}{|c|}{ MIST (MATRIZ DE INOVAÇÃO PARA A SUSTENTABILIDADE NO TURISMO) - SEGMENTO: MEIOS DE HOSPEDAGEM - CASE: HOTEL BANGALÔS DA SERRA } \\
\hline ATRIBUTOS & $\begin{array}{l}\text { CARACTERIZAÇÃO DO MODELO DE } \\
\text { NEGÓCIO INOVADOR }\end{array}$ & PRÁTICAS DE INOVAÇÃO PARA A SUSTENTABILIDADE & $\begin{array}{l}\text { DESAFIOS, METAS E AVALIAÇÃO } \\
\text { GERAL }\end{array}$ \\
\hline 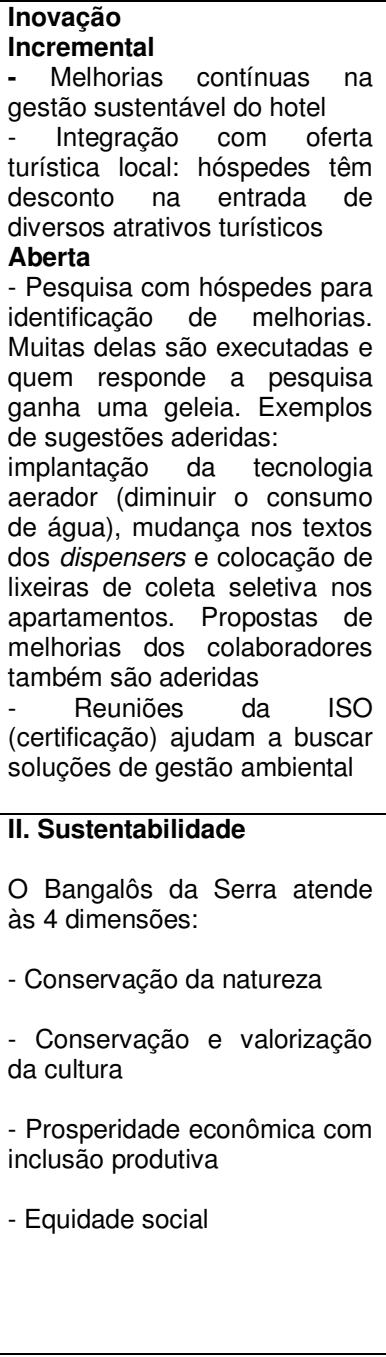 & $\begin{array}{l}\text { Valor ofertado / diferencial } \\
\text { Contato com a natureza. Embora muitos } \\
\text { hóspedes ainda não procurem o hotel por ser } \\
\text { sustentável, quando vão embora ficam satisfeitos } \\
\text { por saber que se hospedaram em um hotel que } \\
\text { tem preocupação ambiental. } \\
\text { Associados / Parceiros: } \\
\text { - Artesãos locais } \\
\text { - Associação de Produtores Orgânicos de } \\
\text { Gramado } \\
\text { - Escola Municipal de Ensino Fundamental } \\
\text { Henrique Bertolucci Sobrinho } \\
\text { - Gramado, Canela e Região das Hortênsias } \\
\text { Convention \& Visitors Bureau } \\
\text { - GramadoZoo } \\
\text { - Kur Estação das Águas } \\
\text { - MiniMundo } \\
\text { - Museu da Moda - MUM } \\
\text { - Museus da Cidade (Museu Hollywood Dream } \\
\text { Cars, Museu de Cera Dreamland, Harley Motor } \\
\text { Show, Super Carros) } \\
\text { - Parque Gaúcho } \\
\text { - Pousadas Serra Gaúcha } \\
\text { - Rasen Bier } \\
\text { - Vinícola Ravanello } \\
\text { - Vinecol (vinhos orgânicos e de comércio justo) } \\
\text { - VISÃO-Agência de Desenvolvimento da Região } \\
\text { das Hortênsias } \\
\text { - Vitta: Experiências em Hospedagem } \\
\text { Sustentável } \\
\text { - Sindicato da Hotelaria, Bares, Restaurantes e } \\
\text { Similares da Região das Hortênsias }\end{array}$ & 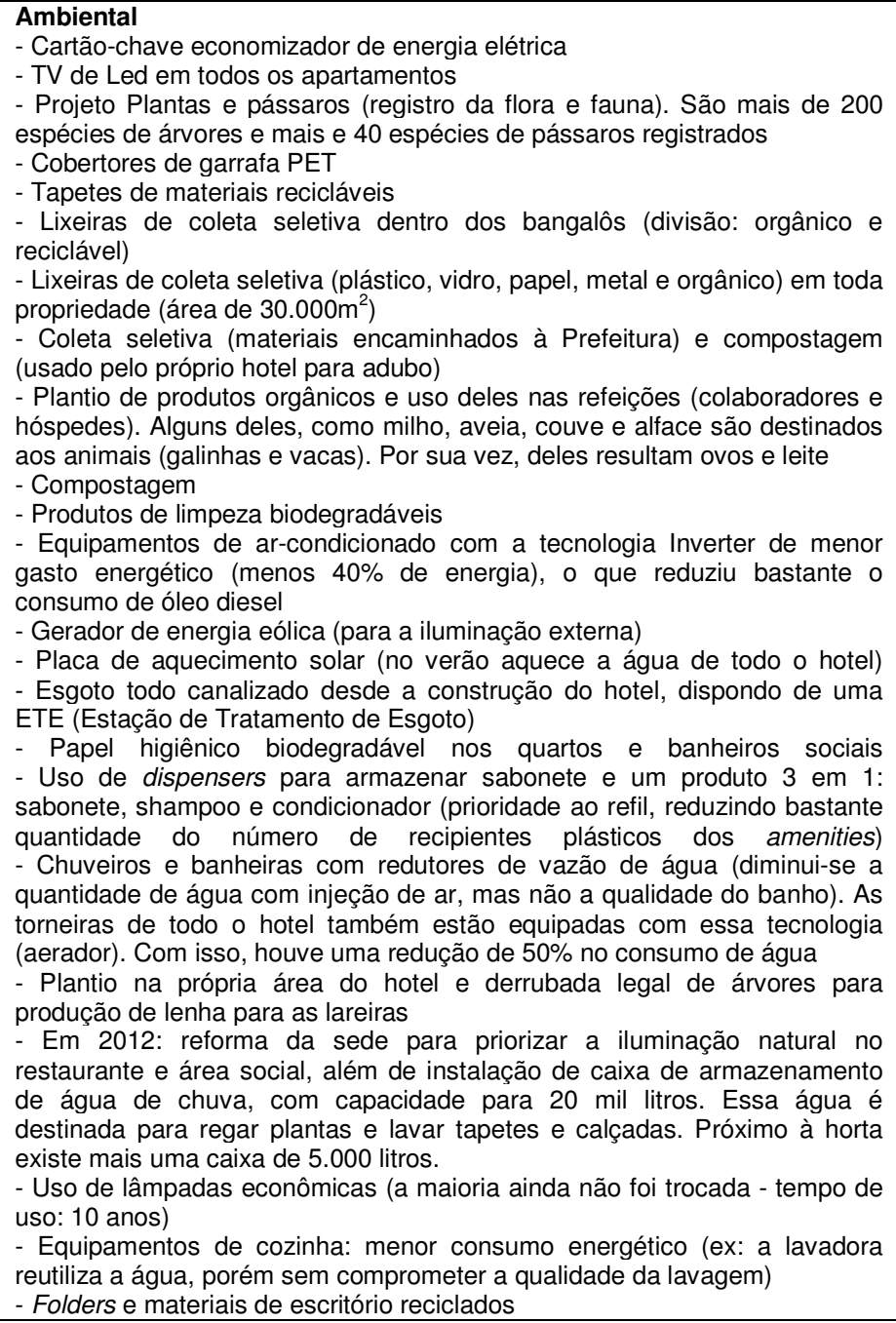 & $\begin{array}{l}\text { Desafios: } \\
\text { - Contato próximo dos proprietários } \\
\text { com seus colaboradores algumas } \\
\text { vezes gera conflitos. Exemplo: a } \\
\text { difícil incorporação dos valores de } \\
\text { sustentabilidade para que adotem } \\
\text { os processos corretos } \\
\text { - A difícil tarefa de levar adiante o } \\
\text { valor da sustentabilidade para os } \\
\text { hóspedes, ajudando-os a } \\
\text { compreender que as ações de } \\
\text { sustentabilidade adotadas pelo hotel } \\
\text { são importantes, e não apenas por } \\
\text { uma questão econômica ou } \\
\text { marketing. } \\
\text { - Pouca vontade dos colaboradores } \\
\text { na busca por formação e } \\
\text { qualificação } \\
\text { - Adequação e registro de todos os } \\
\text { processos para as auditorias }\end{array}$ \\
\hline
\end{tabular}




\begin{tabular}{|c|c|c|c|}
\hline $\begin{array}{c}\text { (Continua) } \\
\text { ATRIBUTOS }\end{array}$ & $\begin{array}{c}\text { CARACTERIZAÇÃO DO MODELO DE } \\
\text { NEGÓCIO INOVADOR }\end{array}$ & PRÁTICAS DE INOVAÇÃO PARA A SUSTENTABILIDADE & $\begin{array}{l}\text { DESAFIOS, METAS E AVALIAÇÃO } \\
\text { GERAL }\end{array}$ \\
\hline & 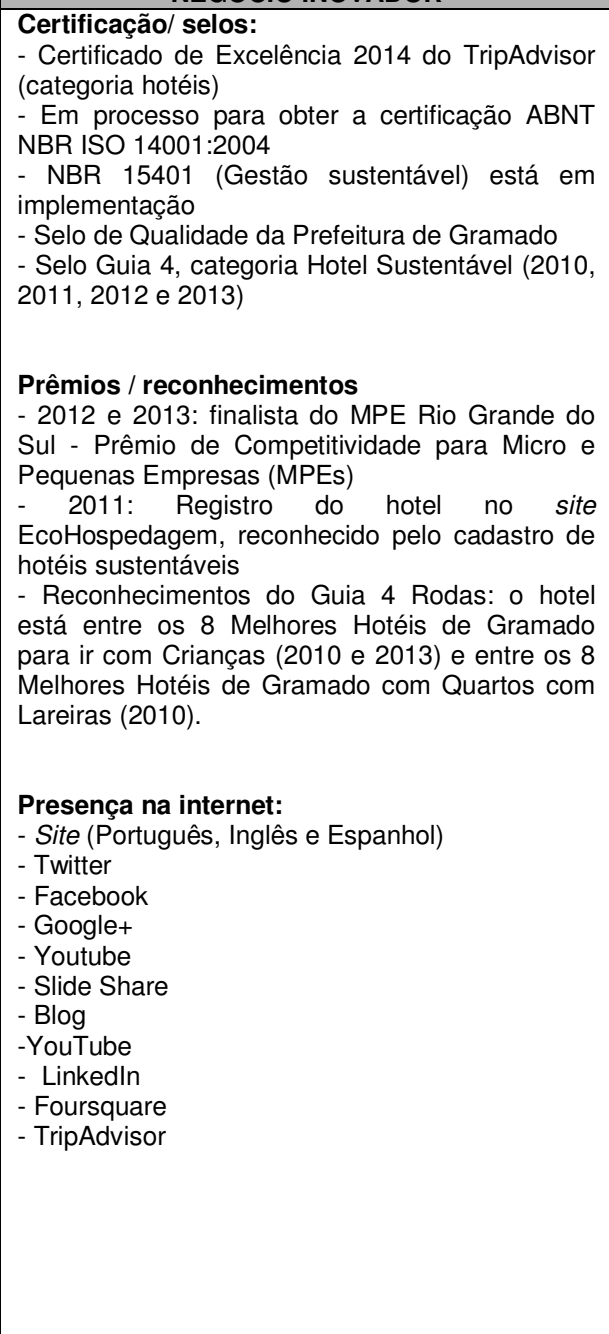 & 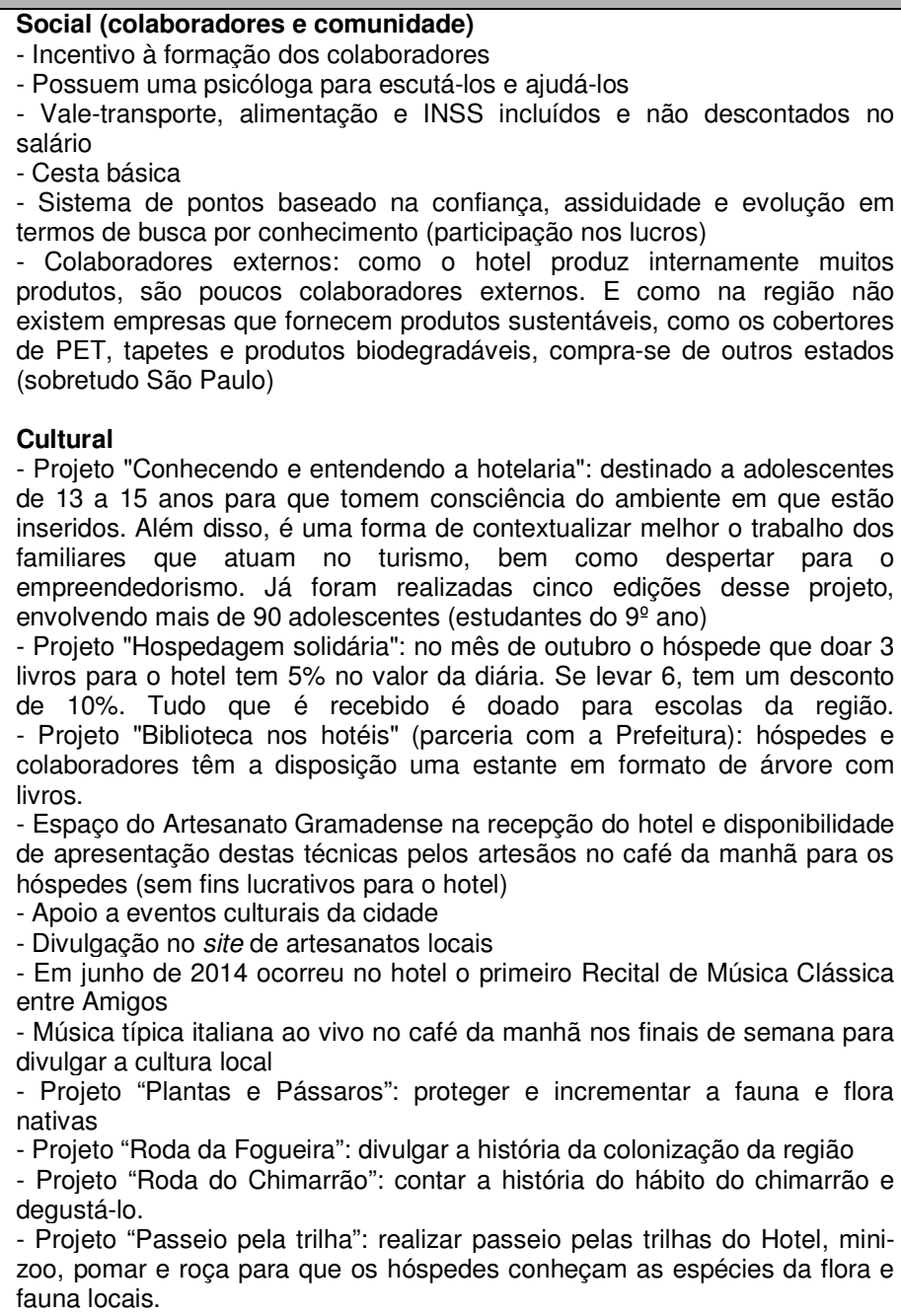 & $\begin{array}{l}\text { Avaliação geral: } \\
\text { Modelo de negócio inovador que } \\
\text { adota princípios de sustentabilidade. } \\
\text { Percebe-se certo equilíbrio entre as } \\
\text { dimensões da sustentabilidade. } \\
\text { Além disso, algumas ações } \\
\text { integram, ao mesmo tempo, pelo } \\
\text { menos duas dimensões da da } \\
\text { sustentabilidade. É um modelo de } \\
\text { negócio que praticamente se auto } \\
\text { sustenta em termos de produção. } \\
\text { Exemplo: frutas e verduras } \\
\text { plantadas na propriedade do hotel } \\
\text { que são utilizadas tanto no } \\
\text { restaurante quanto para alimentar } \\
\text { os animais. Dos resíduos orgânicos } \\
\text { o próprio hotel realiza a a } \\
\text { compostagem. Dos ovos e leite } \\
\text { originados pelos animais se faz } \\
\text { doces e salgados no restaurante } \\
\text { para as refeições dos hóspedes } \\
\text { (produção cíclica). }\end{array}$ \\
\hline
\end{tabular}




\begin{tabular}{|c|c|c|c|}
\hline $\begin{array}{l}\text { (Continua) } \\
\text { ATRIBUTOS }\end{array}$ & $\begin{array}{l}\text { CARACTERIZAÇÃO DO MODELO DE } \\
\text { NEGÓCIO INOVADOR }\end{array}$ & PRÁTICAS DE INOVAÇÃO PARA A SUSTENTABILIDADE & $\begin{array}{c}\text { DESAFIOS, METAS E AVALIAÇÃO } \\
\text { GERAL }\end{array}$ \\
\hline & & $\begin{array}{l}\text { Econômica } \\
\text { - Controle de indicadores de sustentabilidade (sociais, culturais e } \\
\text { econômicos) } \\
\text { - Pesquisa de satisfação } \\
\text { - Hóspedes podem levar geleias, frutas e verduras do pomar/horta (sem } \\
\text { custo) e personalizar seus apartamentos (lista disponível de itens) } \\
\text { - Entre outros eventos, o hotel possui espaço para uma experiência } \\
\text { EcoVivencial (eventos empresariais de contato com a natureza) } \\
\text { - Diárias: de } R \$ 185,00 \text { (solteiro) a } \$ \$ 1.150,00 \text { (quatro pessoas) } \\
\text { - Integração com oferta turística: hóspedes têm desconto na entrada de } \\
\text { diversos atrativos turísticos (museus, cervejarias artesanais e vinícolas) }\end{array}$ & \\
\hline
\end{tabular}

Quadro 22 - MIST do Hotel Bangalôs da Serra: Gramado (RS)

Fonte: Dados da pesquisa (2014). 
A Figura 55 abaixo apresenta algumas fotos da parte externa do Hotel e a Figura 56 algumas fotos de um apartamento.

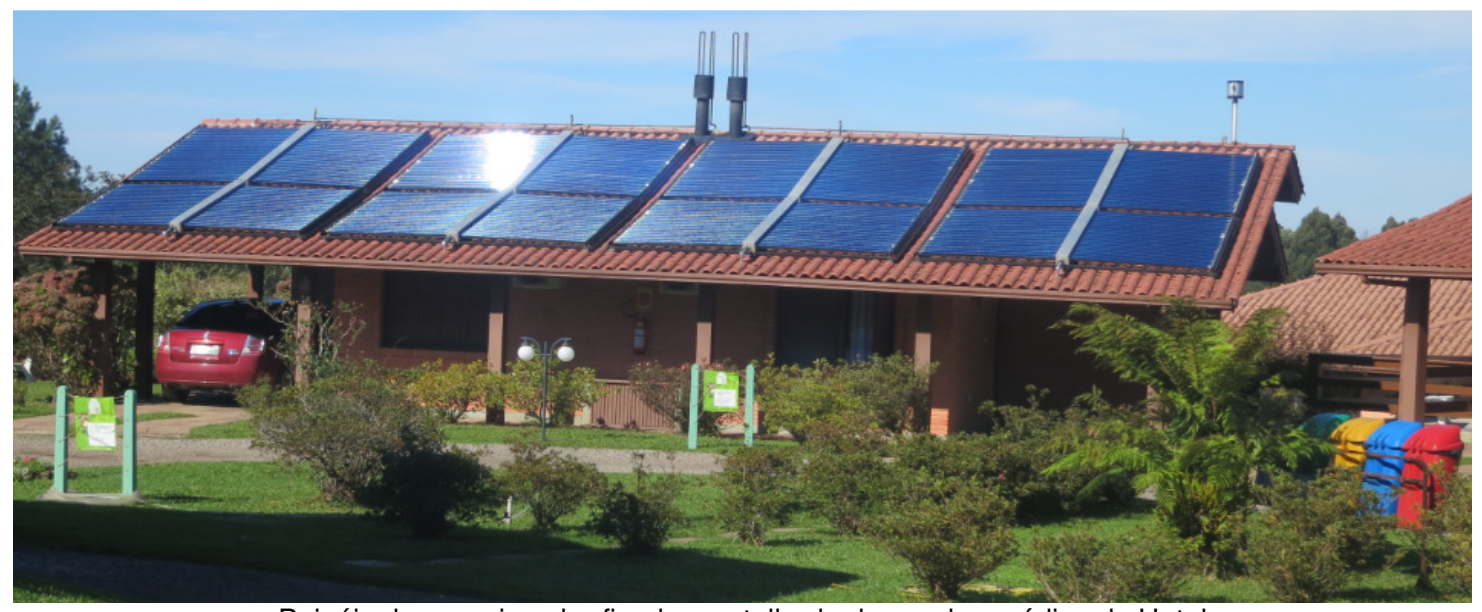

Painéis de energia solar fixados no telhado de um dos prédios do Hotel

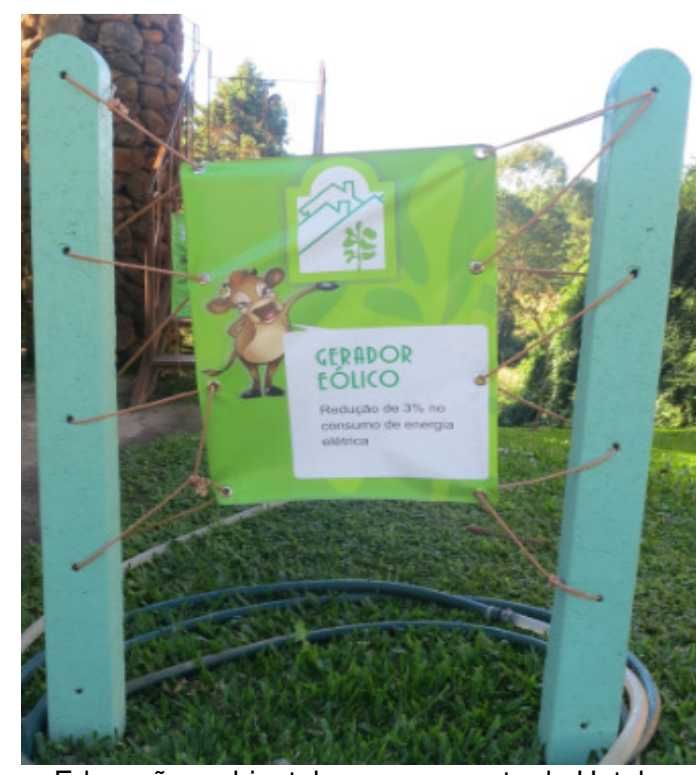

Educação ambiental com a mascote do Hotel: a vaca Genoveva (nesta sinalização: informação sobre a presença de gerador eólico)

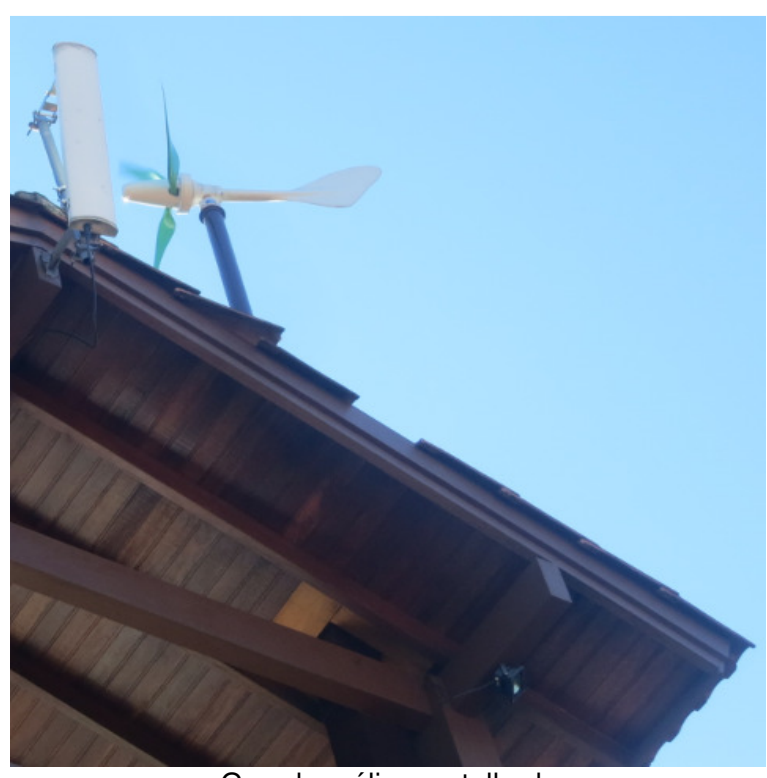

Gerador eólico no telhado

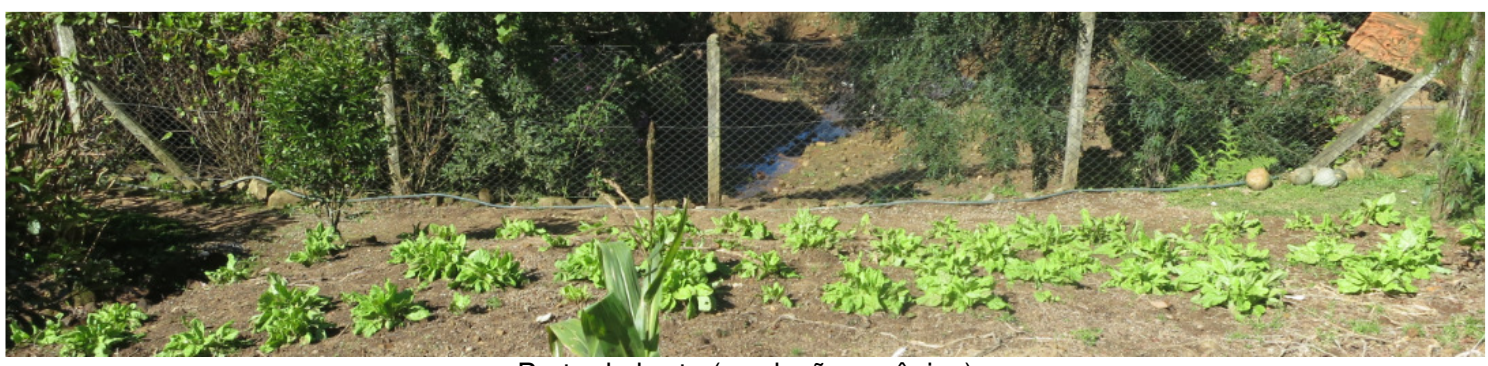

Parte da horta (produção orgânica)

Figura 55 - Fotos do Hotel Bangalôs da Serra (parte I)

Crédito: Daniela Rocco (2014) 


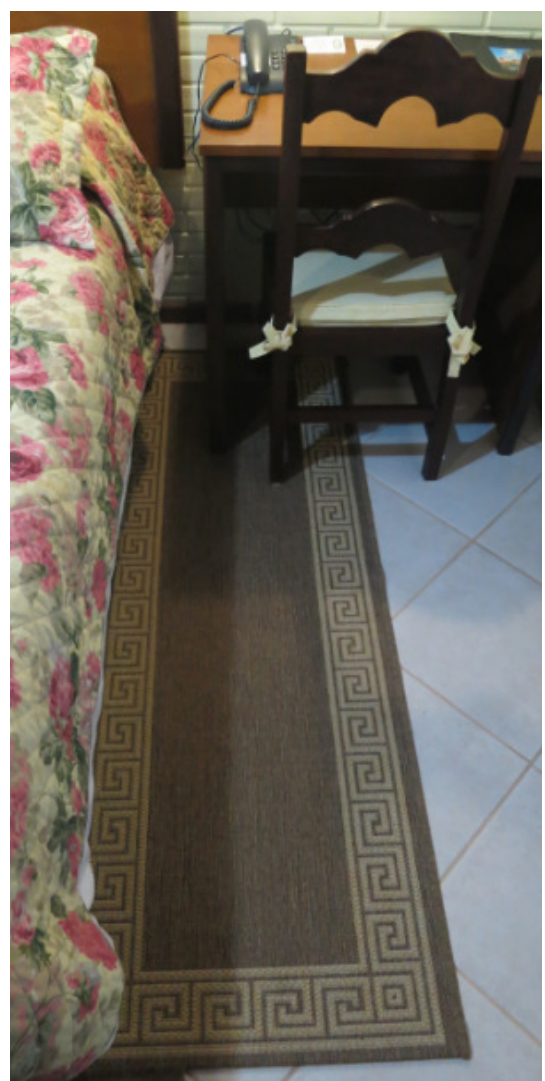

Tapete feito de materiais recicláveis

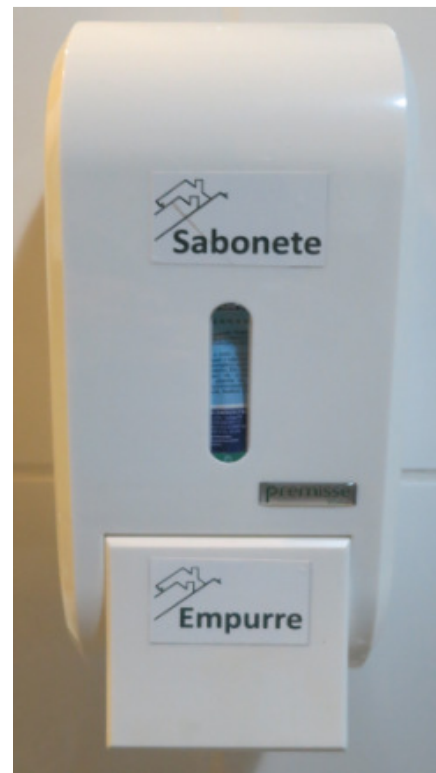

Display para sabonete líquido biodegradável próximo da pia do banheiro (usa-se refis, o que diminuiu a quantidade de recipientes plásticos). Na parte do chuveiro, o display contém um produto 3 em 1: shampoo, condicionador e sabonete (também é biodegradável)

Figura 56 - Fotos do Hotel Bangalôs da Serra (parte II) Crédito: Daniela Rocco (2014)

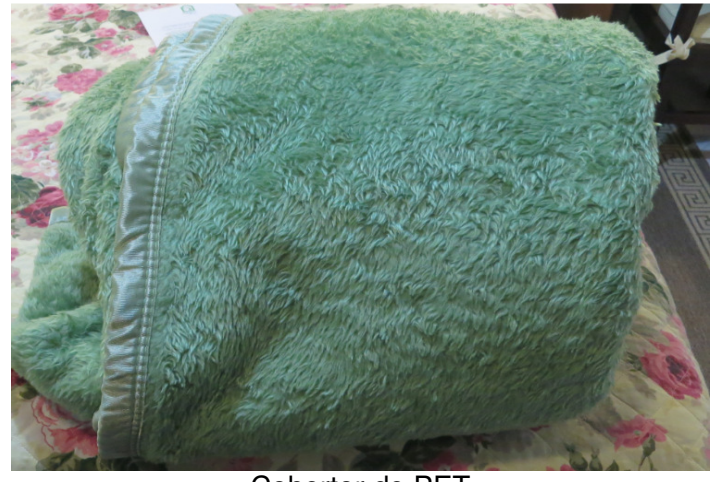

Cobertor de PET

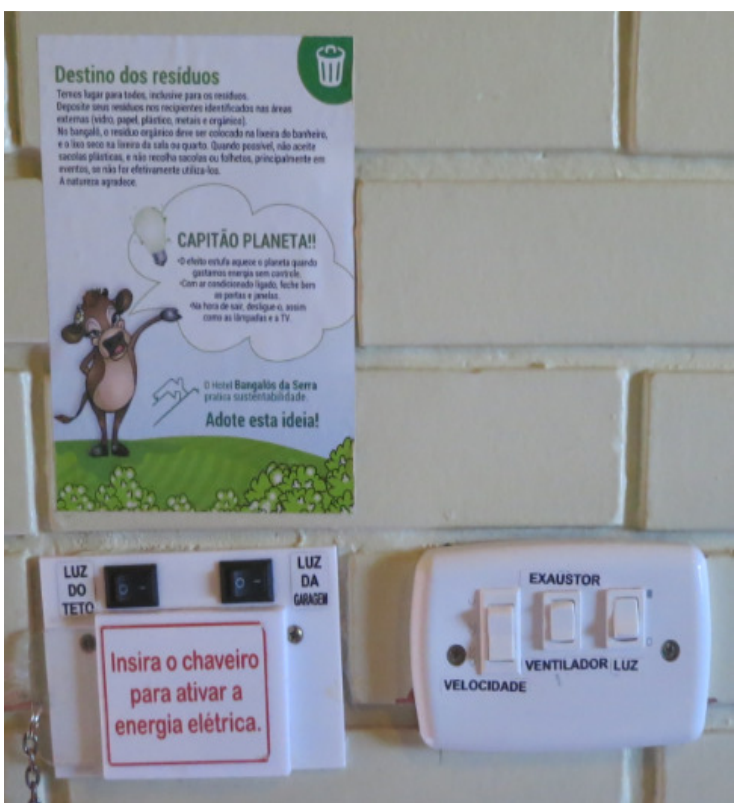

No quarto e no banheiro existem pequenos informes de educação ambiental, cujas mensagens são feitas pela mascote do Hotel

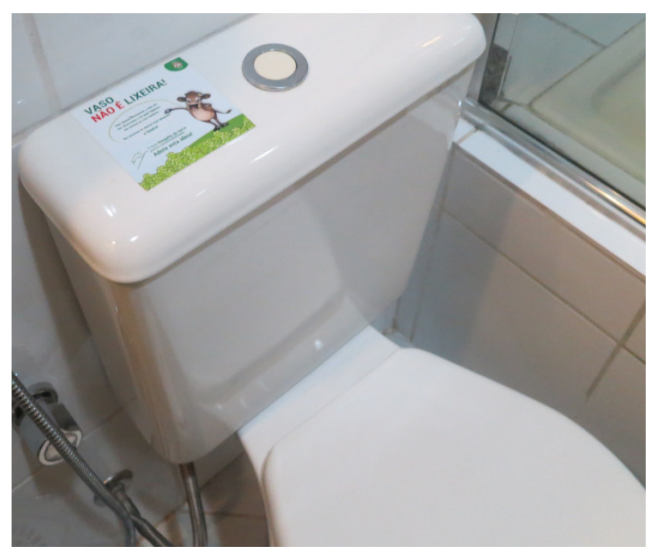




\section{Aplicação MIST: Parque Gaúcho}

O Parque Gaúcho foi inaugurado em novembro de 2011 com o objetivo de resgatar a formação e evolução da cultura gaúcha, bem como disseminar os usos e costumes gaúchos por meio da cultura, gastronomia e lazer. Foi considerado em 2013 pelo Ministério da Cultura como "o principal empreendimento existente no Cone Sul dedicado à história e identidade cultural do tipo característico dos pampas, o gaúcho" (DOU, 2013).

Com uma área total de $120.000 \mathrm{~m}^{2}$, sendo $10.000 \mathrm{~m}^{2}$ de área coberta, o Parque possui: memorial do gaúcho, restaurante temático, arena de shows e domas, cabana de animais crioulos (proteção e resgate cultural), galpão mirim, espaço lúdico de tradições gaúchas para crianças, horta orgânica, herbário, espaço para exposições de arte gaúcha, mangueira para apresentações da lida campeira, espaço para shows artísticos e a cidade dos gaúchos (espaço dedicado à mostra de tipos de habitações dos pampas no século XVIII, assim como os principais utensílios criados para a lida no campo) (PARQUE GAÚCHO, 2012).

No restaurante existem basicamente duas atrações, o Café Gaúcho (pão feito no forno à lenha, linguiça assada na brasa, manteiga artesanal, doce de leite, mel, chimarrão para beber, entre outros) e a Festa Gaúcha, que ocorre no período da noite com música, dança e gastronomia.

Como se pôde constatar, a criação do Parque Gaúcho ainda é muito recente. Além disso, na própria entrevista com o representante do Parque foi possível constatar que primeiramente o foco é capacitar os colaboradores para, aos poucos, aumentar a oferta de atrações. O Quadro 23 a seguir apresenta a aplicação da MIST relativa ao Parque. 


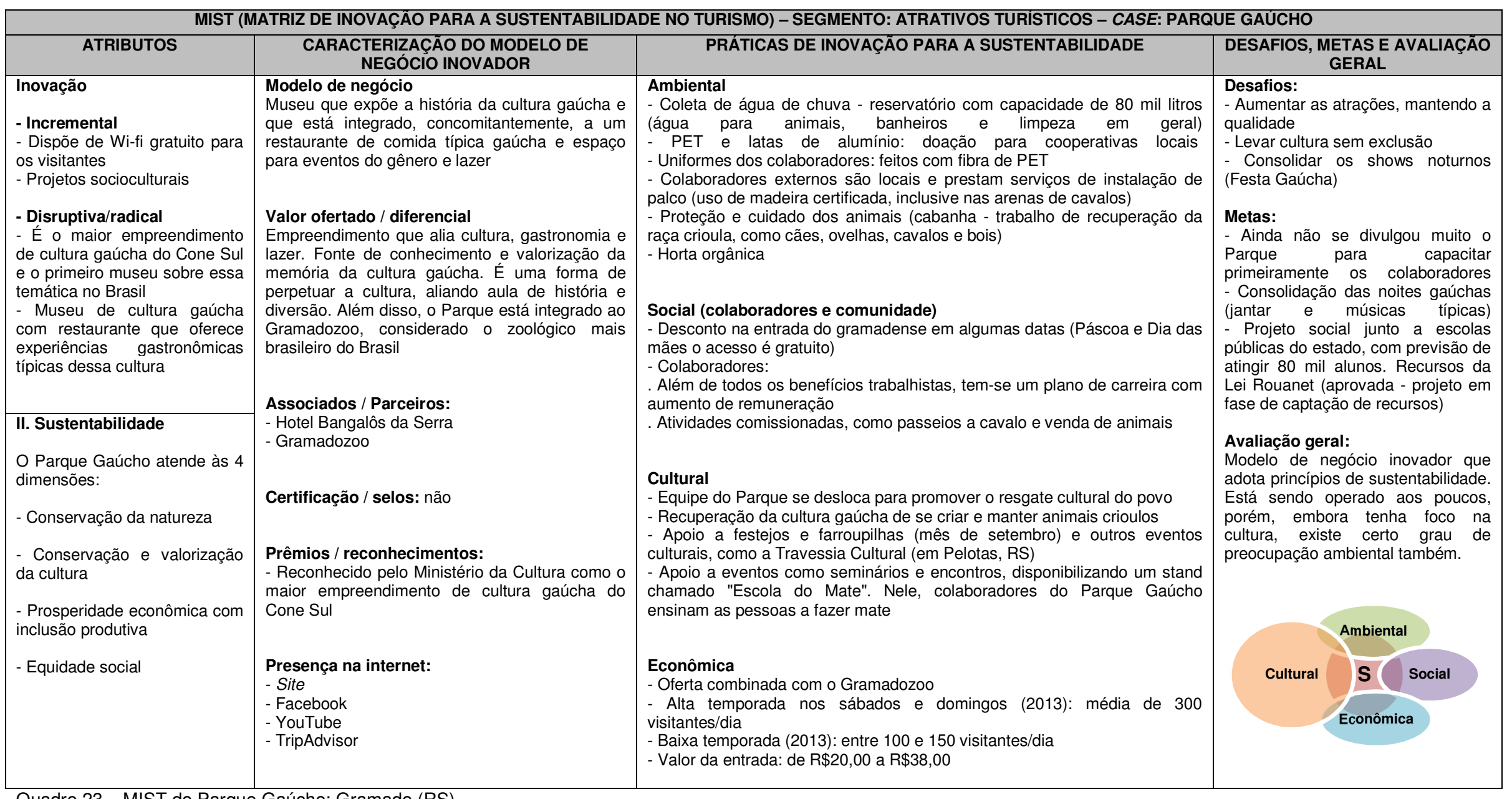

Quadro 23 - MIST do Parque Gaúcho: Gramado (RS)

Fonte: Dados da pesquisa (2014). 
A Figura 57 abaixo apresenta algumas fotos do Parque Gaúcho.

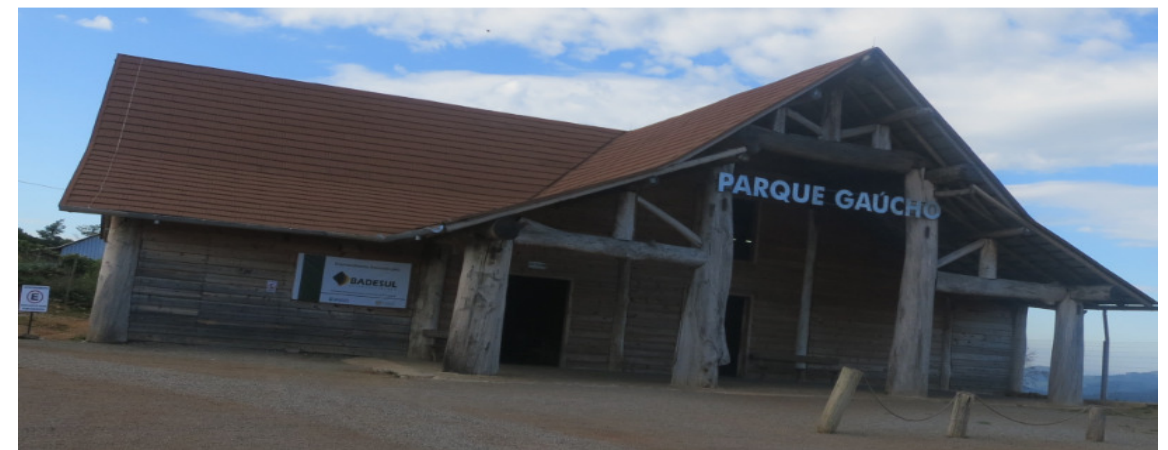

Entrada do Parque Gaúcho
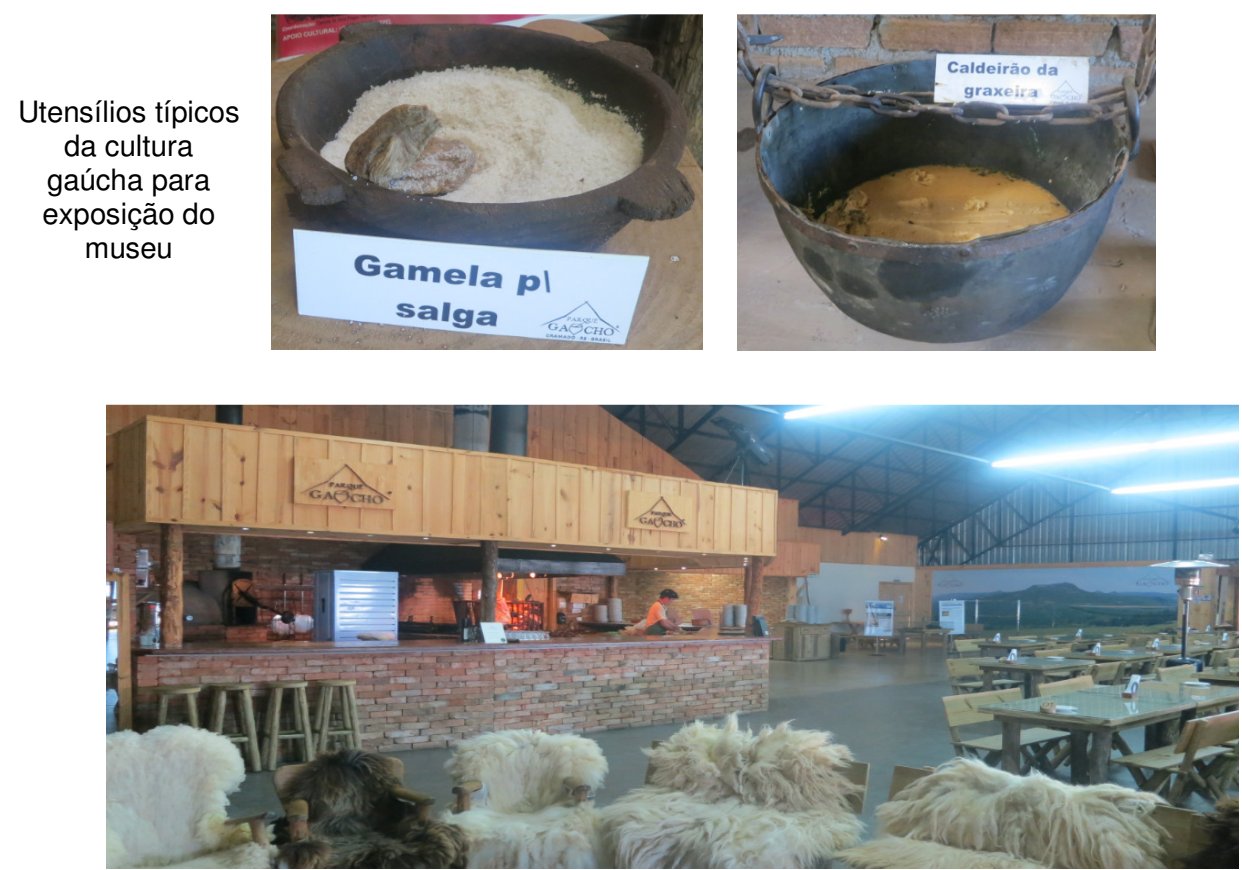

Restaurante do Parque e onde ocorrem os shows noturnos

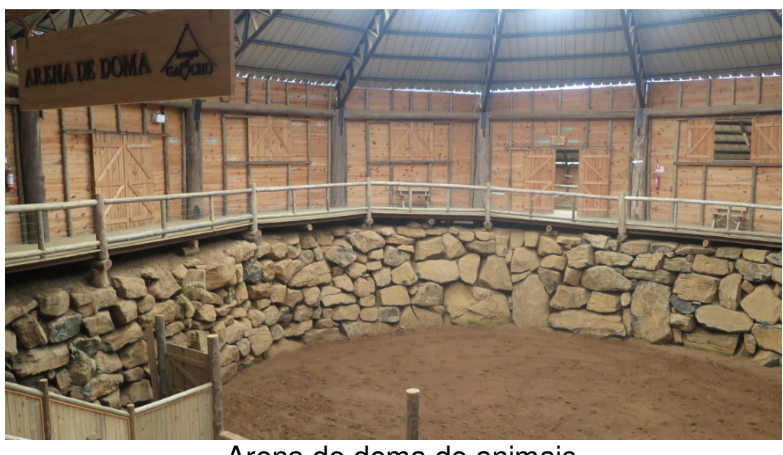

Arena de doma de animais

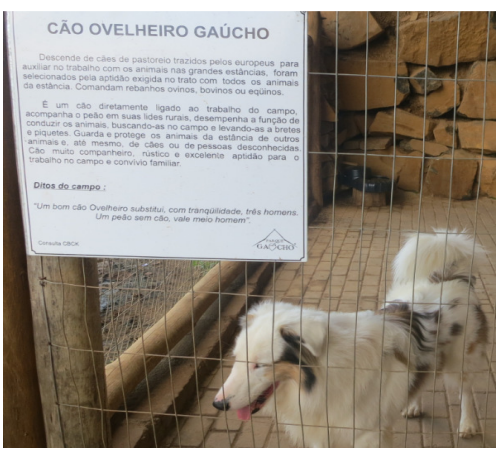

Cão ovelheiro gaúcho

Figura 57 - Fotos do Parque Gaúcho

Crédito: Daniela Rocco (2014) 


\section{Breve caracterização do perfil de turistas de Gramado (RS)}

Foram entrevistados no destino 36 turistas, dentre os quais $53 \%$ são do sexo masculino. A faixa etária mais recorrente da amostra é de 31 a 45 anos, com 47\%. Apenas $6 \%$ dos entrevistados encontram-se na faixa etária entre 18 e 30 anos. São Paulo é o maior estado emissor de turistas para a cidade de Gramado. Em segundo lugar são turistas do Rio de Janeiro e em terceiro, com empate, Minas Gerais e o próprio estado do Rio Grande do Sul. A maior região emissora de turistas para Gramado é a Sudeste, com 64\%. Em segundo lugar também houve empate: Sul e Nordeste, com 14\% cada um. Da região Norte não foi registrado nenhum turista nesta amostra. Vale destacar, nesta breve caracterização, que a maior parte dos turistas entrevistados que visita a cidade é proveniente de capitais, com $58 \%$.

O gráfico 11 a seguir indica a motivação principal do turista entrevistado para conhecer Gramado. De acordo com $22 \%$ dos turistas o estilo arquitetônico foi o fator decisivo. A cultura local foi citada por $14 \%$ dos turistas e tanto o clima serrano da região quanto a limpeza da cidade foram, cada um, indicados pelos turistas, com $11 \%$.

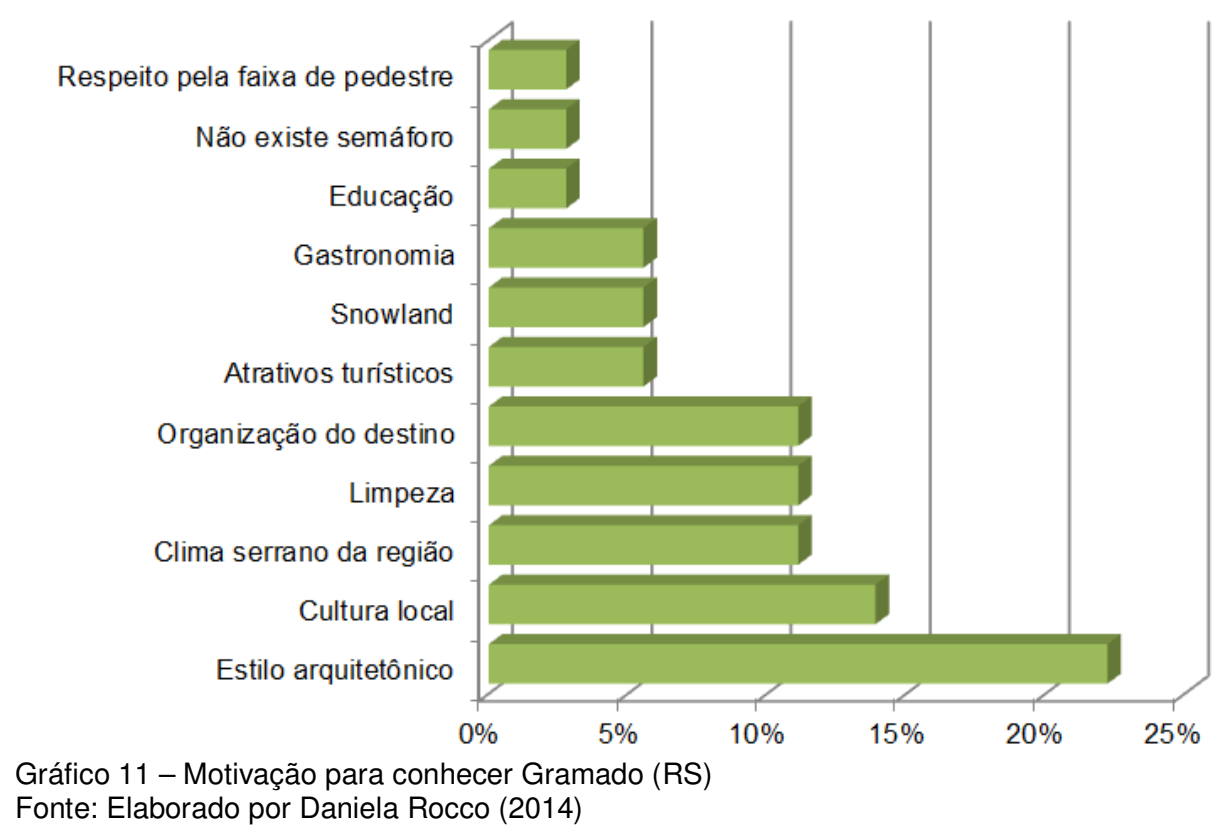

O principal diferencial/inovação de Gramado está no estilo arquitetônico, com 22\%. Para um turista entrevistado, nem Campos do Jordão, localizado em São Paulo e que também possui característica de clima serrano, é tão bonita quanto Gramado, inclusive em termos de arquitetura europeia. O segundo diferencial mais evidente entre os entrevistados 
ficou empatado: cultura local e limpeza receberam, cada uma, indicação de $11 \%$ dos turistas. Vale destacar que nesta pesquisa foi a primeira vez que um atrativo foi citado especificamente, o Snowland, com 6\%. Tal como foi exposto, o Snowland é o primeiro parque de neve indoor das Américas e, portanto, um atrativo bastante inovador de Gramado. Quando questionados se aquele diferencial/inovação foi decisivo para escolher Gramado, $83 \%$ dos entrevistados disseram que sim. Os que disseram não justificaram, de forma geral, assim:

- Diferencial citado: Gastronomia; O que foi decisivo: já conhecia Gramado e gostou da hospitalidade e gastronomia;

- Diferencial citado: Limpeza; O que foi decisivo: veio para conhecer a gastronomia e hospitalidade.

O gráfico 12 está relacionado à frequência que os turistas entrevistados usam serviços turísticos sustentáveis. A maioria disse "às vezes", com 33\%. Em seguida: "quase sempre", com 22\%, "nunca"/ "não sabe", com 17\% cada um e "raramente"/ "sempre", com $6 \%$ cada um. É preciso salientar que "não sabe" significa o desconhecimento do que seja um "serviço turístico sustentável".

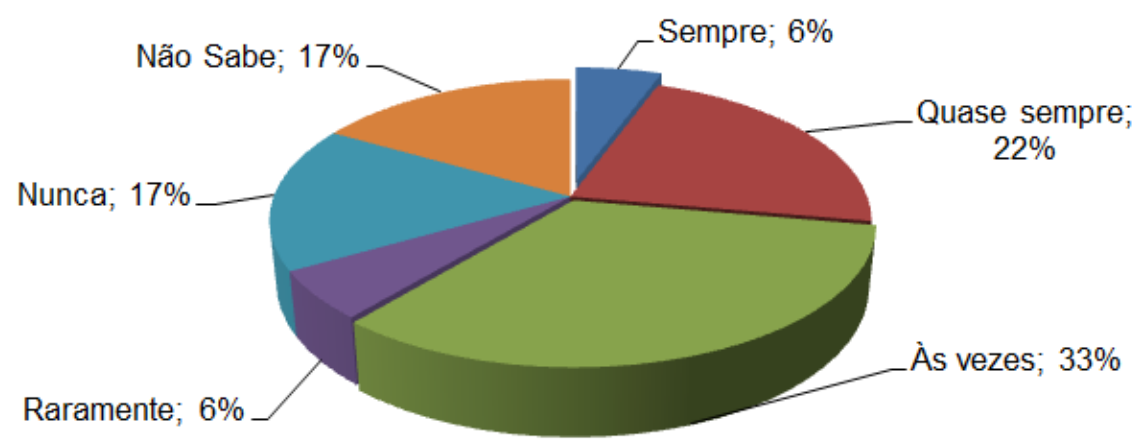

Gráfico 12 - Frequência que usa serviços turísticos sustentáveis: turistas de Gramado (RS) Fonte: Elaborado por Daniela Rocco (2014)

Por fim, é importante salientar as possibilidades de melhoria do destino. A pergunta esteve direcionada sobre o que Gramado deveria oferecer para garantir o retorno do visitante e, assim, tentar identificar caminhos para que o destino se torne ainda mais competitivo. A maioria dos turistas disse que estão satisfeitos (39\%), o que é um resultado bastante positivo. Sendo assim, a primeira sugestão que obteve maior destaque foi a prática de preços mais acessíveis (28\%). As demais sugestões, pulverizadas, estavam relacionadas a casos específicos, como disponibilizar mais alternativas de transporte público, caixas eletrônicos, opções de atrações noturnas para dançar, um aeroporto local e melhorar o acesso de Porto Alegre a Gramado (condições da estrada e sinalização). 


\subsection{INSTITUTO INHOTIM (MG)}

O Instituto Inhotim está localizado na cidade de Brumadinho, que por sua vez está distante cerca de $60 \mathrm{~km}$ de Belo Horizonte, a capital de Minas Gerais.

A própria Prefeitura Municipal de Brumadinho reconhece que "o Inhotim tem se tornado um vetor fundamental para o desenvolvimento socioeconômico do município de Brumadinho e de seu entorno" (BRUMADINHO, 2013). Isto porque a atividade turística emprega diretamente em Brumadinho cerca de 2 mil pessoas e a cidade recebe, por ano, aproximadamente 300 mil visitantes.

Embora o Inhotim seja o principal atrativo turístico cultural e natural da cidade, existem outros atrativos importantes. Dos atrativos culturais destacam-se o Quilombo do Sapé, a Capela Nossa Senhora do Rosário, de São Benedito e as Igrejas Matrizes de São José e São Sebastião. Com relação aos atrativos naturais vale citar: o Parque Estadual da Serra do Rola Moça (além de caminhadas é possível realizar atividades de balonismo e voo livre), o Verde Folhas (prática de arvorismo) e as cachoeiras da Ostra (ou Osta), de Águas Claras, do Areião, da Usina de Piedade e do Paraopeba (MINAS GERAIS, 2012).

Conforme foi exposto, a região estudada apresenta um caso peculiar: se para Brumadinho o Instituto Inhotim é o principal atrativo cultural e natural da cidade, no contexto mais amplo (inclusive no âmbito internacional), o museu assume característica de destino principal e a cidade se torna destino secundário. Caso semelhante é o da capital mineira: existe um grande fluxo turístico cuja motivação principal é conhecer as "cidades históricas" Ouro Preto, Mariana, São João Del Rey e Tiradentes, por exemplo. Para certos turistas Belo Horizonte é cidade de passagem, pois nela está situado o aeroporto internacional mais próximo das "cidades históricas". É preciso destacar que campanhas de turismo têm sido realizadas para que o turista permaneça mais dias na capital. Além disso, tem-se investido muito na oferta turística da cidade, como o "Circuito Cultural da Praça da Liberdade", citado anteriormente.

\section{Aplicacão MIST: Instituto Inhotim}

O Quadro 24 se refere à MIST do Instituto Inhotim, que é um museu de arte contemporânea e botânica. Foi inaugurado em 2006, porém foi na década de 1980 que começou a ser idealizado. Em 2002 foi criada a Fundação do Instituto Cultural Inhotim, uma

\footnotetext{
${ }^{55}$ As expressões "cidades históricas" ou "centros históricos" normalmente são atribuídas a cidades que ainda mantém o estilo arquitetônico barroco de construções como casas e igrejas. No entanto, ao realizar uma análise crítica dessas expressões, é possível entender que todas as cidades (e seus centros) possuem uma história, ainda que recente. Portanto, todas as cidades e centros seriam "históricos".
} 
instituição sem fins lucrativos com a finalidade de conservar, expor e produzir trabalhos contemporâneos de arte, bem como desenvolver ações educativas e sociais (INHOTIM, 2014a).

Hoje o Inhotim é reconhecido como OSCIP (Organização da Sociedade Civil de Interesse Público) pelo governo de Minas Gerais (2008) e pelo governo federal (2009). Em 2010 recebeu o título de Jardim Botânico pela CNJB (Comissão Nacional de Jardins Botânicos). O museu possui uma área de visitação de 110 hectares composta por montanhas, vales, fragmentos florestais, jardins (são 25 ha), lagos, estacionamento, estrutura de recepção com bilheteria, loja de souvernirs, viveiro educador, vandário (orquídeas), teatro, sanitários (inclusive acessíveis), fraldário, vestiário, espaços para locação, 21 galerias de arte de $1.000 \mathrm{~m}^{2}$ (17 de exposição permanente e 4 de exposição temporária), mais 600 obras de arte contemporânea nacional e internacional (exposição permanente e temporária ao ar livre ou nas galerias), área administrativa, dois restaurantes, um bar e uma cafeteria. No museu existe acesso a wi-fi gratuito nos restaurantes, recepção e cafeteria. Com relação às galerias de exposição permanente as obras são de Tunga, Cildo Meireles, Miguel Rio Branco, Hélio Oiticica \& Neville d'Almeida, Adriana Varejão, Doris Salcedo, Victor Grippo, Matthew Barney, Rivane Neuenschwander, Valeska Soares, Janet Cardiff \& George Miller, Doug Aitken, Marilá Dardot, Lygia Pape, Carlos Garaicoa e Cristina Iglesias (INHOTIM, 2014b).

No quesito arte contemporânea tem-se a participação de mais de 100 artistas brasileiros e estrangeiros (representados por 30 países distintos), cujas produções são pautadas em pinturas, esculturas, desenhos, fotografias, vídeos e instalações (INHOTIM, 2014b).

O Inhotim, que está inserido em área remanescente de Mata Atlântica e Cerrado, possui 145 ha de área protegida sob a forma de Reserva Particular de Patrimônio Natural (RPPN), mas esta ainda não está aberta à visitação. A RPPN está localizada na parte sul da Cadeia do Espinhaço, uma das mais relevantes áreas de biodiversidade do mundo. No total são aproximadamente 5.000 espécies botânicas, com cerca de mil espécies e variedades da família das palmeiras (Arecaceae) e mais de 400 espécies e formas da família dos imbés, antúrios e copo-de-leite (Araceae). O Jardim Botânico possui o "Viveiro Educador", de $25.000 \mathrm{~m}^{2}$. Por meio dele é possível desempenhar atividades educativas e de pesquisa, o que contribui para a conservação ex situ da flora (INHOTIM, 2014b). A Figura 58 abaixo mostra uma foto de vista aérea do Instituto. 


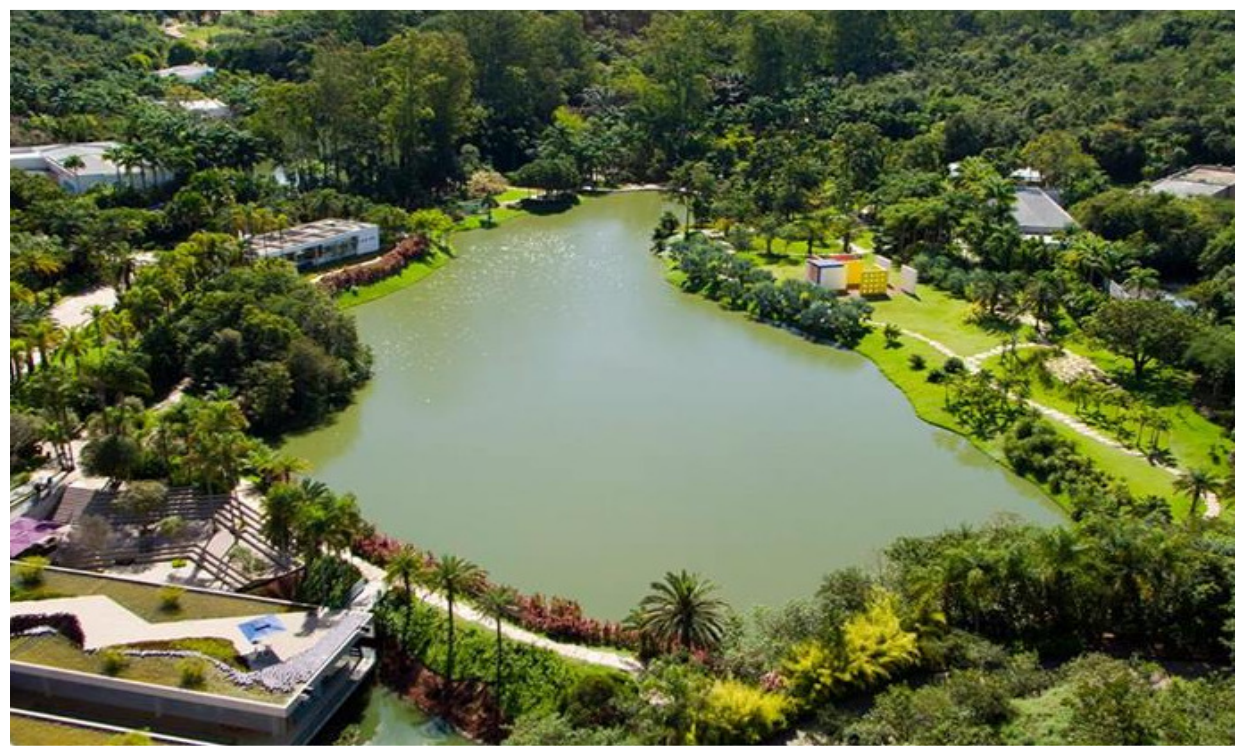

Figura 58 - Vista aérea do Instituto Inhotim

Fonte: Instituto Inhotim (2014)

No tocante às ações educativas, o Instituto atua sob duas perspectivas: Arte e Educação e Educação Ambiental. Toda semana recebe aproximadamente 1.500 alunos das redes particular e pública de ensino de Brumadinho, da capital e região metropolitana. $O$ visitante em geral também pode participar das visitas mediadas de cunho educativo e ambiental (são gratuitas). Em 2007 o Instituto passou a desenvolver mais ações sociais, criando a Diretoria de Inclusão e Cidadania. O objetivo foi fortalecer o capital social da região por meio da valorização da música, arte e cultura. Inclusive, seis comunidades quilombolas da região são beneficiadas com os programas sociais (INHOTIM, 2014a).

Pode-se afirmar que a grande inovação do Instituto Inhotim foi aliar arte contemporânea e botânica em um espaço a céu aberto e localizado em uma cidade que nunca teve grande apelo turístico internacional. Desde a inauguração até o momento o museu recebeu mais de 1 milhão e meio de visitantes, dentre os quais, só em 2013 foram 320.000 visitantes brasileiros e 80.000 visitantes internacionais. Segundo o diretor executivo do Instituto, Antônio Grassi, o Inhotim é o equipamento cultural que mais recebe estrangeiros no Brasil (BRUMADINHO, 2014). O público está assim dividido: 60\% de Minas Gerais, $20 \%$ de outros estados e $20 \%$ de outros países.

A partir da pesquisa exploratória e de campo é possível afirmar que a equipe do Instituto Inhotim busca inovar constantemente e estabelecer relações multidimensionais com a comunidade local por meio da geração de postos de trabalho e desenvolvimento sustentável. Duas vezes por ano os espaços recebem novas mostras culturais, projetos individuais de artistas são expostos anualmente, realizam-se eventos e, no futuro, está prevista a inauguração de um hotel dentro do próprio Inhotim (INHOTIM, 2014a). 
MIST (MATRIZ DE INOVAÇÃO PARA A SUSTENTABILIDADE NO TURISMO) - SEGMENTO: DESTINO / ATRATIVOS TURÍSTICOS - CASE: INSTITUTO INHOTIM

\begin{tabular}{|c|c|c|c|}
\hline \multicolumn{4}{|c|}{ JE INOVAÇÃO PARA A SUSTENTABILIDADE NO TURISMO) - SEGMENTO: DESTINO / ATRATIVOS TURISTICOS - CASE: INSTITUTO INHOTIM } \\
\hline ATRIBUTOS & $\begin{array}{l}\text { CARACTERIZAÇÃO DO MODELO DE } \\
\text { NEGÓCIO INOVADOR }\end{array}$ & PRÁTICAS DE INOVAÇÃO PARA A SUSTENTABILIDADE & $\begin{array}{l}\text { DESAFIOS, METAS E AVALIAÇÃO } \\
\text { GERAL }\end{array}$ \\
\hline $\begin{array}{l}\text { - Incremental } \\
\text { Criações constantes em vários } \\
\text { setores do Instituto, além da } \\
\text { promoção de ações externas } \\
\text { em Brumadinho e Belo } \\
\text { Horizonte } \\
\text { - Disruptiva/radical } \\
\text { Criação do maior museu de } \\
\text { arte contemporânea a céu } \\
\text { aberto do Brasil } \\
\text { Único no mundo que alia } \\
\text { Jardim botânico com arte } \\
\text { contemporânea a céu aberto } \\
\text { É o equipamento cultural } \\
\text { mais visitado por estrangeiros }\end{array}$ & $\begin{array}{l}\text { Modelo de negócio } \\
\text { É uma OSCIP, sem fins lucrativos e que opera a } \\
\text { partir de leis de incentivo à cultura, doações e } \\
\text { entradas. Estimula a valorização cultural, } \\
\text { conservação ambiental, inclusão produtiva e } \\
\text { desenvolvimento econômico regional } \\
\text { Valor ofertado / diferencial } \\
\text { É um dos mais importantes museus de arte } \\
\text { contemporânea a céu aberto do mundo e é, ao } \\
\text { mesmo tempo, Jardim Botânico. Gestão } \\
\text { sustentável } \\
\text { Associados / Parceiros: } \\
\text { - Artistas brasileiros e estrangeiros } \\
\text { - Associação de catadores de Brumadinho } \\
\text { - Prefeitura Municipal de Brumadinho } \\
\text { - Prefeitura Municipal de Belo Horizonte } \\
\text { - New Museum (Nova York, EUA) } \\
\text { - Plantar Carbon } \\
\text { - Centro Universitário Newton Paiva } \\
\text { - Socioambiental Projetos } \\
\text { - Universidade do Estado de Santa Catarina } \\
\text { - Nicho Engenheiros e consultores Ltda } \\
\text { - Centro Universitário Una } \\
\text { - Fundação Getúlio Vargas } \\
\text { - University of Central Lancashire } \\
\text { - Universidade Federal de Minas Gerais } \\
\text { - Faculdade ASA de Brumadinho } \\
\text { - Universidade Federal de Ouro Preto } \\
\text { - Fundação Dom Cabral } \\
\text { - SENAC } \\
\text { - Universidade do Estado de Minas Gerais } \\
\text { - Universidade Federal do Rio Grande do Norte } \\
\text { - Escola da Cidade } \\
\text { - Universidade Federal do Estado do Rio de } \\
\text { Janeiro } \\
\text { - Universidade de São Paulo } \\
\text { - Universidade Federal de Juiz de Fora } \\
\text { - Pontif́cia Universidade Católica de Minas } \\
\text { Gerais } \\
\text { - Universidade de Brasília } \\
\text { - Florida State University } \\
\text { - Universidade de Montreal }\end{array}$ & $\begin{array}{l}\text { Ambiental } \\
\text { Ações internas: } \\
\text { - Jardim Botânico: tem a maior coleção em número de espécies de plantas } \\
\text { vivas entre os jardins botânicos brasileiros. São } 25 \text { hectares e } 5.000 \\
\text { espécies botânicas } \\
\text { - São } 145 \text { hectares de área protegida (RPPN) e remanescente de Mata } \\
\text { Atlântica e Cerrado } \\
\text { - Transição da Mata Atlântica e Cerrado (antigo bosque da Juçara) } \\
\text { - Viveiro educador \& Núcleo de Pesquisa Inhotim, que é formado por: } \\
\text { - Jardim Encantador: possui plantas medicinais, aromáticas e tóxicas } \\
\text { - Jardim das pedras: plantas originárias de desertos e de regiões áridas do } \\
\text { Brasil. } \\
\text { - Estufa equatorial: cultivo de espécies tropicais } \\
\text { - Circuito "Entre Borboletas" (educação ambiental e contato com borboletas) } \\
\text { - Poços artesianos e reservatórios de água para irrigação } \\
\text { - Tratamento dos efluentes: fossas sépticas e estações de tratamento } \\
\text { biológicas } \\
\text { - Crédito de Carbono Inhotim: foi lançado em } 2013 \text { para a compensação de } \\
\text { Emissões de Gases do Efeito Estufa (GEE's) } \\
\text { - Carrinhos elétricos (para o deslocamento entre as galerias mais distantes) } \\
\text { - Resíduos sólidos: parte é doada para a Associação de catadores de } \\
\text { Brumadinho e a outra parte a Prefeitura dá a destinação). } \\
\text { Ações externas: } \\
\text { - Parceria com a Prefeitura para a revitalização dos canteiros de } \\
\text { Brumadinho com projeto paisagístico do Inhotim } \\
\text { - Projeto "Jovens agentes ambientais": são em média } 25 \text { alunos por } \\
\text { semestre e o trabalho final é uma intervenção positiva para Brumadinho }\end{array}$ & $\begin{array}{l}\text { Desafios: } \\
\text { - Ser referência internacional de } \\
\text { sustentabilidade } \\
\text { - Desenvolver projetos inovadores e } \\
\text { de excelência com novas linguagens } \\
\text { artísticas, como teatro, dança, } \\
\text { música e audiovisual } \\
\text { - Encontrar mais profissionais da } \\
\text { área de arte e que possam captar } \\
\text { recursos } \\
\text { Metas: } \\
\text { - Consolidar o Anfiteatro e favorecer } \\
\text { espaços para piqueniques no meio } \\
\text { do bosque } \\
\text { - Criação de: } \\
\text {. Hotel (na área do Instituto) } \\
\text { Condomínios no entorno com o } \\
\text { museu integrado ao processo } \\
\text {. TV Inhotim }\end{array}$ \\
\hline
\end{tabular}




\begin{tabular}{|c|c|c|c|}
\hline $\begin{array}{l}\text { (Continua) } \\
\text { ATRIBUTOS }\end{array}$ & $\begin{array}{c}\text { CARACTERIZAÇÃO DO MODELO DE } \\
\text { NEGÓCIO INOVADOR }\end{array}$ & PRÁTICAS DE INOVAÇÃO PARA A SUSTENTABILIDADE & $\begin{array}{c}\text { DESAFIOS, METAS E AVALIAÇÃO } \\
\text { GERAL }\end{array}$ \\
\hline & $\begin{array}{l}\text { Associados / Parceiros (continuação): } \\
\text { - Pontifícia Universidade Católica de São Paulo } \\
\text { - Universidade Presbiteriana Mackenzie } \\
\text { - Universidade Positivo } \\
\text { - Formatar Consultoria Empresarial } \\
\text { - University of Vienna } \\
\text { - Ferrous } \\
\text { - Universidade Federal Fluminense } \\
\text { - Centro Universitário de Belo Horizonte } \\
\text { - Instituto Metodista Izabela Hendrix } \\
\text { - Chias Marketing } \\
\text { - Universidade Fumec } \\
\text { - FEAD } \\
\text { Certificação/ selos: não } \\
\text { Prêmios / reconhecimentos } \\
\text { - Reconhecida como OSCIP (Organização da } \\
\text { Sociedade Civil de Interesse Público) pelo } \\
\text { governo de Minas Gerais (2008) e pelo governo } \\
\text { federal (2009) } \\
\text { - Em 2010 recebeu o título de Jardim Botânico } \\
\text { pela CNJB (Comissão Nacional de Jardins } \\
\text { Botânicos) } \\
\text { Presença na internet: } \\
\text { - Site (Português e Inglês) } \\
\text { - Twitter } \\
\text { - Facebook } \\
\text { - Youtube } \\
\text { - Instagram }\end{array}$ & 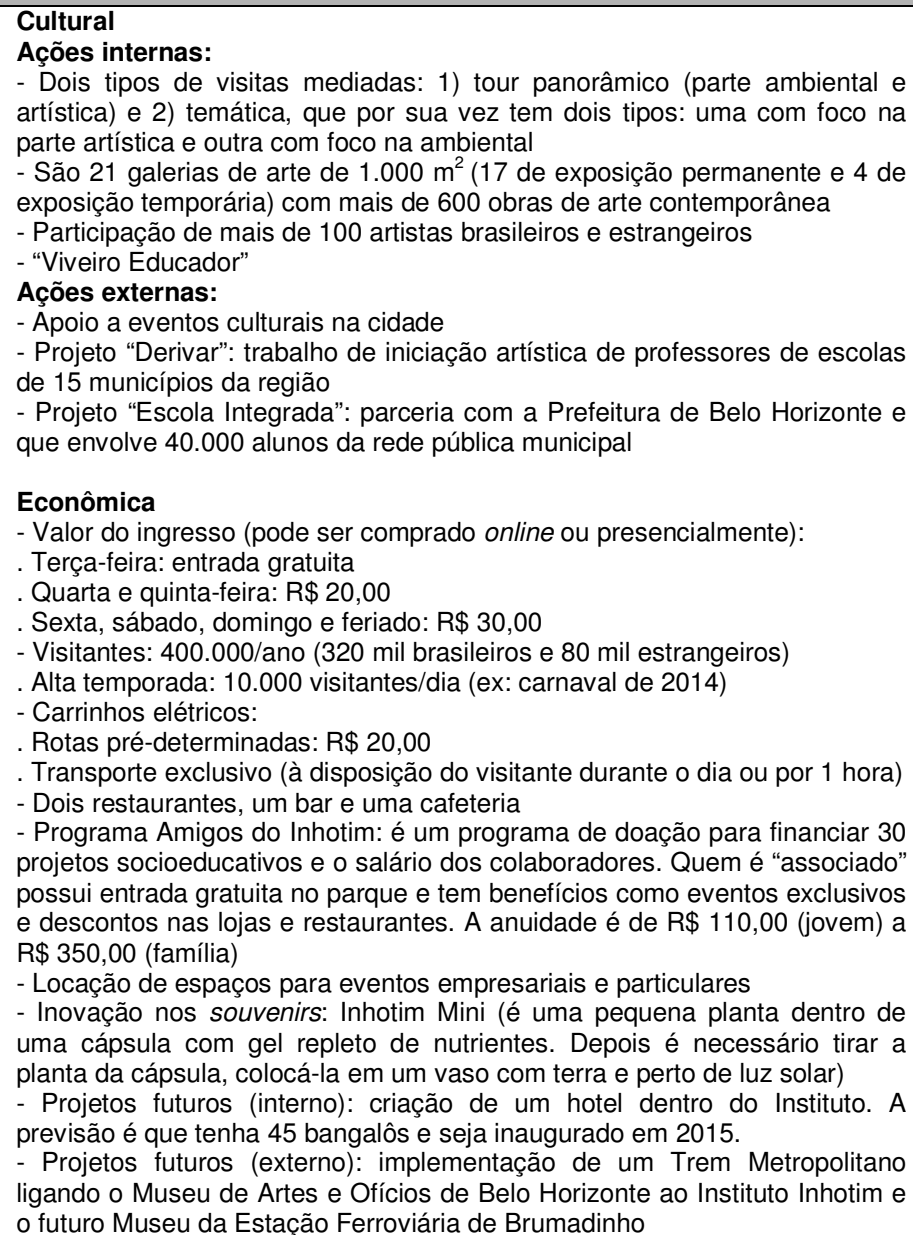 & \\
\hline
\end{tabular}

Fonte: Dados da pesquisa (2014). 
As Figuras 59 e 60 abaixo apresentam algumas fotos do Instituto Inhotim.

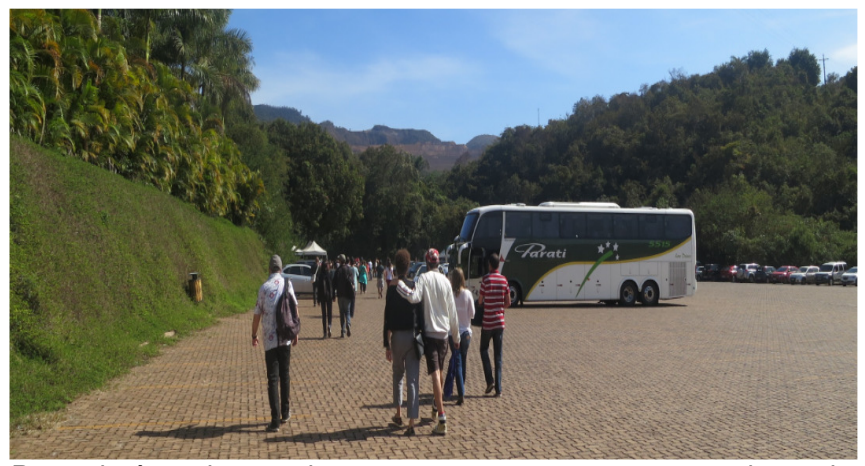

Parte da área de estacionamento com vagas para portadores de necessidades especiais, idosos e ponto de ônibus intermunicipal

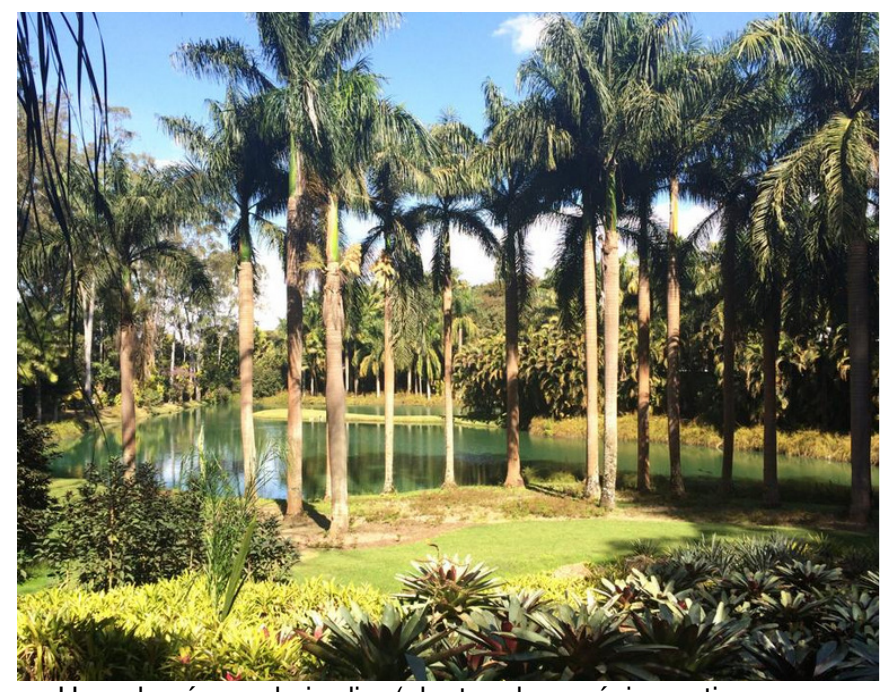

Uma das áreas de jardim (plantas de espécies nativas, em extinção e paisagismo)

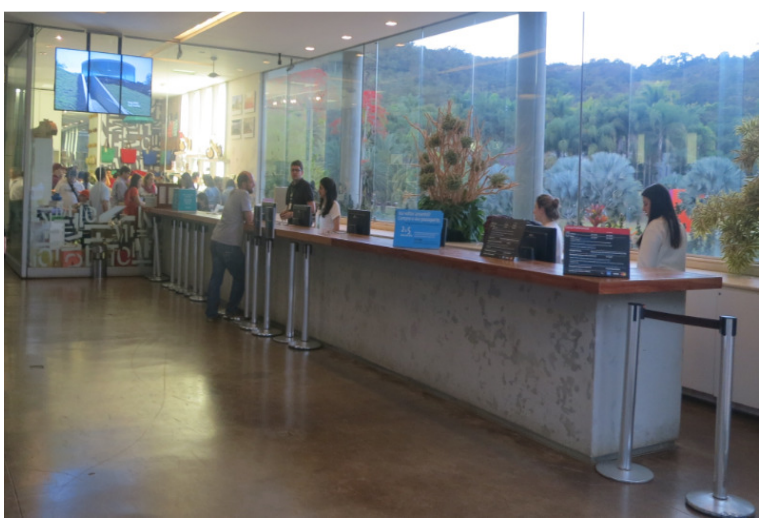

Entrada com estrutura de recepção/bilheteria, loja de souvenirs e sanitários próximos

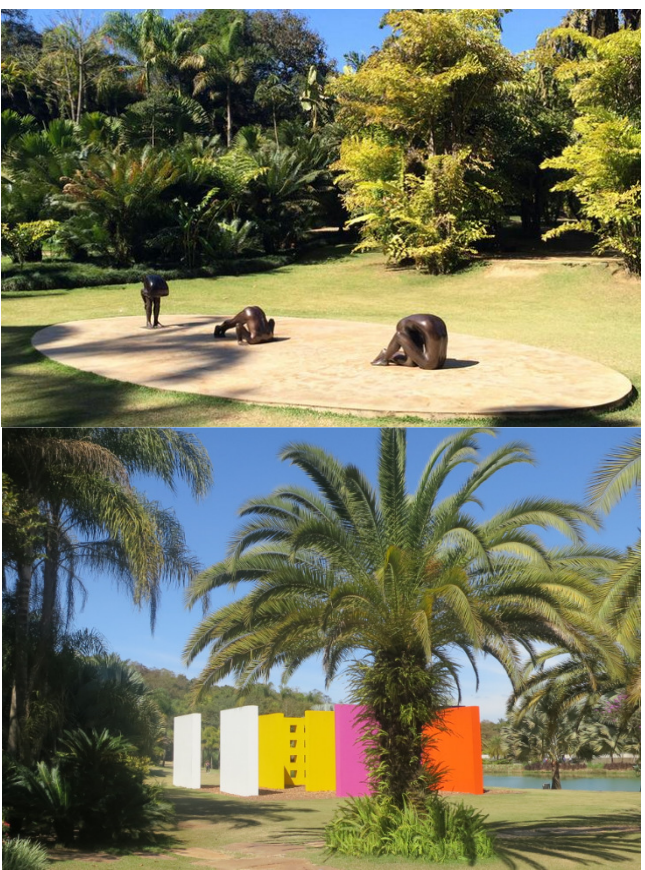

Exemplares de instalações artísticas

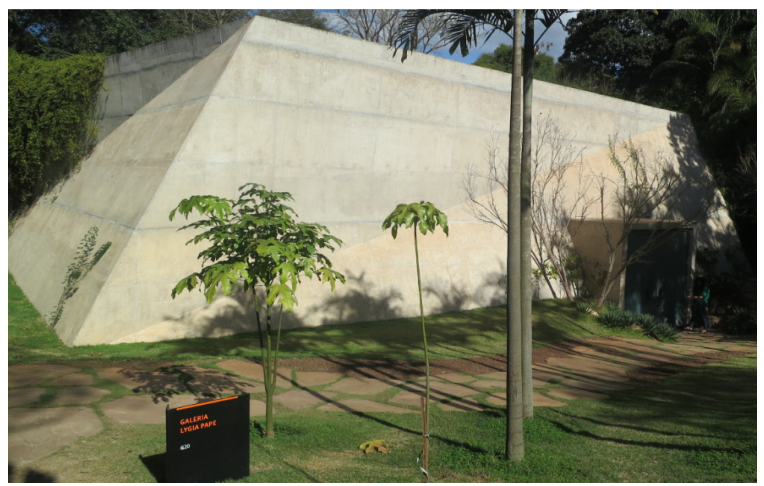

Galeria Lygia Pape

Figura 59 - Fotos do Instituto Inhotim (parte I)

Créditos: Daniela Rocco (2014) 


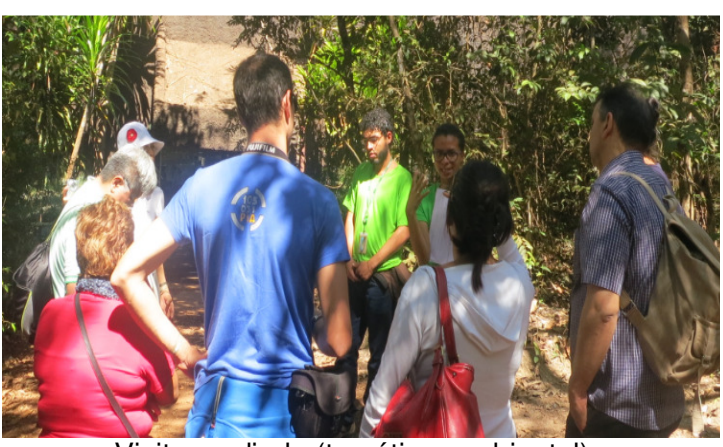

Visita mediada (temática: ambiental)

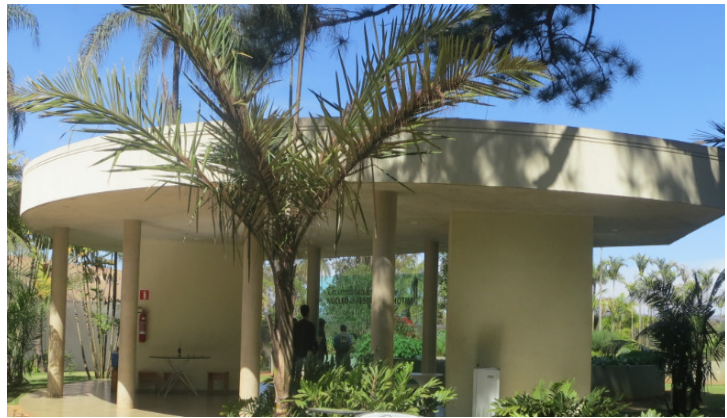

Viveiro educador \& Núcleo de Pesquisa Inhotim

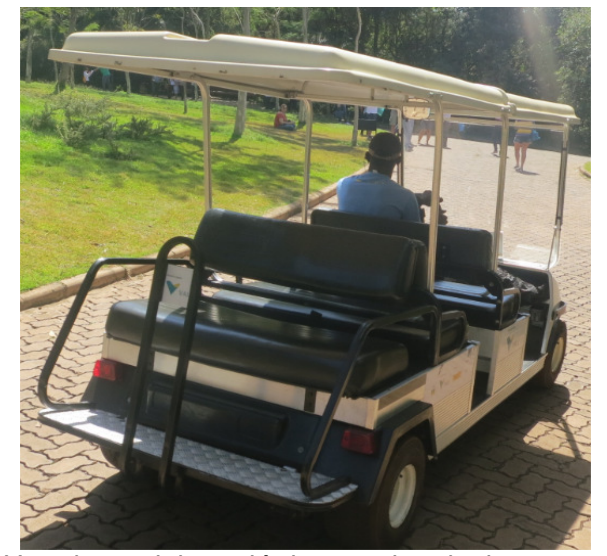

Uso de carrinhos elétricos e piso do tipo paver (ele facilita a infiltração e escoamento da água)

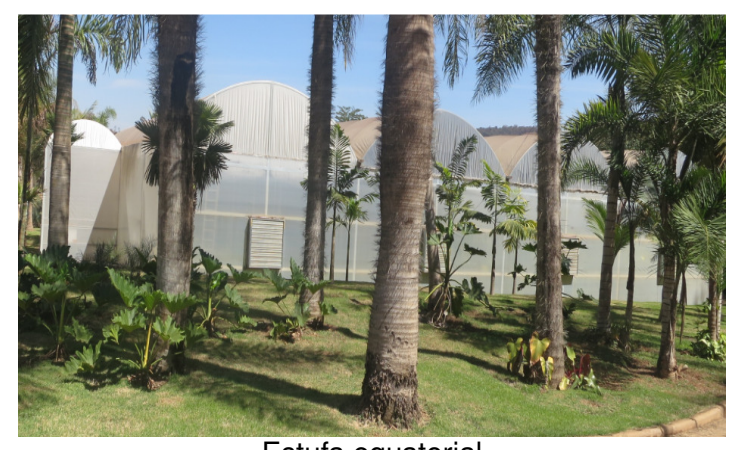

Estufa equatorial

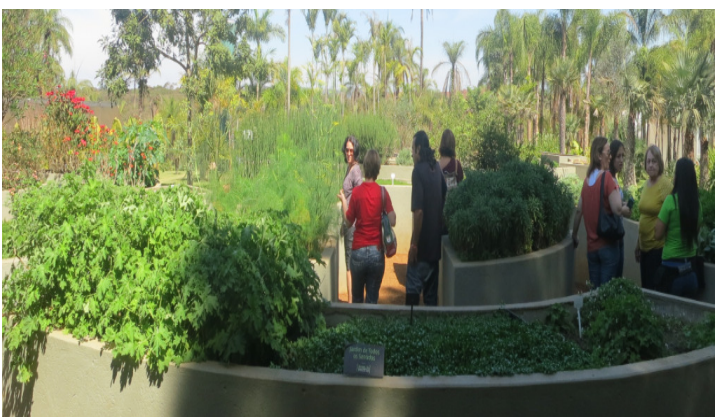

Jardim Encantador (faz parte do Viveiro educador e tem plantas medicinais, aromáticas e tóxicas)

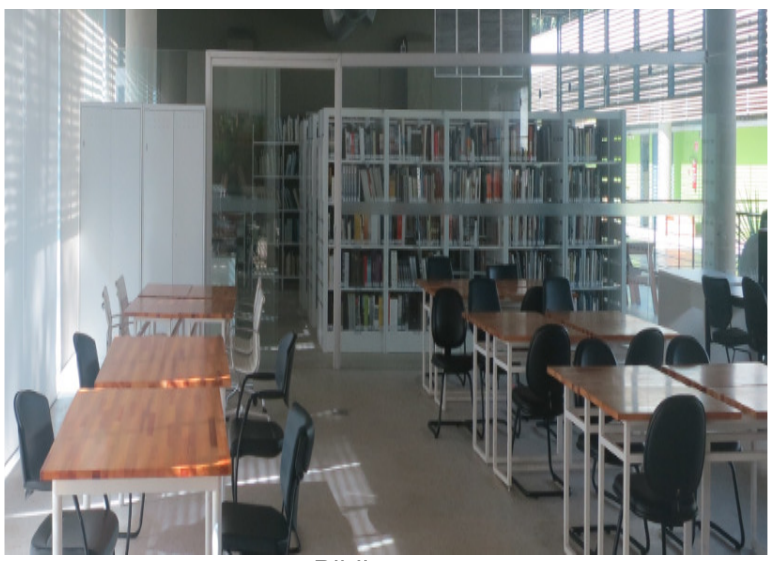

Biblioteca

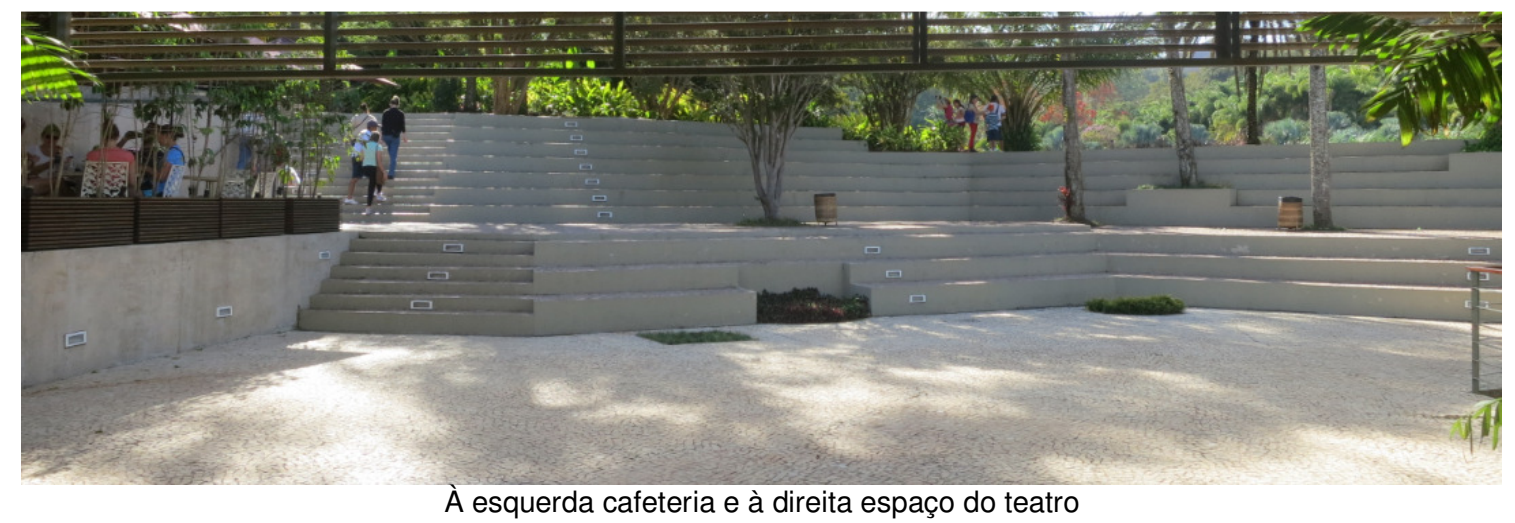

Figura 60 - Fotos do Instituto Inhotim (parte II)

Créditos: Daniela Rocco (2014) 


\section{Breve caracterização do perfil de turistas do Instituto Inhotim (MG)}

Foram entrevistados no destino 45 turistas, dentre os quais $53 \%$ são do sexo feminino. A faixa etária mais recorrente da amostra é de 31 a 45 anos, com 38\%. A faixa etária menos encontrada na amostra foi de 18 a 30 anos, com 13\%. Minas Gerais é o maior estado emissor de turistas para o Instituto Inhotim. Em segundo lugar são turistas do Rio de Janeiro e em terceiro São Paulo. É preciso destacar que não foram pesquisados visitantes de Belo Horizonte, Contagem e Betim (cidades mais próximas de Brumadinho), assim como visitantes da própria cidade de Brumadinho. Isto para trazer à pesquisa uma percepção de quem está mais afastado desses núcleos, precisa pernoitar e, portanto, usufruir serviços turísticos. A maior região emissora de turistas para o Instituto Inhotim é a Sudeste, com $80 \%$ e a região menos evidente nesta amostra é a Norte, com $2 \%$. No caso do Instituto Inhotim, a maior parte dos turistas entrevistados é proveniente de capitais, com 53\%.

O gráfico 13 a seguir indica a motivação principal do turista entrevistado para conhecer o Instituto Inhotim. De acordo com 69\% dos turistas entrevistados a integração entre arte e natureza foi o fator decisivo. A organização do museu e o contato com a natureza ficaram empatados: cada um com $7 \%$.

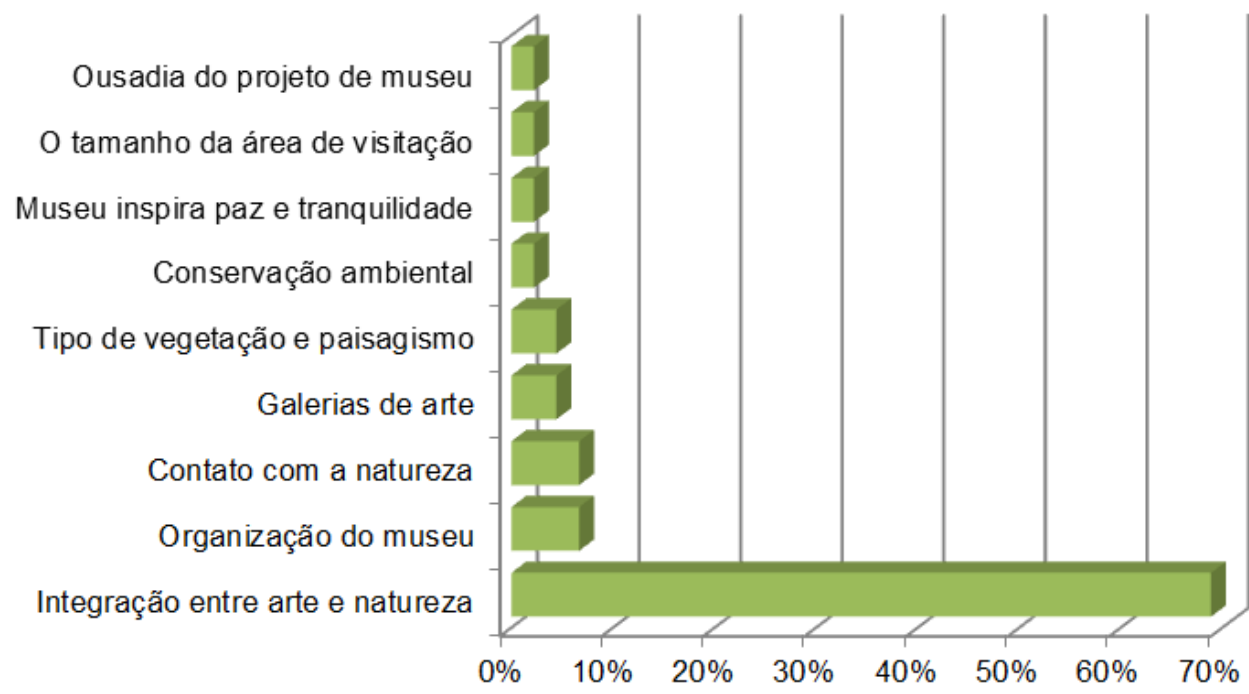

Gráfico 13 - Motivação para conhecer o Instituto Inhotim (MG)

Fonte: Elaborado por Daniela Rocco (2014)

O principal diferencial/inovação do Instituto Inhotim também é a integração entre arte e natureza, com $69 \%$. A organização do museu e o contato com a natureza ficaram empatados: cada um com 7\%. Quando questionados se aquele diferencial/inovação foi decisivo para escolher o Instituto Inhotim, $84 \%$ dos entrevistados disseram que sim. Os que disseram não justificaram, de forma geral, assim: 
- Diferencial citado: Organização do museu; O que foi decisivo: i) integração com a natureza e ii) veio com um amigo(a).

O gráfico 14 está relacionado à frequência que os turistas entrevistados usam serviços turísticos sustentáveis. A maioria disse "às vezes", com 49\%. Em seguida: "não sabe" (16\%), "raramente"/ "sempre" (11\%), "quase sempre" (9\%) e "nunca" (4\%). É preciso salientar que "não sabe" significa o desconhecimento do que seja um "serviço turístico sustentável”.

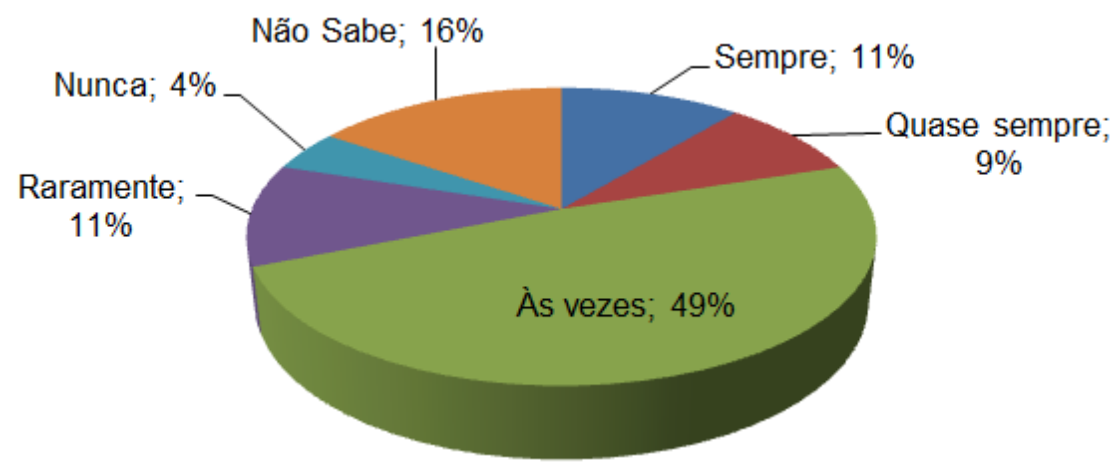

Gráfico 14 - Frequência que usa serviços turísticos sustentáveis: turistas do Instituto Inhotim (MG) Fonte: Elaborado por Daniela Rocco (2014)

Por fim, é preciso mencionar as possibilidades de melhoria do destino/museu, uma vez que, depois que foram identificadas as sugestões e observações, os representantes do Instituto possam avaliar a viabilidade de cada uma. A pergunta esteve direcionada sobre o que o Inhotim deveria oferecer para garantir o retorno do visitante e, assim, tentar identificar caminhos para que o museu se torne ainda mais competitivo. Tal como Gramado (RS), a maioria dos turistas do Inhotim disse que estão satisfeitos (36\%). Sendo assim, a primeira sugestão que obteve maior destaque foi a melhoria do acesso $\mathrm{BH}$-Brumadinho (16\%), e isto inclui: melhorar as condições da estrada, sinalização e acostamento (alguns trechos não têm). A segunda sugestão mais citada foi a prática de preços mais acessíveis (11\%). Com relação à melhoria da informação interna, alguns turistas sugeriram a vinculação de ícones/legendas do mapa nas próprias placas que indicam o direcionamento das galerias. Além disso, um turista sugeriu a presença de placas que informam a direção da saída. Vale destacar, ainda, que o hotel dentro do Inhotim já está sendo construído. Não foi possível chegar até o local, porém a partir de um ponto alto do Inhotim (na área de visitação) é possível ver algumas instalações já construídas. 
O Instituto Inhotim é o segundo maior empregador de Brumadinho (os maiores empregadores da região são quatro mineradoras) e é também considerado hotspot ${ }^{56}$, o que Ihe confere um caráter peculiar em termos de conservação ambiental dos biomas Cerrado e Mata Atlântica.

A região ainda enfrenta diversos desafios, inclusive no âmbito do turismo. Existem casos de turistas que propagam entre as redes sociais que Brumadinho é uma cidade feia e suja e, logo, um completo contraste com o museu. A prefeitura municipal reconhece a importância do museu para a cidade, e são recentes os trabalhos de melhoria da cidade em parceria com o Inhotim. O exemplo mais recente é a doação, pelo Inhotim, de um projeto paisagístico para enfeitar os jardins da cidade com mais de 500 plantas (INHOTIM, 2014c).

\subsection{ANÁLISE COMPARATIVA ENTRE OS TRÊS DESTINOS PESQUISADOS}

De acordo com o gráfico 15 abaixo, com relação aos três destinos turísticos estudados nesta tese, Gramado (RS) é o destino mais desejado dos brasileiros, seguido de Bonito (MS).

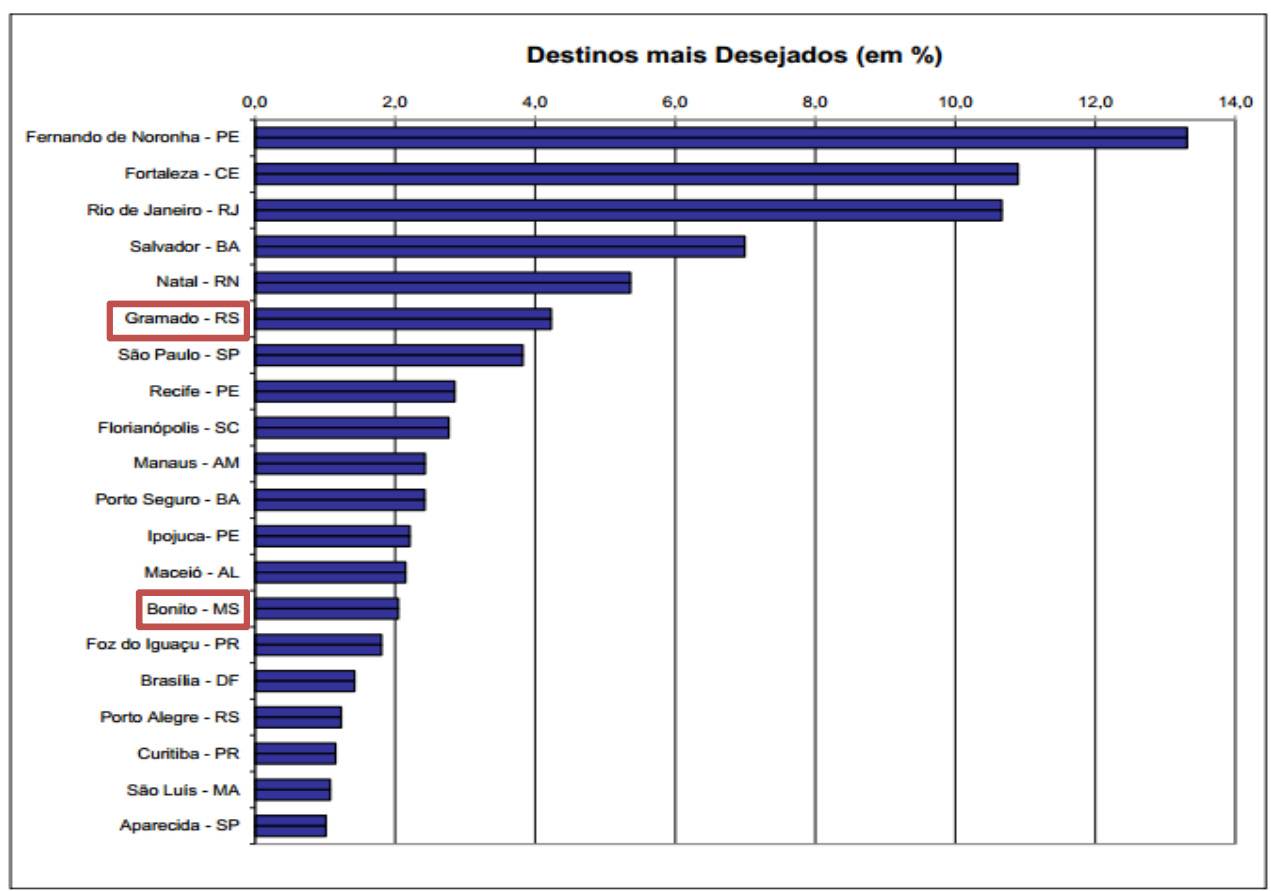

Gráfico 15 - Destinos mais desejados por brasileiros Fonte: FIPE (2012)

\footnotetext{
${ }^{56}$ É "[...] toda área prioritária para conservação, isto é, de alta biodiversidade e ameaçada no mais alto grau. É considerada Hotspot uma área com pelo menos 1.500 espécies endêmicas de plantas e que tenha perdido mais de $3 / 4$ de sua vegetação original” (Cl, 2003?).
} 
O Instituto Inhotim (MG) não consta no ranking do gráfico 15 acima, e nem a cidade de Belo Horizonte (MG), distante do museu cerca de $60 \mathrm{~km}$. Entretanto, a capital mineira é o $4^{\text {a }}$ destino mais visitado do Brasil em relação a motivos que não sejam lazer e negócios (BRASIL, 2013d). Como essa cidade possui o aeroporto internacional mais próximo do museu, podemos pressupor que turistas visitam a capital e/ou destinos turísticos próximos, como é o caso do Inhotim.

As pesquisas de campo realizadas nos três destinos foram importantes para entender os processos e dinâmicas da inovação para a sustentabilidade no turismo brasileiro. O fato de Bonito ser tão premiado, a cidade já começa a receber um tipo de público que também deseja o melhor (é mais exigente). Consequentemente, surgem mais críticas e expectativas não atendidas, como afirmou o representante da SETUR/COMTUR. Segundo entrevista com um taxista de Bonito, "tem gente que vem para cá que acha que é a Disneylandia, acha que tem que ser tudo fácil". Para ele muitos turistas acham ruim ter que passar por estrada de terra e ter que reservar com muita antecedência o acesso aos atrativos.

$\mathrm{Na}$ pesquisa com os turistas em geral não foi identificada a renda dos mesmos, porém alguns resultados quanto à percepção dos turistas de Bonito nos ajuda a pensar de forma abrangente sobre o atual contexto econômico que o Brasil vivencia, bem como levantar algumas hipóteses. O perfil geral dos turistas entrevistados de Bonito é mais exigente, deseja preços mais acessíveis, chegou ao destino pela primeira vez (tinha curiosidade de conhecer/sempre quis conhecer), é proveniente da região Sudeste e gostaria que tivesse mais voos regulares para o aeroporto local, portanto, maior facilidade e comodidade no acesso. Tais características são muito recorrentes entre a nova classe $\mathrm{C}$ do País, que hoje representa $54 \%$ da população. Com o aumento da renda, cresce também o consumo, e isso se reflete, consequentemente, no turismo. Os brasileiros passaram a viajar muito mais, outros, pela primeira vez de avião, sobretudo em função do barateamento dos bilhetes aéreos, que há poucos anos eram extremamente caros. Em função da concorrência entre as companhias aéreas brasileiras, têm-se promoções e sistemas de milhagem que favorecem o crescimento do fluxo de usuários nos aeroportos brasileiros. A nova classe $\mathrm{C}$ gastou só em $2013 \mathrm{R} \$ 1,17$ trilhão, e uma parcela desse valor está relacionada a gastos com viagem. A classe $C$ está mais concentrada na região Sudeste (com $43 \%$ ) e pretende gastar cerca de $R \$ 8,5$ milhões em viagens nacionais (EBC, 2014).

A amostra analisada de turistas dos três destinos turísticos não é representativa. Porém, como já foi mencionado, incita a necessidade de reflexões mais aprofundadas, uma vez que o perfil do turista de Bonito, por exemplo, se aproxima bastante com o perfil da nova classe $C$ do Brasil. Seria oportuno estudar essa questão para verificar se a hipótese se confirma: a maioria dos turistas atuais de Bonito pertence à classe média. O resultado dessa 
pesquisa faria toda diferença para o planejamento turístico da cidade, pois é uma demanda peculiar, que deseja viajar bastante, está mais informada, mas que, ao mesmo tempo, é exigente em termos de qualidade (EBC, 2014; GAZETA DO POVO, 2014). De forma concomitante, é preciso que os atores locais da cidade se reúnam para consolidar a estratégia de marketing direcionada para os públicos-alvo que se deseja realmente atingir, de tal maneira que nesse processo seja sempre respeitada a capacidade de carga dos atrativos.

A pesquisa de campo realizada em Gramado junto aos turistas indica que a principal motivação para se conhecer a cidade é a arquitetura europeia e a própria beleza da cidade como um todo. Embora o turista de Gramado, em geral, não venha à cidade com a motivação de conhecer um "destino sustentável", o fato de ser uma cidade organizada, limpa, bonita, de povo gentil e hospitaleiro, faz com que os turistas se encantem pela cidade e queiram voltar. A pesquisa de campo nesse destino nos permitiu verificar que as inovações produzidas por entes públicos e privados (até mesmo relacionadas à sustentabilidade), geram inúmeros efeitos positivos e sistêmicos, repercutindo sobre a população local e turistas. O destino, assim, se torna mais competitivo, na medida em que oferece distintos produtos turísticos de qualidade. Inclusive, quando os turistas foram questionados sobre o que a cidade poderia melhorar para que eles voltassem, a maioria respondeu que já estava satisfeito e que certamente voltaria. No entanto, de acordo com o trabalho de observação direta associado às respostas de alguns turistas e atores locais, foram identificados os principais pontos fracos da cidade (em termos de turismo):

- Frota de táxi bastante reduzida: na cidade existem menos de 40 táxis, distribuídos em 4 pontos. Contudo, apesar de não existir serviço de transporte público de ônibus no microcentro da cidade, muitas fábricas de chocolate, casas de cafés coloniais e restaurantes oferecem serviço gratuito de transporte, buscando turistas em seus respectivos hotéis e levando-os de volta. Talvez falte mais informação sobre isso, de toda forma, é preciso encontrar uma solução mais viável para o transporte público na cidade, bem como a criação e melhoria de ciclovias;

- Inviabilização do uso de calçadas: algumas localizadas em áreas um pouco distantes do centro estavam inacessíveis em função de plantas e árvores (faltavam podas) e porque estavam danificadas;

- Engarrafamentos na alta temporada: são numerosos nessa época. Embora a Prefeitura Municipal permita que o taxista, titular de uma licença, possa operar com um segundo carro, o problema ainda não foi solucionado com êxito.

Vale salientar que a indicação de amigos e parentes foi decisiva para que muitos turistas entrevistados visitassem os três destinos estudados. Podemos inferir, em relação à iniciativa privada, que as inovações necessárias estão vinculadas a processos e melhorias 
internas para fidelizar os visitantes, pois são eles os maiores propagadores (para o bem ou para o mal) de uma empresa. De acordo com o dramaturgo inglês William Shakespeare, "tentando melhorar muitas vezes estragamos o que é bom". Provavelmente o perfil dos turistas entrevistados não deseja grandiosas inovações com altíssimos investimentos, e sim, o mínimo: acesso facilitado e preços acessíveis. Isso se justifica graças às vantagens comparativas de cada destino, pois estas já estão consolidadas e são os principais diferenciais. É preciso melhorar continuamente considerando cada contexto, cada vocação turística, porém é importante lembrar que Shakespeare nos ensina a ter cautela.

No âmbito territorial do destino (nível: cidade), Bonito e Gramado possuem semelhanças. As mais positivas: são destinos indutores do turismo (BRASIL, 2013a) e estão consolidados, são de pequeno porte (maior facilidade de planejar e gerir), possuem preocupação ambiental (a coleta seletiva é uma realidade), são destinos premiados/reconhecidos, os pedestres são prioridade (respeito às faixas), a saúde pública é satisfatória, a sensação de segurança é muito grande, os turistas reconheceram que os profissionais são bem preparados e hospitaleiros e, por fim, da capital do estado até o referido destino a estrada de acesso é razoavelmente boa e sinalizada. No entanto, a maior parte dos atrativos é de acesso privado, com poucas opções gratuitas de lazer. Ambos os destinos não dispõem de ciclovia no microcentro e possuem dificuldades de contratação de mão-de-obra qualificada e de pessoas que realmente queiram trabalhar. De acordo com a representante do Hotel Bangalôs da Serra (Gramado) existem pessoas que não buscam qualificação justamente pelo fato de que a maioria das empresas da cidade é de caráter familiar. Sendo assim, haveria, teoricamente, dificuldade de crescimento na carreira, pois o cargo máximo que seria conquistado seria a gerência. Isto é um problema que pode surtir efeitos negativos no futuro, pois a qualificação contínua dos recursos humanos é necessária em uma atividade turística que é extremamente dinâmica e competitiva. Além disso, o cidadão que busca sempre por qualificação pode obter outras vantagens, inclusive abrir o próprio negócio com maior respaldo técnico e teórico. Quanto às diferenças, Bonito possui uma oferta de atrativos naturais bastante superior à de Gramado, bem como é mais organizado em relação às formas de acesso aos atrativos que Gramado dispõe. No entanto, a oferta cultural e gastronômica (em termos de quantidade) é muito inferior à de Gramado. É compreensível que a quantidade de estabelecimentos de alimentos e bebidas de Bonito seja menor, pois a população é menor e a quantidade de visitantes que recebe em relação a Gramado é também menor. Porém, se Bonito mantivesse o nível de conservação dos atrativos naturais aliado à uma oferta recorrente de programas culturais (sobretudo gratuitos), a experiência do turista seria melhor. As três principais atrações culturais noturnas de Bonito são pagas (Projeto Jiboia, Aquário Natural e Taboa Fábrica de Encantos), e são poucos os eventos culturais que ocorrem gratuitamente na praça da 
cidade. No tocante à Gramado, quando a cidade não oferta nenhum evento cultural, a programação basicamente fica limitada aos restaurantes. Por fim, em termos de facilidade e comodidade no acesso, Gramado novamente se destaca, pois tem dois aeroportos próximos: o de Porto Alegre e o de Caxias do Sul. Entretanto, Bonito possui aeroporto próprio, ainda que tenha poucos voos regulares (provavelmente para limitar a quantidade de pessoas - controle da capacidade de carga).

Em relação à pesquisa junto ao Instituto Inhotim, a maior parte dos turistas brasileiros é proveniente da região Sudeste e busca no museu a possibilidade de estar em contato com a arte e natureza. Inclusive, esse é o principal diferencial/inovação. É válido sublinhar que não foram realizadas pesquisas com estrangeiros, afinal, o foco desta tese se concentra nos destinos do Brasil e no turismo doméstico. De todo modo, é digno de menção que durante as visitas ao museu foi possível observar a presença de turistas internacionais de distintas nacionalidades. Caberia, portanto, realizar um estudo específico com esse público, de tal modo a identificar, por exemplo, o perfil e a percepção sobre a inovação para a sustentabilidade no turismo de suas cidades e nos destinos que visitam.

Mais que um equipamento turístico (museu), o Instituto Inhotim assumiu em muito pouco tempo um caráter de "microdestino", exercendo grande influência sobre a cidade onde está localizado: Brumadinho. O Instituto foi criado há poucos anos (aberto à visitação em 2006) e mais recentes são os projetos em parceria com a região e a capital mineira. São mais de 30 projetos socioeducativos e com cunho ambiental, no entanto, acreditamos que falta dar maior visibilidade aos mesmos. O projeto inicial foi ousado, inovador e criativo, e ao que tudo indica se consolidará cada vez mais como o maior centro cultural do País que alia conservação ambiental, uma vez que o Inhotim é considerado Jardim Botânico. Existem projetos para facilitar o acesso entre $\mathrm{BH}$ e Brumadinho (por via ferroviária), a construção de um hotel dentro da área de visitação e a criação da TV Inhotim.

O Quadro 25 apresenta uma síntese de informações sobre os três destinos turísticos estudados, visando estabelecer uma base comparativa entre os três e explicitando semelhanças e diferenças. Os resultados mostraram que as vantagens comparativas dos destinos (a vocação natural de cada um) são as mais importantes para os turistas, isto porque em Bonito (MS) o principal diferencial/inovação citado corresponde às belezas naturais, em Gramado (RS) o estilo arquitetônico e no Instituto Inhotim a integração entre arte e natureza.

São destinos turísticos distintos, evidentemente, por seus territórios, características de vegetação e relevo, índices socioeconômicos, número de visitantes, entre outros. No entanto, os três inovam para atingir seus públicos-alvo e são, de fato, competitivos no Brasil. No caso da inovação para a sustentabilidade em Bonito e no Instituto Inhotim, esse processo é percebido de forma clara e direta, contribuindo para a competitividade de ambos. 
Quanto às práticas de inovação para a sustentabilidade de Gramado, pode-se afirmar que são percebidas de maneira indireta. Contudo, elas influenciam diretamente na competitividade desse destino, sobretudo porque o grau de satisfação de quem visita Gramado é elevado, e isto se justifica por tais práticas.

\begin{tabular}{|c|c|c|c|}
\hline $\begin{array}{l}\text { COMPONENTES DE } \\
\text { ANÁLISE }\end{array}$ & BONITO (MS) & GRAMADO (RS) & INSTITUTO INHOTIM (MG) \\
\hline Área & $4.947,72 \mathrm{~km}^{2}$ & $236,93 \mathrm{~km}^{2}$ & $2,6 \mathrm{~km}^{2}$ \\
\hline População & Menor (19.587) & 32.273 & Maior (33.973): Brumadinho \\
\hline IDHM & Pior* $(0,670 \%)$ & Melhor $(0,764 \%)$ & 0,747\%: Brumadinho \\
\hline Desigualdade (Gini) & $0,54 \%$ & Melhor $(0,48 \%)$ & Pior $^{*}(0,57 \%)$ : Brumadinho \\
\hline N. visitantes/ano & 200 mil/ano & 6 milhões/ano & $400 \mathrm{mil} / \mathrm{ano}$ \\
\hline Sustentabilidade & $\begin{array}{c}\text { É percebida de forma direta } \\
\text { pelos turistas (conservação da } \\
\text { natureza: a dimensão ambiental } \\
\text { da sustentabilidade está mais } \\
\text { explícita) }\end{array}$ & $\begin{array}{c}\text { É percebida de forma indireta } \\
\text { pelos turistas (limpeza e } \\
\text { organização da cidade: a } \\
\text { dimensão cultural da } \\
\text { sustentabilidade está mais } \\
\text { explícita) }\end{array}$ & $\begin{array}{l}\text { É percebida de forma direta } \\
\text { pelos turistas (as dimensões } \\
\text { ambiental e cultural da } \\
\text { sustentabilidade estão mais } \\
\text { explícitas) }\end{array}$ \\
\hline $\begin{array}{l}\text { Aplicação geral da } \\
\text { MIST }\end{array}$ & \multicolumn{2}{|c|}{$\begin{array}{c}\text { Em ambos os destinos nenhum ator entrevistado citou casos de } \\
\text { inovação para a sustentabilidade nos segmentos: agências de } \\
\text { viagem e governo/informação turística }\end{array}$} & Não se aplica \\
\hline $\begin{array}{l}\text { Destaque entre as } \\
\text { MIST }\end{array}$ & $\begin{array}{l}\text { Taboa Fábrica de Encantos: } \\
\text { processos mais cíclicos de } \\
\text { reaproveitamento dos insumos }\end{array}$ & $\begin{array}{l}\text { Bangalôs da Serra: processos } \\
\text { mais cíclicos de } \\
\text { reaproveitamento dos insumos }\end{array}$ & $\begin{array}{c}\text { O próprio Instituto Inhotim é } \\
\text { o destaque (objeto de } \\
\text { análise da MIST) }\end{array}$ \\
\hline $\begin{array}{c}\text { Coleta seletiva e } \\
\text { Reciclagem }\end{array}$ & Sim & Sim & Sim \\
\hline $\begin{array}{l}\text { Oferta turística } \\
\text { integrada }\end{array}$ & Não & Sim & Sim \\
\hline \multirow{5}{*}{$\begin{array}{l}\text { Turistas } \\
\text { entrevistados }\end{array}$} & $\begin{array}{l}\text { Maior estado emissor: SP } \\
\text { Região emissora: Sudeste } \\
\text { Perfil: Não capitais }\end{array}$ & $\begin{array}{l}\text { Maior estado emissor: SP } \\
\text { Região emissora: Sudeste } \\
\text { Perfil: Capitais }\end{array}$ & $\begin{array}{c}\text { Maior estado emissor: MG } \\
\text { Região emissora: Sudeste } \\
\text { Perfil: Capitais }\end{array}$ \\
\hline & $\begin{array}{l}\text { Motivação principal: belezas } \\
\text { naturais }\end{array}$ & $\begin{array}{l}\text { Motivação principal: estilo } \\
\text { arquitetônico }\end{array}$ & $\begin{array}{l}\text { Motivação principal: } \\
\text { integração entre arte e } \\
\text { natureza }\end{array}$ \\
\hline & $\begin{array}{c}\text { Principal diferencial/inovação: } \\
\text { belezas naturais }(54 \%) \\
\text { Se este diferencial foi decisivo } \\
\text { para visitar o destino: Sim }(80 \%)\end{array}$ & $\begin{array}{c}\text { Principal diferencial/inovação: } \\
\text { estilo arquitetônico (22\%) } \\
\text { Se este diferencial foi decisivo } \\
\text { para visitar o destino: Sim } \\
\text { (83\%) }\end{array}$ & $\begin{array}{c}\text { Principal } \\
\text { diferencial/inovação: } \\
\text { integração entre arte e } \\
\text { natureza (69\%) } \\
\text { Se este diferencial foi } \\
\text { decisivo para visitar o } \\
\text { destino: Sim (84\%) }\end{array}$ \\
\hline & $\begin{array}{l}\text { Usa serviços turísticos } \\
\text { sustentáveis: } \\
\text { - Às vezes: } 46 \% \\
\text { - Quase sempre: } 30 \% \\
\text { - Sempre: } 14 \% \\
\text { - Raramente: } 2 \% \\
\text { - Nunca: } 6 \%\end{array}$ & $\begin{array}{l}\text { Usa serviços turísticos } \\
\text { sustentáveis: } \\
\text { - Âs vezes: } 33 \% \\
\text { - Quase sempre: } 22 \% \\
\text { - Nunca: } 17 \% \\
\text { - Não sabe: } 17 \% \\
\text { - Sempre: } 6 \% \\
\text { - Raramente: } 6 \%\end{array}$ & $\begin{array}{l}\text { Usa serviços turísticos } \\
\text { sustentáveis: } \\
\text { - Às vezes: } 49 \% \\
\text { - Não sabe: } 16 \% \\
\text { - Raramente: } 11 \% \\
\text { - Sempre: } 11 \% \\
\text { - Quase sempre: } 9 \% \\
\text { - Nunca: } 4 \%\end{array}$ \\
\hline & $\begin{array}{l}\text { Deve melhorar: } \\
\text { - Disponibilizar voos mais } \\
\text { regulares no aeroporto de } \\
\text { Bonito }(16 \%)\end{array}$ & $\begin{array}{c}\text { Deve melhorar: } \\
\text {-39\% estão satisfeitos } \\
\text { - 28\%: preços mais acessíveis }\end{array}$ & $\begin{array}{c}\text { Deve melhorar: } \\
\text { - 36\% estão satisfeitos } \\
\text {-16\%: melhorar o acesso } \\
\text { BH-Brumadinho }\end{array}$ \\
\hline
\end{tabular}

* Pior índice em relação aos dois destinos analisados

Quadro 25 - Quadro comparativo: análise entre Bonito (MS), Gramado (RS) e Instituto Inhotim (MG)

Fonte: Elaborado por Daniela Rocco (2014) 
Com relação à oferta turística, em Bonito não foram identificadas parcerias entre atrativos turísticos e demais equipamentos turísticos. Não obstante, em Gramado identificou-se duas ações de integração da oferta: i) Passaporte com preço especial para a visitação de quatro museus: Museu do Automóvel - Hollywood Dream Cars; o Museu de Cera: Dreamland; o Harley Motor Show e o Super Carros e ii) Aquelas pessoas que estão hospedadas no Hotel Bangalôs da Serra possuem desconto em diversos atrativos e equipamentos turísticos, quais sejam: GramadoZoo; Kur Estação das Águas; MiniMundo; Museu da Moda - MUM; Museus da Cidade (Museu Hollywood Dream Cars, Museu de Cera Dreamland, Harley Motor Show, Super Carros); Parque Gaúcho; Rasen Bier; Vinícola Ravanello; Vinecol (vinhos orgânicos e de comércio justo); VISÃO - Agência de Desenvolvimento da Região das Hortênsias e Vitta: Experiências em Hospedagem Sustentável. Além disso, o Instituto Inhotim está integrado ao "Circuito Cultural Praça da Liberdade" de Belo Horizonte, pois mantém um espaço que chama "Inhotim Escola", que por sua vez se dedica à arte e meio ambiente, oferecendo palestras, debates, mesas-redondas, entre outros com acesso gratuito.

O Centro de Investigaciones Económicas (CINVE) publicou em 2013 o documento "La política de turismo sostenible en Costa Rica como fuente de innovación para servicios de hospitalidad: Innovación y Productividad en el Sector Servicios". Esta pesquisa foi realizada junto ao setor hoteleiro e citou que tanto na Costa Rica quanto na Espanha o gasto dos empresários de hotelaria com pesquisa e desenvolvimento (P\&D) é baixíssimo. De forma geral, tais empresários se posicionam mais como "compradores de tecnologia" que desenvolvedores de suas próprias inovações (CINVE, 2013). Um estudo publicado por Alzua-Sorzabal \& Abad Galzacorta (2008) sobre a inovação na atividade turística do País Basco (Espanha) revelou que a maioria das inovações do setor turístico regional assume a forma "incremental". Caso semelhante é no Brasil, pois o trade turístico investe muito pouco em P\&D e em inovações disruptivas. No ambiente interno das empresas turísticas brasileiras é muito mais comum encontrar inovações incrementais, e isto foi bastante evidente nas pesquisas exploratória e qualitativa desta tese. Talvez o caso mais emblemático de inovação (disruptiva) para a sustentabilidade do turismo brasileiro é voucher único digital, que transformou radicalmente o processo de planejamento e gestão turística de Bonito e cujo modelo é estudado não só por pesquisadores brasileiros, como estrangeiros também. Outro exemplo de inovação disruptiva no contexto da sustentabilidade é a criação do Instituto Inhotim, pois este reúne em um só espaço museu de arte contemporânea a céu aberto e Jardim Botânico, sendo o único do Brasil (e um dos poucos no mundo) nesse formato.

Vale destacar, ainda, que na pesquisa do CINVE (2013) foi identificado um grande esforço do setor hoteleiro da Costa Rica em termos de inovação de marketing. Entretanto, 
há um grande desconhecimento dos turistas quanto ao CST (Certificação para a Sustentabilidade Turística) criado pelo Instituto Costarriquense de Turismo (ICT). Portanto, o efeito na decisão de escolha de um meio de hospedagem ter a CST é quase nulo. Só quando os turistas se hospedam nos hotéis certificados e têm contato direto com as ações de sustentabilidade é que se dão conta dos efeitos positivos do certificado (CINVE, 2013). Na pesquisa feita com os turistas de Gramado, 34\% "não sabem"/nunca utilizaram serviços sustentáveis. Provavelmente eles não se deram conta, tal como no caso da CST da Costa Rica, que as ações de sustentabilidade no turismo influenciam positivamente na experiência turística, e isso se dá por meio de inovações nos processos, nos serviços, no ambiente organizacional, entre outros. Com efeito, tais ações são decisivas para a competitividade de Gramado, uma vez que a experiência do turista é positiva na medida em que ele tem acesso a uma cidade limpa, organizada e com profissionais preparados e hospitaleiros. No caso de Gramado, Instituto Inhotim e até mesmo de Bonito, a percepção ao aplicar a pesquisa junto aos turistas é que foram raros os casos de encontrar aquele que realmente é um "ecoturista" que efetivamente se preocupa com a sustentabilidade do destino. Entretanto, as porcentagens dos turistas dos três destinos que citaram que nunca usaram "serviços turísticos sustentáveis" foram baixas em relação ao acumulado "sempre", "quase sempre" e "às vezes".

Por fim, a MIST permitiu analisar os pilares inovação e sustentabilidade de forma separada e em conjunto. Cada ação de uma organização turística foi analisada considerando suas inovações para a sustentabilidade; e as informações e dados foram cruzados. A Figura 61 facilita a visualização desse processo. A MIST foi construída a partir de dois atributos (inovação e sustentabilidade), variáveis e critérios relacionados a sete segmentos turísticos (1. Meios de transporte; 2. Meios de Hospedagem; 3. Alimentos e bebidas; 4. Atrativos turísticos; 5 . Agências de viagens; 6 . Governo e informação turística e 7. Cooperação/Terceiro setor). Tais segmentos, por sua vez, podem estar inseridos ou em um sistema aberto que contém a cadeia de valor do turismo ou, em um contexto mais avançado de inovação, em uma complexa rede aberta de encadeamentos produtivos e a cadeia de valor do turismo. O nível de complexidade e detalhamento da MIST está associado a esses dois e distintos ambientes. Isto explica porque muitos critérios e variáveis não foram contemplados nas matrizes de cada destino pesquisado. São dois motivos principais: i) porque alguns itens não correspondiam ao perfil do equipamento/atrativo estudado. Exemplo: no caso de "controle de substâncias perigosas" esse item certamente seria perguntado para o entrevistado associado a uma empresa turística de meio de transporte, como avião e ônibus rodoviário e ii) porque todos os casos estudados nesta tese não dispõem de tecnologias avançadas, como ferramentas de buscas inteligentes, gerador 
de itinerários e catálogos multimídia. As inovações ainda são muito tímidas e escassas, tendendo estar mais contextualizas em um sistema aberto com cadeia de valor do turismo.

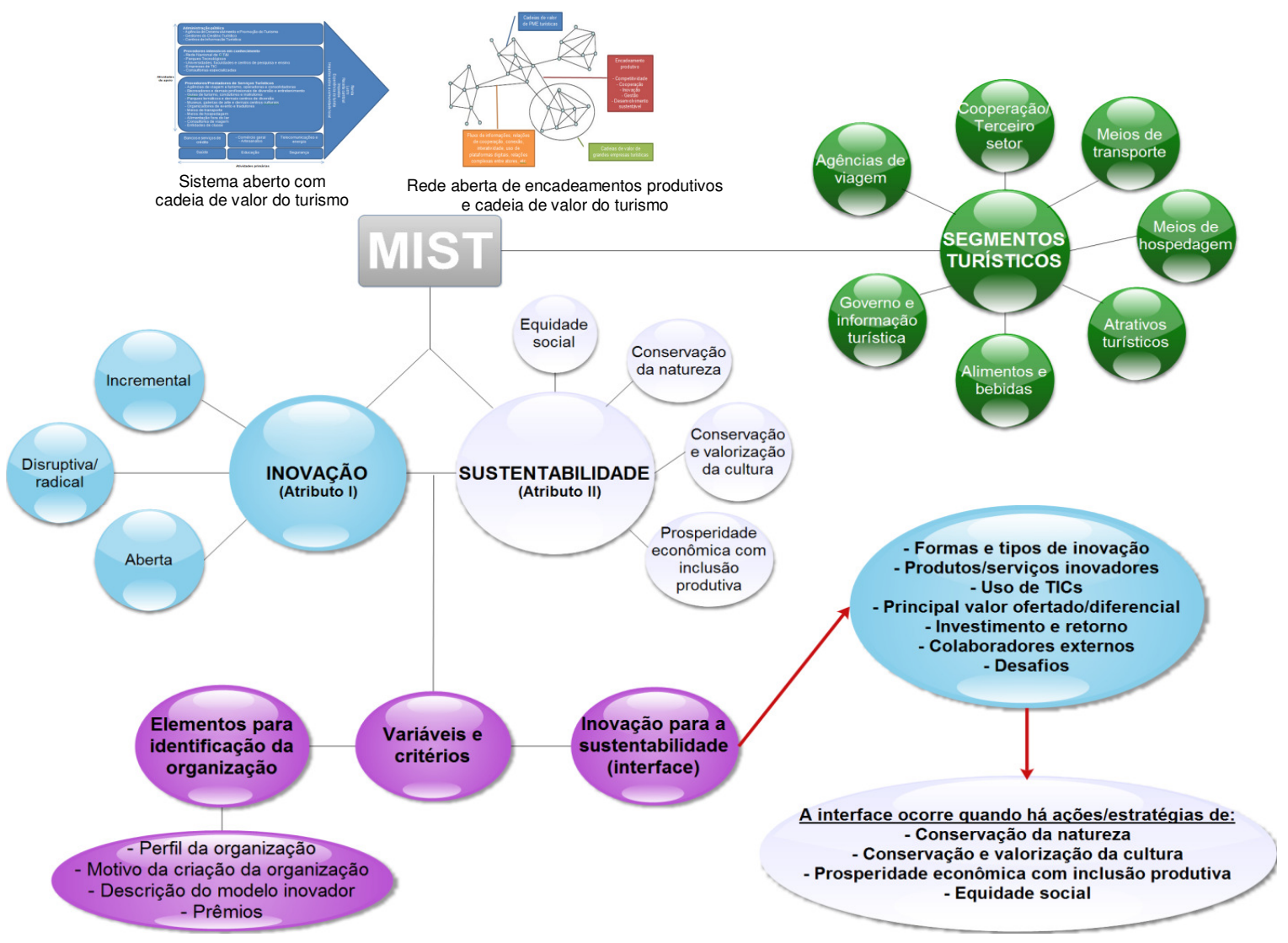

Figura 61 - Mind map da MIST com foco na construção da interface entre inovação e sustentabilidade Fonte: Elaborado por Daniela Rocco (2014)

Na Figura 61 é possível verificar também que as variáveis e critérios foram divididas, na prática, em duas categorias: "elementos para a identificação da organização" e "inovação para a sustentabilidade". Esta interface (da segunda categoria) foi feita da seguinte maneira: os critérios de inovação foram analisados com base nos critérios de sustentabilidade.

Temos ciência que a MIST pode ser uma matriz para auxiliar na análise quanto à interface real entre os pilares inovação e sustentabilidade, tão citados nos modelos de competitividade e que, mesmo assim, estão pouco relacionados (SILVA, 2013). Nossa proposta metodológica, portanto, representou uma etapa inicial de análise e que será passível de aplicação e adequação em trabalhos vindouros, até mesmo de outras áreas.

Na próxima seção, a última deste capítulo, apresentamos não apenas a análise final dos resultados da pesquisa de forma geral, bem como realizamos correlações entre a revisão da literatura, entrevistas junto aos 50 especialistas e as três pesquisas de campo. 


\subsection{ANÁLISE FINAL DOS RESULTADOS DA PESQUISA}

"Es más importante el camino que la posada"

Cervantes

Ao retomarmos toda a reflexão teórica dos capítulos 1 e 2 (pesquisa exploratória) e as pesquisas de campo no exterior e Brasil (pesquisa qualitativa), é possível refletir melhor sobre o objetivo geral deste trabalho, que consiste em identificar e analisar como os destinos turísticos brasileiros adotam inovações para a sustentabilidade. Para iniciar essa reflexão é preciso considerar pelo menos dez premissas da tese. São elas:

\section{Box 4 - As 10 principais premissas da tese}

1. Turismo é experiência;

2. Sistema turístico é composto por múltiplas e complexas cadeias de valor;

3. O setor terciário (serviços) ainda é pouco priorizado nas agendas de governo, mesmo sendo um dos que mais cresce e emprega no mundo (inclusive no Brasil);

4. A competitividade é composta basicamente por cinco pilares essenciais: produtividade, inovação, sustentabilidade, qualidade e marketing. Logo, inovação para a sustentabilidade contribui para a competitividade;

5. A interface entre inovação e sustentabilidade é pouco explorada na literatura sobre competitividade;

6. Inovação e sustentabilidade são capazes de gerar valor para o turismo, que por sua vez oferta valor e é valorado pelos turistas (influência na competitividade);

7. O fator humano é central na produção de valor turístico, valor sustentável e geração de valor por meio da inovação;

8. As inovações repercutem direta e indiretamente no sistema turístico. E sendo a sustentabilidade um valor que é transversal aos processos, a repercussão também é direta e indireta sobre o sistema turístico;

9. Desenvolvimento sustentável é um processo maior que envolve valores de sustentabilidade ambiental, social, cultural e econômica;

10. Apesar de o Brasil ser signatário de diversos acordos ambientais (tendo inclusive sediado a Rio92 e a Rio+20) e tenha uma das legislações ambientais mais avançadas do mundo, possui legislação específica de inovação bastante recente, iniciada em 2004 . Estudos sobre inovação para a sustentabilidade no turismo são ainda mais recentes e precisam de maior aprofundamento.

Como se pôde verificar nos capítulos anteriores, a inovação se manifesta de distintas formas, e tomando por base a relevância do desenvolvimento sustentável para as agendas públicas e privadas, bem como os movimentos socioambientais, é válido afirmar que inovar é também considerar a sustentabilidade nos processos de produção. Após o início da industrialização e até meados do século XX nunca se teve acesso a produtos e serviços que 
agredissem menos o ambiente. Que consumidor da década de 1920, por exemplo, poderia comprar carros híbridos, movidos a gás natural ou biocombustíveis? No caso do turismo especificamente, que turista do início do século XIX se hospedaria em um hotel com uso de tecnologia direcionada para a eficiência energética e do uso da água? Que museu disponibilizaria uma caixa para que os visitantes pudessem depositar na saída os mapas e guias, de tal modo que novos visitantes possam reutilizar os mesmos?

A inovação geralmente é percebida como risco, destruidora de produtos e serviços vigentes e até mesmo insustentável. Ao longo da história, o homem pôde se revelar como um ser evolucionário e revolucionário por natureza, haja vista a invenção da roda, do fogo, as inovações políticas, econômicas e culturais alcançadas por meio de grandes revoluções, entre outras. A sociedade global está (e sempre estará) em processo de inovação, pois além das necessidades, o ser humano é movido pela curiosidade (o que o leva a criar) e também pelo desejo ter mais conforto e diversão, o que o motiva a criar inovações que não necessariamente são indispensáveis à sobrevivência humana. A promessa de um desenvolvimento econômico com equidade social, respaldada pelo atual modelo de produção capitalista não foi cumprida, se tornando, assim, um mito, uma ilusão. Isso se fundamenta na exclusão social e na degradação ambiental e cultural decorrentes do sistema econômico vigente, que produz concentração de renda, aumento do consumo (o que envolve mais extração de recursos do meio ambiente) e provimento de mão-de-obra a baixos custos (FURTADO, 1974).

Por isso, acreditamos que um dos caminhos favoráveis para minimizar a problemática atual é a inovação para a sustentabilidade. Isto quer dizer: um processo que preferencialmente deve ocorrer em todo o ciclo de vida de produtos e serviços e que gere valor às pessoas sem degradar o ambiente ao mesmo tempo. De acordo com Delgado et al. (2008, p. 06, grifo nosso)

[...] no lugar de se ater apenas ao atendimento das demandas do mercado, a geração de inovações voltadas para a sustentabilidade teria que considerar os valores e necessidades da sociedade, visando seu bemestar tanto financeiro quanto o relativo à qualidade de vida.

No capítulo 1 foram apresentados conceitos relativos a valor e proposta de valor nos negócios, que por sua vez se complementam com o capítulo 2, sobre inovação. Ao associar a discussão de ambos os capítulos é preciso ressaltar que se inova ora para propor um novo valor ao mercado, ora para melhorar um produto, um serviço, um processo, um modelo de organização, uma forma de se comercializar (marketing), entre outros. Isso altera o valor final da proposta inicial de valor de um negócio. 
Tal como foi declarado no capítulo 2, a inovação é um pilar que ajuda a sustentar as vantagens competitivas, contudo, paradoxalmente, pode comprometer as próprias vantagens competitivas de um destino turístico, uma vez que alguns processos colaboram para a degradação ambiental e desencadeamento de problemas socioculturais. Em Alves (2013) vimos que na literatura falta uma interface real entre os pilares inovação e sustentabilidade no contexto da competitividade turística.

Para entendermos como poderia ser essa relação entre inovação e sustentabilidade na geração de valor e demais resultados, elaboramos a equação 1 apresentada a seguir. $A$ inovação (processo que gera valor) intersecta com a sustentabilidade (valor transversal aos processos). Isto resulta em geração de valor agregado (produto de inovação e sustentabilidade). Consequentemente, isto implica em competitividade e em desenvolvimento sustentável. Esta lógica se adequa para um cenário de menor ou maior grau de inovação e sustentabilidade, cujos reflexos sobre a competitividade e desenvolvimento sustentável podem ser piores ou melhores (vai depender do contexto).

Inovação $_{(v)} \cap$ sustentabilidade $_{(v)}=$ valor agregado $\rightarrow$ competitividade $\rightarrow$

\section{desenvolvimento sustentável}

\section{Em que:}

Inovação: processo + valor

$\mathrm{n}$ : intersecta com

Sustentabilidade: valor + processo (transversal)

$=$ : igual a

Valor agregado: produto de inovação e sustentabilidade

$\rightarrow$ : implica (em)

Competitividade: resultado do processo da soma e interseção simultânea entre inovação e sustentabilidade

Desenvolvimento sustentável: processo complexo imbuído de valores

No caso do turismo a lógica da equação 2 a seguir é a mesma da equação 1 . O que diferencia é a aplicabilidade junto a uma empresa turística ou no nível do território (destino).

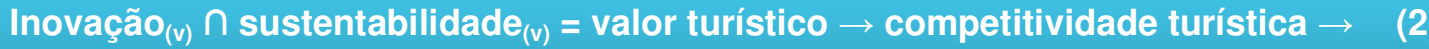

\section{desenvolvimento sustentável do destino turístico}

Essas equações são sintéticas, uma vez que também existem outras variáveis bastante relevantes, como a produtividade, qualidade e marketing. Entretanto, o objetivo de apresentá-las é evidenciar que a inovação e sustentabilidade contribuem para a competitividade e, consequentemente, para o desenvolvimento sustentável.

A Figura 62 abaixo representa uma síntese da reflexão teórica desta tese com os conceitos-chave. Trata-se de uma representação da dinâmica da economia imaterial na rede 
de valor do turismo, cujos inputs (entradas) são a inovação, qualidade, produtividade, sustentabilidade e marketing e os outputs (saídas - resultados) são o valor para as pessoas, a experiência turística, soluções criativas, competitividade e desenvolvimento sustentável. Por sua vez, os outputs retroalimentam toda a rede de valor, já que possui natureza sistêmica. A rede, que é aberta devido às influências e conexões externas, é composta por macrossistemas abertos de valor que, graças à dinâmica da economia de serviços, economia da experiência, economia criativa e sociedade dos sonhos, geram valor turístico e valor sustentável (ambos interagem entre si por meio dos encadeamentos produtivos, que são compostos pela cadeia de valor do turismo). Ela também está associada ao "mundo d.i.", mas o nível de complexidade dependerá do estágio do ciclo de vida de cada destino turístico, tanto a partir de uma escala local quanto internacional.

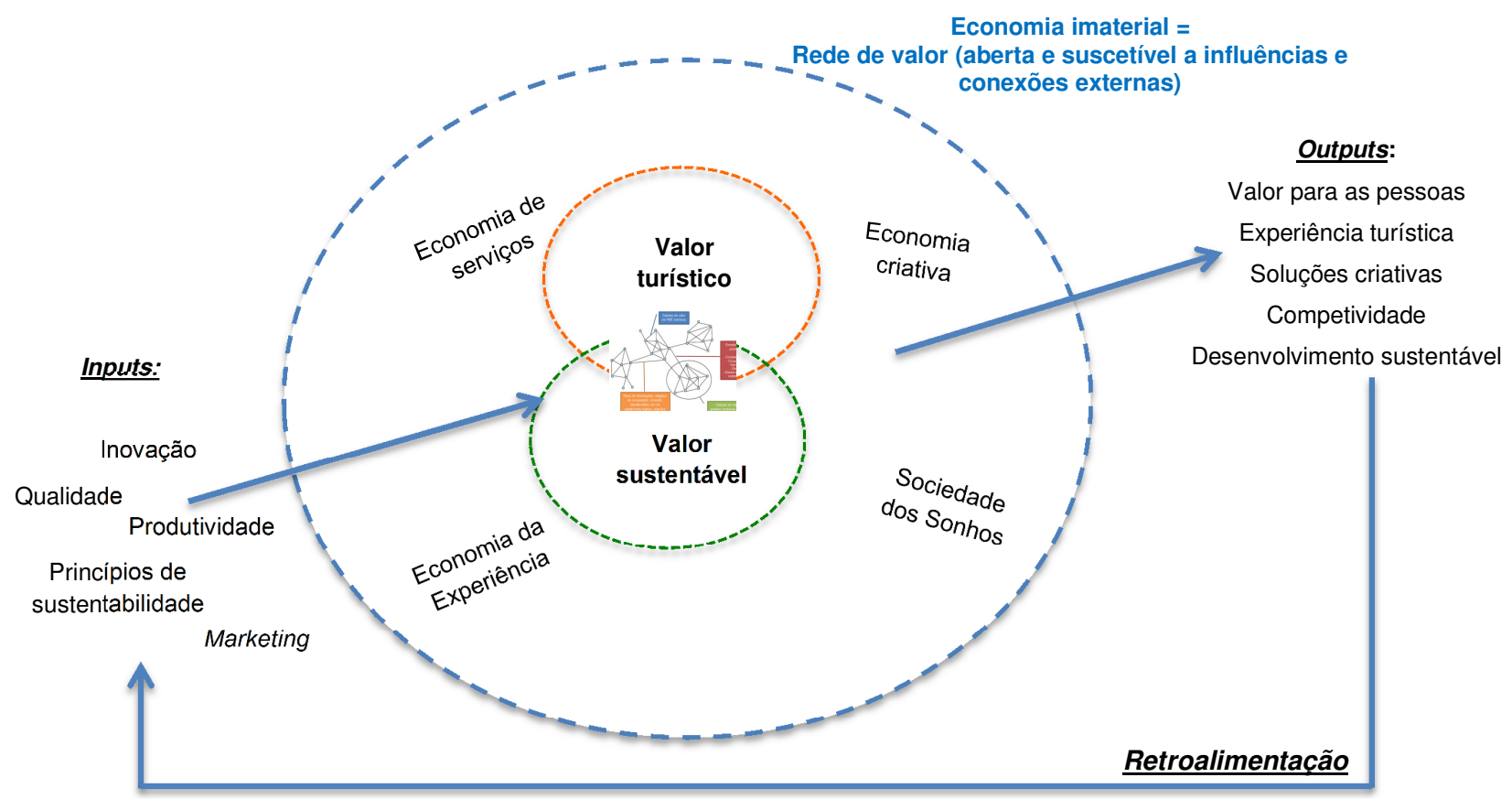

Figura 62 - Representação da dinâmica da economia imaterial na rede de valor do turismo Fonte: Elaborado por Daniela Rocco (2014)

No âmbito empresarial, a rede de valor, no contexto da inovação, está associada à

[...] estratégia competitiva de cada empresa, e principalmente suas antigas opções de mercados, determina suas percepções do valor econômico de uma nova tecnologia. Essas percepções, por sua vez, definem as recompensas que diferentes empresas esperam obter pela busca de inovações incrementais e de ruptura (CHRISTENSEN, 2012, p. 74, grifo nosso).

Quanto à sustentabilidade empresarial existem cinco estágios relacionados à transformação da empresa quando a mesma adota ações sustentáveis. A Figura 63 mostra 
um desses estágios está associado à inovação, pois é o momento que a organização busca coerência das atividades de sustentabilidade entre os setores da própria organização. Nesse processo é preciso também vencer o desafio de se criar capacidades internas para a busca de soluções, bem como garantir o comprometimento e integração de todos os colaboradores da organização, de tal modo que haja, efetivamente, transformação (LAURIANO et al., 2014).

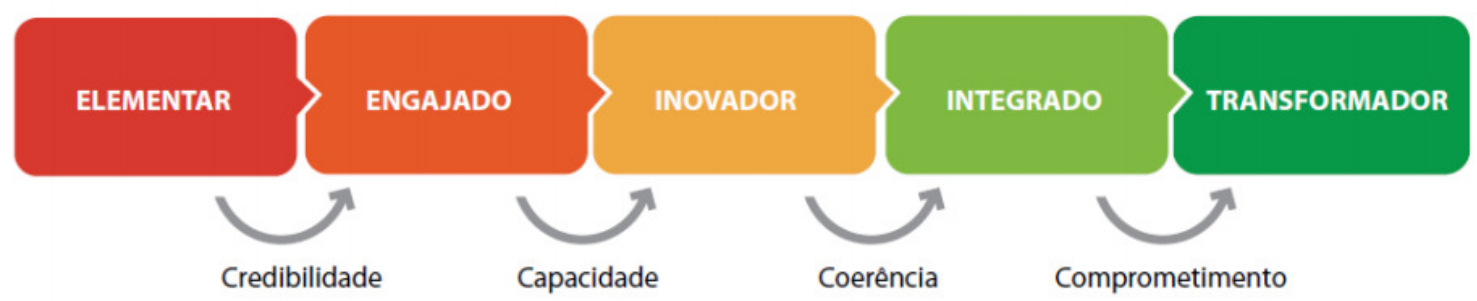

Figura 63 - Como as empresas brasileiras podem avançar a partir da sustentabilidade Fonte: Lauriano et al. (2014).

A lógica da Figura 63 pode ser estendida para um contexto além do ambiente interno das empresas: o destino turístico. No caso dos 40 destinos turísticos brasileiros citados pelos 50 especialistas em turismo e inovação, a maior parte é de pequeno porte. Isto nos permite refletir: será que os destinos turísticos mais sustentáveis são os de pequeno porte? Como tornar as grandes cidades mais sustentáveis? Um destino caracterizado por práticas de turismo de massa não é, obviamente, sustentável, entretanto, é possível inovar nos processos de planejamento e gestão para que esse mesmo destino tenha como valor principal a sustentabilidade. Consequentemente, os resultados positivos viriam no médio e longo prazo. Por outro lado, é muito mais fácil gerenciar uma ilha como a El Hierro (Espanha) (em 2014 ela passou a gerar energia 100\% renovável) que um destino tão grande como a cidade de São Paulo, a maior do Brasil. Não por acaso Bonito (MS) foi citado pelos especialistas como o destino que mais possui práticas de inovação para a sustentabilidade do País. O fato de ser uma cidade pequena contribui para que os processos tenham maior adesão social, entre outros fatores. A Serra Gaúcha, com destaque para Gramado (RS), é pioneira no Brasil em diversos aspectos e o Instituto Inhotim (MG) é o único museu de arte contemporânea a céu aberto com jardim botânico integrado, além de ser um dos poucos neste formato no mundo. A escolha desses três destinos não foi meramente em função da segmentação turística, e sim pela identificação de que tipos e formas de inovação afetam a competitividade turística brasileira.

Ao revisitarmos as duas questões levantadas na Introdução da tese, podemos a partir deste momento traçar algumas evidências. A primeira questão foi: "Quais são as oportunidades, ameaças, pontos fortes, pontos fracos e melhores práticas dos três destinos 
turísticos brasileiros que mais apresentam características de inovação para a sustentabilidade?" Para respondermos essa questão criamos uma Matriz de Análise SWOT. Acróstico de palavras em Inglês, SWOT é formado pelas primeiras letras de: Strengths (Forças), Weaknesses (Fraquezas), Opportunities (Oportunidades) e Threats (Ameaças). Rodrigues et al. (2005) atribuem a Kenneth Andrews e Roland Christensen, professores da Harvard Business School, a criação da Matriz de Análise SWOT. Trata-se de uma metodologia de análise para compreender desde o ambiente interno de uma empresa até a realidade de um país. Ela ajuda a organizar e sistematizar melhor as informações, o que facilita nos processos de tomadas de decisão.

A Matriz de Análise SWOT, que responde ao quinto objetivo específico desta tese, é produto dos estudos realizados no exterior e no Brasil. Ela foi construída, sobretudo, graças à revisão da literatura e observações nas pesquisas de campo. A Figura 64 é o registro dessas pesquisas. 


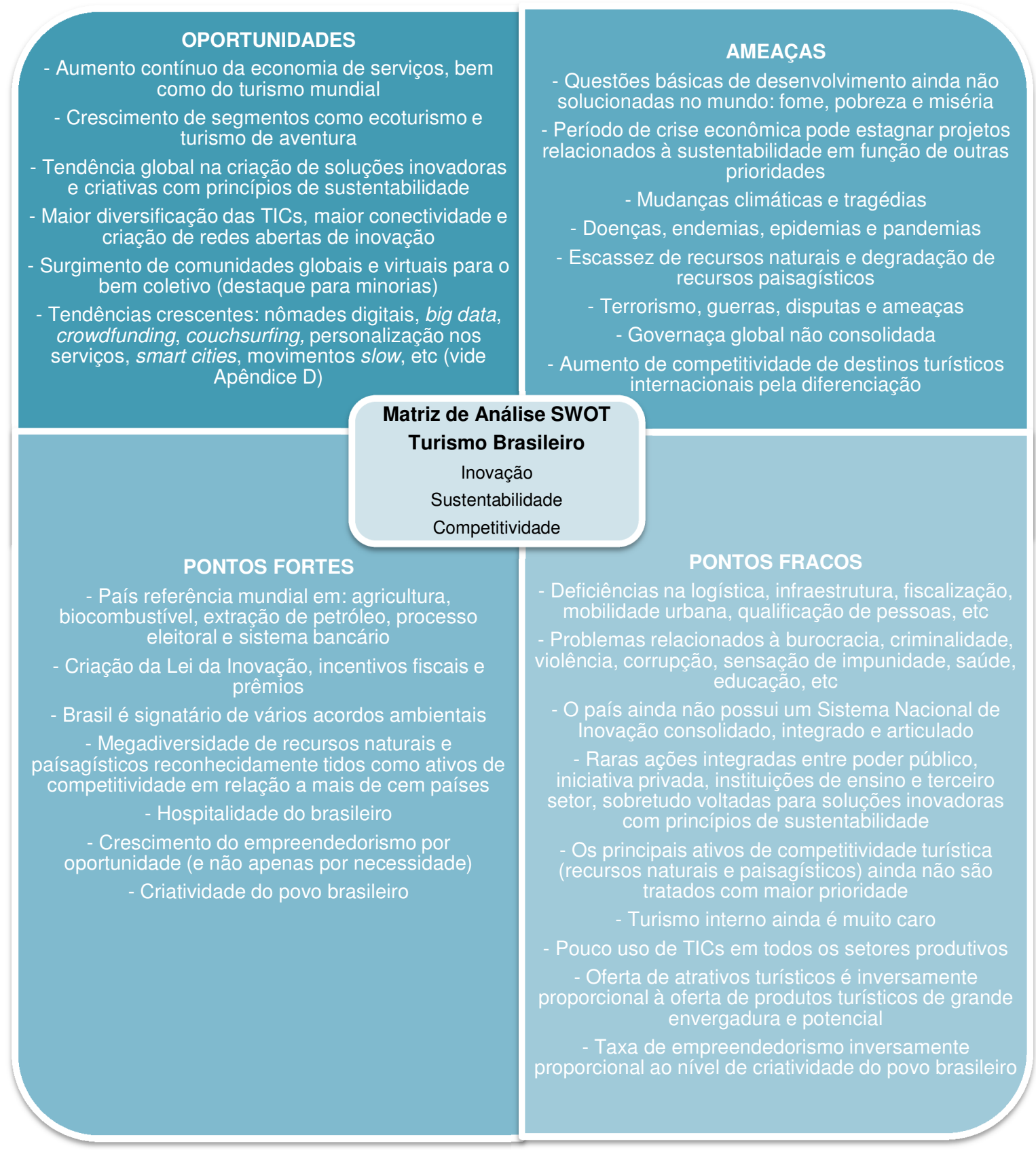

Figura 64 - Matriz de Análise SWOT do Turismo Brasileiro: Inovação, Sustentabilidade e Competitividade Fonte: Elaborado por Daniela Rocco (2014)

Conforme a Figura 64, e a revisão da literatura, o Brasil possui um grande potencial para setores criativos, mas o nível de empreendedorismo é baixo e a burocracia dificulta a abertura de novas iniciativas e novos negócios. Inclusive, essa burocracia, aliada a fatores como defasagem na infraestrutura de transportes e os preços altos, faz com que a competitividade turística seja bastante aquém do real potencial que o Brasil possui. Por outro lado, as oportunidades e pontos fortes sinalizam um cenário bastante favorável para o favorecimento da inovação para a sustentabilidade, como a tendência global por soluções 
inovadoras e a criação recente de leis que incentivam a inovação e o empreendedorismo. $O$ cenário apresentado nessa Matriz de Análise SWOT representa a complexidade dos desafios do País, que ainda vivencia problemas relacionados à burocracia, criminalidade, violência, corrupção, sensação de impunidade, saúde, educação, entre outros e possui deficiências do ponto de vista da infraestrutura, logística, fiscalização e mobilidade urbana. O fato de ser o Brasil "deitado em berço esplêndido", e embora o turismo no País tenha excelente avaliação em termos de hospitalidade, ainda não aproveitou os inúmeros recursos naturais e culturais para formatá-los em produtos turísticos inovadores e sustentáveis, o que poderia dar respaldo simultaneamente à comercialização, valorização e proteção dos próprios recursos e atrativos. No contexto internacional, o Brasil, tal como qualquer outro destino no mundo, está suscetível às mudanças climáticas e tragédias, bem como doenças, endemias, epidemias e pandemias. A questão da crise econômica internacional merece melhor atenção por parte também dos profissionais do turismo, que por sua vez devem estar atentos às mudanças e às possibilidades de inovação.

A segunda questão levantada nesta tese foi: "De que maneira as atividades turísticas baseadas na inovação e na sustentabilidade podem contribuir para a competitividade dos destinos turísticos brasileiros?" Os caminhos são diversos: pode-se adotar desde novas tecnologias e de altíssimo investimento como o Snowland de Gramado até mesmo inovações mais simples de tal modo que haja eficiência e responsabilidade no uso dos recursos. Se um meio de hospedagem, por exemplo, adota medidas inovadoras de economia de água e energia, o valor economizado pode ser revertido em investimentos na própria empresa, o que lhe confere maior competitividade. Tais investimentos podem, inclusive, influenciar positivamente outros pilares da competitividade, tal como qualidade (ex: capacitação dos colaboradores) e marketing (ex: propaganda diferenciada para atingir um novo público-alvo).

Portella (2012, p. 42) afirma que é preciso que o Brasil deixe de "[...] ser o país da mão-de-obra braçal e das cabeças perdidas sem oportunidade para ser o país da inovação, do potencial diversificado, das mentes brilhantes". Para o autor (2012), o valor central da inovação está no conhecimento. O turismo brasileiro, de modo geral, perde a oportunidade de estar vinculado a um sistema nacional de C,T\&I, de auxiliar na qualificação e certificação da mão-de-obra, de criar e consolidar políticas públicas atreladas à fiscalização eficiente e de investir mais em infraestrutura e política de preços. No caso dos empresários, ainda há uma grande perda de informações, pois mesmo no "mundo d.i.", os coprodutores do turismo (os turistas) raramente são envolvidos em processos de gestão de uma organização que busca melhorias dentro de um contexto integrado de inovação aberta.

No capítulo 1 foi apresentado o Quadro 3 referente ao "Ciclo de eras (do pósindustrial à era da emoção)". O Quadro 26, baseado em Portella (2012), apresenta 
exemplos do turismo correlacionados às respectivas características da Era Emoção, bem como práticas turísticas competitivas.

ERA DA EMOÇÃO ERA DA EMOÇÃO NO CONTEXTO DO TURISMO

\begin{tabular}{ll}
\hline Qualidade de vida & - Sustentabilidade (ambiental, social, cultural e econômica) \\
& - "Retorno" à natureza com foco nos segmentos Turismo rural, Ecoturismo e \\
& Turismo de aventura (incentivo à visitação aos parques - "wilderness") \\
& - Revitalização dos espaços públicos \\
& - Mobilidade urbana (ciclovias, metrôs, ônibus, etc.). \\
Rede de parcerias & - Terceiro setor, Poder público e iniciativa privada (a exemplo da Conservation \\
& Strategy Fund). \\
\hline Associação & - Turismo de base comunitária (Exemplo: Rede Tucum) \\
Criatividade e Inovação & - Transversal aos processos e às características da Era da Emoção \\
& - Desenvolvimento e consolidação da economia da cultura (museus, centros e \\
Visão quântica & galerias de artes, etc.). \\
Gestão participativa & Turismo virtual, avatar, hologramas, etc. \\
Cooperação & $\begin{array}{l}\text { - Poder descentralizado do MTur (conselhos, entidades de classe, instâncias de } \\
\text { governança regional, etc.) } \\
\text { - Governanças locais }\end{array}$ \\
- Tribewanted ("tribo" de volunturistas que colaboram financeiramente para o \\
desenvolvimento de comunidades locais sustentáveis e podem, ainda, se hospedar \\
gratuitamente nessas comunidades ou com desconto no valor da diária - \\
detalhamento consta no Apêndice D). \\
- Cooperação entre micro e pequenas empresas.
\end{tabular}

Quadro 26 - A Era da Emoção no contexto do turismo

Fonte: Elaborado por Daniela Rocco (2014) com base em Portella (2012)

É possível verificar, tal como mostra o Quadro 26, que características da Era da Emoção (coluna à esquerda) são encontradas na realidade do turismo (coluna à direita). Como a literatura indica que essa Era tende a se fortalecer, a maneira pela qual as atividades turísticas serão mais competitivas inclui essas características, tendo inclusive aspectos de inovação, criatividade e sustentabilidade incorporadas direta e indiretamente.

Por fim, o desenvolvimento do presente estudo nos ajudou a identificar que Bonito (MS), Fernando de Noronha (PE) e a Serra Gaúcha (RS), em ordem decrescente, são os destinos que mais adotam inovações para a sustentabilidade no turismo brasileiro. Como não foi possível estudar o segundo destino, optamos por considerar um destino de porte menor, porém com características inovadoras e passíveis de comparação com os demais: o Instituto Inhotim (MG).

No que tange à pergunta "como" os destinos turísticos brasileiros adotam essas inovações para a sustentabilidade, foi possível verificar que o trade turístico ainda investe muito pouco em P\&D e em inovações disruptivas, sendo, portanto, as inovações incrementais as mais recorrentes no turismo brasileiro. No âmbito da inovação para a sustentabilidade com característica disruptiva, Bonito é referência pela organização e participação dos atores locais no processo que limita a entrada aos atrativos e o Instituto 
Inhotim porque inovou não só pela vantagem comparativa (integração entre natureza e cultura), como também tem inovado em ações incrementais que valorizam a sustentabilidade e que dão suporte às vantagens competitivas. Um exemplo de inovação para a sustentabilidade com parceria público-privada no nível de atrativo é o da Praça das Etnias em Gramado, que dispõe de energia eólica e solar para iluminar a própria Praça, uma das principais da cidade.

No que se refere ao "como" inovar com os turistas vale ressaltar que o turista em geral deixou de exercer um papel passivo (aquele que só acompanhava os guias, sem demais interações com a comunidade local) e se tornou coprodutor de experiências turísticas. Na Era da Emoção de um "mundo d.i." é possível constatar que o novo perfil de turista deseja colaborar, interagir, informar-se e conectar-se com o mundo e com a si mesmo por meio de experiências, inclusive as virtuais. Além disso, uma demanda pequena, porém crescente, também revela que turistas estão mais atentos à questão da sustentabilidade. Inclusive, um estudo recente da OMT (2012) revelou que mais de um terço dos viajantes é favorável ao turismo que faz uso responsável do meio ambiente. Eles também estão dispostos a pagar entre 2 e 40\% a mais por este tipo de experiência. Em consequência disso, cada vez mais é possível verificar negócios turísticos que inovam e se renovam para atender às expectativas desses consumidores. Exemplos disso são: o uso de trilhas suspensas, amenities biodegradáveis, construção ecológica, uso de novas tecnologias orientadas para a eficiência dos recursos não-renováveis, entre outros.

De forma geral, as evidências encontradas neste trabalho sobre o "como" inovar no turismo brasileiro nos leva a pensar que não são necessários investimentos altíssimos para desenvolver soluções inovadoras, até mesmo com foco na sustentabilidade. Inovações simples, porém importantes, como do hotel Pirá Miúna (Bonito), que oferece café da manhã a la carte na baixa temporada para se evitar o desperdício de comida, são relevantes. Por outro lado, o hotel Bangalôs da Serra (Gramado), investiu um valor alto em busca de certificação ISO 14.001 (gestão ambiental). Quando conquistar, será um dos poucos hotéis com essa certificação (inovação em relação aos demais que não possuem tal certificação). Vale salientar que a MIST preenchida com maior quantidade de informações foi a do Bangalôs da Serra, uma vez que, para se obter a certificação, é preciso registrar sistematicamente todos os processos e ações. Nos demais casos de aplicação da MIST, embora sejam equipamentos/atrativos com perfil de inovação para a sustentabilidade, percebeu-se pouca aderência quanto aos registros contínuos e sistemáticos de informações.

Vale salientar que os resultados indicaram que as vantagens comparativas de cada destino já estão consolidadas e são os principais diferenciais. Esta evidência está alinhada com a pesquisa feita com os 50 especialistas brasileiros, que ressaltaram a importância da criação e fortalecimento das políticas públicas e incentivo ao empreendedorismo. Contudo, a 
literatura nos mostra que o turismo compõe uma das menores pastas do País em termos de destinação de recursos financeiros. Os programas e estratégias de apoio e financiamento público no que diz respeito à inovação têm como prioridade o desenvolvimento de atividades de C,T\&I na indústria em geral. Evidentemente, por ser o turismo de natureza sistêmica, inferimos que os empresários deste setor podem se beneficiar dos instrumentos de fomento dos seguintes programas prioritários da ENCTI (Estratégia Nacional de Ciência, Tecnologia e Inovação 2012-2015): Fomento da economia verde (Energia; Biodiversidade; Mudanças climáticas e Oceanos e zonas costeiras) e C,T\&l para o Desenvolvimento Social (Popularização da C,T\&I e melhoria do ensino de ciências; Inclusão produtiva e tecnologia social; Tecnologias assistivas e Tecnologias para Cidades Sustentáveis). Dos programas secundários da ENCTI existe o fomento à Produção agrícola sustentável; Recursos hídricos; Amazônia e Semiárido e Pantanal e Cerrado (BRASIL, 2012d). São diversos editais do MCTI, da FINEP, do BNDES, do CNPq e das agências de fomento estaduais para o financiamento público da inovação, entretanto raros são aqueles destinados para fomentar o turismo. Perde-se uma grande oportunidade de se preservar os biomas tidos como prioritários na política pública supracitada, e o turismo pode ser uma alternativa para isso. Talvez, por falta de informação e pouca divulgação, os empresários ainda não tenham buscado essas fontes de apoio e financiamento público.

Diante do exposto, é preciso relembrar que a análise do ciclo de vida dos destinos turísticos proposta por Butler (1980) mostra que, quando o destino se encontra em um estágio maduro de desenvolvimento existem basicamente três cenários: renovação, estagnação (não muda, permanece como está) ou declínio (os turistas deixam de visitar e valorizar o destino). O autor (1980) explicita que os destinos podem se renovar com inovações, mas não as especifica. O fato de o turismo ter como "matéria-prima" (inclusive para sobrevivência da própria atividade) os recursos naturais, culturais e paisagísticos, a inovação para a sustentabilidade é uma oportunidade que se abre para aquela renovação indicada por Butler. Inclusive, em alguns casos, é até rentável, pois gera eficiência e redução dos custos, tendendo a propiciar, consequentemente, o aumento de competitividade.

Existem outros caminhos possíveis para a renovação dos destinos turísticos. Hoje é possível estabelecer o real diálogo do trade turístico com centros de pesquisa e ensino, além da adequação das ações e estratégias do poder público, iniciativa privada e terceiro setor ao "mundo d.i.", das conexões, do uso intensivo de TIC, da inovação aberta, das plataformas colaborativas e dos seus novos usuários, agora, coprodutores de experiências turísticas. 


\section{CONCLUSÕES}

"Como será amanhã? Responda quem puder"

Samba, Simone

No "mundo d.i.", embora as inovações tenham proporcionado sensação de conforto, bem-estar e eficiência, ainda existem, paradoxalmente, situações de extrema pobreza, casos lastimáveis de degradação da biodiversidade e perdas incalculáveis do ponto de vista cultural. Hoje se fala do crescimento da economia imaterial e da preponderância dos ativos conhecimento e informação, que são intangíveis. Vivemos em uma sociedade global cujos valores, também intangíveis, estão em crise. Diante do enfrentamento planetário de crises, rupturas, paradoxos, problemas e desafios, é urgente que ações paliativas se ampliem em soluções concretas, estruturais e conjunturais. É necessário, ainda, reconhecer de forma legítima a sustentabilidade como valor, o que pode desencadear, por sua vez, o processo de desenvolvimento sustentável.

No caso do turismo, em 2030 estão previstas as chegadas de 1,8 bilhões de turistas internacionais no mundo, e tal crescimento requer planejamento e gestão para que as práticas desenvolvidas sejam sustentáveis, uma vez que a própria "matéria-prima" do turismo é, sobretudo, a natureza e cultura. O Brasil que é "deitado em berço esplêndido", tão megadiverso, ainda peca por não priorizar a economia imaterial, em detrimento da economia industrial. Por não ser porta-voz mundial do turismo sustentável sendo o maior líder em número de espécies, por seus empresários não serem pioneiros incontestáveis de inovações relacionadas à sustentabilidade nos destinos que atuam e por se ter uma oferta do ponto de vista natural e cultural indiretamente proporcional à quantidade de produtos consolidados e que chegam com eficiência ao turista. Priorizar o turismo no Brasil seria uma oportunidade ímpar para reunir e engajar diretamente diversos stakeholders de mais de 50 segmentos da economia, isto porque o turismo possui uma capilaridade expressiva e peculiar: ao mesmo tempo multisetorial e multidisciplinar.

Por outro lado, embora a atividade turística seja uma das que mais cresce no mundo, se no passado recente ela era conhecida como "indústria sem chaminés", hoje é perceptível a amplitude de impactos negativos que são gerados quando o turismo não é planejado e monitorado. Ademais, é relevante destacar que o turismo não pode ser a atividade principal de uma economia, justamente por assumir características muito específicas, como a instabilidade econômica (derivada, por exemplo, da sazonalidade) e a possibilidade de um determinado destino sofrer catástrofes ambientais, afetando, assim, a visitação de atrativos turísticos. O fato de ser uma atividade econômica complementar não quer dizer que seja 
menos importante e gere menos riqueza local. As mudanças que ocorrem no turismo, ainda que sejam pontuais, são válidas e podem difundir (novos) valores, ideias e atitudes.

No caso da inovação no Brasil, mesmo que esteja em sua "primeira infância", é preciso que mais pessoas sejam capazes de tornar ideias em inovações e inovações que estimulem o desenvolvimento econômico, a inclusão produtiva e o respeito ao ambiente, à cultura e às pessoas. Investe-se ainda muito pouco em fontes limpas de energia, na conservação ambiental, na melhor destinação dos resíduos (permanência de lixões e criação de poucos aterros sanitários), entre outros. Não obstante, existem trabalhos pioneiros e, apesar de o Brasil enfrentar numerosos problemas, é referência mundial em termos de inovação na agricultura, sistemas bancários e sistema eleitoral.

Concluímos que, embora as práticas de inovação para a sustentabilidade sejam ainda muito pontuais e embrionárias, podem ajudar destinos turísticos brasileiros que desejam ser mais competitivos via inovação, principalmente na criação de valor turístico e valor sustentável. As inovações disruptivas no turismo (sobretudo vinculadas à sustentabilidade), por enquanto, são raras no Brasil. Apesar de o País ser signatário de diversos acordos ambientais, tendo inclusive sediado a Rio92 e Rio+20, tenha uma das legislações ambientais mais avançadas do mundo, a literatura evidenciou que possui legislação específica para o incentivo à inovação bastante recente. No entanto, constatamos um esforço de diversas frentes (governamentais, privadas, sociais e de terceiro setor) no diálogo entre inovação e sustentabilidade, e esta pesquisa tentou evidenciar alguns caminhos rumo a ganhos de competitividade turística que prezem as pessoas e o ambiente.

Esta tese apresentou práticas de inovação para a sustentabilidade em destinos turísticos brasileiros no âmbito do poder público, iniciativa privada e terceiro setor. Contudo, alguns exemplos no universo dessas práticas ora tinham foco na dimensão ambiental, ora na social, cultural ou econômica. Idealmente, para que haja de fato desenvolvimento sustentável, é necessária a combinação simultânea dessas dimensões.

No que tange aos destinos turísticos brasileiros com mais práticas de inovação para a sustentabilidade, a maioria deles foi citada por 50 especialistas brasileiros, que por sua vez participaram desta pesquisa por meio de um questionário online. Além da identificação dos principais destinos, os especialistas responderam sobre o grau de importância de 12 práticas previamente listadas de inovação para a sustentabilidade. De acordo com a maioria, as práticas "Incentivo ao empreendedorismo e à gestão empresarial focada na inovação, com programas de financiamento e subvenções econômicas tendo como requisitos a inovação e a sustentabilidade", "Inovações sociais com melhoria das condições de trabalho, educação, saúde, além de socialização nos espaços públicos - repercussão direta/indireta no turismo" e "Políticas públicas menos burocráticas (gestão eficiente), adoção de 'compras públicas verdes' e estímulo à cultura da C,T\&I (Ciência, Tecnologia e 
Inovação) - repercussão direta/indireta no turismo" foram identificadas como as mais importantes (em ordem decrescente) para aumentar a competitividade dos destinos brasileiros. Tais resultados mostram claramente a necessidade de mudanças estruturais e conjunturais para que o turismo se torne mais competitivo, e isto envolve questões relacionadas especialmente a políticas públicas. Com relação ao potencial de disseminação no futuro, as práticas vinculadas às ações de marketing e comunicação social, premiação e incentivo ao empreendedorismo e à gestão empresarial foram as mais citadas em ordem decrescente. Vale mencionar que das 12 práticas listadas nenhuma foi registrada como "sem importância".

Ainda que tais práticas não estejam tão explícitas como no caso de Gramado, são importantes para garantir a boa fruição turística. A criação do voucher único digital em Bonito e a criação do Instituto Inhotim na cidade de Brumadinho são exemplos de inovações disruptivas. No entanto, a forma de inovação mais recorrente entre os três destinos é a incremental. Os tipos de inovação são variados, como organizacional, de marketing, de serviço e inovação social. Porém, com exceção do voucher único digital (inovação do tipo tecnológica), não foram criadas inovações tecnológicas nas empresas estudadas objeto de análise da MIST. Vale acrescentar que até mesmo o referido voucher demanda melhorias, pois ainda são impressas cinco vias, sendo que ele poderia estar disponível em aplicativos de dispositivos móveis como smartphones e tablets.

Nos três destinos turísticos estudados, Bonito, Gramado e Instituto Inhotim, foram significativas as sugestões de melhorias que não dependem diretamente do empresário, como a melhoria dos acessos (rodovia e aéreo). Isso requer políticas públicas e mecanismos de fomento para que as empresas de tais destinos se tornem mais competitivas. Inclusive, isto foi constatado na pesquisa junto aos 50 especialistas. Com um acesso facilitado, a competitividade de um destino tende a aumentar e os preços podem diminuir, e esta foi uma demanda de parte dos turistas entrevistados. Além disso, os preços altos são um grande entrave para a competitividade turística brasileira segundo WEF.

O presente estudo representa uma forma de contribuir para o desenvolvimento científico do País, principalmente por meio da construção de uma metodologia de análise inovadora (a MIST). Trata-se de um estímulo à cultura da $\mathrm{C}, \mathrm{T} \& \mathrm{I}$ e à criação de insumos para políticas públicas que visam aumentar a competitividade dos destinos turísticos brasileiros. É um trabalho de disseminação não apenas da cultura da inovação, mas de uma inovação que dialoga com a sustentabilidade. Constitui um trabalho inovador, não somente pelo tema, mas por sua própria concepção, que é o diálogo entre inovação e sustentabilidade no turismo. Neste sentido, a criação e validação da MIST foi um importante instrumento para organizar e analisar dados e informações de forma estruturada a respeito de equipamentos e atrativos turísticos. A posteriori ela pode servir para que os próprios atores engajados na 
atividade turística façam suas respectivas análises. A MIST pode ser referência para que os destinos turísticos com mais características de inovação para a sustentabilidade possam fortalecer ainda mais suas ações, pois ela ajuda a organizar as informações por meio de um check-list estruturado. Também pode ser referência para aqueles destinos/empresas turísticas que não foram citados neste trabalho, mas que almejam aumento de competitividade. Com a grade de análise construída é possível aplicar a matriz e comparar os dados e informações obtidos com experiências de outros destinos turísticos, sejam eles nacionais e internacionais (benchmarking). É preciso deixar claro que a MIST pode ser aplicada em quaisquer organizações provenientes de distintos setores econômicos. Isto porque sua estrutura básica (atributos, variáveis e critérios) não muda e bastaria apenas extrair o foco do turismo. A Matriz passaria a receber então outros nomes, como MISA (Matriz de Inovação para a Sustentabilidade na Agricultura), MISI (Matriz de Inovação para a Sustentabilidade na Indústria), entre outros.

Registrar aqui o principal contributo do presente trabalho seria incoerente, pois ele já nasceu plural e, além disso, é inédito no País, porque pela primeira vez se buscou identificar os destinos turísticos brasileiros que mais se destacam por suas práticas de inovação para a sustentabilidade no turismo. De forma inovadora, fizemos uma reflexão teórica do turismo no "mundo d.i.", relacionando-o à economia imaterial e à noção de rede de valor aberta constituída por encadeamentos produtivos e cadeia de valor do turismo. São também inéditas a cartografia temática com a indicação dos 40 destinos turísticos mais citados, a Matriz de Análise SWOT sobre o tema e a MIST. Tudo isso é apenas uma pequena contribuição diante da complexidade da disseminação real do turismo sustentável no mundo. Há, portanto, muito que ser feito, como o desenvolvimento de pesquisas quantitativas sobre o tema que cruzem com os resultados iniciados nesta pesquisa e que podem ser objeto de estudo de outros pesquisadores. Recomendamos também a análise qualitativa dos demais destinos citados pelos especialistas, de tal modo a identificar e compreender outras especificidades de inovação para a sustentabilidade que porventura possam surgir.

A literatura e os "saberes vivos e vividos" nos leva a pensar que somos armas de autodestruição e ao mesmo tempo a esperança para um futuro melhor. Se haverá bom uso ou não das inovações no futuro, cabe a todos nós decidirmos isso hoje. Esta tese não termina no papel impresso e nem no pdf visto da tela de um computador, smartphone ou tablet, mas continua sob a forma da plataforma e-tese. Assim, podemos consolidar uma grande rede aberta de inovação colaborativa para o turismo.

Bem-vindo ao Innovatur:

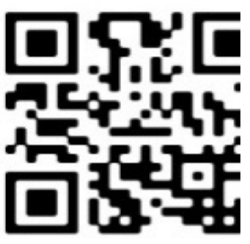




\section{REFERÊNCIAS BIBLIOGRÁFICAS}

"[...] muitas coisas não se aprendem nos livros e sim em contato com a natureza. Ela é o grande livro aberto aos que sabem ler nele".

João de Vasconcelos Sobrinho

ABETA. Associação Brasileira das Empresas de Ecoturismo e Turismo de Aventura. Manual de boas práticas de acessibilidade em ecoturismo e turismo. Belo Horizonte, 2010. Disponível em: <http://aventurasegura.org.br/wpcontent/uploads/2011/08/Brasil_ABETA_Vol_11_Acessibilid ade_Manual_Boas_Praticas.pdf>. Acesso em: 10 jun. 2012.

ABRAMOVAY, Ricardo. Muito além da economia verde. São Paulo: Ed. Abril, 2012.

AGARWAL, S. The resort cycle revisited: implications for resorts. Tourism, Recreation and Hospitality Management, 5: 195-208, 1994.

AGÊNCIA ESTADO. Anac propõe regulação para drones no Brasil. Estadão, 2014. Disponível em: <http://www.estadao.com.br/noticias/geral,anac-propoe-regulacao-paradrones-no-brasil,1134192,0.htm>. Acesso em 17 jul. 2014

AGRA FILHO, Severino Soares; ANDRADE, José Célio Silveira; FIGUERÔA, Edmundo Sá Barreto; COSTA, Dora Parente; KIPERSTOK, Asher (coord.). Inovação e meio ambiente: elementos para o desenvolvimento sustentável na Bahia. Salvador: Centro de Recursos Ambientais, Construindo os recursos do amanhã, v. 2, 2003.

AGROVENTURES ADVENTURE PARK. Shweeb - The World's ONE and ONLY! Agroventures Adventure Park, 2014. Disponível em: <http://www.agroventures.co.nz/Shweeb>. Acesso em: 16 jul. 2014.

ALBUQUERQUE, Eduardo da Motta e. Ideias fundadoras. Revista Brasileira de Inovação, vol. 3, n. 1, jan./jun., 2004.

ALMEIDA, Maria Geralda de. Turismo e os Novos Territórios no Litoral Cearense. In: RODRIGUES, Adyr A. B. (Org.) Turismo e geografia: reflexões teóricas e enfoques regionais. 2. ed. São Paulo: Hucitec, 1999.

ANGELO, F. D.; GALINA, S. V. R.; JABBOUR, C. J. C. Inovação Ambiental: das imprecisões conceituais a uma definição comum no âmbito da Gestão Ambiental pró-ativa, GEPROS Gestão da Produção, Operações e Sistemas, ano 6, n. 4, pp. 143-155, 2011.

ÁLVARES, Daniela Fantoni; ROCCO, Daniela Maria Carneiro. Experiências de economia criativa e práticas inovadoras: uma reflexão sobre a cidade de Brasília/DF, Brasil. In: Seminario Internacional de Innovación y Competitividad en Áreas Turísticas, 2014, Alicante. Innovación y Competitividad en Áreas Turísticas - Actas del Seminário Internacional - Bloque Temático II. Alicante: Instituto Universitário de Investigaciones Turísticas de la Universidad de Alicante, 2014. v. 2. p. 01-20.

ALVES, Simone. Modelo de mensuração da competitividade turística sustentável de municípios no Brasil. 2013. 341f. Tese (Doutorado em Administração) - Universidade Federal do Rio de Janeiro, Brasil. 
ALZUA-SORZABAL, Aurkene; ABAD GALZACORTA, Marina. Innovación en la actividad turística vasca: hacia un modelo competitivo en la C.A. de Euskadi. ROTUR - Revista de Ocio y Turismo, n. 01, p. 65-86, 2008.

AMIT, Raphael; ZOTT, Christoph. Creating Value Through Business Model Innovation. MTI Sloan Management Review, March 20, 2012.

ARBIX, Glauco. Inovar ou inovar: a indústria brasileira entre o passado e o futuro. São Paulo: Editora Papagaio, 2007.

AVENTURA SEGURA. Página principal. Belo Horizonte, 2014. Disponível em: $<$ http://www.aventurasegura.org.br/>. Acesso em 10 mai. 2014.

BAÑOS, P. J; JIMÉNEZ, F. K. A. Propuesta de un modelo de competitividad de destinos turísticos, Estudios y Perspectivas en Turismo, Vol. 21 (2012), pp. 977-995.

BARBIERI, José Carlos; VASCONCELOS, Isabella Freitas Gouveia de; ANDREASSI, Tales; VASCONCELOS, Flávio Carvalho de. Inovação e Sustentabilidade: Novos Modelos e Proposições. RAE, São Paulo, v. 50, n. 2. pp. 146-154, 2010.

BARBIERI, José Carlos; ÁLVARES, Antonio Carlos Teixeira. Modelo de inovação contínua: exemplo de um caso de sucesso. In: Anais do XVII Simpósio de Administração da Produção, Logística e Operações Internacionais, 2014, São Paulo, FGV, p. 01-17.

BARBOSA, Jaqueline. Artista cria colagens que interagem com o ambiente de forma criativa. Hypeness, 2013. Disponível em: <http://www.hypeness.com.br/2013/06/artistaespalha-colagens-pela-cidade-que-interagem-com-o-ambiente-de-forma-criativa/>. Acesso em 17 jul. 2014.

BASSO, Karen G. Furlan. Abordagens do turismo em zoneamentos ecológicoeconômicos nas cinco regiões brasileiras. 2009. 185f. Dissertação (Mestrado em Geografia) - Departamento de Geografia, Universidade de Brasília, Brasília.

BATTELLE, R\&D Magazine. Global R\&D Funding Forecast 2014. R\&D Magazine R\&D Magazine/Battelle: 2014. Disponível em: <http://www.rdmag.com/sites/rdmag.com/files/gff2014-5_7\%20875x10_0.pdf>. Acesso em: 06 jul. 2014.

BBC BRASIL. Crescimento do turismo atenua crise na Europa. Paris, 2011. Disponível em: $\quad$ http://www.bbc.co.uk/portuguese/noticias/2011/10/111025_turismo_df_is.shtml>. Acesso em 17 jul. 2014.

BBC BRASIL. Medellín é eleita a cidade mais inovadora do mundo. Brasília, 2013. Disponível em: <http://www.bbc.co.uk/portuguese/noticias/2013/03/130302_medellin_premio_.shtml>. Acesso em 17 jul. 2014.

BESSANT, J. R; TIDD, Joseph. Inovação e empreendedorismo. Porto Alegre: Bookman, 2009.

BIZ, Alexandre Augusto; NEVES, Augusto José; BETTONI, Eduardo Michelotti. O Comportamento dos Consumidores Turísticos no Uso da Telefonia Móvel. Caderno Virtual de Turismo. Rio de Janeiro, v. 14, n. 1, p.34-48, abr. 2014.

BOFF, Leonardo. Sustentabilidade: O que é - O que não é. Petrópolis: Vozes, 2012. 
BONITO. Prefeitura Municipal de Bonito. Conheça Bonito. Bonito, 2014. Disponível em: <http://www.bonito.ms.gov.br/>. Acesso em 14 jul. 2014.

BOISIER, Sérgio. El desarrollo en su lugar: el territorio en la sociedad del conocimiento. Santiago de Chile. Instituto de Geografia da Pontificia Universidad Católica de Chile, 2003.

BRASIL. Constituição da República Federativa do Brasil de 1988. Brasília, 1988. Disponível em: <http://www.planalto.gov.br/ccivil_03/constituicao/constituicao.htm>. Acesso em: 13 jul. 2014.

BRASIL. Presidência da República. Lei no 11.771, de 17 de setembro de 2008. Brasília: 2008. Disponível em: <http://www.planalto.gov.br/ccivil_03/_ato20072010/2008/lei/l11771.htm>. Acesso em: 08 out. 2014.

BRASIL. Ministério da Cultura. Plano da Secretaria da Economia Criativa: políticas, diretrizes e ações (2011-2014), Brasília: MinC, 2011.

BRASIL. Ministério do Turismo. 2011: recordes nos desembarques domésticos. Brasília, 2012a. Disponível em: <http://www.turismo.gov.br/turismo/noticias/todas_noticias/201201181.html>. Acesso em: 06 jun. 2014.

BRASIL. Ministério do Turismo. Índice de competitividade do turismo nacional: 65 destinos indutores do desenvolvimento turístico regional - Relatório Brasil 2011. Brasília: MTur, 2012b.

BRASIL. Ministério de Ciência, Tecnologia e Inovação. Fontes de financiamento. Brasília, 2012c. Disponível em: <http://www.mct.gov.br/index.php/content/view/724.html?execview=\#tlt>. Acesso em: 07 jun. 2014.

BRASIL. Ministério de Ciência, Tecnologia e Inovação. Estratégia Nacional de Ciência, Tecnologia e Inovação 2012-2015 - Balanço das Atividades Estruturantes 2011. Brasília: MCTI, 2012d.

BRASIL. Ministério do Turismo. Índice de competitividade do turismo nacional: destinos indutores do desenvolvimento turístico regional - Relatório Brasil 2013. Brasília: MTur, $2013 a$.

BRASIL. Ministério do Turismo. Concurso da CGU: dupla premiação para o MTur. Brasília, 2013b. Disponível em: <http://www.turismo.gov.br/turismo/noticias/todas_noticias/201312094.html>. Acesso em: 12 jul. 2014.

BRASIL. Ministério do Turismo. Bonito é premiado por turismo sustentável. Brasília, 2013c. Disponível em: <http://www.turismo.gov.br/turismo/noticias/todas_noticias/20131112.html>. Acesso em: 12 jul. 2014.

BRASIL. Ministério do Turismo. Estudo da demanda turística internacional 2006-2012. Brasília, 2013d. Disponível em: <http://www.dadosefatos.turismo.gov.br/export/sites/default/dadosefatos/demanda_turistica/i nternacional/download_internacional/Demanda_Turxstica_Internacional_-

_Fichas_Sinteses_-_2006-2012_reparado_nota_FOZ.pdf>. Acesso em: 12 jul. 2014. 
BRASIL. Ministério do Turismo. Turismo brasileiro avança em competitividade. Brasília, 2014a. Disponível em: <http://www.turismo.gov.br/turismo/noticias/todas_noticias/ 20140127.html>. Acesso em: 27 jun. 2014.

BRASIL. Ministério do Turismo. Dados e fatos - Estudos, pesquisas e dados sobre o setor de Turismo. Brasília, 2014b. Disponível em: <http://www.dadosefatos.turismo.gov.br/dadosefatos/home.html>. Acesso em: 27 jun. 2014.

BRASIL. Ministério do Turismo. Copa: estrangeiros deixaram US\$ 1,4 bilhão no país. Brasília, 2014c. Disponível em: <http://www.turismo.gov.br/turismo/noticias/todas_noticias/20140725_3.html>. Acesso em: 10 mar. 2014.

BRASIL. Portal Inovação. Cartograma do Portal Inovação. Brasília, 2014d. Disponível em: <http://www.portalinovacao.mct.gov.br/pi/\#/pi/ferramentas/cartograma>. Acesso em: 10 mar. 2014.

BRASIL. Ministério do Turismo. Brasil sedia conferência de ecoturismo. Brasília, 2014e. Disponível em: <http://www.turismo.gov.br/turismo/noticias/todas_noticias/20140426.html>. Acesso em: 12 jul. 2014.

BRASIL. Ministério do Turismo. Institucional - Programas e Ações. Brasília, 2014f. Disponível em: <http://www.turismo.gov.br/turismo/home.html>. Acesso em: 07 out. 2014.

BRASIL. Ministério do Turismo. Embratur lança guia de viagem interativo. Brasília, 2014g. Disponível em: <http://www.turismo.gov.br/turismo/noticias/todas_noticias/20140605_7.html>. Acesso em: 07 out. 2014.

BRASIL. Instituto Brasileiro de Turismo. The Green house - a menor distância entre o utilizador e a natureza, 2014h. Disponível em: <http://www.greenhousebrasil.com/pt>. Acesso em: 07 out. 2014.

BRUMADINHO. Prefeitura Municipal de Brumadinho. Inhotim. Brumadinho, 2013. Disponível em: <http://www.brumadinho.mg.gov.br/inhotim>. Acesso em: 30 jul. 2014.

BRUMADINHO. Prefeitura Municipal de Brumadinho. Seminário discute Plano Municipal de Desenvolvimento Turístico. Brumadinho, 2014. Disponível em: $<$ http://www.brumadinho.mg.gov.br/noticia/seminario-discute-plano-municipal-dedesenvolvimento-turistico>. Acesso em: 30 jul. 2014.

BRUNDTLAND, G. H. (Org.). Nosso futuro comum. 2.ed. Rio de Janeiro: Editora Fundação Getúlio Vargas, 1991.

BUHALIS, Dimitrios. Marketing the competitive destination of the future. Tourism Management, Special Issue: The Competitive Destination, Vol. 21, n. 1, pp. 97-116, 2000.

BUHALIS, Dimitrios; AMARANGGANA, Aditya. Smart Tourism Destinations. Information and Communication Technologies in Tourism, 2014.

BUTLER, R. The concept of a tourism area of life cycle of evolution: implications for management of resources. Canadian Geographer, 19(1): 5-12, 1980. 
BUZAN, Tony. Mind Maps at Work: How to Be the Best at Your Job and Still Have Time to Play. New York: Plume, 2005.

CACHAÇA TABOA. Cachaça Taboa. Bonito, 2014. Disponível em: <http://www.cachacataboa.blogspot.com.br/>. Acesso em: 16 jul. 2014.

CAIADO, Aurílio Sérgio Costa. Economia criativa. São Paulo: FUNDAP, 2011.

CALDEIRA, Roberto. O turismo e a sustentabilidade: viabilidade para as próximas gerações. In: SOUZA, Marcos Gouvêa de. Metaconsumidor: a transformação do mercado pela percepção do consumidor global sobre sustentabilidade e consumo consciente. São Paulo: GS\&MD, 2010.

CALDEIRA-PIRES, Armando; SOUZA-PAULA, Maria Carlota de; VILLAS BÔAS, Roberto C. (Org.). A avaliação do ciclo de vida: a ISO 14040 na América Latina. Brasília: ABIPTI, 2005.

CANACINTRA. Câmara Nacional da Indústria de Transformação. Canacintra - Unidad para Transformar a México. Cidade do México, 2014. Disponível em: <http://www.canacintra.org.mx/principal/>. Acesso em 17 jul. 2014.

CÂNDIDO, Luciane Aparecida. Turismo em áreas naturais protegidas. Caxias do Sul: Educs, 2003.

CAPORALI, Renato; VOLKER, Paulo (orgs). Metodologia de Desenvolvimento de Arranjos Produtivos Locais: projeto PROMOS - SEBRAE - BID versão 2.0. Brasília, Sebrae, 2004.

CASTELLS, Manuel. A sociedade em rede. 2.ed. Rio de Janeiro: Paz e Terra, 1999.

CASTELLS, Manuel. Fim de milênio. 3. ed. São Paulo: Paz e Terra, 2002.

CASTELLS, Manuel. A Sociedade em Rede: do Conhecimento à Política. In: CASTELLS, Manuel; CARDOSO, Gustavo (Orgs.). A Sociedade em Rede: Do Conhecimento à Acção Política. Lisboa: Imprensa Nacional - Casa da Moeda, 2006.

CENTRO DE ESTUDIOS EN HOTELERIA SUSTENTABLE. Portada. Buenos Aires, 2014. Disponível em: <http://www.hotelsandsustainability.org/index.htm>. Acesso em 17 jul. 2014.

CETESB; PNUMA. A produção mais limpa e o consumo sustentável na América Latina e Caribe. São Paulo, 2004.

CHESBROUGH, H. Open Innovation: The New Imperative for Creating and Profiting from Technology. Harvard Business School Press, 2003.

CHOZICK, Amy. As Young Lose Interest in Cars, G.M. Turns to MTV for Help. The New York Times, Business DayMedia \& Advertising, 2012. Disponível em: <http://www.nytimes.com/2012/03/23/business/media/to-draw-reluctant-young-buyers-gmturns-to-mtv.html?pagewanted=1\&_r=2\&\#>. Acesso em 17 jul. 2014.

CHRISTENSEN, Clayton. O dilema da inovação: quando as novas tecnologias levam empresas ao fracasso. São Paulo: M. Books do Brasil Editora, 2012.

CHRISTENSEN, Clayton. The Innovator's Dilemma: the Revolutionary book that will change the way you do business. Nova York: HarperBusiness, 2000. 
Cl. Conservação Internacional do Brasil. Hotspots. Belo Horizonte, 2003?. Disponível em: <http://www.conservation.org.br/como/index.php?id=8>. Acesso em: 02 ago. 2014.

CICtourGUNE. Centro de Investigación Cooperativa en Turismo. Tourism Systems in the Digital Age. San Sebastián, 2014. Disponível em: $<$ http://www.tourgune.org/es/26/82/0/0/areas-de-conocimiento-tourism-systems-in-the-digitalage-.html>. Acesso em 17 jul. 2014.

CIDADES INOVADORAS. ONU aponta Curitiba como modelo de cidade sustentável. Curitiba, $2012 . \quad$ Disponível em: <http://www.cidadesinovadoras.org.br/curitiba2030/News12505content179298.shtml>.

Acesso em: 02 ago. 2014.

CLARÍN. El consumidor "I": inteligente inflexible, informado e impulsive. Buenos Aires, 2011. Disponível em: <http://www.clarin.com/sociedad/consumidor-inteligente-inflexibleinformado-impulsivo_0_447555346.html>. Acesso em: 03 mar. 2012.

CONCHA Y TORO. Sustentabilidad. Santiago, 2014. Disponível em: <http://www.conchaytoro.com/web/sustentabilidad/?lang=es>. Acesso em 17 jul. 2014.

COOPER, Chris; FLETCHER, John; WANHILL, Stephen; GILBERT, David; SHEPHERD, Rebecca. Turismo: princípios e práticas. Porto Alegre: Bookman, 2002.

COOPER, Chris; HALL, Michael; TRIGO, Luiz Gonzaga. Turismo contemporâneo. Rio de Janeiro: Elsevier, 2011.

CROUCH, G. I.; RITCHIE, J. R. B. Tourism, competitiveness, and societal prosperity. Journal of Business Research, Vol. 44, n. 3, pp. 137-152, 1999.

$\mathrm{CROUCH}$, Geoffrey I. Modelling destination competitiveness: a survey and analysis of the impact of competitiveness attributes, Australia: STCRC, 2007.

CRUZ, Renato. O desafio da inovação: a revolução do conhecimento nas empresas brasileiras. São Paulo: Editora SENAC, 2011.

CNC. Confederação Nacional do Comércio de Bens, Serviços e Turismo. A Competitividade nos Setores de Comércio, de Serviços e do Turismo no Brasil: Perspectivas até 2015. Relatório Executivo/Confederação Nacional do Comércio de Bens, Serviços e Turismo (CNC); Serviço Brasileiro de Apoio às Micro e Pequenas Empresas (Sebrae). Brasília: CNC; Sebrae, 2008.

COELHO, Margarida Hatem Pinto; SAKOWSKI, Patrícia A. Morita. IPEA (Texto para Discussão) - Perfil da mão-de-obra do Turismo no Brasil nas atividades características do Turismo e em ocupações. Brasília: Rio de Janeiro: Ipea, 2014. Disponível em: <http://www.ipea.gov.br/portal/images/stories/PDFs/TDs/td_1938.pdf>. Acesso em: 08 out. 2014.

COSTA, Helena Araújo. Mosaico da Sustentabilidade em Destinos Turísticos: cooperação e conflito de micro e pequenas empresas no roteiro integrado Jericoacoara Delta do Parnaíba - Lençóis Maranhenses. 2009. 296f. Tese (Doutorado em Desenvolvimento Sustentável) - Centro de Desenvolvimento Sustentável, Universidade de Brasília, Brasília.

COSTA, Helena; SOUTO-MAIOR, Alice. Sistemas produtivos locais em turismo: relacionamentos estratégicos e aglomeração territorial como vantagens competitivas. 
Revista Acadêmica do Observatório de Inovação em Turismo. FGV, Ebape Revista Acadêmica, v. I - n. 1 - Junho de 2006.

CMDS. Cúpula Mundial sobre Desenvolvimento Sustentável. Cúpula mundial sobre desenvolvimento sustentável: declaração de Joanesburgo e plano de implementação. Brasília: Ministério do Meio Ambiente, 2003.

CSF. Conservation Strategy Fund. Sobre. Sebastopol (Califórnia), 2012. Disponível em: <http://conservation-strategy.org/pt/page/conserva\%C3\%A7\%C3\%A3o-

estrat\%C3\%A9gica>. Acesso em: 02 ago. 2014.

CSF. Conservation Strategy Fund. Annual Report 2013. Sebastopol (Califórnia), 2013. Disponível em: <http://conservation-strategy.org/pt/annual-report/2013-0>. Acesso em: 02 ago. 2014.

CINVE. Centro de Investigaciones Económicas. La política de turismo sostenible en Costa Rica como fuente de innovación para servicios de hospitalidad: Innovación y Productividad en el Sector Servicios. Documento de trabajo/Working Paper N ${ }^{\circ} 2013$ (SS-IP) -10 - Special Series "Promoting Innovation in the Services Sector: Towards Productivity and Competitiveness" (SS-IP). Costa Rica: 2013.

CURITIBA. Prefeitura Municipal de Curitiba. Com veículos elétricos, Curitiba dá início a programa de mobilidade sustentável. Curitiba, 2014. Disponível em: $<$ http://www.curitiba.pr.gov.br/noticias/com-veiculos-eletricos-curitiba-da-inicio-a-programade-mobilidade-sustentavel/32038>. Acesso em: 02 ago. 2014.

DAHL, Arthur L. The big picture: comprehensive approaches. In: MOLDAN, B.; BILHARZ, S (Orgs). Sustainability indicators: report of the project on indicators of sustainable development. Chichester: John Wiley \& Sons Ltd., 1997.

DEBBAGE, K. Oligopoly and the resort cycle in the Bahamas. Annals of Tourism Research, 17: 513-527, 1990.

DE BES, Fernando Trías; KOTLER, Philip. A bíblia da inovação. São Paulo: Leya, 2011.

DELGADO, Natalia Aguilar; CRUZ, Luciano Barin; PEDROZO, Eugenio Avila; SILVA, Tania Nunes da. Empreendedorismo orientado para a sustentabilidade: as inovações no caso da Volkmann. Cad. EBAPE.BR [online], vol.6, n. 3, pp. 01-21, 2008.

DIAS, Reinaldo. Introdução ao turismo. São Paulo: Atlas, 2005.

DOLAN, S., GARCIA, S. Gestão por Valores: um guia corporativo para viver, manter-se vivo e ganhar a vida no século XXI. Rio de Janeiro: Qualitymark, 2006.

DOU. Diário Oficial da União. Secretaria de Fomento e Incentivo à Cultura - Portaria n. 626, de 19 de novembro de 2013. Brasília, 2013. Disponível em: <http://www.jusbrasil.com.br/diarios/61902026/dou-secao-1-20-11-2013-pg-7>. Acesso em: 30 jul. 2014.

DRUCKER, Peter F. Inovação e Espírito Empreendedor. São Paulo: Pioneira, 1986.

DURBARRY, Ramesh. Tourism and economic growth: the case of Mauritius. Tourism Economics. Vol. 10, No. 4, p. 389-401, 2004. 
DUPEYRAS, Alain; MACCALLUM, Neil. Indicators for Measuring Competitiveness in Tourism: A Guidance Document - OCDE Tourism Papers, 2013/02, OCDE Publishing. 2013. Disponível em: <http://dx.doi.org/10.1787/5k47t9q2t923-en>. Acesso em: 15 mar. 2014.

EBC. Empresa Brasileira de Comunicação. Classe média brasileira representa $54 \%$ da população. Brasília, 2014. Disponível em: <http://agenciabrasil.ebc.com.br/geral/noticia/2014-02/classe-media-brasileira-representa54-da-populacao>. Acesso em: 16 jul. 2014.

ECODESENVOLVIMENTO. Calor do metrô vai aquecer casas em Londres e cortar $60 \%$ das emissões de carbono. São Paulo, 2013. Disponível em: $<$ http://www.ecodesenvolvimento.org/posts/2013/novembro/calor-do-metro-vai-aquecerresidencias-em-londres?tag=energia $>$. Acesso em 17 jul. 2014.

EDQUIST, C. Introduction. Em Edquist, C. (ed.): Systems of Innovation. Pinter, London, 1997, p. 1-15.

ETZKOWITZ, H.; LEYDESDORFF, L. The transformation of university-industry-government relations. Eletronic Journal of Sociology, 5 (4), 2001.

EUROPEAN COMMISSION. Policy \& Background. Bélgica: Bruxelas, 2014a. Disponível em: $\quad<$ http://ec.europa.eu/environment/europeangreencapital/about-the-award/policyguidance/index.html>. Acesso em: 10 mar 2014.

EUROPEAN COMMISSION. Innovation Union. Bélgica: Bruxelas, 2014b. Disponível em: $<$ http://ec.europa.eu/research/innovation-union/index_en.cfm?section=icapital>. Acesso em: 10 jul. 2014.

EUROPEAN COMMISSION. Barcelona, Capital Europea de la Innovación. Bélgica: Bruxelas, 2014c. Disponível em: <http://europa.eu/rapid/press-release_IP-14-239_es.htm>. Acesso em: 10 jul. 2014.

FAPESP. Fundação de Amparo à Pesquisa do Estado de São Paulo. Desenvolvimento sustentável requer transformação também na ciência. Rio de Janeiro/FAPESP: 2012. Disponível em: $<$ http://agencia.fapesp.br/desenvolvimento_sustentavel_requer_transformacao_tambem_na_ ciencia_/15723/>. Acesso em: 10 jul. 2014.

FESTA DA COLÔNIA. A festa. Gramado, 2014. Disponível em: <http://www.festadacoloniagramado.com.br/index.html>. Acesso em 29 jul. 2014.

FELIX, Gabriel. Alemanha terá rodovia exclusiva para bikes. Ciclo Vivo, 2013. Disponível em: <http://ciclovivo.com.br/noticia/alemanha-tera-rodovia-exclusiva-para-bikes>. Acesso em: 16 jul. 2014.

FIPE. Fundação Instituto de Pesquisas Econômicas. Caracterização e dimensionamento do turismo doméstico no Brasil - 2010/2011 - Relatório executivo - Produto 6. São Paulo: FIPE/MTur, 2012.

FITZSIMMONS, James A.; FITZSIMMONS, Mona J. Administração de serviços. 6. ed. São Paulo: Bookman, 2010. 
FTA. Fouta Trekking Aventure. Historique de Fouta Trekking Aventure. FTA, 2014. Disponível em: <http://www.foutatrekking.org/index.php/notre-association>. Acesso em: 16 jul. 2014.

FURTADO, Celso. O Mito do Desenvolvimento Econômico. 4. ed. Rio de Janeiro: Paz e Terra, 1974.

FONSECA, Igor Ferraz da; BURSZTYN, Marcel. Mercadores de moralidade: a retórica ambientalista e a prática do desenvolvimento sustentável. Ambiente \& Sociedade, Campinas v. X, n. 2, p. 171-188, jul.-dez. 2007.

FONTANELLA, Bruno José Barcellos; MAGDALENO JÚNIOR, Ronis. Saturação teórica em pesquisas qualitativas: contribuições psicanalíticas. Psicologia em Estudo, vol. 17, núm. 1, enero-marzo, 2012, pp. 63-71.

FONTENELLE, Isleide. Para uma crítica ao discurso da inovação: saber e controle no capitalismo do conhecimento. RAE (Revista de Administração de Empresas), vol. 52, n. 1, jan-fev, 2012.

FRANCO, José Luiz de Andrade. A Contribuição do Turismo na Preservação e na Socioeconomia das Nações: Uma Perspectiva Histórica. In: II Congresso de Natureza, Turismo e Sustentabilidade (CONATUS), 23 a 27 de outubro de 2011, Cuiabá/MT.

FREEMAN, Christopher. The national system of innovation in historical perspective. Cambridge Journal of Economics, n. 19, p. 5-24, 1995.

FREEMAN, Christopher. The economics of industrial innovation. Harmondsworth: Penguin Books, 1974.

FREITAS, Carlos Cesar Garcia; MAÇANEIRO, Marlete Beatriz; KUHL, Marcos Roberto; SEGATTO, Andrea Paula; DOLIVEIRA, Sergio Luis Dias; LIMA, Luiz Fernando de. Transferência tecnológica e inovação por meio da sustentabilidade. Rev. Adm. Pública, vol. 46, n. 2, Rio de Janeiro, Mar/Apr, 2012.

FUNDAÇÃO DOM CABRAL - FDC. Estado da gestão para a sustentabilidade no Brasil 2014. FDC: Nova Lima, 2014. Disponível em: <http://www.fdc.org.br/imprensa/Paginas/noticia.aspx?noticia=51>. Acesso em: 15 mar. 2014.

GALLOUJ, Faïz. Economia da inovação: um balanço dos debates recentes. In: BERNARDES, Roberto (Orgs). Inovação em serviços intensivos em conhecimento. São Paulo: Saraiva, 2007, pp. 03-24.

GALEMBECK, Fernando. Inovação para a sustentabilidade. Quím. Nova, São Paulo, v. 36, n. 10, 2013.

GARCÍA, Gema. Turistas espaciales. El País, 2014. Disponível em: <http://elpais.com/elpais/2014/05/09/album/1399628881_293011.html\#1399628881_293011 _1399628925>. Acesso em: 16 jul. 2014.

GARCIA, Maria José G. Figueiredo. Em busca do conceito de valor. Cadernos de Semiótica Aplicada, vol. 1, n. 2, dezembro de 2003.

GASTAL, Susana; MOESCH, Marutschka Martini. Turismo, políticas públicas e cidadania. São Paulo: Aleph, 2007. 
GAZETA DO POVO. Classe média está mais exigente ao consumir. Gazeta do Povo, $2014 . \quad$ Disponível em: <http://www.gazetadopovo.com.br/economia/conteudo.phtml?id=1448413\&tit=Classe-mediaesta-mais-exigente-ao-consumir\#ancora>. Acesso em: 16 jul. 2014.

GEORGESCU-ROEGEN, Nicholas. Métodos em ciência econômica. Edições Multiplic, 1 (2), dezembro de 1980, p. 115-127.

GEORGESCU-ROEGEN, Nicholas. The entropy law and the economic process. Cambridge: Harvard University Press, 1971.

GIL, A. C. Como elaborar projetos de pesquisa. 4. ed. São Paulo: Atlas, 2002.

GOBIERNO VASCO. Estrategia de desarrollo sostenible de Euskadi 2020. Bilbao, Espanha, 2011. Disponível em: <http://www.ecoeuskadi2020.net/pdf/es/EcoEuskadiEstrategia.pdf>. Acesso em: 15 mai. 2013.

GOLDANI, Ângela. Turismo e Parque Eólico: possibilidades para o município de Osório (Rio Grande do Sul, Brasil). Turismo \& Sociedade, Curitiba, v. 6, n. 2, p. 424-439, abril de 2013.

GOLLUB, James; HOSIER, Amy; WOO, Grace. Using cluster-based economic strategy to minimize tourism leakages. 2004. Disponível em: <http://fama2.us.es:8080/turismo/turismonet1/economia\%20del\%20turismo/economia\%20de $1 \% 20$ turismo/desarrollo\%20del\%20turismo\%20clusters\%200MT.pdf>. Acesso em: 06 set. 2010.

GORZ, André. O imaterial - crescimento, valor e capital. São Paulo: Annablume, 2005.

GOVINDARAJAN, Vijay; TRIMBLE, Chris. O outro lado da inovação: a execução como fator critico de sucesso. Rio de Janeiro: Elsevier, 2010.

GRAMADO. Prefeitura Municipal de Gramado. Pontos turísticos. Gramado, 2014a. Disponível em: <http://www.gramado.rs.gov.br/index.php/Atrativos/Pontos-Turisticos.html>. Acesso em 14 jul. 2014.

GRAMADO. Prefeitura Municipal de Gramado. Anunciado WiFi gratuito permanente para a Rua Coberta. Gramado, 2014b. Disponível em:<http://www.gramado.rs.gov.br/index.php/Turismo/Anunciado-WiFi-gratuito-permanentepara-a-Rua-Coberta.html>. Acesso em 14 jul. 2014.

GRECHI, Dores Cristina. O desenvolvimento turístico sob a ótica da economia institucional: uma análise do caso de Bonito (MS). 2011. 294f. Tese (Doutorado em Economia) - Universidade Federal do Rio Grande do Sul.

GSTC. Global Sustainable Tourism Council. Criterios Globales de Turismo Sostenible para Destinos. Washington, D.C., 2012. Disponível em: <http://www.gstcouncil.org/>. Acesso em: 03 jul 2014.

GUARÇONI, Elidio Armando Exposto; PAULA, Cláudio Coelho de; COSTA, Andrea Ferreira da. Bromeliaceae do Parque Estadual da Serra do Rola-Moça, Minas Gerais. Rodriguésia 61, (3): 467-490, 2010.

GUIA BONITO. Aplicativo Guia Bonito. Disponível na Apple Store, 2014. 
HALL, C. Introduction. In: BUTLER, R. The tourism area life cycle: applications and modifications. Vol. 1, Aspects of tourism: 28. Channel View Publications, England, 2006.

HALLACK, Nathália; BURGOS, Andrés; ROCCO, Daniela Maria Carneiro. Turismo de base comunitária: estado da arte e experiências brasileiras. AmbientalMENTE sustentable, ano VI, vol. I, n. 11-12, janeiro-dezembro, 2011.

HART, Stuart. Sustainable Value. New York, 2011. Disponível em: <http://www.stuartlhart.com/sustainablevalue.html>. Acesso em: 10 de jun. 2012.

HART, Stuart L.; MILSTEIN, Mark B. Criando valor sustentável. RAE executivo, vol. 3, n. 2, mai/jul, 2004.

HART, Stuart; SIMANIS, Erik. Innovation from the Inside Out. MIT Sloan Management Review, $\quad$ v. $50, \quad$ n. $4, \quad 2009 . \quad$ Disponível $\quad$ em: <http://www.stuartlhart.com/sites/stuartlhart.com/files/50414.pdf>. Acesso em: 10 de jun. 2012.

HART, Stuart; MILSTEIN, Mark. Creating sustainable value. Academy of Management Executive, vol. 17, n. 2, 2003. Disponível em: <http://e4sw.org/papers/Hart_Milstein.pdf>. Acesso em: 10 de jun. 2012.

HIAR, Alberto. A corrupção que corrói a indústria criativa. IstoÉ: 2014. Disponível em: <http://www.istoedinheiro.com.br/blogs-e-colunas/post/20140825/corrupcao-que-corroi-

industria-criativa/4637.shtml>. Acesso em: 11 set. 2014.

HIRSCHMAN, Elizabeth C.; HOLBROOK, Morris B. Hedonic Consumption: Emerging Concepts, Methods and Propositions. Journal of Marketing, v. 46, p. 92-101, 1982a.

HOLBROOK, Morris B.; HIRSCHMAN, Elizabeth C. The Experiential Aspects of Consumption: Consumers Fantasies, Feelings and Fun. Journal of Consumer Research, v. 9, p. 132-140, 1982b.

HORBACH, J.; RAMMER, C.; RENNINGS, K. Determinants of eco-innovations by type of environmental impact - The role of regulatory push/pull, technology push and market pull, Ecological Economics, vol. 28, pp. 112-122, 2012.

HORLINGS, Ina; MARSDEN, Terry. Rumo ao desenvolvimento espacial sustentável? Explorando as implicações da nova bioeconomia no setor agroalimentar e na inovação regional. Sociologias, Porto Alegre, v. 13, n. 27, ago., 2011.

HOTEL PIRÁ MIÚNA. O Hotel. Bonito, 2014. Disponível em: <http://www.piramiunahotel.com.br/hotel.htm>. Acesso em: 16 jul. 2014.

HUNTER, C. Sustainable Tourism as an Adaptative Paradigm. Annals of Tourism Research, v. 24, n. 4, p. 850-867, 1997.

HUNTER, C. Aspects of the sutainable tourism debate from an natural resources perspective. In: HARRIS, R. G., T.; WALL, G. (EDS) (org.). Sustainable Tourism: a global perspective. Oxford, 2002, p.3-33.

HYPENESS. Estado na Alemanha conseguirá viver somente com energia limpa em 2014. Redação Hypeness, 2014.2 Disponível em: <http://www.hypeness.com.br/2014/06/estado-alemao-conseguira-viver-somente-comenergia-limpa-em-2014/>. Acesso em: 16 jul. 2014. 
IBM. International Business Machines. Cidades Mais Inteligentes. IBM, 2014. Disponível em: <http://www.ibm.com/smarterplanet/br/pt/smarter_cities/overview/>. Acesso em 17 jul. 2014.

IBGE. Instituto Brasileiro de Geografia e Estatística. PINTEC - Pesquisa de inovação (Notas técnicas 2008). Brasília: IBGE. Disponível em: <http://www.pintec.ibge.gov.br/downloads/METODOLOGIA/Notas\%20Tecnicas/notas\%20tec nicas\%202008.pdf>. Acesso em: 13 mar 2014.

IMD. IMD releases its 25th Anniversary World Competitiveness Rankings. Suíça, 2013. Disponível em: <http://www.imd.org/news/World-Competitiveness-2013.cfm>. Acesso em: 07 jan. 2014.

INHOTIM. Instituto Inhotim. Inhotim. Brumadinho, 2014a. Disponível em: <http://www.inhotim.org.br/>. Acesso em: 14 jul. 2014.

INHOTIM. Instituto Inhotim. Release. Brumadinho, 2014b. Disponível em: <http://www.inhotim.org.br/contato/imprensa/artigo-4/>. Acesso em: 30 jul. 2014.

INHOTIM. Instituto Inhotim. Brumadinho mais verde. Brumadinho, 2014b. Disponível em: <http://www.inhotim.org.br/blog/brumadinho-mais-verde/>. Acesso em: 30 jul. 2014.

INNOBASQUE. Agencia Vasca de Innovación. Nuestro proyecto. Bilbao, 2008?. Disponível em: < http://www.innobasque.com/home.aspx?tabid=10>. Acesso em: 13 mar. 2014.

INNOBASQUE. Agencia Vasca de Innovación. Sistema Vasco de Innovación. Bilbao, 2013?. Disponível em: <http://www.innobasque.com/home.aspx?tabid=932>. Acesso em: 13 mar. 2014.

INOVAÇÃO TECNOLÓGICA. Metrópole inteligente na Ásia custará menos que Copa do Mundo de 2014. Inovação Tecnológica, 2013. Disponível em: $<$ http://www.inovacaotecnologica.com.br/noticias/noticia.php?artigo=metropole-inteligenteasia-custara-menos-copa-mundo\&id=010125130508\#.Uy1oWfldWSo>. Acesso em: 16 jul. 2014.

JABOUR, C. J. C. Resgatando o conceito de tecnologia ambiental. In: Encontro Nacional da Anpad, 31, Rio de Janeiro: ANPAD, 2007.

JENSEN, Rolf. The Dream Society: How the Coming Shift from Information to Imagination Will Transform Your Business. Nova York: McGraw-Hill, 1999.

JODI EATS. Food walks. Jodi Eats, 2013. Disponível em: <http://www.jodieats.com/walks/>. Acesso em: 16 jul. 2014.

KELMAN, Jerson. Agências reguladoras e responsabilidade socioambiental. In: ZYLBERSZTAJN, David. Sustentabilidade e geração de valor: a transição para o século XXI. Rio de Janeiro: Elsevier, 2010.

KIM, Chan; MAUGBOURNE, Renée. A estratégia do Oceano Azul. Campusb, 2005.

KOHN, Stephanie. Big Data nos esportes: US Open e Copa das Confederações. Olhar Digital, 2013. Disponível em: <http://olhardigital.uol.com.br/pro/noticia/38665/38665>. Acesso em 17 jul. 2014. 
KON, Anita. Economia de serviços: teoria e evolução no Brasil. Rio de Janeiro: Elsevier, 2004.

KON, Anita. Serviços de conhecimento: uma agenda para a indução do desenvolvimento econômico. In: BERNARDES, Roberto (Orgs). Inovação em serviços intensivos em conhecimento. São Paulo: Saraiva, 2007, pp. 79-112.

KRONEMBERGER, Denise Maria Penna; CLEVELARIO JUNIOR, Judicael; NASCIMENTO, José Antônio Sena do; COLLARES, José Enilcio Rocha; SILVA, Luiz Carlos Dutra da. Desenvolvimento sustentável no Brasil: uma análise a partir da aplicação do barômetro da sustentabilidade. Soc. nat. (Online), Uberlândia, v. 20, n. 1, jun, 2008.

LARA, Alexander Prado. Empreendedorismo Corporativo: a Nova Fronteira da Inovação? Caderno de Ideias FDC (Fundação Dom Cabral), Cl 1301, Nova Lima, 2013.

LATOUCHE, Serge. O decrescimento. Por que e como? In: Léna, Philippe; Nascimento, Elimar Pinheiro do (Orgs). Enfrentando os limites do crescimento sustentabilidade, decrescimento e prosperidade. Rio de Janeiro: Garamond, 2012, pp.45-55.

LAURIANO, Lucas Amaral; BUENO, João Henrique Dutra; SPITZECK, Heiko. Estado da Gestão para a Sustentabilidade - 2014. Fundação Dom Cabral: FDC, 2014.

LAYRARGUES, Philippe P. Educação para a Gestão Ambiental: a cidadania no enfrentamento político dos conflitos sócio-ambientais. In: LOUREIRO, C. F. B. et al (Orgs.) Sociedade e Meio Ambiente: A Educação Ambiental em Debate. São Paulo: Cortez, 2000, pp. 87-155.

LAZZAROTTI; Fábio; DALFOVO, Michael Samir; HOFFMANN, Valmir Emil. O Quê, Como e Onde da Inovação: Análise da Produção Científica em Administração sob a Perspectiva da Abordagem de Schumpeter. In: XXVI Simpósio de Gestão da Inovação Tecnológica, Vitória (ES) - 28 a 30 de novembro de 2010.

LEIPER, N. Environmental impacts and ecosystems for tourism. Tourism Management, $p$. 160-189, 1995.

LEMOS, Leandro de. O valor turístico na economia da sustentabilidade. São Paulo: Aleph, 2005.

LOHMANN, Guilherme; PANOSSO NETTO, Alexandre. Teoria do turismo: conceitos, modelos e sistemas. 2. ed. São Paulo: Aleph, 2012.

LOUREIRO, Carlos Frederico. O movimento ambientalista e o pensamento crítico: uma abordagem política. Rio de Janeiro: Quartet, 2006.

LOWITT, Eric. The Future of Value. Boston, 2011. Disponível em: <http://www.ericlowitt.com/thefutureofvalue/>. Acesso em: 10 de jun. 2012.

MACHADO, Vilma de Fátima. A produção do discurso do Desenvolvimento Sustentável: de Estocolmo à Rio-92. 2005. 328f. Tese (Doutorado). Universidade de Brasília, Programa de Pós-Graduação em Desenvolvimento Sustentável, Brasília.

MACHADO, Virgílio Miguel; COSTA, Carlos Manuel Martins da. Poder e sistemas de turismo: uma visão aplicada ao regime jurídico dos empreendimentos turísticos. Encontros Científicos, Faro, n. 5, 2009. 
MARINHO, Heliana. Cidades criativas, turismo e revitalização urbana. In: REIS, Ana Carla Fonseca; MARCO, Kátia de. (Orgs). Economia da Cultura - ideias e vivências. Rio de Janeiro: Publit, 2009.

McCONNELL, Ben; HUBA, Jackie. Buzzmarketing - Criando Clientes Evangelistas: Como clientes fiéis tornam-se uma força voluntária de vendas através do marketing boca a boca. São Paulo: Mbooks do Brasil Editora Ltda., 2005.

MEADOWS, Denis et al. Limites do Crescimento: Um relatório par ao Projeto do Clube de Roma sobre o Dilema da Humanidade, 1972.

MEDEIROS, Janine Fleith de; RIBEIRO, José Luis Duarte; CRUZ, Cassiana Maris Lima. Inovação ambientalmente sustentável e fatores de sucesso na percepção de gestores da indústria de transformação. Cad. EBAPE.BR, Rio de Janeiro , v. 10, n. 3, Set. 2012.

MELO. Luísa de. As 10 empresas mais inovadoras da América do Sul. Exame, 2014. Disponível em: <http://exame.abril.com.br/negocios/noticias/as-10-empresas-maisinovadoras-da-america-do-sul-2\#6>. Acesso em 17 jul. 2014.

MELGUIZO, Jorge. Medellin, uma Cidade Criativa. In: REIS, Ana Carla Fonseca; KAGEYAMA, Peter (Orgs). Cidades Criativas - Perspectivas. São Paulo: Garimpo de Soluções, 2011, pp. 44-49.

MEIRELLES, Dimária Silva e. "O Conceito de Serviço". Revista de Economia Política, São Paulo, vol. 26, no 1 (101), pp. 119-136, janeiro-março 2006.

MILLER, Kenton R. Em busca de um novo equilíbrio: diretrizes para aumentar as oportunidades de conservação da biodiversidade por meio do manejo biorregional. Brasília: Ibama, 1997.

MILES, Ian. Serviços e inovação na Europa. In: BERNARDES, Roberto (Orgs). Inovação em serviços intensivos em conhecimento. São Paulo: Saraiva, 2007, pp. 79-112.

MINAS GERAIS. Governo de Minas Gerais. Brumadinho. Belo Horizonte, 2012. Disponível em: <http://www.minasgerais.com.br/destinos/brumadinho/>. Acesso em: 30 jul. 2014.

MINIWIZ. iGreen 5D Entertainment Center. Miniwiz, 2014. Disponível em: <http://www.miniwiz.com/miniwiz/en/projects/igreen-5d-entertainment-center>. Acesso em: 16 jul. 2014.

MORETZ, Tassia. De olho na mata: Google lança mapa do desmatamento em tempo real. TechTudo, 2014. Disponível em: <http://www.techtudo.com.br/noticias/noticia/2014/02/deolho-na-mata-google-lanca-mapa-do-desmatamento-em-tempo-real.html>. Acesso em 17 jul. 2014.

MPI. Martin Prosperity Institute. Creativity and Prosperity: The Global Creativity Index. Toronto: MPI e Universidade de Toronto, 2011.

MURILLO, Pedro; SEVILLANO, Elena G. El Hierro se independiza del petróleo. El País, 2014.
$<$ http://sociedad.elpais.com/sociedad/2014/06/27/actual

em:

<http://sociedad.elpais.com/sociedad/2014/06/27/actualidad/1403820049_378892.html

2014>. Acesso em: 16 jul. 2014.

NASH, Roderick. Wilderness and the American Mind. Yale: Yale University Press, 1989. 
NASCIMENTO, Elimar Pinheiro do. Trajetória da sustentabilidade: do ambiental ao social, do social ao econômico. Estud. avançados [online], 2012, vol. 26, n. 74, pp. 51-64.

NOBRE, Marcos. Desenvolvimento sustentável: origens e significado atual. In: NOBRE, Marcos; AMAZONAS, Maurício de Carvalho. Desenvolvimento sustentável: a institucionalização de um conceito. IBAMA: Brasília, 2002.

NORDIN, S.; SVENSSON, B. The Significance of Governance. In: Innovative Tourism Destinations. 55th AIEST Conference: Innovation in Tourism Brainerd/Minnesota (USA), 2005.

NUSSBAUM, Bruce. "Innovation" is Dead. Herald The Birth of "Transformation" as The Key Concept for 2009. Business Week, 31 de dezembro de 2008. Disponível em: <http://www.businessweek.com/innovate/NussbaumOnDesign/archives/2008/12/innovation_i s_d.html>. Acesso em: 24 mar. 2014.

O'BRIEN, Terrence. Google Earth Tour Builder lets you tell stories through maps. Engadget, 2014. Disponível em: <http://www.engadget.com/2013/11/11/google-earth-tourbuilder/?ncid=rss_truncated>. Acesso em 17 jul. 2014.

OCDE. Organização para Cooperação Econômica e Desenvolvimento. Manual de Oslo: proposta de diretrizes para coleta e interpretação de dados sobre inovação tecnológica. Paris: OCDE/FINEP, 2004.

OCDE. Organização para Cooperação Econômica e Desenvolvimento. Manual de Oslo: diretrizes para coleta e interpretação de dados sobre inovação. Paris: OCDE/FINEP, 2005.

OCDE. Organização para Cooperação Econômica e Desenvolvimento. Manual de Frascati: Proposta de Práticas Exemplares para Inquéritos sobre Investigação e Desenvolvimento Experimental. Portugal: OCDE, 2007.

OLIVEIRA, Maicon Gouvêa de. Método de análise do processo de decisão do planejamento da inovação: uma contribuição para a avaliação e seleção de propostas de produtos inovadores. 2012. 202f. Tese (Doutorado em Engenharia de Produção) Escola de Engenharia de São Carlos - Universidade de São Paulo, São Carlos.

OLIVEIRA, Murilo de Alencar Souza; ROSSETTO, Adriana Marques. Políticas Públicas para o Turismo Sustentável no Brasil - Evolução e Perspectivas de Crescimento para o Setor. Revista Turismo Visão e Ação - Eletrônica, Vol. 15 - no 3, set-dez 2013, p. 322-339.

OLIVEIRA, Rafael da Silva; GOMES, Elisa Silva; AFONSO, Júlio Carlos. O Lixo Eletroeletrônico: Uma Abordagem para o Ensino Fundamental e Médio. Química Nova na Escola, vol. 32, n. 4, nov., 2010.

OLMOS, Ximena. La huella de carbono en el comercio internacional: el caso de las viñas chilenas. Magister en Estrategia Internacional y Política Comercial - Estudio de caso, Universidad de Chile, 2012.

OMT. Organização Mundial de Turismo. UNWTO Tourism Highlights 2014 Edition. Madri, 2014. Disponível em: <http://mkt.unwto.org/publication/unwto-tourism-highlights-2014edition>. Acesso em 30 jun. 2014. 
OMT. Organização Mundial de Turismo. Tourism in the Green Economy. Madri, 2012. Disponível em: <http://www.wtoelibrary.org/content/t21l16/fulltext?p=fd760ff2c29249f18cfb1f8ffa00b194\&pi= 0\#section=1171179\&page=2\&locus=96>. Acesso em 04 jun. 2013.

OMT. Organização Mundial de Turismo. Sustainable Development of Tourism. Madri, 2005. Disponível em: <http://sdt.unwto.org/en/content/about-us-5>. Acesso em 04 jun. 2012.

OMT. Organização Mundial de Turismo. Agenda 21 for the travel \& tourism industry: Towards environmentally sustainable development. Londres: WTTC, 1996.

O'NEILL, Siobhan. TripAdvisor GreenLeaders launches in Europe to showcase ecofriendly hotels. Green Hotelier, 2014. Disponível em: <http://www.greenhotelier.org/ournews/industry-news/tripadvisor-greenleaders-launches-in-europe-to-showcase-eco-friendlyhotels/>. Acesso em 17 jul. 2014.

ONU. Organização das Nações Unidas. Kyoto Protocol to the United Nations Framework Convention on Climate Change. Kyoto. 1998.

ONU. Organização das Nações Unidas. População mundial deve atingir 9,6 bilhões em 2050, diz novo relatório da ONU. Brasília, 2013. Disponível em: <http://www.onu.org.br/populacao-mundial-deve-atingir-96-bilhoes-em-2050-diz-novorelatorio-da-onu/>. Acesso em 07 jul. 2014.

ONU. Organização das Nações Unidas. Fatos sobre as cidades: a situação. Brasília, 2012. Disponível em: <http://www.onu.org.br/rio20/temas-cidades/>. Acesso em 07 jul. 2014.

OSTROM, E. Governing the commons: the evolution of institutions for collective action. Cambrigde: Cambrigde University Press, 1990.

OSTROM, E. How types of goods and property rights jointly affect collective action. Journal of Theoretical Politics, v. 15, n. 3, p. 239-270, 2003.

PACKARD, Vance Oakley. Estratégia do desperdício. São Paulo: IBRASA, 1965.

PANOSSO NETTO, Alexandre. Filosofia do turismo: teoria e epistemologia. São Paulo: Aleph, 2005.

PANOSSO NETTO, Alexandre; GAETA, Cecilia (Orgs). Turismo de experiência. São Paulo: Editora SENAC, 2010.

PARQUE GAÚCHO. Histórico: um resgate antropológico da formação do gaúcho. Gramado, 2012. Disponível em: <http://parquegaucho.com.br/historico>. Acesso em: 30 jul. 2014.

PARQUE PARA TODOS. Carara: un parque para todos. Costa Rica, 2014. Disponível em: <http://www.parqueparatodos.info/index.php?option=com_content\&view=frontpage\&ltemid=1 \&lang=en>. Acesso em 17 jul. 2014.

PASSAPORTE VERDE. Eu cuido do meu destino. Passaporte Verde, 2014. Disponível em: <http://www.passaporteverde.org.br/>. Acesso em: 13 set. 2014.

PASTOR, L. M.; OÑA, M. V. S.; SIGNES, A. P. ¿Cómo medimos la Ecoinnovación? Análisis de indicadores en el Sector Turístico. Tec Empresarial, vol. 5, n. 2, pp. 15-25, 2011. 
PAVITT, K. What we know about the strategic management of technology. In: PAVITT, C. Technology Management and Systems of Innovation. Elgar Publishing, Massachusetts, 1999, p. 61-70.

PEGN. Pequenas Empresas Grandes Negócios. Empresa australiana de ecoturismo faz passeios à noite usando óculos militares de visão noturna. PEGN, 2010. Disponível em: <http://revistapegn.globo.com/Revista/Common/0,,EMl186164-17180,00-

EMPRESA+AUSTRALIANA+DE+ECOTURISMO+FAZ+PASSEIOS+A+NOITE+USANDO+O CULOS+MILITA.html>. Acesso em: 16 jul. 2014.

PEGN. Pequenas Empresas Grandes Negócios. Casas de garrafas de vidro viram ponto turístico no Canadá. PEGN, 2011. Disponível em: $<$ http://revistapegn.globo.com/Revista/Common/0,,EMl255352-17180,00-

CASAS+DE+GARRAFAS+DE+VIDRO+VIRAM+PONTO+TURISTICO+NO+CANADA.html> . Acesso em: 16 jul. 2014.

PENA, Luiz Carlos Spiller; BRASILEIRO; lara Lucia Gomes; SANTOS, Ana Rosa Domingues. Turismo e Sustentabilidade em Territórios de Assentamentos Rurais da Reforma Agrária. In: VII SEMINÁRIO DA ASSOCIAÇÃO NACIONAL PESQUISA E PÓSGRADUAÇÂO EM TURISMO, Anais do Seminário ANPTUR, São Paulo: Universidade Anhembi Morumbi, 2010.

PIRES, P.S. Dimensões do ecoturismo. São Paulo: SENAC, 2002.

PINE II, B; GILMORE, James H. The Experience Economy: Work Is Theatre \& Every Business a Stage. Boston: Harvard Business School Press, 1999.

PLONSKI, Guilherme Ary. Bases para um movimento pela inovação tecnológica no Brasil. São Paulo Perspec., São Paulo , v. 19, n. 1, mar., 2005.

PNUD. Programa das Nações Unidas para o Desenvolvimento. Os objetivos de Desenvolvimento do Milênio. Brasília: 2012. Disponível em: <http://www.pnud.org.br/ODM.aspx>. Acesso em: 23 mar. 2014.

POLANYI, Karl. A Grande Transformação - as origens de nossa época. Ed. Campus: Rio de Janeiro, 1988.

PORTELLA, Fernando. Engenharia Cultural: Como transformar ideias em projetos e projetos em realidade. Rio de Janeiro: Cidade Viva: Instituto Cultural Cidade Viva, 2012.

PORTER, Michael E.; VAN DER LINDE, Claas. Green and Competitive: Ending the Stalemate. Harvard Business Review, set-out, 1995.

PORTER, Michael E. Vantagem competitiva: criando e sustentando um desempenho superior. 37 ed. Rio de Janeiro: Elsevier, 1989.

PORTUGAL. Plano de Desenvolvimento Turístico do Conselho de Sesimbra. Sesimbra, [s.d.]. Disponível em: < http://sesimbra.pt/planodeturismo/2/cadeia_valor.html>. Acesso em: 11 jun. 2012.

POULSEN, Anders Berg. An Organic Approach to City Design. GRASP, Dinamarca, nov., 2013. 
PRASS, Ronaldo. Entenda o que são os 'QR Codes', códigos lidos pelos celulares. G1, 2011. Disponível em: <http://g1.globo.com/tecnologia/noticia/2011/05/entenda-o-que-sao-osqr-codes-codigos-lidos-pelos-celulares.html>. Acesso em: 16 jul. 2014.

PROTEJA BRASIL. Sobre o Proteja Brasil. Proteja Brasil, 2014. Disponível em: <http://www.protejabrasil.com.br/br/>. Acesso em: 28 set. 2014.

PUB. Public Utilities Board. The Singapore Water Story: Investing in R\&D to overcome our water challenges. 2013.2 Disponível em: $<$ http://mssc.squarespace.com/storage/summit/2013/presentations/presNeo.pdf>. Acesso em: 16 jul. 2014.

QUALITY COAST. Global Sustainable Tourism Review (GSTR): coast and islands. Holanda, 2014?. Disponível em: <http://www.qualitycoast.info/alldestinations.htm>. Acesso em: 03 jul 2014.

RADONS, D. L.; BATTISTELLA, L. F.; GROHMANN, M. Z. Vantagem competitiva das empresas: qual a influência da inovação verde? Revista Brasileira de Administração Científica, v.3, n.3, pp. 97-111, 2012.

RAO, Jay; CHUÁN, Fran. Innovación 2.0 ¿Por qué cuando hablamos de innovación nos olvidamos de las personas? Barcelona: Profit Editorial, 2012.

RECANTO ECOLÓGICO RIO DA PRATA. Recanto Ecológico Rio da Prata. Bonito, 2014. Disponível em: <http://www.riodaprata.com.br/>. Acesso em: 16 jul. 2014.

REIS, Ana Carla Fonseca. Cidades Criativas: análise de um conceito em formação e da pertinência de sua aplicação à cidade de São Paulo. 2011. 312f. Tese (Doutorado). Universidade de São Paulo, Faculdade de Arquitetura e Urbanismo, São Paulo.

REIS, Ana Carla Fonseca; KAGEYAMA, Peter (Orgs). Cidades Criativas - Perspectivas. São Paulo: Garimpo de Soluções, 2011.

REIS, Ana Carla Fonseca; MARCO, Kátia de (Orgs). Economia da Cultura - ideias e vivências. Rio de Janeiro: Publit, 2009.

REIS, Ana Carla Fonseca. Cidades criativas, turismo cultural e regeneração urbana. In: REIS, Ana Carla Fonseca; MARCO, Kátia de. (Orgs). Economia da Cultura - ideias e vivências. Rio de Janeiro: Publit, 2009.

RIFKIN, Jeremy. The Age of Access: The New Culture of Hypercapitalism Where All of Life Is a Paid-For Experience. New York: Paperback, 2001.

RODRIGUES, Jorge Nascimento; CARDOSO, Jaime Fidalgo; NUNES, Catarina; EIRAS; RUBEN. 50 Gurus Para o Século XXI. 1. ed. Lisboa: Centro Atlântico, 2005.

ROGERS, Everett M. Diffusion of innovations. 4. ed. New York: The Free Pass, 1995.

ROMA PASS. Le card. Roma, 2014. Disponível em: < http://www.romapass.it/>. Acesso em: 16 jul. 2014.

SACHS, Ignacy. Estratégias de transição para o século XXI: desenvolvimento e meio ambiente. São Paulo: Nobel/Fundap, 1993. 
SACHS, Ignacy. Caminhos para o desenvolvimento sustentável. Organização: Paula Yone Stroh. Rio de Janeiro, Garamond, 2002.

SACHS, Ignacy. Desenvolvimento: Includente, Sustentável, Sustentado. Rio de Janeiro: Garamond, 2004.

SACHS, Ignacy. De Volta à mão invisível: os desafios da Segunda Cúpula da Terra no Rio de Janeiro. Estudos Avançados [on line], São Paulo, v. 26, p. p. 5-20, 2012. Disponível em:

<http://www.scielo.br/scielo.php?script=sci_pdf\&pid=S010340142012000100002\&lng=en\&nri \&tlng=pt>. Acesso em: 10 jun. 2012.

SANTOS, Milton. O País Distorcido: o Brasil, a globalização e a cidadania. São Paulo: Publifolha, 2002.

SCHUMPETER, Joseph. Capitalismo, Socialismo e Democracia. Editado por George Allen e Unwin Ltd., traduzido por Ruy Jungmann. Rio de Janeiro: Editora Fundo de Cultura, 1961.

SCOTT, Noel; COOPER, Chris. Innovation for sustainable urban tourism: Some thoughts on best practice, Revista de Administração Pública, 44 (5): 1171-190, set/out., 2010.

SEBRAE. Serviço de Apoio às Micro e Pequenas Empresas. Termo de referência para atuação do sistema Sebrae no setor de serviços. Brasília: SEBRAE, 2008.

SEBRAE. Serviço de Apoio às Micro e Pequenas Empresas. O que é uma empresa startup? Belo Horizonte, 2011.2 Disponível em: <http://www.sebraemg.com.br/atendimento/bibliotecadigital/documento/Texto/O-que-e-umaempresa-startup>. Acesso em: 16 jul. 2014.

SEBRAE. Serviço de Apoio às Micro e Pequenas Empresas. Encadeamento produtivo de serviços: novas oportunidades, novos desafios. Oportunidades \& Negócios - Boletim do SEBRAE. Brasília: SEBRAE, 2012.

SENAI. Serviço Nacional de Aprendizagem Industrial. Fortalecimento do PR por meio do Empreendedorismo Inovador. Fórum Futuro 10, Curitiba, 2012.

Reunião com os Reitores das Universidades do PR, e o Secretário-chefe da Casa Civil

SETUR RS. Secretaria do Turismo do Rio Grande do Sul. Setur premia os melhores do turismo no Rio Grande do Sul. Porto Alegre, 2013. Disponível em: <http://www.turismo.rs.gov.br/conteudo/2354/setur-premia-os-melhores-do-turismo-no-riogrande-do-sul>. Acesso em: 29 jul. 2014.

SHWEEB. What is the Shweeb. Shweeb, 2014. Disponível em: <http://www.shweeb.co.nz/Shweeb/what-is-the-shweeb_IDL=1_IDT=2185_ID=12883_.html>. Acesso em: 16 jul. 2014.

SICHE, Raúl; AGOSTINHO, Feni; ORTEGA, Enrique; ROMEIRO, Ademar. Índices versus indicadores: precisões conceituais na discussão da sustentabilidade de países. Ambiente e Sociedade, Campinas, v. X, n. 2, p. 137-148, jul-dez. 2007.

SILVA, Jorge Antonio Santos. Turismo, crescimento e desenvolvimento: uma análise urbano-regional baseada em cluster. 2004. 480f. Tese (Doutorado em Ciências da Comunicação) - Escola de Comunicações e Artes da Universidade de São Paulo, São Paulo. 
SILVA, José Marcos da; SANTOS, Mariana Olívia Santana dos; AUGUSTO, Lia Giraldo da Silva; GURGEL, Idê Gomes Dantas. Desenvolvimento sustentável e saúde do trabalhador nos estudos de impacto ambiental de refinarias no Brasil. Saúde soc., São Paulo, v. 22, n. 3, Sept. 2013.

SOLOW, R. M. The Economics of Resources or the Resources of Economics, American ER, May, pp. 1-14, 1974.

STAL, Eva. Inovação: como vencer esse desafio empresarial. São Paulo: Clio Editora, 2006.

TABOA BAR. Taboa Bar. Bonito, 2014. Disponível em: <http://taboa.com.br/default.php>. Acesso em: 16 jul. 2014.

TAGLIABUE, John. The Dutch Prize Their Pedal Power, but a Sea of Bikes Swamps Their Capital. The New York Times, 2013. Disponível em: <http://www.nytimes.com/2013/06/21/world/europe/a-sea-of-bikes-swamps-amsterdam-acity-fond-of-pedaling.html?pagewanted=all>. Acesso em: 16 jul. 2014.

TANIMOTO, Armando Hirohumi. A economia medida pela Análise de Fluxo de Massa (AFM): a desmaterialização da economia nos países desenvolvidos sustentada pelos recursos naturais dos países emergentes, a exemplo do Brasil. 2010. 154f. Tese (Doutorado em Desenvolvimento Sustentável) - Centro de Desenvolvimento Sustentável, Universidade de Brasília, Brasília.

TASSO, João Paulo Faria; NASCIMENTO, Elimar Pinheiro do; ASSAD, Luís Tadeu. Turismo e Sustentabilidade: a produção associada ao turismo como instrumento de desenvolvimento local. In: Anais do Seminário Internacional de Turismo, 11, 2009, Curitiba: OBSTUR/UFPR: UNIVERSIDADE POSITIVO, 2009.

TELES, Reinaldo; RAIMUNDO, Sidnei; CABRAL, Edson; NOGUEIRA, Silvia; LIMA, Thalita; MATHEUS, Fabricio; PERUSSI, Regina; KANNI, Fernando. Turismo e meio ambiente. Rio de Janeiro: Elsevier, 2011.

TEODÓSIO, Armindo dos Santos de Sousa. Cidades como Objeto de Desejo: gestão e sustentabilidade emulados no espaço urbano. Envolverde, 2014. Disponível em: $<$ http://envolverde.com.br/ambiente/cidades-como-objeto-de-desejo-gestao-esustentabilidade-emulados-espaco-urbano/>. Acesso em: 16 jul. 2014.

TOMAZZONI, Edegar Luis. Modelo APL TUR aplicado à Região das Hortênsias (Rio Grande do Sul - Brasil). 2007. 385f. Tese (Doutorado em Ciências da Comunicação) Universidade de São Paulo, São Paulo.

TOUR DA EXPERIÊNCIA. Tour da experiência - felicidade. Tour da Experiência: 2014. Disponível em: <http://www.tourdaexperiencia.com.br/inicio>. Acesso em: 28 set. 2014.

TRIBEWANTED. Tribewanted: off-grid community experiences in Europe \& Africa. Tribewanted, 2014. Disponível em: <http://www.tribewanted.com/>. Acesso em: 16 jul. 2014.

TRIGO, Luiz Gonzaga Godoi. A viagem como experiência significativa. In: PANOSSO NETTO, Alexandre; GAETA, Cecilia (Orgs). Turismo de experiência. São Paulo: Editora SENAC, 2010, pp. 21-41.

TROTT, Paul; HARTMANN, Dap. Whay open innovation is old wine in a new bottles. International Journal of Innovation Management. Vol. 13, n. 4, pp.715-736, 2009. 
UNICAMP. Universidade Estadual de Campinas. Índice Brasil de Inovação (IBI): manual informativo sobre o procedimento de adesão das empresas. Campinas: UNICAMP/Equipe IBI, 2007.

VALDUGA, Vander. Do Modelo Sistêmico Linear Turístico ao da Unitas-multiplex. Uma Análise Crítica da Corrente Sistêmica e Suas Limitações no Campo Turístico. In: V Seminário de Pesquisa em Turismo do MERCOSUL (SeminTUR) Turismo: Inovações da Pesquisa na América Latina, Universidade de Caxias do Sul, RS, Brasil, 27 e 28 de Junho de 2008.

VAN BELLEN, Hans Michael. Indicadores de sustentabilidade: uma análise comparativa. 2. Ed. Rio de Janeiro: Editora FGV, 2006.

VALDESOL S. A. Un sendero para todos en Parque Nacional Carara, Costa Rica. Costa Rica, $2013 . \quad$ Disponível em: <http://valdesolsa.com/docs/sendero\%20universal\%20carara.html>. Acesso em: 16 jul. 2014.

VEIGA, José Eli da. Sustentabilidade: a legitimação de um novo valor, São Paulo: SENAC, 2010a.

VEIGA, José Eli da. Indicadores de sustentabilidade. Estud. avançados, São Paulo , v. 24, n. 68, $2010 \mathrm{~b}$.

VERHAGEN, Evert. Qualidade líquida de cidade. In: REIS, Ana Carla Fonseca; Kageyama, Peter. (Orgs). Cidades Criativas - Perspectivas. São Paulo: Garimpo de Soluções, 2011.

VEYRET, Yvette; ARNOULG, Paul (org.). Atlas des développements durables: un monde inégalitaire, des expériences novatrices, des outils pour l'avenir. Paris: Autrement, 2008.

VIAGEM E TURISMO. Prêmio Viagem e Turismo 2013/14, 2013. Disponível em: <http://viajeaqui.abril.com.br/materias/premio-viagem-e-turismo-2013-2014-noticias>.

Acesso em: 22 jul. 2014.

VIEIRA; Daniel Pires; HOFFMANN, Valmir Emil. Competitividade e desenvolvimento: um estudo em destinos indutores do turismo brasileiro. Revista Alcance - Eletrônica, vol. 20 - n. 03 - p. 400-416 - jul./set. 2013.

VILLENEUVE, Claude; RIFFON, Olivier. Comment réaliser une analyse de développement durable? Guide d'utilisation de la grille d'analyse de la Chaire de recherche et d'intervention en éco-conseil. Quebec, 2011.

VINCENT, James. Starpath: a spray-on coating that makes paths glow in the dark. The Independent, 2013. Disponível em: <http://www.independent.co.uk/life-style/gadgets-andtech/news/starpath-a-sprayon-coating-that-makes-paths-glow-in-the-dark-8899443.html>.

Acesso em: 16 jul. 2014.

VIOTTI, E. B. Fundamentos e Evolução dos Indicadores de CT\&I. In: VIOTTI, E. B.; MACEDO, Mariano M. (editores). Indicadores de Ciência e Tecnologia e Inovação no Brasil. Editora Unicamp, Campinas, 2003.

VIRGIN GALACTIC. Booking. Virgin Galactic, 2014. Disponível em: <http://www.virgingalactic.com/>. Acesso em: 16 jul. 2014. 
VEUGELERS, Reinhilde. Which policy instruments to induce clean innovating? Research Policy, vol 41, issue 10, december 2012, pages 1770-1778, 2012.

VOLUNTOURISM. History of VolunTourism. Santa Cruz de la Sierra, 2011. Disponível em: <http://www.voluntourism.org/inside-history.html>. Acesso em: 16 jul. 2014.

WANG, Lucy. LEGOLAND Florida Becomes Nation's First Theme Park to be Powered by $100 \%$ Renewable Energy on Earth Day. Disponível em: < http://inhabitat.com/legolandflorida-becomes-nations-first-renewable-energy-powered-theme-park-on-earth-day/>. Acesso em 17 jul. 2014.

WEF. World Economic Forum. The Global Competitiveness Report 2011-2012. Geneva, WEF, 2012. Disponível em: <http://www3.weforum.org/docs/WEF_GCR_Report_201112.pdf>. Acesso em: 15 jun. 2014.

WEF. World Economic Forum. The Global Competitiveness Report 2012-2013. Geneva, WEF, 2013a. Disponível em: <http://www3.weforum.org/docs/WEF_GlobalCompetitivenessReport_2012-13.pdf>. Acesso em: 15 jun. 2014.

WEF. World Economic Forum. The Travel \& Tourism Competitiveness Report 2013 Reducing Barriers to Economic Growth and Job Creation. Geneva: WEF, 2013b. Disponível em: <http://www3.weforum.org/docs/WEF_TT_Competitiveness_Report_2013.pdf>. Acesso em: 15 jun. 2014.

WEARING, S.; NEIL, J. Ecoturismo: impactos, potencialidades e possibilidades. São Paulo: Manole, 2001.

WEAVER, D.B. A broad context model of destination development scenarios. Tourism Management, v. 21, p. 217-224, 2000.

ZANETI, Izabel; SÁ, Lais. A educação ambiental como instrumento de mudança na concepção de gestão dos resíduos sólidos domiciliares e na preservação do meio ambiente. Anais do Encontro Nacional da ANPPAS, Indaiatuba, SP, 6-9 nov., 2002. 


\section{APÊNDICE A - Questionário online enviado a especialistas em turismo e inovação}

Pagina 1 de 1

\section{Formulário online - Tese Daniela Rocco (CDS/UnB)}

O objetivo da tese é "analisar como a inovaçăo para a sustentabilidade pode contribuir para a competitividade de destinos turísticos brasileiros". Orientador: Dr. Elimar Pinheiro do Nascimento. Instituição: Centro de Desenvolvimento Sustentável (CDS) da Universidade de Brasília (UnB).

Público-alvo: Pesquisadores, professores universitários, funcionários públicos, empresários e demais especialistas que atuam (ou iá atuaram) sobretudo nas áreas de inovacăo e turismo.

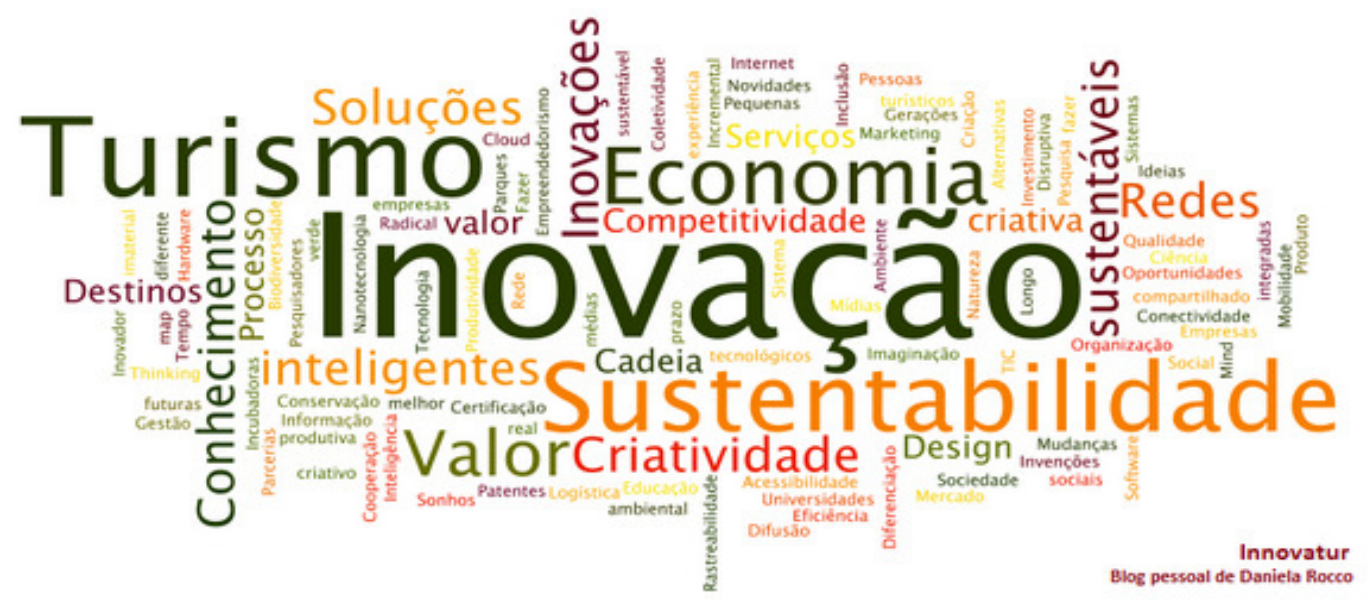

Ocupação principal:

Professor(a) universitário(a)

Funcionário(a) público(a)/representante do governo

Empresário(a)

Consultor(a) especialista autônomo(a)

Outro:

Nome/sobrenome:*

Seu nome será mantido com privacidade, e precisamos dele aqui apenas para identificar os respondentes.

Há quanto tempo trabalha/trabalhou na área de turismo/inovação (em anos completos)?*
Até 3 anos
De 4 a 7 anos
- De 8 a 11 anos
- De 12 a 15 anos
( De 18 a 19 anos
Mais de 20 anos 
1. Consultando a literatura especializada e entrevistando especialistas identifiquei e listei abaixo 12 práticas de inovações vinculadas à sustentabilidade nos destinos turísticos. Marque apenas as 3 práticas mais importantes para os destinos turísticos BRASILEIROS.*

Considere: - INOVAÇÃ́O: criaçăo/melhoria de produto, serviço, processo, marketing, organizaçăo, modelo de negócio, de meio ambiente, tecnológica e inovaçăo social / - SUSTENTABILIDADE: equidade social, prosperidade econômica e conservaçäo da natureza e cultura

$\square$ Políticas públicas menos burocráticas (gestăo eficiente), adoçăo de "compras públicas verdes" e estímulo à cultura da C.T\&l (Ciência, Tecnologia e Inovaçäo) - repercussäo direta/indireta no turismo.

$\square$ Plataforma de intercâmbio gratuito de informações gerida por alianças público-privadas para fomentar a cooperaçăo, especialmente entre micro e pequenas empresas de turismo.

$\square$ Certificacão de destinos e empresas turísticas - Sistema de Gestão Ambiental, de Qualidade, do Trabalho e Eventos Sustentáveis, além de iniciativas voluntárias e selos.

$\square$ uso das TIC (Tecnologia da Informaçăo e Comunicaçăo) destinadas a turistas (facilitaçăo da mobilidade) e para o planejamento e prevençäo de impactos negativos (ex: geoprocessamento para identificar pontos de crimes e prevenir queimadas).

$\square$ Incentivo ao empreendedorismo e à gestäo empresarial focada na inovaçăo, com programas de financiamento e subvençōes econômicas tendo como requisitos a inovaçăo e a sustentabilidade.

Acóes de marketing e comunicaçäo social que ampliem a consciência pública sobre a necessidade de modelos de negócios mais sustentáveis, incentivando inclusive a redução do consumo - repercussão direta/indireta no turismo.

- Aplicaçăo de taxas de uso ambiental retornando à sociedade como forma de investimento em inovacöes e sustentabilidade, como melhoria da infraestrutura, manutençăo de trilhas, proteção dos ecossistemas, uso de novas tecnologias, entre outros.

$\square$ Uso de veículos e meios de transporte (rodoviário, ferroviário, aéreo e hidroviário) ecologicamente adequados com reduçăo da pegada ecológica (ex: biocombustivel, energia solar, energia eólica, etc).

$\square$ Premiaçăo de iniciativas de inovaçöes vinculadas à sustentabilidade nos destinos turísticos.

- Inovaçōes sociais com melhoria das condições de trabalho, educação, saúde, além de socializaçăo nos espaços públicos - repercussäo direta/indireta no turismo.

$\square$ Atividades econômicas nos destinos turísticos que sejam de uso sustentável da biodiversidade, valorizando a cultura local e considerando os princípios de mercado justo/economia solidária.

$\square$ Criaçăo/consolidação de programas de eficiência energética e gestão da água e resíduos nas empresas, instituições públicas e terceiro setor - repercussăo direta/indireta no turismo.

2. Em relação às 12 práticas já listadas, qual é o grau de importância de cada uma delas para os destinos turísticos BRASILEIROS (em geral) quanto à COMPETITIVIDADE?*

Considere: COMPETITIVIDADE como resultado de produtividade, qualidade, inovaçäo e sustentabilidade.

Muito importante Importante Menos importante Sem importância Näo sabe

\begin{tabular}{|c|c|c|c|c|c|}
\hline $\begin{array}{l}\text { Políticas públicas } \\
\text { menos burocráticas } \\
\text { (gestäo eficiente). } \\
\text { adoçäo de "compras } \\
\text { públicas verdes" e } \\
\text { estímulo à cultura da } \\
\text { C.T\&l (Ciência, } \\
\text { Tecnologia e } \\
\text { Inovaçäo) - } \\
\text { repercussäo } \\
\text { direta/indireta no } \\
\text { turismo. }\end{array}$ & 0 & 0 & 0 & 0 & 0 \\
\hline $\begin{array}{l}\text { Plataforma de } \\
\text { intercâmbio gratuito } \\
\text { de informaçöes } \\
\text { gerida por alianças } \\
\text { público-privadas para } \\
\text { fomentar a } \\
\text { cooperaçäo. } \\
\text { especialmente entre } \\
\text { micro e pequenas } \\
\text { empresas de turismo. }\end{array}$ & 0 & 0 & 0 & 0 & 0 \\
\hline $\begin{array}{l}\text { Certificaçäo de } \\
\text { destinos e empresas } \\
\text { turísticas - Sistema } \\
\text { de Gestão } \\
\text { Ambiental, de } \\
\text { Qualidade, do } \\
\text { Trabalho e Eventos } \\
\text { Sustentáveis, além } \\
\text { de iniciativas } \\
\text { voluntárias e selos. }\end{array}$ & 0 & 0 & 0 & 0 & 0 \\
\hline
\end{tabular}


O uso das TIC

(Teconologia da

Informaçäo e

Comunicação)

destinadas a turistas

(facilitação da

mobilidade) e para o

planejamento $e$

O

$\bigcirc$

○

prevençăo de
impactos negativos

(ex:

geoprocessamento

para identificar

pontos de crimes e

prevenir queimadas).

Incentivo ao

empreendedorismo e

à gestão empresarial

focada na inovaçäo.

com programas de

finsncismento e

subvenções

econômicas tendo

como requisitos a

inovaçăo e a

sustentabilidade.

Ações de marketing $e$

comunicaçäo social

que ampliem a

consciência pública

sobre a necessidade

de modelos de

negócios mais

sustentáveis.

○

$\circ$

○

incentivando

inclusive a redução

do consumo -

repercussão

direta/indireta no turismo.

Aplicação de taxas

de uso ambiental

retornando à

sociedade como

forma de

investimento em

inovaçöes e

sustentabilidade,

como melhoria da

infraestruturg,

manutenção de

trilhas, proteçäo dos

ecossistemas, uso de

novas tecnologias.

entre outros.

Uso de veículos e

meios de transporte

(rodoviário.

ferroviário, aéreo e

hidroviário)

ecologicamente

adequados com

redução da pegada

ecológica (ex:

biocombustivel.

energia solar.

energis eólica, etc).

Premiação de

iniciativas de

inovaçöes vinculadas

à sustentabilidade

nos destinos

turísticos. 


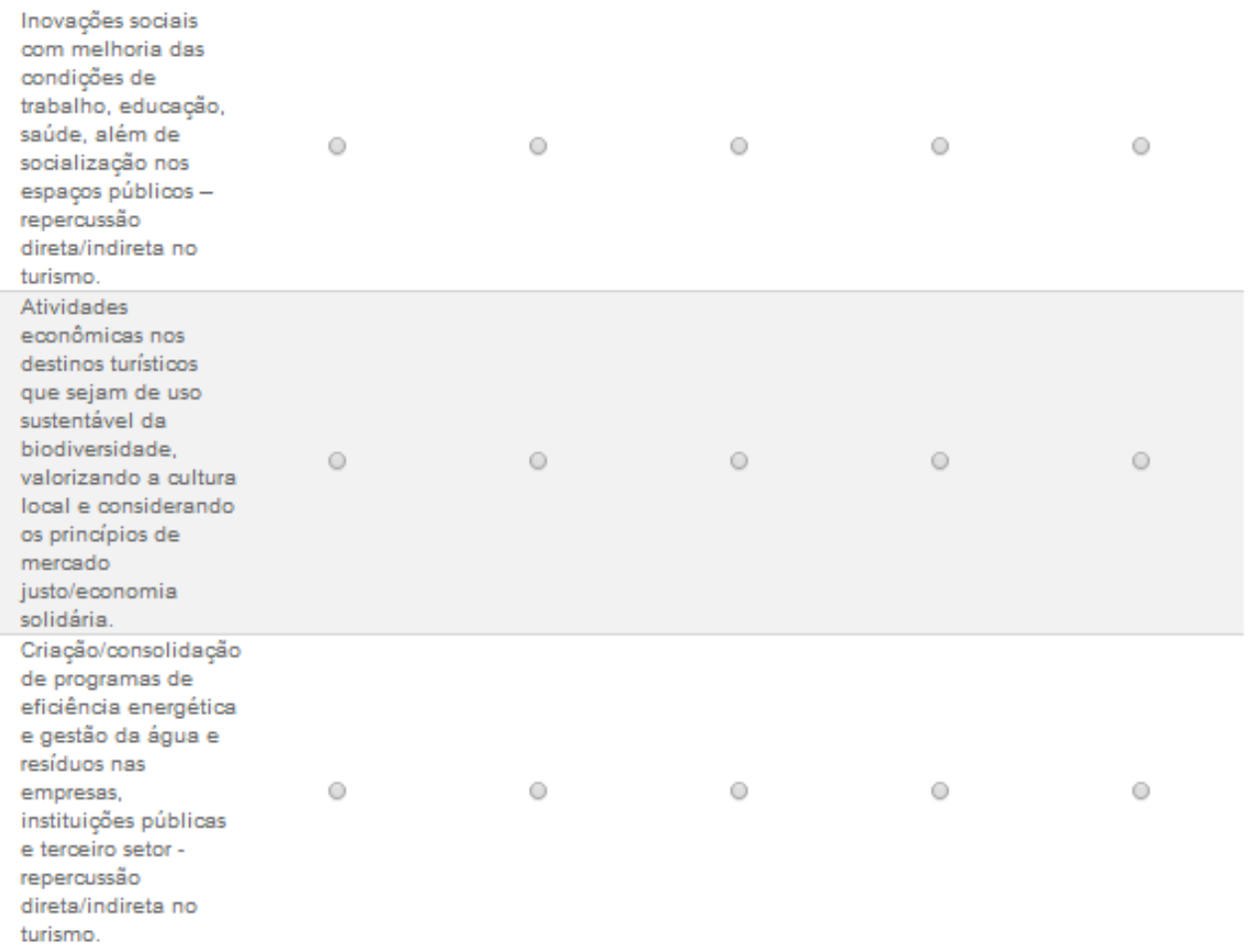

3. Existiria outra prática inovadora vinculada à sustentabilidade que é adotada (ou poderia ser adotada) nos destinos turísticos BRASILEIROS? Caso sim, especifique. Se não, o espaço abaixo pode ficar em branco. Considere: - INOVAÇÃO: criaçăo/melhoria de produto, serviço, processo, marketing, organização, modelo de negócio, de meio ambiente, tecnológica e inovaçăo social / SUSTENTABILIDADE: equidade social, prosperidade econômica e conservaçăo da natureza e cultura

4. Em sua opinião, qual é o destino turístico BRASILEIRO que mais possui inovações vinculadas à sustentabilidade. Se possivel, justifique.*

Considere: - DESTINO: cidade ou município e UF (especificaçăo mínima) / - INOVAÇÃO: criaçăo/melhoria de produto, serviço, processo, marketing, organização, modelo de negócio, de meio ambiente, tecnológica e inovação social / . SUSTENTABILIDADE: equidade social, prosperidade econômica e conservaçăo da natureza e cultura

a) Cite abaixo o 20. destino turístico BRASILEIRO que em sua opinião mais possui inovações vinculadas à sustentabilidade. Se possivel, justifique."

Considere: - DESTINO: cidade ou municipio e UF (especificaçăo mínima) / - INOVAÇÃO: criaçäo/melhoria de produto, serviço, processo, marketing, organização, modelo de negócio, de meio ambiente, tecnológica e inovaçăo social / . SUSTENTABILIDADE: equidade social, prosperidade econômica e conservaçăo da natureza e cultura

b) Cite abaixo o 3o. destino turístico BRASILEIRO que em sua opinião mais possui inovações vinculadas à sustentabilidade. Se possivel, justifique."

Considere: - DESTINO: cidade ou municipio e UF (especificaçăo mínima) / - INOVAÇÃO: criaçäo/melhoria de produto, serviço, processo, marketing, organizaçăo, modelo de negócio, de meio ambiente, tecnológica e inovaçäo social / . SUSTENTABILIDADE: equidade social, prosperidade econômica e conservaçăo da natureza e cultura 
5. Em sua opinião, quanto às 12 práticas já listadas, qual é o potencial de disseminação nos destinos turísticos BRASILEIROS no longo prazo?*

Políticas públicas menos

burocráticas (gestäo

eficiente), adoção de

"compras públicas verdes" e

estímulo à cultura da C,T\&l

0

(Ciência, Tecnologia e

Inovaçäo) - repercussão

direta/indireta no turismo.

Plataforma de intercâmbio

gratuito de informaçöes

gerida por alianças público-

privadas para fomentar a

cooperação, especialmente

entre micro e pequenas

empresas de turismo.

Certificaçäo de destinos e

empresas turísticas - Sistema

de Gestăo Ambiental, de

Qualidade, do Trabalho e

Eventos Sustentáveis, além

de iniciativas voluntárias e

selos.

O uso das TIC (Tecnologia

da Informaçăo e

Comunicaçăo) destinadas a

turistas (facilitaçäo da

mobilidade) e para o

planejamento e prevenção

de impactos negativos (ex:

geoprocessamento para

identificar pontos de crimes

e prevenir queimadas).

Incentivo ao

empreendedorismo e à

gestăo empresarial focada

na inovaçäo, $\infty \mathrm{m}$

programas de

financiamento e subvencöes

econômicas tendo como

requisitos a inovaçăo e a

[repetem-se as 12 práticas]

ITEM NÃO OBRIGATÓRIO - Compreendendo que não conseguimos esgotar todas as possibilidades, lhe convidamos para nos ajudar ainda mais a enriquecer esta pesquisa. Portanto, se deseja acrescentar comentários sobre inovação, sustentabilidade e competitividade nos destinos turísticos (nacionais e/ou internacionais), tenha certeza de que serão bastante bem-vindos! Muito obrigada de qualquer modo!

A previsăo de conclusăo desta pesquisa é julho de 2014, e uma vez publicada a tese de doutorado, a mesma será enviada a todos os profissionais e pesquisadores que colaboraram respondendo este formulário. 
APÊNDICE B - Formulário aplicado junto a atores locais do poder público e trade turístico

1) Breve caracterização sobre o(a) entrevistado: sexo, idade e ocupação

2) Em sua opinião, quais são os 3 principais fatores que contribuem para a competitividade turística de Bonito/Gramado/Instituto Inhotim?

3) A literatura diz que a inovação e sustentabilidade são importantes pilares da competitividade. Como esses dois pilares podem contribuir para a competitividade turística de Bonito/Gramado/Instituto Inhotim?

4) Mostrar tabela abaixo e perguntar: Qual empreendimento de cada segmento visto aqui nesta tabela possui mais inovações com princípios de sustentabilidade? Citar, descrever e justificar [No caso do Instituto Inhotim esta tabela não foi apresentada, pois a MIST já foi aplicada diretamente junto à entrevistada].

\begin{tabular}{|l|l|l|l|l|l|l|}
\hline \multicolumn{7}{|c|}{ INOVAÇÕES COM PRINCIPIOS DE SUSTENTABILIDADE NOS 7 SEGMENTOS TURÍSTICOS } \\
\hline (1) Transporte & (2) Hospedagem & $\begin{array}{l}\text { (3) Alimentos e } \\
\text { bebidas }\end{array}$ & $\begin{array}{l}\text { (4) Atrações } \\
\text { turisticas }\end{array}$ & $\begin{array}{l}\text { (5) Agências } \\
\text { de viagens }\end{array}$ & $\begin{array}{l}\text { (6) Governo e } \\
\text { informação } \\
\text { turística pública }\end{array}$ & $\begin{array}{l}\text { (7) Cooperação / } \\
\text { ONG / OSCIP }\end{array}$ \\
\hline & & & & & & \\
\hline & & & & & & \\
\hline
\end{tabular}

5) Qual é o grau de importância dessas inovações com princípios de sustentabilidade para a competitividade turística de Bonito/Gramado/Instituto Inhotim?

6) Desafios futuros 
APÊNDICE C - Formulário aplicado junto aos turistas (Bonito/Gramado/Instituto Inhotim)

N Formulário:

Local:

Data:

1) Cidade onde mora atualmente (cidade/estado):

2) O que o(a) motivou a conhecer Bonito/Gramado/Instituto Inhotim?

3) Em sua opinião, o que Bonito/Gramado/Instituto Inhotim tem de mais diferente (algo inovador) em relação a outros destinos turísticos brasileiros?

4) Esse aspecto diferente/inovador foi decisivo para visitar Bonito/Gramado/Instituto Inhotim?
a) $\mathrm{Sim}$
b) Não
c) Nem que sim, nem que não
d) Não sabe

5) Com que frequência o(a) senhor(a) usa serviços turísticos sustentáveis?

a) Sempre

b) Quase sempre

c) Às vezes

d) Raramente

e) Nunca

f) Não sabe

6) $O$ que Bonito/Gramado/Instituto Inhotim deveria oferecer para o(a) senhor(a) voltar para cá outras vezes?

7) Idade:
a) $18-30$ anos
b) 31-45 anos
c) $46-60$ anos
d) Acima de 61 anos

8) Sexo:

a) Feminino

b) Masculino 


\section{APÊNDICE D - Tendências futuras e práticas de inovação para a sustentabilidade em destinos turísticos internacionais e brasileiros}

O objetivo deste apêndice é apresentar algumas experiências pontuais de inovação para a sustentabilidade no turismo da América Latina (exceto Brasil), Europa, Ásia e Oceania. A identificação de tais experiências ocorreu graças à pesquisa doutoral na Europa (o contato com os pesquisadores do ClCtourGUNE contribuiu bastante), entrevista com representantes do trade turístico da Espanha e Portugal e pesquisa exploratória (revisão da literatura).

As experiências atuais e tendências futuras listadas a seguir, sejam elas internacionais e nacionais, possuem repercussões diretas e indiretas sobre a atividade turística. Tomando por base que o turismo é um complexo sistema, optamos por destacar também algumas "inovações indiretas", pois estas contribuem bastante para dinamizar o sistema turístico. Podem ser inovações que impactam indiretamente no turismo, na sustentabilidade e/ou inovações vinculadas à sustentabilidade que não influenciam diretamente no sistema turístico.

Aparentemente, a maior parte das experiências expostas nesta seção possui foco em duas ou três dimensões da sustentabilidade abordadas nesta tese (ambiental, social, cultural e econômica). Idealmente, para que uma empresa ou território seja sustentável, deveria existir a combinação simultânea de todas as dimensões. Para verificar se determinada prática listada aborda todas as dimensões da sustentabilidade, como o caso de Nairobi (Quênia), é preciso aprofundar o estudo caso-a-caso, o que não é a finalidade deste capítulo. Das experiências internacionais que serão mencionadas não sabemos realmente quais seriam os impactos negativos sobre a biodiversidade, a real destinação e tratamento dos resíduos, problemas socioculturais, entre outros. É preciso sempre ter reflexão crítica quanto às "pseudoiniciativas sustentáveis" que visam conquistar uma imagem positiva junto à sociedade e mercado em geral. Na academia, essa atitude é conhecida como "greenwashing" (branqueamento ecológico ou ecobranqueamento), e as pessoas/empresas que se comportam assim são em geral conhecidas como "free riders" (caronistas - no contexto: aqueles que se aproveitam de um benefício, mas que não contribuem para obtêlo) (FONSECA \& BURSZTYN, 2007).

No entanto, é importante dar visibilidade a essas experiências de inovação para a sustentabilidade, pois podem representar, efetivamente, um câmbio de paradigma na relação sociedade-ambiente-governo-mercado. Elas podem, ainda, ser fontes de inspiração para que os entes públicos e privados do Brasil também desenvolvam algo melhor ou semelhante com vistas ao aumento de competitividade do País. 


\section{INICIATIVAS INOVADORAS DE TURISMO E TENDÊNCIAS FUTURAS PELO}

MUNDO

A Figura 65 abaixo apresenta, em formato mind map, uma forma diferenciada de representação de um destino turístico inovador. Quem criou essa representação foi o professor Dr. Oriol Miralbell Izard, que se dedica a estudos de turismo, tecnologia e inovação nos destinos turísticos há mais de 25 anos e hoje está vinculado à Universidade Aberta da Catalunha. O professor Izard intitulou seu mind map de "Map of ICT in the destination studied at the ENTER Conference editions of 2013 and 2014". Para criá-lo, ele utilizou o Coggle (https://coggle.it), que é uma ferramenta gratuita e online capaz de produzir mind maps.

No modelo destino turístico inovador da Figura 65 não é possível saber se a sustentabilidade é considerada, porém pressupomos que ela seja tratada de forma transversal a todos os elementos presentes. Alguns deles, como Smartcities (Smart Tourism Intelligence), Redes sociais e Gamification serão detalhados em tópicos que serão apresentados a seguir. 


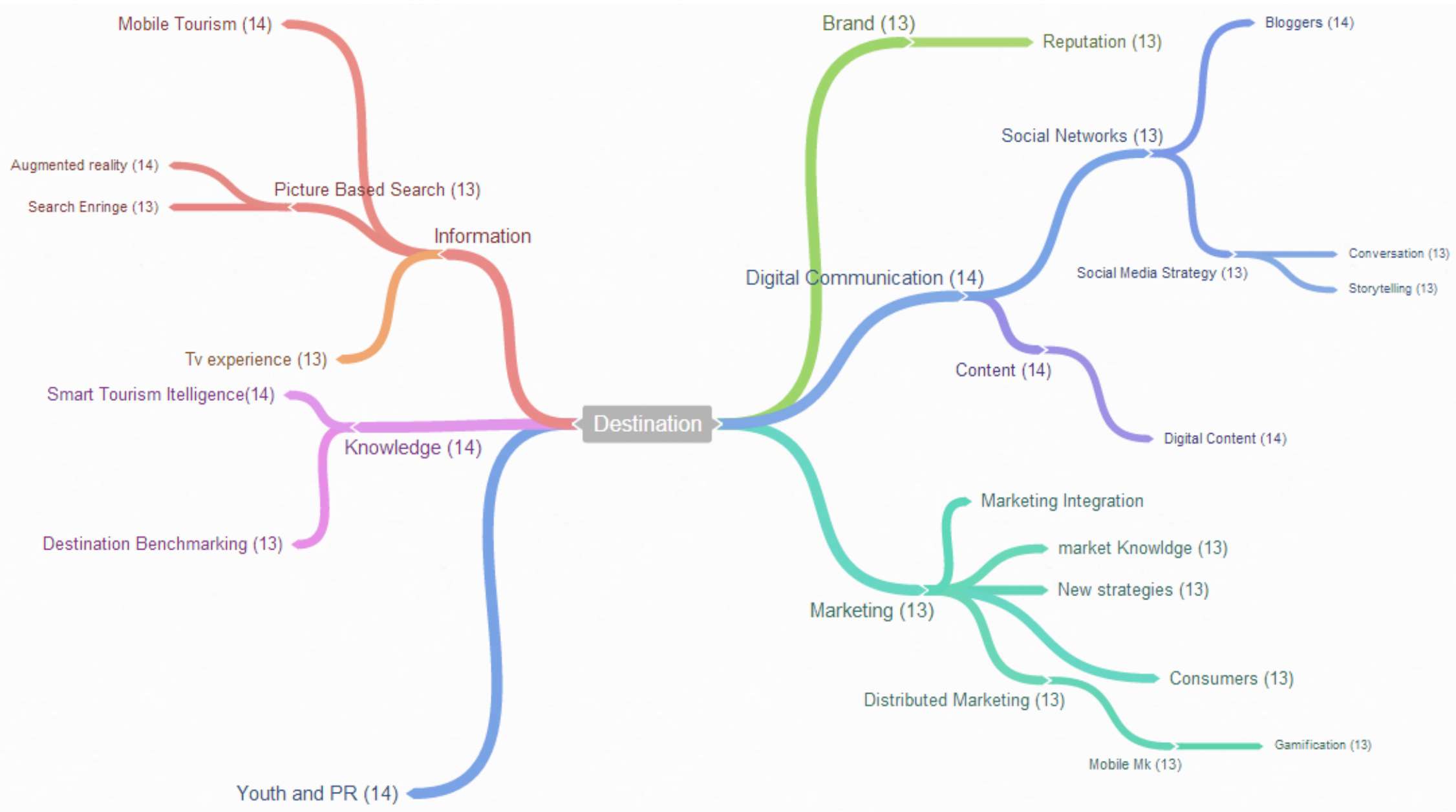

Figura 65 - Mind map de destino turístico inovador

Fonte: Elaborado pelo professor Dr. Oriol Miralbell Izard (disponível em:

https://coggle.it/diagram/534670b6faa1b4b83f0016b0/cef887329a66c11a77910fa46efad9674e0c8890ea0492e585e77af461a6ecd1) 
- Nômades digitais: o caso de Jodi Ettenberg, canadense, blogueira, que conhece centenas de países e oferece passeios gastronômicos personalizados mundo afora

Em 2008 Jodi Ettenberg deixou seu emprego após trabalhar cinco anos como advogada em uma empresa de Nova York. O motivo era largar tudo que fazia para viajar pelo mundo por um ano. A história de ganhar dinheiro com isso foi quando começou a compartilhar com familiares e amigos fotos e fatos curiosos de suas viagens em seu site (http://www.legalnomads.com/). Ocorre que isso se tornou um grande sucesso e até hoje essa "aventura" Ihe rende consultorias, palestras e os benefícios das publicações de seus livros, entre eles, o The Food Traveler's Handbook.

Além de ser especialista em sopas, Jodi realiza tours gastronômicos personalizados para pequenos grupos naquela cidade em que ela está vivendo atualmente, o que lhe permite maior flexibilidade. No site desses passeios gastronômicos (http://www.jodieats.com/), Jodi relata que as pessoas the perguntavam se poderiam se juntar a ela (JODI EATS, 2013). Sempre há uma demanda de turistas que deseja ter uma experiência diferenciada em termos de gastronomia, e o tipo de serviço customizado que Jodi oferece, que é o de explorar junto com ela aromas e sabores, é uma inovação que tende a crescer cada vez mais. Esta lógica também vai de encontro com o próximo tópico.

\section{- Personalização crescente nos serviços: Personal Trip Advisor, Personal} Assistent e Rent a local friend

Uma grande tendência atual está relacionada a trabalhos de consultoria altamente especializada. Em Nova York e demais grandes centros urbanos o trabalho do personal assistent é muito comum, uma vez que esse profissional organiza agendas pessoais de outras pessoas. Ele pode atuar também no âmbito dos negócios, organizando as agendas de reuniões dos empresários. No Brasil, particularmente em São Paulo, um serviço também bastante especializado é o de profissionais que realizam o soft landing ("aterrissagem suave"), dando suporte a expatriados que estão na cidade e que precisam de referências como hospitais, escolas, supermercados, noções de segurança, entre outros. $\mathrm{Na}$ área do turismo tem sido evidenciado o trabalho do Personal Trip Advisor, um profissional que oferece serviço customizado de planejamento e organização de viagens. Vale destacar, por fim, o Rent a local friend (http://www.rentalocalfriend.com/), uma forma inovadora de contratar moradores locais para acompanhar turistas em passeios pela cidade. 


\section{- Big Data: a tecnologia da informação a favor dos megaeventos}

A IBM tem produzido, via big data (vide conceito abaixo na Figura 66), um trabalho de coleta de dados em redes sociais para apoiar a tomada de decisões de organizações.

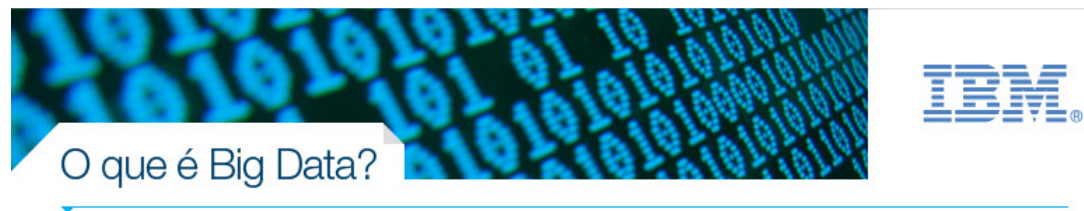

Big Data é um termo utilizado para descrever grandes volumes de dados e que ganha cada vez mais relevância à medida que a sociedade se depara com um aumento sem precedentes no número de informações geradas a cada dia. As dificuldades em armazenar, analisar e utilizar grandes conjuntos de dados têm sido um considerável gargalo para as companhias.
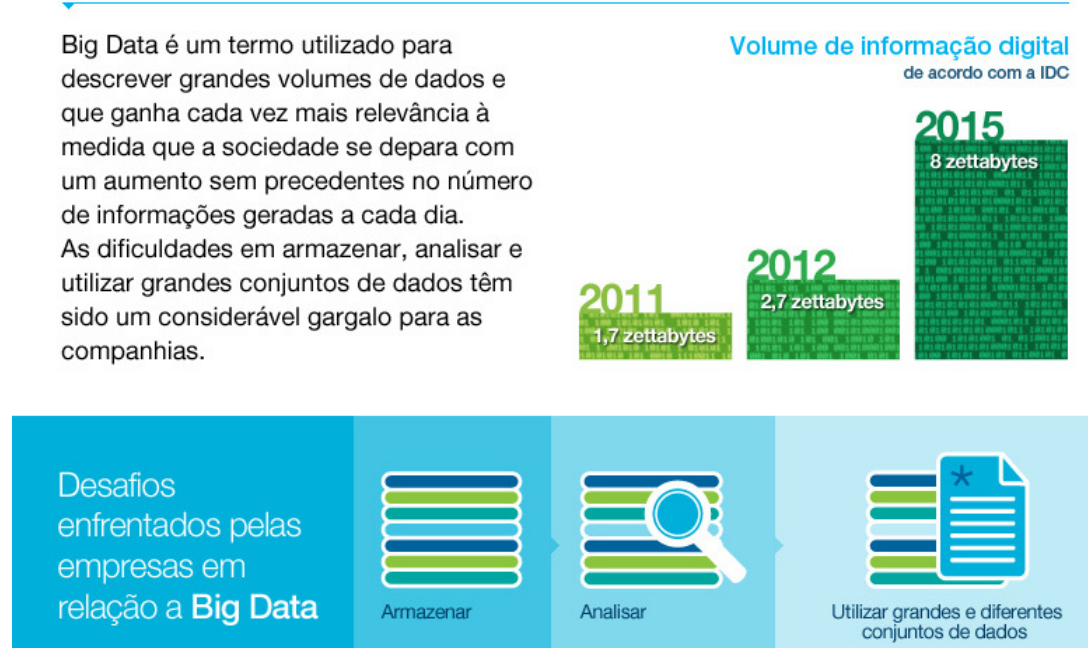

Figura 66 - O que é Big Data?

Fonte: IBM (2014).

Para a Copa das Confederações que ocorreu em 2013 a empresa analisou cerca de 5 milhões de tweets durante os jogos do Brasil e repassou ao técnico da Seleção Brasileira os principais insights. É como se a IBM ajudasse o técnico na escalação da Copa, tendo em vista que foram consideradas as opiniões dos torcedores (KOHN, 2013). O uso de big data no turismo é uma grande tendência para o futuro. O CICtourGUNE (Centro de pesquisa em turismo localizado no País Basco) já vem utilizando esse recurso para mapear "ilhas de calor" de pontos turísticos mais visitados a partir de informações advindas de redes sociais como o Twitter. Uma representação de como o Centro trabalha a partir da lógica do big data é exibida na Figura 67 abaixo. 


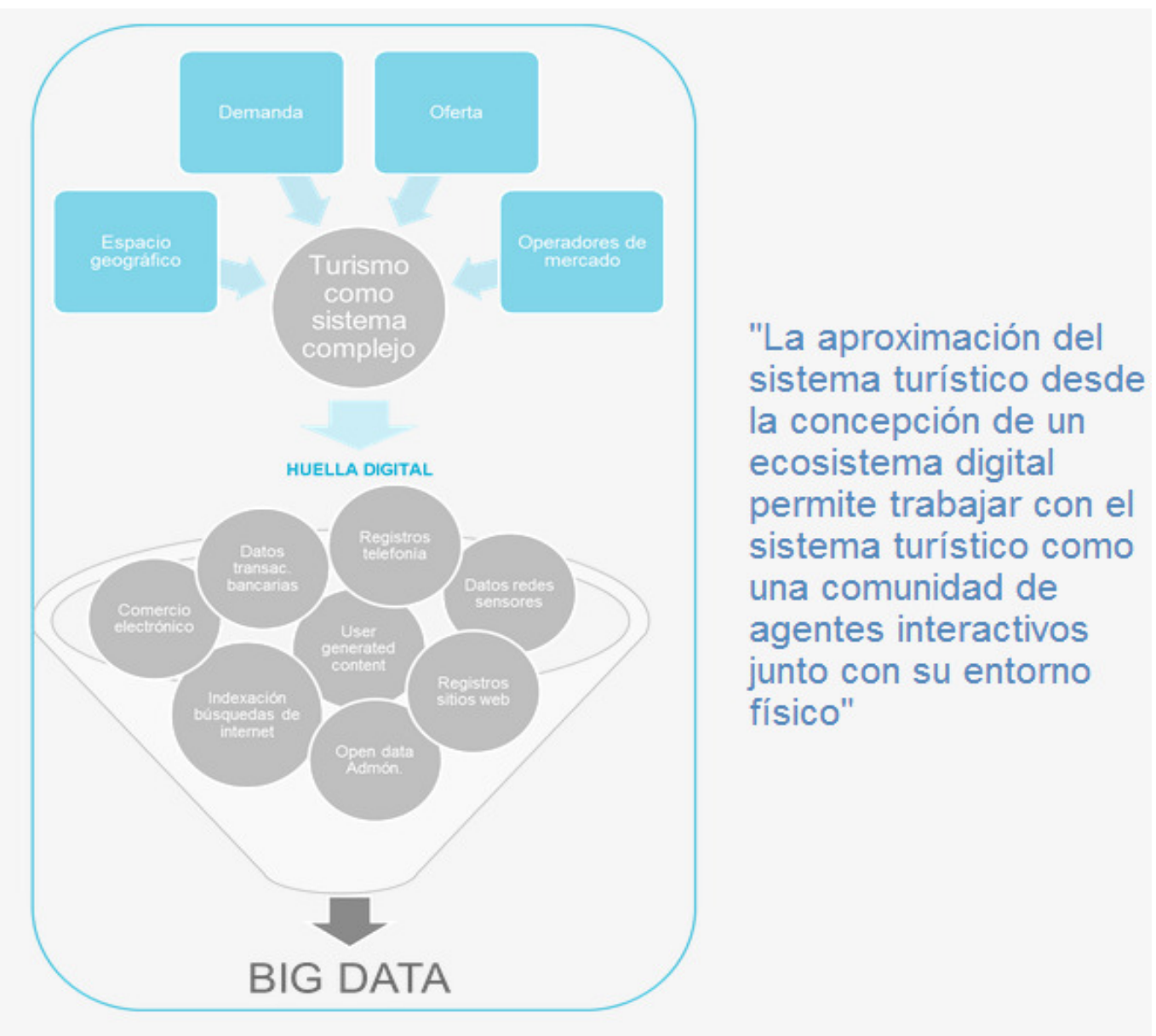

Figura 67 - Big data no sistema turístico segundo CICtourGUNE Fonte: CICtourGUNE (2014).

\section{- Movimentos Slow}

Em contraposição ao fast food, o jornalista italiano Carlo Petrini criou o movimento Slow Food (http://www.slowfood.com/), como resposta ao desejo de valorização cultural das bebidas e alimentos locais, assim como do prazer de se comer bem e saudavelmente. Hoje o Movimento Slow Food é uma organização global sem fins lucrativos com mais de 150 países adeptos, que se aliam ao compromisso com a comunidade e meio ambiente, uma vez que se preza por alimentos que tenham três princípios interligados: que sejam bons, limpos e justos.

A filosofia do movimento "slow" se difundiu pelo mundo inteiro e foi incorporada em outras áreas, entre elas o segmento de viagens e turismo. Assim nasceu o Slow Travel, que consiste naquelas viagens em que os visitantes possam se conectar com a comunidade receptora e valorizar os produtos locais. É um tipo de experiência distinta em relação àquelas viagens rápidas e a negócios (TRIGO, 2010). 


\section{- Couchsurfing}

O Couchsurfing é uma rede social de hospitalidade que conecta viajantes (guests) que desejam se hospedar gratuitamente em outra cidade e anfitriões (hosts) dispostos a abrir suas casas. A tradução literal da expressão couch surfing é "surfando no sofá", porém a experiência de hospedagem vai muito além de sua expressão. Além do próprio sofá, o viajante (guest) pode se acomodar também em sacos de dormir, colchonetes ou até camas em quartos privativos. Basicamente, o processo funciona desta maneira: primeiro é preciso realizar cadastro do perfil da pessoa no site (https://www.couchsurfing.org/) ou aplicativo disponível para Android e IOS com fotos e informações específicas. Feito isso, a pessoa pode acessar perfis tanto de guests quanto de potenciais hosts. Além de fotos e detalhamentos do perfil de cada membro (chamado de couchsurfer), é possível ter acesso inclusive a depoimentos positivos, neutros e negativos da experiência de hospedagem com determinado host. Vale lembrar que ao host lhe é permitido aceitar ou não os pedidos de hospedagem e, ainda, se oferecer somente para passear com os viajantes.

Criado em 2004 por Casey Fenton, Daniel Hoffer, Sebastian Le Tuan e Leonardo Bassani da Silveira, o Couchsurfing é uma plataforma global e virtual que agrega mais de sete milhões de membros, distribuídos em mais de 100 mil cidades e que se conectam pela internet e pela relação de confiança e respeito. Evidentemente, essa é uma forma inovadora de se economizar com hospedagem e estabelecer intercâmbio cultural; ou não, a experiência pode gerar, em casos específicos, problemas como a perda da segurança e confiança.
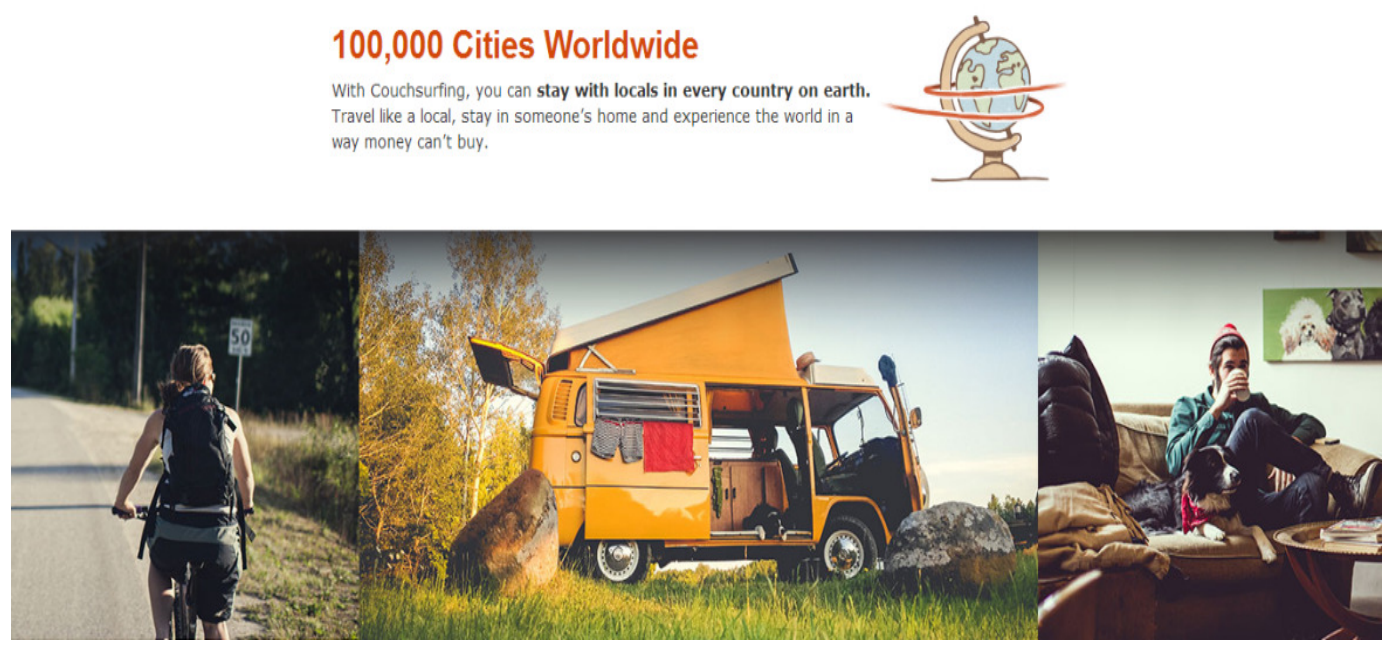

Figura 68 - Imagem extraída do site Couchsurfing (2014)

Autor: Couchsurfing

Fonte: https://www.couchsurfing.org/ 


\section{- Crowdfunding}

Trata-se de um financiamento coletivo, cujos recursos financeiros são captados geralmente por uma rede de pessoas físicas, sendo normalmente efetuado via internet. Exemplos mais "clássicos" de crowdfunding no Brasil são o "Criança Esperança" e o "Teleton". Muitas são as maneiras de aplicação desse modo peculiar de financiamento, como o cada vez mais frequente caso de um conjunto de fãs que faz uma espécie de "vaquinha virtual". Isto consiste desde o financiamento para a produção do CD e/ou DVD da banda favorita até para trazer aquela banda internacional que há anos não vem ao país (ou que até mesmo que nunca veio). Neste sentido, se o valor é realmente alcançado, todos aqueles que ajudaram se beneficiam de alguma forma. No turismo, o crowdfunding começa a ser adotado, e no capítulo 4 foi apresentado um caso de crowdfunding de turismo sustentável que ocorreu em Minas Gerais.

\section{- TripAdvisor e a relação com "hotéis ecológicos” pelo mundo}

O site britânico TripAdvisor hoje é um dos mais influentes do mundo no quesito localização e detalhes sobre serviços e equipamentos turísticos. Recentemente o site lançou - Programa GreenLeaders em parceria com a International Tourism Partnership, a Carbon Trust, a Reino Unido Green Building Council e o Programa das Nações Unidas para o Ambiente (PNUMA). O objetivo desse Programa é amparar visitantes de todo o mundo no planejamento de viagens ecológicas, e isso ocorre, basicamente, com a indicação de meios de hospedagem que possuem práticas responsáveis no quesito ambiental no site do TripAdvisor (O'NEILL, 2014).

\section{- Inovações sociais}

As inovações sociais pelo mundo merecem destaque, como o caso do sinal de trânsito em Nova York que emite sinais sonoros simpáticos aos pedestres (Figura 69) e a montagem em um espaço público da cidade de Bilbao que remete a um ambiente de sala de estar. A colocação desse "cenário" é um convite para que o cidadão se sinta em "em casa" no espaço público que também pertence a ele (Figura 70). 


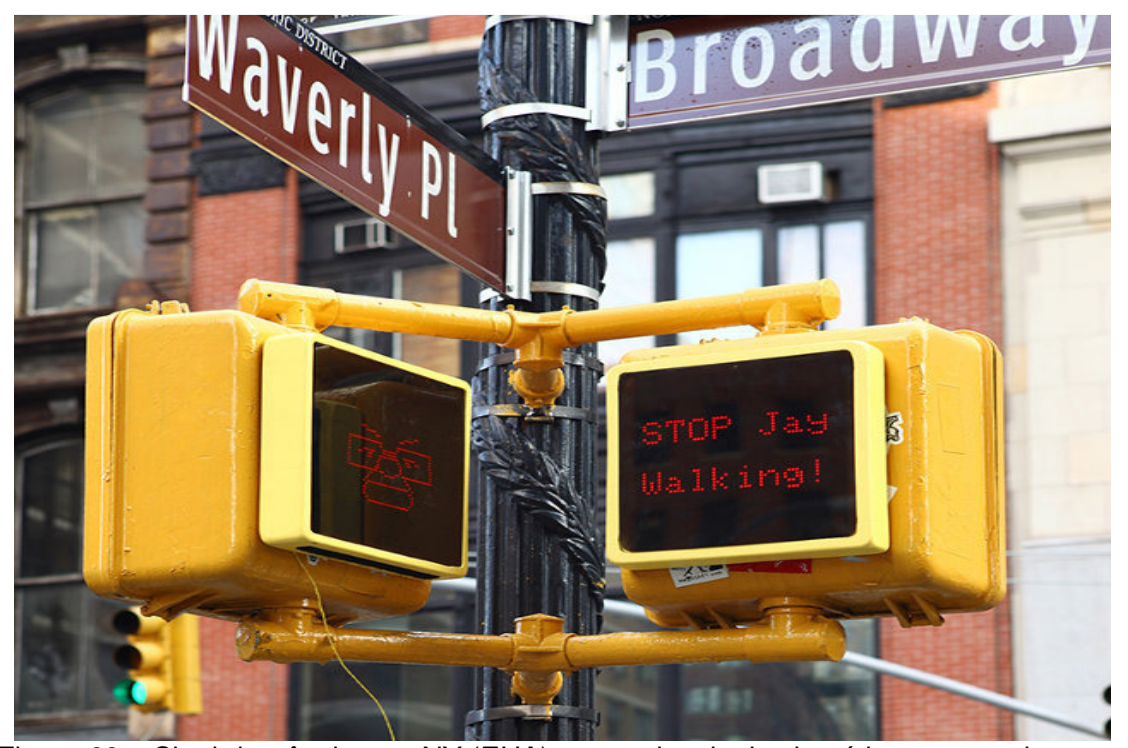

Figura 69 - Sinal de trânsito em NY (EUA) que emite sinais simpáticos aos pedestres Crédito: Autor desconhecido

Fonte: Foto extraída do site fastcoexist.com

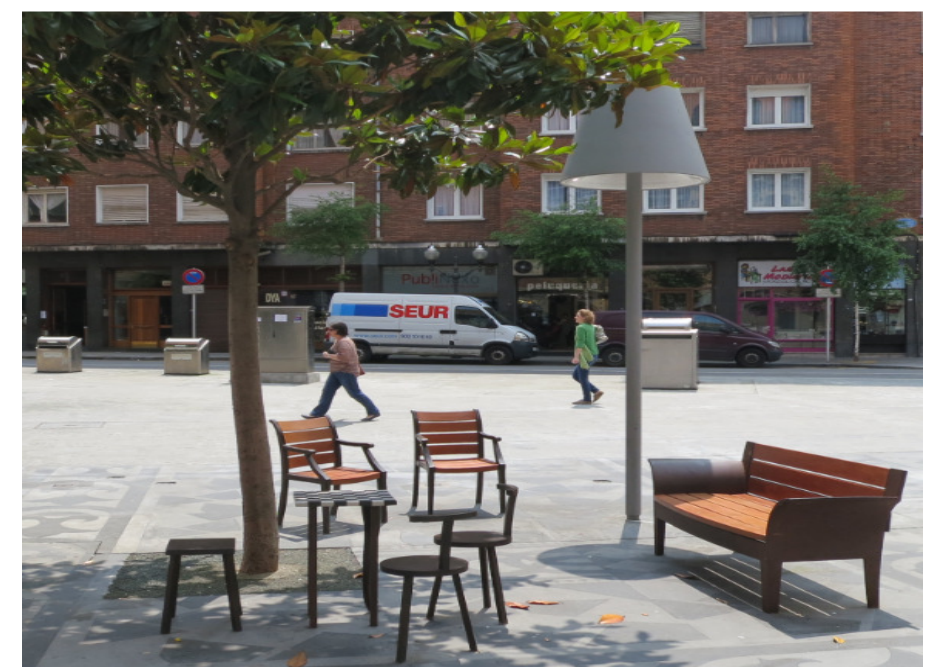

Figura 70 - Espaço público de convivência social em Bilbao (Espanha) Crédito: Daniela Rocco (2013)

A inovação social também pode ser estimulada pela iniciativa privada, como é o caso da Duracell, que construiu um ponto de ônibus no Canadá cujo aquecimento interno só era gerado se as pessoas dessem as mãos umas às outras, tal como mostra na sequência de imagens da Figura 71 abaixo. 


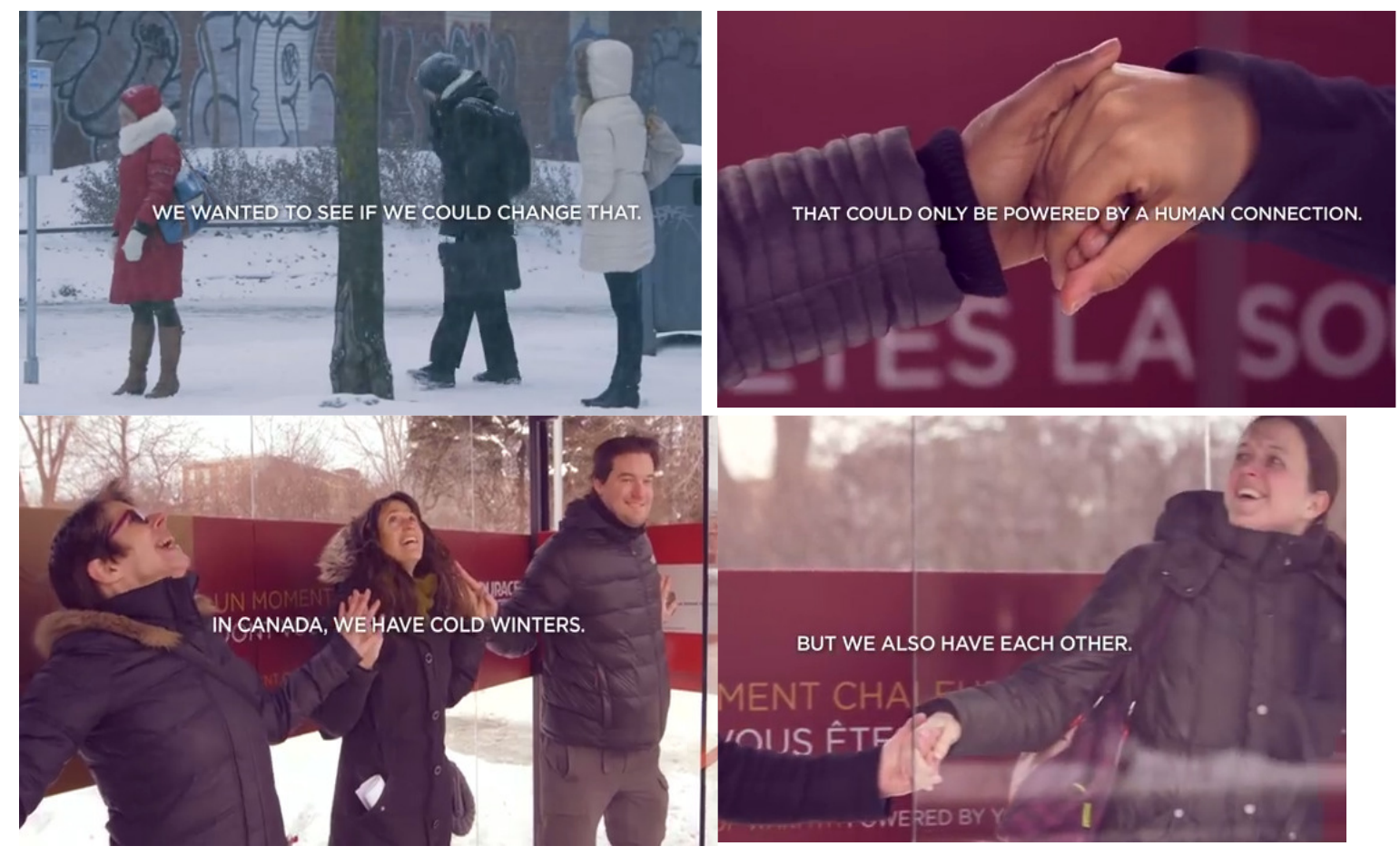

Figura 71 - Imagens extraídas do vídeo da campanha Moments of Warmth (Canadá) Autor: Official Duracell

Fonte: https://www.youtube.com/watch?v=-mQZqKLiMlg

\section{- Street art e demais intervenções urbanas}

Tem se tornado cada vez mais comum no Brasil e várias cidades pelo mundo a arte de rua, também conhecida como "street art". A Figura 72 apresenta apenas um exemplo do universo de obras de arte em ruas, calçadas e fachadas de prédios. O conjunto de imagens abaixo mostra o trabalho do francês Levalet. A técnica do artista é colar pôsteres (paste-up) em paredes e fazê-los "interagir" com algum objeto tridimensional e com as pessoas que ali passam (BARBOSA, 2013). 


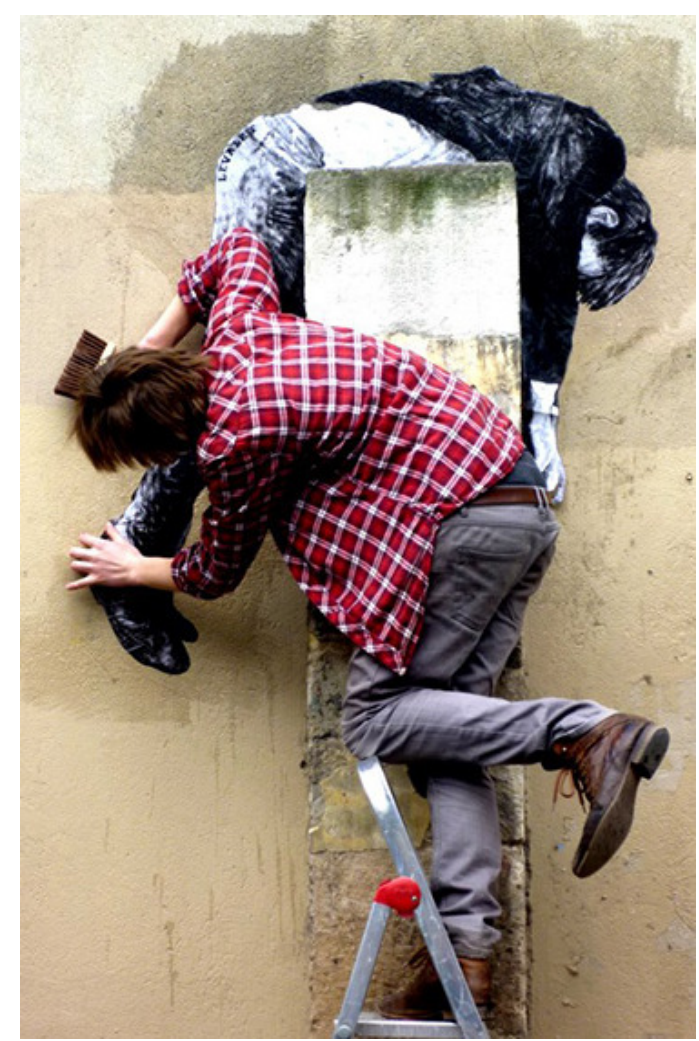

Figura 72 - Street art by Levalet Crédito: Levalet (2013)
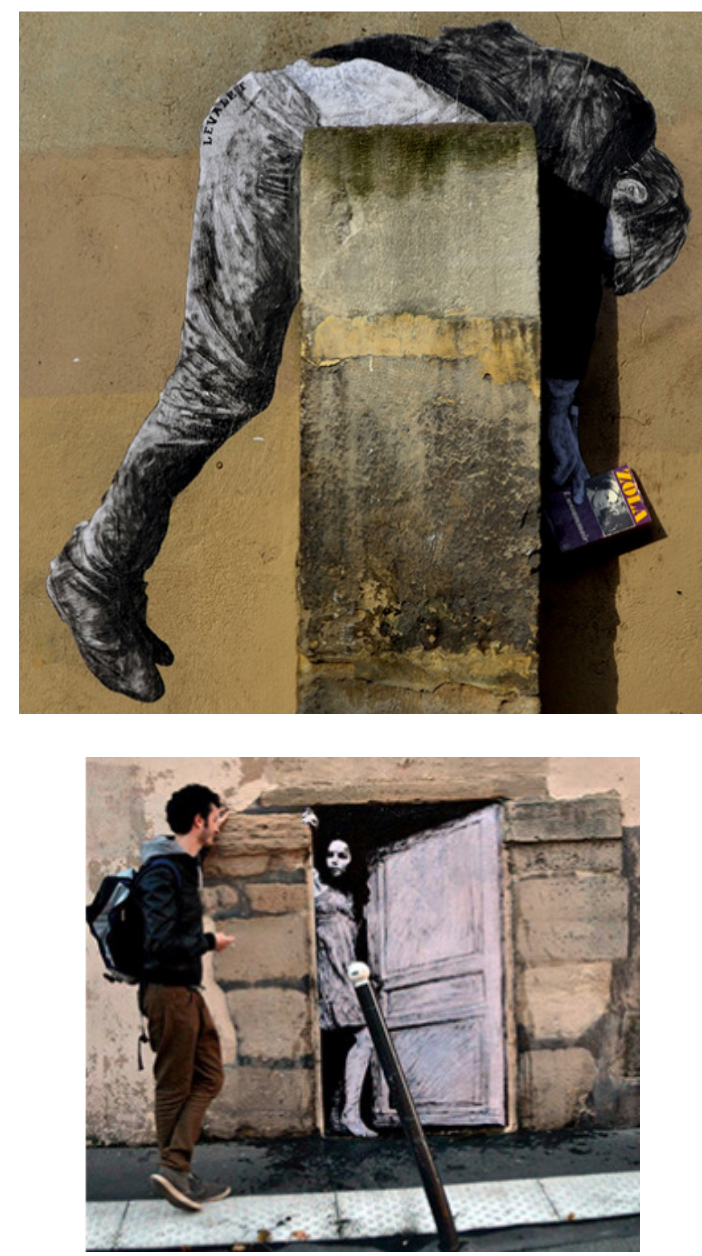

- Uso dos drones como instrumentos de planejamento, gestão e divulgação de destinos turísticos

Os drones são veículos aéreos sem tripulação, comandados a distância por mecanismos eletrônicos e que foram criados para fins militares. Como sabemos, muitas tecnologias como essas sempre chegam à realidade do cidadão comum. É o caso do computador, internet e vários outros equipamentos. Existem diversos usos do drone (para o bem e para o mal), porém destacamos que essa tecnologia pode ser usada para fiscalizar o desmatamento e, até mesmo, filmar imagens incríveis de um destino turístico, mostrando às pessoas uma forma de conhecê-lo a partir de outra perspectiva.

A empresa Pumba Produccions adotou essa inovação e divulgou em 2013 um filme diferenciado com os principais pontos da cidade Barcelona (Espanha), tal como mostra na Figura 73. 


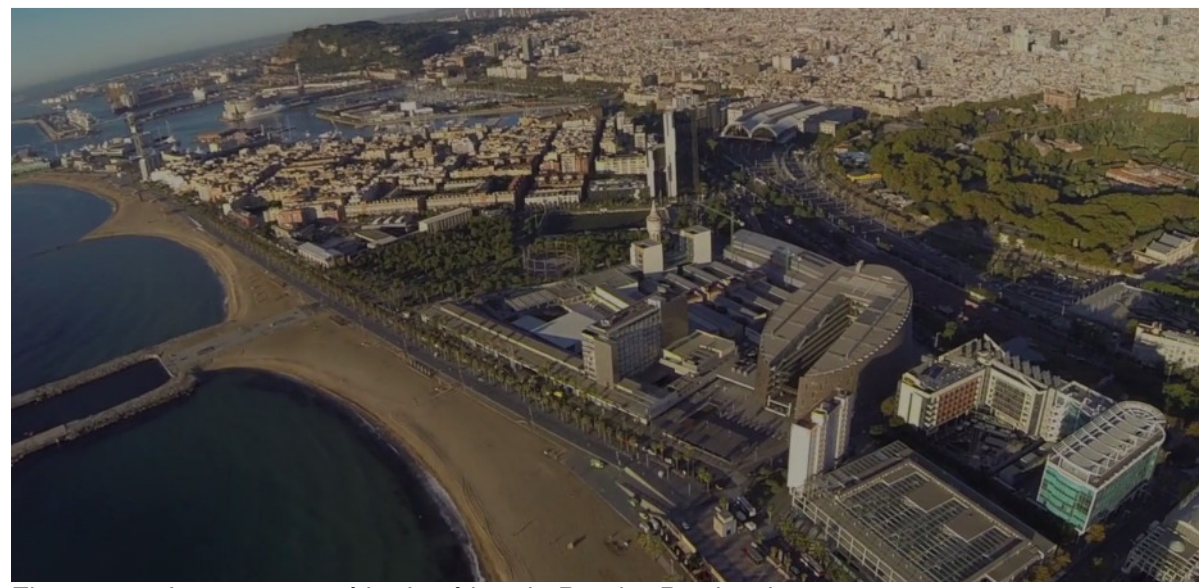

Figura 73 - Imagem extraída do vídeo da Pumba Produccions

Fonte: pumbaproduccions.com

No Brasil estuda-se, por meio da ANAC (Agência Nacional de Aviação Civil), a criação de uma proposta de regulamentação dos drones (AGÊNCIA ESTADO, 2014).

- Diversificação de modelos negócios de grandes empresas de tecnologia: o caso da Google e IBM

- Google, quais são seus negócios?

Qual é o negócio da Google? Na verdade, é mais apropriado questionar hoje quais são os negócios da Google. De buscador de informações (até o momento, core business da empresa), passou a inovar em outras áreas: criou um óculos de realidade aumentada (Google Glass), é inventor de mapas interativos concatenados com histórias reais de turistas, investidor em energias renováveis e até criador de mapa mundial do desmatamento (MORETZ, 2014; O'BRIEN, 2014).

\section{- IBM: preparando um futuro de Smartcities}

A IBM há poucos anos começou a diversificar sua forma de atuação, entre elas, criar soluções inovadoras para as "smartcities" (cidades inteligentes). Segundo a empresa, existem três eixos principais para se implementar mudanças: 1) planejamento e gerenciamento; 2) infraestrutura e 3) humano. Cada eixo possui áreas específicas de atuação, tal como mostra na Figura 74 (IBM, 2014). 


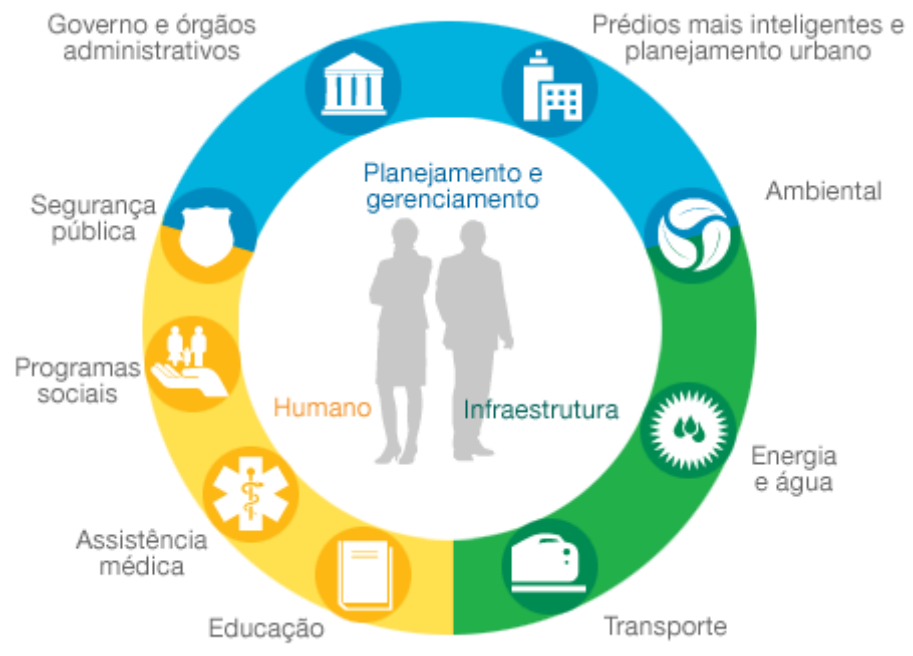

Planejamento e gerenciamento (US)

Insights a longo prazo com base na análise de dados abrangentes, acompanhados através de gerenciamento diário eficiente, ajudam uma cidade a permanecer vital e segura para seus cidadãos e negócios. Saiba mais sobre soluções de planejamento e gerenciamento (US) para cidades mais inteligentes.
Infraestrutura (US)

Serviços fundamentais - como rodovias, trânsito em massa $e$ utilitários - tornam uma cidade desejável e habitável, mas a chave desejável e habitável, mas a chave
para mantê-los viáveis é preparação para mudança constante. Saiba mais sobre

soluções de infraestrutura (US) para cidades mais inteligentes.
Humano (US)

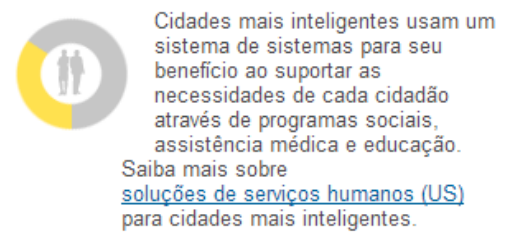

Figura 74 - Smartcities

Fonte: IBM (2014)

\section{- Hospedagens alternativas: o caso da Airbnb}

O CEO e cofundador da Airbnb (www.airbnb.com), Brian Chesky, estava desempregado e até mesmo passou fome antes de ter a ideia de criar uma empresa que movimenta o mercado online de aluguel de quartos, apartamentos e casas durante viagens. Hoje a Airbnb está presente em 92 países e 34.000 cidades, envolvendo mais de 600.000 usuários. Inovações disruptivas no mercado de viagens e turismo como essas ainda não são muito comuns, porém esta é uma forte tendência mundial e, portanto, merece atenção e estudo.

\section{- Jardins verticais}

O botanista Patrick Blanc (http://www.verticalgardenpatrickblanc.com/realisations) é considerado um dos precursores da atual concepção de jardim vertical, inclusive Blanc possui instalações em diversos países. Os jardins verticais são uma forma de contribuir para 
a qualidade e a umidade do ar, o isolamento acústico e térmico, entre outros benefícios. A Figura 75 exibe alguns exemplos de jardins verticais no mundo.

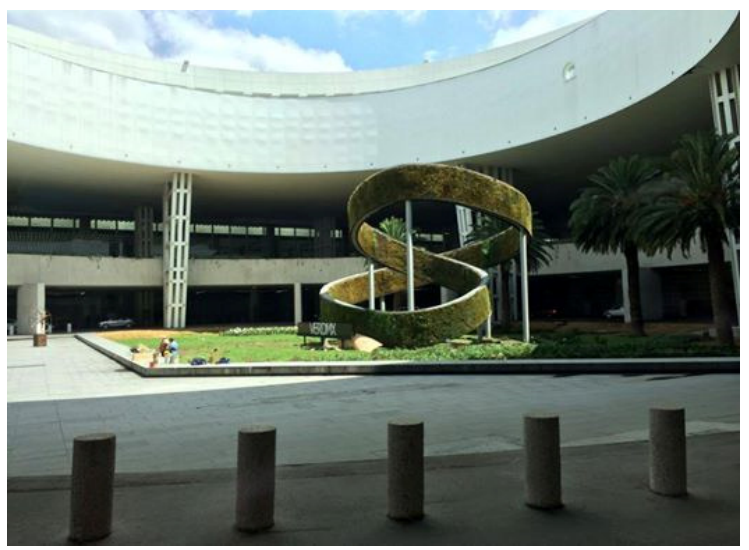

Cidade do México

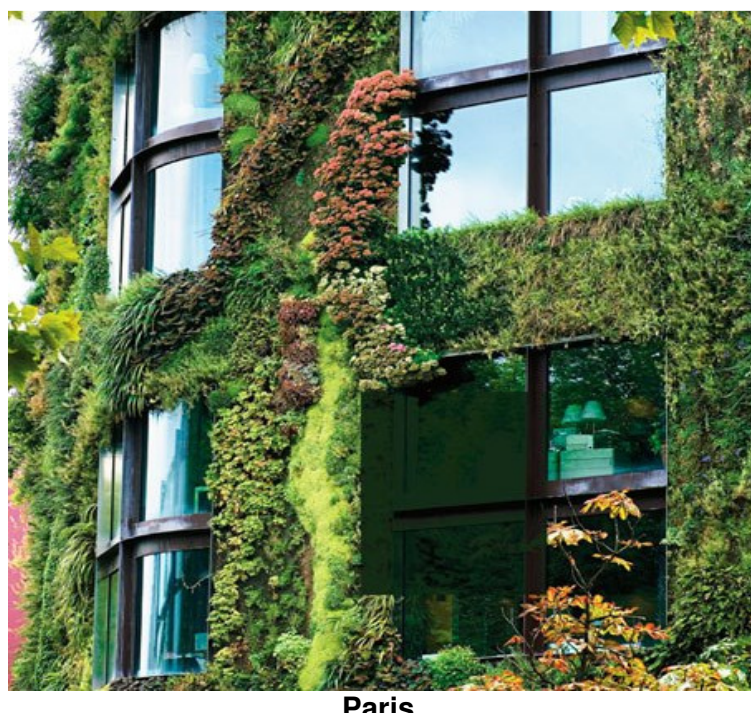

Paris

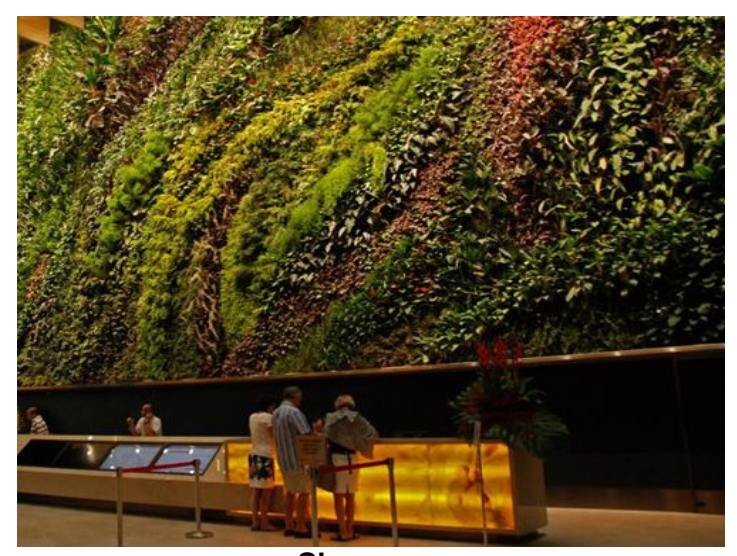

Singapura

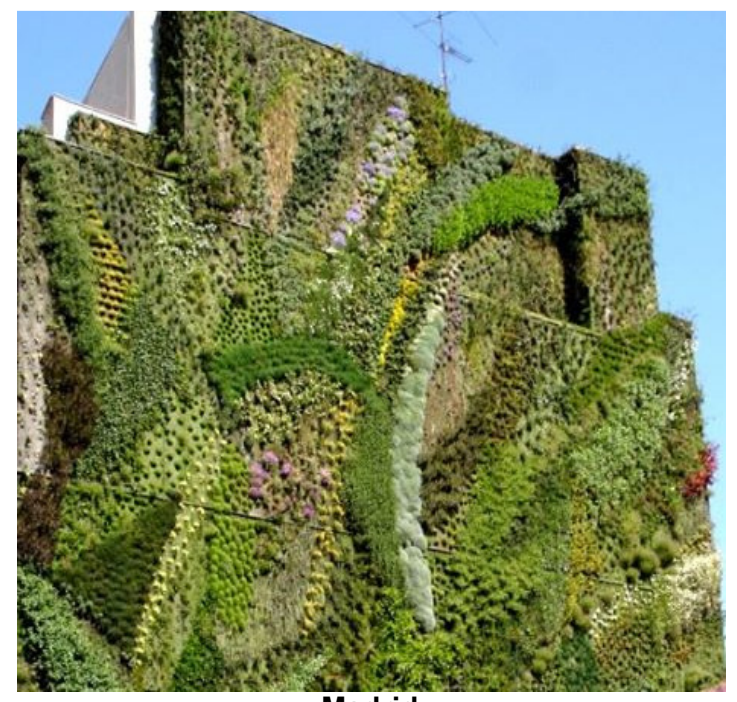

Madrid

Figura 75 - Exemplares de jardins verticais pelo mundo

Fonte: Foto Cidade do México (Daniela Rocco, 2014). As demais fotos: Autor desconhecido.

\section{- Tecnologia QR Code}

O QR Code é um código de barras em 2D que, ao ser scaneado por meio de um aplicativo de celular ou tablet, abre um site com conteúdo pré-determinado por seu criador. Esse código bidimensional foi usado pela primeira vez em 1994 pela empresa japonesa Denso-Wave para identificar peças de carros. Porém foi a partir de 2003 que o QR Code passou a ser amplamente usado por usuários de dispositivos móveis (PRASS, 2011). A Figura 76 mostra dois casos de uso do $Q R$ Code. O primeiro, à direita, é um "menu digital", cujas informações do cardápio aparecem quando se escanea o código ali presente. 
À esquerda, o caso do $Q R$ Code colocado no calçadão do Rio de Janeiro e que serve como fonte de informação fácil para os turistas.
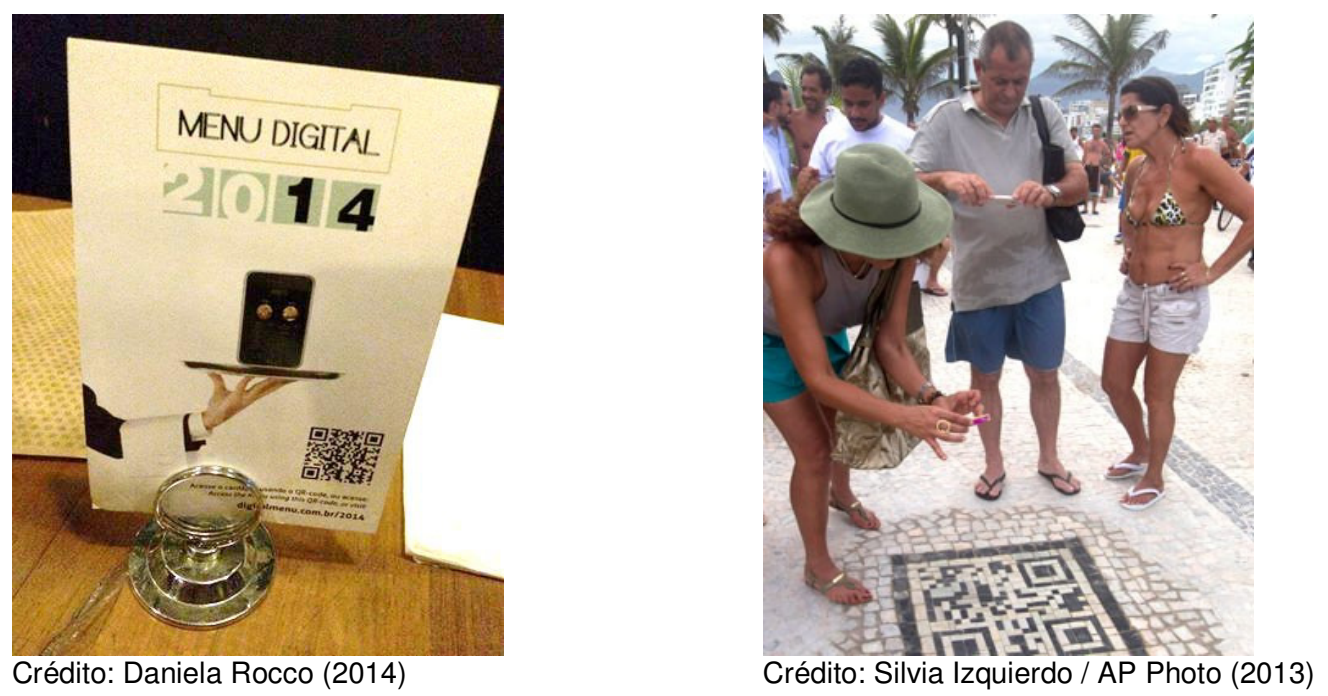

Figura 76 - Exemplos de uso de $Q R$ Code

- Gamification

Este conceito, criado em 2008, mas que ganhou popularidade em 2010, está relacionado ao uso de elementos de design e mecânicas de jogo para melhorar a experiência do usuário com uma marca. Devemos lembrar que a "gameficação" não é jogo e muito menos possui como objetivo principal vender mais produtos/serviços, muito embora esta possa ser uma consequência da boa experiência do usuário que se relaciona com a marca. Além disso, a "gameficação" também pode ser adotada no ambiente interno das empresas, com a finalidade de incentivar o envolvimento e engajamento dos próprios colaboradores (BUHALIS \& AMARANGGANA, 2014).

Como pôde ser visto, o conceito é ainda muito recente, e o uso da "gameficação" no turismo é algo igualmente novo. No entanto, esta é uma forte tendência de mercado no futuro, sobretudo porque turismo é experiência. O grande desafio é saber: Como podemos melhorar essa experiência? Como fidelizar os usuários, fazendo com que eles possam ter uma excelente experiência a partir dos serviços que as empresas prestam? Existem muitas técnicas e estratégias para melhorar a relação usuário-marca por meio da experiência, e a "gameficação" pode ser adotada de várias maneiras na atividade turística. Citamos dois exemplos: 1) Foursquare (não é apenas uma plataforma virtual para fazer check-in virtual quando a pessoa chega a algum estabelecimento, como restaurante, hotel, sorveteria, entre outros. O Foursquare é também uma forma de promover o relacionamento entre os usuários 
de uma mesma empresa/marca, participação de promoções, diário pessoal e compartilhamento de experiências) e 2) Programas de fidelidade de companhias aéreas e de hotéis (sistema de pontuação, relação com a marca e benefícios) (BUHALIS \& AMARANGGANA, 2014).

\section{- Volunturismo: o caso da Tribewanted}

O volunturismo ou "turismo voluntário" é, basicamente, o resultado da combinação de serviço voluntário com a realização de uma viagem (VOLUNTOURISM, 2011), e esta experiência cada vez mais está se disseminando entre as práticas inovadoras de turismo. Caso é o da Tribewanted, uma "tribo" de volunturistas que colaboram financeiramente para o desenvolvimento de comunidades locais sustentáveis e podem, ainda, se hospedar gratuitamente nessas comunidades ou com desconto no valor da diária. A história da Tribewanted começou em 2006, quando Ben Keene, o fundador da empresa, criou uma parceria com uma comunidade local da llha de Vorovoro, no Pacífico. A finalidade foi construir uma comunidade sustentável por um período de três anos com a assessoria de uma plataforma virtual. Os membros dessa plataforma não só colaboraram financeiramente para a construção da comunidade, como também sugeriam ações de sustentabilidade para serem adotadas no local e até votavam quais seriam as lideranças locais. Atualmente a Tribewanted mantém três comunidades: a fazenda Monestevole, na Úmbria (Itália), a praia de John Obey, em Serra Leoa e a praia de Guludo, em Moçambique. O processo de filiação ao Tribewanted ocorre de duas formas: 1) membros vitalícios (de 1.000 a 2.750 euros), dando direito, entre benefícios, a 5 diárias por ano, em qualquer uma das três comunidades e durante períodos festivos e 2) membros que pagam mensalmente uma cota de 10 a 30 euros/mês, dando direito a uma diária por ano. A todos os membros são dados desconto de $20 \%$ nas diárias e atividades desenvolvidas pela empresa (TRIBEWANTED, 2014).

O fundador da Tribewanted, Ben Keene, escreveu um livro sobre o primeiro ano da "tribo", que inclusive foi tema de um documentário do canal BBC. Hoje ele atua com Filippo Bozotti e Amy Carter-James. A filosofia da empresa, que já gerou uma receita de mais de 3 milhões de euros e criou mais de 100 postos de empregos, é reverter os ganhos em projetos locais. Segundo a organização, o turismo é vetor de desenvolvimento social e econômico. Além disso, as viagens só possuem sentido e se tornam memoráveis quando as pessoas se conectam umas com as outras de forma autêntica, e esta é a proposta das três "tribos" (TRIBEWANTED, 2014). 


\title{
- A revolução ponto.com das startups
}

O conceito de startup ainda não está consolidado na literatura, muito embora seja usado há anos nos EUA. De acordo com o SEBRAE (2011), startup

\begin{abstract}
[...] é uma empresa nova, até mesmo embrionária ou ainda em fase de constituição, que conta com projetos promissores, ligados à pesquisa, investigação e desenvolvimento de ideias inovadoras. Por ser jovem e estar implantando uma ideia no mercado, outra característica das startups é possuir risco envolvido no negócio. Mas, apesar disso, são empreendimentos com baixos custos iniciais e são altamente escaláveis, ou seja, possuem uma expectativa de crescimento muito grande quando dão certo $[\ldots]$...
\end{abstract}

Mesmo com a "bolha da internet" (1996-2001) e com a proliferação de empresas "ponto.com" no mundo inteiro, cabe evidenciar que nem toda startup é uma empresa de internet. No entanto, as empresas líderes neste mercado são a Google, Yahoo e Ebay.

Recentemente têm sido criados encontros internacionais de startups, e tais encontros já compõem o calendário de eventos de várias cidades brasileiras. O movimento de startups em Belo Horizonte já é tão latente que até existe um "cluster" dessas empresas no bairro São Pedro, denominado "San Pedro Valley" (http://www.sanpedrovalley.org/new/), que por sua vez faz alusão ao maior cluster de inovação do mundo: o Vale do Silício, localizado na Califórnia (EUA). Além disso, em outras cidades brasileiras existem grandes polos de inovação, como o Porto Digital de Recife (PE) (http://www.portodigital.org/), o Sapiens Parque de Florianópolis (SC) (http://www.sapiensparque.com.br/), o Parque Tecnológico Itaipu do Paraná (PR) (http://www.pti.org.br/) e o Porto Maravilha no Rio de Janeiro (RJ) (http://www.portomaravilha.com.br/), que ainda está em construção.

A Figura 77 mostra como o Sapiens Parque está estruturado e suas principais formas de atuação, inclusive no turismo.

\section{Parque de Inovação}

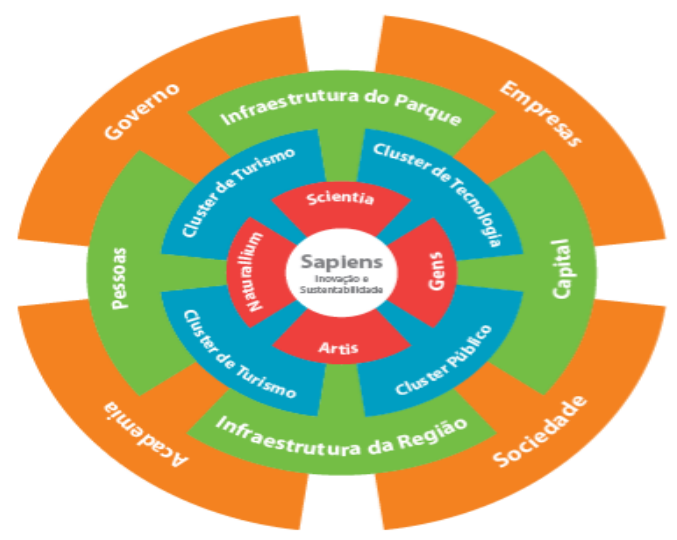




Pilares SAPIENS
Scientia - Unidades
acadêmicas e de P\&D voltadas
para a geração de
conhecimentos cientificos e
tecnológicos avançados.
Artis - Galerias, Escolas,
Museus e outras iniciativas de
Arte e Cultura que contribuam
para agregar o fator humano e
gerar um ambiente criativo
Naturallium - Projetos e
empreendimentos voltados
para a preservação e
sustentabilidade ambiental do
parque e ecossistemas
conectados.
Gens - Ações e programas de
promoção de qualificação,
desenvolvimento regional e
integração positiva do Sapiens
com o entorno da região
com

\section{Clusters SAPIENS}

Tecnologia - Empresas e empreendimentos inovadores, principalmente nas áreas de Energia Sustentável, Economia
Criativa, Life Sciences e TICs

Turismo - Equipamentos e empreendimentos para promoção do turismo de alto valor agregado baseado em eventos, cultura, comércio esportes.

Serviços - Empresas e profissionais em áreas de serviços empresariais (gestão, finanças, jurídico, etc. educação e treinamento, saúde, hospitais, clínicas, etc. Público - Projetos, unidades avançadas e iniciativas avançadas e iniciativas público que venham estimular e apoiar a inovação no Estado

\section{Estrutura SAPIENS}

Infraestrutura Urbanistica Conceito de "laboratório no ambito dos sistemas fisicos, comunicação, edificações sustentáveis, etc. Infraestrutura Região Integração do Parque com os sistemas de infraestrutura urbana da cidade, aeroportos, mobilidade etc.

Pessoas - Programas e ações voltados para a formação ou qualificação de pessoas e para a oferta de qualidade de vida dos profissionais.

Capital - Estratégias e modelos profissionais para atração de investimentos de venture capital, real

estate/imobiliário e politicas de incentivo a região.

\section{Atores SAPIENS}

Governo - Pessoas e órgãos do governo nos âmbitos, ederal, estadual e municipal nos segmentos executivo, legislativo e judiciário.

Empresas - Empresas que deverão se instalar e operar no Sapiens, empresas de investimento e construção, parceiros de negócios, etc.

Academia - Universidades, centros de P\&D, pesquisadores e outras instituições geradoras de conhecimentos.

Sociedade - Entidades organizadas da sociedade civil com interesse socintade com interesse em interagir implantar no parque.

Figura 77 - Parque de Inovação (Sapiens)

Fonte: http://www.sapiensparque.com.br/

\section{- Turismo espacial}

O pequeno povoado de sete mil habitantes em Truth or Consequences, no estado do Novo México, tem se preparado para ser o centro mundial do turismo espacial, onde abrigará o Porto Espacial América (America Spaceport). Esta empreitada é do grupo Virgin America, cujo proprietário, o britânico Richard Branson, é um dos homens mais inovadores do mundo em termos de aviação (GARCíA, 2014). Em 2015 a Virgin Galactic enviará um grupo de multimilionários à estratosfera por um valor de US\$250.000 por pessoa (VIRGIN GALACTIC, 2014). A Figura 78 mostra à esquerda a imagem da sala de controle do Porto Espacial e à direita a imagem do SpaceShipTwo, a aeronave que levará os "turistas espaciais".

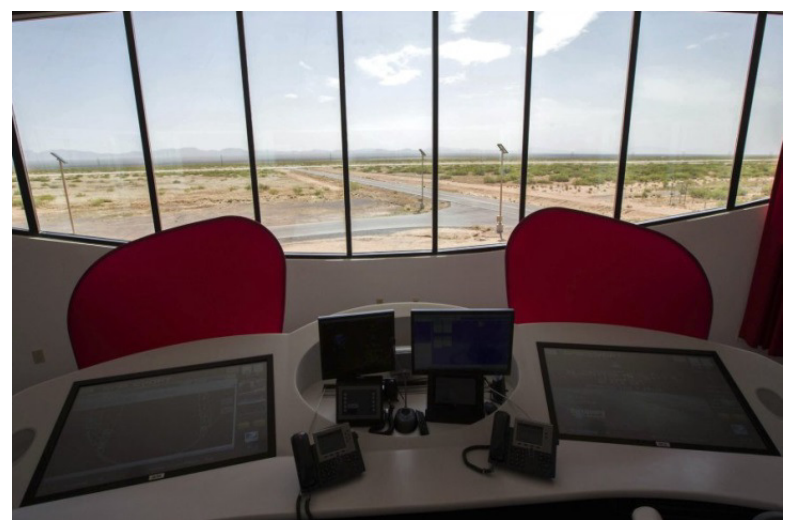

Sala de Controle do Porto Espacial (1)

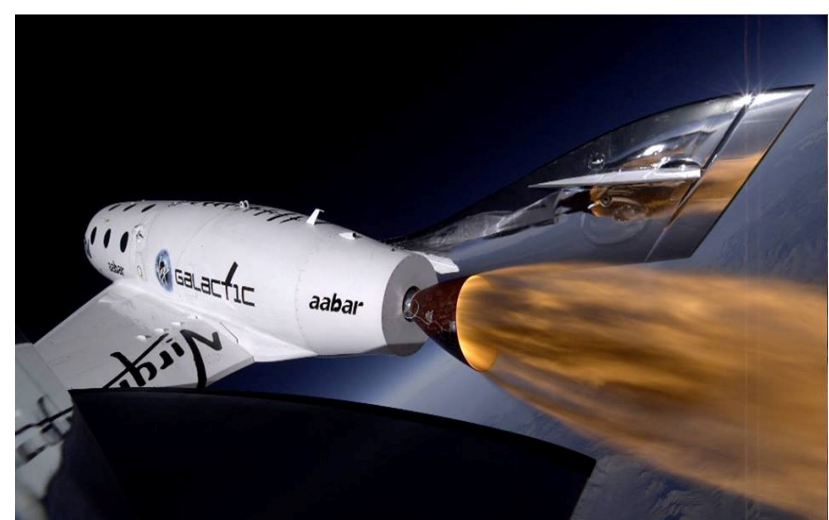

Virgin Galactic (2)

Figura 78 - Turismo espacial

Fonte: Lucy Nicholson - Reuters (1) e Virgin Galactic (2) 


\section{- Turismo virtual}

Como foi exposto, a inovação não é só tecnologia, porém, é um fator de extrema relevância para a competitividade de diversos destinos turísticos. Sabemos que a tomada de decisão sobre o futuro se planeja hoje, e o limite é decidir se seremos pessoas-turistasusuários cyberborg ou autômatos inteligentes. O documentário "Visões do futuro: a revolução da inteligência", apresentado pelo renomado físico Michio Kaku, nos convida a refletir: seremos no futuro "robôs com mais componentes biológicos ou pessoas com mais componentes eletrônicos?" Mais ainda: teremos no futuro a possibilidade de criar novos mundos, recriar nossa mente, ter o computador como essência de nossas vidas, enfim, ter o domínio da inteligência como nunca na história da humanidade. Por meio da inteligência artificial poderemos ter em nossas roupas computadores que vão monitorar nossa saúde, como se tivéssemos um médico 24 horas/dia e que emitirão comandos quando ficarmos doentes. Atualmente, conforme o documentário, já existem implantes cerebrais para tratar alguns problemas de saúde, e acredita-se que no futuro teremos um aperfeiçoamento dos nossos cérebros por meio de nano chips de memória, quase invisíveis. É a tecnologia da informação que se transportará das máquinas para dentro de nossos próprios corpos.

Neste contexto, o que dizer do "turismo virtual"? Cada vez mais isso tem se tornado realidade, muito embora esse tema precise de uma longa reflexão. De todo modo, a respeito da tecnologia tridimensional, Kaku dá o exemplo da teleimersão. Em tempo real as imagens de nossos corpos podem estar em qualquer lugar do mundo. Por sua vez, isto pode reduzir viagens aéreas com fins de negócios, cujos acordos certamente serão realizados no mundo virtual. Este não é um futuro muito distante. O documentário revela que mais de 30 milhões de pessoas no mundo passam em média 20h/semana em mundos virtuais. Um exemplo é o Second Life, jogo online de autoinvenção infinita. Cada pessoa/jogador tem o(s) seu(s) avatar(es), e nessa "brincadeira" são mais de 5 milhões de residentes apenas no Second Life. Inclusive, existem negócios de verdade, e a pessoa pode comprar, com seu avatar, produtos que chegam ao mundo real (basta ter cartão de crédito e dinheiro). É evidente que as implicações sociais sobre isso são preocupantes na dicotomia redes sociais virtuais versus redes sociais reais. Afinal, como será viver no futuro (e até mesmo no presente) com múltiplas personalidades, identidades? 
PRÁTICAS DE INOVAÇÃO PARA A SUSTENTABILIDADE EM DESTINOS TURÍSTICOS INTERNACIONAIS: O QUE O BRASIL PODE APRENDER E ADAPTAR À REALIDADE DO PAÍS?

Nesta seção apresentamos algumas experiências pontuais de inovação para a sustentabilidade no turismo da América Latina (com exceção do Brasil), Europa, Ásia e Oceania.

\section{AMÉRICA LATINA}

\section{- CANADÁ}

Na cidade de Vancouver $90 \%$ da energia é produzida através de ondas marítimas, vento, painéis solares e hidrelétricas (TEODÓSIO, 2014). Em Cap-Egmont, na província da Ilha do Príncipe Eduardo, o canadense Nernard Rudolfsky criou uma vila reciclada, cujas casas são compostas, no total, por mais de 25 mil garrafas de vidro. Esta vila recebe diversos turistas e é administrada pela filha de Rudolfsky. A Figura 79 apresenta a foto de uma das casas da vila (PEGN, 2011).
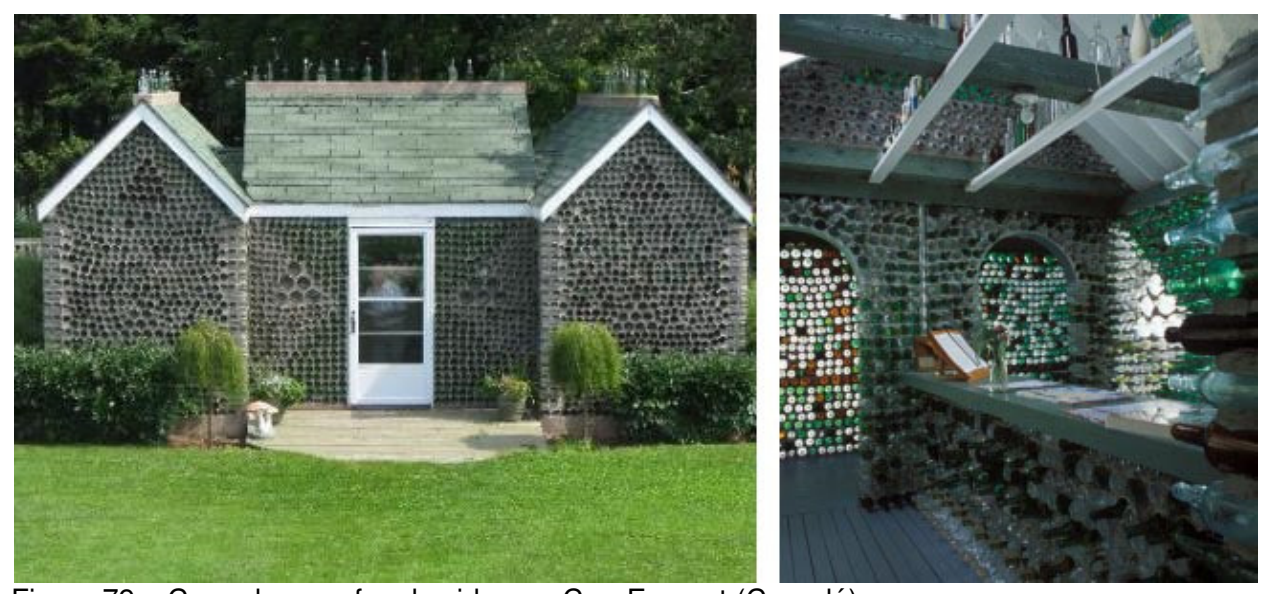

Figura 79 - Casa de garrafas de vidro em Cap-Egmont (Canadá) Crédito: Autor desconhecido Fonte: PEGN (2011)

\section{- ESTADOS UNIDOS}

\section{- Orlando}

O Legoland (vide Figura 80), situado na Flórida, é o único parque temático do mundo que possui atração alimentada por energia solar: o Imagination Zone. No dia 23 de abril de 2014, dedicado ao Dia da Terra, a energia de todo o parque foi só a solar (WANG, 2014). 


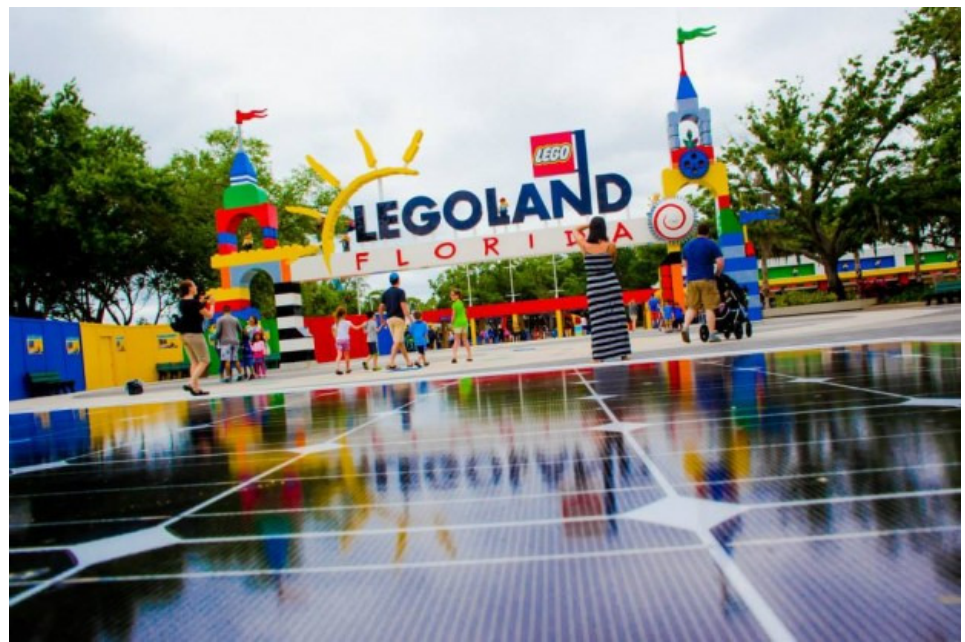

Figura 80 - Uso de energia solar no Legoland (EUA)

Crédito: Autor desconhecido

Fonte: Wang (2014)

\section{Box 5 - Inovações tecnológicas para estacionamento de carros}

Do ponto de vista da inovação tecnológica, esse estacionamento é bastante prático, uma vez que oferece conforto, facilidade e grande disponibilidade de vagas. Com ele os condutores de carros deixariam de circular menos na cidade em busca de vagas. Isso, consequentemente, gera um efeito positivo, sobretudo na diminuição de $\mathrm{CO}_{2}$ emitido. Embora tecnologias como essas da foto sejam interessantes e bemvindas no curto prazo, cristalizam no longo prazo a cultura do ir e vir com o automóvel. No turismo, o maior responsável por emissão de $\mathrm{CO}_{2}$ não são os aviões, e sim os carros particulares.

Não obstante, várias cidades do mundo têm dado maior prioridade às ciclovias e demais soluções relacionadas ao uso da bicicleta como alternativa viável de mobilidade urbana. $\mathrm{O}$ NY Times divulgou em 2012 a tendência crescente entre os jovens da cidade que preferem comprar uma bicicleta, e não um carro. Amsterdam cada vez mais tem se tornado um exemplo clássico nessa direção.

Fonte: Chozick (2012)

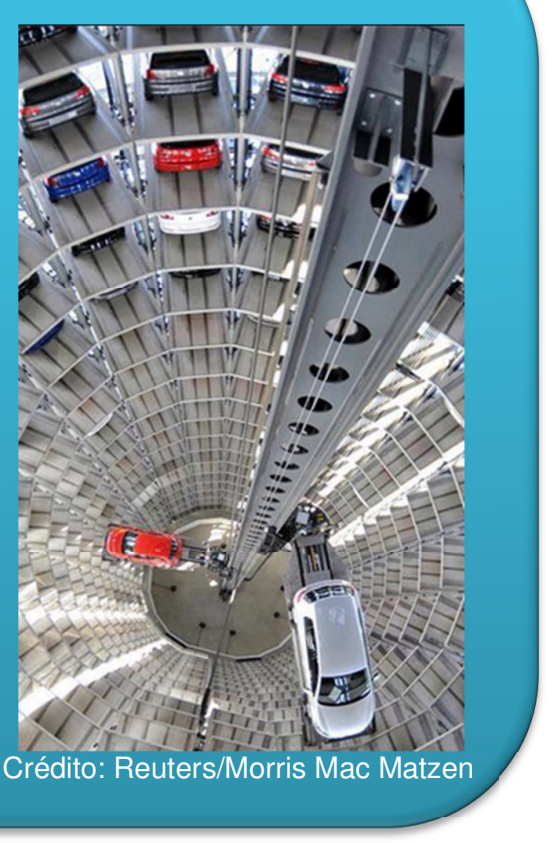

\section{- MÉXICO}

$\mathrm{Na}$ década de 1940 o México vivenciava grandes mudanças econômicas. Surgiu, então, a Câmara Nacional da Indústria de Transformação (CANACINTRA) (http://www.canacintra.org.mx/principal/), como forma de agrupar os principais representantes do setor industrial do País. Hoje a Canacintra possui 80 delegações no 
México, divididas por sua vez em 15 regiões, cinco escritórios na Cidade do México e uma sede nacional. Trabalha-se com 13 setores industriais e 102 ramos especializados. A missão institucional é:

Representar, defender e promover, no âmbito do quadro legal e dos valores expressos na Carta da Terra, os interesses dos sócios e do setor industrial do México, influenciando de forma eficaz no desenvolvimento, sustentabilidade, inovação, competitividade e integração das indústrias, setores e regiões através de serviços de alta qualidade articulados pelo Centro Integral de Serviços (CANACINTRA, 2014, tradução e grifo nosso).

No âmbito do turismo, a Canacintra cria e executa projetos de desenvolvimento urbano integral e sustentável, desenvolvimento ecoturístico (Tao Gardens) e complexos turísticos (parques aquáticos e hotéis).

\section{- costa RICA}

$\mathrm{Na}$ década de 1990 a Costa Rica se posicionou como o primeiro destino de ecoturismo do mundo e desde então diversos setores têm incentivado a implementação de medidas sustentáveis. Um exemplo é a criação do sistema de Certificação para a Sustentabilidade Turística (CST) do Instituto Costarricense de Turismo (ICT) na inovação de serviços, processos, mercado e organização (CINVE, 2013).

Um exemplo bastante inovador que também vale destacar é a criação, em 2013, da primeira trilha $100 \%$ acessível do País. Ela está localizada no Parque Nacional Carara, possui 1,2 km de extensão (parte foi construída com concreto permeável para absorver a água), placas de informação sobre fauna e flora com QR Codes que levam a vídeos, esculturas de barro de animais para que deficientes visuais possam tocá-los (feitas pelos estudantes da Universidade Nacional) e mapa da trilha em braile. Algumas dessas ações são mostradas nas fotos da Figura 81 . Mais de 400 mil pessoas na Costa Rica possuem alguma deficiência, e a implementação dessa trilha foi resultado de uma iniciativa entre a comunidade local, empresários e sistema nacional de conservação. A campanha "Um parque para todos", que foi veiculada na mídia, também contribuiu financeiramente para que a trilha fosse adaptada para receber quaisquer pessoas (PARQUE PARA TODOS, 2013). 


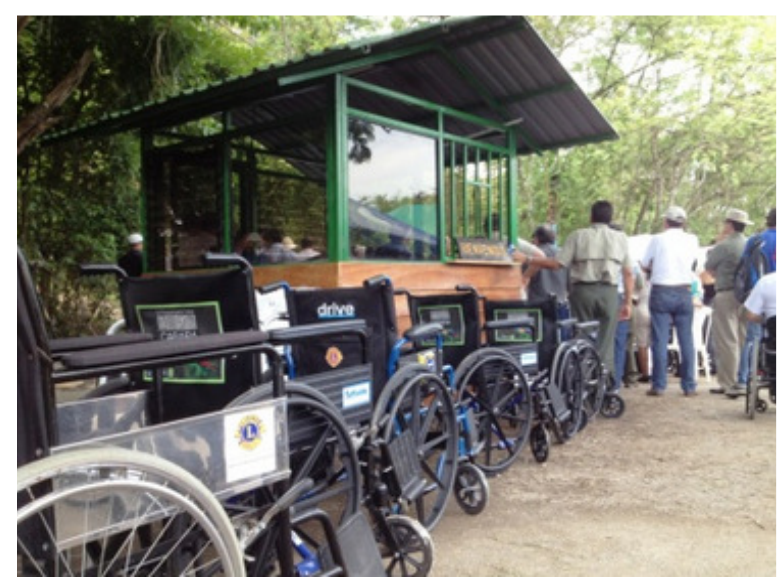

Disponibilização de cadeiras de roda para uso no local (exemplo: pessoas com mobilidade reduzida como idosos)

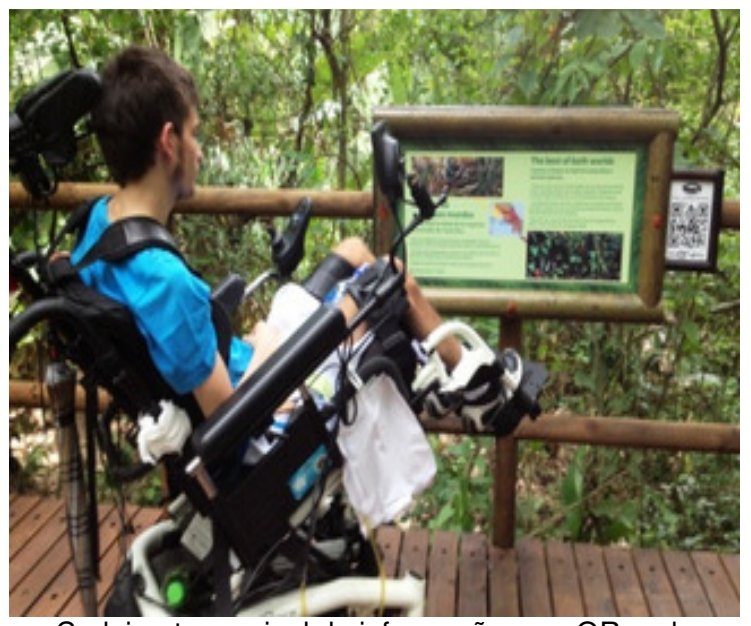

Cadeirante e painel de informação com QR-code

Figura 81 - Inovações do Parque Nacional Carara (Costa Rica)

Fonte: VALDESOL S. A. (2013)

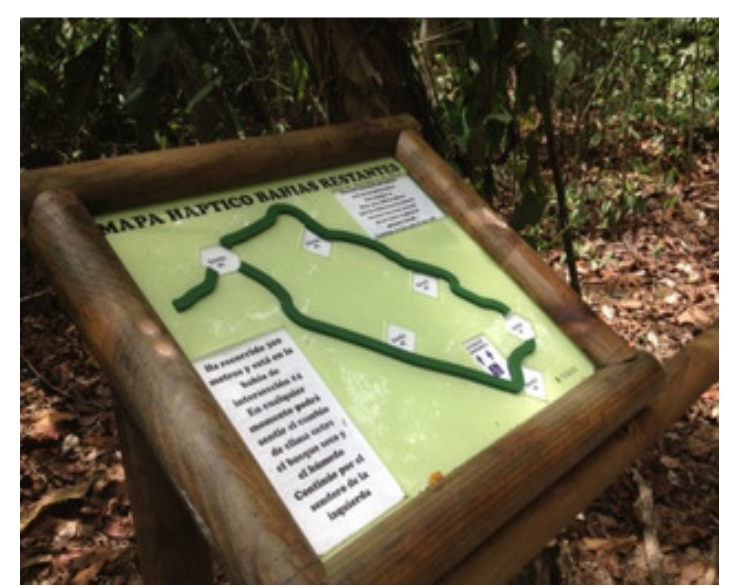

Mapa da trilha em braile

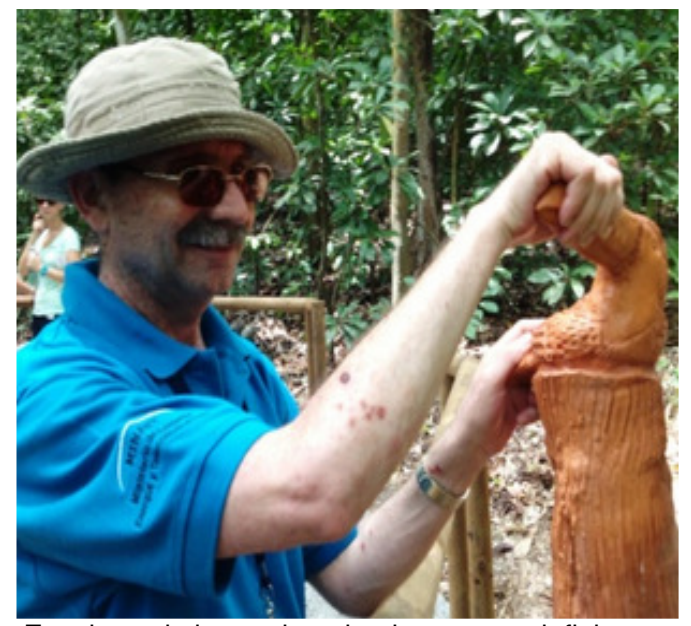

Escultura de barro de animal para que deficientes visuais possam tocá-lo e identificar a espécie

\section{- COLÔMBIA}

\section{- Medellín}

De cidade mais violenta do mundo em 1991 a cidade premiada como a mais inovadora do mundo em 2013 (BBC BRASIL, 2013). Esta é Medellín, que adota um conceito inovador de "publicness", sobretudo por meio de incentivos à cultura e educação. São muitos exemplos, como: criação de bibliotecas-parque, centros culturais, casas de leitura, entre outros (vide Figura 82). Com tantas transformações, o turismo tem aumentado bastante na cidade e está vinculado à lógica da economia criativa e da inovação social (MELGUIZO, 2011). 


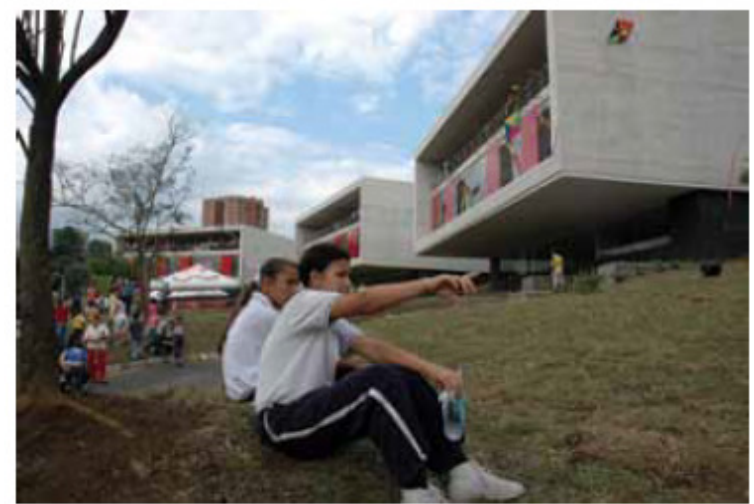

Parque Biblioteca La Ladera

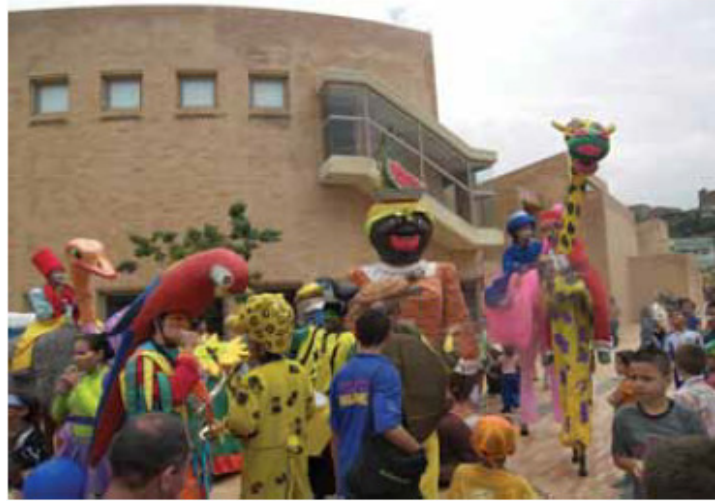

Centro Cultural (antigo lixão)

Figura 82 - Inovações sociais em Medellín (Colômbia)

Fonte: Melguizo (2011)

- CHILE

\section{- Santiago}

Em 2014 a empresa chilena Monte Alto Renovable foi considerada a $5^{\underline{a}}$ mais inovadora da América do Sul pela Fast Company. Esta empresa

[...] ajuda hotéis e comunidades a adotarem serviços de energia de biomassa. Ela administra gastos iniciais com a energia renovável, financia compras de equipamentos, instalação e manutenção em troca de contratos de abastecimento de combustível de longo prazo. A companhia lançou o seu primeiro projeto comercial no ano passado e espera substituir aproximadamente 1 milhão de quilowatts-hora (Kwh) de energia produzida por diesel por energia de biomassa, o que significa a não emissão de até 8 mil toneladas de dióxido de carbono ao ano e uma economia de $\mathbf{5 0}$ mil dólares com combustíveis anualmente (MELO, 2014, grifo nosso).

Vale destacar também a vinícola Concha y Toro, que é a maior do País, recebe diversos visitantes anualmente e é a primeira vinícola do mundo a aderir o "May Day Network Chile", que é uma iniciativa internacional que envolve mais de 1.500 empresas com o compromisso de combater as mudanças climáticas por meio de ações concretas de diminuição das emissões de $\mathrm{CO}_{2}$. Além disso, a Cono Sur (que pertence à Concha y Toro) foi considera em 2002 como a primeira vinícola da América do Sul que obteve dupla certificação: ISO 9.001 (gestão da qualidade) e ISO 14.001 (gestão ambiental) (OLMOS, 2012; CONCHA Y TORO, 2014). 


\section{- ARGENTINA}

\section{- Buenos Aires}

Um instituto de pesquisa que se destaca na cidade portenha na área de inovação, sustentabilidade e turismo é o Centro de Estudos de Hospitalidade Sustentável. Sua missão é dar assessoria, com respaldo acadêmico, a empresas turísticas que desejam se tornar sustentáveis, bem como gerar conceitos e modelos de negócios inovadores (CENTRO DE ESTUDIOS EN HOTELERIA SUSTENTABLE, 2014).

\section{EUROPA}

Como já foi exposto, de acordo com a Comissão Europeia (Meio Ambiente), atualmente dois em cada três europeus vivem em cidades (EUROPEAN COMMISSION, 2014a). As áreas urbanas concentram a maior parte dos desafios ambientais que nossa sociedade enfrenta, e os esforços para unir compromisso e inovação para resolvê-los são grandes desafios. Neste sentido, o Prêmio Capital Verde da Europa (European Green Capital) foi concebido para promover e premiar esses esforços, bem como estimular as autoridades locais a criarem ações mais comprometidas com o meio ambiente, facilitando, por sua vez, o intercâmbio das melhores práticas entre as cidades europeias. Em 2012 a cidade de Vitoria (País Basco, Espanha) ganhou o prêmio, em 2013 foi a cidade de Nantes (França) e em 2014 foi Copenhagen (Dinamarca).

Outra premiação da Comissão Europeia que merece destaque é o concurso Capital Europeia da Inovação ou iCapital. Esse concurso, que foi lançado em 2013, objetiva premiar aquela cidade que tenha a melhor estratégia de "ecossistema de inovação", em que pese a conexão entre organizações públicas e privadas, centros de pesquisas e cidadãos a partir de quatro premissas: inovação, inspiração, integração e interação. Na primeira edição do prêmio iCapital, cuja cerimônia de entrega ocorreu em março de 2014, candidataram-se 58 cidades dos Estados-Membros europeus. Barcelona (Espanha) venceu "por introduzir a utilização das novas tecnologias para aproximar a cidade dos cidadãos". Segundo o relatório da premiação, desde 2011 a prefeitura de Barcelona tem posto em prática o projeto "Barcelona, a cidade das pessoas" (EUROPEAN COMMISSION, 2014b). Nele, está prevista a inserção de novas tecnologias para aumentar o crescimento econômico e bem-estar coletivo por meio de cinco ações, conforme estão expostas na Figura 83 a seguir. 


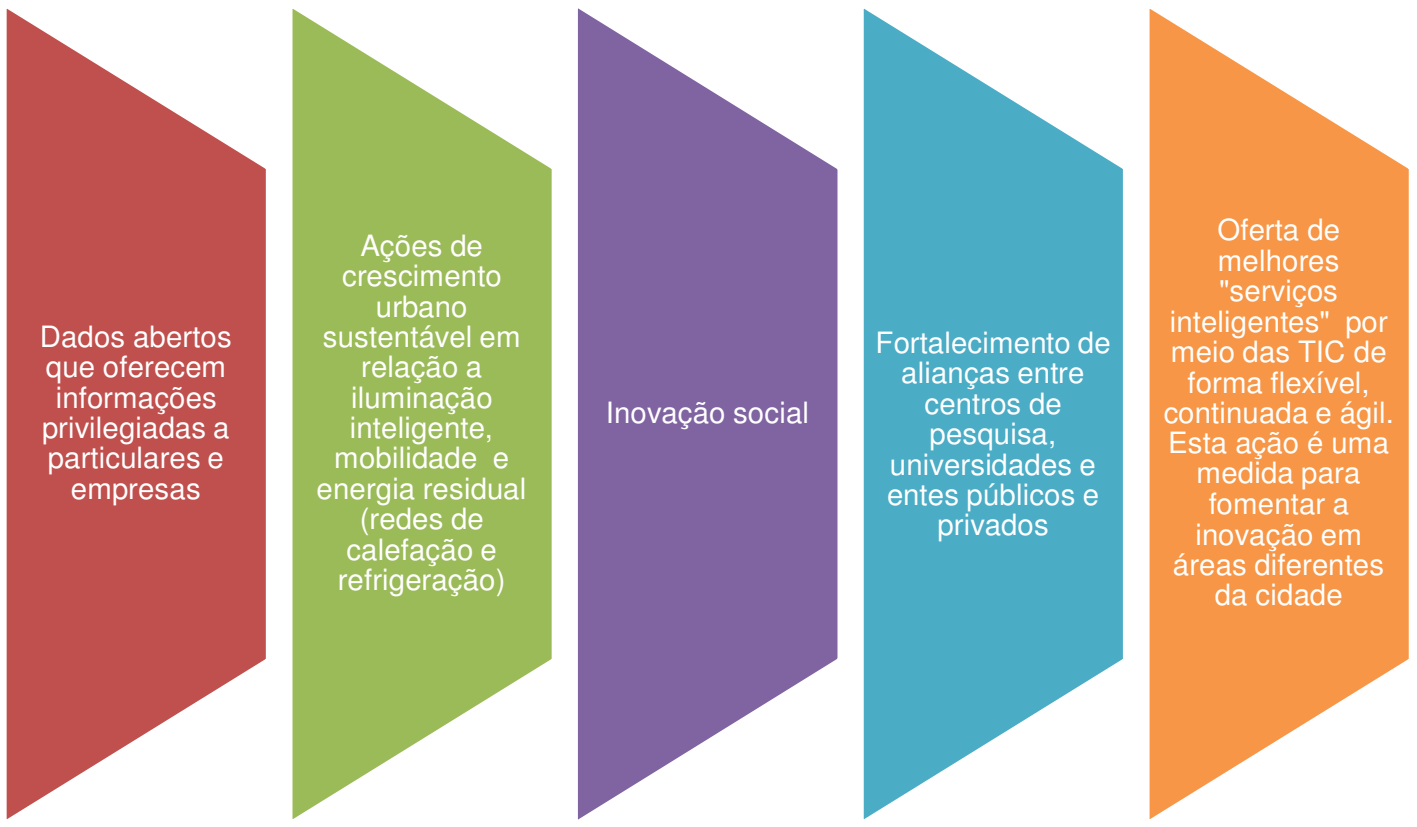

Figura 83 - Inovações do projeto "Barcelona, a cidade das pessoas"

Fonte: Elaborado por Daniela Rocco (2014) com base em EUROPEAN COMMISSION (2014c).

Finalmente, merece destaque o "Prêmio OMT de Excelência e Inovação no Turismo". Todos os anos a Organização Mundial do Turismo (OMT) realiza essa premiação com o intuito de reconhecer e evidenciar entre as Américas, Europa, Ásia e Pacífico, África e Oriente médio, personalidades, empresas e associações que promovem a inovação e a respectiva aplicação de conhecimento no turismo. Esta iniciativa aporta os avanços mais recentes na área, bem como estimula efeitos transversais em termos sociais e de governança. Em janeiro de 2014 foram anunciados os ganhadores do Prêmio em relação a quatro categorias e respectivas ações desenvolvidas no ano de 2013 (vide Figura 84). São elas:

- Inovação em Políticas Públicas e Governança: Projeto de turismo responsável em Kumarakom, Departamento de Turismo, Governodo Kerala, Índia;

- Inovação nas Empresas: Arromanches 1944, Biplan (França);

- Inovação nas Organizações não governamentais: Da caridade ao empreendedorismo social, Soluções e Tecnologias Ecoturísticas de Borneo (BEST), Malásia;

- Inovação em Pesquisa e Tecnologia: Portal 3D AR Visual, DSP Studio \& Momentum Studio, Croácia. 


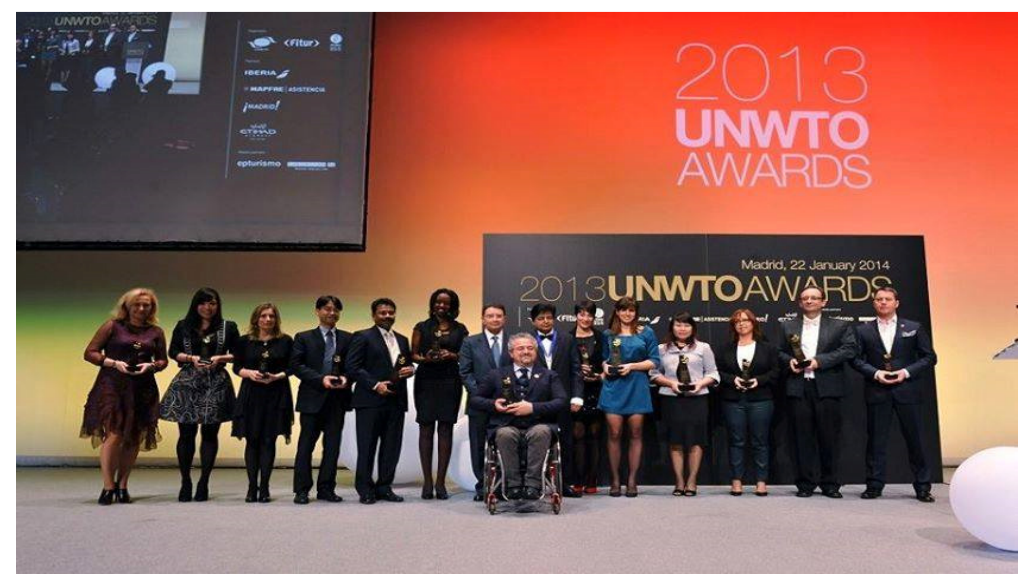

Figura 84 - Cerimônia de Premiação do Prêmio Ulises de Inovação da OMT Crédito: OMT (2014)

\section{- REINO UNIDO}

\section{- Cambridge}

O Starpath (do inglês, "caminho das estrelas") é um spray de revestimento de pavimentos criado pela empresa britânica Pro-teq (http://www.proteqsurfacing.com/pathways.html) capaz de absorver a energia dos raios ultravioleta no período do dia e tarde e liberá-los a noite (vide Figura 85). Essa inovação está sendo testada em uma trilha de 150 metros do Parque Christ's Pieces, em Cambridge (Reino Unido). Assim, há uma forte tendência para que haja redução dos gastos com energia e, consequentemente, diminuição de custos com iluminação pública (VINCENT, 2013).

Essa inovação não substitui a iluminação convencional, no entanto, contribui na redução de energia elétrica e deixa os parques urbanos mais bonitos e atraentes tanto para moradores quanto visitantes.

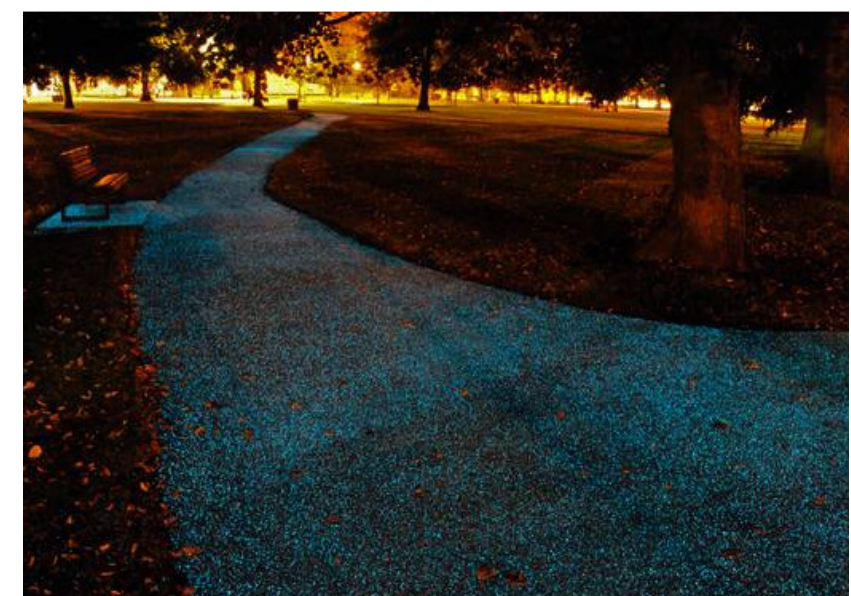

Figura 85 - Starpath Parque Christ's Pieces, em Cambridge (Reino Unido) Crédito: Pro-teq (2014) 


\section{- Londres}

Em 2013 foi proposto na prefeitura de Londres um grande projeto com princípio de inovação para a sustentabilidade: o calor gerado no metrô da cidade por passageiros e máquinas será revertido em energia para aquecer as residências no inverno. O ganho, além da economia de energia, é reduzir em $60 \%$ as emissões de $\mathrm{CO}_{2}$ da cidade. O sistema criado desviará o calor de uma área de ventilação para uma rede térmica, que por sua vez estará interligada a 500 casas (ECODESENVOLVIMENTO, 2013). Na lógica do turismo, se entre os passageiros do metrô existem turistas, e se realmente haverá redução nas emissões de $\mathrm{CO}_{2}$, a cidade ficará mais agradável para eles também em termos de qualidade do ar.

\section{- AMSTERDÃ}

Amsterdã é conhecida mundialmente como a "capital das bicicletas". O governo estima que a cidade tenha 800 habitantes e 880 mil bicicletas (quatro vezes a quantidade de carros). O uso de bicicleta aumentou $40 \%$ nas duas últimas décadas e hoje a circulação urbana com carro corresponde a $22 \%$ e com bicicleta $32 \%$. O uso do veículo de duas rodas é tão intenso que os cidadãos enfrentam problemas de lotação nos bicicletários, tal como mostra na Figura 86 (TAGLIABUE, 2013).

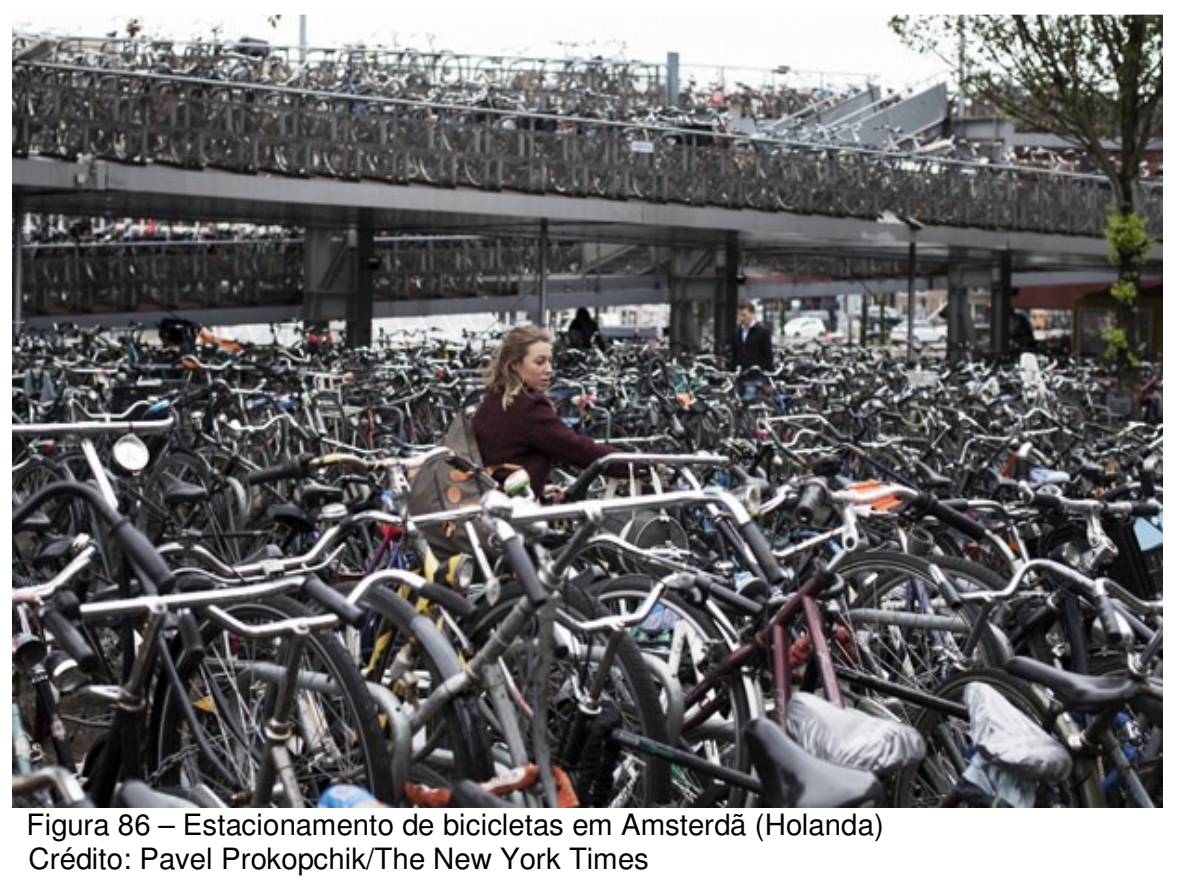




\section{- portugal}

- Porto

A Associação Bandeira Azul da Europa (ABAE) é uma Organização não Governamental de Ambiente (ONGA) sem fins lucrativos, cuja atuação é na área de educação para o desenvolvimento sustentável. Em 1987 foi criado o Programa Bandeira Azul e desde então ele colabora para a proteção do ambiente marinho e melhor conservação das praias.

A Figura 87 a seguir mostra a presença da Bandeira Azul na praia dos Carneiros da cidade de Porto. A presença de tal bandeira é indicador também de praia limpa, presença de contêineres de coleta seletiva, informação disponível sobre a qualidade da água e banheiro feminino e masculino.

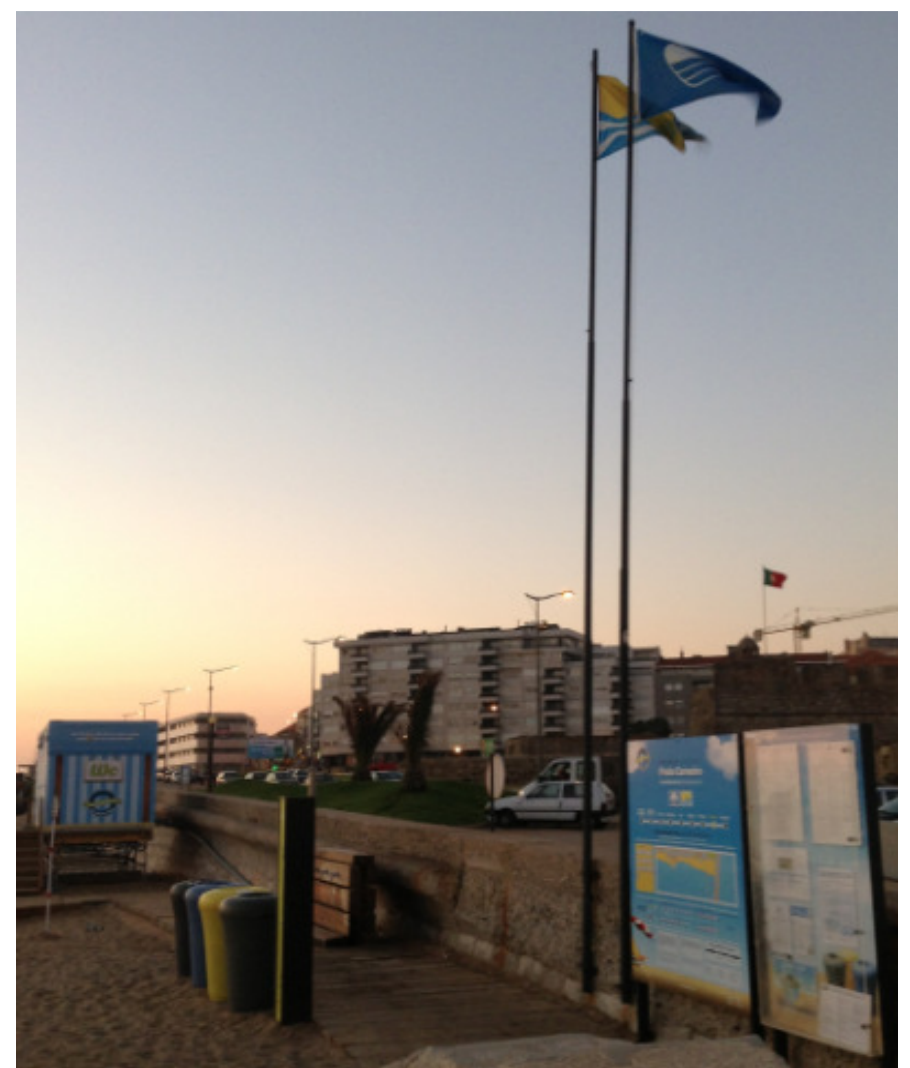

Figura 87 - Praia dos Carneiros em Porto (Portugal) com a Bandeira Azul Crédito: Daniela Rocco (2013).

Outra iniciativa inovadora na cidade é a produção de um artesanato peculiar. Como se sabe, os vinhos do Porto são mundialmente conhecidos, e considerando que sempre 
existem sobras de cortiça para a fabricação da rolha, estas são usadas para a criação de bolsas, carteiras e objetos de decoração, tal como mostra a Figura 88.

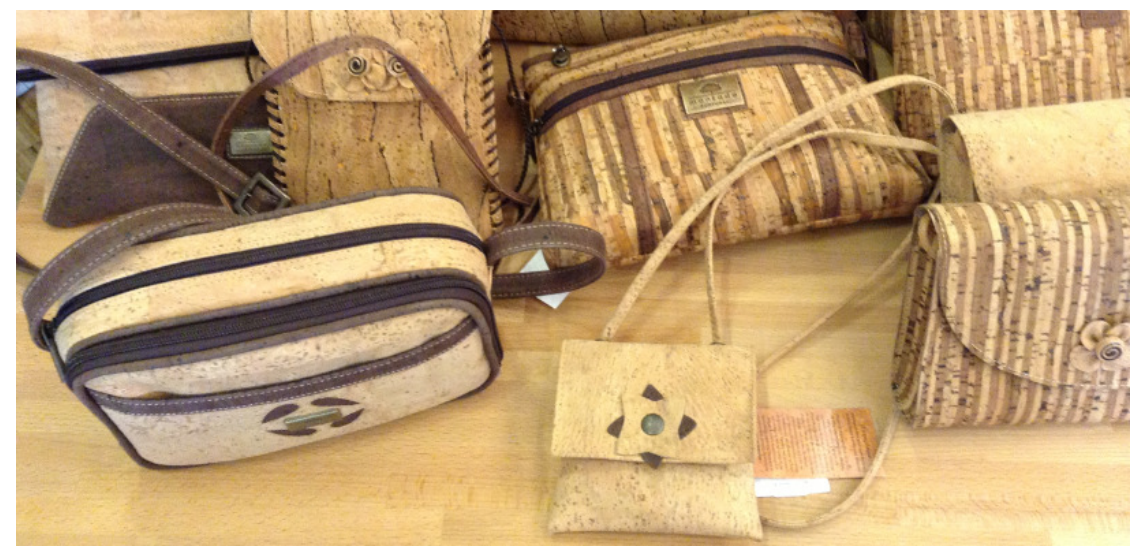

Figura 88 - Artesanato feito de cortiça em Porto (Portugal) Crédito: Daniela Rocco (2013).

\section{- Lisboa}

A Figura 89 apresenta um caso de inovação social na cidade por meio da combinação entre o convívio de pessoas e aproximação com a natureza.

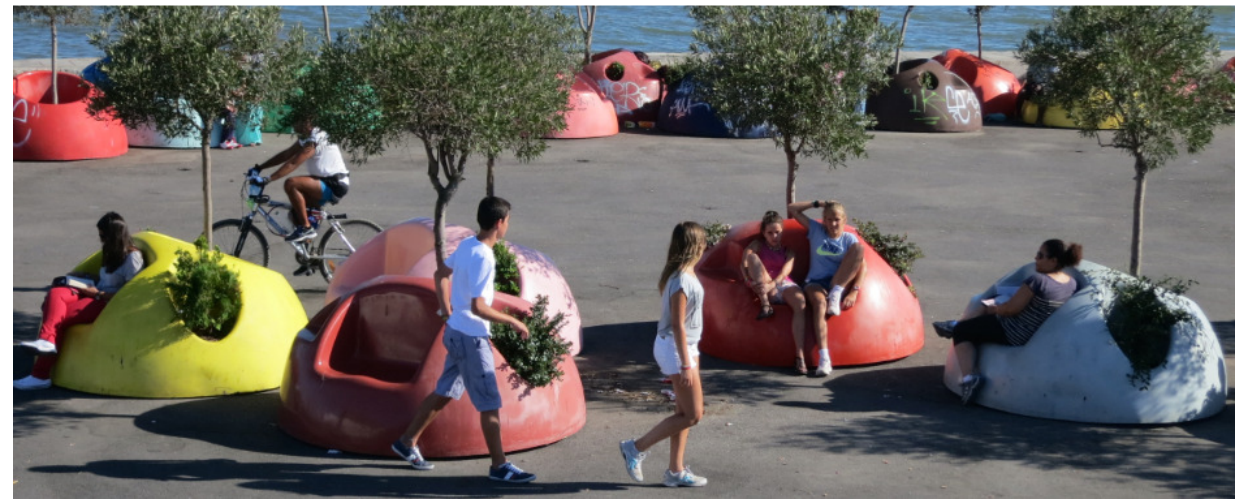

Figura 89 - Inovação social em Lisboa (Portugal)

Crédito: Daniela Rocco (2013).

\section{- ESPANHA}

Na Europa em geral existe um compromisso com a sustentabilidade, e isto consta em agendas públicas locais de governo, ações da iniciativa privada e no Programa Horizonte 2020 da Comissão Europeia (http://ec.europa.eu/programmes/horizon2020/). 
A Figura 90 mostra ônibus de quatro cidades espanholas que são movidos a gás natural. Inclusive, as próprias companhias de transporte público enfatizam que seus ônibus são "limpos e silenciosos". Esta também é uma tendência que cada vez mais se encontra nas grandes cidades do mundo.

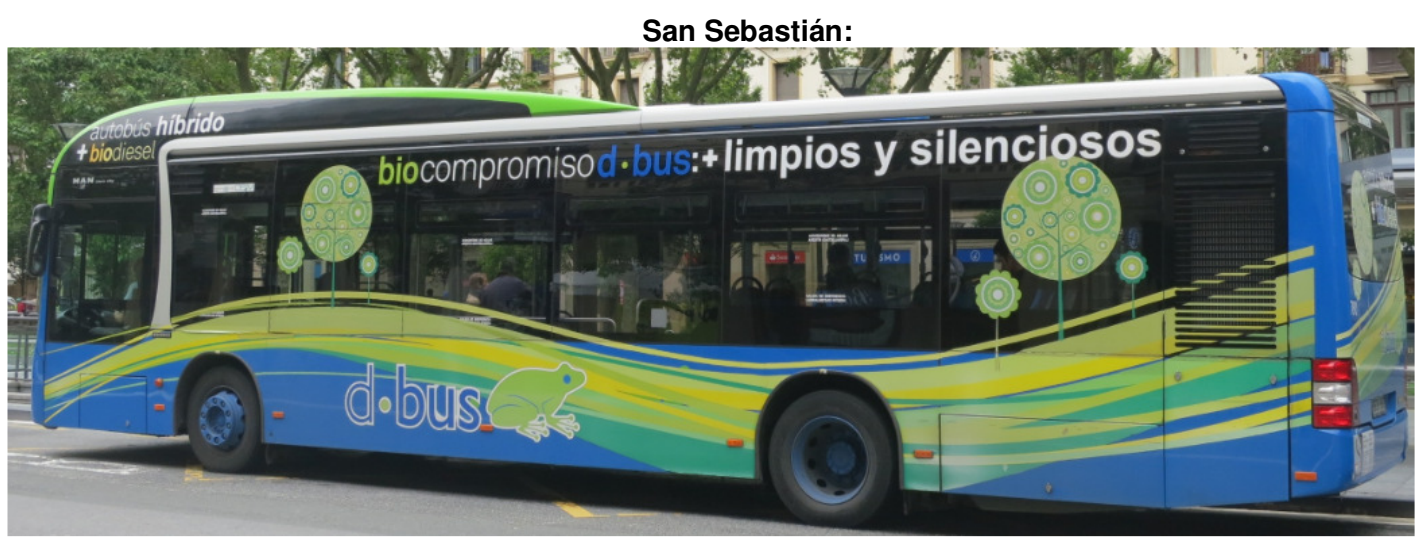

Toledo:
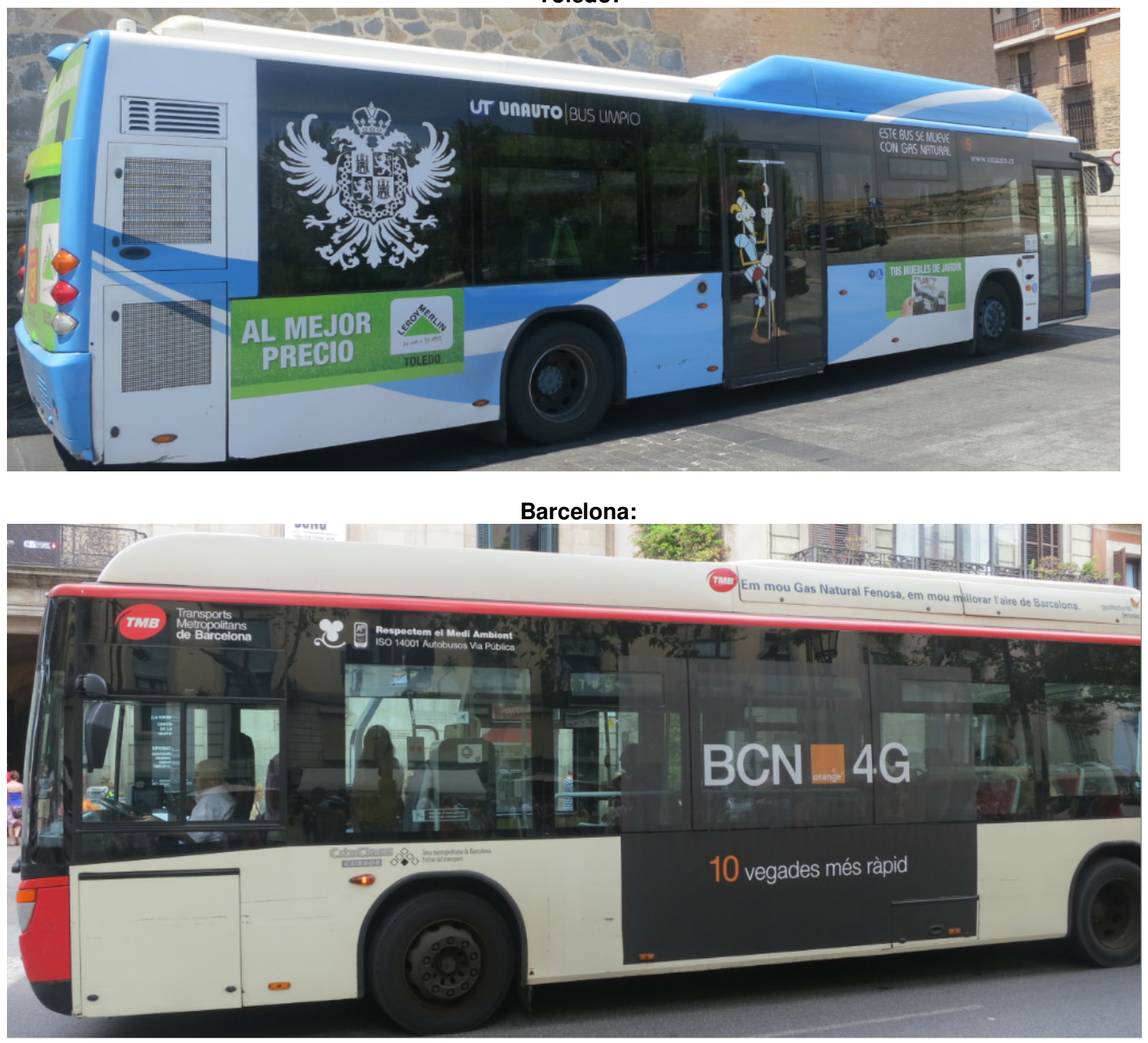
Sevilha:

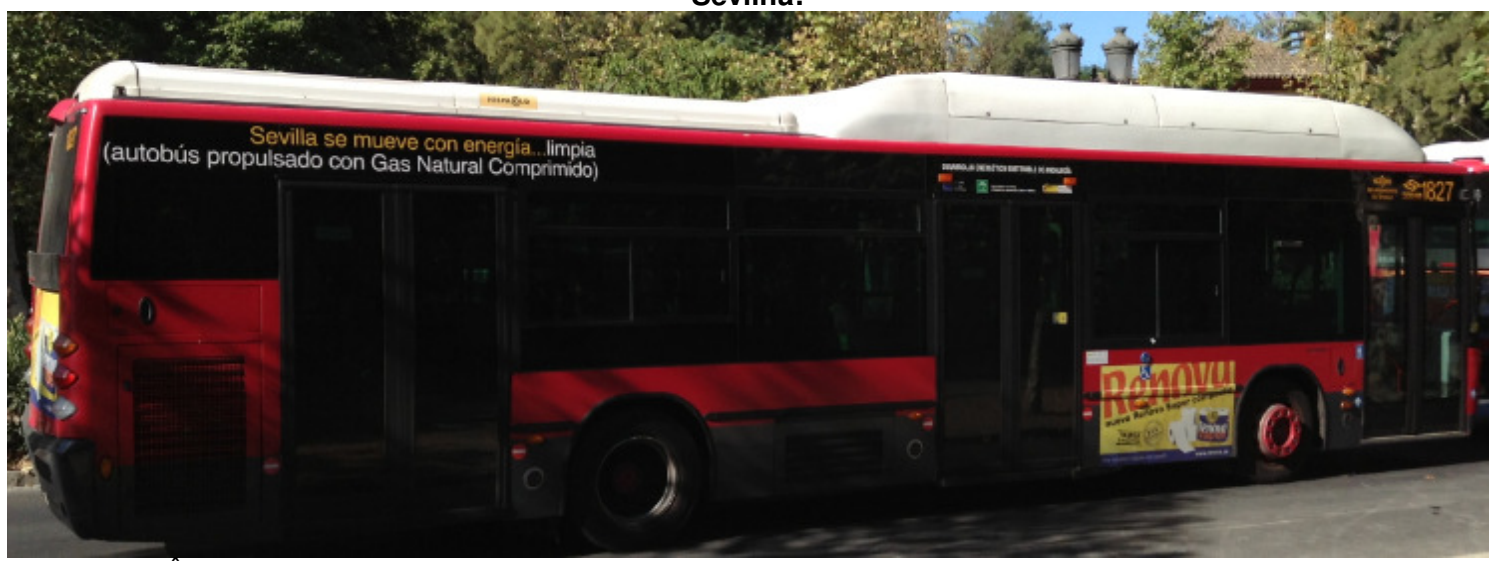

Figura 90 - Ônibus silenciosos e que se movem com gás natural na Espanha Crédito: Daniela Rocco (2013).

\section{- Bilbao}

No Aeroporto Internacional de Bilbao (Espanha) é possível encontrar pontos de emergência como esse da Figura 91 abaixo com um equipamento que pode salvar vidas em casos de paradas cardíacas: o desfibrilador. Infelizmente, em função da crise econômica, a equipe médica do Aeroporto não existe mais, por isso foram colocados esses pontos, com os contatos de emergência anexados a eles. O ideal seria manter tais equipamentos e profissionais da saúde sempre in loco, de toda forma, é uma medida inovadora para atender casos emergenciais.

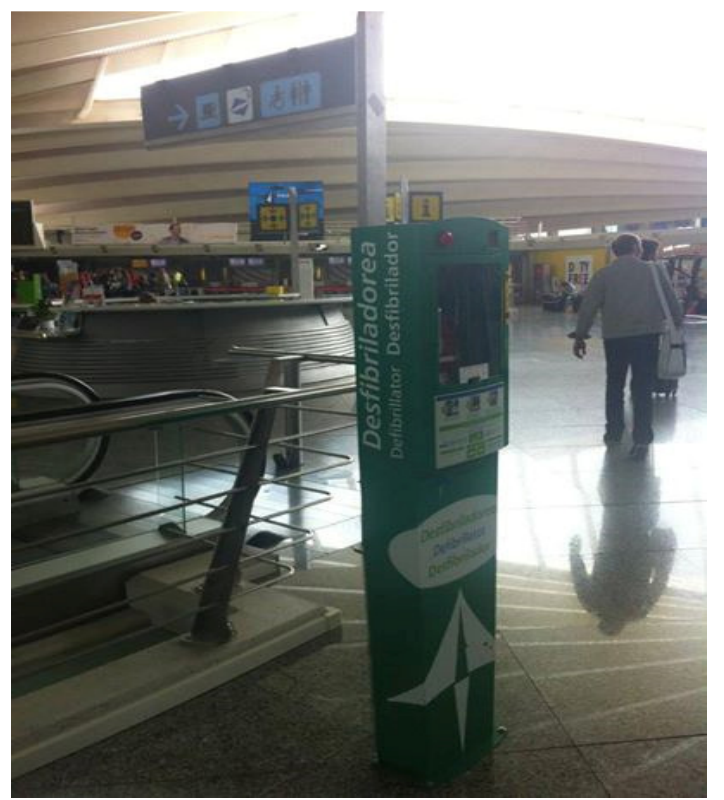

Figura 91 - Desfibrilador no Aeroporto Internacional de Bilbao (Espanha) Crédito: Daniela Rocco (2013). 


\section{- Guernika}

O serviço de car sharing é um novo modelo de negócio que vem sendo cada vez mais adotado não só por residentes, como turistas também. Trata-se de uma forma de alugar carros estacionados em pontos estratégicos de cidades. Basicamente, o usuário faz uma inscrição, a reserva e recebe um cartão para desbloquear o carro ou, dependendo da empresa, pode fazer isso com o próprio cartão de crédito. É possível reservar o carro por hora ou dias, por meio de site, aplicativo e telefone. A diferença é que algumas empresas usam carros elétricos e outras não (como é o caso, ainda, da pioneira desse negócio no Brasil, a Zazcar). A Figura 92 mostra um ponto de recarga de carros elétricos, que é alimentado por energia solar. Vale ressaltar que a maior emissão de $\mathrm{CO}_{2}$ no turismo não ocorre por aviões, e sim por via terrestre, sobretudo pelo carro (COOPER et al., 2002). O car sharing com carros elétricos é uma excelente iniciativa, porém deve ser associado com outras formas inteligentes e criativas de mobilidade urbana.

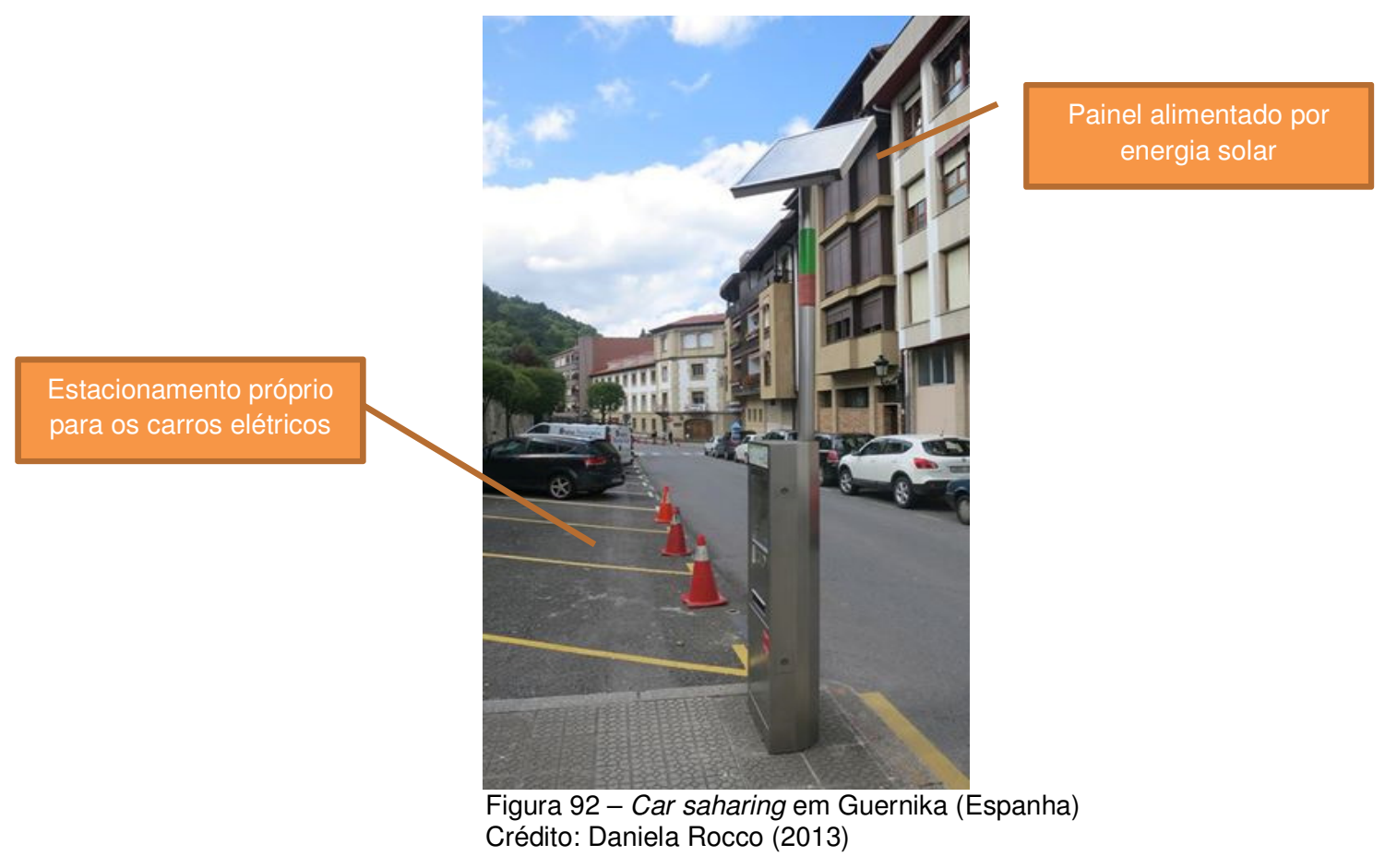

- Ilha El Hierro: a primeira ilha do mundo abastecida 100\% por energia renovável

A Ilha El Hierro, localizada nas Ilhas Canárias, tornou-se dia no dia 27 de junho de 2014 a primeira ilha do mundo que é abastecida 100\% por energia renovável. Esse projeto existe há 30 anos e foi executado pela empresa Gorona del Viento El Hierro, S.A. (http://www.goronadelviento.es/index.php). Para isso, foi criada uma central hidroeólica para 
suprir a demanda energética, conforme demonstra a Figura 93. Foi construído na Ilha um Parque Eólico com 5 grandes aerogeradores e a energia excedente é desviada para a estação de bombeio da água, que também foi criada. Se os aerogeradores não produzirem energia, um dispositivo fará com que a água desça em alguns tubos para, assim, produzir energia hidroelétrica. Em caso de emergência, como falha do sistema, a central de combustível diesel (que era utilizada desde então) será acionada. O custo total do projeto foi de 67,5 milhões de euros, entretanto, com a central hidroeólica, se deixará de consumir anualmente 6.000 toneladas de diesel (aproximadamente 40.000 barris de petróleo), serão evitadas 18.700 toneladas de emissões de $\mathrm{CO}_{2}$ por ano e, além disso, estima-se que serão economizados, por ano, mais de 1,8 milhões de euros. Segundo a empresa que construiu esse megaempreendimento, 600 milhões de pessoas (entre elas, 17 milhões de europeus) vivem em ilhas em todo o mundo. Se projetos como esses da Ilha El Hierro fossem adotados por outras ilhas do mundo, seriam diversos ganhos para a economia, sociedade e meio ambiente. A Ilha El Hierro possui projetos futuros de sustentabilidade, como, por exemplo, fazer com que no ano de 2020 os 6.000 carros que circulam na ilha sejam elétricos (MURILLO \& SEVILLANO, 2014).

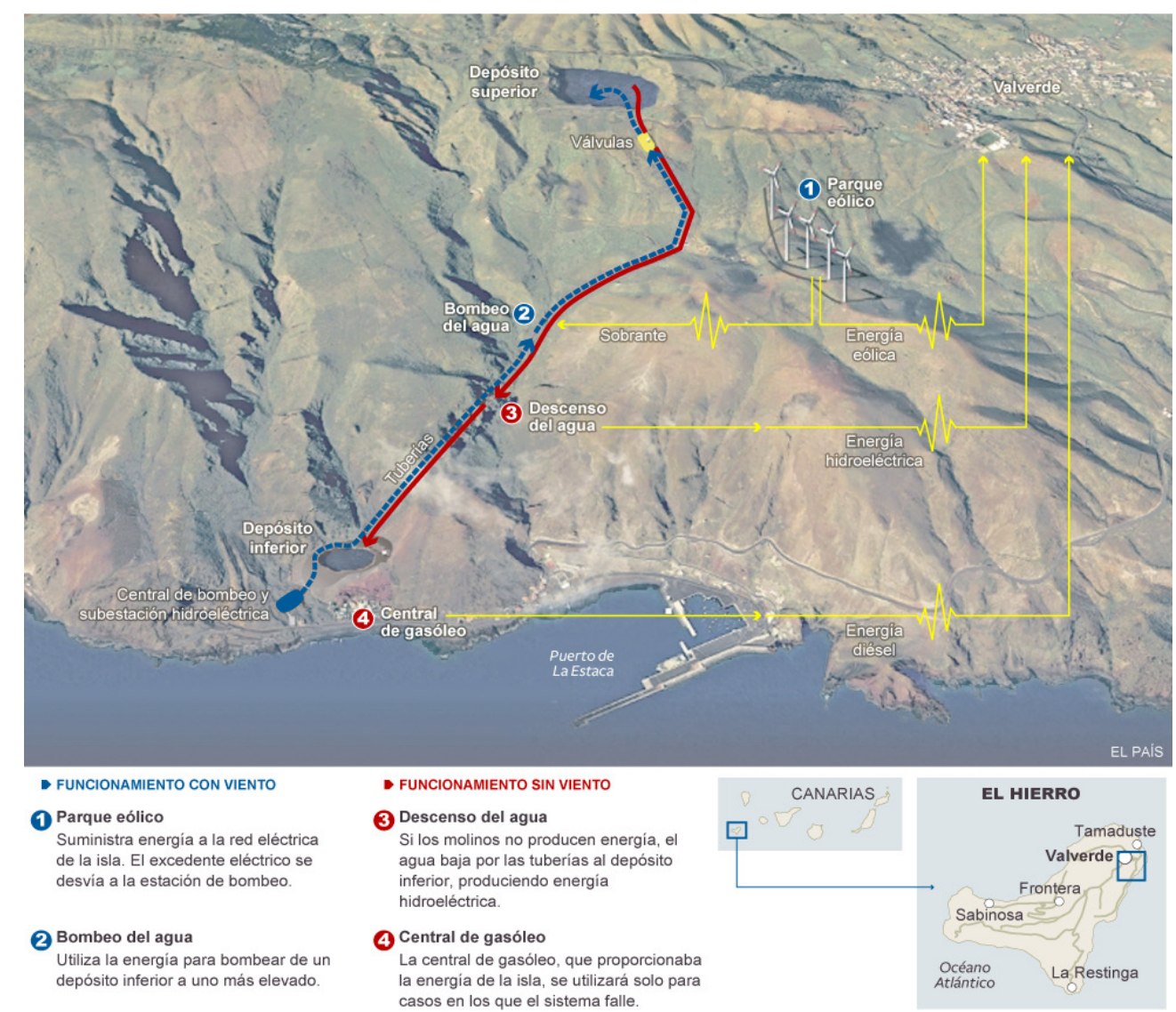

Figura 93 - Funcionamento central hidroeólica da llha El Hierro, abastecida 100\% por energia renovável Fonte: El País (2014). 


\section{- Valência}

Nesta cidade há um grande incentivo da Prefeitura para a disponibilização de táxis ecológicos. Na Figura 94, à esquerda, é a foto de um desses táxis, que por sua vez indica na porta do carro a seguinte mensagem: "Funciono a gás, sou ecológico e economizo até $50 \%$ em relação aos combustíveis convencionais" (esta é a principal proposta de valor da frota de táxi local, portanto, um diferencial em relação a outras empresas do ramo). Quanto à foto da direita, esta foi tirada de um dos maiores parques da cidade. Como pode ser visto, há uso de $Q R$ Code, e este foi adotado para ser uma das estratégias de educação ambiental do parque, que ainda conta com acesso Wi-fi gratuito.
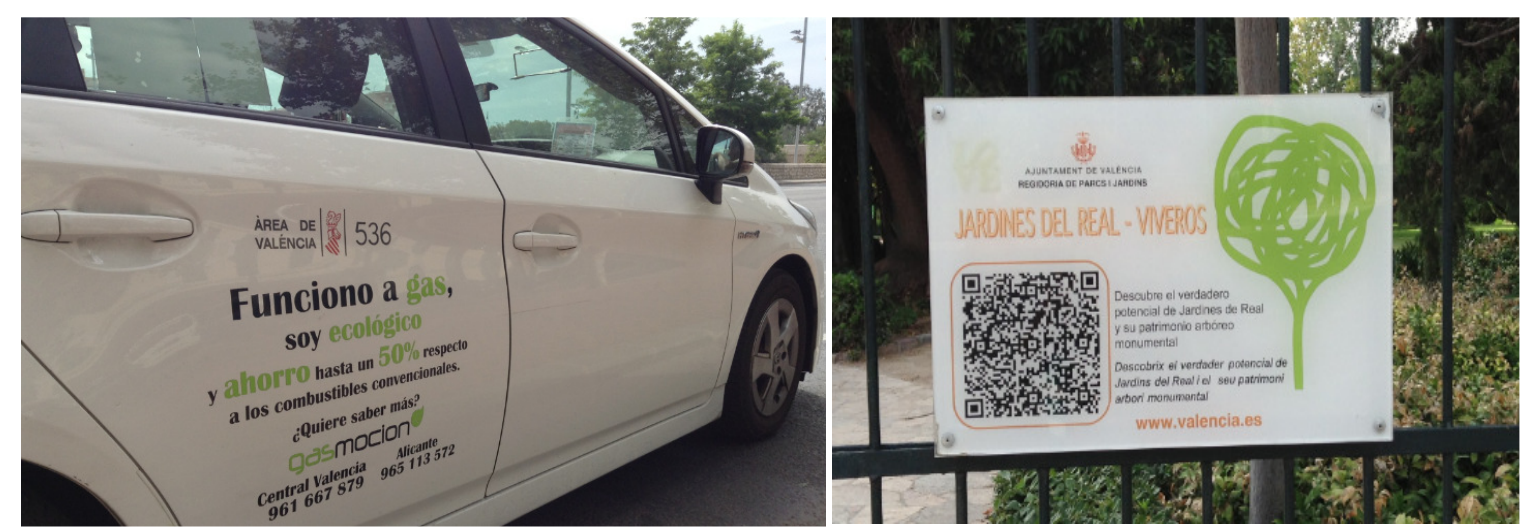

Figura 94 - Ações de inovação para a sustentabilidade em Valência (Espanha)

Crédito: Daniela Rocco (2013)

\section{- Barcelona (iCapital 2014)}

Como já foi exposto, em 2014 Barcelona foi considerada a Capital Europeia da Inovação de acordo com a Comissão Europeia (EUROPEAN COMMISSION, 2014b).

Segundo o site da prefeitura da cidade (http://www.22barcelona.com/), o projeto 22@ Barcelona transformou uma área da cidade chamada Poblenou em um bairro inovador onde estão localizadas instituições públicas e privadas que operam sob a égide da inovação. Sem dúvida, é um audacioso projeto de renovação urbana e de um novo modelo de cidade. É preciso ressaltar que o investimento público em infraestrutura é de 180 milhões de euros e a finalidade é promover a cidade internacionalmente, além de torná-la ainda mais competitiva. A Figura 95 a seguir apresenta algumas boas práticas adotadas na cidade. 


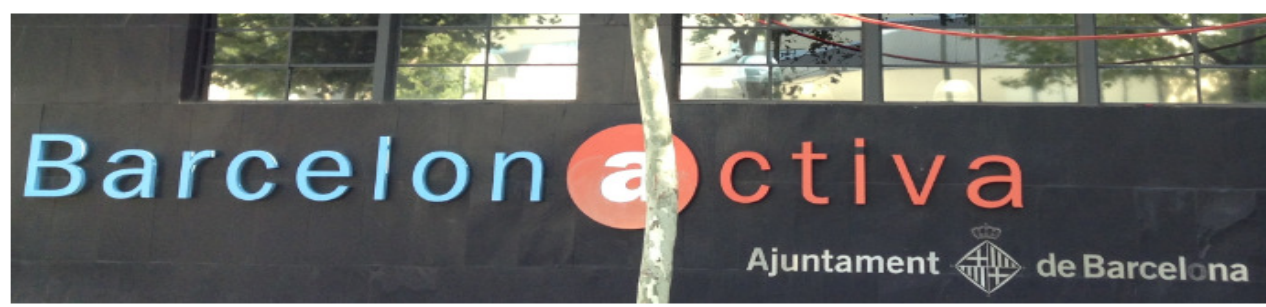

O Barcelona Activa, localizado no 22@ Barcelona, está integrado nas áreas de Economia, Empresa e Emprego. Esta instituição é responsável pela organização executiva de políticas de promoção econômica da Prefeitura de Barcelona.

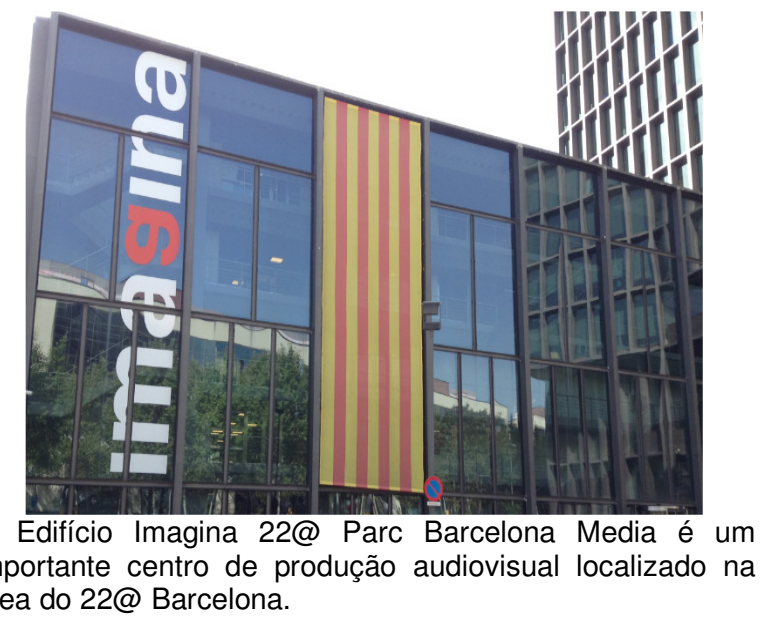
área do 22@ Barcelona.

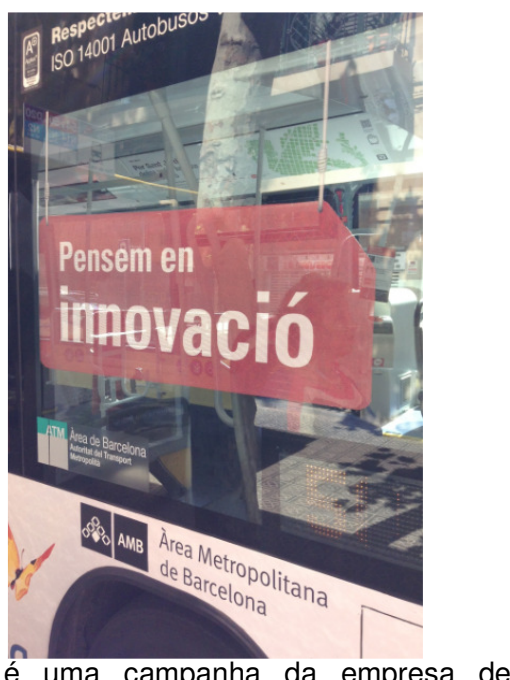

Esta é uma campanha da empresa de inovação. Além disso, o ônibus é silencioso e é movido a gás natural. A empresa possui certificações como Gestão da Qualidade, Saúde e Segurança no Trabalho e Gestão ambiental.

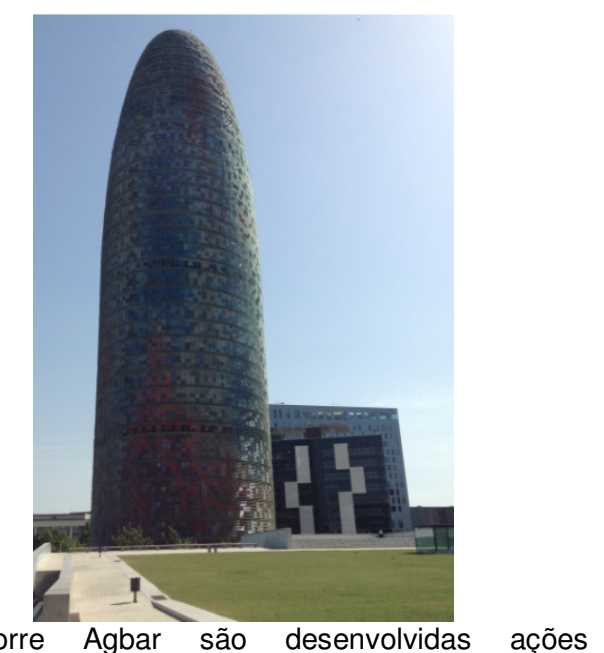

específicas de inovação na gestão da água da cidade. Também está localizada na zona 22@ Barcelona.

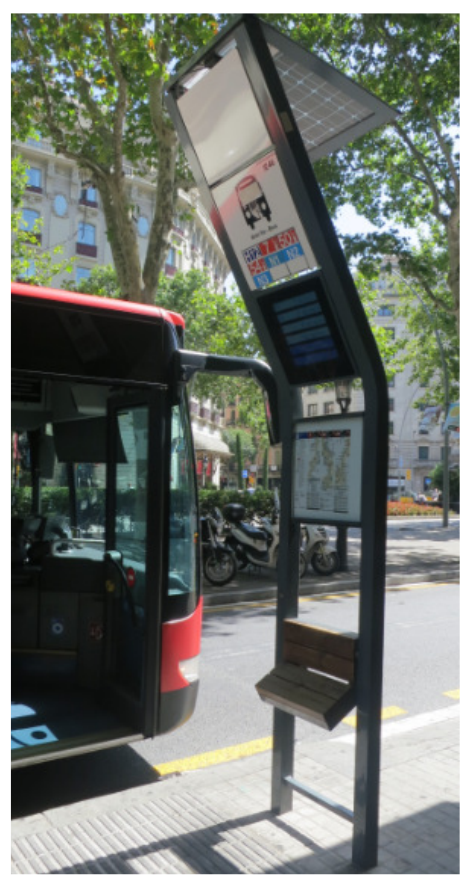

Painel com informações dos horários dos ônibus com o uso de energia solar. A escolha desse painel foi feita por meio de concurso público e venceu 0 projeto de estudantes universitários. 


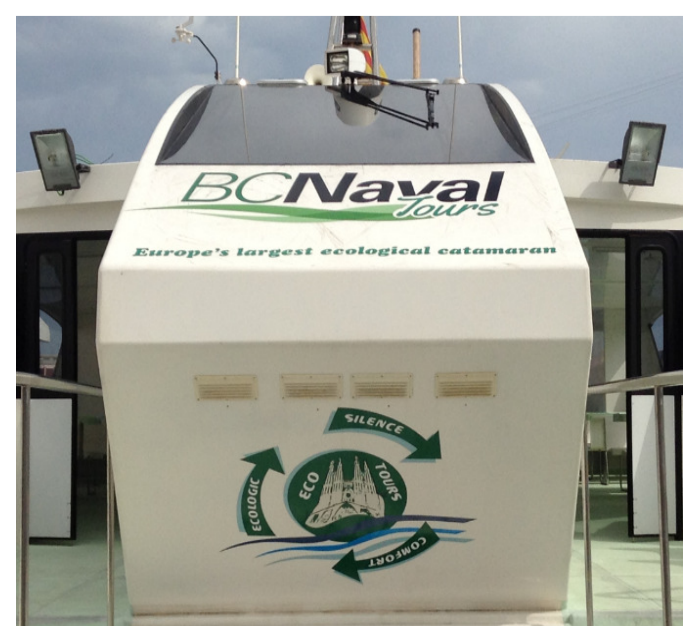

Embarcação ecológica para passeios turísticos (uso de energia solar)

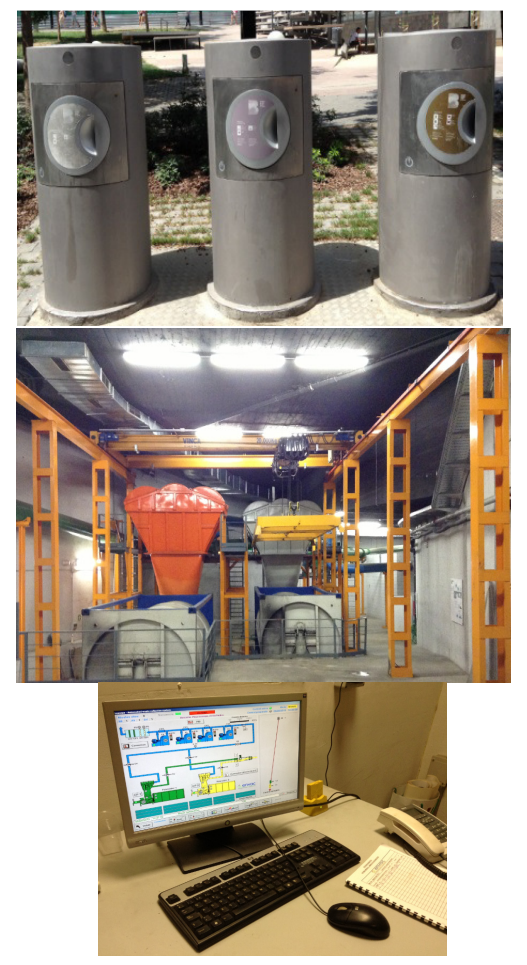

Este é o inovador sistema pneumático de coleta de resíduos. Ele foi pioneiro em Barcelona e hoje cidades como Madrid, Pamplona, Vitoria-Gasteiz, Sevilla, Sabadell, Córdova e Reus também dispõem desta tecnologia. O sistema conta com centrais de armazenamento com tubulações subterrâneas de uma extensão de 5 metros. Os resíduos descem por essas tubulações chegam em um grande contêiner, de onde se faz, via tecnologia, serapação dos resíduos para posteriores encaminhamentos (tratamento e reciclagem).

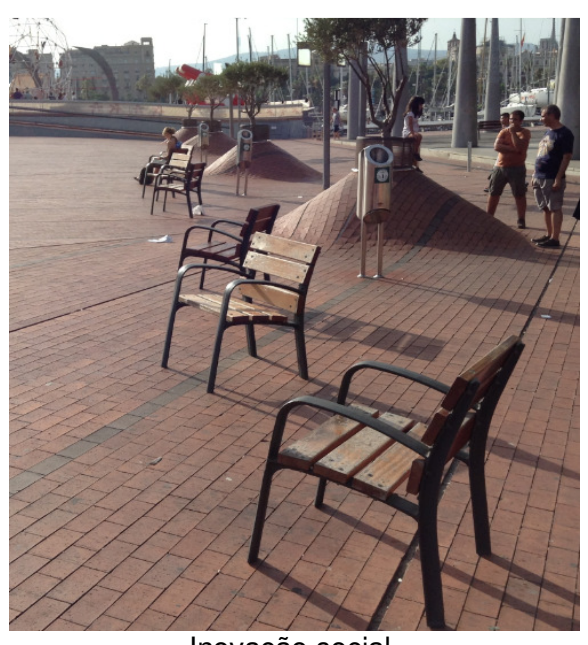

Inovação social

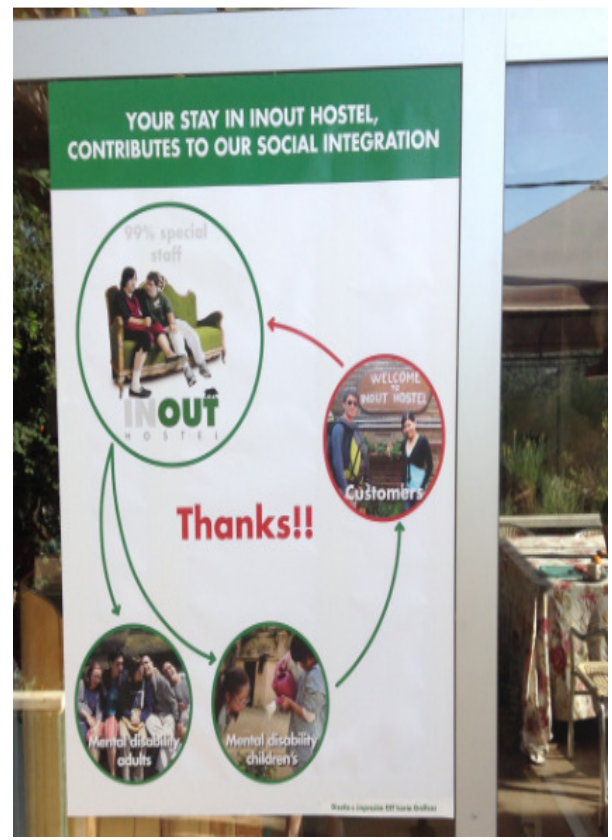

Inovação social: este é um hostel (albergue) cujo staff é quase $100 \%$ composto por pessoas com síndrome de down e pessoas portadoras de necessidades especiais.

Figura 95 - Casos de inovação para a sustentabilidade em Barcelona (Espanha) Crédito: Daniela Rocco (2013). 
- Madrid

A Figura 96 mostra que na cidade os taxis que são "ecológicos" (pelo uso de gás natural) possuem uma faixa específica na porta (de cor vermelha). Um caso interessante é o do Museu Rainha Sofia, pois está disponível na saída do museu uma caixa para que as pessoas possam devolver os mapas e programações culturais. A finalidade é para reuso e é até uma medida inovadora de educação ambiental, pois existem pessoas que amassam, jogam fora. Além disso, se menos pessoas levassem para suas casas esses materiais (que às vezes depois são jogados fora), menor seria o uso de papel e tinta.

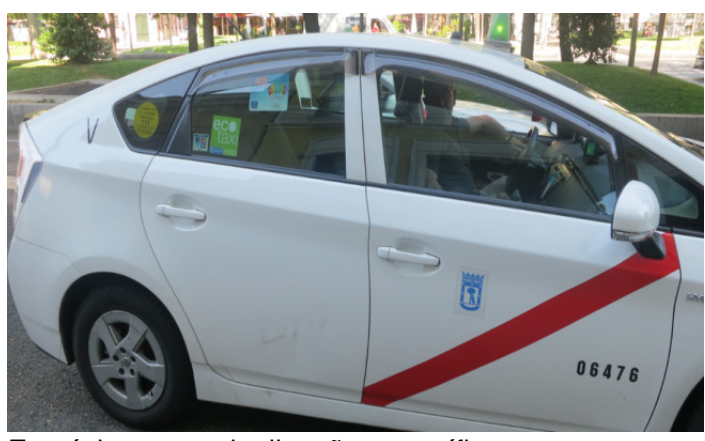

Ecotáxis - com sinalização específica

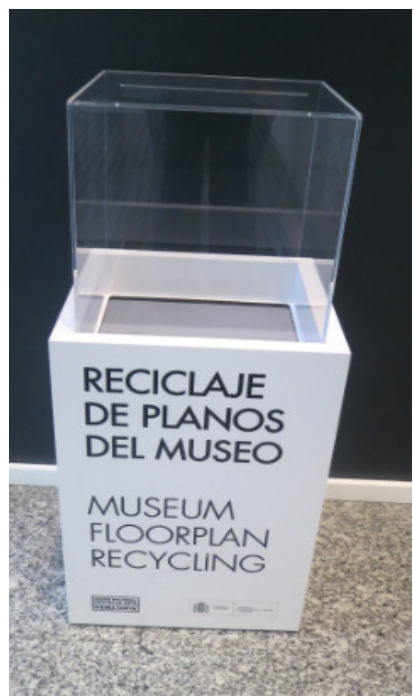

Caixa de reuso de mapas e programações culturais do Museu Rainha Sofia

Figur 96 - Casos de inovação para a sustentabilidade em Madrid (Espanha) Crédito: Daniela Rocco (2013).

\section{Box 6 - BlaBlaCar: a viagem compartilhada}

O BlaBlaCar é uma rede social que conecta motoristas com passageiros para ratear os custos de uma viagem, como a gasolina, por exemplo. Essa rede nasceu na Espanha e seu principal canal de comunicação é por meio do Facebook, tendo mais de um milhão de pessoas que "curtiram"/se conectaram a este canal.

As vantagens dessa rede social, cuja lógica começa a se disseminar por outros países, é que se apresenta como uma forma organizada e confiável para estimular viagens compartilhadas, beneficiando tanto o motorista, que deixaria de pagar o total dos custos para chegar a um destino, quanto o passageiro, que possivelmente paga bem menos que uma viagem convencional, podendo, inclusive conhecer novas pessoas e formar amizades. Além disso, essa iniciativa é uma alternativa também para a redução de $\mathrm{CO}_{2}$. 


\section{- FRANÇA}

\section{- Paris}

Para aliviar a sensação de calor, o governo de Paris tem criado no período do verão uma praia artificial de cerca de $1 \mathrm{~km}$ na beira do Rio Sena, estendendo-se desde o Museu do Louvre até o Canal Saint-Martin. Existe uma programação cultural que inclui aulas gratuitas e festival de música. Além disso, a praia é acessível a pessoas portadoras de necessidades especiais. Este é um exemplo de inovação social, e a Figura 97 mostra isso.

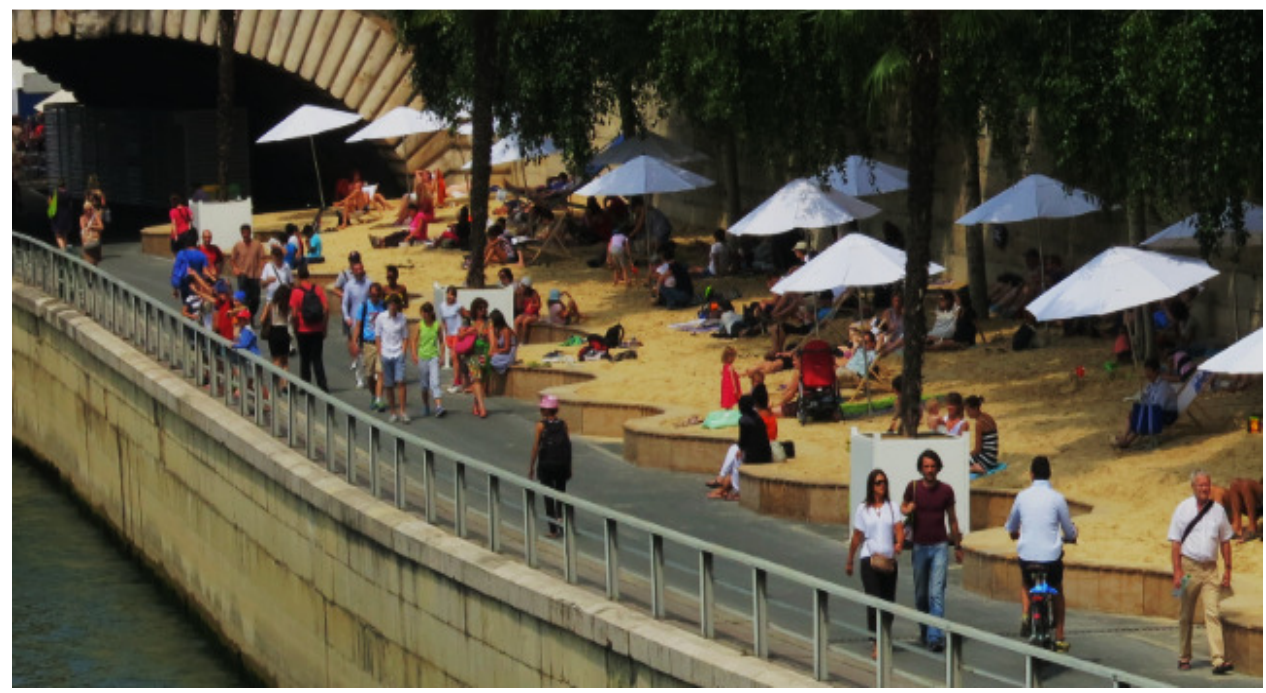

Figura 97 - Praia artificial em Paris (França) Crédito: Daniela Rocco (2013)

\section{- ITÁLIA}

\section{- Roma}

O Roma Pass (http://www.romapass.it/) é um passaporte especialmente criado para que turistas e residentes tenham acesso facilitado a atrativos e transporte público (ônibus e metrô) da cidade. Esta é uma iniciativa estabelecida a partir da parceria entre a Câmara Municipal de Roma, o Ministério de Artes e Atividades Culturais e a ATAC, que é a empresa de transporte público local. É possível comprar dois tipos de passaporte. Por um custo de 28 euros, o Roma Pass 48h dá acesso ilimitado durante dois dias a diversos museus e transporte público, além de entrada gratuita em um museu ou um sítio arqueológico, como o Coliseu. O outro tipo de passaporte, que custa 36 euros, além de proporcionar as mesmas vantagens de acesso a museus e transporte público, dá direito a entrada gratuita a dois museus e/ou sítios arqueológicos e oferece descontos no serviço de contratação de guias de turismo. Para ambas as modalidades existe um acesso específico para entrada do 
Coliseu (evitando grandes filas) e um kit composto por três itens: 1) Cartão Roma Pass: é individual e intransferível. Utilizado para entrar nos museus, acessar o transporte público livremente (durante o período vigente) e obter descontos em estabelecimentos como sorveterias; 2) Mapa de Roma: um mapa da cidade com todos os pontos de informação turística, estações de metrô, museus e outros locais de interesse (informações como endereços completos, número do telefone, dias/horários que estão fechados e respectivas informações sobre pontos de ônibus e estações de metrô mais próximas de cada atrativo). Além disso, nesse material está disponível a indicação dos museus cujas entradas são gratuitas, pagas e que possuem descontos mediante a apresentação do cartão Roma Pass e 3) Roma è: é um aplicativo de informações turísticas da cidade e que está disponível aos usuários do passaporte para download (ROMA PASS, 2014).

Iniciativas como essas são bastante comuns em diversos destinos turísticos, pois é uma forma inovadora de integrar oferta turística e transporte público, gerando maior competitividade e, consequentemente, menor emissão de $\mathrm{CO}_{2}$, uma vez que geralmente os adeptos desses tipos de passaporte privilegiam o ônibus e metrô. Optamos por destacar o passaporte de Roma porque circular com carros particulares pelas ruas da cidade é um grande desafio, bem como encontrar estacionamentos (em muitos deles o valor é elevado).

\section{- ALEMANHA}

A Alemanha tem sido uma grande referência entre os países que investem em energias renováveis, inclusive, já criou 96 mil postos de trabalho nessa área. Durante o meio do dia, a energia de todo País é 74\% limpa. No ano de 2011 a cidade de Wildpoldsried gerou $321 \%$ de energia renovável e faturou, com a venda do excedente, 4 milhões de euros. No estado de Schleswig-Holstein (região norte do País), a projeção é que a partir de 2014 toda a energia utilizada seja renovável. Segundo o relatório da Associação Alemã para a Energia Eólica, até o ano de 2030 estima-se que a capacidade eólica marítima seja de até 25.000 MW e no continente de até 6.000 MW (HYPENESS, 2014).

Os alemães têm investido também em ciclovias e ecopontes, muito embora uma das maiores referências mundiais desse campo seja a Holanda. A Figura 98 mostra, à esquerda, a foto da Highway A20, que possui uma ecoponte para travessia de animais silvestres. Por sua vez, a foto à direita mostra um trecho da rodovia Autobahn que é fechado aos domingos para passeios. Vale ressaltar que será construída até 2021 uma rodovia de $60 \mathrm{~km}$ de extensão exclusivamente para ciclistas. Esse trecho será entre Dortmund a Duisburg, pois ambos são grandes centros industriais e a atual via de acesso que conecta esses dois centros é uma das mais congestionadas do País (FELIX, 2013). 


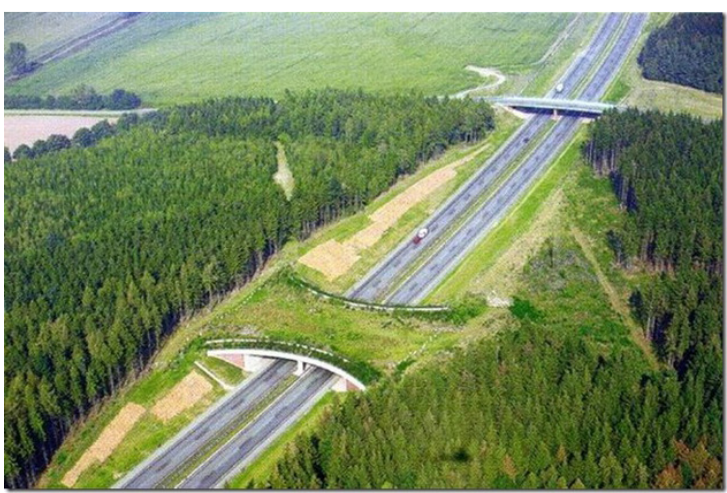

Ecoponte da Highway A20 (Alemanha)

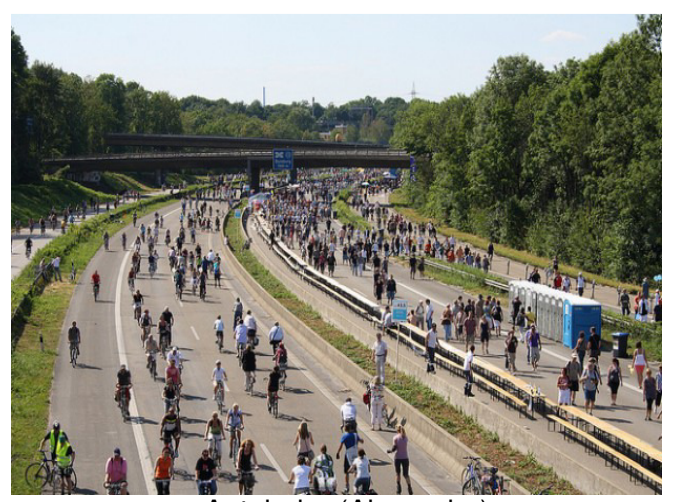

Autobahn (Alemanha)

Figura 98 - Casos de inovação para a sustentabilidade na Alemanha Crédito: Foto (C) Autobahn Online

\section{- RÚSSIA}

\section{- Moscou}

Em função dos Jogos Olímpicos de Inverno que ocorreram em fevereiro de 2014 na Rússia, foi criada no metrô de Moscou uma forma interessante de chamar atenção de moradores e turistas para o grandioso evento. Como mostra na Figura 99, cada pessoa que fizesse trinta agachamentos em até dois minutos recebia automatica e gratuitamente uma passagem de metrô. Trata-se de uma inovação social por meio dos Jogos Olímpicos, cuja campanha é uma maneira inteligente e saudável de associar exercícios físicos e esportes no dia a dia das pessoas.
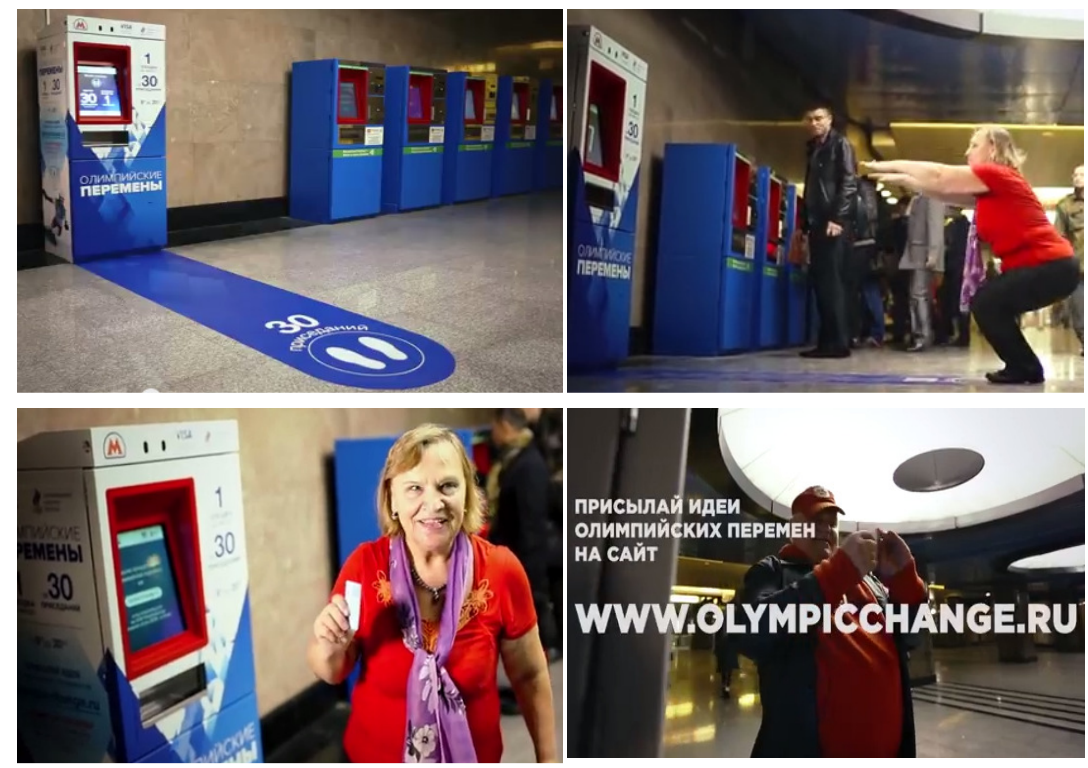

Figura 99 - Fotos extraídas do vídeo da campanha da Olympic Change (Rússia) Autor: Olympic Change

Fonte: https://www.youtube.com/watch?v=0jo9M1cPSPI 


\section{ÁFRICA}

- GUINÉ

A Fouta Trekking Aventure (FTA) (http://www.foutatrekking.org/) é uma associação turística criada em 1998 por dois jovens de Guiné interessados no desenvolvimento do turismo de Fouta Djallon (Guiné). A concepção da associação reside no desenvolvimento sustentável, no intercâmbio cultural e na valorização da cultura guineense. Com relação aos principais serviços prestados, vale destacar: organização de excursões em trilhas, promoção do destino, apoio à criação de acampamentos comunitários, capacitação de atores locais para recepcionar os visitantes, bem como na gestão de seus micro negócios e dar suporte a moradores para a implantação de projetos agrícolas, viveiros, entre outros. Desde então, as ações, que para o local foram (e são) inovadoras, têm contribuído para a criação de novos postos de trabalho, o que influencia, consequentemente, na diminuição do êxodo rural e outros benefícios em termos de sustentabilidade (FTA, 2014).

\section{- QUÊNIA}

\section{- Nairobi (capital) e outras regiões do País}

A ONG Ocean Sole possui como finalidade principal retirar os resíduos do oceano (sobretudo chinelos perdidos, recorrentemente encontrados nas praias) e transformá-los em brinquedos e peças decorativas. Ao empregar aproximadamente 100 pessoas, já foram extraídas mais de 400 toneladas de resíduos, entre eles com característica de borracha. Essa iniciativa começou em 1997, quando Julie Church, uma conservacionista queniana, liderava um projeto de conservação na Reserva Marinha de Kiunga. Hoje a atuação da Ocean Sole já recebeu prêmios e seus produtos são solicitados para serem expostos em grandes eventos de moda e museus. Trata-se de um projeto de base local que beneficia o meio ambiente por meio da despoluição das praias e oceano, permite o acesso a praias mais limpas para moradores e turistas, contribui para a redução da pobreza, gerando emprego e renda e estimula práticas inovadoras e criativas na região. A Figura 100 expõe algumas fotos que foram extraídas do site da ONG. 

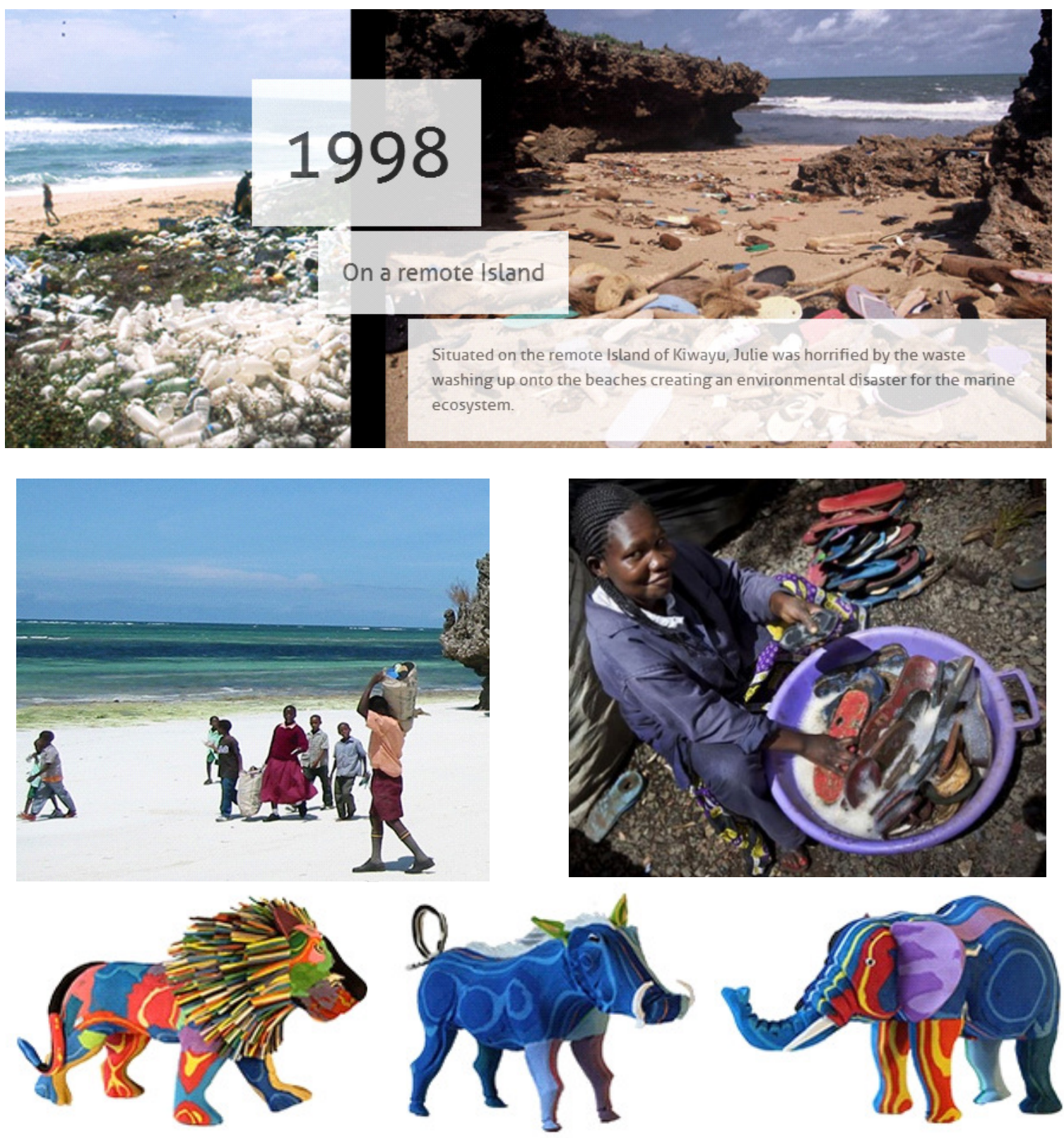

Figura 100 - Conjunto de fotos extraídas do site da ONG Ocean Sole (Quênia) Autor: Ocean Sole (2014)

Fonte: http://www.ocean-sole.com/

\section{ÁSIA}

Cidades inovadoras com princípios de sustentabilidade serão cada vez mais tendência no futuro. Surgem, assim, audaciosos projetos de "cidades inteligentes" em países como Catar, China e Malásia. Inclusive neste País já está sendo construída a Iskandar Malásia, que será a primeira smart city do sudeste asiático (INOVAÇÃO 
TECNOLÓGICA, 2013). Os reflexos disso sobre o turismo, consequentemente, são inevitáveis, pois surgem hotéis, parques temáticos e muitas outras atrações inovadoras com princípios de sustentabilidade como as que serão apresentadas a seguir.

- MALÁSIA

Está sendo construída a smart city Iskandar Malásia (http://www.iskandarmalaysia.com.my/), conforme mostra a imagem de divulgação contida na Figura 101. Tal construção está embasada em ações de sustentabilidade, como integração social, redução das emissões de $\mathrm{CO}_{2}$ e uso de tecnologias que minimizem impactos ambientais. De acordo com especialistas internacionais, a criação de "cidades inteligentes" como essas são modelos de desenvolvimento urbano, sobretudo porque a população mundial concentrada na urbe tende a crescer e diversos problemas estão associados a esse crescimento (INOVAÇÃO TECNOLÓGICA, 2013).

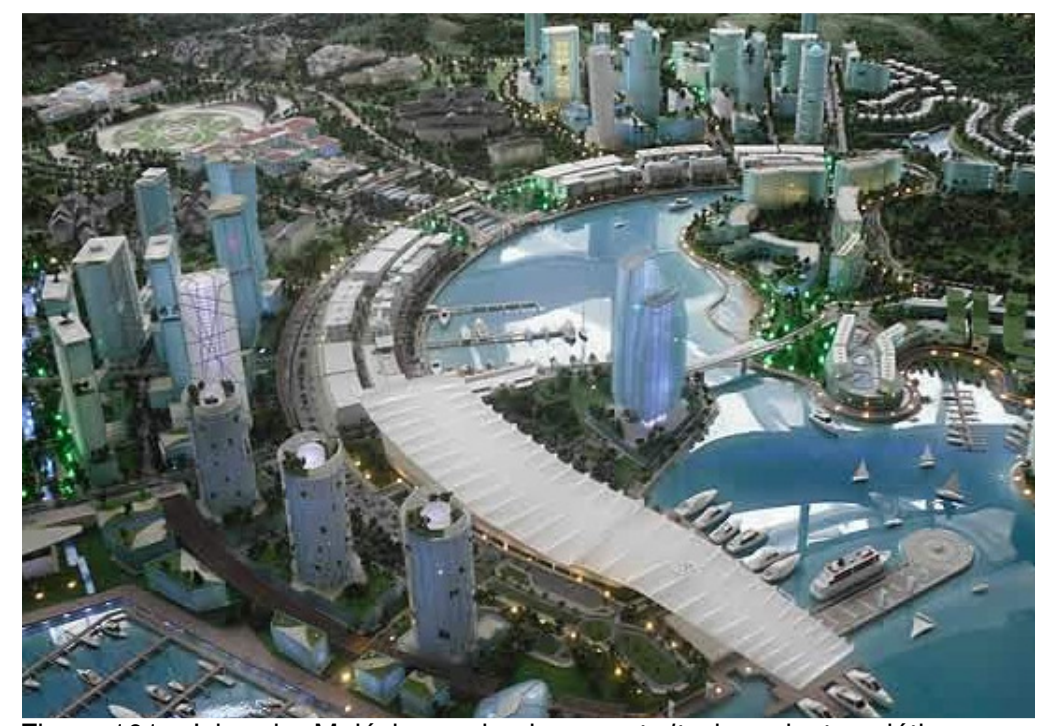

Figura 101 - Iskandar Malásia, a primeira smart city do sudeste asiático Fonte: http://www.iskandarmalaysia.com.my/

\section{- CHINA}

O iGreen é o Museu de Aviação com cinema 5D que será construído em breve com o reaproveitamento de CD e DVD, e a Figura 102 mostra o projeto da parte externa e interna. A previsão é que a conclusão desse museu seja feita em 2015 (MINIWIZ, 2014). 


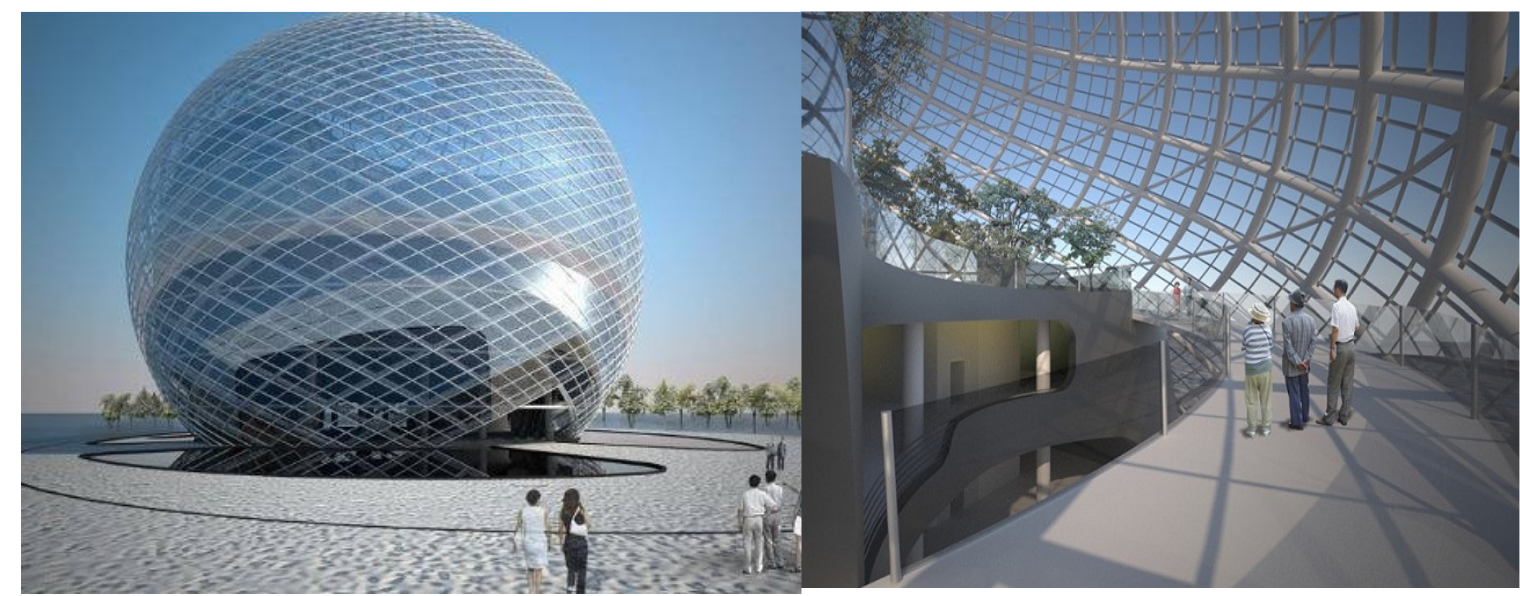

Figura 102 - Novo museu de aviação na China: iGreen

Crédito: Miniwiz (2014)

\section{- JAPÃO}

\section{- Tóquio}

Se na Holanda, que é a "capital mundial das bicicletas", já começam a existir problemas por falta de bicicletários (TAGLIABUE, 2013), em Tóquio a empresa Giken (http://www.giken.com/en/developments/eco_cycle/) encontrou uma solução inovadora: a criação de um estacionamento subterrâneo e automático de bicicletas, tal como demonstra a Figura 103.

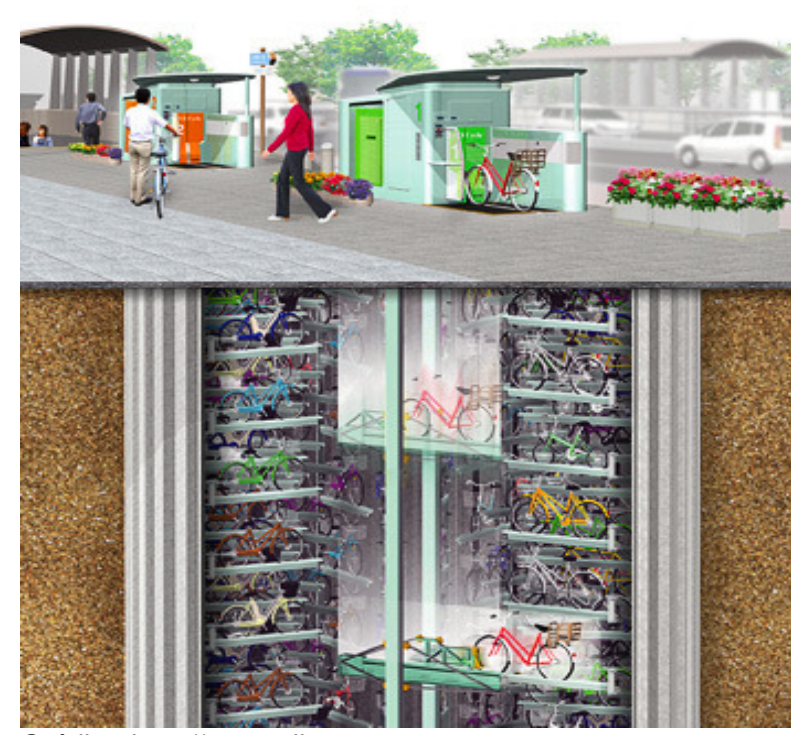

Crédito: http://www.giken.com

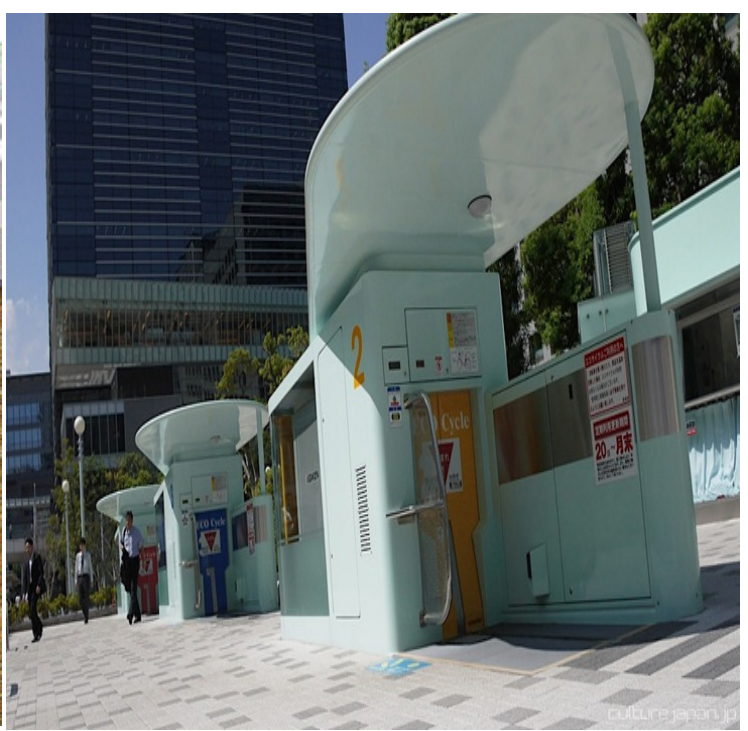

Crédito: Autor desconhecido

Figura 103 - Estacionamento automático de bicicletas em Tóquio (Japão) Fonte: Giken (2014) 


\section{- SINGAPURA}

Há 40 anos a situação de Singapura era caótica, com recursos hídricos escassos, enchentes frequentes, rios poluídos, pouquíssimos casos de saneamento básico e condições de saúde precárias. Hoje, graças a um intenso processo de transformação urbana, o País se converteu em um dos casos mais bem-sucedidos de sistema de Gestão Integrada dos Recursos Hídricos Urbanos do mundo.

Para isso foi necessário um conjunto de diversas inovações, entre elas: dragagens e melhorias das infraestruturas, construção de sistemas de saneamento básico, capacitação da população, importação de água, adoção de reuso de água, dessalinização da água, gestão dos resíduos, gestão das águas residuais, gestão das águas pluviais e transformação social com realocação de pessoas, comércio, serviços e indústrias. A todo esse processo foram agregadas campanhas voltadas para a conservação e valorização da água, inclusive como forma de lazer (PUB, 2013), como mostra a Figura 104.
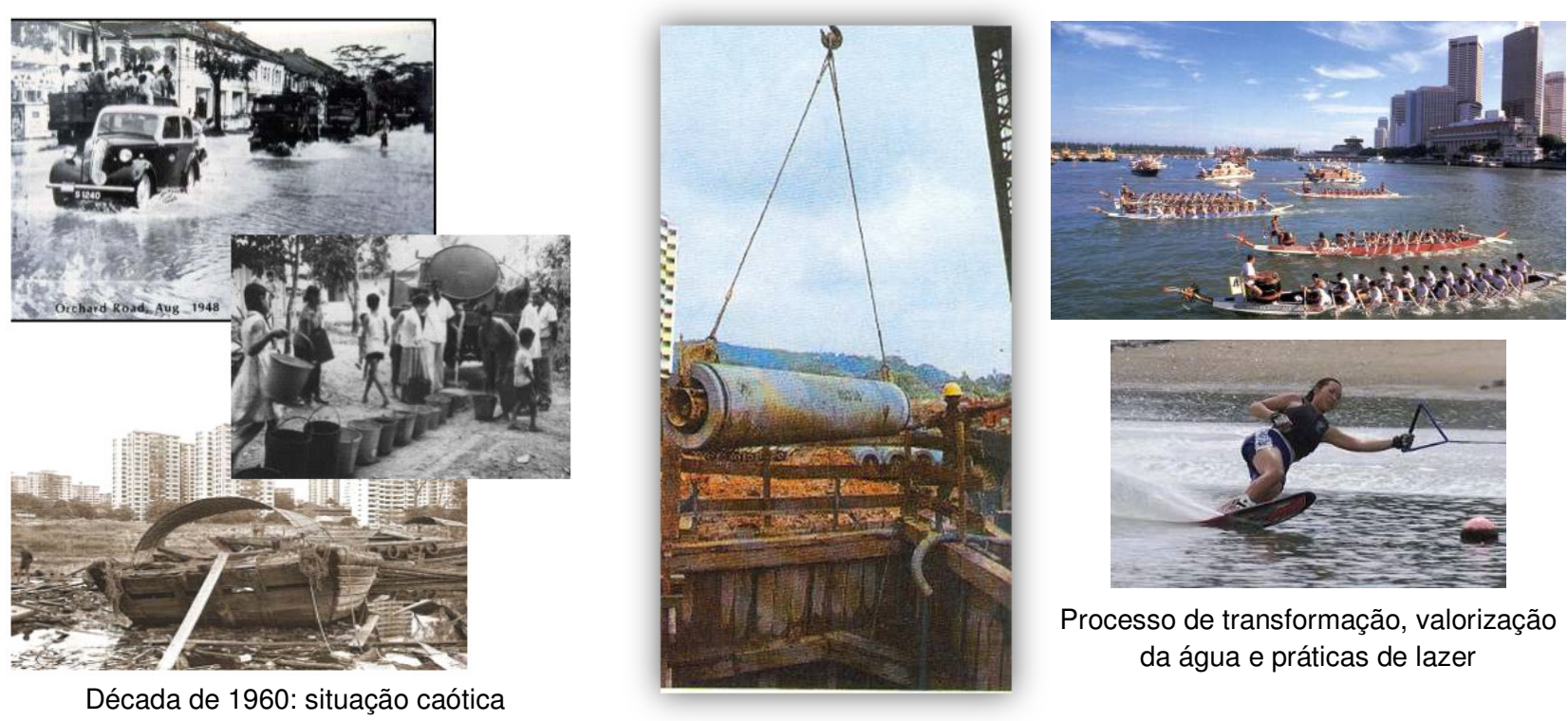

Processo de transformação, valorização da água e práticas de lazer

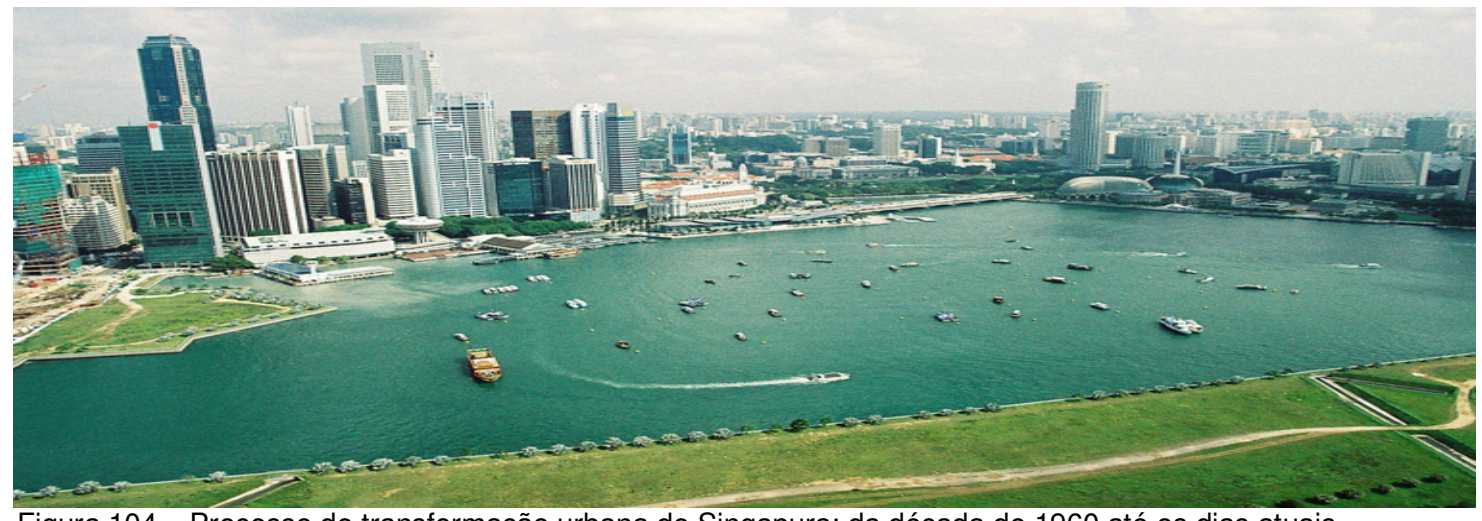

Figura 104 - Processo de transformação urbana de Singapura: da década de 1960 até os dias atuais Fonte: PUB (2013) 


\section{OCEANIA}

\section{- AUSTRÁlia}

No parque australiano Nightcap National é possível realizar passeios noturnos com o uso de óculos militares próprios para visão noturna, tal mostra a Figura 105. Diferente das lanternas, tais óculos não prejudicam os animais, e nem os afastam. Com isso, é possível ter uma melhor experiência no passeio, uma vez que é maior a probabilidade de observar animais de hábitos noturnos, como gambás, coalas e sapos. Existe uma empresa que realiza esse passeio pela floresta que dura três horas e custa em média 99 dólares australianos por pessoa, o equivalente a $\mathrm{R} \$ 170$ (PEGN, 2010).
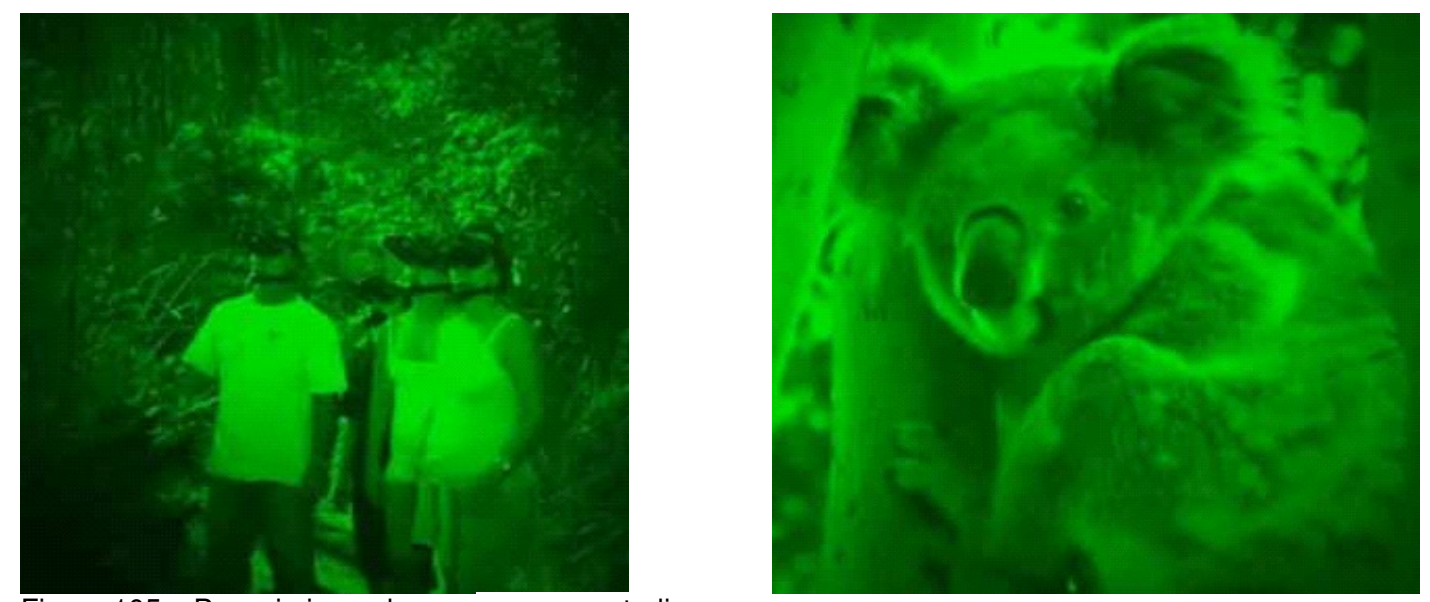

Figura 105 - Passeio inovador em parque australiano Crédito: PEGN (2010)

\section{- NOVA ZELÂNDIA}

A Nova Zelândia é referência mundial em Ecoturismo e Turismo de Aventura, não somente por suas belezas naturais, mas porque nos principais destinos turísticos desses segmentos foram criados modernos e inovadores equipamentos de segurança para atividades radicais.

\section{- Rotorua}

Em 2008 a Google promoveu uma campanha para reunir ideias que pudessem ajudar a maior quantidade de pessoas no mundo. Intitulada como "10^100", a campanha recebeu mais de 150.000 ideias, e foi selecionado o projeto "Drive innovation in public transportation". Após a escolha da melhor ideia, a empresa buscou alguém que pudesse 
executá-la, cujo valor destinado foi US\$ 1 milhão. Surgiu, assim, o Shweeb (http://www.shweeb.co.nz), um veículo construído a partir de valores sustentáveis e que é, ao mesmo tempo, monotrilho e bicicleta (o único do mundo de tração humana). Hoje o veículo é uma das atrações do parque de diversões Agroventures Adventure (http://www.agroventures.co.nz/). No futuro, a ideia é que, tal como mostra as primeiras imagens da Figura 106 abaixo, o Shweeb seja levado às cidades, se configure como uma alternativa viável, limpa e eficiente de transporte, facilite a mobilidade urbana e, inclusive, reduza a quantidade de acidentes (SHWEEB, 2014; AGROVENTURES ADVENTURE PARK, 2014).
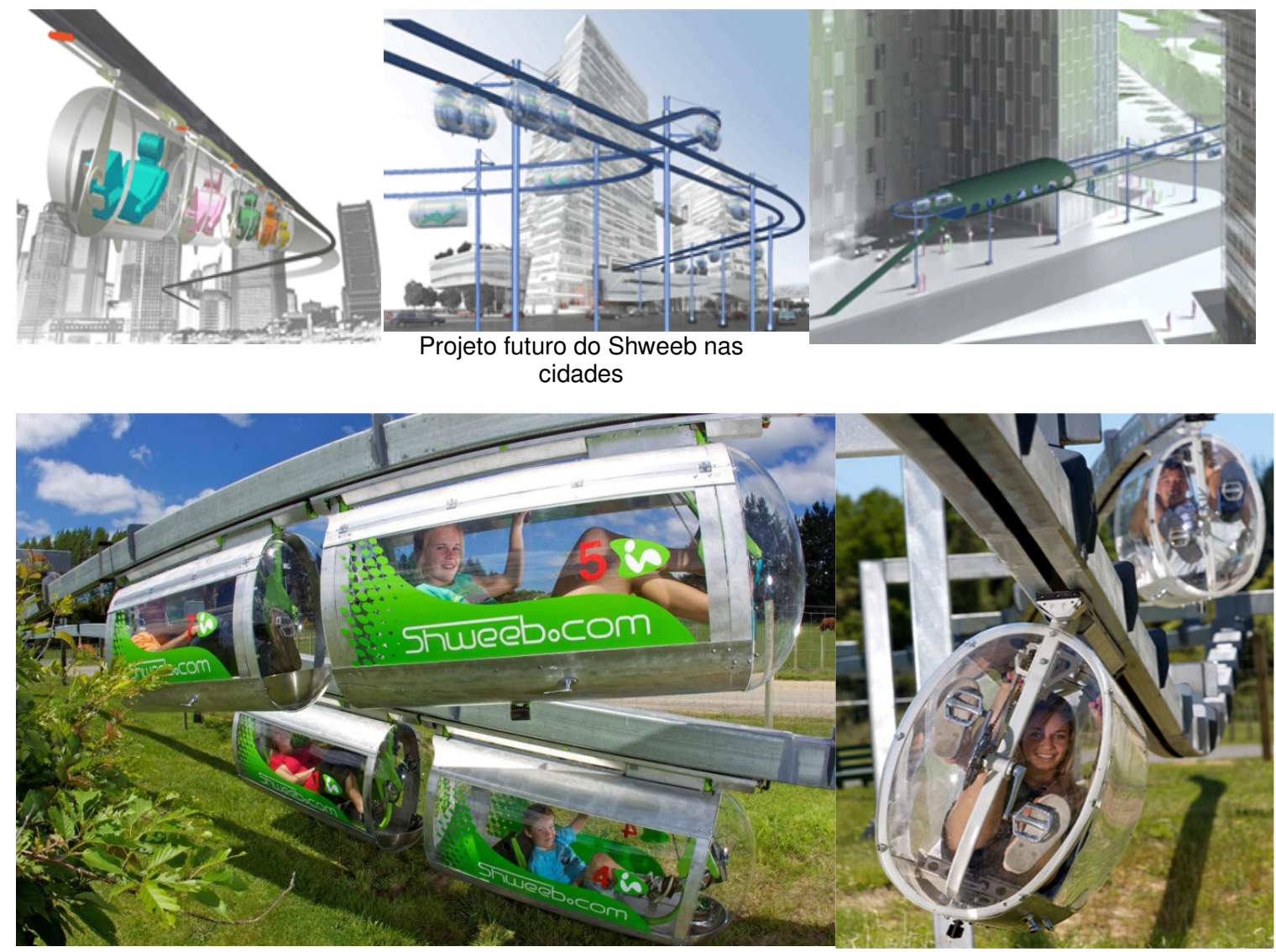

O Shweeb no Agroventures Adventure Park - Rotorua (Nova Zelândia)

Figura 106 - Brinquedo inovador em parque da Nova Zelândia Crédito: Shweeb (2014) e Agroventures Adventure Park (2014) 


\section{EXPERIÊNCIAS DE DESTINOS TURÍSTICOS BRASILEIROS: MAPEANDO}

CENÁRIOS DE INOVAÇÃO PARA A SUSTENTABILIDADE

\section{AMAZONAS (AM)}

Destino: Hotel de Selva Ariaú Amazon Towers

Inovação: Hotel de Selva

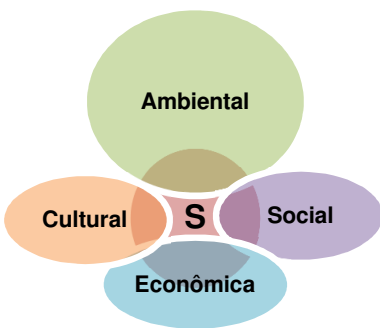

Iniciativa: privada

Breve contextualização da inovação: O Hotel, situado dentro da Floresta Amazônica, possui estrutura adequada para receber hóspedes e oferece atividades de caráter sustentável para despertar o interesse e incentivar a conservação, como observação noturna de jacarés e passeio pela mata e aldeias indígenas para conhecer a cultura local.

Fontes: Especialista (Consultora, Rio de Janeiro, até 3 anos de experiência) e Hotel de Selva Ariaú Amazon Towers (http://www.ariau.tur.br/pagina/id/1/)

Destino: Central de Turismo Comunitário

Inovação: Plataforma online que facilita o turismo comunitário na Amazônia Iniciativa: parceria entre terceiro setor e iniciativa privada

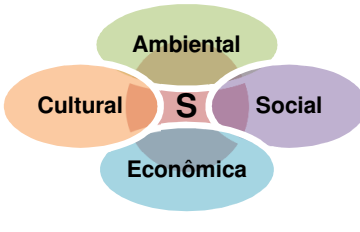

Breve contextualização da inovação: A Central de Turismo Comunitário visa promover o comércio justo nos roteiros de turismo comunitário da Amazônia e contribuir para que as populações locais possam ter mais autonomia e serem beneficiadas pelo turismo sustentável. Trata-se de uma plataforma online que disponibiliza informações e facilita a comunicação entre os visitantes e os empreendimentos turísticos comunitários.

Fontes: Especialista (Consultora, Distrito Federal, até 3 anos de experiência) e Central de Turismo Comunitário (http://www.amazoniacomunitaria.org/)

\section{PARÁ (PA)}

Destino: Floresta Nacional (FLONA) do Tapajós (Santarém/Belterra) Inovação: Organização do turismo sustentável em uma FLONA Iniciativa: poder público e sociedade civil

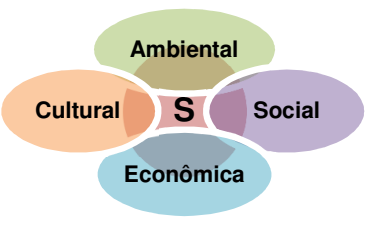


Breve contextualização da inovação: Segundo o site do ICMBio (Instituto Chico Mendes de Conservação da Biodiversidade), o manejo sustentável com a participação de povos tradicionais e indígenas é referência no Brasil e América Latina e movimenta $R \$$ 4.000.000,00 por ano. Os recursos são revertidos para o desenvolvimento social da própria comunidade e conservação da FLONA do Tapajós. Uma inovação que merece destaque, além da forma de organização dos atores locais, é a realização da Jungle Marathon, a maratona de selva mais importante do mundo.

Fonte: ICMBio (http://www.icmbio.gov.br/flonatapajos/)

\section{MARANHÃO (MA)}

Destino: Parque Nacional da Chapada das Mesas e o município de Carolina (entorno) Inovação: Em desenvolvimento

Iniciativa: público-privada

Breve contextualização da inovação: Segundo o especialista participante desta pesquisa (consultor especialista, Rio de Janeiro, de 16 a 19 anos de experiência), "apesar de ser um destino ainda pouco conhecido reúne várias iniciativas de inovações, todas elas muito direcionadas para a sustentabilidade". Foram poucas fontes de pesquisa encontradas, no entanto, é possível afirmar que a região começa a se despontar no segmento de turismo de aventura e tem sido palco de cenas de novelas, documentários e filmes. A opção de registrar esse destino nesta tese vale, também, para realizar aprofundamento teórico sobre o mesmo no futuro, já que Brotas (SP) e Socorro (SP) são, ainda, destinos-referência no segmento citado. Por não ter acesso a informações mais específicas sobre quais seriam as inovações, optamos por não dispor o pictograma.

Fonte: Agência Sebrae/MA (http://www.ma.agenciasebrae.com.br/sites/asn/uf/MA/Turismode-aventura-ganha-novo-destino-no-Maranh\%C3\%A3o)

\section{CEARÁ (CE)}

Destino: Fortaleza

Inovação: Hibribus

Iniciativa: pública (Prefeitura Municipal de Fortaleza)

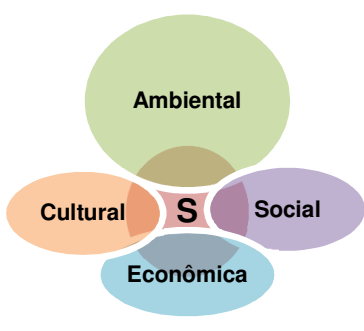


Breve contextualização da inovação: É o primeiro ônibus da cidade que usa biodiesel e é elétrico. Com ele, há uma redução de $35 \%$ de combustível e emite-se, consequentemente, menos $\mathrm{CO}^{2}$. Implementação: fevereiro/2014 (vide Figura 107).

Fonte: Prefeitura de Fortaleza (http://www.fortaleza.ce.gov.br/noticias/meioambiente/prefeitura-realiza-testes-com-onibus-sustentavel)

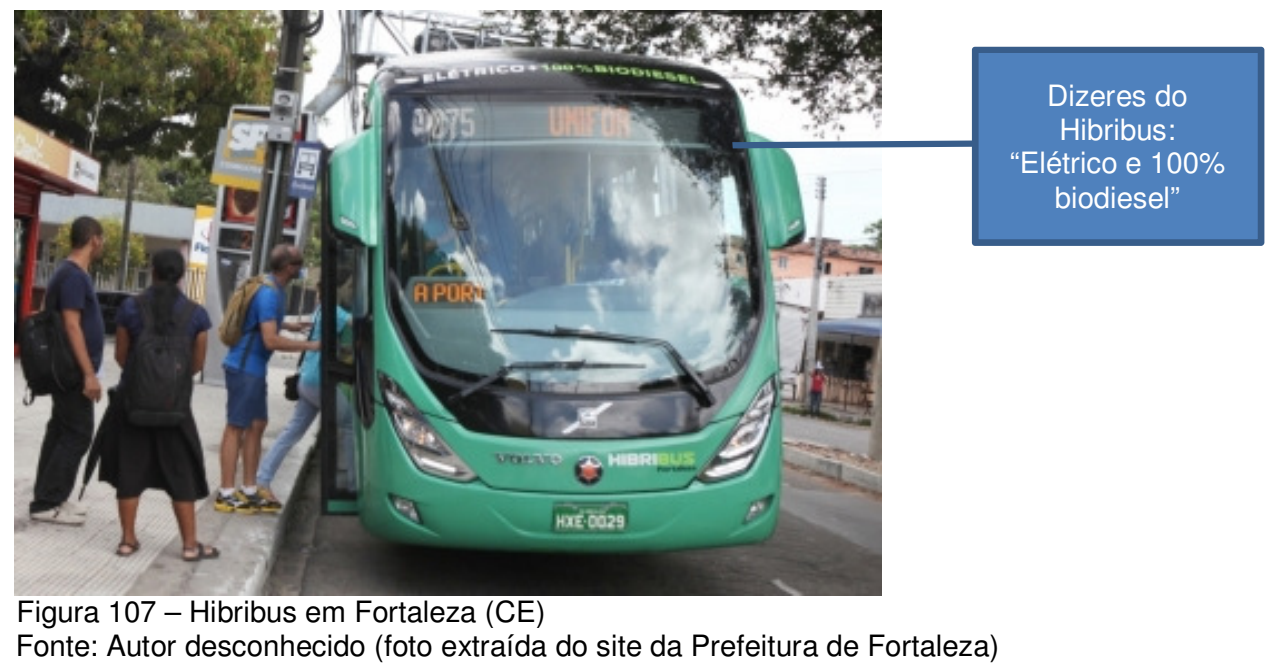

Destino: Guaramiranga

Inovação: Festival de Jazz e Blues de Guaramiranga Iniciativa:

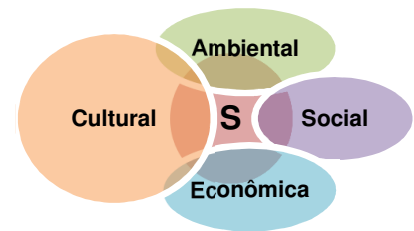

Breve contextualização da inovação: Como foi exposto no capítulo 1, o município inovou ao criar o Festival de Jazz e Blues de Guaramiranga, que hoje é, principalmente, um instrumento de valorização cultural e geração de emprego e renda no local.

Fonte: Especialista (Consultora, São Paulo, mais de 20 anos de experiência).

\section{PERNAMBUCO (PE)}

Destino: Arquipélago de Fernando de Noronha

Inovação: Limitação do número de visitantes (capacidade de carga)

Iniciativa: parcerias público-privadas

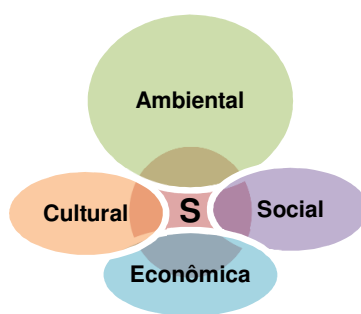

Breve contextualização da inovação: Fernando de Noronha é o destino que os brasileiros mais desejam conhecer no País (FIPE, 2012), foi tombado pela UNESCO como "Sítio do Patrimônio Mundial Natural em 2011 e possui a praia mais bonita do mundo, segundo o 
prêmio Traveller's Choice 2014 promovido pelo site Trip Advisor. O arquipélago também foi um dos destinos mais citados pelos especialistas participantes desta pesquisa quanto a práticas de inovação para a sustentabilidade. Isto porque têm sido desenvolvidos diversos trabalhos de conservação da natureza, que inclui controle de visitação mediante pagamento obrigatório de Taxa de Preservação Ambiental, trilhas suspensas (inclusive com acessibilidade para pessoas portadoras de necessidades especiais e pessoas de mobilidade reduzida), mirantes e estrutura (construída de forma sustentável) de chuveiros, banheiro, guarda-volumes, lanchonete e aluguel de equipamentos para mergulho. Em uma parte da ilha existem restrições legais de uso e ocupação do solo, uma vez que é Parque Nacional Marinho. No entanto, é possível, do ponto de vista legal, realizar concessões (temporárias) para que empresas turísticas possam operar dentro dessa área conforme ações e processos pré-estabelecidos. Após o tempo de concessão, tudo o que foi construído ficará como legado para a ilha. Segundo alguns especialistas desta pesquisa existe bastante informação dos guias para os turistas (são realizadas palestras de boas-vindas com equipes de biólogos) e é rígido o controle de visitação nos atrativos por parte dos atores locais. Uma curiosidade que vale destacar é que a classificação (extraoficial) dos meios de hospedagem da ilha é por "golfinho" (de 1 a 3 golfinhos), semelhante à classificação por estrelas.

Fontes: Especialistas participantes da pesquisa e Governo do Estado de Pernambuco (http://www.noronha.pe.gov.br/)

Destino: Litoral pernambucano

Inovação: Praia Sem Barreiras

Iniciativa: pública

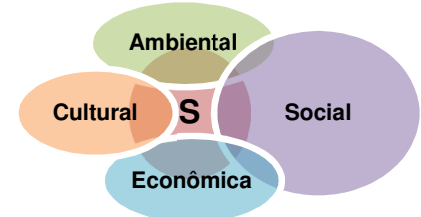

Breve contextualização da inovação: O Praia Sem Barreiras é um projeto inovador da Secretaria de Turismo de Pernambuco para que pessoas portadoras de necessidades especiais e com mobilidade reduzida possam tomar banho de mar assistido nas praias do Sueste (Fernando de Noronha), da Boa Viagem (Recife), Porto de Galinhas (Ipojuca) e Bairro Novo (Olinda). Nessas praias são colocadas esteiras de acesso até o mar, que são usadas pelos profissionais para levar os visitantes em "cadeiras anfíbias", tal como mostra a Figura 108. O projeto foi premiado em 2013 pelo MTur e pela Braztoa.

Fonte: Governo do Estado de Pernambuco (http://www.pe.gov.br/b/3297) 


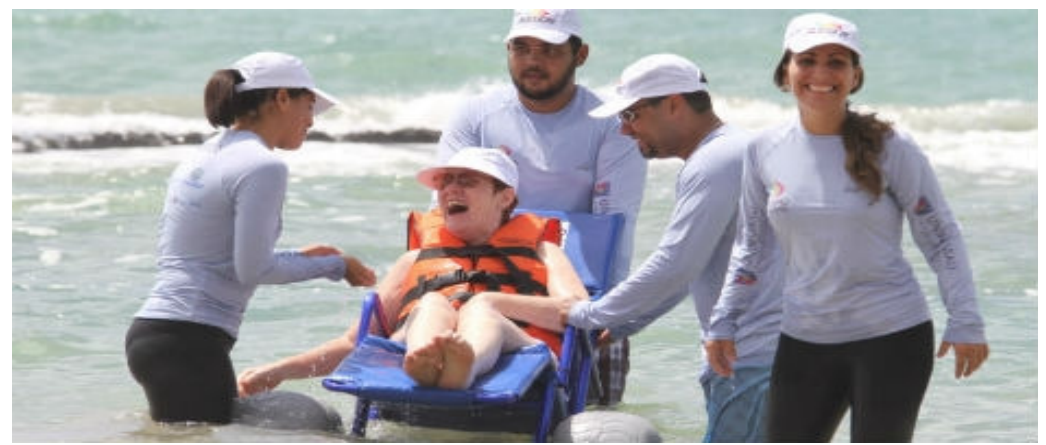

Figura 108 - Praia sem barreiras em Recife (PE)

Fonte: Bobby Fabisak/JC Imagem

\section{BAHIA (BA)}

Destino: Santo André, distrito de Santa Cruz Cabrália

Inovação: Organização social do turismo

Iniciativa: parceria privada com sociedade civil

Breve contextualização da inovação: Segundo o especialista participante Santo André é "um pequeno território onde os proprietários de excelentes residências à beira mar conseguiram se unir com moradores locais, descendentes de pescadores, recuperando a história, a cultura e preservando a biodiversidade". Embora o vilarejo esteja próximo de um dos maiores destinos de turismo de massa do País (Porto Seguro, Arraial D'Ajuda e Trancoso), conserva o patrimônio natural e cultural com o engajamento de atores locais. Por não ter acesso a informações mais específicas sobre quais seriam as inovações, optamos por não dispor o pictograma. Todavia, é um caso peculiar e que também merece destaque.

Fonte: Especialista (Empresário, Rio de Janeiro, mais de 20 anos de experiência) e Jornal do Sol (http://www.jornaldosol.com.br/?/turismo/114/)

\section{MATO GROSSO (MT)}

Destino: Hotel Cristalino Lodge (Alta Floresta)

Inovação: Tecnologias usadas para conservação ambiental

Iniciativa: privada

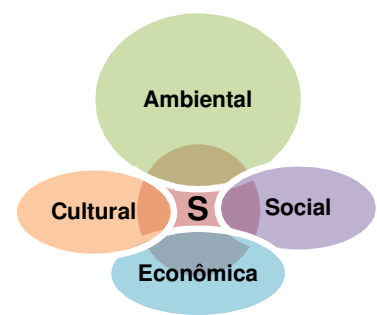

Breve contextualização da inovação: Esta foi indicação de um especialista (Professor universitário, São Paulo, de 16 a 19 anos de experiência). Em termos de conservação ambiental, as ações são: reciclagem e separação do lixo inorgânico, aquecimento da água com energia solar, tratamento dos efluentes cinzas com um sistema orgânico de permacultura, tratamento dos efluentes negros com um sistema de camadas de filtros e 
bacia de evapotranspiração, construção arquitetônica priorizando a ventilação natural, adoção de produtos de limpeza biodegradáveis, troca racional da roupa de cama e de banho (diminuição do consumo de água e energia), capacitação dos colaboradores quanto ao uso responsável dos recursos e correta condução dos visitantes nas trilhas, preferência por produtos orgânicos, limitação dos grupos de trilhas (máximo oito visitantes/grupo), oferta de número limitado de acomodações (são 16 unidades) e criação da Fundação Cristalino, cujo comitê é composto por biólogos, cientistas e gestores. Com relação às ações socioculturais são desenvolvidos projetos junto a escolas da região e trabalhos de pesquisa.

Fonte: Hotel Cristalino Lodge (http://cristalinolodge.com.br/pt/).

\section{DISTRITO FEDERAL (DF)}

Destino: Brasília

Inovação: Guia turístico com mapa das árvores frutíferas da cidade

Iniciativa: acadêmica

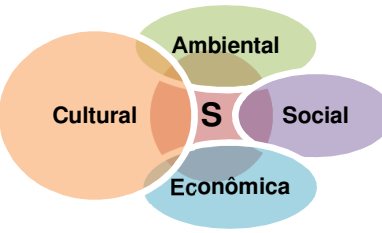

Breve contextualização da inovação: Em 2013 a então estudante da Universidade de Brasília Gabriela Bilá criou um guia turístico diferenciado para a capital federal como resultado de seu trabalho de conclusão de curso da Faculdade de Arquitetura e Urbanismo. Para que o guia fosse viabilizado, inclusive em inglês, ela optou pelo financiamento coletivo (crowdfunding) e, assim, em 2014 foi publicado o "Novo Guia de Brasília" (https://www.facebook.com/novoguiadebrasilia). Em função da Copa do mundo que seria realizada na cidade, Bilá pensou em produzir um material turístico que fosse além da arquitetura de Oscar Niemeyer. Uma das grandes inovações do guia é a criação de um mapa da cidade com pontos que indicam a presença de árvores frutíferas (muitas delas típicas do bioma Cerrado), tal como mostra a Figura 109.

Fonte: UnB Agência (http://unb.br/noticias/unbagencia/unbagencia.php?id=8217) 


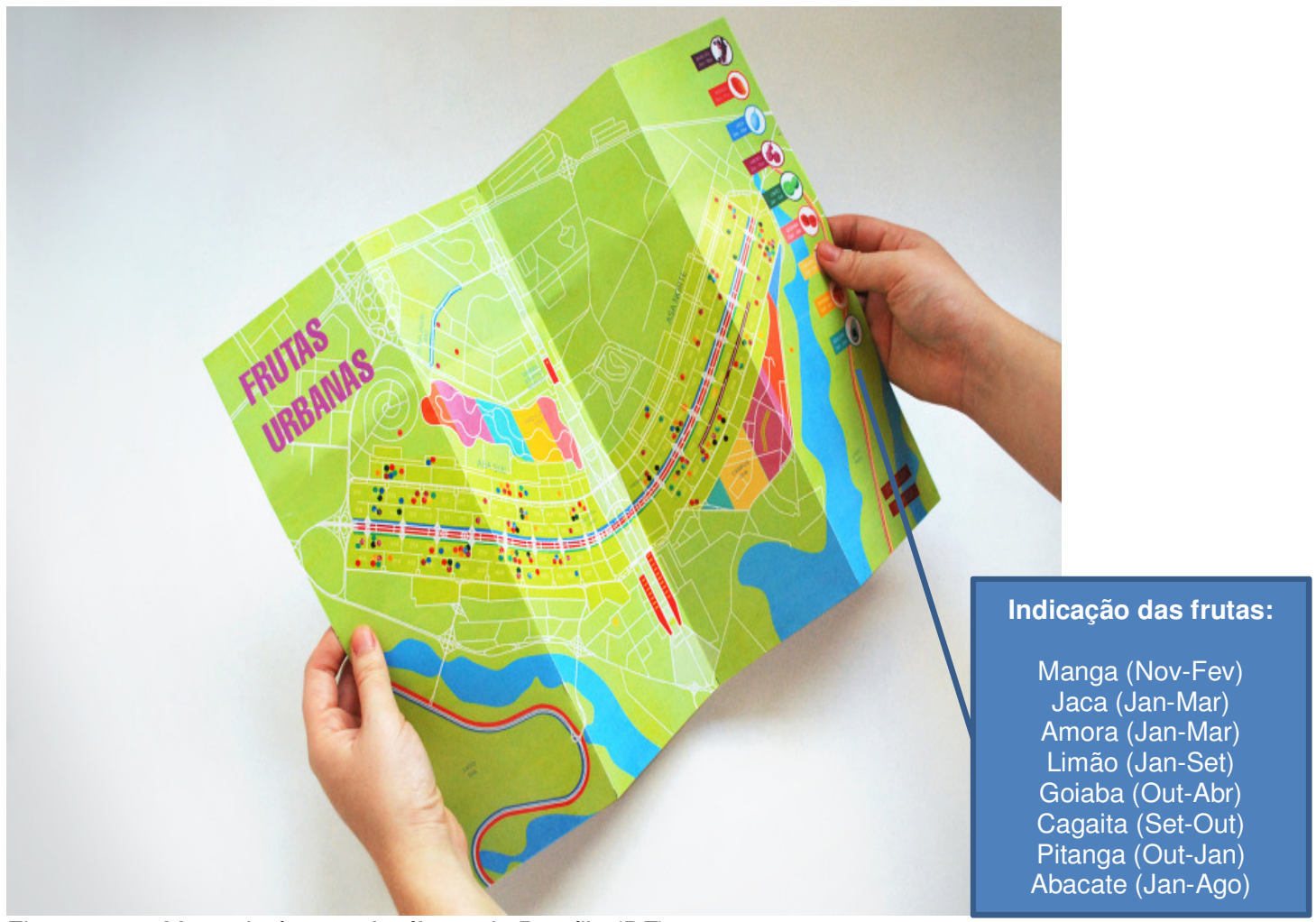

Figura 109 - Mapa de árvores frutíferas de Brasília (DF) Crédito: Autor desconhecido (2014)

\section{GOIÁS (GO)}

Destino: Pirenópolis

Inovação: Calendário de eventos culturais

Iniciativa: público-privada

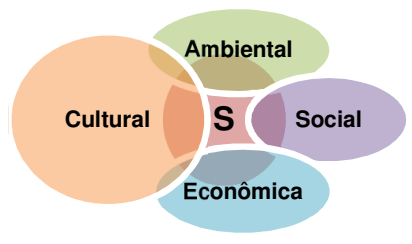

Breve contextualização da inovação: Segundo especialista (consultora, Distrito Federal, até 3 anos de experiência), o município criou um calendário de eventos coerente com as características culturais, históricas e ambientais da própria localidade. Exemplos: Slow Filmes (Festival Internacional de Cinema e Alimentação), Canto da primavera, Flipiri (Festa Literária).

Fonte: Especialista (Consultora, Distrito Federal, até 3 anos de experiência) FLIPIRI - 5ª Festa Literária de Pirenópolis 


\section{RIO DE JANEIRO (RJ)}

A cidade do Rio de Janeiro, de maneira geral, tem se destacado pelos diversos eventos que sedia e por buscar alternativas inovadoras, como a sanção da Lei $n^{\circ} 12.924$ (Lixo Zero) e a criação do Museu de Arte do Rio (MAR), do Porto Maravilha e de novos roteiros turísticos baseados na experiência. Um desses roteiros inclui a Rua do Lavradio, localizada no centro da cidade. Atualmente ela vem se tornando um grande polo de turismo cultural, pois a Rua e arredores se transformaram consideravelmente. Um dos motivos do sucesso é a parceria público-privada para dar evidência aos antiquários locais. Em termos de sustentabilidade, em 2014 foi finalista do concurso "We love cities", promovido pela Rede WWF (World Wide Fund for Nature).

No estado, segundo especialistas participantes desta pesquisa, também existem diversas iniciativas inovadoras para mobilizar, qualificar e engajar os stakeholders do trade turístico, de tal modo que os roteiros criados tenham proposta para além das praias. O Tour da Experiência proposto para a Serra Carioca é uma inovação evidente desses processos.

Destino: Vale do Café

Inovação: Site do Inventário das Fazendas de Café

Iniciativa: público-privada

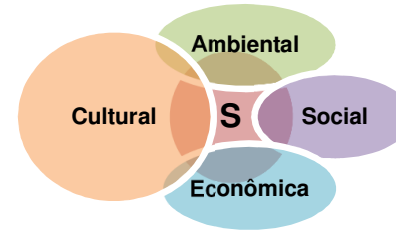

Breve contextualização da inovação: Segundo o especialista (empresário, Rio de Janeiro, mais de 20 anos de experiência), há mais de 20 anos os atores locais do Vale do Café buscavam se organizar para superar a crise da (queda) do café. Atualmente a região tem investido bastante em turismo cultural. Inclusive, foi criado o site do Inventário das Fazendas de Café do Rio de Janeiro (www.institutocidadeviva.org.br/inventarios) e um guia cultural com indicação dos atrativos. Em 3 anos de criação do site foram 7,5 milhões de acessos.

Fonte: Especialista (Empresário, Rio de Janeiro, mais de 20 anos de experiência).

Destino: Paraty

Inovação: Festa Literária Internacional de Paraty (FLIP)

Iniciativa: terceiro setor

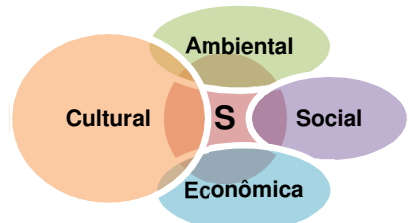

Breve contextualização da inovação: A cidade foi citada por alguns especialistas porque a FLIP tem contribuído bastante para o desencadeamento de transformações urbanas positivas. A FLIP, que é uma organização sem fins lucrativos, visa atuar na resolução de 
problemas de infraestrutura e valorização do patrimônio cultural e literatura, de tal modo que a população local se aproprie dos espaços públicos.

Fonte: http://www.flip.org.br/

\section{SÃO PAULO (SP)}

A cidade de São Paulo e especialmente a região do ABC Paulista convivem com a superpopulação, "superlotação" e "superpoluição" e, paradoxalmente, com o nascimento e desenvolvimento de práticas inovadoras com princípios de sustentabilidade. A necessidade de se melhorar a mobilidade urbana e proporcionar mais qualidade de vida para os moradores contribuíram para que surgissem diversos casos na capital dignos de menção, como jardins verticais, Bike Sampa, Escola de Inovação social, substituição de vagas de estacionamento por espaços de convivência e ciclovias, entre outros. No espaço físico escasso de São Paulo, existe um espaço sem limites para a criatividade e inovação, que podem ser grandes aliadas na busca por melhores condições de trabalho e vida social. Prédios inteligentes, sistemas de rodízios, esquemas de caronas solidárias, inclusão de trabalho noturno para aqueles funcionários que possuem hábitos noturnos e valorização da gastronomia brasileira fazem parte de um grande rol de inovações que repercutem direta e indiretamente o turismo, inclusive sob uma lógica sistêmica de sustentabilidade. No estado tem-se no corredor Diadema-São Paulo a circulação do $1^{\circ}$ ônibus elétrico brasileiro (100\% bateria) e em São Bento do Sapucaí os visitantes de uma fazenda podem escolher frutas direto do pé. Deste estado surgem diversas ideias, iniciativas, novos conceitos e práticas, assim como se replica ideias vindas de outras localidades.

Destino: São Paulo

Inovação: Eco-temakeria

Iniciativa: privada

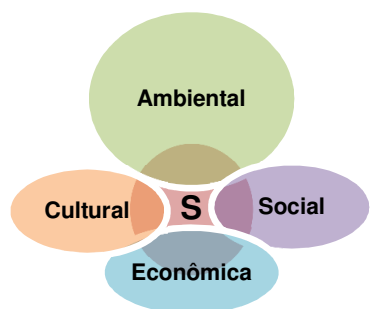

Breve contextualização da inovação: Trata-se de um empreendimento que comercializa temakes (comida japonesa) em uma van (vide Figura 110), que por sua vez está equipada com painéis de energia solar e hastes eólicas, proporcionando autonomia energética (geralmente são 12 horas). Além disso, utiliza-se biodiesel e PET nas embalagens. A 
empresa afirma também que realiza coleta seletiva, porém, analisando o negócio do ponto de vista da sustentabilidade, é preciso considerar todo o ciclo de vida. Isto é: neste caso, é preciso identificar para quem e para onde cada tipo de resíduo é encaminhado, bem como se o destino final é ecológico, como a reutilização, compostagem, reciclagem, entre outras alternativas.

Fonte: Navan (http://www.navan.com.br/)

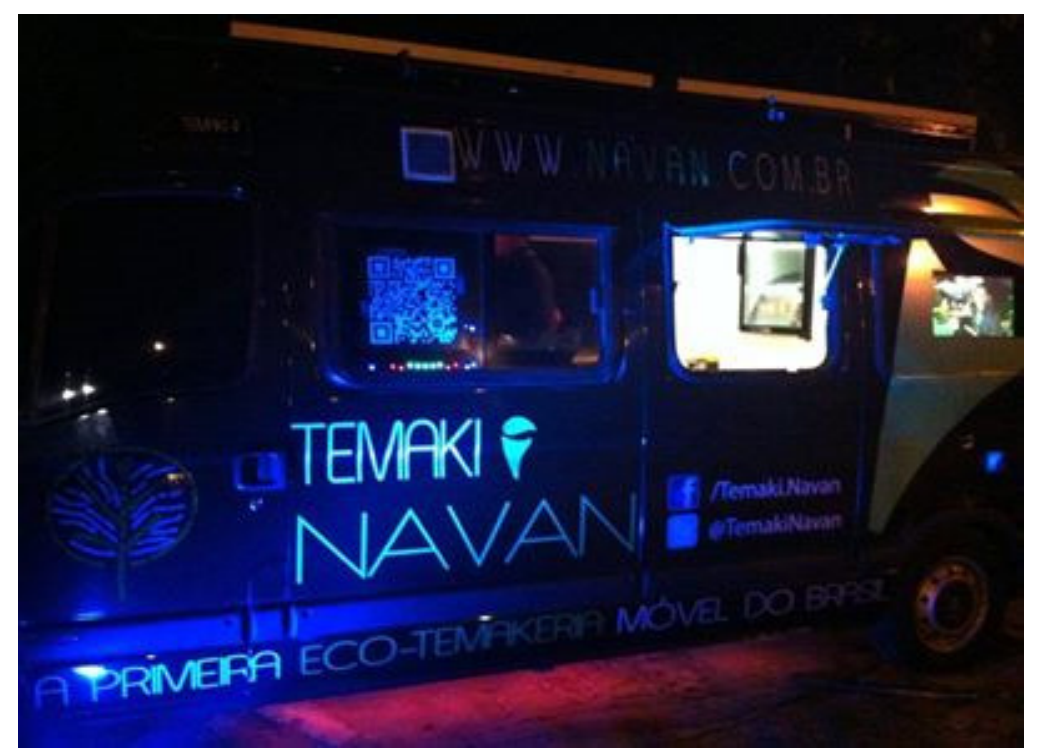

Figura 110 - Eco-temakeria em São Paulo (SP)

Crédito: Temaki Navan

Destino: Brotas e Socorro

Inovação: Acessibilidade no segmento turismo de aventura

Iniciativa: poder público, iniciativa privada, terceiro setor e sociedade

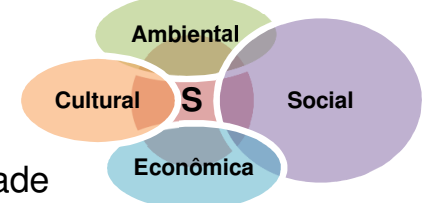

Breve contextualização da inovação: Os dois destinos turísticos foram citados por alguns especialistas, justamente porque ambos foram pioneiros no Brasil no segmento turismo de aventura. Brotas foi pioneira ao viabilizar práticas de rapel em cachoeiras. Além disso, os dois destinos foram os primeiros do País a disponibilizar um sistema de adequação de atrativos de turismo de aventura para pessoas portadoras de necessidades especiais e mobilidade reduzida. Na região, alguns meios de hospedagem utilizam painéis de energia solar para aquecer a água dos chuveiros.

Fonte: Especialistas participantes da pesquisa e Sebrae (http://www.rj.agenciasebrae.com.br/sites/asn/uf/RJ/Pioneirismo,-associativismo-ecriatividade-s\%C3\%A3o-segredos-de-Brotas-e-Socorro-como-destinos-tur\%C3\%ADsticos). 


\section{PARANÁ (PR)}

Curitiba é conhecida nacional e mundialmente por seu modelo de gestão sustentável, já premiada como Cidade mais Verde do Mundo (Global Green City Award) e por ter um dos melhores sistemas de transporte sustentável do mundo (Sustainable Transport Award e ILEC - International Institute for Energy Conservation). A capital paranaense é conhecida pela criação de comunidades inteligentes, programas de carbono zero, lixo zero, planejamento urbano sustentável (sobretudo em relação à mobilidade), edifícios e habitações verdes, por ter um dos melhores sistemas públicos de ensino do Brasil, melhores projetos de design, uma das cidades mais arborizadas do País e por ser a primeira capital 100\% adequada para o saneamento básico. Em 2014 a prefeitura lançou o projeto Curitiba Ecoelétrico para que a frota do município tenha pelo menos dez carros e três micro-ônibus movidos a eletricidade (CIDADES INOVADORAS, 2012; CURITIBA, 2014).

Destino: Curitiba

Inovação: Impactometro® e parceria entre ImpacTour e Loon Solar Boat Iniciativa: privada

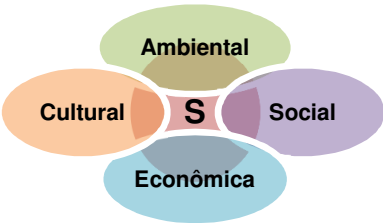

Breve contextualização da inovação: A ImpacTour é uma startup brasileira (http://www.impactour.org/) que criou o Impactometro®, um algoritmo capaz de medir a pegada ecológica de turistas desde o tipo de transporte utilizado até duração da viagem e os serviços que utiliza. Esse algoritmo contempla critérios relacionados às dimensões ambiental, cultural, social e econômica da sustentabilidade. No site da empresa é possível, ao mesmo tempo, compartilhar roteiros turísticos e receber dicas daqueles que são mais sustentáveis. Além disso, a ImpacTour é a única empresa representante no Brasil da Loon Solar Boat, embarcação 100\% movida a energia solar (no Brasil ainda não há nenhuma embarcação com essa tecnologia). Com o intuito de obter financiamento para trazer uma embarcação como essa para o País, a ImpacTour tem adotado duas formas de financiamento: crowdfunding (coletivo, pessoas físicas) e sponsorship (patrocínio, empresas). A ação mais recente de crowdfunding foi o projeto "\#CheerForPeace" (\#TorcidaPelaPaz). Cada contribuição financeira permitia o plantio de três árvores, pratos de comida seriam doados e camisas de futebol seriam doadas para crianças.

Fonte: Blog da ImpacTour (http://blog.impactour.org/solar-boat-tours.html). 
Destino: Foz do Iguaçu

Inovação: Parque Tecnológico Itaipu (PTI)

Iniciativa: privada - parcerias público-privadas e com o terceiro setor

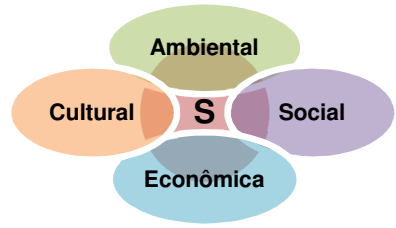

Breve contextualização da inovação: $\mathrm{P}$ PTI foi criado pela Itaipu Binacional (http://www.pti.org.br/) em 2003 e sua área, que corresponde a 116 hectares, reúne centros e laboratório de pesquisa, instituições de ensino e empresas. A atuação do PTI não apenas se limita ao território brasileiro, pois se estende ao Paraguai e Argentina, tal como demonstra a Figura 111. Em 2007 a Fundação PTI passou a operar e gerir o Complexo Turístico Itaipu (CTI) (https://www.turismoitaipu.com.br/pt). Diversas inovações foram desenvolvidas desde então pela Fundação, quais sejam: i) contratação de ex-barrageiros para serem guias do atrativo "visita panorâmica"; ii) em 2012 foi lançado o atrativo "Test Drive Veículo Elétrico"; iii) reabertura do Ecomuseu com uma maquete de 76 metros quadrados e iv) nova iluminação da barragem (que é um dos atrativos do CTI) com projeto de lightning design. Em 2013 a Itaipu foi considerada um dos principais atrativos turísticos do Brasil e do continente de acordo com a pesquisa Travellers Choice 2013 do site TripAdvisor, sendo o terceiro principal ponto de referência do Brasil (atrás do Cristo Redentor, no Rio de Janeiro e da Rua das Pedras, em Búzios) e o 15ํponto de referência da América do Sul. No mesmo ano, o CTI recebeu 586.307 visitantes. Dentre diversos programas criados pela Fundação PTI é possível destacar o de Turismo Sustentável, que visa articular e fomentar ações de pesquisa, inovação e planejamento para o turismo da região. Para que o programa seja executado requer a interação com atores internos, regionais, nacionais e internacionais. Além disso, cabe ressaltar os trabalhos desenvolvidos pelo Instituto Polo Internacional Iguassu. Este Instituto é uma associação de direito privado, sem fins econômicos e que objetiva apoiar e desenvolver o turismo na Região Trinacional do Iguassu e do Mercosul. Uma das áreas de estudo do Instituto é a inovação em turismo.

Fonte: Parque Tecnológico Itaipu (http://www.pti.org.br/) 


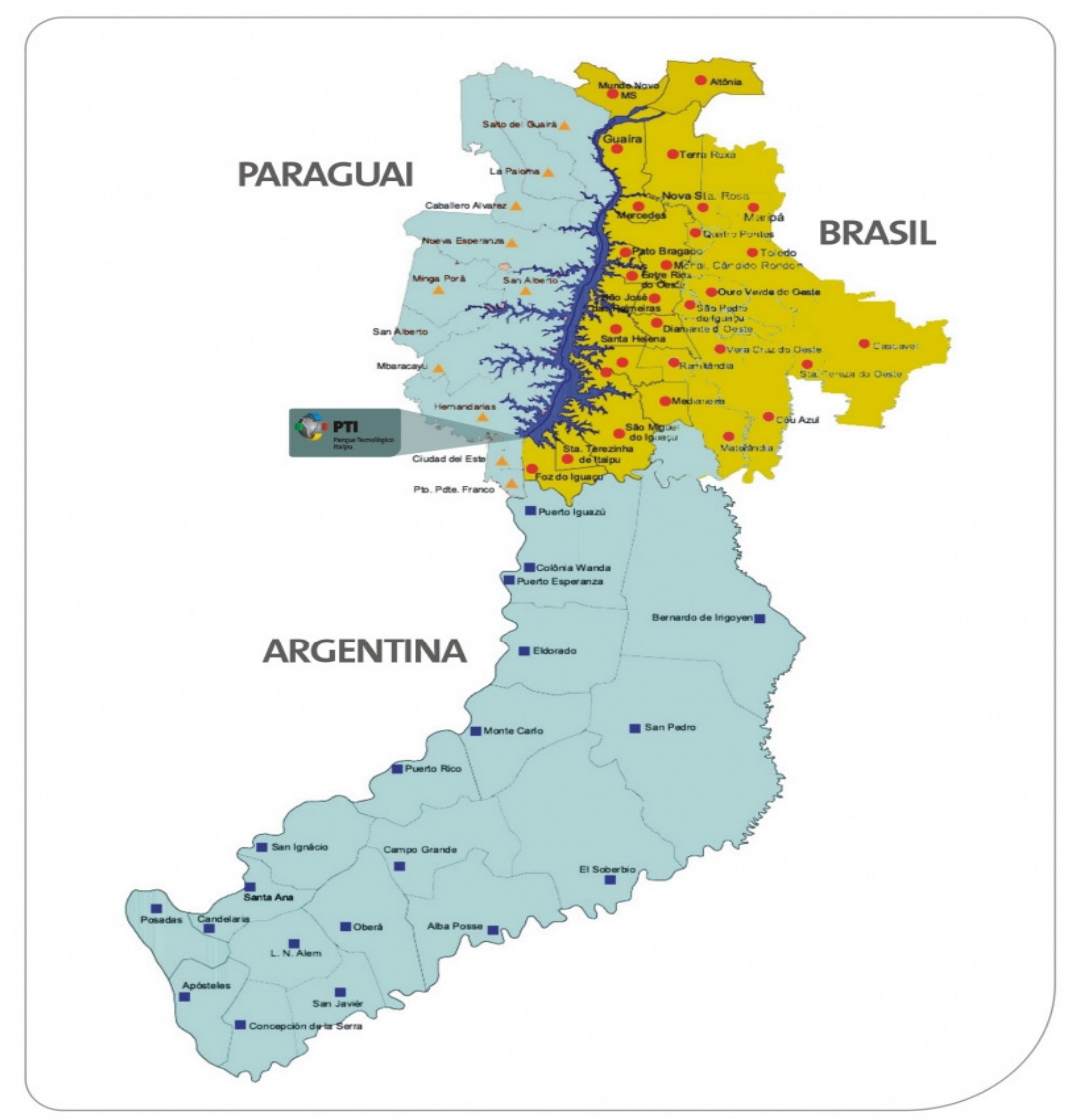

ÁREA DE INFLUÊNCIA - PARQUE TECNOLÓGICO ITAIPU

ÁREA DE ABRANGÊNCIA - BACIA DO PARANÁ III (BR)

ÁREA DE INTERESSE - MISIONES (ARG) E MUNICÍPIOS LINDEIROS (PY)

Figura 111 - Mapa das áreas geográficas de atuação Parque Tecnológico Itaipu (PTI) Fonte: http://www.pti.org.br/

\section{SANTA CATARINA (SC)}

Destino: Anitápolis, Urubici, Rancho Queimado e Santa Rosa de Lima - Região das Encostas da Serra Geral (SC) Inovação: Acolhida na Colônia

Iniciativa: associativismo

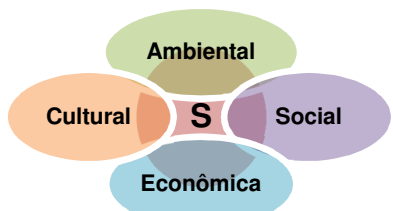

Breve contextualização da inovação: Segundo a especialista (Professora universitária, São Paulo, de 16 a 19 anos de experiência), "[...] além de inovar é preciso conseguir manter, aprimorar e ampliar os processos de inovação, envolvendo novas gerações, questões que preocupam e estão incorporadas nas ações do pessoal da Acolhida [na Colônia]". Criada em 
1999, a Acolhida na Colônia é uma associação que integra 180 famílias de agricultores e que está vinculada à rede francesa Accueil Paysan. Segundo informações do site da associação, "temos como proposta valorizar o modo de vida no campo através do agroturismo ecológico. Seguindo essa proposta, nós, agricultores familiares de Santa Catarina, abrimos nossas casas para o convívio do nosso dia-a-dia. O objetivo é compartilhar com você nosso saber fazer, nossas histórias e cultura, nossas paisagens... oferecemos hospedagens simples e aconchegantes com direito a conversas na beira do fogão a lenha, a tradicional fartura de nossas mesas e passeios pelo campo". Desde a criação, a associação já recebeu seis prêmios.

Fonte: Especialista (Professora universitária, São Paulo, de 16 a 19 anos de experiência) e Acolhida na Colônia (http://www.acolhida.com.br/).

Destino: Blumenau

Inovação: Oktoberfest

Iniciativa: público-privada e sociedade

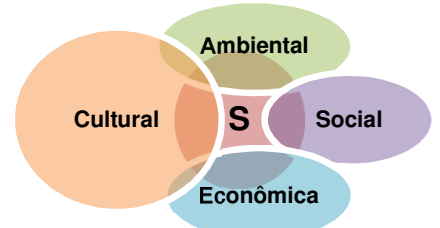

Breve contextualização da inovação: Segundo o especialista (Consultor, Santa Catarina, mais de 20 anos de experiência), em função da uma tragédia ambiental que ocorreu em 1984 (enchente que devastou a cidade), Blumenau se mobilizou para reconstruir e resgatar "a bravura dos colonizadores. Para festejar criaram a Oktoberfest". Hoje é a segunda maior festa alemã do mundo (perde somente para a Oktoberfest da Alemanha). Além da valorização cultural e criação de empregos (diretos e indiretos), os resíduos são encaminhados para reciclagem e parte deles retorna sob a forma de produtos, como sacolas (em dois anos foram encaminhados para reciclagem 7,7 mil metros de lonas utilizadas na decoração do evento) e camisas (feitas de fibras de garrafas PET).

Fonte: Especialista (Consultor, Santa Catarina, mais de 20 anos de experiência) e Oktoberfest (http://www.oktoberfestblumenau.com.br/). 


\section{ANEXO 1 - Critérios de sustentabilidade segundo OMT/GSTC}

\section{A. DEMOSTRAR UNA GESTION SOSTENIBLE EFICAZ}

\section{A1 Estrategia de turismo sostenible}

El destino ha establecido y se encuentra implementando una estrategia de varios años en turismo sostenible, que se encuentra públicamente disponible, se ajusta a su escala y toma en consideración los impactos ambientales, socio-culturales, de calidad, salud y seguridad, incluyendo sus impactos acumulados.

\section{A2 Organización de gestión turística}

El destino cuenta con una organización funcional responsable, que propicie un acercamiento coordinado al turismo sostenible el cual cuente con la participación del sector turístico, gobierno local y comunidad participativa con responsabilidades delegadas a las partes responsables para administrar temas ambientales, socio-culturales y de turismo sostenible.

\section{A3 Monitoreo del turismo sostenible}

El destino cuenta con un programa para monitorear, reportar públicamente y respaldar las respuestas a temas acumulativos ambientales, socio-culturales y de turismo sostenible a nivel de destino.

\section{A4 Administración turística estacional}

El destino cuenta con programas diseñados para minimizar los efectos de la variabilidad estacional del turismo, donde sean apropiados, mientras que reconoce el impacto ecológico y cultural de tales programas.

\section{A5 Adaptación al cambio climático}

El destino cuenta con un programa para identificar los riesgos asociados con el cambio climático y promueve la adaptación en el desarrollo, localización, diseño y manejo que contribuirá a la sostenibilidad y fortalecimiento del destino para enfrentar los cambios potenciales.

\section{A6 Inventario de sitios atractivo}

El destino cuenta con un proceso continuo para identificar sus activos y atractivos turísticos claves, así como para identificar los impactos potenciales clave (positivos o negativos) en los mismos.

\section{A7 Diseño y construcción}

El destino cuenta con requisitos de planificación y leyes relacionadas a la planificación, localización, diseño, construcción, materiales, renovación, demolición y estudio de impacto para proteger su patrimonio natural y cultural.

\section{A8 Accesibilidad al sitio}

Sitios clave de atracción turística con infraestructura y facilidades en el destino, incluyendo alojamientos, facilidades que brinden alimentación y bebidas, así como los medios de transporte para llegar al lugar, son accesibles para personas con necesidades especiales, donde sean apropiados, y se cumple con todos los requisitos legales con respecto a su accesibilidad.

\section{A9 Derechos de propiedad locales}

Las adquisiciones de propiedad son legales, cumplen con los derechos indígenas y de comunidades locales, incluyendo su libre, previo e informado consentimiento, y no requieren un reasentamiento involuntario.

\section{A10 Monitoreo de la satisfacción del turista}

El destino cuenta con un programa y política para medir y reportar acerca de la satisfacción, percepciones, conductas e inquietudes del turista.

\section{A11 Sostenibilidad del sector privado}

El sector turístico en el destino ha implementado políticas específicas para un turismo sostenible, o programas de certificación fidedignos y programas que aseguren la calidad. 


\section{A12 Seguridad del turismo}

El destino cuenta con un programa in situ para combatir el crimen relacionado con el turismo y peligros para la salud y la seguridad

\section{A13 Preparación para el manejo de crisis}

El destino ha establecido y provisto los recursos para un plan de preparación de manejo de crisis que se encuentre disponible para turistas, empresas turísticas y organizaciones y las comunidades locales.

\section{A14 Mercadeo del turismo sostenible}

El destino cuenta con un programa para desarrollar y promover productos y servicios sostenibles que sean compatibles con sus condiciones ecológicas, sociales y culturales.

\section{A15 Materiales de promoción}

Los materiales de promoción son exactos y completos en relación al destino, sus productos y servicios, e incluyen declaraciones acerca de la sostenibilidad del destino. Los mismos no prometen más allá de aquello que proveen.

\section{B. MAXIMIZAR LOS BENEFICIOS SOCIALES Y ECONÓMICOS PARA LA COMUNIDAD LOCAL Y MINIMIZAR LOS IMPACTOS NEGATIVOS}

\section{B1 Beneficio económico}

La contribución económica del turismo para la economía del destino es monitoreada y reportada públicamente.

\section{B2 Oportunidades locales de trabajo}

El destino brinda oportunidades justas y equitativas de empleo en el sector turístico, capacitación para mujeres, jóvenes, minorías y otras poblaciones vulnerables, incluyendo pago de salarios justos, y brinda oportunidades de capacitación para posiciones de manejo y dirección, a la vez que restringe el trabajo infantil.

\section{B3 Participación Pública}

El destino cuenta con un programa para motivar y facilitar la participación pública en la planificación turística y toma de decisiones de manera continua.

\section{B4 Satisfacción local}

Las aspiraciones de las comunidades, sus inquietudes y satisfacciones en relación al turismo son monitoreadas de manera regular y son compartidas públicamente por el destino.

\section{B5 Acceso local}

El destino protege el acceso local a sitios y atractivos naturales, históricos, arqueológicos, religiosos, espirituales y culturales, incluyendo el uso de la tierra y recurso hídricos, derechos de vía, transporte y alojamiento.

\section{B6 Conciencia turística}

El destino brinda a los residentes del destino programas regulares para crear una conciencia turística.

\section{B7 Prevención de la explotación}

El destino ha implementado una política en contra de la explotación comercial, sexual o de cualquier otro tipo de explotación y acoso, particularmente de niños, adolescentes, mujeres y minorías.

\section{B8 Apoyo a la comunidad local}

El sector turístico y actores interesados se encuentran activamente involucrados en el impulso y apoyo de iniciativas de desarrollo e infraestructura adecuadas para la comunidad.

\section{B9 Principios de comercio justo}

El destino cuenta con un programa in situ que apoya a las pequeñas empresas locales y promueve el uso de productos y servicios locales sostenibles así como los principios de comercio justo que se ubiquen en áreas 
naturales, históricas y culturales (tales como alimentación y bebidas, artesanías, artes, productos agrícolas, etc.)

B10 Desempeño de empresas turísticas

El destino cuenta con programas que apoyen la sostenibilidad económica de la pequeña y mediana empresa,

relacionadas al sector turístico.

\section{MAXIMIZAR BENEFICIOS A LAS COMUNIDADES, A LOS VISITANTES Y AL PATRIMONIO CULTURAL Y MINIMIZAR LOS IMPACTOS NEGATIVOS}

\section{C1 Protección de los sitios atractivos}

El destino cuenta con una política y programa para conservar sus atracciones turísticas naturales y culturales claves para asegurar que los paisajes, ecosistemas y hábitats se encuentran identificados. Sus amenazas han sido identificadas y evaluadas. Se busca la sostenibilidad de su acceso y manejo.

\section{C2 Plan de manejo de visitantes}

El destino cuenta con un plan de manejo de visitantes para los sitios atractivos clave, incluyendo medidas para preservar y proteger sitios clave de valor natural y cultural

\section{C3 Conducta de los visitantes e interpretación en los sitios vulnerables}

El destino ha desarrollado lineamientos para la interpretación, así como códigos de conducta para visitantes de los sitios cultural y ecológicamente vulnerables con el fin de minimizar el impacto de los visitantes y maximizar su disfrute.

\section{C4 Protección al patrimonio cultural}

No se venden, comercializan o exhiben artículos históricos y arqueológicos, salvo que sea permitido por la ley.

\section{C5 Interpretación de los sitios}

Se brinda a los visitantes, en diferentes idiomas, información e interpretación acerca de los entornos naturales, cultura local y patrimonio cultural. Se incluye también información sobre la conducta apropiada al momento de visitar las áreas naturales, culturas vivas, sitios patrimonio cultural y comunidades.

\section{C6 Protección a la propiedad y derechos de la comunidad}

El destino contribuye a la protección y conservación de los derechos de propiedad intelectual de las comunidades locales y de los derechos de propiedad de sitios que son local, histórica, arqueológica, cultural y espiritualmente importantes para el destino.

\section{C7 Viajes filantrópicos}

El destino motiva las contribuciones de los turistas para el desarrollo de la comunidad y para la conservación de la biodiversidad, incluyendo el apoyo a áreas protegidas y áreas de gran importancia debido a su valor culturas y de biodiversidad.

\section{MAXIMIZAR LOS BENEFICIOS PARA EL MEDIO AMBIENTE Y MINIMIZAR LOS IMPACTOS NEGATIVOS}

\section{D1 Evaluación de la situación del medio ambiente}

El destino ha identificado los principales retos ambientales que enfrenta y cuenta con políticas y procesos para enfrentarlos.

\section{D2 Protección del ecosistema}

El destino cuenta con un sistema para medir el impacto del turismo y manejar los impactos del turismo intensivo sobre sus paisajes y ecosistemas, incluyendo hábitats de vida silvestre vulnerable o amenazada.

\section{D3 Conservación de la energía}

El destino cuenta con un programa para promover la conservación de la energía, para medir y reducir la dependencia de combustibles fósiles y motivar a las empresas turísticas a monitorear y conservar la energía, así como motivar el uso de energía de fuentes renovables. 


\section{D4 Reducción de gases de efecto invernadero}

El destino cuenta con un programa in situ para asistir a los operadores de turismo en la medición y reducción de sus emisiones de gases de efecto invernadero y motiva al sector turístico a participar en iniciativas que compensen y reduzcan su huella de carbono.

\section{D5 Conservación del recurso hídrico}

El destino cuenta con un programa para monitorear y conservar el agua que utiliza a nivel de destino y para motivar a las empresas turísticas a monitorear y conservar y el agua.

\section{D6 Consumo de agua}

El suministro de agua que se utiliza para el turismo a nivel de destino es ecológicamente sostenible y no afecta negativamente el uso que la comunidad hace de ella, toma en consideración los impactos acumulados en general de su uso en toda superficie local y subterránea.

\section{D7 Calidad del agua de superficie y agua de mar}

El destino cuenta con un sistema in situ para monitorear la calidad del agua tanto de fuentes de agua potable como de áreas acuáticas.

\section{D8 Manejo de residuos}

El destino cuenta con sistemas in situ para asegurar que los desechos generados por los sitios y empresas turísticas son debidamente tratados, reutilizados o desechados de manera segura, sin algún efecto adverso para la población local y el medio ambiente.

\section{D9 Reducción de la contaminación por desechos sólidos}

El destino cuenta con un sistema in situ para garantizar que los desechos por actividades relacionadas el turismo sean minimizados, reutilizados o reciclados. Cualquier mecanismo de disposición de desechos sólidos residuales del turismo y de las comunidades de apoyo es sostenible, con metas cuantitativas para minimizar los desechos que no sean reutilizables o reciclables.

\section{D10 Reducción de la contaminación}

El destino implementa prácticas para minimizar la contaminación causada por desechos de agua, vertederos, erosión, ruido, luz, sustancias nocivas, compuestos que deterioren el ozono y aire, y contaminantes del agua y de la tierra, además requiere a las empresas turísticas el implementar estas prácticas.

\section{D11 Transporte local}

El destino cuenta con una política y plan in situ para motivar el uso de transporte de bajo impacto, incluyendo el uso de transporte público.

\section{D12 Gestión ambiental}

El destino solicita a las empresas turísticas el contar con un plan de manejo ambiental el cual incluya medidas de control de la vegetación, vertederos, evitar la introducción de especies invasivas e implementar otras medidas de control para evitar la contaminación.

\section{D13 Conservación de la biodiversidad, ecosistemas y paisajes}

El destino cuenta con un programa in situ para cumplir con los lineamientos internacionales relacionados a la protección, recolección, y captura de vida silvestre (hábitats de fauna y flora) así como para el manejo de impactos del turismo en la vida silvestre. 


\section{ANEXO 2 - Tabelas geradas pelo Sistema PNUD (Comparação entre Bonito, Brumadinho e Gramado)}

Legenda:

Melhor índice

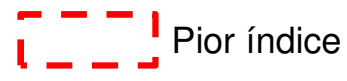

\begin{tabular}{|c|c|c|c|c|c|c|}
\hline & $\begin{array}{l}\text { \% de pessoss em } \\
\text { domicílios em que } \\
\text { ninguem tem } \\
\text { fundsmental } \\
\text { completo } \\
2010\end{array}$ & 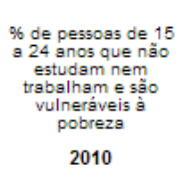 & $\begin{array}{l}\text { \% de pessoss de } 18 \\
\text { anos ou mais sem } \\
\text { fundamental } \\
\text { complete e em } \\
\text { ocupaçąo informal } \\
2010\end{array}$ & $\begin{array}{l}\text { \% de pessoss em } \\
\text { domicilios } \\
\text { vulneráveis a } \\
\text { pobreza e em que } \\
\text { ninguem tem } \\
\text { fundamental } \\
\text { completo. } \\
2010\end{array}$ & $\begin{array}{c}\text { \% de pessoss em } \\
\text { domicilios } \\
\text { vulneráveis à } \\
\text { pobreza e } \\
\text { dependentes de } \\
\text { idosos } \\
2010\end{array}$ & $\begin{array}{c}\text { \% de pessoas } \\
\text { vulneráveis à } \\
\text { pobreza e que } \\
\text { gastam mais de ums } \\
\text { hora atée o trabalho } \\
2010\end{array}$ \\
\hline Brasil & 24,92 & 11,61 & 35,24 & 13,46 & 2,42 & 1,42 \\
\hline Bonito (MS) & [38,48] & {$[7, \overline{8} \mathbf{7}$} & {$[41,197$} & {$[18, \overline{76}]$} & 1,807 & [0,53 ] \\
\hline Brumadinho (MG) & 25,09 & $6, \overline{04}$ & 34,92 & $8 \overline{2} 28$ & 2,08 & 0,38 \\
\hline Gramado (RS) & 21,26 & 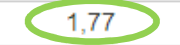 & & 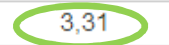 & 0,37 & 0,00 \\
\hline
\end{tabular}

\begin{tabular}{|c|c|c|c|c|c|c|}
\hline & $\begin{array}{l}\text { \% de mulheres de } 10 \\
\text { a } 14 \text { anos que } \\
\text { tiveram filhos } \\
2010\end{array}$ & $\begin{array}{l}\text { \% de mulheres de } 15 \\
\text { a } 17 \text { snos que } \\
\text { tiveram filhos } \\
2010\end{array}$ & $\begin{array}{l}\text { \% de mäes chefes de } \\
\text { familis sem } \\
\text { fundlamental } \\
\text { cumplemental } \\
\text { completo eom } \\
\text { filhos menores de } \\
\text { anos } \\
2010 \\
2010\end{array}$ & $\begin{array}{c}\text { \% de pessogs em } \\
\text { domicilios sem } \\
\text { energia elétrica } \\
2010\end{array}$ & $\begin{array}{c}\text { \% de pessogs em } \\
\text { domicílios com } \\
\text { paredes } \\
\text { inadequadss } \\
2010\end{array}$ & 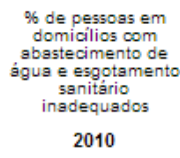 \\
\hline Brasil & 0,44 & 6,94 & 17,23 & 1,42 & 3,42 & 6,12 \\
\hline Bonito (MS) & 0,47 & 【9,51 $\mathbf{~}$ & ᄂ25,79| & 0,22 & $\lfloor 5, \overline{3} \mathbf{~}$ & 1,25 \\
\hline Brumadinho (MG) & {$[0,54 \mathbf{I}$} & 2,60 & 11,82 & L0,94 & 0,13 & |1, 68 | \\
\hline Gramado (RS) & 0,00 & 2,44 & 11,41 & 0,00 & 1,11 & 0,09 \\
\hline
\end{tabular}

\begin{tabular}{|c|c|c|c|c|c|}
\hline & $\begin{array}{l}\text { Mortalidade } \\
\text { infantil } \\
2010\end{array}$ & $\begin{array}{c}\% \text { de crianças } \\
\text { extremamente } \\
\text { pobres } \\
2010\end{array}$ & $\begin{array}{c}96 \text { de oriançss em } \\
\text { domicílios em que } \\
\text { ninguém tem } \\
\text { fundamental } \\
\text { completo } \\
2010\end{array}$ & $\begin{array}{c}\% \text { de crianças de } \\
4 \text { a } 5 \text { anos fora da } \\
\text { escola } \\
2010\end{array}$ & $\begin{array}{c}\% \text { de crianças de } \\
6 \text { a } 14 \text { anos fora } \\
\text { da escola } \\
2010\end{array}$ \\
\hline Brasil & 16,70 & 11,47 & 30,39 & 19,90 & 3,31 \\
\hline Bonito (MS) & L18,00 & 2,17 & [42,63 & L37,06 & 2,70 \\
\hline Brumadinho (MG) & 13,30 & {$[2, \overline{70}]$} & 26,15 & 9,27 & 1,60 \\
\hline Gramado (RS) & 10,60 & 1,10 & 21,80 & 27,66 & {$[3, \overline{14}]$} \\
\hline
\end{tabular}

\begin{tabular}{|c|c|c|c|c|c|}
\hline & $\begin{array}{c}\text { \% da populaçăo em } \\
\text { domicilios comm aggus } \\
\text { encanada } \\
2010\end{array}$ & $\begin{array}{c}\text { \% da populaçăo em } \\
\text { domicílios com } \\
\text { banheiro éagua } \\
\text { encanadgu } \\
2010\end{array}$ & $\begin{array}{c}\text { \% da populacăo em } \\
\text { domicílios comm } \\
\text { coleta ta de lixo } \\
2010 \\
2010\end{array}$ & $\begin{array}{c}\text { \% da populaçăo em } \\
\text { domicilios com } \\
\text { energila elétrica } \\
2010 \\
2010\end{array}$ & $\begin{array}{c}\text { \%o da populaçăo en } \\
\text { domicililos com } \\
\text { densidade } \gg 2 \\
2010\end{array}$ \\
\hline Brasil & 92,72 & 87,16 & 97,02 & 98,58 & 27,83 \\
\hline Bonito (MS) & 95,54 & 95,93 & 99,51 & 99,78 & 28,73 \\
\hline Brumadinho (MG) & [-82,68 & 97,92 & ᄂ $98.74^{7}$ & L99,06? & 16,77 \\
\hline Gramado (RS) & 96,24 & {$[92,25]$} & 100,00 & 100,00 & 10,20 \\
\hline
\end{tabular}




\begin{tabular}{|c|c|c|c|c|c|c|}
\hline & $\begin{array}{c}\text { \% dos ocupados com } \\
\text { fundamental } \\
\text { completo }-18 \text { anos } \\
\text { ou mais } \\
2010\end{array}$ & $\begin{array}{c}\% \text { dos ocupados com } \\
\text { médio completo - } 18 \\
\text { anos ou mais } \\
2010\end{array}$ & $\begin{array}{c}\text { \% dos ocupados com } \\
\text { superior completo- } \\
18 \text { anos ou mais } \\
\mathbf{2 0 1 0}\end{array}$ & $\begin{array}{c}\% \text { dos ocupados no } \\
\text { setor agropecuário- } \\
18 \text { anos ou mais } \\
2010\end{array}$ & $\begin{array}{c}\% \text { dos ocupados no } \\
\text { setor comércio }-18 \\
\text { anos ou mais } \\
2010\end{array}$ & $\begin{array}{c}\% \text { dos ocupados no } \\
\text { setor serviços - } 18 \\
\text { anos ou mais } \\
2010\end{array}$ \\
\hline Brumadinho (MG) & 55,80 & 39,11 & 13,01 & 9,89 & 10,64 & 46,91 \\
\hline Bonito (MS) & 45,90 & 30,84 & 10,39 & 24,60 & 13,95 & 45,82 \\
\hline Gramado (RS) & 63,19 & 39,03 & 9,77 & 5,76 & 14,47 & 47,06 \\
\hline Brasil & 62,29 & 44,91 & 13,19 & 13,55 & 15,38 & 44,29 \\
\hline
\end{tabular}

\begin{tabular}{|c|c|c|c|c|c|c|}
\hline & $\begin{array}{c}40 \% \text { mais } \\
\text { pobres } \\
2010\end{array}$ & $\begin{array}{c}60 \% \text { mais } \\
\text { pobres } \\
2010\end{array}$ & $\begin{array}{c}80 \% \text { mais } \\
\text { pobres } \\
2010\end{array}$ & $\begin{array}{c}\text { Percentual da renda } \\
\text { apropriada pelos } \\
10 \% \text { mais ricos } \\
2010\end{array}$ & $\begin{array}{l}\text { Índice de Gini } \\
2010\end{array}$ & $\begin{array}{c}\text { Índice de Theil } \\
-L \\
2010\end{array}$ \\
\hline Brumadinho (MG) & 11,03 & 21,52 & 36,67 & 50,57 & 0,57 & 0,59 \\
\hline Bonito (MS) & 11,52 & 22,54 & 39,79 & 44,79 & 0,54 & 0,51 \\
\hline Gramado (RS) & 14,44 & 27,17 & 45,64 & 39,77 & 0,48 & 0,39 \\
\hline Brasil & 8,59 & 19,23 & 36,60 & 48,93 & 0,60 & 0,68 \\
\hline
\end{tabular}

\begin{tabular}{|c|c|c|c|c|}
\hline & $\begin{array}{l}\text { Renda per } \\
\text { capita } \\
2010\end{array}$ & $\begin{array}{c}\% \text { de } \\
\text { extremamente } \\
\text { pobres } \\
2010\end{array}$ & $\begin{array}{c}\% \text { de pobres } \\
2010\end{array}$ & $\begin{array}{c}\% \text { de } \\
\text { vulneráveis à } \\
\text { pobreza } \\
2010\end{array}$ \\
\hline Brumadinho (MG) & 910,31 & โ1,51] & 5,83 & 19,94 \\
\hline Bonito (MS) & $\overline{\mid} 6 \overline{1}, 03$ & 1,33 & 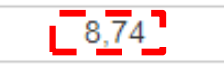 & [32,007 \\
\hline Gramado (RS) & 1045,52 & 0,32 & 2,18 & 7,48 \\
\hline Brasil & 793,87 & 6,62 & 15,20 & 32,56 \\
\hline
\end{tabular}

\begin{tabular}{|c|c|c|c|c|c|c|}
\hline & $\begin{array}{c}\text { Taxa de } \\
\text { analfabetismo- } \\
11 \text { a } 14 \text { anos } \\
2010\end{array}$ & $\begin{array}{c}\text { Taxa de } \\
\text { analfabetismo- } \\
15 \text { anos ou mais } \\
2010\end{array}$ & $\begin{array}{c}\text { Taxa de } \\
\text { analfabetismo- } \\
15 \text { a } 17 \text { anos } \\
2010\end{array}$ & $\begin{array}{c}\text { Taxa de } \\
\text { analfabetismo- } \\
18 \text { anos ou mais } \\
2010\end{array}$ & $\begin{array}{c}\text { Taxa de } \\
\text { analfabetismo- } \\
18 \text { a } 24 \text { anos } \\
2010\end{array}$ & $\begin{array}{c}\text { Taxa de } \\
\text { analfabetismo- } \\
25 \text { anos ou mais } \\
2010\end{array}$ \\
\hline Brumadinho (MG) & 1,05 & 6,38 & 0,86 & 6,77 & 0,74 & 7,95 \\
\hline Bonito (MS) & {$[2, \overline{24}]$} & $-9, \overline{31}$ & $-0, \overline{93}$ & ᄂ $9 \overline{99}$ & $-1, \overline{94} 7$ & $-11, \overline{6} 47$ \\
\hline Gramado (RS) & 0,90 & 2,82 & $\overline{0,65}$ & 2,96 & $0, \overline{62}$ & 3,36 \\
\hline Brasil & 3,24 & 9,61 & 2,20 & 10,19 & 2,61 & 11,82 \\
\hline
\end{tabular}

\begin{tabular}{|c|c|c|c|c|c|}
\hline & $\begin{array}{c}\text { Esperança de } \\
\text { vida ao } \\
\text { nascer } \\
2010\end{array}$ & $\begin{array}{l}\text { Mortalidade } \\
\text { infantil } \\
2010\end{array}$ & $\begin{array}{c}\text { Taxa de } \\
\text { fecundidade } \\
\text { total } \\
2010\end{array}$ & $\begin{array}{c}\text { Taxa de } \\
\text { envelhecimento } \\
2010\end{array}$ & $\begin{array}{c}\text { Razão de } \\
\text { dependência } \\
2010\end{array}$ \\
\hline Brasil & 73,94 & 16,70 & 1,89 & 7,36 & 45,92 \\
\hline Bonito (MS) & $\left.\overline{7} 4 \overline{8}{ }^{6}\right]$ & [18,00 & 2,29 & 5,95 & 48,41 \\
\hline Brumadinho (MG) & 76,39 & 13,30 & 1,65 & 7,63 & 42,29 \\
\hline Gramado (RS) & 76,64 & 10,60 & 1,48 & 8,14 & 40,09 \\
\hline
\end{tabular}

